\author{
UNIVERSIDADE DE SÃO PAULO \\ FACULDADE DE ODONTOLOGIA DE BAURU
}

FÁTIMA CAROLINA PINTO BERNARDES

Judicialização como mecanismo de efetivação do direito fundamental à saúde 



\section{UNIVERSIDADE DE SÃO PAULO \\ FACULDADE DE ODONTOLOGIA DE BAURU}

FÁTIMA CAROLINA PINTO BERNARDES

Judicialização como mecanismo de efetivação do direito fundamental à saúde

Tese apresentada à Faculdade de Odontologia de Bauru da Universidade de São Paulo para obtenção do título de Doutor em Ciências no Programa de Ciências Odontológicas Aplicadas, na área de concentração Saúde Coletiva.

Orientador: Prof. Dr. José Roberto de Magalhães Bastos.

Versão corrigida 
Bernardes, Fátima Carolina Pinto Judicialização como mecanismo de efetivação do direito fundamental à saúde/Fátima Carolina Pinto Bernardes - Bauru, 2020. 248 p. : il. ; $31 \mathrm{~cm}$.

Tese (Doutorado) - Faculdade de Odontologia de Bauru. Universidade de São Paulo

Orientador: Prof. Dr. José Roberto de Magalhães Bastos

Nota: A versão original desta tese encontra-se disponível no Serviço de Biblioteca e Documentação da Faculdade de Odontologia de Bauru - FOB/USP.

Autorizo, exclusivamente para fins acadêmicos e científicos, a reprodução total ou parcial desta tese, por processos fotocopiadores e outros meios eletrônicos.

Assinatura:

Data:

Comitê de Ética da FOB-USP

Protocolo no: 29183020.5 .0000 .5417

Data: $12 / 02 / 2020$ 
ERRATA 

FOLHA DE APROVAÇÃO 



\section{DEDICATÓRIA}

Dedico este trabalho à minha amada filha Rafaela, fonte de inspiração, minha melhor companhia, um orgulho. Filha, ainda bem que eu tenho você!!!

A meu avô Wilson ("in memoriam"), quem desde cedo me fez ver a importância do saber, abdicando de inúmeros projetos em prol da minha formação.

À minha avó Maria de Lourdes ("in memoriam"), pela persistência e determinação herdadas.

Aos meus pais, Luciano e Mara, por eu existir. 



\section{AGRADECIMENTOS}

Agradeço a Deus, sempre, pelo caminho percorrido até hoje.

Ao meu orientador, Professor Doutor José Roberto de Magalhães Bastos, por acreditar no meu projeto de pesquisa, oportunizando meu ingresso neste programa de Doutorado.

À querida Professora Doutora Sílvia Helena de Carvalho Sales Peres, pelos valiosos ensinamentos partilhados durante a elaboração desta tese.

Ao meu amigo Luiz Carlos Rodrigues, funcionário do Município de Bauru há mais de 40 anos, que me ajudou diretamente na coleta de dados deste trabalho. Lú, sem você eu não teria conseguido!

Ao pai da Rafaela, José Eduardo, maior incentivador da minha carreira acadêmica.

Aos amigos de uma vida toda: Valéria Godoy, Marisa Gebara, Flávia Negrão, Márcia Sato, Iriana Munhoz, Júlio Marin, Eliara Vale, Cibele Pasqualini. Em cada café, em cada encontro, vocês me fortaleceram...

À minha afilhada Isadora, agradeço a Deus por mais esse presente. Isa, que orgulho de você!!!

Aos meus tios, Márcio e Ana, sempre presentes em minha vida.

Ao Diego Ortega Pereira, especialista em informática, ajuda imprescindível na elaboração dos gráficos e tabelas que ilustraram este trabalho.

À Sílvia Cristina Tonin Costa, Secretária de Departamento FOB-USP, pela paciência e colaboração inestimáveis à execução deste trabalho.

Aos funcionários da biblioteca da FOB-USP, por todo auxílio e atenção dedicados ao longo do curso. 

"Mesmo quando tudo parece desabar, cabe a mim decidir entre rir ou chorar, ir ou ficar, desistir ou lutar; porque descobri, no caminho incerto da vida, que o mais importante é o decidir".

Cora Coralina 



\section{RESUMO}

O direito à saúde, a partir da Constituição Federal de 1988, ganhou status de direito fundamental, elencado expressamente no rol dos direitos sociais. O aumento da demanda na área da saúde, o surgimento de novas especialidades e técnicas, aliados à insuficiência de profissionais e estabelecimentos de saúde, levam à busca do cidadão pelo Poder Judiciário, dando origem a um fenômeno crescente, denominado judicialização da saúde. Neste trabalho, abordaremos o assunto no âmbito do Município de Bauru, no período de 2014 a 2017. O objetivo geral é verificar se a judicialização da saúde é um mecanismo para efetivação dos direitos fundamentais. Para tanto, realizaremos uma análise descritiva das ações judiciais propostas, verificando o impacto orçamentário anual e administrativo, bem como os reflexos na efetivação dos direitos fundamentais. Resultados: foram pesquisados 712 processos, com um impacto orçamentário de $\mathrm{R} \$ 4.926 .131,49$. Dentre os objetos pleiteados, fralda foi o insumo mais requisitado, com 407 pedidos. A via processual utilizada em grande parte nas ações analisadas foi o mandado de segurança. A pesquisa confirmou uma realidade já conhecida na área jurídica, a judicialização é um fenômeno crescente e com abrangência cada vez maior, tendo em vista a pluralidade dos objetos encontrados nas ações judiciais. Conclusão: a judicialização deve ser vista como mecanismo de efetivação do direito fundamental à saúde. Neste contexto, imperativa se faz a abordagem da judicialização da saúde e suas consequências práticas e sociais. É necessário repensar os mecanismos de controle e de garantia ao acesso universal, igualitário e de qualidade do direito à saúde, à luz dos princípios constitucionais, da reserva do possível, do mínimo existencial e da dignidade da pessoa humana.

Palavras-Chave: Judicialização da Saúde. Efetividade. Direitos Fundamentais. Dignidade da Pessoa Humana. 



\section{ABSTRACT \\ Judicialization as a mechanism to enforce the fundamental right to health}

The right to health, since the Federal Constitution of 1988, gained status of fundamental right, listed explicitly in the roll of social rights. The increasing demand in the health area, the appearing of new specialties and techniques, together with the insufficiency of health professionals and establishments, lead to the citizen's search for the Judiciary, giving rise to a growing phenomenon, called health judicialization. In this work, we will approach the subject in the scope of the Municipal District of Bauru, from 2014 to 2017. The general objective is to verify if the judicialization of health is a mechanism for the realization of the fundamental rights. To do so, we will carry out a descriptive analysis of the proposed lawsuits, verifying the annual and administrative budgetary impact, as well as the reflexes in the realization of the fundamental rights. Results: 712 processes were researched, with a budgetary impact of $R \$$ $4,926,131.49$. Among the objects requested, diaper was the most requested input, with 407 orders. The procedural route used in large part in the analyzed actions was the writ of security. The research confirmed a reality already known in the legal area, judicialization is a growing phenomenon and with increasing coverage, in view of the plurality of objects found in lawsuits. Conclusion: judicialization should be seen as a mechanism for the realization of the fundamental right to health. In this context, it is imperative to approach the judicialization of health and its practical and social consequences. It is necessary to reconsider the mechanisms of control and guarantee to the universal, equal and quality access of the right to health, in light of the constitutional principles, of the reserve of the possible, the minimum existential and the dignity of the human person.

Keywords: Health Judicialization. Effectiveness. Fundamental Rights. Human Being Dignity. 



\section{LISTA DE ILUSTRAÇÕES}

FIGURA 01 - Percentual dos Objetos das Ações Judiciais Correspondente ao Ano de 2014

FIGURA 02 - Percentual dos Objetos das Ações Judiciais Correspondentes ao Ano de 2015 .

FIGURA 03 - Percentual dos Objetos das Ações Judiciais Correspondentes ao Ano de 2016.

FIGURA 04 - Percentual dos Objetos das Ações Judiciais Correspondentes ao Ano de 2017...

FIGURA 05 - Percentual dos Objetos das Ações Judiciais Correspondentes ao Período de 2014 a $2017 .$.

FIGURA 06 - Tipos de Ação Judicial.

FIGURA 07 - Total de Processos Judiciais..

FIGURA 08 - Alimentação Especial...

FIGURA 09 - Apresentação de Prontuário .................................................... 78

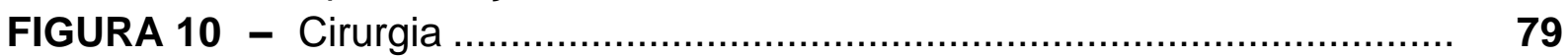

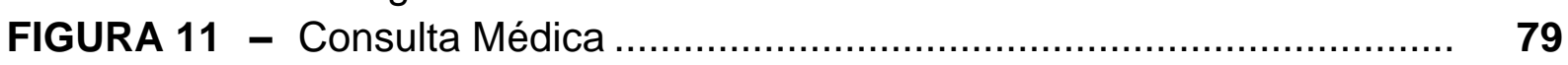

FIGURA 12 - Cuidador / Home Care …................................................. $\quad 80$

FIGURA 13 - Dano Material e Moral ................................................... $\quad 80$

FIGURA 14 - Insumos / Material Hospitalar............................................. 81

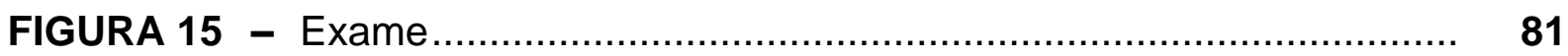

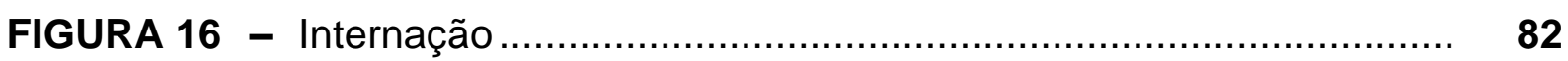

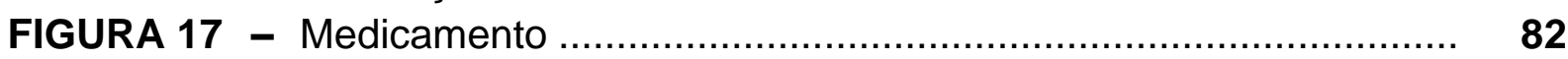

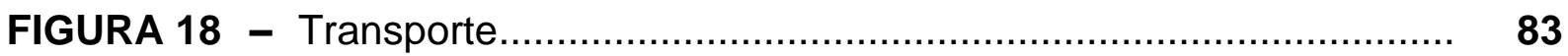

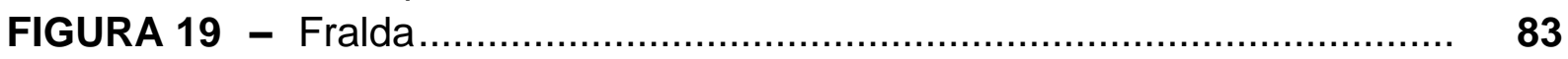

FIGURA 20 - Segredo de Justiça ............................................................. 83

FIGURA 21 - Custo Anual por Centro de Custo .......................................... $\quad 85$

FIGURA 22 - Custo Anual Medicamento Judicial .......................................... 85

FIGURA 23 - Custo Anual Material Hospitalar.......................................... 86

FIGURA 24 - Custo Total por Ano …………......................................... 86 



\section{LISTA DE TABELAS}

TABELA 01 - Processos Pesquisados Correspondentes ao Ano de 2014 ...... 72

TABELA 02 - Processos Pesquisados Correspondentes ao Ano de 2015 ....... 73

TABELA 03 - Processos Pesquisados Correspondentes ao Ano de 2016 ....... 74

TABELA 04 - Processos Pesquisados Correspondentes ao Ano de 2017 ...... 75

TABELA 05 - Visão Geral dos Processos Pesquisados de Acordo com 0 Objeto Correspondente ao Período de 2014 a 2017 ................. $\quad 76$

TABELA 06 - Total dos Processos Pesquisados por Tipo de Ação Judicial .... $\quad 77$

TABELA 07 - Custo Anual da Judicialização da Saúde .................................... 84 



\section{LISTA DE ABREVIATURAS E SIGLAS}

$\begin{array}{lll}\text { ADPF } & - & \text { Ação de Descumprimento de Preceito Fundamental } \\ \text { AgR } & - & \text { Agravo } \\ \text { Ampl. } & - & \text { Ampliada } \\ \text { ANVISA } & - & \text { Agência Nacional de Vigilância Sanitária } \\ \text { Art. } & - & \text { Artigo } \\ \text { Atual. } & - & \text { Atualizada } \\ \text { Aum. } & - & \text { Aumentada } \\ \text { CC } & - & \text { Código Civil } \\ \text { CF } & - & \text { Constituição Federal de 1988 } \\ \text { CNJ } & - & \text { Conselho Nacional de Justiça } \\ \text { CPC } & - & \text { Código de Processo Civil } \\ \text { D.J. } & - & \text { Data do Julgamento } \\ \text { D.P. } & - & \text { Data da Publicação } \\ \text { Ed. } & - & \text { Edição } \\ \text { Inc. } & - & \text { Inciso } \\ \text { Min. } & - & \text { Ministro } \\ \text { NAT-JUS } & - & \text { Núcleos de Apoio Técnico ao Judiciário } \\ \text { RE } & - & \text { Recurso Extraordinário } \\ \text { Rel. } & - & \text { Relator } \\ \text { REsp. } & - & \text { Recurso Especial } \\ \text { Ss. } & - & \text { Seguintes } \\ \text { STF } & - & \text { Supremo Tribunal Federal } \\ \text { STJ } & - & \text { Superior Tribunal de Justiça } \\ \text { SUS } & - & \text { Sistema Único de Saúde } \\ \text { TJSP } & - & \text { Tribunal de Justiça do Estado de São Paulo } \\ \text { Vol. } & - & \text { Volume }\end{array}$



Sumário 

SUMÁRIO

1 INTRODUÇÃO

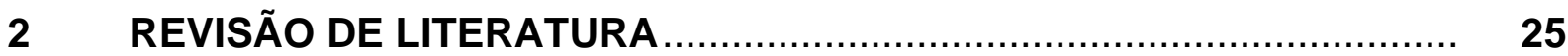

$2.1 \quad$ Direito à saúde ...................................................................... 26

2.2 Repartição de competências entre os entes federados: o modelo do SUS

2.3 Dignidade da pessoa humana ........................................................ 36

2.3.1 Considerações preliminares ............................................................. 36

2.3.2 Evolução histórica do conceito de dignidade ......................................... $\quad 37$

2.3.3 O conceito de dignidade em Kant......................................................... 43

2.3.4 Algumas acepções conferidas ao conceito de dignidade ........................ $\quad 45$

2.4 O custo da judicialização da saúde: entre o princípio da reserva do possível e a teoria do mínimo existencial

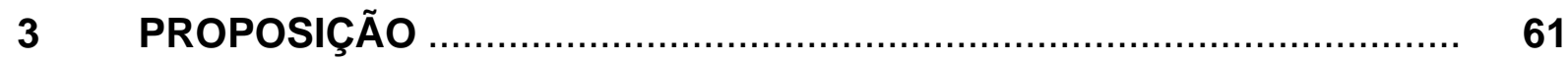

$4 \quad$ MATERIAL E MÉTODOS ................................................................ 65

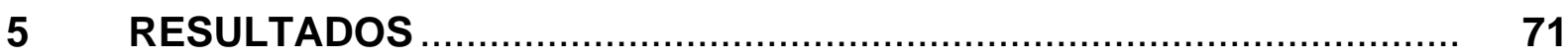

5.1 Ações judiciais contra o Município de Bauru - período 2014 a 2017 ... 71

5.2 Dos objetos pesquisados .......................................................... 78

5.3 Do impacto orçamentário das ações judiciais no Município de Bauru - período 2014 a 2017

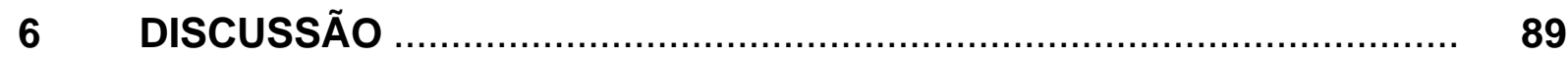

6.1 Sugestão de política pública ……....................................................... 93

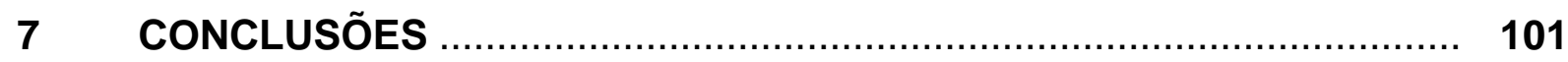

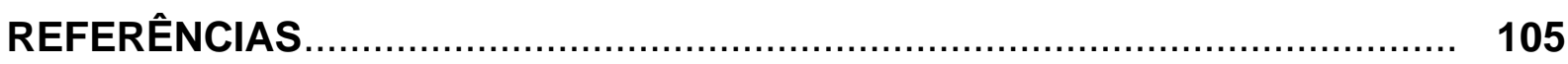

APÊNDICE A - Tabela com a Relação dos Processos Judiciais Pesquisados

ANEXO A - Aprovação Comitê de Ética e Pesquisa .................................... 235

ANEXO B - Provimento no 84/2019 ................................................ 241

ANEXO C - Resolução CNJ no 238/2016 ............................................... 245 

1 Introdução 



\section{INTRODUÇÃO}

O processo de redemocratização do país culminou com a promulgação da Constituição Federal de 1988.

Dentre os inúmeros princípios e direitos consagrados, a nova Carta emerge com uma característica peculiar, a de garantidora dos direitos fundamentais.

Neste contexto, a Constituição Federal de 1988, em seu Título II, classifica o gênero "direitos e garantias fundamentais" em quatro grupos: direitos e deveres individuais e coletivos; direitos sociais; direitos de nacionalidade e direitos políticos.

Para José Afonso da Silva (2014), os direitos fundamentais:

[...] se concretizam em garantias de uma convivência digna, livre e igual de todas as pessoas. [...] trata de situações jurídicas sem as quais a pessoa humana não se realiza, não convive e, às vezes, nem mesmo sobrevive. Tais direitos a todos devem ser, não apenas formalmente reconhecidos, mas concreta e materialmente efetivados (grifou-se).

A doutrina (SARLET, 2012), por sua vez, classifica os direitos fundamentais em gerações de direitos, também chamadas de dimensões dos direitos fundamentais. Seguindo o ideário da Revolução Francesa - liberdade, igualdade, fraternidade - apresentam-se os direitos de primeira, segunda e terceira dimensão, havendo quem sustente já uma quarta (BONAVIDES, 2010), quinta e até sexta dimensão de direitos fundamentais (FACHIN, 2015).

Os direitos de primeira dimensão se caracterizam pela passagem de um Estado autoritário para um Estado de Direito, fazendo eclodir o respeito às liberdades individuais frente ao absenteísmo estatal. Traduzem o valor da liberdade do indivíduo em relação ao Estado e, por isso, recebem a denominação de liberdades públicas.

Os direitos de segunda dimensão foram impulsionados pela Revolução Industrial europeia, a partir do século XIX, e evidenciam os direitos sociais, culturais e econômicos, correspondentes aos direitos de igualdade prenunciados na Revolução Francesa. 
Os direitos de terceira dimensão são direitos transindividuais, isto é, aqueles que vão além dos interesses do indivíduo, na medida em que buscam a proteção da humanidade, como, por exemplo, direito ao meio ambiente, ao patrimônio histórico.

Trilhando esse caminho, o direito à saúde, constitucionalmente consagrado, na qualidade de direito social, integra a segunda dimensão dos direitos fundamentais.

Assim, podemos dizer que os direitos sociais, como dimensão dos direitos fundamentais do homem, são prestações positivas proporcionadas pelo Estado direta ou indiretamente, enunciadas em normas constitucionais, que possibilitam melhores condições de vida aos mais fracos, direitos que tendem a igualização de situações sociais desiguais (SILVA, 2014).

O Constituinte de 1988, em seu art. 6º, expressamente elencou os direitos sociais, conforme segue:

Art. 6: São direitos sociais a educação, a saúde, a alimentação, o trabalho, a moradia, o transporte, o lazer, a segurança, a previdência social, a proteção à maternidade e à infância, a assistência aos desamparados, na forma desta Constituição (grifou-se).

Posteriormente, no art. 196, do Diploma Constitucional, o legislador originário trouxe o acesso universal e igualitário para o direito à saúde, conferindo ao Estado a atribuição precípua de atender as demandas do cidadão na área da saúde:

Art. 196. A saúde é direito de todos e dever do Estado, garantido mediante políticas sociais e econômicas que visem à redução do risco de doença e de outros agravos e ao acesso universal e igualitário às ações e serviços para sua promoção, proteção e recuperação.

Quanto à aplicabilidade prática, via de regra, as normas constitucionais garantidoras dos direitos fundamentais têm aplicação imediata, ${ }^{1}$ ou seja, possuem todos os meios e elementos necessários à sua correta aplicação. Todavia, algumas dessas normas dependem de providências posteriores que Ihes garantam a eficácia, como é o caso das normas que tratam dos direitos sociais (SILVA, 2014).

$1 \quad$ Art. 5o, $\S 1^{\circ}$, da Constituição Federal de 1988: As normas definidoras dos direitos e garantias fundamentais têm aplicação imediata. 
Após a Constituição de 1988, além dos direitos sociais, a dignidade da pessoa humana, igualmente, encontra um vasto campo normativo tendente à valorização do cidadão, assumindo um novo reconhecimento, sendo alçada ao status de fundamento da República Federativa do Brasil, nos termos do art. 1ํ, inc. III, da Carta Magna.

Nesse contexto, a atuação do Poder Judiciário encontra terreno fértil para o implemento do direito à saúde, suprindo eventuais omissões legislativas e conferindo garantia à sua efetivação, tudo isso sob o prisma dos direitos fundamentais e da dignidade da pessoa humana.

Quanto maior o número de leis e quanto mais direitos são constitucionalizados com o intuito de regulamentar uma diversidade de matérias, maior será a atuação do Poder Judiciário, surgindo a todo instante o que se chama de judicialização (BARROSO, 2014).

Importante destacar que a busca pelo Poder Judiciário também foi constitucionalmente consagrada, representada pelo Princípio do Amplo Acesso à Justiça, também chamado de Princípio da Inafastabilidade do Controle Jurisdicional, conforme se depreende do art. $5^{\circ}$, inc. XXXV, da Carta de 1988:

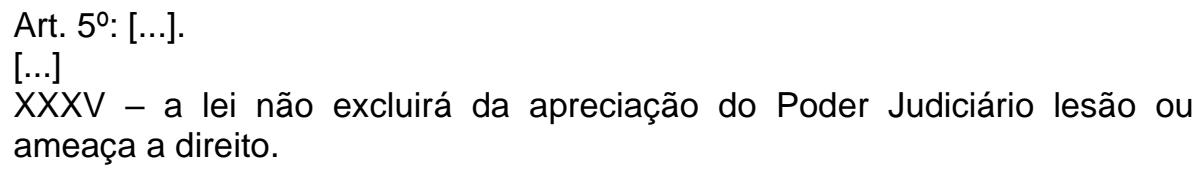
ameaça a direito.

Poder invocar a atividade jurisdicional é um verdadeiro direito público subjetivo, o qual compreende mais que um simples direito de agir, mas também um direito contra quem se age (SILVA, 2014).

No âmbito do direito à saúde, além das omissões legislativas supra citadas, o aumento da demanda, o surgimento de novas especialidades e técnicas, aliados à insuficiência de profissionais e estabelecimentos de saúde, acarretam um descontentamento generalizado e a busca pelo Judiciário é providência iminente (MAPELLI JUNIOR, 2017).

Há uma dicotomia latente quando se fala em judicialização da saúde: parte da população tem acesso a medicamentos e a tratamentos muitas vezes 
caríssimos, enquanto a maior parte morre nas filas de hospitais e ambulatórios em todo o país.

O insuficiente sistema de saúde brasileiro luta para equilibrar os gastos públicos, ao passo que se depara com inúmeras medidas judiciais determinando o cumprimento imediato de tutelas individuais, em busca da efetivação do direito à saúde (CORVINO, 2017).

Não se discute o conteúdo da norma constitucional que estabelece a saúde como direito de todos e dever do Estado (em sentido amplo), porque este, sem dúvida, é um direito inerente ao ser humano, sem o qual nenhum outro seria possível ou usufruível.

Também não se questiona 0 direito à saúde consagrado constitucionalmente no artigo 196 do Texto Fundamental, como direito de todos e dever do Estado. Entretanto, vale salientar, assim como faz José Joaquim Gomes Canotilho (1994), que: "[...] o direito à prestação não corresponde, rigorosamente, ao dever de prestação do Estado, contido na imposição legiferante; o âmbito normativo daquele direito pode ser mais amplo ou mais restrito que o deste dever".

Nesse diapasão, a Lei Federal ํo 8.080/90, denominada Lei Orgânica da Saúde, já no seu primeiro artigo determina que os serviços de saúde, em todo o território nacional, serão regulados por essa lei, definindo as competências dos entes federados, na questão de saúde.

Tudo isso, aliás, a decorrer da competência comum, prevista no art. 24, inc. XII, da Lei Maior. ${ }^{2}$

Por sua vez, o Estado de São Paulo, respeitando as normas gerais editadas pela União, promulgou a Lei Complementar oㅜ 791/95, denominado Código de Saúde.

2 Art. 24 da Constituição Federal de 1988: Compete à União, aos Estados e ao Distrito Federal legislar concorrentemente sobre:

$[\ldots]$

XII - previdência social, proteção e defesa da saúde. 
A legislação estadual, em seus arts. 15, parágrafo único e 17, estabelece a competência supletiva do Estado, nos serviços e ações de saúde a serem desenvolvidos nos Municípios.

Verifica-se, pelo teor das normas, a existência de uma repartição de competências entre os entes federados, razão pela qual incumbe ao Estado, de forma supletiva, suprir qualquer serviço ou ação de saúde nos Municípios.

Assim, não se pode negar efetividade ao Texto Constitucional, nem mesmo às leis que, por determinação da Carta Magna, regulamentam o consagrado direito à saúde. Isso porque há uma tendência no Poder Judiciário em atribuir aos Municípios grande parte da responsabilidade pelo atendimento às demandas na área da saúde.

Ocorre que, se já há norma infraconstitucional regulamentando de forma clara as competências e as atribuições de cada ente federativo, não deveria, em tese, o Judiciário ignorá-las, sob o fundamento que há solidariedade entre os entes federados.

Tal situação levaria ao descompasso do princípio federativo, cláusula pétrea do nosso Texto Constitucional. Os Municípios, que já possuem orçamento bem limitado, em comparação aos Estados-Membros e à União, veem-se obrigados, por determinação judicial, a realizar ações e a utilizar recursos orçamentários próprios em tarefas que não são de sua responsabilidade, claramente definidas nas regras infraconstitucionais.

A preocupação com o impacto da judicialização nos municípios é justificável. Há casos em que uma única ação pode comprometer todo o orçamento da saúde de uma cidade de pequeno porte (PIERRO, 2017).

Em notícia publicada no sítio do Superior Tribunal de Justiça - STJ, referido Tribunal coloca sobre o desafio de ponderar demandas individuas e coletivas. ${ }^{3}$

Para o Presidente da época da Primeira Seção do Superior Tribunal de Justiça, Ministro Teori Albino Zavascki:

3 Disponível em: <http://www.stj.jus.br>. Acesso em: 05 out. 2018. 
[...] não existe um direito subjetivo constitucional de acesso universal, gratuito, incondicional e a qualquer custo a todo e qualquer meio de proteção à saúde. $\mathrm{O}$ direito à saúde deve ser entendido como um sistema de proteção à saúde que dá oportunidades iguais para as pessoas alcançarem os mais altos níveis de saúde possíveis.

\title{
E pondera:
}

[...] isso não significa que a garantia constitucional não tenha eficácia. Há certos deveres estatais básicos que devem ser cumpridos. Assim, a atuação judicial ganha espaço quando inexistem políticas públicas ou quando elas são insuficientes para atender minimamente (grifouse).

Deve-se salientar que, em recente manifestação do Supremo Tribunal Federal, o Ministro Gilmar Mendes enfrentou a questão, no tocante aos medicamentos de alto custo, quando do julgamento do $R E$ no 566.471 , que já conta com decisão final, a ser abordada no decorrer deste trabalho, fixando a seguinte tese de repercussão geral:

\begin{abstract}
O reconhecimento do direito individual ao fornecimento, pelo Estado, de medicamento de alto custo, não incluído em Política Nacional de Medicamentos ou em Programa de Medicamentos de Dispensação em Caráter Excepcional, depende da comprovação da imprescindibilidade adequação e necessidade -, da impossibilidade de substituição do fármaco e da incapacidade financeira do enfermo e dos membros da família solidária, respeitadas as disposições sobre alimentos dos artigos 1.694 a 1.710 do Código Civil. ${ }^{4}$
\end{abstract}

Assim, procurar-se-á efetuar uma avaliação crítica da atuação do Poder Judiciário na efetivação do direito fundamental à saúde, levando-se em conta a reserva do possível, o mínimo existencial e o Princípio da Separação de Poderes, à luz da dignidade da pessoa humana.

O estudo em questão não busca considerações eminentemente teóricas, na medida em que o foco central do trabalho será a análise prática da judicialização da saúde no Município de Bauru, por meio de uma avaliação retrospectiva, verificando os reflexos orçamentários e administrativos no que tange ao montante despendido com a judicialização, à execução de políticas públicas, bem como à efetivação de direitos fundamentais do cidadão.

4 Disponível em: <http://www.stf.jus.br>. Acesso em: 04 jan. 2019. 
Há uma verdadeira explosão de ações judiciais objetivando o fornecimento de medicamentos, insumos, vagas para internação, agendamento de cirurgias, dentre tantas outras demandas ligadas à saúde. Todavia, muito mais que uma questão jurídica, o problema também é social, de gestão.

Assim, a ausência de políticas públicas, aliada ao fato de uma prestação de serviços deficiente e à precariedade do sistema público de saúde levam ao fenômeno da judicialização da saúde.

Neste contexto, imperativa se faz a análise das consequências advindas dessa interferência do Poder Judiciário, principalmente no que tange à gestão administrativa e ao impacto orçamentário.

O presente estudo justifica-se diante da constatação acerca da atuação crescente do Poder Judiciário para garantia do direito à saúde.

O Estado Democrático de Direito, por si só, não garante a efetivação do direito à saúde, oportunidade em que há um elevado contingente quantitativo de ações judiciais individuais, ou seja, é o cidadão buscando o Poder Judiciário para implementar esse direito.

Em suma, pretende-se demonstrar se a judicialização da saúde pode ser considerada ou não um mecanismo de efetivação de direitos fundamentais. Daí a necessidade premente da abordagem do tema em questão, realçando-se a importância da análise da judicialização nos processos na área da saúde, no âmbito do Município de Bauru. 

2 Revisão de Literatura 



\section{REVISÃO DE LITERATURA}

A literatura científica, normalmente, aborda o direito à saúde sob o prisma constitucional dos direitos sociais, compreendendo a judicialização da saúde como instituto garantidor de direitos fundamentais da pessoa humana, verdadeiro ativismo judicial onde o Estado, representado aqui pelo Poder Judiciário, intervém cada vez mais no Poder Executivo a fim de suprir a carência crescente de políticas públicas de saúde.

Raramente as discussões doutrinárias apresentam dados estatísticos sobre $o$ assunto.

Em âmbito constitucional, tratando-se de direitos sociais, é frequente a afirmação no sentido de que os direitos econômicos e sociais, como dimensão dos direitos fundamentais do homem, se caracterizam por prestações positivas proporcionadas pelo Estado, cujo objetivo primordial é possibilitar melhores condições de vida àqueles mais necessitados, buscando a efetivação da igualdade real (SILVA, 2014).

Historicamente, o surgimento dos direitos sociais está ligado ao início do capitalismo industrial, onde a classe operária se organizava em movimentos de resistência e afirmação contra as desigualdades sociais e as deficiências do Estado Liberal, dando origem no século XX ao Welfare State, Estado do BemEstar Social, cujo modelo é de um governo protagonista na manutenção e promoção do bem-estar político e social do país e de seus cidadãos (COMPARATO, 1999).

Neste contexto, o Welfare State emerge como uma garantia cidadã ao bem-estar da população, no sentido de, pela ação positiva, o Estado ser um verdadeiro afiançador da qualidade de vida do indivíduo, levando, num momento posterior ao aprofundamento da fórmula, a qual passou de Estado do Bem-Estar Social para Estado Democrático de Direito (STRECK, 2004).

Com a promulgação da Constituição Federal de 1988, o direito à saúde adquiriu status de direito fundamental e garantiu ao cidadão atendimento integral, 
ganhando força a ideia de que o juiz de direito, ao perceber a inércia estatal ou ineficiência, deve supri-la por meio de uma ordem, dando origem à constitucionalização da saúde e à judicialização dos direitos sociais (MAPELLI JúNIOR, 2017).

Os ideários da Constituição de 1988, chamada Constituição Cidadã, vêm expressos no art. 3o ${ }^{2}$ intitulados em forma de objetivos da República Federativa do Brasil, dentre eles, construir uma sociedade livre, justa e solidária, reduzir as desigualdades sociais e promover o bem de todos. Tudo isso sob o prisma da dignidade da pessoa humana, alçada a fundamento da República, nos termos do art. $1^{\circ}$, inc. III, da Carta de $1988{ }^{6}$

E para atingir esses objetivos fundamentais, o Estado tem que se organizar no facere e praestare, incidindo sobre a realidade social. É aí que o Estado Social de Direito se transforma em Estado Democrático de Direito (GRINOVER, 2009).

\subsection{Direito à Saúde}

Constitucionalmente, o direito à saúde foi previsto, pela primeira vez, no rol dos direitos sociais do art. 6o da Magna Carta de 1988.

Os direitos sociais, enquanto direitos fundamentais, se inserem na classificação de segunda dimensão (ou segunda geração), sendo conceituados como "[...] aqueles que garantem ao cidadão o poder de exigir prestações positivas por parte do Estado, pela busca do bem-estar social" (HUTZLER, 2018).

5 Art. 3o da Constituição Federal de 1988: Constituem objetivos fundamentais da República Federativa do Brasil:

I - construir uma sociedade livre, justa e solidária;

II - garantir o desenvolvimento nacional;

III - erradicar a pobreza e a marginalização e reduzir as desigualdades sociais e regionais;

IV - promover o bem de todos, sem preconceitos de origem, raça, sexo, cor, idade e quaisquer outras formas de discriminação.

$6 \quad$ Art. $1^{\circ}$ da Constituição Federal de 1988: A República Federativa do Brasil, formada pela união indissolúvel dos Estados e Municípios e do Distrito Federal, constitui-se em Estado Democrático de Direito e tem como fundamentos:

[...]

III - a dignidade da pessoa humana. 
O amadurecimento histórico e democrático trouxe a necessidade de um vasto catálogo de direitos fundamentais, abrangendo os direitos sociais e dentro deles, o direito à saúde (ADAES, 2016).

A saúde deve ser considerada o primeiro e o primordial direito social, na medida em que sem saúde não há sequer vida digna, não há trabalho (MENDES, 2013).

No âmbito infraconstitucional, as principais legislações sobre o assunto são a Lei Federal ํㅜ 8.080, de 19 de setembro de 1990, que dispõe sobre as condições para a promoção, proteção e recuperação da saúde, a organização e o funcionamento dos serviços correspondentes e dá outras providências, e a Lei Complementar Estadual no 791, de 09 de março de 1995, que estabelece o Código de Saúde no Estado de São Paulo.

A Lei Federal no 8.080/90, denominada Lei Orgânica da Saúde, em seu art. $2^{\circ}$, traz a saúde atrelada expressamente ao conceito de direito fundamental:

Art. $2^{\circ}$ : A saúde é um direito fundamental do ser humano, devendo o Estado prover as condições indispensáveis ao seu pleno exercício.

É bem verdade que os direitos a prestações positivas do Estado encontraram terreno fértil, sem precedentes, na Constituição de 1988, conferindo-se um capítulo específico aos direitos sociais dentro do tópico concernente aos direitos e garantias fundamentais (SARLET, 2012).

A implementação dos direitos sociais exige a construção de um novo paradigma, pautado por valores de inclusão, capazes de assegurar um desenvolvimento mais igualitário e democrático, nos âmbitos local, regional e global, inspirado na crença absoluta da prevalência da dignidade humana (PIOVESAN, 2010).

Neste contexto, a Constituição Federal prevê expressamente a universalidade da saúde como direito de todos e dever do Estado, que deve ser garantido mediante políticas sociais e econômicas (art. 196).

No mesmo sentido é o art. $2^{\circ}$, $\S 1^{\circ}$, da Lei ํo 8.080/90: 
Art. 20: [...].

$\S 1^{\circ}$ - O dever do Estado de garantir a saúde consiste na formulação e execução de políticas econômicas e sociais que visem à redução de riscos de doenças e de outros agravos e no estabelecimento de condições que assegurem acesso universal e igualitário às ações e aos serviços para a sua promoção, proteção e recuperação.

A imensa desigualdade social e econômica, em especial no Brasil, dificulta a efetivação do direito à saúde, na medida em que a justiça social é componente fundamental do direito ao desenvolvimento, propiciando igualdade de oportunidade a todos no acesso de recursos básicos e na distribuição de renda (PIOVESAN, 2010).

Os problemas pertinentes à eficácia do direito à saúde devem-se muito mais à implementação e manutenção de políticas públicas do que à falta de legislação específica. Em outras palavras, o problema não é de inexistência, mas de execução administrativa pelos entes federados. O direito à saúde deve ser implementado mediante ações específicas (dimensão individual) e mediante amplas políticas públicas (dimensão coletiva) (MENDES; BRANCO, 2012).

O direito fundamental à saúde passou a ser considerado direito subjetivo e, nessa condição, passível de ser exigido judicialmente, razão pela qual, quando o Judiciário intervém compelindo o administrador a fornecer um medicamento ou um determinado tratamento a alguém está, na verdade, cumprindo um comando constitucional a assegurar esse direito e, assim, efetivá-lo (BRAZ; MONTENEGRO, 2010).

Quanto mais os governantes se omitem em programar e implementar políticas sociais, principalmente num país com profundas desigualdades como 0 nosso, mais se legitima a intervenção do Poder Judiciário para garantir ao cidadão o mínimo existencial que Ihe propicie uma vida digna (CARLOS NETO, 2018).

\subsection{Repartição de competências entre os entes federados: o modelo do SUS}

A estrutura federativa do Brasil no que tange à inteligência dos preceitos acerca do direito à saúde estabelecidos na Constituição Federal de 1988 nos traz 
uma competência estatal a indicar uma evidente solidariedade entre os entes federados quanto à responsabilidade por políticas públicas. ${ }^{7}$

Nesse sentido, o modelo constitucional do Sistema Único de Saúde (SUS) traz um desenho institucional que pressupõe um consenso administrativo entre os entes federados para repartição de competências, objetivando as organizações dos serviços e ações na área da saúde de forma regional e hierarquizada, aptas a garantirem o acesso universal e a assistência integral (MAPELLI, 2017).

Art. 4ํ da Lei Federal ํํ 8.080/90: O conjunto de ações e serviços de saúde, prestados por órgãos e instituições públicas federais, estaduais e municipais, da Administração direta e indireta e das fundações mantidas pelo Poder Público, constitui o Sistema Único de Saúde (SUS).

$\S 1^{\circ}$ - Estão incluídas no disposto neste artigo as instituições públicas federais, estaduais e municipais de controle de qualidade, pesquisa e produção de insumos, medicamentos, inclusive de sangue e hemoderivados, e de equipamentos para saúde.

$\S 2^{\circ}-$ A iniciativa privada poderá participar do Sistema Único de Saúde (SUS), em caráter complementar.

O sistema, como o próprio nome já diz, é único, apresentando a mesma doutrina e os mesmos princípios em todo território nacional, sob a responsabilidade dos entes federados por meio de formas autônomas de governo, com comando único em cada nível de gestão (MENDES, 2013).

O art. 200 da Constituição Federal de 1988 elenca, num rol meramente exemplificativo, as atribuições do SUS:

Art. 200: Ao sistema único de saúde compete, além de outras atribuições, nos termos da lei:

I - controlar e fiscalizar procedimentos, produtos e substâncias de interesse para a saúde e participar da produção de medicamentos, equipamentos, imunobiológicos, hemoderivados e outros insumos;

II - executar as ações de vigilância sanitária e epidemiológica, bem como as de saúde do trabalhador;

III - ordenar a formação de recursos humanos na área de saúde;

IV - participar da formulação da política e da execução das ações de saneamento básico;

$\mathrm{V}$ - incrementar, em sua área de atuação, o desenvolvimento científico e tecnológico e a inovação (Redação dada pela Emenda Constitucional ํo 85, de 2015);

$\mathrm{VI}$ - fiscalizar e inspecionar alimentos, compreendido o controle de seu teor nutricional, bem como bebidas e águas para consumo humano;

7 Vide arts. 23, II; 24, XII; 30, V e VI; 196 e 198, I, todos da Constituição Federal de 1988. 


\begin{abstract}
VII - participar do controle e fiscalização da produção, transporte, guarda e utilização de substâncias e produtos psicoativos, tóxicos e radioativos;

VIII - colaborar na proteção do meio ambiente, nele compreendido o do trabalho.
\end{abstract}

Além de determinar a instituição de um sistema único e integrado de saúde, o constituinte originário definiu, de forma ampla, as suas atribuições (MENDES; BRANCO, 2012).

À iniciativa privada compete a participação no SUS em caráter complementar (art. 199, $\S 1^{\circ}$ da Constituição Federal de 1988 e art. 4ํㅗ $\S 2^{\circ}$ da Lei $n^{\circ}$ 8080/90).

Os princípios e diretrizes constitucionais do Sistema Único de Saúde (SUS) são (MAPELLI, 2017):

a) Universalidade: a saúde é um direito de cidadania de todas as pessoas e cabe ao Estado assegurar este direito, sendo que o acesso às ações e serviços deve ser garantido a todas as pessoas, independentemente de sexo, raça, ocupação, ou outras características sociais ou pessoais.

b) Equidade: o objetivo desse princípio é diminuir desigualdades. Apesar de todas as pessoas possuírem direito aos serviços, as pessoas não são iguais e, por isso, têm necessidades distintas. Em outras palavras, equidade significa tratar desigualmente os desiguais, investindo mais onde a carência é maior.

c) Integralidade: este princípio considera as pessoas como um todo, atendendo a todas as suas necessidades. Para isso, é importante a integração de ações, incluindo a promoção da saúde, a prevenção de doenças, o tratamento e a reabilitação. Juntamente, o princípio de integralidade pressupõe a articulação da saúde com outras políticas públicas, para assegurar uma atuação intersetorial entre as diferentes áreas que tenham repercussão na saúde e qualidade de vida dos indivíduos.

d) Igualdade: deve ser dado o mesmo tratamento a todos os usuários do SUS, sem qualquer discriminação ou preconceito.

e) Gratuidade: o usuário não pode ser compelido a efetuar qualquer tipo de pagamento aos serviços prestados pelo SUS. 
f) Regionalização e Hierarquização: a prestação dos serviços deve ser realizada por meio de divisões territoriais, de acordo com a complexidade, levandose em consideração o grau menos complexo ao mais complexo.

g) Descentralização: compete aos municípios a execução das ações e serviços de saúde, permanecendo os estados e a união como corresponsáveis.

h) Participação social: se dá por meio da participação da comunidade em Conferências de Saúde e Conselhos de Saúde.

i) Informação: abrange dois aspectos, o direito do paciente e de sua família ao tratamento dado e o real estado de saúde e o dever do Estado na divulgação de informações quanto aos serviços de saúde e sua respectiva utilização pelos usuários.

Os objetivos do SUS, consagrados no art. 5ํ da Lei no 8.080/90 são: (i) a identificação e divulgação dos fatores condicionantes e determinantes da saúde; (ii) a formulação de política de saúde destinada a promover, nos campos econômico e social, a observância do disposto no $\S 1^{\circ}$ do art. $2^{\circ}$ desta lei; e, (iii) a assistência às pessoas por intermédio de ações de promoção, proteção e recuperação da saúde, com a realização integrada das ações assistenciais e das atividades preventivas.

Inclui-se ainda no campo de atuação do SUS a execução das seguintes ações: (i) de vigilância sanitária; (ii) de vigilância epidemiológica; (iii) de saúde do trabalhador; e, (iv) de assistência terapêutica integral, inclusive farmacêutica (art. $6^{\circ}$ ).

As atribuições comuns da União, dos Estados, do Distrito Federal e dos Municípios estão elencadas no art. 15 a Lei Federal ํㅜ 8080/90, in verbis:

\footnotetext{
Art. 15: A União, os Estados, o Distrito Federal e os Municípios exercerão, em seu âmbito administrativo, as seguintes atribuições:

I - definição das instâncias e mecanismos de controle, avaliação e de fiscalização das ações e serviços de saúde;

II - administração dos recursos orçamentários e financeiros destinados, em cada ano, à saúde;

III - acompanhamento, avaliação e divulgação do nível de saúde da população e das condições ambientais;

IV - organização e coordenação do sistema de informação de saúde;

$V$ - elaboração de normas técnicas e estabelecimento de padrões de qualidade e parâmetros de custos que caracterizam a assistência à saúde;

VI - elaboração de normas técnicas e estabelecimento de padrões de qualidade para promoção da saúde do trabalhador;
} 
VII - participação de formulação da política e da execução das ações de saneamento básico e colaboração na proteção e recuperação do meio ambiente;

VIII - elaboração e atualização periódica do plano de saúde;

IX - participação na formulação e na execução da política de formação e desenvolvimento de recursos humanos para a saúde;

X - elaboração da proposta orçamentária do Sistema Único de Saúde (SUS), de conformidade com o plano de saúde;

$\mathrm{XI}$ - elaboração de normas para regular as atividades de serviços privados de saúde, tendo em vista a sua relevância pública;

XII - realização de operações externas de natureza financeira de interesse da saúde, autorizadas pelo Senado Federal;

XIII - para atendimento de necessidades coletivas, urgentes e transitórias, decorrentes de situações de perigo iminente, de calamidade pública ou de irrupção de epidemias, a autoridade competente da esfera administrativa correspondente poderá requisitar bens e serviços, tanto de pessoas naturais como de jurídicas, sendo-lhes assegurada justa indenização;

XIV - implementar o Sistema Nacional de Sangue, Componentes e Derivados;

$\mathrm{XV}$ - propor a celebração de convênios, acordos e protocolos internacionais relativos à saúde, saneamento e meio ambiente;

$\mathrm{XVI}$ - elaborar normas técnico-científicas de promoção, proteção e recuperação da saúde;

XVII - promover articulação com os órgãos de fiscalização do exercício profissional e outras entidades representativas da sociedade civil para a definição e controle dos padrões éticos para pesquisa, ações e serviços de saúde;

XVIII - promover a articulação da política e dos planos de saúde;

XIX - realizar pesquisas e estudos na área de saúde;

$X X$ - definir as instâncias e mecanismos de controle e fiscalização inerentes ao poder de polícia sanitária;

$\mathrm{XXI}$ - fomentar, coordenar e executar programas e projetos estratégicos e de atendimento emergencial.

As competências dos entes federados foram previstas no art. 16 e seguintes do mesmo diploma legal, a seguir:

Art. 16: À direção nacional do Sistema Único da Saúde (SUS) compete:

I - formular, avaliar e apoiar políticas de alimentação e nutrição;

II - participar na formulação e na implementação das políticas:

a) de controle das agressões ao meio ambiente;

b) de saneamento básico; e

c) relativas às condições e aos ambientes de trabalho;

III - definir e coordenar os sistemas:

a) de redes integradas de assistência de alta complexidade;

b) de rede de laboratórios de saúde pública;

c) de vigilância epidemiológica; e

d) vigilância sanitária;

IV - participar da definição de normas e mecanismos de controle, com órgão afins, de agravo sobre o meio ambiente ou dele decorrentes, que tenham repercussão na saúde humana;

V - participar da definição de normas, critérios e padrões para o controle das condições e dos ambientes de trabalho e coordenar a política de saúde do trabalhador;

$\mathrm{VI}$ - coordenar e participar na execução das ações de vigilância epidemiológica; 
VII - estabelecer normas e executar a vigilância sanitária de portos, aeroportos e fronteiras, podendo a execução ser complementada pelos Estados, Distrito Federal e Municípios;

VIII - estabelecer critérios, parâmetros e métodos para o controle da qualidade sanitária de produtos, substâncias e serviços de consumo e uso humano;

IX - promover articulação com os órgãos educacionais e de fiscalização do exercício profissional, bem como com entidades representativas de formação de recursos humanos na área de saúde;

$X$ - formular, avaliar, elaborar normas e participar na execução da política nacional e produção de insumos e equipamentos para a saúde, em articulação com os demais órgãos governamentais;

$X I$ - identificar os serviços estaduais e municipais de referência nacional para o estabelecimento de padrões técnicos de assistência à saúde;

XII - controlar e fiscalizar procedimentos, produtos e substâncias de interesse para a saúde;

XIII - prestar cooperação técnica e financeira aos Estados, ao Distrito Federal e aos Municípios para o aperfeiçoamento da sua atuação institucional;

XIV - elaborar normas para regular as relações entre o Sistema Único de Saúde (SUS) e os serviços privados contratados de assistência à saúde;

$\mathrm{XV}$ - promover a descentralização para as Unidades Federadas e para os Municípios, dos serviços e ações de saúde, respectivamente, de abrangência estadual e municipal;

XVI - normatizar e coordenar nacionalmente o Sistema Nacional de Sangue, Componentes e Derivados;

XVII - acompanhar, controlar e avaliar as ações e os serviços de saúde, respeitadas as competências estaduais e municipais;

XVIII - elaborar o Planejamento Estratégico Nacional no âmbito do SUS, em cooperação técnica com os Estados, Municípios e Distrito Federal;

XIX - estabelecer o Sistema Nacional de Auditoria e coordenar a avaliação técnica e financeira do SUS em todo o Território Nacional em cooperação técnica com os Estados, Municípios e Distrito Federal (vide Decreto no 1.651, de 1995);

Parágrafo único: A União poderá executar ações de vigilância epidemiológica e sanitária em circunstâncias especiais, como na ocorrência de agravos inusitados à saúde, que possam escapar do controle da direção estadual do Sistema Único de Saúde (SUS) ou que representem risco de disseminação nacional (grifo nosso).

Art. 17: À direção estadual do Sistema Único de Saúde (SUS) compete: I - promover a descentralização para os Municípios dos serviços e das ações de saúde;

II - acompanhar, controlar e avaliar as redes hierarquizadas do Sistema Único de Saúde (SUS);

III - prestar apoio técnico e financeiro aos Municípios e executar supletivamente ações e serviços de saúde;

IV - coordenar e, em caráter complementar, executar ações e serviços:

a) de vigilância epidemiológica;

b) de vigilância sanitária;

c) de alimentação e nutrição; e

d) de saúde do trabalhador;

$\mathrm{V}$ - participar, junto com os órgãos afins, do controle dos agravos do meio ambiente que tenham repercussão na saúde humana;

VI - participar da formulação da política e da execução de ações de saneamento básico;

VII - participar das ações de controle e avaliação das condições e dos ambientes de trabalho; 
VIII - em caráter suplementar, formular, executar, acompanhar e avaliar a política de insumos e equipamentos para a saúde;

IX - identificar estabelecimentos hospitalares de referência e gerir sistemas públicos de alta complexidade, de referência estadual e regional;

X - coordenar a rede estadual de laboratórios de saúde pública e hemocentros, e gerir as unidades que permaneçam em sua organização administrativa;

XI - estabelecer normas, em caráter suplementar, para o controle e avaliação das ações e serviços de saúde;

XII - formular normas e estabelecer padrões, em caráter suplementar, de procedimentos de controle de qualidade para produtos e substâncias de consumo humano;

XIII - colaborar com a União na execução da vigilância sanitária de portos, aeroportos e fronteiras;

XIV - o acompanhamento, a avaliação e divulgação dos indicadores de morbidade e mortalidade no âmbito da unidade federada (grifo nosso).

\section{Art. 18: À direção municipal do Sistema de Saúde (SUS) compete:}

I - planejar, organizar, controlar e avaliar as ações e os serviços de saúde e gerir e executar os serviços públicos de saúde;

II - participar do planejamento, programação e organização da rede regionalizada e hierarquizada do Sistema Único de Saúde (SUS), em articulação com sua direção estadual;

III - participar da execução, controle e avaliação das ações referentes às condições e aos ambientes de trabalho;

IV - executar serviços:

a) de vigilância epidemiológica;

b) vigilância sanitária;

c) de alimentação e nutrição;

d) de saneamento básico; e

e) de saúde do trabalhador;

V - dar execução, no âmbito municipal, à política de insumos e equipamentos para a saúde;

VI - colaborar na fiscalização das agressões ao meio ambiente que tenham repercussão sobre a saúde humana e atuar, junto aos órgãos municipais, estaduais e federais competentes, para controlá-las;

VII - formar consórcios administrativos intermunicipais;

VIII - gerir laboratórios públicos de saúde e hemocentros;

IX - colaborar com a União e os Estados na execução da vigilância sanitária de portos, aeroportos e fronteiras;

X - observado o disposto no art. 26 desta Lei, celebrar contratos e convênios com entidades prestadoras de serviços privados de saúde, bem como controlar e avaliar sua execução;

$\mathrm{XI}$ - controlar e fiscalizar os procedimentos dos serviços privados de saúde;

XII - normatizar complementarmente as ações e serviços públicos de saúde no seu âmbito de atuação (grifo nosso).

Art. 19: Ao Distrito Federal competem as atribuições reservadas aos Estados e aos Municípios (grifo nosso).

Por sua vez, o Estado de São Paulo, respeitando as normas gerais editadas pela União, promulgou a Lei Complementar n 791/95, denominado Código de Saúde.

A legislação estadual, em seus artigos 15, parágrafo único e 17, estabelece a competência do Estado, nos seguintes termos: 
Art. 15: Compete à direção estadual do SUS, além da observância do disposto nos artigos $2^{\circ}$ e 12 deste Código, fundamentalmente:

[...]

Parágrafo único - O Estado executará, supletivamente, serviços e ações de saúde nos Municípios, no limite das deficiências locais e de comum acordo com a direção local do SUS (grifo nosso).

Art. 17: Compete, ainda, à direção estadual do SUS:

[...]

IX - organizar, fiscalizar, controlar e participar da produção e distribuição de medicamentos, de componentes farmacêuticos básicos, produtos químicos, biotecnológicos, imunobiológicos, hemoderivados e outros de interesse para a saúde, facilitando à população o acesso a eles (grifo nosso).

Muito embora se fale em uma solidariedade constitucional para implementação de políticas públicas, verifica-se, pelo teor dos dispositivos citados, a existência de uma repartição de competências entre os entes federados, razão pela qual incumbe ao Estado, de forma supletiva, suprir qualquer serviço ou ação de saúde nos Municípios.

Não há dúvida de que existe uma maior facilidade no acionamento do Poder Público Municipal diante da proximidade com o requerente. Mas tal situação, em tese, macularia o princípio federativo, colocando o ente municipal em situação ainda mais precária e, principalmente, interferindo no andamento das ações de saúde que competem ao Município, quais sejam, de Atenção Básica e Vigilância em Saúde.

Em que pese toda divisão de competência entre os entes federados no âmbito da saúde, em 23 de maio de 2019, o Plenário do Supremo Tribunal Federal fixou tese de repercussão geral sobre a matéria constitucional contida no Recurso Extraordinário (RE) 855178 - leading case, no sentido de que há responsabilidade solidária de entes federados para o fornecimento de medicamentos e tratamentos de saúde. Com a fixação da tese, a Corte reafirmou sua jurisprudência sobre o tema.

O texto, aprovado por maioria dos votos, versa o seguinte:

Os entes da federação, em decorrência da competência comum, são solidariamente responsáveis nas demandas prestacionais na área da saúde e, diante dos critérios constitucionais de descentralização e hierarquização, compete à autoridade judicial direcionar o cumprimento conforme as regras de repartição de competências e determinar o ressarcimento a quem suportou o ônus financeiro. 
Em suma, União, Estados, Distrito Federal e Municípios podem ser acionados judicialmente, em conjunto ou separadamente, para responder pelas demandas na área da saúde.

\subsection{Dignidade da pessoa humana}

\subsubsection{Considerações preliminares}

Num mundo repleto de desigualdades, onde os mais variados tipos de preconceito afloram no nosso dia a dia, a dignidade da pessoa humana surge como mecanismo chancelador para o resgate de direitos e garantias ainda hoje não perpetrados.

Ao longo dos séculos, a humanidade sentiu e vivenciou a necessidade do reconhecimento da pessoa humana como sujeito de direitos, portadora de vontade própria, passando a proclamar a dignidade como atributo inerente ao ser humano e, a partir daí, prevê-la nos ordenamentos constitucionais.

Especificamente no âmbito da legislação brasileira constitucional, a dignidade assume posição de fundamento da República, prevista expressamente como tal no art. $1^{\circ}$, inc. III, da Constituição Federal.

Somente procedendo-se à análise da evolução histórica por que passou o conceito de dignidade da pessoa humana, através de um processo lento e contínuo de transformação axiológica, é que podemos vislumbrar a posição ocupada pela dignidade hoje, bem como sua imprescindibilidade no reconhecimento pelo Estado dos direitos do homem, como indivíduo e dentro da sociedade, mas de forma separada e independente da vida social e política.

É inegável que toda evolução nos traz a oportunidade de efetuarmos uma comparação entre o passado e o presente, ensejando a possibilidade de verificação das contradições existentes, permitindo, assim, a superação das falhas, visando à formação de um mundo melhor e mais justo para as gerações vindouras.

Seja como for, o que realmente importa é refletir sobre alguns momentos de afirmação e reconhecimento da dignidade da pessoa humana no seu percurso histórico. 


\subsubsection{Evolução histórica do conceito de dignidade}

Antes mesmo de ser disciplinada pelo direito positivo, a dignidade da pessoa humana, embora com conotação diversa da atribuída nos dias de hoje, já era reconhecida na antiguidade clássica e, posteriormente, no ideário cristão.

O pensamento filosófico predominante na antiguidade clássica tratava a dignidade como atributo conferido ao homem conforme a classe social por ele ocupada. Nesse sentido, além de refletir o status social conquistado pelo indivíduo, a dignidade era mensurável e variava de pessoa para pessoa. Sob este prisma, Ingo Sarlet (2001) nos traz importante contribuição ao salientar que:

No pensamento filosófico e político da antiguidade clássica, verifica-se que a dignidade (dignitas) da pessoa humana dizia, em regra, com a posição social ocupada pelo indivíduo e o seu grau de reconhecimento pelos demais membros da comunidade, daí poder falar-se em uma qualificação e modulação da dignidade, no sentido de se admitir a existência de pessoas mais dignas ou menos dignas.

Para a filosofia grega, o homem era um animal político ou social, conforme preceituava Aristóteles. Havia uma interdependência do homem em relação ao Estado, razão pela qual a existência do indivíduo não era reconhecida por si só, mas sempre dentro do âmbito político e social, confundindo-se muitas vezes a vida do homem com a vida do Estado. Nesse aspecto, cumpre mencionar os ensinamentos do ilustre jurista Miguel Reale (1997), in verbis:

Aos olhos dos gregos e dos romanos a comunidade política representava a
máxima expressão da realidade ética alcançada pelo homem. Só se
compreendia a plenitude da personalidade dentro do Estado e pelo Estado,
e era tão-somente como membro efetivo de uma comunidade política,
participante de seus órgãos diretores em maior ou menor escala, que o
homem se revestia da qualidade de cidadão, com a qual se confundia a
qualidade de ser livre.

Assim, conforme salientado acima, o indivíduo era totalmente subordinado ao Estado greco-romano e dependente da ordem política constituída, ficando à mercê das garantias e dos direitos conferidos pelo Estado, sem o reconhecimento e 0 respeito do homem enquanto ser humano livre e portador de dignidade.

Entretanto, já no pensamento estóico, a dignidade era considerada uma qualidade inerente a todo ser humano e, justamente por isso o homem se distinguia 
das demais criaturas existentes na face da Terra. Aqui, a dignidade deixa de ser mensurada, passando a ser atribuída de forma igualitária a todo e qualquer indivíduo. O homem, considerado filho de Zeus, era detentor de direitos inatos e iguais para todos, não obstante as diferenças e qualidades individuais.

Aos poucos, gradativamente, os povos da antiguidade foram descobrindo que o ser humano era livre, possuía vontade própria para agir e decidir conforme os seus interesses, ou seja, possuía autodeterminação e, portanto, era dotado de dignidade. Nesse período, a escravidão, embora ainda fosse admitida, passa a ser condenada como instituto contrário aos preceitos da razão natural e, dessa forma, começa a perder a legitimidade em que se baseia até ser expurgada definitivamente da sociedade.

A doutrina de Cristo, dentre outras coisas, pregava a igualdade dos semelhantes, razão pela qual aconselhava os senhores de escravos a não abusar da condição que ostentavam em relação aos seus servos, sob pena de caírem em desgraça aos olhos de Deus. Foi assim que, ao longo do tempo, de forma gradativa e contínua, o ideário cristão conseguiu enfraquecer o instituto da escravidão, conferindo também aos escravos, enquanto seres humanos, o atributo da dignidade.

Ao verificar que a dignidade era única, ou seja, igual para todos e que o respeito ao semelhante era imprescindível para uma convivência pacífica dentro do Estado, começa a ser adotada a famosa regra que determina: "[...] não faças a outro o que não queres que façam a ti" (ALVES, 2001). Neste período, para que a dignidade fosse reconhecida, deixa de ter relevância os atributos materiais do homem, bastando simplesmente estar vivo e ser pessoa humana.

Ainda na antiguidade clássica, a preocupação com a dignidade e os direitos do homem levaram à positivação, razão pela qual tiveram origem as primeiras legislações garantidoras de direitos e tendentes a proteger o indivíduo. São elas: o Código de Hamurabi, da Babilônia e da Assíria e o Código de Manu, na Índia (ALVES, 2001).

Cumpre mencionar que, tanto no Antigo quanto no Novo Testamento, embora a dignidade não seja citada de forma expressa, podemos encontrar diversas 
referências a ela, principalmente no sentido de que o ser humano foi criado à imagem e semelhança de Deus, razão pela qual é portador de um valor próprio, intrínseco, o que the impede de ser transformado em simples objeto ou coisa desprovida de vontade. Dessa forma, sendo imagem e semelhança de Deus, o homem deve ser respeitado nessa condição que ostenta.

A partir daí, o conceito de dignidade, mesmo não sendo totalmente desconhecido ao pensamento antigo ocidental, adquire a devida importância com o Cristianismo, mais especificamente com a filosofia patrística, sendo depois desenvolvida pelos escolásticos, oportunidade em que o indivíduo começa a ser reconhecido como pessoa possuidora de direitos subjetivos e portadora de vontade própria, independente do ente político, sendo capaz de escolher seu destino e autodeterminar-se de acordo com seus objetivos. Aos poucos, o homem deixa de ser visto como cidadão, passando a ser visto como ser humano, dotado de dignidade, que deve ser respeitado, livre de qualquer ligação de ordem política e social com o Estado.

A liberdade trazida pelo Cristianismo serve também para explicar o pecado, uma vez que confere ao homem - na qualidade de ser livre - a possibilidade e escolher e decidir sobre sua salvação ou sobre sua perdição. Sendo imagem e semelhança de Deus, a fonte dessa liberdade deriva exclusivamente desse Ser Superior. Assim, ao Cristianismo se deve também a formação do caminho para o reconhecimento do ser humano como pessoa e, a partir daí, como sujeito detentor de dignidade (SESSAREGO, 2001).

Segundo observa a doutrina de Jorge Miranda (1998: "A dignidade da pessoa pressupõe a autonomia vital da pessoa, a sua autodeterminação relativamente ao Estado, às demais entidades públicas e às outras pessoas".

Ao adquirir essa condição de liberdade $^{8}$, de autonomia e de autodeterminação, a dignidade traz o reconhecimento dos direitos fundamentais,

8 Sobre o atributo da liberdade, Carlos Fernández Sessarego (2001) salienta que: "La conceptión exclusiva o eminentemente racional del ser humano fue vigorosamente cuestionada em la primera itad del siglo XX. Los filósofos, em lo essencial, rescatan y desarrollan los postulados cardinales del Cristianismo em torno a la liberdade del ser humano. Como resultado de sus indagaciones no es más la rázon sino la liberdade el centro, el núcleo, de la existência". 
passando a colocar o Direito e o Estado em planos distintos. Nesse sentido, Fernando Ferreira dos Santos (1999) assevera que:

A proclamação do valor distinto da pessoa humana terá como conseqüência lógica a afirmação de direitos específicos de cada homem, 0 reconhecimento de que, na vida social, ele, homem, não se confunde com a vida do Estado [...].

A contribuição maior do cristianismo, através de uma ideologia eminentemente apolítica, consiste, em síntese, numa transferência do Direito, que passa do Estado para o indivíduo. Daí dizer-se que a vida social não se mistura, não se confunde com a vida do Estado, razão pela qual a dignidade é proveniente do próprio homem e não do Estado aristocrático que imperava na época.

Sendo apolítico, o cristianismo também deu ensejo a uma grande revolução, proporcionando a separação do caráter religioso do Estado antigo, passando a distinguir o âmbito religioso e o político. Nesse sentido, outra ruptura importante decorrente do cristianismo verificou-se entre o Estado e a Igreja, distinguindo os direitos de César e os de Deus, contrariando a crença local nos deuses pagãos e nas figuras mitológicas, que, de certa forma, integravam a administração pública na medida em que os ministros religiosos eram ministros do Estado. Assim, começa a ser propagada a existência de um só Deus, justo, universal, imparcial e que era comum a todos os homens, não fazendo distinção de qualquer espécie. Conforme preceitua Luis Maria Desimoni (1999):

[...] la religión se desvinculava de la política em razón de que, según expresiones del próprio Jesús, su reino no era de este mundo, y se debía dar a Dios lo que era de Dios y al César lo que era del César. De tal modo quedaba delimitado el poder temporal del espiritual, lo cual no evito luchas de poderes a lo largo de la historia.

A mensagem trazida pelo cristianismo ressalta, dentre outras coisas, não apenas o respeito ao homem em si, mas também, ao seu semelhante, segundo podemos constatar em inúmeras passagens transcritas na Bíblia Sagrada:

Amarás o Senhor teu Deus de todo o teu coração, e de toda a tua alma, e de todo o teu pensamento. Esse é o primeiro mandamento. O segundo é semelhante a esse: Amarás o teu próximo como a ti mesmo. Deste dois mandamentos depende toda a lei e os profetas. ${ }^{9}$

9 Cf. Evangelho segundo São Matheus, capítulo 22, versículos 37 a 40. 
Sob o ponto de vista cristão, o fundamento da dignidade da pessoa humana encontra-se em Deus. Nesse sentido, na expressão de Cleber Francisco Alves (2001), in verbis:

E o homem estará seguro quando tiver consciência de que sua dignidade é intangível não porque assim o decidiu uma assembléia internacional ou uma assembléia nacional constituinte, mas porque assim o prescreve a Lei Eterna.

Todavia, essa dignidade não deriva propriamente do homem ou de sua posição social, mas de sua condição de imagem e semelhança de Deus. Conforme preceitua Gregório Peces-Barba Martínez (2002), a seguir:

[...] el cristianismo otorgará al hombre una singularidad primordial, derivada de su condición infinita e inabarcable a la imagen y semejanza de Dios. Pero esa dignidad no derivará de un mérito propio, ni de su posición social, ni se empaña por su estatuto de pecador, no será una dignidad propia, sino derivada de la imagen de Dios, proyectada sobre las criaturas. No se contempla la dignidad desde el hombre, sino desde Dios.

Ao considerar o homem imagem e semelhança de Deus, o cristianismo traz a ideia de igualdade, uma vez que, sendo o Deus único, justo e imparcial, estes homens não podem ser diferenciados entre si, merecendo todos o mesmo respeito $\mathrm{e}$ o mesmo tratamento por parte do Estado e dos demais seres humanos.

Contudo, a fim de evitarmos uma abordagem utópica do assunto, necessário se faz o esclarecimento no sentido de que a igualdade proferida pelo cristianismo era uma igualdade meramente formal, aparente, uma vez que as maiores desigualdades e discriminações eram permitidas e encobertas pelo manto da legalidade e da hipocrisia vigentes na época. Aqui, cumpre transcrever os ensinamentos de Fábio Konder Comparato (2003), in verbis:

Mas essa igualdade universal dos filhos de Deus só valia, efetivamente, no plano do sobrenatural, pois o cristianismo continuou admitindo, durante muitos séculos, a legitimidade da escravidão, a inferioridade natural da mulher em relação ao homem, bem como a dos povos americanos, africanos e asiáticos colonizados, em relação aos colonizadores europeus.

Merece destaque também a contribuição de São Tomás de Aquino, que sustentou a concepção de inspiração baseada no cristianismo e no estoicismo, referindo-se expressamente ao termo "dignitas humana" como qualidade que possibilita ao ser humano agir de forma livre e racional, determinando seu destino, 
sua própria existência. Por meio da racionalidade o homem se torna responsável por seu próprio destino, constituindo um valor absoluto, um fim em si mesmo, momento em que passa a ser livre para agir e escolher seus caminhos.

Posteriormente, alguns séculos depois, o movimento iluminista, também denominado humanista, surge dando ensejo à crença veemente na razão humana, sendo responsável pela mudança do enfoque da religiosidade como fundamento da dignidade, substituindo-a pelo próprio homem. A partir daí, tem início a preocupação com os direitos individuais e o exercício de um poder menos arbitrário e mais democrático, com raízes em valores diversos, tais como, a igualdade e a fraternidade. O indivíduo passa a ser reconhecido com dignidade própria e autônoma, que não é mais oriunda de Deus ou do Estado. O século XVIII passa a ser o denominado "século das luzes", dando origem à afirmação de que o ser humano começa a brilhar com luz própria.

Assim, percorrendo o caminho histórico através dos séculos passados, é possível evidenciar a evolução sofrida pelo conceito de dignidade e a mudança no tratamento conferido ao ser humano pelo Estado, pela Igreja e pelos seus semelhantes.

O fato é que, nos dias de hoje, a dignidade ocupa posição de destaque nos diversos ordenamentos jurídicos do ocidente e em grande parte do mundo. Neste sentido, segundo comenta Ana Paula de Barcelos (2002):

Um dos poucos consensos teóricos do mundo contemporâneo diz respeito ao valor essencial do ser humano. [...] a dignidade da pessoa humana é hoje considerada, sob vários pontos de vista, o pressuposto filosófico de qualquer regime jurídico civilizado e das sociedades democráticas em geral.

No Brasil, a dignidade é colocada com status de fundamento da República Federativa, conforme se depreende da leitura do art. 1ํㅜㄹ. inc. III, da Constituição Federal, consistindo em valor essencial para a ordem jurídica constitucional brasileira.

Na seara internacional, a dignidade foi amplamente consagrada no pósguerra, mais precisamente após as barbáries decorrentes do período nazista e 
fascista. Em diversos países como Alemanha, Portugal e Espanha, a dignidade passou a ser juridicizada, alcançando também estatura constitucional.

\subsubsection{O conceito de dignidade em Kant}

Seguindo o curso histórico, Kant nos traz uma formulação mais consistente acerca da natureza do homem e suas relações com tudo que o cerca. Sua concepção sobre a dignidade da pessoa humana teve grande importância na mudança do enfoque que era dado ao conceito e, por isso mesmo, pode ser constatada até os dias de hoje no pensamento filosófico atual.

Preliminarmente, a teoria kantiana coloca o sujeito como centro da teoria do conhecimento, distinguindo as formas do conhecimento em a priori ou puro e a posteriori ou empírico. A primeira forma sustenta que o conhecimento independe da experiência, ocasião em que é considerado universal. A segunda forma limita o conhecimento aos dados da experiência, que são colocados à disposição para o sujeito. Após essa observação, Kant propõe uma mudança no sentido de que os objetos passem a se amoldar ao nosso conhecimento, tornando o sujeito peça fundamental na operação do conhecimento e imprescindível ao ato de conhecer. A partir daí, inicia-se a reflexão filosófica sobre o homem e sua importância no mundo em que habita. (Kant, 1960)

Em momento posterior, Kant volta seu interesse ao estudo da moralidade em face do agir do ser humano. Sob este aspecto, a moralidade não deve ser buscada na natureza do homem ou nas circunstâncias do mundo, uma vez que ela deve guardar relação com todos os seres racionais. Dessa forma, o fundamento da moralidade consiste no respeito à lei, que deve ser universal e válida para todos, cuja atribuição se configura no poder de determinar toda e qualquer vontade.

Entretanto, esta lei que submete o homem tem como autor o próprio homem e, portanto, guarda nele o seu fim, a sua vontade legisladora universal. Temse aí, então, a autonomia da vontade, ligando todos os seres racionais através de leis comuns que obrigam a todos e os tornam portadores de dignidade. 
Trilhando este caminho, segundo Immanuel Kant, o homem é visto como um fim em si mesmo, uma vez que somente ele é dotado de vontade própria, fato esse que o caracteriza como ser racional, consistindo em fundamento da dignidade humana. Daí a impossibilidade do homem ser tratado como simples objeto desprovido de vontade.

Todas as coisas estão a serviço do homem, constituindo um meio para atingir um fim. Dessa forma, o homem deve ser considerado como valor absoluto, não podendo ser usado como instrumento e, exatamente por isto, é possuidor de dignidade.

Partindo da natureza racional do ser humano, Kant afirma que a autonomia da vontade, ou seja, a capacidade de determinar-se e de agir de acordo com certas leis, é um atributo exclusivo dos seres racionais e fundamento da dignidade da pessoa humana, razão pela qual só os seres racionais possuem a faculdade de agir de acordo com leis e princípios. Neste sentido, o filósofo de Crítica da Razão Pura preceitua que:

[...] o Homem, e, duma maneira geral, todo ser racional, existe como um fim em si mesmo, não simplesmente como meio para uso arbitrário desta ou daquela vontade. Pelo contrário, em todas as suas acções, tanto nas que se dirigem a outros seres racionais, ele tem sempre de ser considerado como um fim. [...] os seres cuja existência depende, não em verdade da nossa vontade, mas da natureza, têm, contudo, se são seres irracionais, apenas um valor relativo como meios e por isso se chamam coisas, ao passo que os seres racionais se chamam pessoas, porque a sua natureza os distingue como fins em si mesmos, quer dizer, como algo que não pode ser empregado como simples meio e que, por conseguinte, limita nessa medida todo o arbítrio (e é um objeto de respeito) (KANT, 1960).

Nesse diapasão, Kant nos traz o conceito de que a liberdade e a autonomia também devem ser vistas como fundamento da dignidade. $O$ homem como fim em si mesmo deve ser um homem livre, independente para agir e alcançar seus objetivos, pautando-se por sua vontade própria, sem interferências externas, principalmente do Estado e da Igreja. Nesse sentido, o Direito e o Estado é que devem atuar em função do homem e não o contrário. É justamente nessa capacidade de decidir, através de um comportamento racional e inteligente, de escolher seus próprios caminhos, que consiste a autonomia.

Sob este prisma, Gregorio Peces-Barba Martínez (2002) salienta, in verbis: 
$Y$ ese hombre que es el centro del mundo aparece también centrado en el mundo, es decir, es un hombre secularizado, independiente, que decide por sí mismo, que piensa y crea por sí mismo, que se comunica y dialoga con los demás hombres y que decide libremente sobre su moralidad privada.

No mesmo sentido, Fábio Comparato (2003) ressalta:

Ora, a dignidade da pessoa não consiste apenas no fato de ser ela, diferentemente das coisas, um ser considerado e tratado, em si mesmo, como um fim em si e nunca como um meio para a consecução de determinado resultado. Ela resulta também do fato de que, pela sua vontade racional, só a pessoa vive em condições de autonomia, isto é, como ser capaz de guiar-se pelas leis que ele próprio edita.

Adotando-se a concepção kantiana para a dignidade da pessoa humana, toda e qualquer tentativa de instrumentalização do homem deve ser imediatamente, de plano, rejeitada, sob pena de afronta a esse atributo inato e exclusivo dos seres racionais, que são em última análise livres para agir e escolher seu próprio destino. Isso porque a dignidade constitui valor incondicional, que não se submete à transação ou abdicação, nem tampouco pode ser utilizada como meio para atingir determinado objetivo.

\subsubsection{Algumas acepções conferidas ao conceito de dignidade}

Historicamente, do ponto de vista conceitual, a dignidade foi tratada de diversas formas. Seguindo a classificação conferida por Miguel Reale, também adotada por Fernando Ferreira dos Santos, podemos elencar três concepções: individualismo, transpersonalismo e personalismo (REALE, 1998).

Seguindo a ordem mencionada acima, o individualismo apresenta como característica a afirmação de que cada ser humano deve cuidar de si mesmo, dos seus próprios interesses, pois, só assim, estar-se-ia alcançando os interesses coletivos, bem como a tão almejada realização do bem comum. Sob este prisma, "[...] a ordem social justa não é outra coisa senão o resultado da satisfação do bem do indivíduo como indivíduo" (REALE, 1998).

Para o individualismo, o Estado deve ter uma função extremamente limitada, consistente em tutelar e proteger as liberdades individuais, oportunidade em que cada homem pode realizar os seus objetivos, proporcionando, via de 
consequência, a verificação do bem comum. Dessa forma, a lei deve ser sempre interpretada de forma a garantir os direitos individuais, protegendo-os do poder estatal.

Posição contrária é a sustentada pelo transpersonalismo, salientando que o bem de todos leva ao alcance do bem individual. Nesse sentido, o Estado deve pautar sua conduta visando aos interesses coletivos, que apresentam preponderância sobre os interesses individuais. Aqui, o homem deixa de ser visto como valor supremo, que está acima de todas as coisas, passando a ser considerado dentro do contexto social em que está inserido. Os adeptos dessa corrente são os socialistas, cujo maior representante é Marx.

Segundo Márcio Sotelo Felippe (1996), o bem comum deve se referir de forma concreta e efetiva em relação a cada indivíduo, caso contrário não pode ser considerado bem e, muito menos, comum. Neste contexto, o bem comum não pode colocar-se em oposição aos direitos inalienáveis do homem, uma vez que este, considerado em si mesmo, trata-se de verdadeiro fim, o que leva à constatação de que não há conceito de bem comum que não seja o conceito relativo a direitos humanos. Daí porque o Estado deve ser visto como verdadeira ordem normativa garantidora dos direitos humanos, o que, uma vez estendido sob a ótica da dignidade da pessoa humana, consolida-se como expressão da racionalidade.

Por fim, a terceira corrente denominada personalismo rejeita as duas concepções anteriores, pautando seu posicionamento pela necessidade de análise de cada caso, mediante as circunstâncias que se apresentem, objetivando uma compatibilização dos interesses individuais com os interesses coletivos, buscando sempre alcançar o valor justo que melhor se refira ao valor da pessoa humana.

O indivíduo deve ceder ao todo, até e enquanto não seja ferido o valor da pessoa, ou seja, a plenitude do homem enquanto homem. Toda vez que se quiser ultrapassar a esfera da 'personalidade' haverá arbítrio (REALE, 1998).

Ao buscar o valor da pessoa humana, o personalismo acaba por consagrar o indivíduo como valor supremo. Entretanto, esse mesmo indivíduo deve reconhecer os interesses dos demais indivíduos. Daí a necessidade da compatibilização analisada caso a caso proposta pelo personalismo. 


\subsection{0 custo da judicialização da saúde: entre o princípio da reserva do possível e a teoria do mínimo existencial}

A partir da fase inaugural do constitucionalismo moderno, surge a ideia de um direito fundamental ao mínimo existencial, no sentido de que cada cidadão tenha direito a um conjunto de prestações estatais aptas a garantir uma vida digna, uma subsistência abarcada por condições satisfatórias de trabalho, moradia, saúde, integridade física e psíquica etc. (CORVINO, 2017). Trata-se de verdadeiro corolário do Princípio da Dignidade da Pessoa Humana.

[...] o mínimo existencial corresponde ao conjunto de situações
materiais indispensáveis à existência humana digna; existência aí
considerada não apenas como experiência física - a sobrevivência e a
manutenção do corpo - mas também espiritual e intelectual. [...] a não
garantia de tais condições elementares importa o desrespeito do
princípio jurídico da dignidade da pessoa humana sob o aspecto
material [...]. Em suma, mínimo existencial e núcleo material do princípio
da dignidade da pessoa humana descrevem o mesmo fenômeno
(BARCELOS, 2011).

O mínimo existencial deve coexistir com a reserva do possível e, ambos, formam um verdadeiro arcabouço para a judicialização da saúde. De um lado, o direito do cidadão a condições mínimas de vida aptas a garantir sua sobrevivência. De outro lado, a necessidade de recursos frente ao tão combalido orçamento público.

Em princípio, não cabe ao Poder Judiciário avaliar as escolhas de políticas públicas adotadas pelo Executivo. Isso porque há certa margem de discricionariedade dos agentes políticos para efetivação dos direitos sociais, dentre eles, o direito à saúde, até por conta da legitimidade democrática (eleição) (ADAES, 2016).

O fato é que, embora a judicialização tenha tido início na década de 1990, até hoje falta um movimento efetivo do Poder Executivo no sentido da implantação de políticas públicas de saúde, tergiversando sobre a questão e lançando o cidadão nos braços do Poder Judiciário que se vê obrigado a implementar tais políticas, fugindo do seu papel original (MENDES, 2013).

Todavia, tratando-se de direitos sociais a prestações estatais necessárias para compor o mínimo existencial, perfeitamente admitida a 
exigibilidade judicial por se entender que tais direitos compõem o núcleo essencial da dignidade da pessoa humana e do direito à vida e à integridade física (HUTZLER, 2018).

Os gastos públicos devem ser otimizados para uma aplicação prioritária na efetivação dos direitos sociais, sem os quais as pessoas não teriam as condições mínimas de sobrevivência com dignidade (maximização do mínimo existencial) (CAMBI, 2009)

Para tanto, há que se buscar o mínimo existencial no núcleo dos valores constitucionais da dignidade da pessoa humana, na solidariedade, na cláusula do Estado Social e no princípio da igualdade (CAMBI, 2009).

O mínimo existencial é garantido por meio de condições materiais de existência, baseado no conceito de dignidade, o que não deprecia os direitos sociais, ao contrário, os fortalece como dimensão essencial na expressão de uma cidadania reivindicatória (CARLOS NETO, 2018).

Ao invés do Direito Estatal, deve-se perquirir o Direito justo, ou seja, aquilo que corresponde às necessidades legítimas da sociedade, no sentido de que os interesses do todo sempre deverão prevalecer sobre os intentos de grupos privilegiados e minorias elitistas (WOLKMER, 2001).

Trilhando esse caminho, um dos principais argumentos utilizados nas teses de defesa da Fazenda Pública nas ações para obtenção de prestações positivas do Estado é a "reserva do possível".

Trata-se de instituto baseado na alegação de que deve haver recursos públicos disponíveis, com previsão orçamentária específica, aptos a atender aquilo que se demanda. Dessa forma, o cidadão poderia exigir do Poder Público a prestação daquilo que necessita nos limites da razoabilidade financeira estatal (CORVINO, 2017).

Deve-se reconhecer, portanto, que a efetivação dos direitos sociais passa pela existência da disponibilidade econômica, exigindo adequada aplicação e controle dos recursos públicos. 
Nesse sentido é o voto do Ministro Celso de Mello, do Supremo Tribunal Federal, na ADPF no 45-9:

\begin{abstract}
Não deixo de conferir, no entanto, assentadas tais premissas, significativo relevo ao tema pertinente à 'reserva do possível' (STEPHEN HOLMES/CASS R. SUNSTEIN, The Cost of Rights, 1999, Norton, New York), notadamente em sede de efetivação e implementação (sempre onerosas) dos direitos de segunda geração (direitos econômicos, sociais e culturais), cujo adimplemento, pelo Poder Público, impõe e exige, deste, prestações estatais positivas concretizadoras de tais prerrogativas individuais e/ou coletivas. É que a realização dos direitos econômicos, sociais e culturais - além de caracterizar-se pela gradualidade de seu processo de concretização - depende, em grande medida, de um inescapável vínculo financeiro subordinado às possibilidades orçamentárias do Estado, de tal modo que, comprovada, objetivamente, a incapacidade econômico-financeira da pessoa estatal, desta não se poderá razoavelmente exigir, considerada a limitação material referida, a imediata efetivação do comando fundado no texto da Carta Política. Não se mostrará lícito, no entanto, ao Poder Público, em tal hipótese - mediante indevida manipulação de sua atividade financeira e/ou político-administrativa - criar obstáculo artificial que revele o ilegítimo, arbitrário e censurável propósito de fraudar, de frustrar e de inviabilizar o estabelecimento e a ação, em favor da pessoa e dos cidadãos, de condições materiais mínimas de existência (RTJ no 175/1212-1213, Rel. Min. Celso de Mello).
\end{abstract}

Em que pese o voto do ministro Celso de Mello supra citado, na prática, a reserva do possível vem sendo rechaçada pela jurisprudência majoritária, seja por submeter a efetividade dos direitos fundamentais à discricionariedade do administrador, seja por condicionar o mínimo existencial a questões orçamentárias (MAPELLI JÚNIOR, 2017).

A título exemplificativo, podemos citar a decisão do Superior Tribunal de Justiça, em recurso repetitivo, na qual se delimitou que o direito fundamental à saúde deve prevalecer sobre os interesses financeiros da Fazenda Nacional. $\mathrm{Na}$ visão dos ministros:

[...] é possível ao magistrado determinar, de ofício ou a requerimento das partes, o bloqueio ou sequestro de verbas públicas como medida coercitiva para o fornecimento de medicamentos pelo Estado na hipótese em que a demora no cumprimento da obrigação acarrete risco à saúde e à vida do demandante (STJ, REsp. no 1.069.810/RS).

Dessa interpretação decorrem inúmeras condenações do Estado a práticas terapêuticas caríssimas e, muitas vezes, sem eficácia comprovada, independentemente de argumentos sobre a existência ou não de recursos públicos disponíveis. 
Se por um lado o orçamento público deve priorizar programas sociais de governo e políticas públicas de saúde, é bem verdade que o orçamento estatal é finito, sendo praticamente impossível o atendimento ilimitado das demandas da população.

Do ponto de vista teórico, a questão pode ser enfrentada e resolvida facilmente, mas a realidade nos mostra outra vertente, sobretudo diante daqueles que interpretam a Constituição Federal sob o prisma da concretização imediata dos direitos. Isso porque se todos os recursos públicos forem destinados à saúde, certamente outros programas de governo carecerão de atendimento, com consequências igualmente danosas.

Argumenta-se que o Poder Judiciário, competente para concretizar a justiça em cada caso concreto (microjustiça), na maioria das vezes não teria condições de analisar as consequências globais da destinação de recursos públicos em benefício de uma determinada pessoa, em detrimento do todo (AMARAL, 2001).

Por outro lado, os defensores da judicialização da saúde sustentam que a concretização pelo Judiciário do direito à saúde é indispensável para a realização da dignidade da pessoa humana. Assim, pelo menos o mínimo existencial de cada um dos direitos sociais deve ser objeto de apreciação judicial (MENDES; BRANCO, 2012).

Inexistindo recursos suficientes, não pode o Estado ficar inerte. Nesse sentido:

AGRAVO REGIMENTAL NO AGRAVO DE INSTRUMENTO. FORNECIMENTO DE MEDICAMENTO S/A PACIENTE HIPOSSUFICIENTE. OBRIGAÇÃO DO ESTADO.

Paciente carente de recursos indispensáveis à aquisição dos medicamentos de que necessita. Obrigação do Estado em fornecê-los. Precedentes. Agravo regimental a que se nega provimento (STF, AlAgR. no 604949, Rel. Min. Eros Grau, DJU 24/11/2006).

ADMINISTRATIVO. CONTROLE JUDICIAL DE POLÍTICAS PÚBLICAS. POSSIBILIDADE EM CASOS EXCEPCIONAIS - DIREITO À SAÚDE. FORNECIMENTO DE MEDICAMENTOS. MANIFESTA NECESSIDADE. OBRIGAÇÃO SOLIDÁRIA DE TODOS OS ENTES DO PODER PÚBLICO. NÃO OPONIBILIDADE DA RESERVA DO POSSÍVEL AO MÍNIMO EXISTENCIAL. NÃO HÁ OFENSA À SÚMULA 126/STJ. 
1. Não podem os direitos sociais ficar condicionados à boa vontade do Administrador, sendo de suma importância que o Judiciário atue como órgão controlador da atividade administrativa. Seria uma distorção pensar que o princípio da separação dos poderes, originalmente concebido com o escopo de garantia dos direitos fundamentais, pudesse ser utilizado justamente como óbice à realização dos direitos sociais, igualmente importantes.

2. Tratando-se de direito essencial, incluso no conceito de mínimo existencial, inexistirá empecilho jurídico para que o Judiciário estabeleça a inclusão de determinada política pública nos planos orçamentários do ente político, mormente quando não houver comprovação objetiva da incapacidade econômico-financeira da pessoa estatal.

3. In casu, não há impedimento jurídico para que a ação, que visa a assegurar $o$ fornecimento de medicamento $s$, seja dirigida contra 0 Município, tendo em vista a consolidada jurisprudência do STJ: 'o funcionamento do Sistema Único de Saúde (SUS) é de responsabilidade solidária da União, Estados-membros e Municípios, de modo que qualquer dessas entidades têm legitimidade ad causam para figurar no polo passivo de demanda que objetiva a garantia do acesso à medicação para pessoas desprovidas de recursos financeiros' (REsp. 771.537/RJ, Rel. Min. Eliana Calmon, Segunda Turma, DJ 03/10/2005).

4. Apesar de o acórdão ter fundamento constitucional, o recorrido interpôs corretamente o Recurso Extraordinário para impugnar tal matéria. Portanto, não há falar em incidência da Súmula 126/STF.

5. Agravo Regimental não provido (STJ, $2^{\underline{a}}$ Turma, AgRg. no REsp. oㅜ 1107511/RS, Rel. Ministro Herman Benjamin, julgado em 21/11/2013, DJe 06/12/2013).

PROCESSUAL CIVIL. ADMINISTRATIVO. RECURSO ORDINÁRIO EM MANDADO DE SEGURANÇA. DIREITO LÍQUIDO E CERTO. FORNECIMENTO DE MEDICAMENTO S. HEPATITE C. PROTEÇÃO CONSTITUCIONAL À SAÚDE, À VIDA E À DIGNIDADE DA PESSOA HUMANA. LAUDO EMITIDO POR MÉDICO NÃO CREDENCIADO PELO SISTEMA ÚNICO DE SAÚDE (SUS). EXAMES REALIZADOS EM HOSPITAL ESTADUAL. PROTOCOLO CLÍNICO E DIRETRIZES TERAPÊUTICAS DO MINISTÉRIO DA SAÚDE.

1. A ordem constitucional vigente, em seu art. 196, consagra o direito à saúde como dever do Estado, que deverá, por meio de políticas sociais e econômicas, propiciar aos necessitados não 'qualquer tratamento', mas o tratamento mais adequado e eficaz, capaz de ofertar ao enfermo maior dignidade e menor sofrimento.

2. Sobreleva notar, ainda, que hoje é patente a ideia de que a Constituição não é ornamental, não se resume a um museu de princípios, não é meramente um ideário; reclama efetividade real de suas normas. Destarte, na aplicação das normas constitucionais, a exegese deve partir dos princípios fundamentais, para os princípios setoriais. E, sob esse ângulo, merece destaque o princípio fundante da República que destina especial proteção a dignidade da pessoa humana. 3. Sobre o tema não dissente o Egrégio Supremo Tribunal Federal, consoante se colhe da recente decisão, proferida em sede de Agravo Regimental na Suspensão de Segurança 175/CE, Relator Ministro Gilmar Mendes, julgado em 17/03/2010, cujos fundamentos se revelam perfeitamente aplicáveis ao caso sub examine, conforme noticiado no Informativo no 579 do STF, 15 a 19 de março de 2010, in verbis: [...].

4. Last but not least, a alegação de que o impetrante não demonstrou a negativa de fornecimento do medicamento por parte da autoridade, reputada coatora, bem como o desrespeito ao prévio procedimento administrativo, de observância geral, não obsta o deferimento do pedido 
de fornecimento dos medicamento $s$ pretendidos, por isso que o sopesamento dos valores em jogo impede que normas burocráticas sejam erigidas como óbice à obtenção de tratamento adequado e digno por parte de cidadão hipossuficiente.

5. Sob esse enfoque manifestou-se o Ministério Público Federal: ‘[...] não se mostra razoável que a ausência de pedido administrativo, supostamente necessário à dispensação do medicamento em tela, impeça o fornecimento da droga prescrita. A morosidade do trâmite burocrático não pode sobrepor-se ao direito à vida do impetrante, cujo risco de perecimento levou à concessão da medida liminar às fls.79 [...]' (fl. 312).

6. In casu, a recusa de fornecimento do medicamento pleiteado pelo impetrante, ora Recorrente, em razão de o mesmo ser portador de vírus com genótipo 3a, quando a Portaria no 863/2002 do Ministério da Saúde, a qual institui Protocolo Clínico e Diretrizes Terapêuticas, exigir que o medicamento seja fornecido apenas para portadores de vírus hepatite $\mathrm{C}$ do genótipo 1 , revela-se desarrazoada, mercê de contrariar relatório médico acostado às fl. 27.

7. Ademais, o fato de o relatório e a receita médica terem emanado de médico não credenciado pelo SUS não os invalida para fins de obtenção do medicamento prescrito na rede pública, máxime porque a enfermidade do impetrante foi identificada em outros laudos e exames médicos acostados aos autos (fls. 26/33), dentre eles, o exame 'pesquisa qualitativa para vírus da Hepatite $\mathrm{C}(\mathrm{HCV})$ ' realizado pelo Laboratório Central do Estado, vinculado à Secretaria Estadual de Saúde do Estado do Paraná, o qual obteve o resultado 'positivo para detecção do RNA do Vírus do HCV' (fl. 26).

8. Recurso Ordinário provido, para conceder a segurança pleiteada na inicial, prejudicado o pedido de efeito suspensivo ao presente recurso (fls. 261/262), em razão do julgamento do mérito recursal e respectivo provimento (STF, 1ํㅡ Turma, RMS no 24.197/PR, Rel. Ministro Luiz Fux, julgado em 04/05/2010, DJe 24/08/2010).

DIREITOS CONSTITUCIONAL, ADMINISTRATIVO E PROCESSUAL CIVIL - AÇÃO ORDINÁRIA ONDE CIDADÃ BUSCA A CONDENAÇÃO DOS ENTES FEDERATIVOS A FORNECER-LHE MEDICAMENTO DE ALTO CUSTO ( SOLIRIS ), NÃO INCLUÍDO NA RELAÇÃO NACIONAL DE MEDICAMENTO S ESSENCIAIS/RENAME E NÃ̃O APROVADO PELA ANVISA, DESTINADO AO TRATAMENTO DE MOLÉSTIA GRAVE (HEMOGLOBINÚRIA PAROXÍSTICA NOTURNA - HPN) - SENTENÇA DE PROCEDÊNCIA (COM ANTECIPAÇÃO DE TUTELA E FIXAÇÃO DE ASTREINTES) MANTIDA - SUPREMACIA DO DIREITO CONSTITUCIONAL À SAÚDE (APANÁGIO DA DIGNIDADE HUMANA), QUE DEVE SER ZELADO EM NÍVEL DO SUS POR TODOS OS ENTES DA FEDERAÇÃO (SOLIDARIEDADE), EM RELAÇÃO AO QUAL NÃO PODEM SER OPOSTAS A BUROCRACIA DO PODER PÚBLICO E NEM AS QUESTÕES ORÇAMENTÁRIAS - É CORRETO O DESEMPENHO DO PODER JỦDICIÁRIO (ART. 5 , XXXV, DA CF) EM ASSEGURAR TAL DIREITO, QUE EMERGE DA MAGNA CARTA E DA LEI N 8.080/90 - MATÉRIA PRELIMINAR REPELIDA - APELAÇÕES E REMESSA OFICIAL DESPROVIDAS.

1. A saúde é um direito social (art. $6^{\circ}$ ) decorrente do direito à vida (art. $5^{\circ}$ ), disciplinado no artigo 196 e seguintes da Constituição Federal, e sua prestação em natureza ampla é preconizada na Lei nํ 8.080/90 que regulamentou o art. 198 da Constituição (SUS). Diante disso, é insofismável a ilação segundo a qual cabe ao Poder Público obrigatoriamente a garantia da saúde mediante a execução de política de prevenção e assistência à saúde, com a disponibilização de amplos serviços de atendimento à população, envolvendo prevenção, de 
doenças, vacinações, tratamentos (internações, inclusive) e prestação de remédios.

2. 'O funcionamento do Sistema Único de Saúde é de responsabilidade solidária da União, dos Estados e dos Municípios, de modo que qualquer um desses entes tem legitimidade ad causam para figurar no polo passivo de demanda que objetiva a garantia do acesso a medicamento s para tratamento de problema de saúde' (STJ, AgRg. no REsp. 1017055/RS, Rel. Ministro CASTRO MEIRA, SEGUNDA TURMA, julgado em 11/09/2012, DJe 18/09/2012). Múltiplos precedentes.

3. Cidadão acometida de Hemoglobinúria Paroxística Noturna - HPN. Trata-se da chamada doença de Marchiafava e Michelli, uma rara anemia hemolítica crônica de início insidioso e curso crônico, ocasionada por um defeito na membrana dos eritrócitos (proteína protetora). Quando o quadro evolui uma das maiores complicações é a trombose, sendo que os dois locais mais preocupantes são nas veias supra-hepáticas e no sistema nervoso central. Outros possíveis problemas incluem as crises dolorosas abdominais (de etiologia ainda incerta) e as infecções recorrentes, pois ocorre a destruição dos glóbulos vermelhos. Medicação pretendida: 'SOLIRIS' (nome comercial), que tem como princípio ativo a substância ECULIZUMABE, é aprovado para o combate contra a doença na União Europeia e nos Estados Unidos da América, conforme decisões da European Medicines Agency - EMA e Food and Drug Administration - FDA, que aprovaram o medicamento desde, respectivamente, 20.06.2007 e 16.03.2007. Fármaco que não foi aprovado pela ANVISA e não consta do RENAME; mesma situação que acontece no Canadá e na Escócia.

4. Na medida em que dificilmente se pode falar que o controle da indústria farmacêutica no Brasil é superior ao exercido pela European Medicines Agency - EMA e pela Food and Drug Administration - FDA, sobra apenas uma desculpa para a negativa governamental em incluir o 'SOLIRIS' no âmbito da ANVISA: o medicamento é caro! Ainda: o parecer $\mathrm{n}^{\circ}$ 1.201/2011-AGU/CONJUR-Ministério da Saúde/HRP destaca que o SUS tem uma terapêutica adequada para o combate da doença, Transplante de células Tronco Hematopoiéticas (TCTHa); sucede que o Relator consultou a PORTARIA № 931 DE 2 DE MAIO DE 2006, do Ministro da Saúde, que aprova o Regulamento Técnico para Transplante de Células-Tronco Hematopoéticas e, no meio de uma gigantesca burocracia destinada a regular tais transplantes, não conseguiu localizar a alegada 'indicação' de que o SUS pode custear esse difícil procedimento em favor de quem porta Hemoglobinúria Paroxística Noturna - HPN.

5. Resta difícil encontrar justificativa para se negar a uma pessoa doente de Hemoglobinúria Paroxística Noturna - HPN o medicamento 'SOLIRIS', ainda que seja caro, quando a atual Relação Nacional de medicamento $s$ Essenciais/RENAME (Portaria MS/GM no 533, de 28 de março de 2012) contempla três fitoterápicos: Hortelã (para tratamento da síndrome do cólon irritável), Babosa (para queimaduras e psoríase) e Salgueiro (para a dor lombar). Os limites enunciativos dessa Relação Nacional de medicamento s Essenciais/RENAME e os supostos limites orçamentários do Poder Público (de difícil justificativa quando se sabe que há verbas públicas destinadas a propaganda da 'excelência' do Governo de ocasião) não podem ser manejados se colidem diretamente contra o direito à vida, contra o direito social de integralidade do acesso à saúde e contra a essencial dignidade da pessoa humana.

6. Calha recordar que ao decidir sobre tratamentos de saúde e fornecimento de remédios o Poder Judiciário não está se investindo da função de cogestor do Poder Executivo, ao contrário do que os apelantes frisam; está tão somente determinando que se cumpra o 
comando constitucional que assegura o direito maior que é a vida, está assegurando o respeito que cada cidadão merece dos detentores temporários do Poder Público, está fazendo recordar a verdade sublime que o Estado existe para o cidadão, e não o contrário. $\mathrm{Na}$ verdade, o Judiciário está dando efetividade ao art. 6ํㅜ inc. I, 'd', da Lei no 8.080/90 que insere no âmbito da competência do SUS a assistência terapêutica integral, inclusive farmacêutica.

7. A recomendação $\mathrm{n}^{\circ} 31$ do $\mathrm{CNJ}$ foi atendida na decisão de fls. 88, posteriormente homologada pelo despacho de fls. 251, de modo que não há que se falar em descumprimento da recomendação; ademais, uma recomendação de órgão administrativo, por mais venerável e importante que seja, como é o caso do CNJ, não pode impedir que a jurisdição seja prestada a quem a reclama, sob pena de afronta ao art. $5^{\circ}, \mathrm{XXXV}$ da Constituição.

8. A matéria aqui tratada já foi objeto de apreciação pela Presidência do Supremo Tribunal Federal em sede de dois pedidos de suspensão de segurança (nos 4316 e 4304), tendo o então Min. Cesar Peluso repelido a mesma ladainha que aqui assoma: o valor da droga e a ausência de registro na ANVISA.

9. Corretas a antecipação de tutela com fixação de astreintes, bem como a imposição de honorária (módica) (TRF 3a Região, AC no 2010.61.10.008456-0, Relator Desembargador Federal JOHONSOM DI SALVO, D.E. Publicado em 17/06/2013).

Ainda que o Poder Público demonstre exaustivamente sua incapacidade financeira, deverá compatibilizar seu orçamento com o mínimo existencial, já que os direitos fundamentais formam um dos pilares da República Federativa do Brasil (ADAES, 2016).

No mesmo sentido, Carlos Neto (2018) defende que:

[...] a escassez de recursos orçamentários não pode ser obstáculo para a garantia dos direitos sociais, que são as condições essenciais da vida humana, pois, desta forma, acaba por violar o preceito básico e fundamental da Constituição Federal: o princípio da dignidade humana. [...] a garantia a um mínimo existencial é requisito necessário para a sobrevivência do indivíduo, pois se não possui as condições necessárias para uma vida digna, os direitos sociais prestacionais não estão sendo eficazes. E no que tange ao mínimo existencial destinado à saúde, viola-se também o direito à vida, pois sem saúde não se vive.

Segundo Hutzler (2018), a primeira grande causa da judicialização foi a redemocratização do país com a promulgação da Constituição de 1988, trazendo uma espécie de constitucionalização abrangente de diversas matérias que antes eram tratadas pelo legislador ordinário, o que expandiu a demanda por justiça na sociedade brasileira.

O incremento demasiado nos custos se verifica quando as condenações judiciais determinam a compra de medicamentos de uma marca específica, sem 
registro na ANVISA, dependentes de importação ou não previstos na relação do SUS (MAPELLI JÚNIOR, 2017).

Em recente decisão, ${ }^{10}$ o Supremo Tribunal Federal julgou que o Estado não é obrigado a fornecer medicamentos de alto custo solicitados judicialmente, quando não estiverem previstos na relação do Programa de Dispensação de Medicamentos em Caráter Excepcional, do Sistema Único de Saúde (SUS). As situações excepcionais ainda serão definidas na formulação da tese de repercussão geral. A decisão, tomada no julgamento do Recurso Extraordinário (RE) ํo 566.471, atinge mais de 42 mil processos sobre mesmo tema.

O caso sub judice diz respeito à recusa do Estado do Rio Grande do Norte ao fornecimento de citrato de sildenafila para o tratamento de cardiomiopatia isquêmica e hipertensão arterial pulmonar a uma senhora idosa e carente, com fundamento no alto custo do medicamento e na ausência de previsão de fornecimento no programa estatal de dispensação de medicamentos. A paciente ingressou com ação judicial para pleitear que o estado fosse obrigado a fornecer o remédio. O juízo de primeiro grau determinou a obrigação do fornecimento, decisão que foi confirmada pelo Tribunal de Justiça estadual.

A maioria dos ministros - oito votos no total - desproveu o recurso tendo como condutor o voto do relator, ministro Marco Aurélio, proferido em setembro de 2016. A vertente vencedora entendeu que, nos casos de remédios de alto custo não disponíveis no sistema, o Estado pode ser obrigado a fornecê-los, desde que comprovadas a extrema necessidade do medicamento e a incapacidade financeira do paciente e de sua família para sua aquisição. $O$ entendimento também considera que o Estado não pode ser obrigado a fornecer fármacos não registrados na agência reguladora.

O ministro Edson Fachin abriu divergência e votou em favor do fornecimento imediato do medicamento solicitado, tendo em vista que, durante 0 trâmite do processo, ele foi registrado e incluído na política de assistência à saúde.

10 Decisão proferida em 11 de março de 2020. Recurso Extraordinário (RE) ㄲo 566.471. Disponível em: <http://www.stf.jus.br>. Acesso em: 10 mai. 2020. 
$\mathrm{Na}$ última sessão, o ministro Alexandre acompanhou o relator. No seu entendimento, o excesso de judicialização da saúde tem prejudicado políticas públicas, pois decisões judiciais favoráveis a poucas pessoas, por mais importantes que sejam seus problemas, comprometem o orçamento total destinado a milhões de pessoas que dependem do Sistema Único de Saúde (SUS). "Não há mágica orçamentária e não há nenhum país do mundo que garanta acesso a todos os medicamentos e tratamentos de forma generalizada", afirmou o Ministro do Supremo Tribunal Federal, Alexandre de Moraes. ${ }^{11}$

Também votaram na aludida sessão as ministras Rosa Weber e Cármen Lúcia e os ministros Ricardo Lewandowski, Gilmar Mendes e Luiz Fux. Todos acompanharam o entendimento do relator pelo desprovimento do recurso. Em seus votos, eles salientaram que, em caráter excepcional, é possível a concessão de medicamentos não registrados na lista da Anvisa. Nesse sentido, fizeram a ponderação entre diversos argumentos, como as garantias constitucionais (entre elas a concretização dos direitos fundamentais, o direito à vida e à dignidade da pessoa humana), o limite do financeiramente possível aos entes federados, tendo em vistas restrições orçamentárias, o desrespeito às filas já existentes e o prejuízo a outros interesses idênticos. ${ }^{12}$

O fato é que todos os ministros apontaram condicionantes em seus votos, que serão analisadas na produção da tese de repercussão geral.

Conforme se verifica, começa a haver uma preocupação do Poder Judiciário, inclusive do seu órgão máximo, o STF, com o que podemos chamar de "excesso de judicialização".

Neste sentido, imperativa se faz a fixação de regras, de critérios objetivos para a concessão dos medicamentos e insumos pleiteados via judicial. Se, por um lado, o cidadão tem direito a um determinado medicamento ou tratamento específico, ao Estado compete regulamentar tal direito para que ele não se torne

11 Supremo Tribunal Federal. Notícia STF. Estado não é obrigado a fornecer medicamentos de alto custo não registrados na lista do SUS (atualizada). 2020. Disponível em: <http://portal.stf.jus.br/ noticias/verNoticiaDetalhe. asp?idConteudo=439095\&ori=1 >. Acesso em: 11 mar. 2020.

12 Supremo Tribunal Federal. Notícia STF. Estado não é obrigado a fornecer medicamentos de alto custo não registrados na lista do SUS (atualizada). 2020. Disponível em: <http://portal.stf.jus.br/ noticias/verNoticiaDetalhe.asp?idConteudo=439095\&ori=1 >. Acesso em: 11 mar. 2020. 
abusivo e se transforme em ato ilícito, ${ }^{13}$ a teor do que preceitua o art. 187 do Código Civil brasileiro.

Além da recente decisão proferida pelo Supremo, outro exemplo de regulamentação da judicialização da saúde é a edição do Provimento № 84/19, da Corregedoria Nacional de Justiça, que dispõe sobre o uso e o funcionamento do Sistema Nacional de Pareceres e Notas Técnicas (e-NatJus).

De acordo com o Provimento em questão, os Magistrados Estaduais e os Magistrados Federais com competência para processar e julgar ações que tenham por objeto o direito à saúde, ainda que durante o plantão judicial, quando levados a decidir sobre a concessão de determinado medicamento, procedimento ou produto, poderão solicitar apoio técnico ao Núcleo de Apoio Técnico do Judiciário (NAT-JUS) do seu Estado ou ao NAT-JUS NACIONAL.

O apoio técnico previsto no caput do art. 1ำ do Provimento no 84/2019, quando solicitado, deverá ser materializado por meio do Sistema Nacional de Pareceres e Notas Técnicas (e-NatJus), hospedado no sítio do Conselho Nacional de Justiça, podendo ser acessado através do link: <www.cnj.jus.br/e-natjus $>$.

O sistema tem o objetivo de dar ao magistrado fundamentos para decidir com segurança, baseado em evidência científica, sobre a concessão ou não, em sede de liminar, de fármaco, órtese, prótese ou qualquer outra tecnologia em saúde. Assim, os juízes podem consultar o e-NatJus em busca de pareceres e notas técnicas que tivessem examinado as questões de saúde demandadas pelos cidadãos que judicializam suas emergências médicas. O sistema funciona, também, com a participação do Hospital Sírio-Libanês, na capacitação dos integrantes dos núcleos de cada estado quando da elaboração de notas técnicas e no encaminhamento de pedidos de pareceres técnicos científicos formulados pelos Comitês Estaduais da Saúde do Poder Judiciário. ${ }^{14}$

13 Art. 187 do Código Civil: Também comete ato ilícito o titular de um direito que, ao exercê-lo, excede manifestamente os limites impostos pelo seu fim econômico ou social, pela boa-fé ou pelos bons costumes.

14 Comitês Estaduais da Saúde do Poder Judiciário. Pedidos Urgentes de Remédios à Justiça Passarão por Análise de Médicos. 2019. Disponível em: <http://web.trf3.jus.br/noticias/ Noticias/Noticia/Exibir/384689 >. Acesso em: 05 nov. 2019. 
Cumpre mencionar também a Resolução № 238, de 06 de setembro de 2016 do CNJ, que dispõe sobre a criação e manutenção, pelos Tribunais de Justiça e Regionais Federais de Comitês Estaduais da Saúde, bem como a especialização de vara em comarcas com mais de uma vara de Fazenda Pública.

Embora os direitos sociais demandem o emprego de recursos públicos para a sua garantia, ao que se denomina dimensão prestacional positiva por parte do Estado, a intervenção do Poder Judiciário ante a omissão estatal de políticas públicas suficientes a garantir tais direitos violaria o princípio da separação de poderes e da reserva do possível (MENDES; BRANCO, 2012).

Todavia, há quem entenda que a intervenção judicial para adequar distorções no orçamento público para o implemento de políticas de saúde além de ser legitimada pela Constituição Federal, corresponde a um verdadeiro dever do Estado-juiz no exercício do devido controle sobre o ato administrativo, o que não fere a harmonia e o princípio da separação entre os poderes (HUTZLER, 2018).

Importante destacar que a reserva do possível, enquanto limitação fática à implementação dos direitos fundamentais, exige que o Poder Público assuma o ônus da prova ${ }^{15}$, ou seja, não basta dizer que não há orçamento disponível, mas deve provar especificamente a inexistência de recursos (CAMBI, 2009) e, mais, no âmbito da saúde, deve provar o que vem sendo executado.

15 Art. 373 do Código de Processo Civil. 
3 Proposição 



\section{PROPOSIÇÃO}

Com base na literatura apresentada, seguem abaixo os objetivos do presente estudo.

a) Geral: analisar o fenômeno da judicialização da saúde como mecanismo para efetivação dos direitos fundamentais.

\section{b) Específicos:}

$\checkmark$ Analisar a repartição de competências, no âmbito da saúde, entre os entes federados: União, Estados, Distrito Federal e Municípios, à luz da Constituição Federal, da legislação infraconstitucional disciplinadora do assunto e da dignidade da pessoa humana;

$\checkmark$ Analisar os dados oriundos das ações judiciais, na área da saúde, em relação ao Município de Bauru, no período de 2014 a 2017;

$\checkmark$ Analisar a reserva do possível e o mínimo existencial na efetivação do direito fundamental à saúde;

$\checkmark$ Analisar a importância da judicialização para o implemento de políticas públicas locais na área da saúde pública;

$\checkmark$ Identificar as ações judiciais na área da saúde, com procedência do pedido, no âmbito do Município de Bauru/SP;

$\checkmark$ Verificar o impacto orçamentário ocasionado pela judicialização da saúde, no âmbito do Município de Bauru, referente ao período de 2014 a 2017. 

4 Material e Métodos 



\section{MATERIAL E MÉTODOS}

Inicialmente o presente trabalho foi apresentado ao Comitê de Ética e Pesquisa em Seres Humanos da Faculdade de Odontologia de Bauru, Universidade de São Paulo, tendo sido objeto de análise e aprovação no dia 04 de março de 2020 (ANEXO A).

A amostra utilizada foi de 712 processos.

Os métodos utilizados na elaboração do presente estudo foram:

a) Bibliográfico: utilizado durante todo o estudo com base em obras, revistas científicas e jurisprudência dos Tribunais, que tratem de forma genérica e específica sobre o tema objeto do presente estudo. Referente às bases de dados utilizadas, parte do material de apoio foi extraída de sites como: Pubmed, Scielo, Lilacs, Google Acadêmico e Dedalus. Valeu-se, também, de sites de nossos Tribunais de Justiça, inclusive dos Superiores Tribunais - Superior Tribunal de Justiça e Supremo Tribunal Federal - para a extração de julgados pertinentes à pesquisa.

Os descritores utilizados na pesquisa foram: judicialização, judicialização da saúde, saúde pública, saúde coletiva, direitos fundamentais e direito à saúde.

b) Banco de Dados: foi efetuado levantamento dos processos usando para tanto o banco de dados da Procuradoria do Município de Bauru e da Secretaria Municipal de Saúde, no que se refere às ações judiciais, bem como utilizamos o sistema e-SAJ, do Tribunal de Justiça do Estado de São Paulo - TJSP.

Para tanto, utilizamos os seguintes critérios de elegibilidade:

- CRITÉRIOS DE INCLUSÃO:

- ações judiciais - área da saúde - propostas em relação ao Município de Bauru;

- ações judiciais propostas no período de 2014 a 2017;

- ações judiciais julgadas, pelo menos, em $1^{\underline{a}}$ instância; 
- ações judiciais de obrigação de dar e de fazer.

\section{- CRITÉRIOS DE EXCLUSÃO:}

- ações judiciais propostas em relação ao Estado de São Paulo e à União, exclusivamente ou em solidariedade com o Município de Bauru;

- ações judiciais de obrigação de fazer para internação compulsória (hipóteses de drogaditos ou doenças mentais).

Para a seleção dos processos judiciais, utilizamos, quanto ao objeto da demanda, as seguintes variáveis:

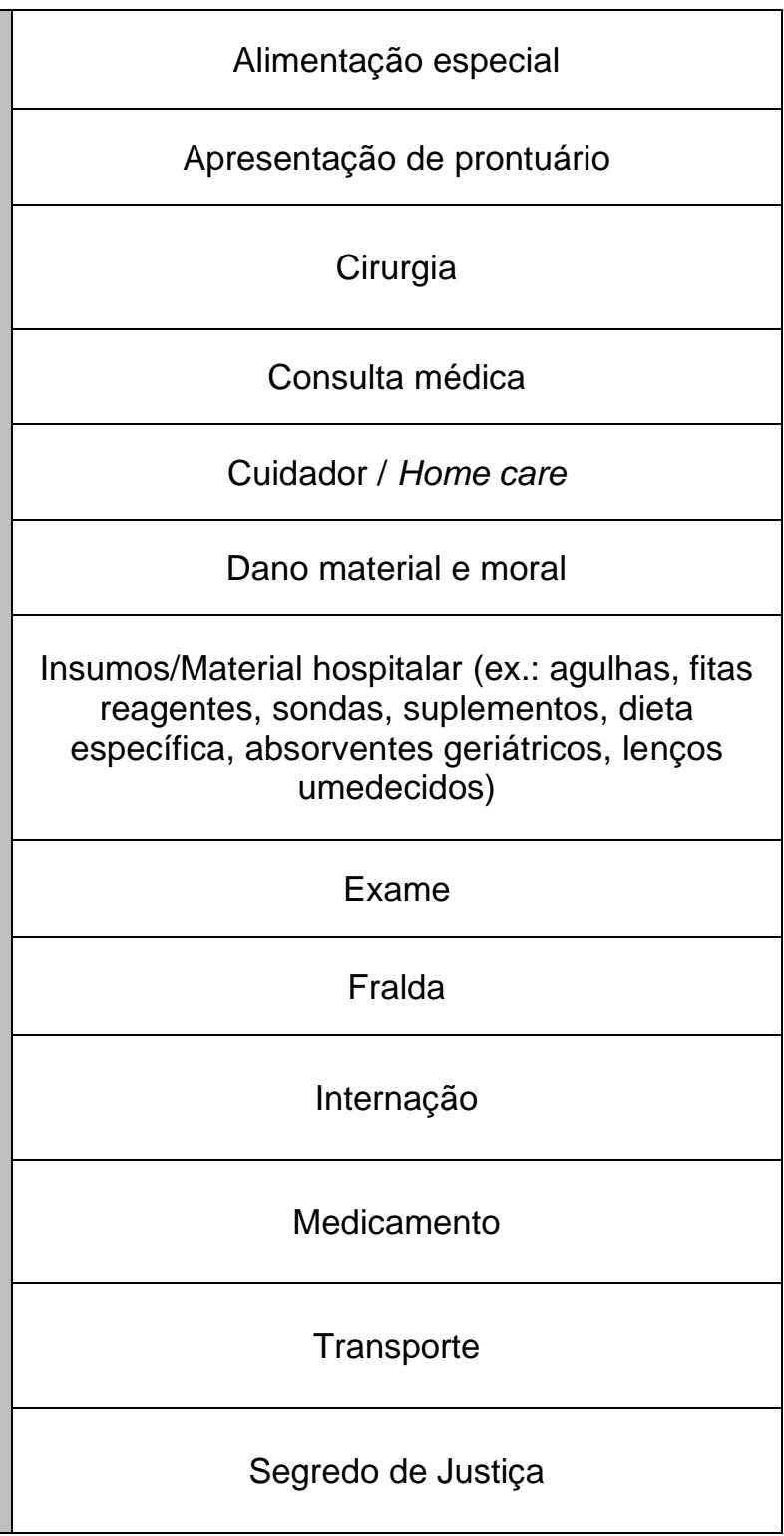


Cumpre ressaltar que não foram consideradas na pesquisa ações judiciais sobre outros temas relevantes de saúde, igualmente levados à apreciação do Poder Judiciário, como contratação de profissionais, repasses de verbas, reformas de hospitais etc.

Também a pesquisa ficou delimitada aos processos distribuídos a partir de 01 de janeiro de 2014 até 31 de dezembro de 2017. Assim, não foram analisados os processos distribuídos antes de 2014 e que, por ventura, tenham tido andamento nos anos posteriores para cumprimento de uma medida liminar, por exemplo, ou mesmo uma sentença de mérito.

Por derradeiro, importante destacar que o Município de Bauru não possui um sistema eletrônico de cadastramento de ações judiciais na área da saúde, que apresente um catálogo das demandas propostas de acordo com o objeto, o tipo de ação, o ano, o valor etc. Assim, toda pesquisa foi feita caso a caso, de acordo com o registro de entrada de processos administrativos na Procuradoria do Município e na Secretaria Municipal de Saúde, com pedidos judiciais ligados à saúde.

Entendemos que a informatização é medida urgente, devendo ser implementada num futuro próximo, pois possibilitará a melhoria de mecanismos de gestão, o cumprimento mais célere das decisões judiciais, além da economia de tempo e de dinheiro. 

5 Resultados 



\section{RESULTADOS}

\subsection{Ações judiciais contra o município de Bauru - período 2014 a 2017}

A pesquisa foi realizada ano a ano, a partir de 2014 e depois foram juntados todos os resultados, a fim de obter um panorama geral dos processos judiciais e as respectivas demandas da população.

Uma amostragem pequena foi catalogada como "segredo de justiça" diante da impossibilidade de consulta eletrônica dos autos do processo. Isso ocorre, na maioria das vezes, quando a parte autora é menor de idade ou incapaz.

Apesar de uma pequena oscilação no ano de 2017 (Tabela 04), verificase o aumento anual das demandas individuais na área da saúde, ampliando por via de consequência a intervenção do Poder Judiciário para o cumprimento do direito fundamental à saúde.

De todos os itens pesquisados, com relação ao ano de 2014, de um total de 131 processos, verifica-se que não houve pedido de apresentação de prontuário médico, nem ações judiciais objetivando a condenação do Município de Bauru ao pagamento de danos morais e/ou materiais (Tabela 01). O item mais solicitado foi fralda, com um total de 63 pedidos.

Os pedidos judiciais para apresentação de prontuário médico, normalmente, se destinam a comprovar eventual erro médico no atendimento do paciente para posterior ingresso de ação indenizatória contra o Poder Público. 
Tabela 01 - Processos Pesquisados Correspondentes ao Ano de 2014

\begin{tabular}{|c|c|c|}
\hline OBJETO DOS PROCESSOS & NÚMERO DE AÇÕES & TOTAL \\
\hline ALIMENTAÇÃO ESPECIAL & 08 & \multirow{13}{*}{131} \\
\hline $\begin{array}{l}\text { APRESENTAÇÃO DE } \\
\text { PRONTUÁRIO }\end{array}$ & 00 & \\
\hline CIRURGIA & 02 & \\
\hline CONSULTA MÉDICA & 17 & \\
\hline CUIDADOR / HOME CARE & 02 & \\
\hline DANO MATERIAL E MORAL & 00 & \\
\hline $\begin{array}{l}\text { INSUMOS/MATERIAL } \\
\text { HOSPITALAR }\end{array}$ & 01 & \\
\hline EXAME & 01 & \\
\hline FRALDA & 63 & \\
\hline INTERNAÇÃO & 01 & \\
\hline MEDICAMENTO & 26 & \\
\hline TRANSPORTE & 05 & \\
\hline SEGREDO DE JUSTIÇA & 05 & \\
\hline
\end{tabular}

Fonte: Banco de Dados da Procuradoria do Município e da Secretaria Municipal de Saúde.

Figura 01 - Percentual dos Objetos das Ações Judiciais Correspondentes ao Ano de 2014

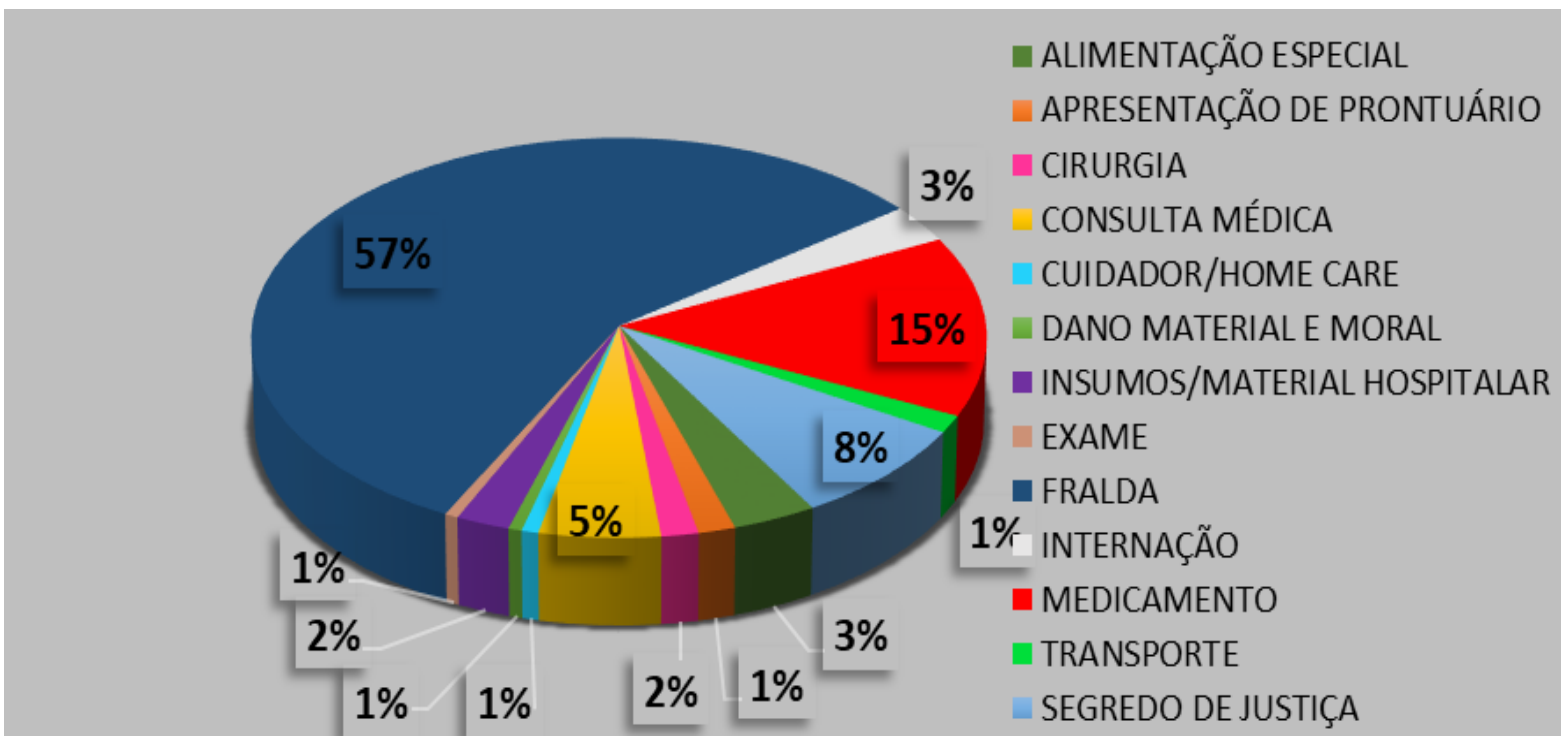

A Tabela 02 apresenta os processos pesquisados no ano de 2015, sendo 163 demandas analisadas, onde constatou-se a ausência de pedidos para fornecimento de cuidador/home care e ações objetivando a condenação do Município ao pagamento de dano moral/material. $O$ item mais solicitado judicialmente foi fralda, com um total de 86 pedidos. 
Tabela 02 - Processos Pesquisados Correspondentes ao Ano de 2015

\begin{tabular}{|c|c|c|}
\hline OBJETO DOS PROCESSOS & NÚMERO DE AÇÕES & $\overline{T O T A L}$ \\
\hline ALIMENTAÇÃO ESPECIAL & 04 & \multirow{13}{*}{163} \\
\hline $\begin{array}{l}\text { APRESENTAÇÃO DE } \\
\text { PRONTUÁRIO }\end{array}$ & 02 & \\
\hline CIRURGIA & 02 & \\
\hline CONSULTA MÉDICA & 09 & \\
\hline CUIDADOR / HOME CARE & 0 & \\
\hline DANO MATERIAL E MORAL & 0 & \\
\hline $\begin{array}{l}\text { INSUMOS/MATERIAL } \\
\text { HOSPITALAR }\end{array}$ & 02 & \\
\hline EXAME & 02 & \\
\hline FRALDA & 86 & \\
\hline INTERNAÇÃO & 05 & \\
\hline MEDICAMENTO & 34 & \\
\hline TRANSPORTE & 03 & \\
\hline SEGREDO DE JUSTIÇA & 14 & \\
\hline
\end{tabular}

Fonte: Banco de Dados da Procuradoria do Município e da Secretaria Municipal de Saúde.

Figura 02 - Percentual dos Objetos das Ações Judiciais Correspondentes ao Ano de 2015

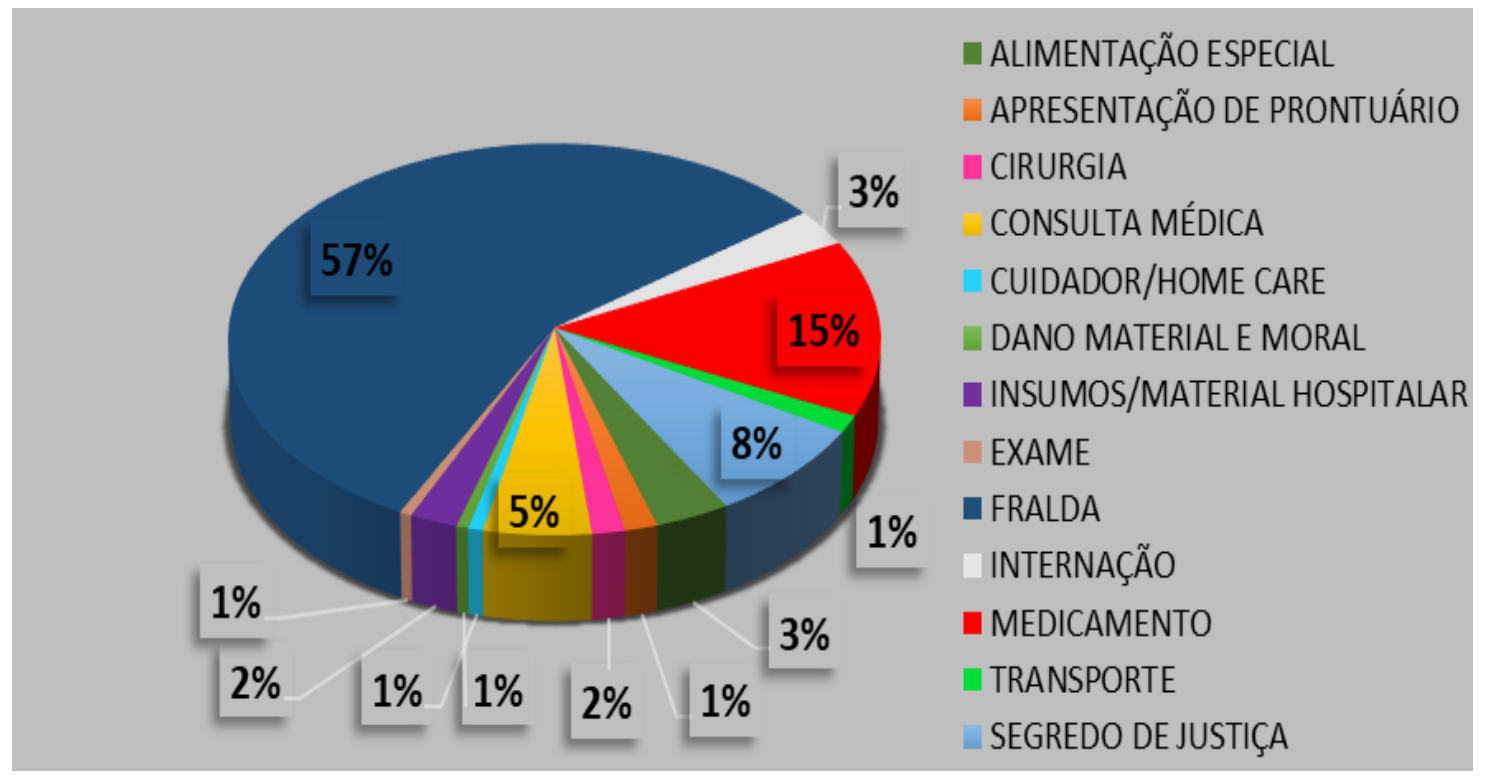

$\mathrm{Na}$ Tabela 03 foram analisados um total de 235 processos durante 0 ano de 2016, onde constatou-se que apenas o item referente a requerimentos de exames médicos não foi objeto de pedido judicial. Merece destaque novamente 0 item fralda, onde tivemos 145 pedidos. 
Tabela 03 - Processos Pesquisados Correspondentes ao Ano de 2016

\begin{tabular}{|c|c|c|}
\hline OBJETO DOS PROCESSOS & NÚMERO DE AÇÕES & TOTAL \\
\hline ALIMENTAÇÃO ESPECIAL & 09 & \multirow{13}{*}{235} \\
\hline APRESENTAÇÃO DE PRONTUÁRIO & 04 & \\
\hline CIRURGIA & 04 & \\
\hline CONSULTA MÉDICA & 04 & \\
\hline CUIDADOR / HOME CARE & 01 & \\
\hline DANO MATERIAL E MORAL & 02 & \\
\hline INSUMOS/MATERIAL HOSPITALAR & 07 & \\
\hline EXAME & 0 & \\
\hline FRALDA & 145 & \\
\hline INTERNAÇÃO & 08 & \\
\hline MEDICAMENTO & 27 & \\
\hline TRANSPORTE & 01 & \\
\hline SEGREDO DE JUSTIÇA & 23 & \\
\hline
\end{tabular}

Fonte: Banco de Dados da Procuradoria do Município e da Secretaria Municipal de Saúde.

Figura 03 - Percentual dos Objetos das Ações Judiciais Correspondentes ao Ano de 2016

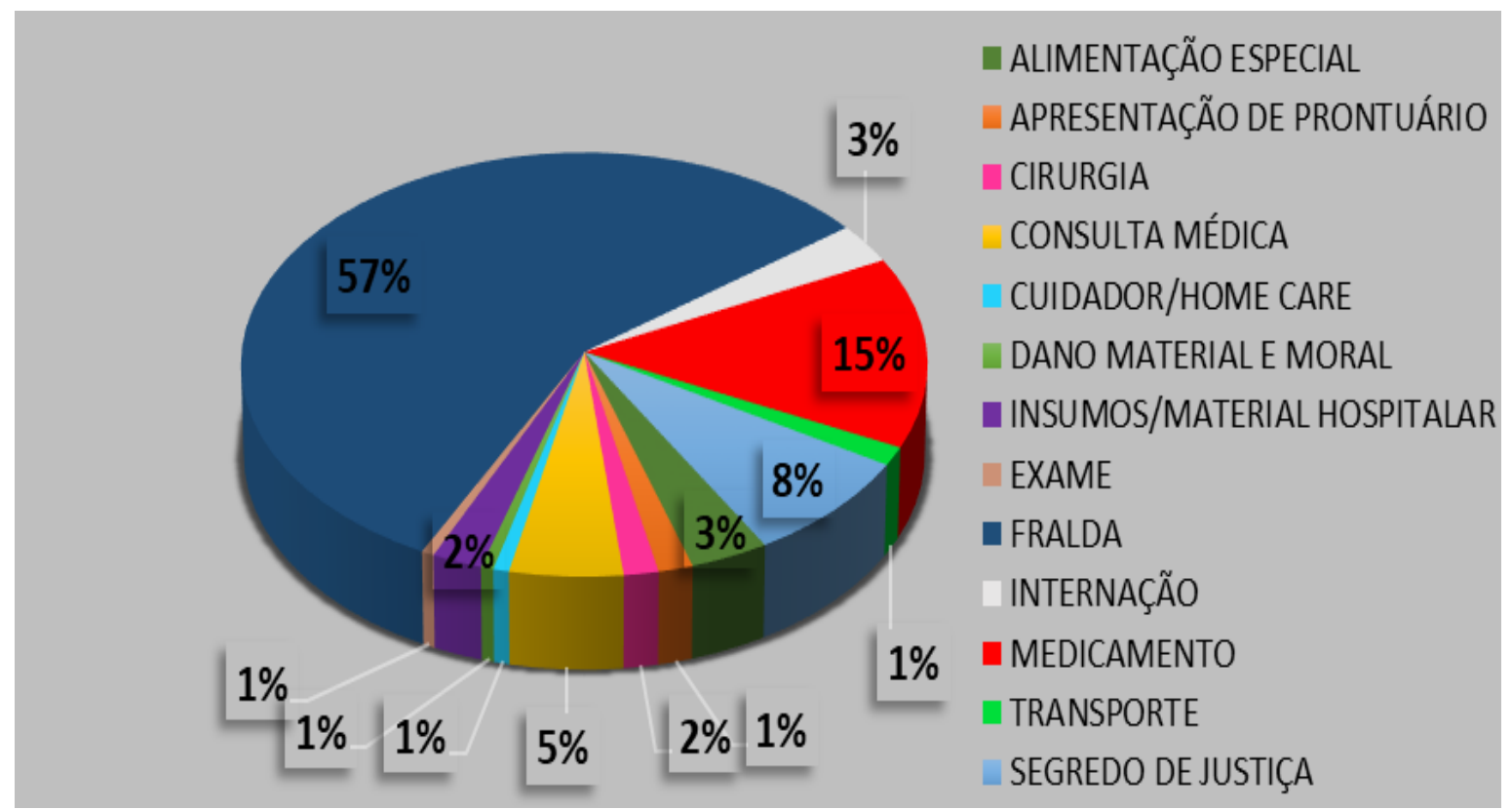

A Tabela 04 corresponde à análise de 183 processos, do ano de 2017, onde todos os objetos pesquisados tiveram ao menos um pedido judicial. Mais uma vez se comprova a maior demanda local por fraldas, apresentando 113 pedidos. 
Tabela 04 - Processos Pesquisados Correspondentes ao Ano de 2017

\begin{tabular}{|c|c|c|}
\hline OBJETO DOS PROCESSOS & NÚMERO DE AÇÕES & TOTAL \\
\hline ALIMENTAÇÃO ESPECIAL & 04 & \multirow{13}{*}{183} \\
\hline APRESENTAÇÃO DE PRONTUÁRIO & 05 & \\
\hline CIRURGIA & 03 & \\
\hline CONSULTA MÉDICA & 06 & \\
\hline CUIDADOR / HOME CARE & 02 & \\
\hline DANO MATERIAL E MORAL & 02 & \\
\hline INSUMOS/MATERIAL HOSPITALAR & 06 & \\
\hline EXAME & 01 & \\
\hline FRALDA & 113 & \\
\hline INTERNAÇÃO & 08 & \\
\hline MEDICAMENTO & 17 & \\
\hline TRANSPORTE & 01 & \\
\hline SEGREDO DE JUSTIÇA & 15 & \\
\hline
\end{tabular}

Fonte: Banco de Dados da Procuradoria do Município e da Secretaria Municipal de Saúde.

Figura 04 - Percentual dos Objetos das Ações Judiciais Correspondentes ao Ano de 2017

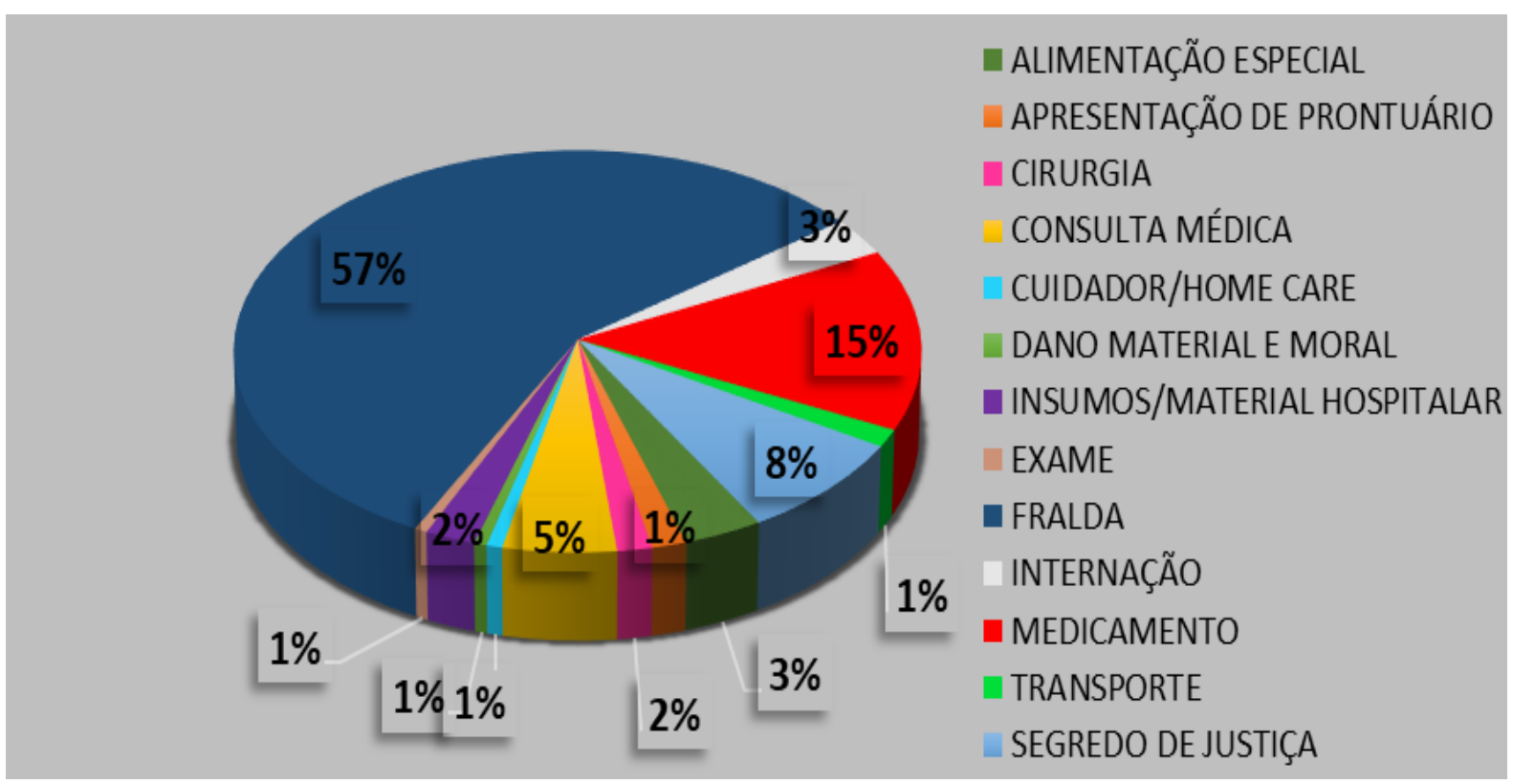

A Tabela 05 traz um panorama geral de todos os processos judiciais pesquisados, no período de 01 de janeiro de 2014 a 31 de dezembro de 2017, analisando-se os diversos objetos requeridos nas demandas na área da saúde no Município de Bauru. 
Tabela 05 - Visão Geral dos Processos Pesquisados de Acordo com o Objeto Correspondente ao Período de 2014 a 2017

\begin{tabular}{|l|c|}
\hline \multicolumn{1}{|c|}{ OBJETO DOS PROCESSOS } & NÚMERO DE AÇÕES \\
\hline ALIMENTAÇÃO ESPECIAL & 25 \\
\hline APRESENTAÇÃO DE PRONTUÁRIO & 11 \\
\hline CIRURGIA & 11 \\
\hline CONSULTA MÉDICA & 36 \\
\hline CUIDADOR / HOME CARE & 05 \\
\hline DANO MATERIAL E MORAL & 04 \\
\hline INSUMOS/MATERIAL HOSPITALAR & 16 \\
\hline EXAME & 04 \\
\hline FRALDA & 407 \\
\hline INTERNAÇÃO & 22 \\
\hline MEDICAMENTO & 104 \\
\hline TRANSPORTE & 10 \\
\hline SEGREDO DE JUSTIÇA & 57 \\
\hline
\end{tabular}

Fonte: Banco de Dados da Procuradoria do Município e da Secretaria Municipal de Saúde.

Figura 05 - Percentual dos Objetos das Ações Judiciais Correspondentes ao Período de 2014 a 2017

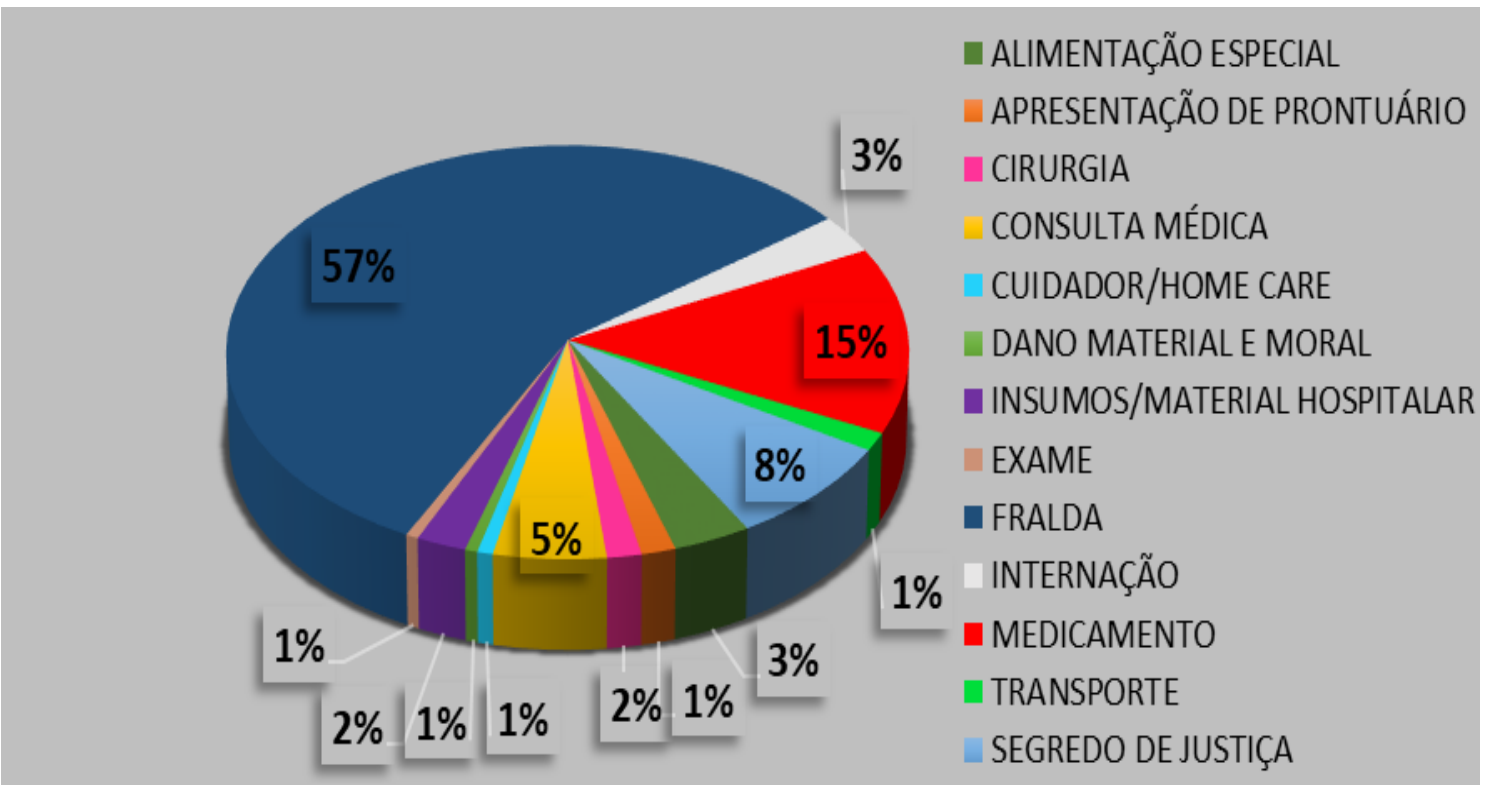

A grande maioria das ações de saúde pesquisadas utiliza o rito do mandado de segurança, conforme demonstra a Tabela 06, apresentando um total de 518 ações mandamentais contra 194 pedidos em outros ritos. 
Tabela 06 - Total dos Processos Pesquisados por Tipo de Ação Judicial

\begin{tabular}{|c|c|c|c|c|c|}
\hline Tipo de Ação & 2014 & 2015 & 2016 & 2017 & TOTAL \\
\hline Mandado de Segurança & 101 & 128 & 187 & 102 & 518 \\
\hline Outros Procedimentos & 30 & 35 & 48 & 81 & 194 \\
\hline TOTAL & 131 & 163 & 235 & 183 & 712 \\
\hline
\end{tabular}

Fonte: Banco de Dados da Procuradoria do Município e da Secretaria Municipal de Saúde.

Figura 06 - Tipos de Ação Judicial

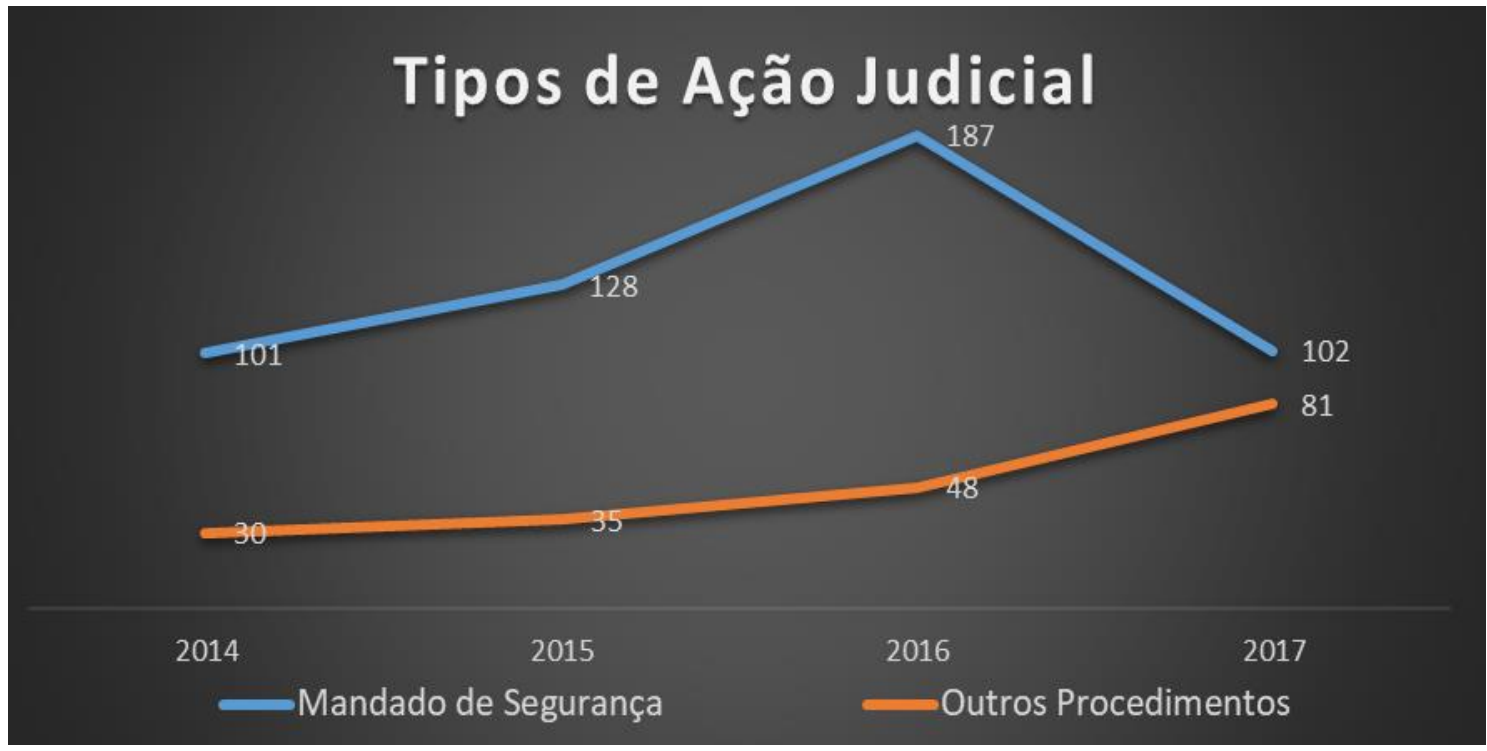

Figura 07 - Total de Processos Judiciais

TOTAL PROCESSOS JUDICIAIS

250

200

150

100

50

0

163

131

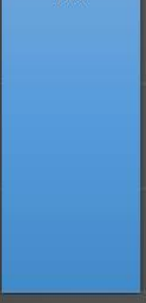

2015

2016 


\subsection{Dos objetos pesquisados}

Cada objeto pleiteado judicialmente também foi catalogado individualmente em forma de gráficos, possibilitando a análise de todo período pesquisado, conforme segue:

\section{Figura 08 - Alimentação Especial}

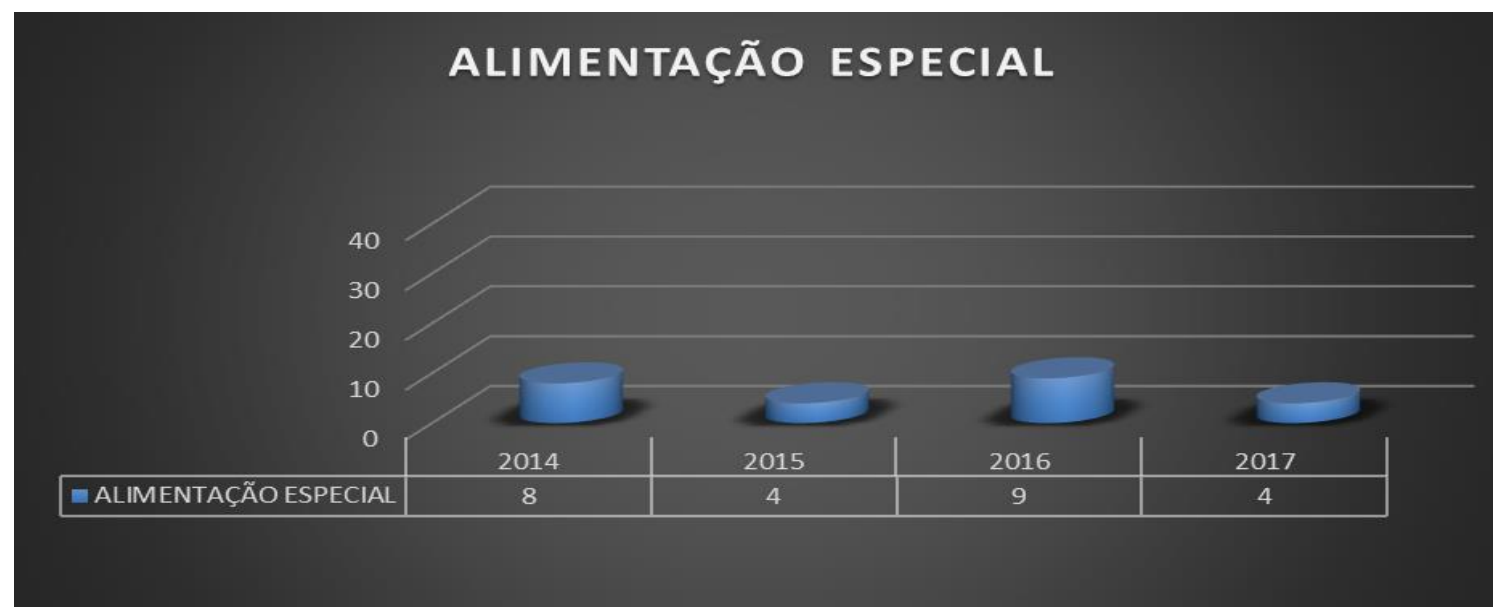

O objeto judicializado "alimentação especial" esteve presente ao longo de todos os anos pesquisados (Figura 08), ainda que em quantidade pouco significativa se comparada ao número total de processos judiciais analisados.

Pedidos judiciais para apresentação de prontuário médico ocorreram também em pequena quantidade (Figura 09), com exceção do ano de 2014, onde não foi localizado esse tipo de objeto nos processos pesquisados.

\section{Figura 09 - Apresentação de Prontuário}

\section{APRESENTAÇÃO DE PRONTUÁRIO}

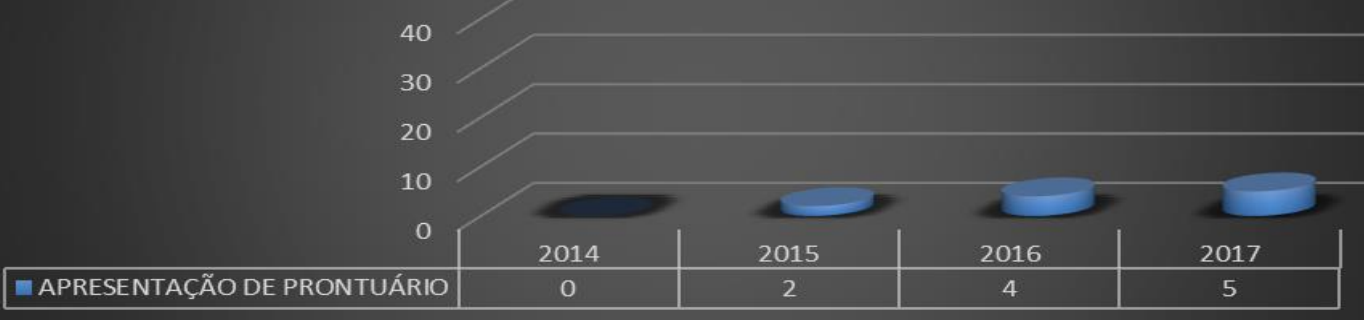


Requerimentos judiciais para realização de cirurgia apresentaram uma amostragem pouco significativa (Figura 10) nos anos pesquisados, com apenas dois pedidos em 2014 e 2015, quatro pedidos em 2016 e três pedidos em 2017.

\section{Figura 10 - Cirurgia}

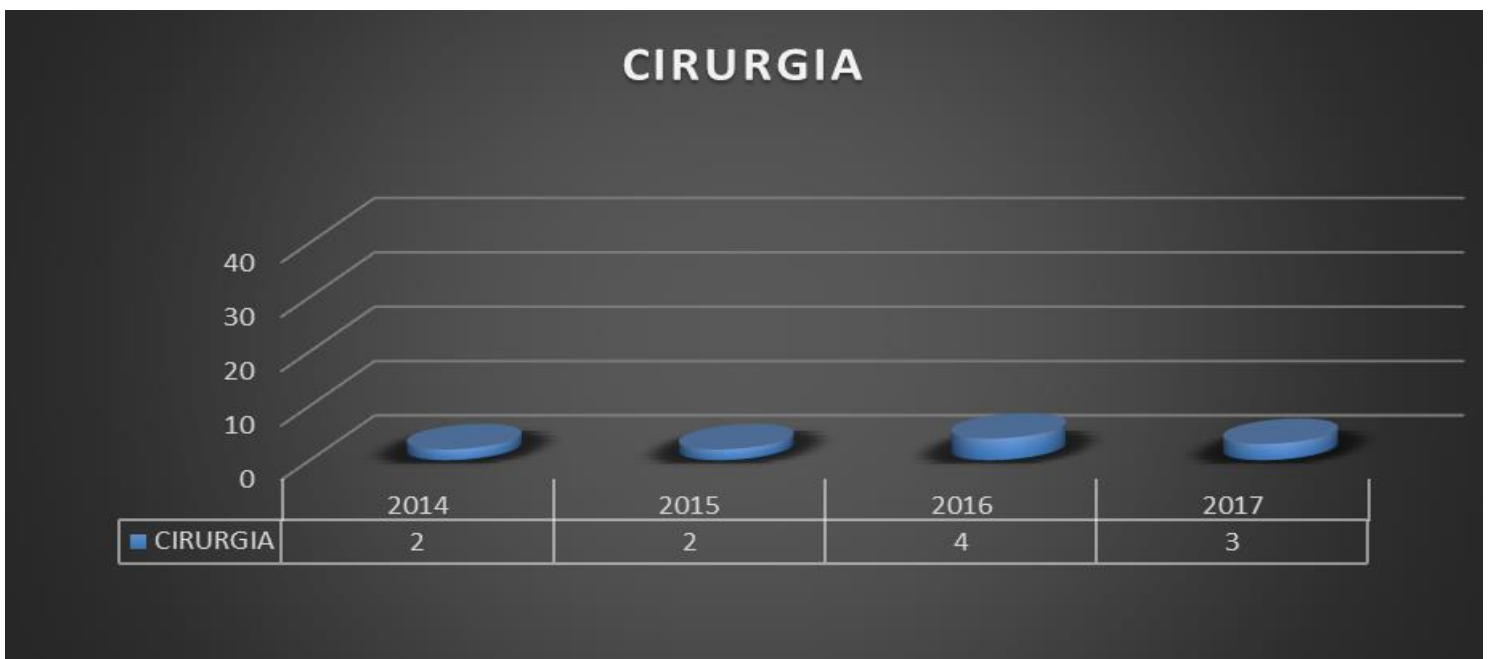

Consulta médica foi objeto de pedido em todos os anos pesquisados, apresentando o maior número de ações no ano de 2014, perfazendo 17 processos judiciais (Figura 11).

Pedidos judiciais para fornecimento de cuidador/home care apresentaram dados pouco significativos, apenas duas ações em 2014 e 2017, uma ação em 2016 e nenhuma demanda com esse objeto em 2015.

\section{Figura 11 - Consulta Médica}

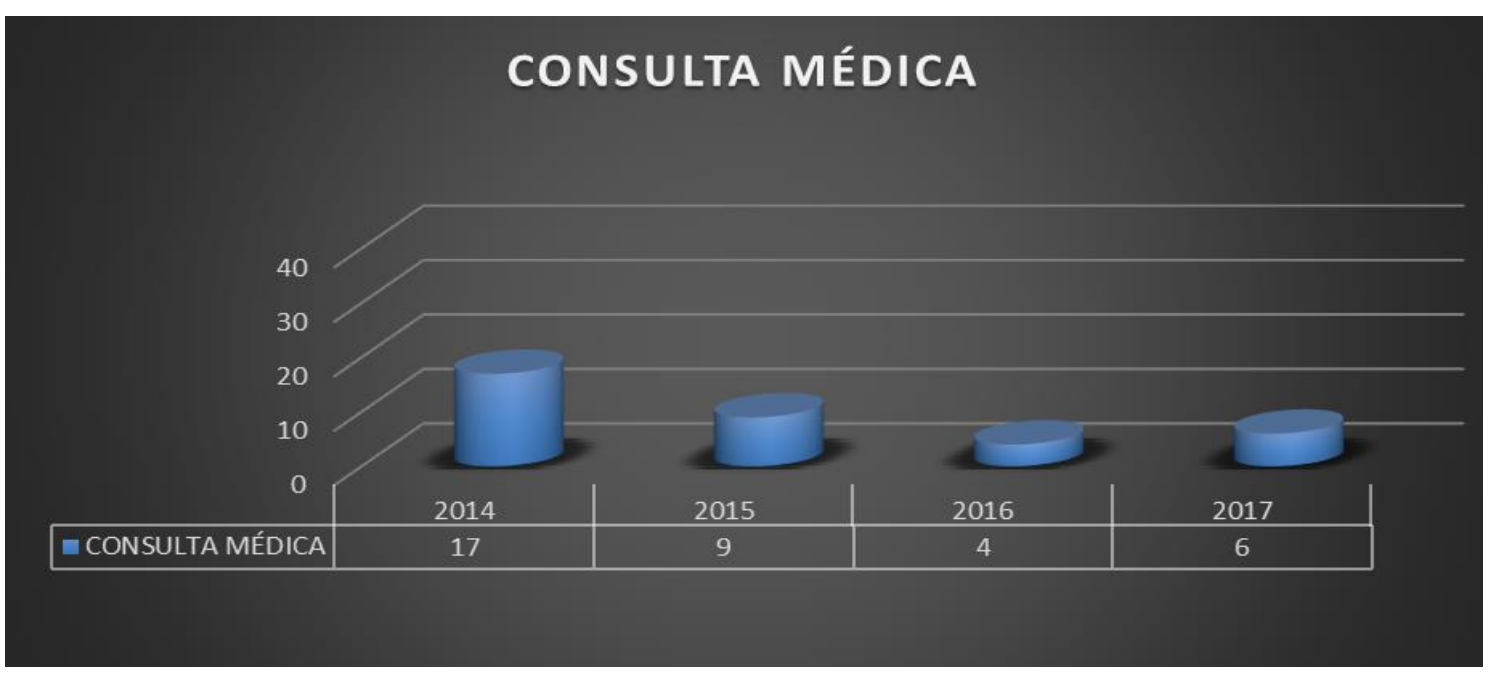


Figura 12 - Cuidador / Home Care

\section{CUIDADOR/HOME CARE}

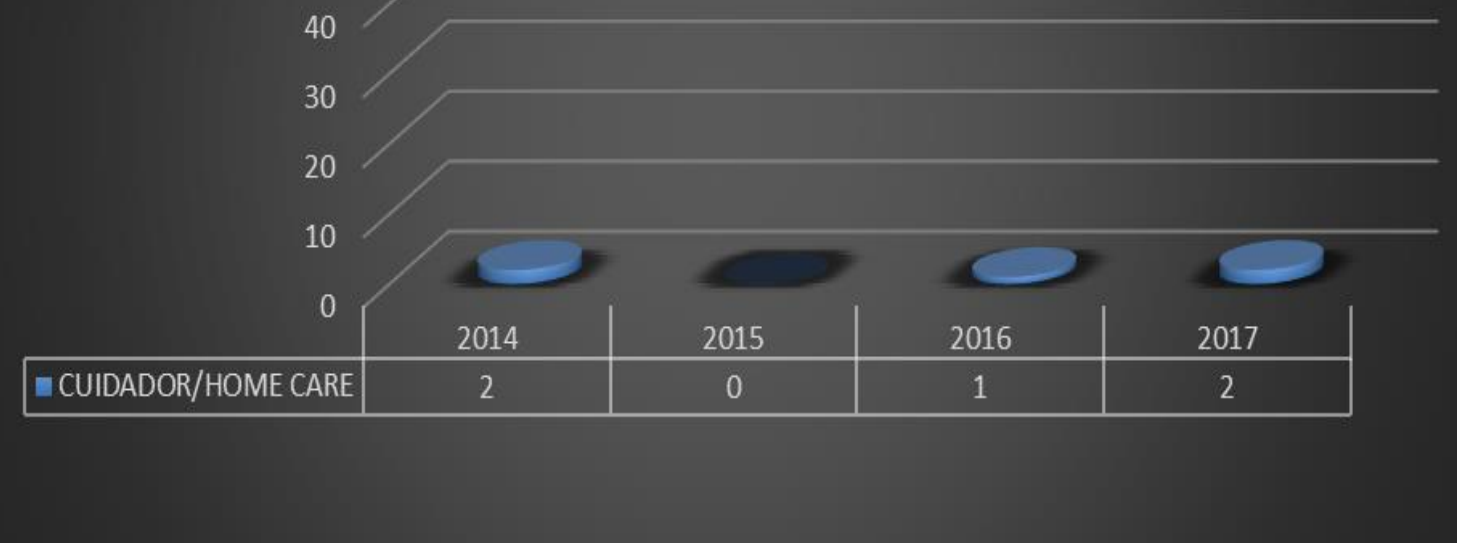

Conforme salientado acima, pedidos judiciais de dano moral/material não apresentaram dados relevantes, constando apenas duas ações nos anos de 2016 e 2017 (Figura 13).

Figura 13 - Dano Material e Moral

\section{DANO MATERIAL E MORAL}


Figura 14 - Insumos / Material Hospitalar

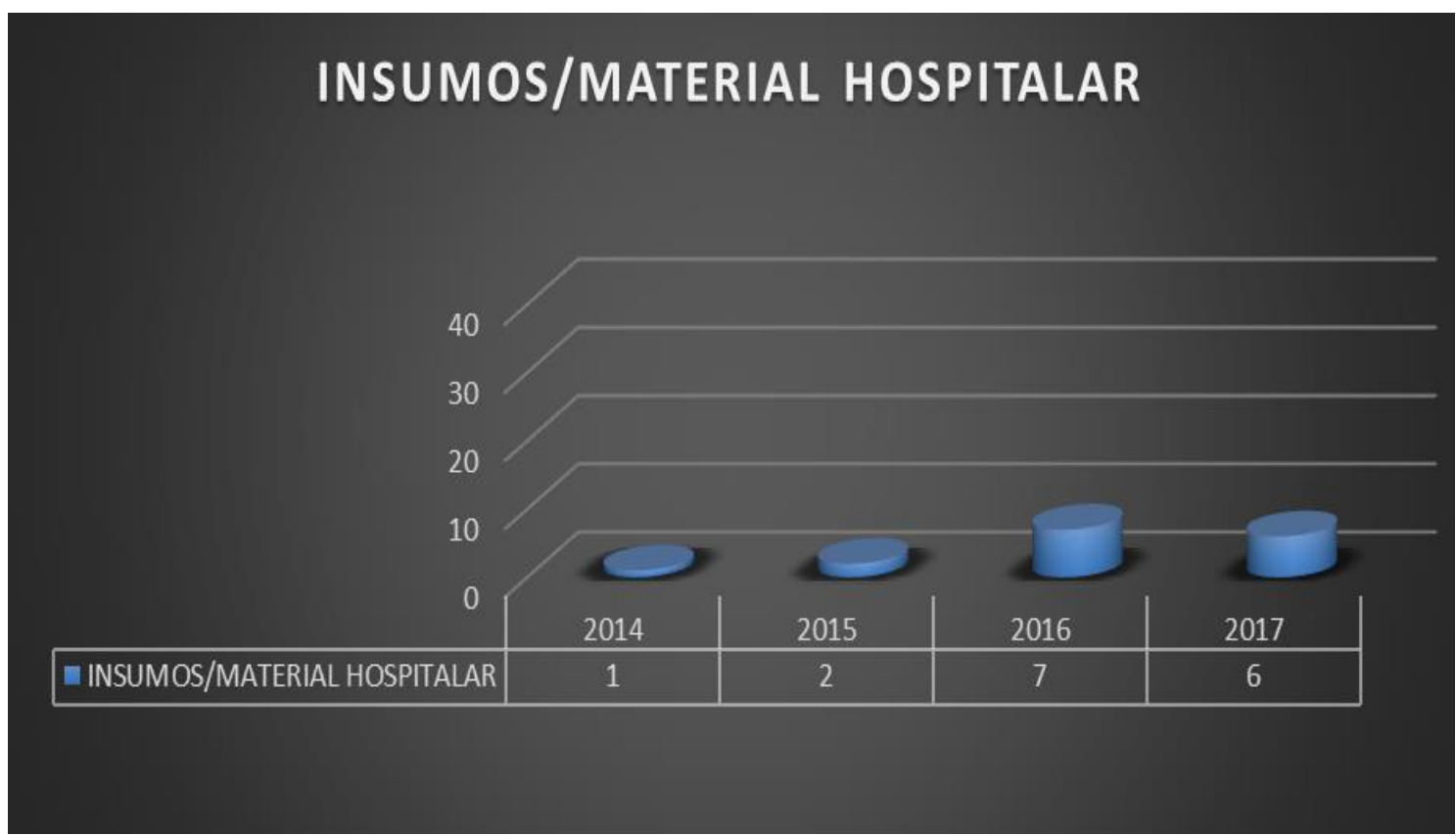

Insumos diversos/material hospitalar constam em todos os anos pesquisados (Figura 14), assim como pedidos judiciais para internação ambulatorial e em UTI (Figura 16).

Figura 15 - Exame

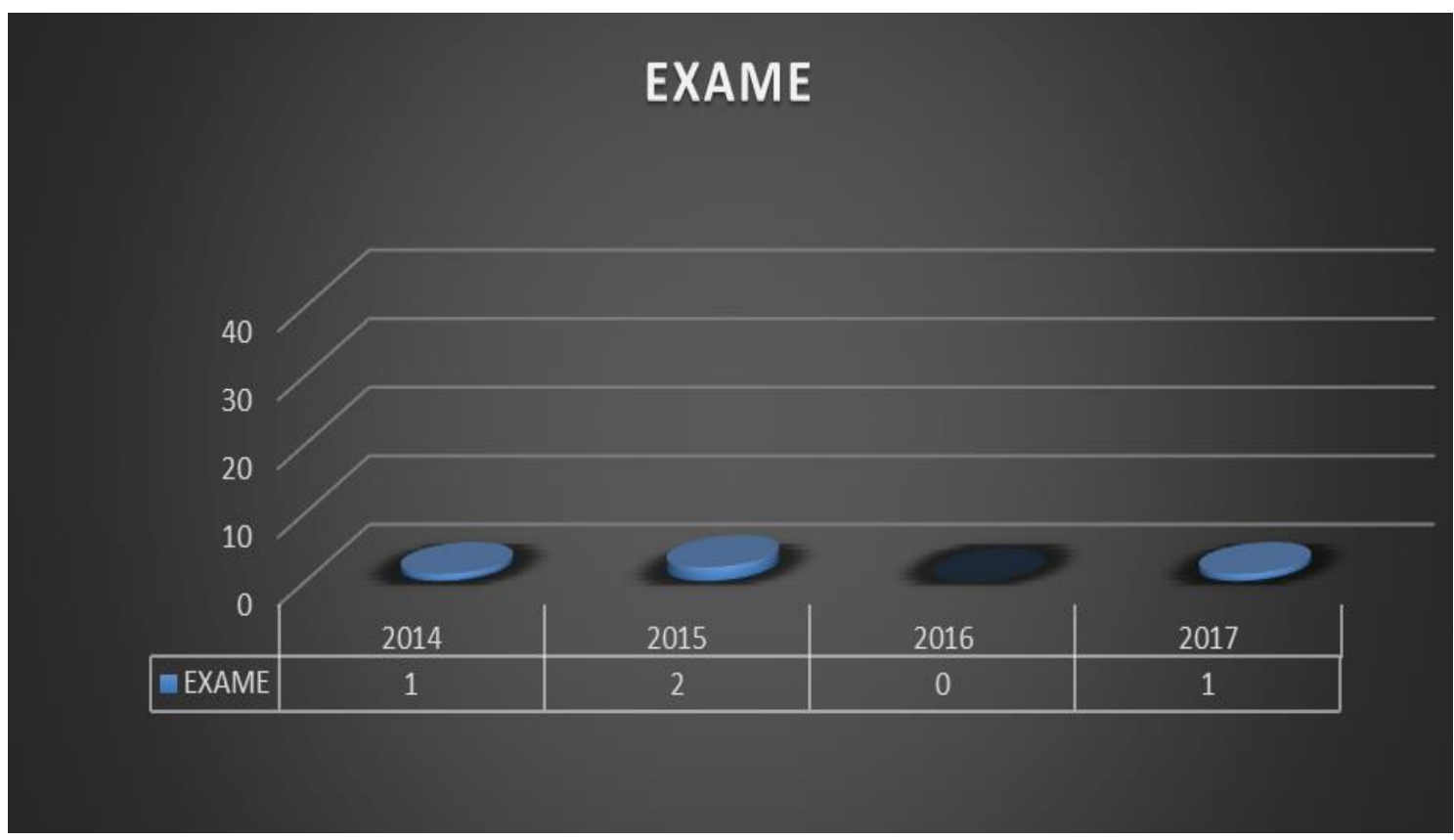


Figura 16 - Internação

\section{INTERNAÇÃO}

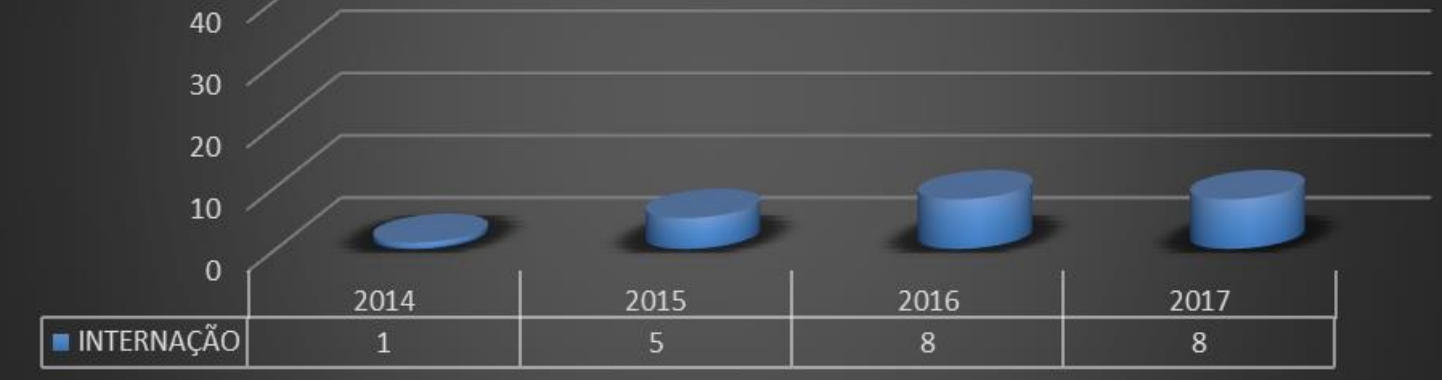

Com grande destaque, os itens que mais aparecem nos processos judiciais pesquisados são o fornecimento de medicamentos diversos (Figura 17) e fraldas (Figura 19). Ações judiciais objetivando pedidos de transporte para realização de um determinado tratamento, normalmente, hospitalar, apresentaram apenas cinco pedidos em 2014, três em 2015 e um pedido em cada ano de 2016 e 2017 (Figura 18).

Figura 17 - Medicamento

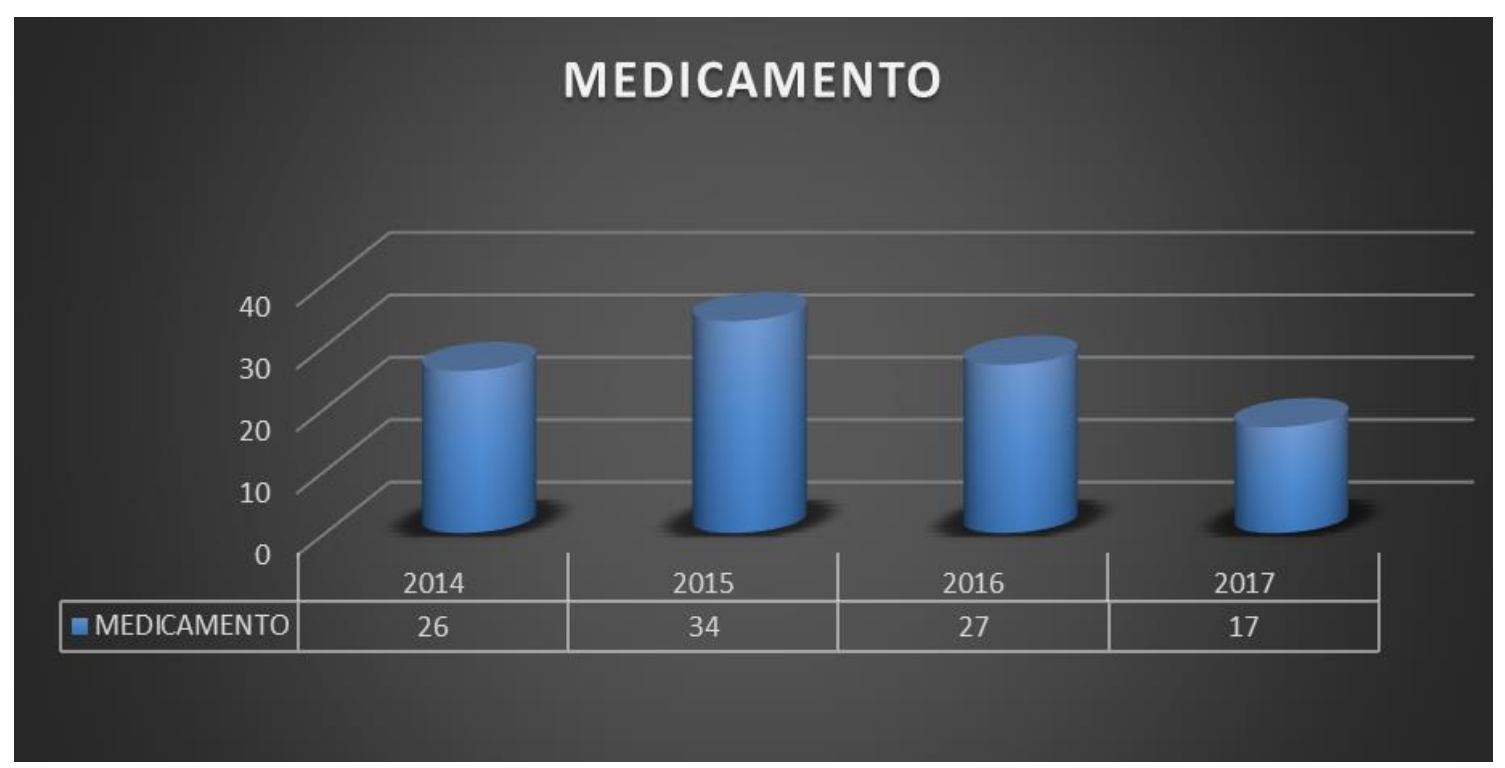


Figura 18 - Transporte

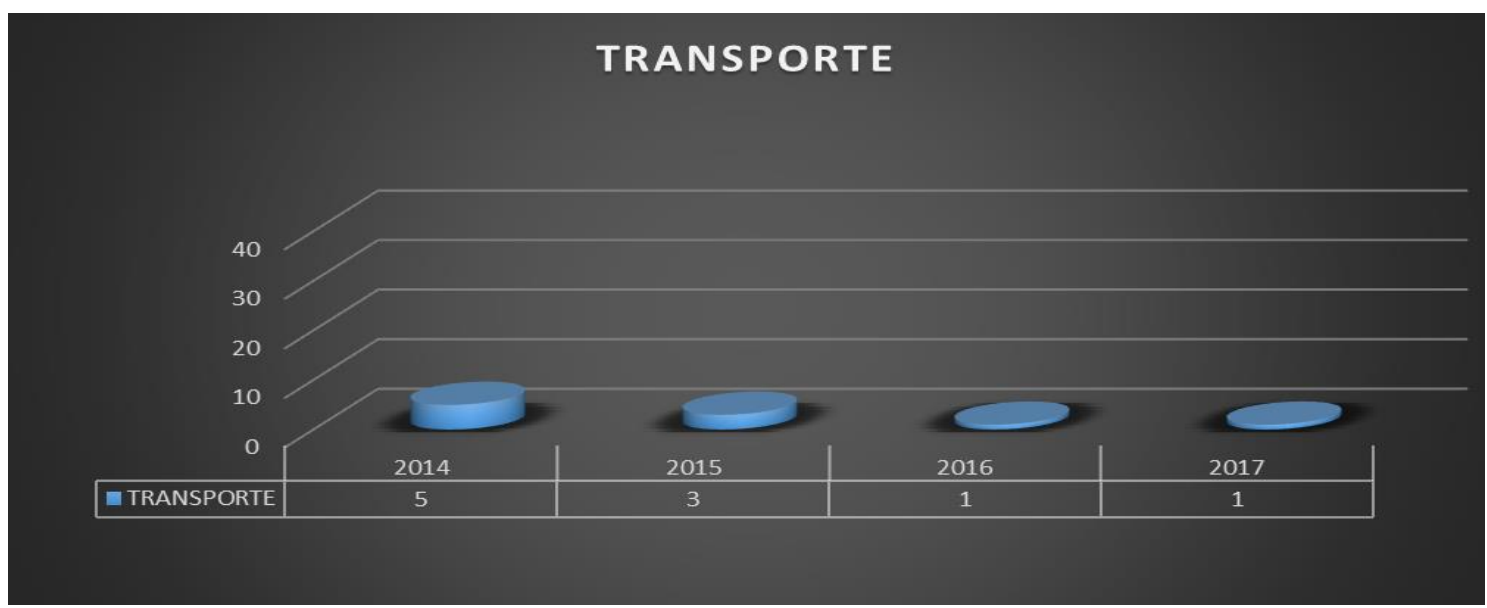

Figura 19 - Fralda

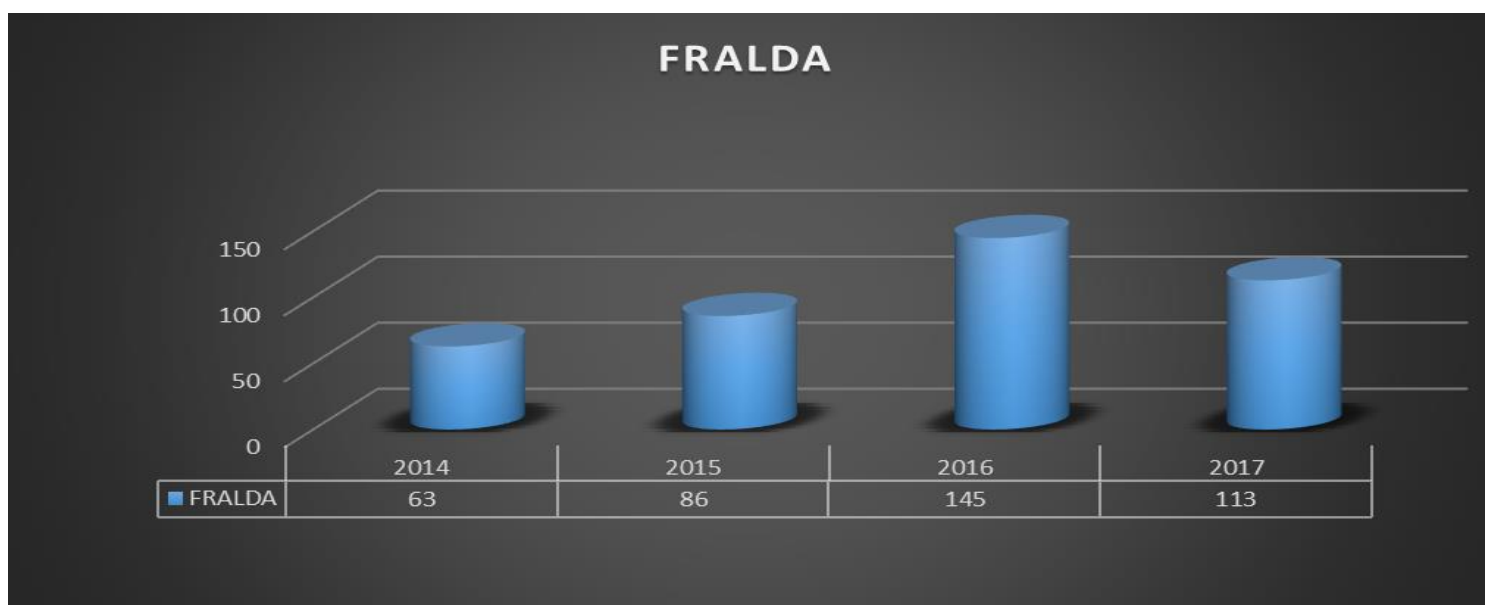

Figura 20 - Segredo de Justiça

\section{SEGREDO DE JUSTIÇA}

30

20

10

0 
5.3 Do impacto orçamentário das ações judiciais no Município de Bauru período 2014 a 2017

Segundo apurado junto à Secretaria Municipal de Saúde e à Secretaria Municipal de Economia e Finanças, os valores orçamentários destinados às ações judiciais de saúde são divididos em duas fontes de custeio: medicamento judicial e material hospitalar decorrente de cumprimento de mandado judicial. São os denominados centros de custo.

Conforme salientado acima, o sistema administrativo no Município não é integralmente informatizado, razão pela qual não há dados específicos de quanto foi gasto com cada item de saúde objeto desta pesquisa, no período de 2014 a 2017.

A empresa contratada atualmente responsável pela coleta e informatização dos dados é a SMARAPD Informática Ltda.

A Tabela 07 demonstra que medicamento judicial lidera 0 gasto orçamentário na saúde, perfazendo um total de $R \$ 2.663 .856,81$ (dois milhões, seiscentos e sessenta e três mil, oitocentos e cinquenta e seis reais e oitenta e um centavos) para o período pesquisado, enquanto material hospitar perfaz o montante de $R \$$ 2.262.274,68 (dois milhões, duzentos e sessenta e dois mil, duzentos e setenta e quatro reais e sessenta e oito centavos).

\section{Tabela 07 - Custo Anual da Judicialização da Saúde}

\begin{tabular}{|c|c|c|c|c|c|c|}
\hline \multicolumn{7}{|c|}{ Custo Anual Separado por Centro de Custo (Reais) } \\
\hline $\begin{array}{c}\text { Centro } \\
\text { de } \\
\text { Custo }\end{array}$ & $\begin{array}{c}\text { Descrição do } \\
\text { Centro de } \\
\text { Custo }\end{array}$ & 2014 & 2015 & 2016 & 2017 & TOTAL \\
\hline 304 & $\begin{array}{c}\text { MEDICAMENTO } \\
\text { JUDICIAL }\end{array}$ & $486.749,22$ & $1.237 .487,62$ & $628.900,71$ & $310.719,26$ & $2.663 .856,81$ \\
\hline $\begin{array}{c}\text { MATERIAL } \\
\text { HOSPITALAR } \\
\text { MJ }\end{array}$ & $296.156,44$ & $122.268,93$ & $1.070 .535,12$ & $773.314,19$ & $2.262 .274,68$ \\
\hline \multicolumn{1}{|c|}{ TOTAL } & $\mathbf{7 8 2 . 9 0 5 , 6 6}$ & $\mathbf{1 . 3 5 9 . 7 5 6 , 5 5}$ & $\mathbf{1 . 6 9 9 . 4 3 5 , 8 3}$ & $\mathbf{1 . 0 8 4 . 0 3 3 , 4 5}$ & $\mathbf{4 . 9 2 6 . 1 3 1 , 4 9}$ \\
\hline
\end{tabular}

Fonte: SMARAPD. 
Figura 21 - Custo Anual por Centro de Custo

\section{Custo Anual por Centro de Custo}

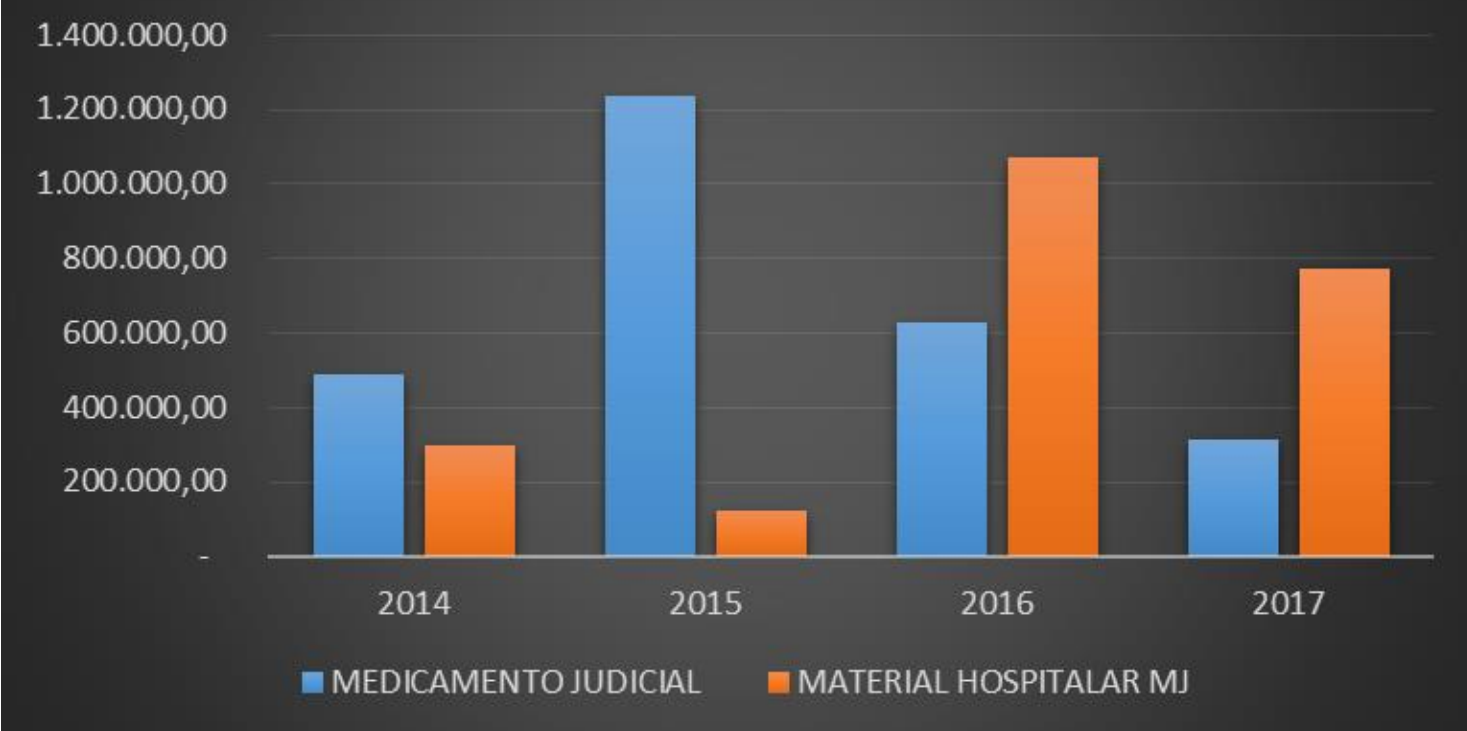

Os medicamentos tiveram maior gasto no ano de 2015, conforme demonstrado na Figura 22, enquanto os materiais hospitalares apresentaram gasto mais significativo no ano de 2016 (Figura 23).

Figura 22 - Custo Anual Medicamento Judicial

\section{Custo Anual Medicamento Judicial}

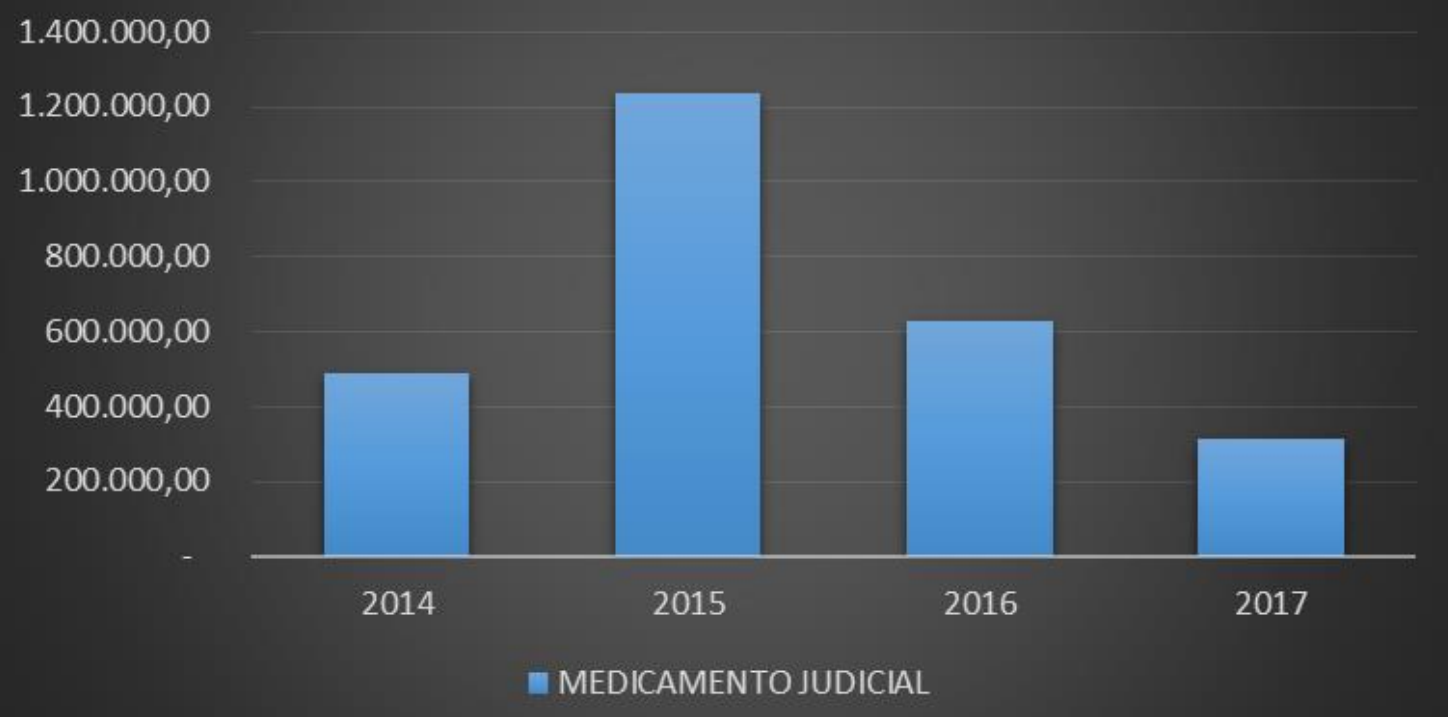


Figura 23 - Custo Anual Material Hospitalar

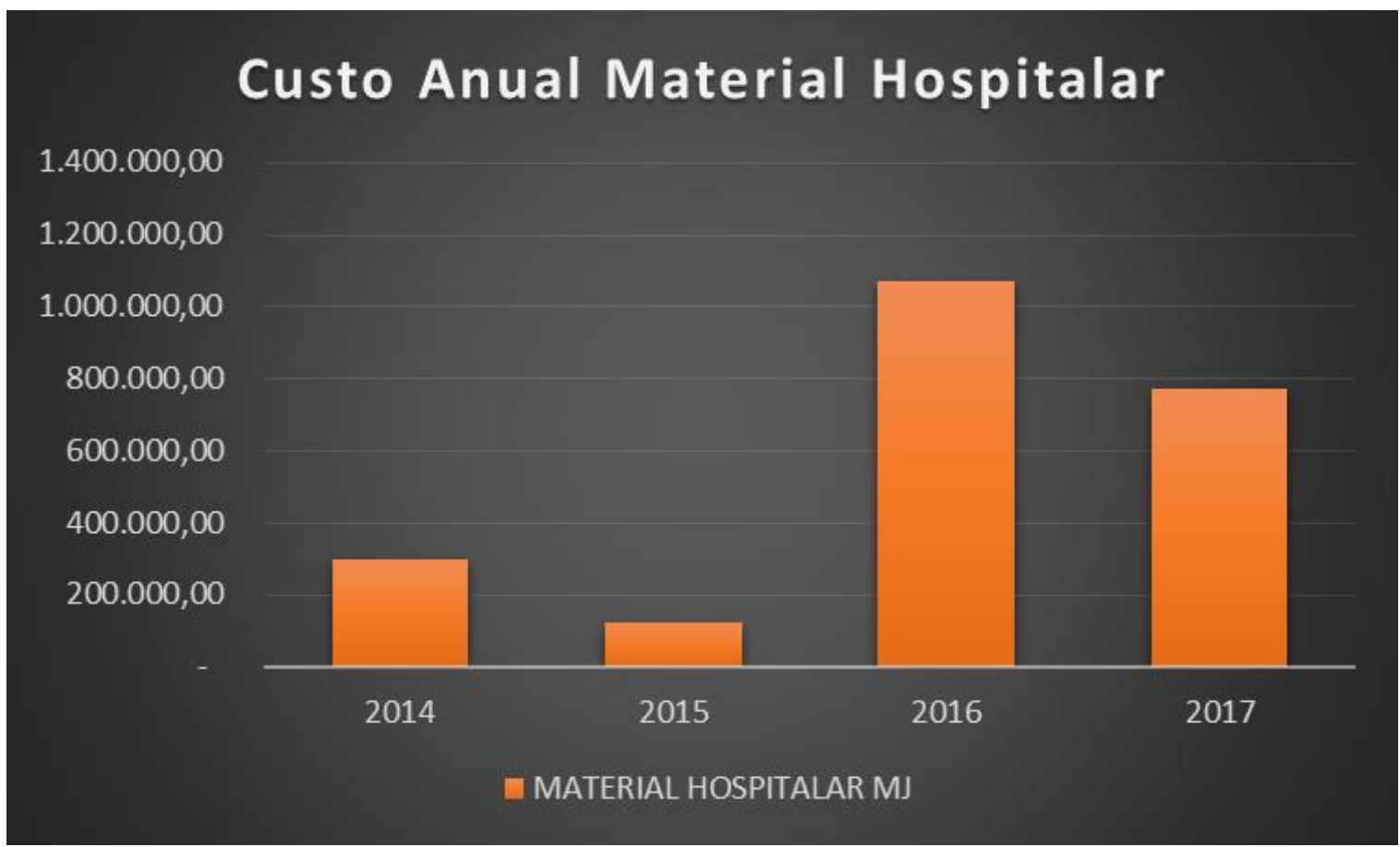

Dentre o período pesquisado - 2014 a 2017 - o ano de 2016 apresentou maior custo despedido com a judicialização (Figura 24).

Figura 24 - Custo Total por Ano

\section{Custo Total por Ano}

\section{$1.800 .000,00$ \\ $1.600 .000,00$ \\ $1.400 .000,00$ \\ $1.200 .000,00$ \\ $1.000 .000,00$ \\ $800.000,00$ \\ $600.000,00$ \\ $400.000,00$ \\ $200.000,00$}
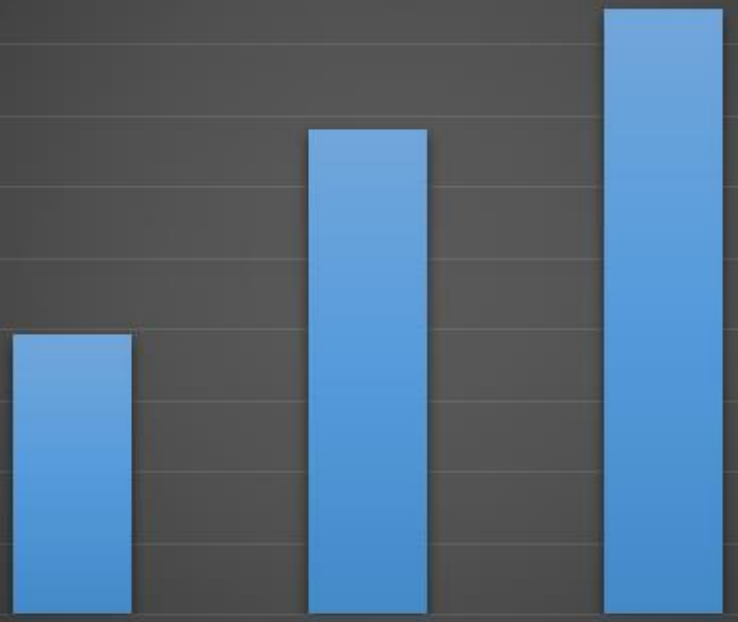

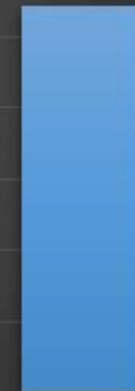

2017 
6 Discussão 



\section{DISCUSSÃO}

Dos 712 processos judiciais pesquisados, no período de 2014 a 2017, 25 tiveram como objeto alimentação especial, 36 buscavam agendamento de consulta médica, 11 tiveram como pedido a apresentação de prontuário médico, também foram 11 pedidos de cirurgia, 05 pleitearam o fornecimento de cuidador/home care, 04 processos eram de dano moral/material e 04 objetivando a realização de exames diversos, 16 pedidos de insumos/material hospitalar, internação hospitalar somaram 22 pedidos, medicamentos foram 104 ações, transporte de paciente apenas $10 \mathrm{e}$, com grande destaque, foram 407 ações propostas requerendo o fornecimento de fraldas. Importante destacar que 57 processos correram em segredo de justiça, o que não nos permitiu uma análise detalhada.

Num Estado Democrático de Direito, todas as atividades administrativas podem ser submetidas ao controle do Poder Judiciário, na medida em que "[...] a lei não excluirá da apreciação do Poder Judiciário lesão ou ameaça a direito" (art. $5^{\circ}$, inc. XXXV da Constituição Federal de 1988).

O preceito constitucional supra citado, evidentemente, engloba as políticas públicas, as quais devem ser criadas visando à concretização de direitos fundamentais, dentre eles, o direito à saúde aqui tratado. Um dos grandes desafios é a dificuldade de acesso integral.

Muito embora inúmeros sejam os programas sociais, o fato é que as necessidades humanas são infinitas, abrindo um amplo espaço para a atuação jurisdicional em prol dos necessitados.

Evidentemente, é trabalho árduo e constante a difícil equação em equilibrar os anseios da comunidade jurisdicionada e o dinheiro público necessário a tanto.

Se, por um lado, o Poder Público deve ampliar os recursos financeiros, ano a ano, para abranger os itens de carência social na área da saúde, repetidos frequentemente nas ações judiciais, por outro, compete ao Estado orientar a população, em termos de conscientização sobre a importância ou não de um determinado pedido, inclusive com orientação técnica clínica a respeito de eventuais caminhos alternativos de tratamento. 
Neste sentido, conforme mencionado no Capítulo 2.4, começa a haver uma preocupação dos tribunais com o excesso de judicialização. Prova disso é a recente decisão ${ }^{16}$ do Supremo Tribunal Federal onde julgou que o Estado não é obrigado a fornecer medicamentos de alto custo solicitados judicialmente, quando não estiverem previstos na relação do Programa de Dispensação de Medicamentos em Caráter Excepcional, do Sistema Único de Saúde (SUS).

Aludida decisão do Supremo Tribunal Federal ressaltou que, em caráter excepcional, é possível a concessão de medicamentos não registrados na lista da Anvisa. Nesse sentido, os ministros fizeram a ponderação entre diversos argumentos, como as garantias constitucionais, entre elas, a concretização dos direitos fundamentais, o direito à vida e à dignidade da pessoa humana.

Quanto aos medicamentos, insumos, tratamentos, sem registro na ANVISA e, por via de consequência, não disponibilizados pelo SUS, a questão na via judicial já costumava ser resolvida invocando-se o direito à vida, à saúde e à dignidade da pessoa humana.

[...] no controvertido tema do direito à saúde, sobretudo quando envolvidos procedimentos médicos e medicamentos não oferecidos no âmbito do Sistema Único de Saúde - SUS, a dignidade humana também costuma ser invocada como argumento último, que encerra a discussão. A circunstância de que o orçamento da saúde é finito e que, portanto, em muitas situações, destinar os recursos ao atendimento de uma pretensão judicial é retirá-los de outros destinatários, agrega complexidade ao debate. Com frequência, a ponderação adequada a se fazer envolve a vida, a saúde e a dignidade de uns versus a vida, a saúde e a dignidade de outros (BARROSO, 2010, p 32).

A Resolução oㅜ 238, de 06 de setembro de 2016, do CNJ (Anexo C), que dispõe sobre a criação e manutenção, pelos Tribunais de Justiça e Regionais Federais de Comitês Estaduais da Saúde, bem como a especialização de vara em comarcas com mais de uma vara de Fazenda Pública, também deve ser encarada como mais uma medida no enfrentamento da judicialização.

Certamente, diante da complexidade do tema, as varas especializadas em saúde pública contribuíram para uma padronização das decisões judiciais, com

16 Decisão proferida em 11 de março de 2020. Recurso Extraordinário (RE) № 566.471. Disponível em: <http://www.stf.jus.br>. Acesso em: 10 mai. 2020. 
apoio técnico adequado e uma maior capacitação dos magistrados em direito sanitário.

Não foi objeto de análise a condição financeira dos autores dos processos, mas a prática mostra que, via de regra, são pessoas mais instruídas e com maior poder aquisitivo que têm ciência dos seus direitos e a forma de exercêlos, que conhecem os mecanismos de acesso ao Judiciário.

Os resultados demonstram a variedade de objetos pleiteados judicialmente: alimentação/dieta especial, apresentação de prontuário médico, cirurgia, agendamento de consulta médica, condenação em dano moral e/ou material, cuidador/home care, realização de exames, fornecimento de fraldas, material hospitalar, insumos diversos, medicamentos e transporte para realização de tratamentos específicos ou curativos de rotina, além de pedidos para internações ambulatoriais e em UTI.

Estudo análogo (MAPELLI JÚNIOR, 2017) também constatou a diversidade de produtos objeto das ações judiciais no Estado de São Paulo, o que dificulta, sobremaneira, a organização da atividade administrativa.

Com exceção do ano de 2017, os demais anos pesquisados mostraram um aumento crescente da judicialização da saúde no âmbito do Município de Bauru. Essa possível redução de ações judiciais no ano de 2017, acreditamos que seja devida muito mais a uma falha de controle administrativo interno com relação ao cadastramento dos processos, já que a informatização é incipiente, do que propriamente uma diminuição da judicialização na área da saúde. Isso porque quando se fala em judicialização da saúde, há sempre um aumento e não uma diminuição.

Dados semelhantes (fonte: Tribunal de Justiça do Rio de Janeiro, com acesso em 04/01/2019), demonstram o crescimento de demandas judiciais ajuizadas na área da saúde, no Estado do Rio de Janeiro, as quais passaram de 36 mil ações em 2013 para 40 mil em 2014, 43 mil em 2015, 45 mil em 2016, 49 mil em 2017e 50 mil em 2018.

O mesmo se verifica em pesquisa realizada (MAPELLI JÚNIOR, 2017) com dados do Sistema CODES da Secretaria de Estado da Saúde de São Paulo, onde se confirma a expansão das demandas individuais por medicamentos e outros 
insumos de saúde, apresentando 9385 ações judiciais em 2010, 11.633 em 2011, 12.031 em 2012, 14.080 em 2013 e 14.383 em 2014.

Constatamos que o objeto mais frequentemente requerido nas ações pesquisadas foi fralda, sendo 63 pedidos no ano de 2014, 86 pedidos no ano de 2015, 145 pedidos no ano de 2016 e 113 pedidos no ano de 2017.

A Tabela 01 se refere ao ano de 2014 e teve um total de 131 processos pesquisados. Não constatamos pedidos para apresentação de prontuário médico, nem pedidos de dano moral/material.

A Tabela 02 se refere ao ano de 2015 e teve um total de 163 processos pesquisados. Não constatamos pedidos para fornecimento de cuidador/home care, nem pedidos de apresentação de prontuário.

A Tabela 03 se refere ao ano de 2016 e teve um total de 235 processos pesquisados. Não constatamos pedidos de exames médicos.

A Tabela 04 se refere ao ano de 2017 e teve um total de 183 processos pesquisados, onde houve acionamento do Poder Judiciário para todos os itens (objeto) elencados na pesquisa.

Por fim, a Tabela 05 traz todos os anos pesquisados, perfazendo um total de 712 processos.

Pedidos judiciais para fornecimento de cuidador/home care apresentaram dados pouco significativos (Figura 12), o que sugere uma investigação posterior mais detalhada na jurisprudência dos tribunais sobre o deferimento judicial de ações com esse objeto.

Conforme salientado acima, a intenção da pesquisa foi demonstrar a variedade dos objetos requeridos na via judicial quando se fala em judicialização da saúde. Assim, optamos por elencar os mais variados objetos, ainda que em alguns anos não tenha havido nenhuma constatação de um determinado item.

Os tipos de ação judicial foram separados em mandado de segurança e outros procedimentos. Isso porque a grande maioria das ações na área da saúde se dá via mandado de segurança, conforme demonstra a Tabela 06, onde consta um 
total de 518 ações judiciais via mandado de segurança, para o período total pesquisado, contra 194 ações onde foram adotados outros procedimentos para viabilizar o direito de ação. Os "outros procedimentos" englobam medidas cautelares, ações de rito ordinário e sumaríssimo, ação civil pública e ações coletivas.

Quanto ao impacto orçamentário, dentre o período pesquisado, o ano de 2016 apresentou o maior custo com a judicialização da saúde, o que é plenamente justificado pelo número de ações judiciais apuradas, ou seja, os dados mostraram um maior número de ações judiciais no ano de 2016 - 235 processos, sendo que os anos de 2014, 2015 e 2017 tiveram 131, 163 e 183 ações ajuizadas, respectivamente.

De tudo o que visto até aqui, merece destaque o uso do processo judicial como caminho predominante para a solução do acesso aos serviços de saúde, incluídos bens e medicamentos necessários a um determinado tratamento.

De fato, seja porque a Administração resista sobre a relevância do próprio bem ou serviço como melhor opção ao paciente, seja porque insuficientes a dotações orçamentárias, há muito vive o Judiciário um aumento significativo de demandas, como o demonstram as pesquisas e dados coletados ao longo do presente trabalho, destaque para o item fralda, o qual apresentou o maior número de pedidos nos processos judiciais pesquisados.

Neste contexto, o Princípio da Separação dos Poderes não pode ser utilizado para obstar o direito à saúde, com espectro constitucional. Ao contrário, rememorando-se que a saúde é direito fundamental, expressão máxima da dignidade da pessoa humana, os tribunais devem estar atentos a demandas reparadoras de lesão ou ameaça a esse bem jurídico indisponível. ${ }^{17}$

\subsection{Sugestão de política pública}

Objetivando diminuir a judicialização da saúde, o Poder Executivo Municipal poderia disponibilizar à população o fornecimento de fraldas, mediante

17 Supremo Tribunal Federal, RE № 271.286 Agr/RS. 
receituário médico, nos postos de saúde e na farmácia popular, uma vez que a grande maioria dos processos pesquisados tem como objeto esse insumo.

Importante destacar que o objeto fralda tratado neste trabalho se refere apenas a insumo de saúde, no caso, fralda geriátrica ou fralda infantil para crianças com patologia. Daí a necessidade da política pública ora proposta incidir tão somente para a área da saúde, não englobando, por óbvio, o fornecimento de fraldas às crianças recém nascidas ou na tenra idade.

A implementação desse tipo de política pública, certamente, traria grandes benefícios econômicos ao Município, na medida em que o ente estatal deixaria de ser condenado ao pagamento de honorários advocatícios e custas processuais nas ações judiciais com esse objeto que, como vimos nos resultados da pesquisa, são a grande maioria.

Também, o fornecimento de fraldas nos postos de saúde e na farmácia popular evitaria toda movimentação da máquina administrativa, em especial, da Procuradoria do Município, responsável pela elaboração das defesas nos processos judiciais, desperdício de tempo e dinheiro, uma vez que é pacífico o entendimento dos tribunais no sentido da concessão desse tipo de insumo. Sobre o assunto, seguem os julgados abaixo:

MANDADO DE SEGURANÇA - Fornecimento de fraldas geriátricas descartáveis - Dever do Estado, direito do povo - Art. 196 da Constituição da República, norma programática que não constitui promessa constitucional inconsequente (STF, $2^{\text {a }}$ Turma, AgRE no 273834-4-RS, Rel. Min. Celso de Mello) - Segurança concedida - Sentença mantida Reexame necessário e recurso de apelação desprovidos (TJ/SP - Apelação / Reexame Necessário no 990101745380 - Relator(a): J. M. Ribeiro de Paula - Órgão julgador: 12a ${ }^{\mathrm{a}}$ Câmara de Direito Público - Data do julgamento: 04/08/2010).

MANDADO DE SEGURANÇA - Fornecimento de Fraldas geriátricas descartáveis - Dever do Estado, direito do povo - Art. 196 da Constituição da República, norma programática que não constitui promessa constitucional inconsequente (STF, 2 a Turma, AgRE no 273834-4-RS, Rel. Min. Celso de Mello) - Segurança concedida - Sentença mantida - Reexame necessário e recurso de apelação desprovidos (TJ/SP - Apelação no 994092570203 (9730485800) - Relator(a): J. M. Ribeiro de Paula - Órgão julgador: $12^{\mathrm{a}}$ Câmara de Direito Público - Data do julgamento: 23/06/2010).

APELAÇÃO CÍVEL - MANDADO DE SEGURANÇA E PRESTAÇÃO DE SERVIÇO PÚBLICO - O Sistema Único de Saúde é financiado com recursos da seguridade social, da União, dos Estados Membros, do Distrito Federal e dos Municípios, além de outras fontes, razão pela qual o Estado é 
parte legítima para responder aos termos da presente demanda - Preliminar rejeitada - A impetrante é portadora de incontinência urinaria e necessita do uso de fraldas geriátricas descartáveis - Não obtenção junto ao Poder Público - Ausência de condições financeiras para custeá-las - O Artigo 196 da Constituição Federal é norma de eficácia imediata e assegura a todo cidadão o direito à saúde, como dever do Estado - Direito que não se limita apenas ao aspecto hospitalar, mas também ao fornecimento, pelo Poder Público, da terapia e respectivo remédio ao necessitado - Inaplicabilidade da teoria da reserva do possível, dada natureza do bem jurídico tutelado Precedente - Poder Judiciário que apenas atribui efetividade ao mandamento constitucional - Reexame necessário e recurso voluntário não providos (TJ/SP - Apelação / Reexame Necessário no 994092349910 (9926145000) - Relator(a): Osvaldo de Oliveira - Órgão julgador: 12 Câmara de Direito Público - Data do julgamento: 23/06/2010).

MANDADO DE SEGURANÇA - FORNECIMENTO GRATUITO DE FRALDAS GERIÁTRICAS ADMISSIBILIDADE - REQUISITOS FÁTICOS EXIGIDOS PARA A CONCESSÃO - COMPROVAÇÃO OBRIGATORIEDADE DA ADMINISTRAÇÃO PÚBLICA, POR MEIO DO SUS, DE FORNECER INSUMOS MÉDICOS AO NECESSITADO PROCEDÊNCIA DA AÇÃO MANTIDA - RECURSOS IMPRO VIDOS (TJ/SP - Apelação / Reexame Necessário no 990101462818 - Relator(a): Ferraz de Arruda - Órgão julgador: 13 $3^{\text {a }}$ Câmara de Direito Público - Data do julgamento: 16/06/2010).

[...] urinaria e fecal - Necessidade de fraldas geriátricas descartáveis Dever do Estado em prestar a assistência pretendida, sobretudo diante da impossibilidade financeira do impetrante - Jurisprudência pacífica sobre 0 assunto - Segurança mantida - Recursos ex officio e voluntário desprovidos (TJ/SP - Apelação / Reexame Necessário no 990100795791 - Relator(a): Wanderley José Federighi - Órgão julgador: $12^{\mathrm{a}}$ Câmara de Direito Público - Data do julgamento: 23/06/2010).

MANDADO DE SEGURANÇA - FORNECIMENTO DE FRALDAS DESCARTÁVEIS - Dever do Estado de prestar atendimento integral à saúde (art. 198, II, da CF) - Tutela constitucional do direito à vida (artigo 196 da CF) - Preliminares afastadas - Concessão da segurança Sentença mantida - Recurso voluntário e reexame necessário improvidos (TJ/SP Apelação / Reexame Necessário no 990101354721 - Relator(a): Burza Net - Órgão julgador: 12a Câmara de Direito Público - Data do julgamento: 23/06/2010).

MANDADO DE SEGURANÇA - OBJETIVO - FORNECIMENTO PELA AUTORIDADE IMPETRADA DE CADEIRAS DE RODAS E FRALDAS DESCARTÁVEIS PARA PORTADORA DE GRAVE SEQUELA NEUROMOTORA - DIREITO LÍQUIDO E CERTO ASSEGURADO PELO ART. 196 DA CONSTITUIÇÃO FEDERAL - ORDEM CONCEDIDA SENTENÇA CONFIRMADA (TJ/SP - Apelação/Reexame Necessário ํo 994060776728 (5738745000) - Relator(a): Ricardo Feitosa - Órgão julgador: 4a Câmara de Direito Público - Data do julgamento: 05/07/2010).

MANDADO DE SEGURANÇA - Fornecimento de Fraldas geriátricas descaráveis - Dever do Estado, direito do povo - Art. 196 da Constituição da República, norma programática que não constitui promessa constitucional inconsequente (STF, 2ª Turma, AgRE no 273834-4-RS, Rel. Min. Celso de Mello) - Segurança concedida - Sentença mantida Reexame necessário e recurso de apelação desprovidos (TJ/SP - Apelação 
/ Reexame Necessário no 990101080079 - Relator(a): J. M. Ribeiro de Paula - Órgão julgador: 12 ${ }^{\mathrm{a}}$ Câmara de Direito Público - Data do julgamento: 04/08/2010).

APELAÇÃO - Mandado de Segurança - Fornecimento gratuito de fraldas geriátricas - Inadmissibilidade de recusa pela Administração Pública Defesa de direito indisponível (direito à saúde) de pessoa enferma e hipossuficiente - $\mathrm{O}$ atendimento ao impetrante é medida de rigor, ante a proteção constitucionalmente prevista que se relaciona com o direito à vida e à dignidade da pessoa humana - Inteligência do art. 196 da Constituição Federal - Reexame necessário desacolhido e recurso voluntário desprovido (TJ/SP - Apelação / Reexame Necessário no 990100238817 - Relator(a): Sérgio Gomes - Órgão julgador: 9 ${ }^{a}$ Câmara de Direito Público - Data do julgamento: 07/07/2010).

SAÚDE. Idosa que sofre de cardiopatia e em recuperação de infecção de intestino e bexiga. Ação julgada procedente para obrigar o Município de Franca a fornecer ao autor o medicamento OMEPRAZOL e a Fazenda do Estado a the fornecer fraldas e os medicamentos IMOSEC e PLAMET. Necessidade comprovada por prescrições médicas da rede pública de saúde e não impugnada de forma fundada pelas rés. Condenação amparada no artigo 196 da Constituição Federal. Recursos oficial, que se considera interposto, e voluntário improvidos, com observação (TJ/SP Apelação no 990102692256 - Relator(a): Antonio Carlos Villen - Órgão julgador: 10 ${ }^{\underline{a}}$ Câmara de Direito Público - Data do julgamento: 09/08/2010).

OBRIGAÇÃO DE FAZER - Prestação de serviço público - Fornecimento de fraldas geriátricas descartáveis e de dieta especial do tipo Nutren 1.0, para portadora de esclerose múltipla, síndrome parkinsoniana, atrofia e enrijecimento dos membros superiores e inferiores - Direito constitucional à saúde - Artigo 196 da Constituição da República. Sentença de procedência confirmada. HONORÁRIOS ADVOCATÍCIOS - Fixação em $\mathrm{R} \$ 600,00$ - Valor que se mostra razoável e nos limites do artigo 20, $\S \S$ $3^{\circ}$ e $4^{\circ}$ do CPC - Inexistência de impedimento de imposição de honorários de sucumbência ao advogado da parte vencedora, mesmo que integre o convênio $\mathrm{OAB} /$ Defensoria Pública, já que as verbas possuem natureza distinta, não se podendo falar em confusão. Recurso improvido (TJ/SP - Apelação no 990.10.203618-9 - Relator(a): Carlos Eduardo Pachi - Órgão julgador: 6 ${ }^{\underline{a}}$ Câmara de Direito Público - Data do julgamento: 14/06/2010).

MEDICAMENTO - OBRIGAÇÃO DE FAZER COM PEDIDO DE TUTELA ANTECIPADA - Liminar concedida - Resistência da entidade pública em fornecer fraldas para IDOSA, portadora de diversos problemas de saúde Presentes os requisitos para a concessão - Verossimilhança dos fatos articulados na exordial e prova documental inequívoca - Atribuição do Sistema Único de Saúde do Estado de assistência clínica integral, inclusive medicamentos e insumos - Inteligência do disposto nos artigos 196 da Constituição Federal e 219 da Estadual - Jurisprudência dominante que estabelece o dever inarredável do Poder Público - Sentença mantida Recurso voluntário da ré improvido (TJ/SP - Apelação no 990101184532 Relator(a): Rebouças de Carvalho - Órgão julgador: 9a Câmara de Direito Público - Data do julgamento: 16/06/2010).

OBRIGAÇÃO DE FAZER - Prestação serviço público - Fornecimento de fraldas a portador de tetraparesia estática com retardo do desenvolvimento neuropsicomotor - Alegado direito à vida e à saúde, cabendo ao Estado 
propiciar o atendimento médico da impetrante, fornecendo os insumos prescritos - É necessário que esse direito venha a ser respeitado e implementado pelo Estado, destinatário do comando Constitucional? Recursos não providos (TJ/SP - Apelação oํ 994092480674 (9856915400) - Relator(a): Magalhães Coelho - Órgão julgador: $3^{\text {a }}$ Câmara de Direito Público - Data do julgamento: 13/04/2010).

Sendo a saúde um direito fundamental, compete ao Estado promover os meios adequados para a sua efetivação, principalmente quando se constata a necessidade de um determinado insumo, o qual, ano a ano, vem sendo judicializado pela população.

A reserva do possível não é fator integrante do direito fundamental à saúde, mas cláusula limitadora, daí porque a efetivação desse direito só será alcançada se houver priorização das ações nessa área.

Paralelamente à implantação da política pública ora proposta, imperativa se faz a informatização urgente de toda a administração municipal. Nos dias de hoje é inaceitável não sabermos, por exemplo, quanto se gasta anualmente com um determinado insumo de saúde, medicamento ou tratamento específico. 
7 Conclusões 



\section{CONCLUSÕES}

A judicialização da saúde não envolve apenas os profissionais de direito, mas também os gestores públicos, os profissionais da saúde e toda a sociedade civil. Se, por um lado, o Poder Judiciário deve atuar para a concretização dos direitos fundamentais do cidadão, expressão máxima da dignidade da pessoa humana, por outro lado, é bem verdade que as decisões judiciais impactam diretamente nas políticas públicas previamente fixadas pelos governos locais e nas possibilidades orçamentárias.

Na prática, o mínimo existencial deve se compatibilizar com a reserva do possível. O bom senso é a medida que se impõe, daí a necessidade de fixação de critérios objetivos, leis e regulamentos específicos para a judicialização ora debatida, além da ampliação das políticas públicas na área da saúde.

Dentro das limitações orçamentárias, o Estado deve priorizar a aplicação dos recursos públicos na concretização do direito fundamental à saúde, em respeito ao mínimo existencial e à dignidade da pessoa humana.

Não há qualquer afronta ao princípio da separação de poderes quando o Judiciário intervém nas decisões administrativas estatais, buscando a efetivação do direito à saúde. Tal atribuição emana da Constituição Federal e, portanto, é legítima e garante o ideário trazido pelo Estado Democrático de Direito, tendo em vista que o direito fundamental à saúde é verdadeira expressão da dignidade da pessoa humana.

Uma vez violado o mínimo existencial, através da omissão na efetividade do direito fundamental à saúde, surge o direito à judicialização.

No tocante aos tratamentos, medicamentos e insumos ainda sem comprovação efetiva, muitas vezes de altíssimo custo, logo, não registrados na ANVISA e ofertados pelo SUS, transfere-se à justiça o verdadeiro papel de protagonista, à qual muitas vezes incumbirá decidir quem vai morrer e quem vai viver, na medida em que tais condições de eficácia dificultarão a incorporação desses tratamentos em políticas públicas de acesso universal e igualitário. 
A pesquisa confirmou uma realidade já conhecida dos que atuam na área jurídica. A judicialização trata-se de fenômeno crescente e com abrangência cada vez maior tendo em vista a diversidade dos objetos das ações judiciais.

Isso porque, "[...] quanto maior o número de leis e de direitos constitucionalizados, maior será a atuação do Poder Judiciário, surgindo a todo instante o que se chama de judicialização" (BARROSO, 2014).

No contexto da presente pesquisa, apresento as conclusões:

a) a judicialização da saúde atua como mecanismo de efetivação dos direitos fundamentais, na medida em que garante ao jurisdicionado o acesso universal e igualitário preconizado na Carta Constitucional e na legislação infraconstitucional;

b) muito embora exista na área da saúde uma repartição de competências entre os entes federados, há por outro lado uma solidariedade constitucional para implementação de políticas públicas, o que estende a efetivação direta do direito à saúde, igualmente de forma solidária, aos Estados, Municípios, União e Distrito Federal, com maior facilidade de acionamento do Poder Público Municipal, em razão da proximidade local;

c) as ações judiciais, na área da saúde, no período de 2014 a 2017 foram em sua grande maioria procedentes, com pedido liminar deferido;

d) na prática, pelo teor das decisões judiciais, verifica-se que a teoria do mínimo existencial deve coexistir com o princípio da reserva do possível, sendo rechaçado o argumento isolado de falta de recursos orçamentários;

e) em virtude da quantidade de ações judiciais pleiteando o fornecimento de fraldas no Município de Bauru, a política pública proposta é de que seja disponibilizado esse insumo nos postos de saúde e farmácias populares, mediante receituário médico;

f) os 712 processos judiciais pesquisados apresentaram um impacto orçamentário de $\mathrm{R} \$ 4.926 .131,49$, conforme informações obtidas junto à Secretaria Municipal de Economia e Finanças de Bauru. 
Por derradeiro, se a judicialização da saúde vai retroceder ou aumentar, é um exercício de futurologia que não cabe adentrarmos neste momento, mas o fato é que a escassez de políticas públicas, as escolhas equivocadas do administrador para o emprego do dinheiro público, as dificuldades orçamentárias, vêm alimentando a judicialização, a qual se utiliza desse arranjo institucional entre os três poderes democráticos para avançar na história. 

$\underline{\text { Referências }}$ 



\section{REFERÊNCIAS}

ABRAHAM, M. Políticas públicas e o seu controle judicial na área da saúde: uma crítica à reserva do possível no Brasil. In: QUEIROZ, L. C. S. de; ABRAHAM, M.; CAMPOS, C. A. A. (orgs.). Estado fiscal e tributação. $2^{\mathrm{a}}$ ed. Rio de Janeiro: GZ, 2015.

ADAES, C. T. S. Leitura jurisprudencial do direito à saúde. In: Revista do Tribunal Regional Federal 1aㅡ Região, vol. 28, $n^{\circ s} 03 / 04$, p. 25-45. Brasília/DF, mar./abr. 2016.

ALBERGARIA NETO, J. S. de; GONTIJO, J. F. R. Análise econômica da judicialização da saúde: a necessária atenção aos custos dos direitos pelo Poder Judiciário. In: Juris Plenum, vol. 14, oㅜ 80. Caxias do Sul, mar./abr. 2018.

ALCÂNTARA, G. C. S. Judicialização da saúde: uma reflexão à luz da teoria dos jogos. In: Revista CEJ, vol. 16, no 57, p. 88-94. São Paulo, mai./ago. 2012. Disponível em: <http://www.jf.jus.br/ojs2/index.php/revcej/article/view/1592/1569>. Acesso em: 26 mar. 2013.

ALCARÁ, M.; AMARAL, S. T. (orgs.). Direito à saúde: a efetividade constitucional por meio de tutelas jurídicas. Olinda: Livro Rápido, 2016.

ALCARÁ, M.; GARABINI, V. M. B. (orgs.). Direito processual à saúde: a concretização de direitos e a efetivação de tutelas. Olinda: Livro Rápido, 2017.

ALEXY, R. Teoria de los derechos fundamentales. Madrid: Centro de Estudios Politicos y Constitucionales, 2002.

ALVES, A. J. Z. V.; SANTOS, C. L. dos. Anamnese e o juiz: contribuições à efetividade sistêmica da tutela antecipada antecedente nas ações individuais de saúde. In: Revista de Processo, vol. 42, № 266, p. 341-363. São Paulo, abr. 2017.

ALVES, C. F. O princípio constitucional da dignidade da pessoa humana: o enfoque da doutrina social da igreja. Rio de Janeiro: Renovar, 2001.

ALVES, D. G.; CARDOSO, H. R. Direito à saúde: por uma prestação ética do estado. Rio de Janeiro: Lumen Juris, 2017. 
ALVES, L. de S.; RETES, T. A. L. Judicialização da saúde. Belo Horizonte: D’Plácido, 2018.

ALVES, R. de A. V. Legalidade financeira e ativismo judicial: judicialização das políticas públicas. In: Revista da Seção Judiciária do Rio de Janeiro, nº 28, p. 141-166. Rio de Janeiro, ago. 2010.

"Judicialização", ativismo judicial e direito constitucional financeiro: uma análise da atividade judicial em matéria de saúde e educação. In: GOMES, M. L.; ALVES, R. de A. V.; ARABI, A. Y. M. (coords.). Direito financeiro e jurisdição constitucional. Curitiba: Juruá, 2016.

AMARAL, G. Direito, escassez e escolha. Renovar: Rio de Janeiro, 2001.

ANTUNES, E. H.; GONÇALVES, J. B. Redução da judicialização e efetivação das políticas públicas sob o enfoque do planejamento e gestão sistêmicos. In: Revista da Procuradoria-Geral do Estado do Rio Grande do Sul, vol. 32, oㅡ 67, p. 09-23. Porto Alegre, jan./jun. 2011.

ARAUJO JÚNIOR, E. J. R. de. A atuação do Poder Judiciário no acesso ao Sistema Único de Saúde (SUS): o caso do Tribunal de Justiça do Estado de São Paulo. In: DUARTE, C. S. (org.) et al. Reflexões acadêmicas para superar a miséria e a fome. Bauru: Canal 06, 2016.

ARAÚJO, C. P. de. A judicialização da saúde e a necessidade de assessoramento técnico do juiz para decidir. In: RIBEIRO, R. A. (org.) et al. A seguridade social em questão: da normatividade à jurisprudência. Belo Horizonte: D'Plácido, 2016.

ARAÚJO, C. P. de; LÓPEZ, É. M. P.; JUNQUEIRA, S. R. S. Judicialização da saúde: saúde pública e outras questões. Porto Alegre: Verbo Jurídico, 2016.

ARAÚJO, J. S. de. Os desafios da decisão judicial na concretização do direito à saúde. In: Revista dos Tribunais, vol. 105, nº 963, p. 111-127. São Paulo, jan. 2016.

ARCE Y FLOREZ, J. El derecho civil constitucional. 3르 ed. rev. atual. e ampl. Madrid: Civitas, 1991.

ARENDT, H. A condição humana. Tradução de Roberto Raposo. Posfácio de Celso Lafer. 10ª ed. Rio de Janeiro: Forense Universitária, 2001. 
ASENSI, F. D. Judicialização da saúde e Conselho Nacional de Justiça: perspectivas e desafios. In: Fórum Administrativo - Direito Público, vol. 16, no 186, p. 34-46. Belo Horizonte, ago. 2016.

ASENSI, F. D.; PINHEIRO, R. Judicialização da saúde no Brasil: dados e experiência. Brasília/DF: Conselho Nacional de Justiça, 2015.

BAHIA, A. G. M. F.; CASTRO, J. A. O Estado Democrático de Direito e a efetivação dos direitos sociais: o fenômeno da judicialização da saúde. In: Revista de Informação Legislativa [eletrônica], vol. 51, no 203, p. 127-141. Brasília/DF, jul./set. 2014.

BARBOSA, O. P. de A. et al. Os dilemas da bioética e da judicialização da saúde no Brasil. In: Revista Bonijuris, vol. 29, № 649, p. 16-23. Curitiba, dez. 2017.

BARCELOS, A. P. de. A eficácia jurídica dos princípios constitucionais e o princípio da dignidade da pessoa humana. Rio de Janeiro: Renovar, 2011.

O direito constitucional à saúde: o caminho percorrido e algumas reflexões para o futuro. In: FERRARI, S.; MENDONÇA, J. V. (orgs.). Direito em público: homenagem ao professor Paulo Braga Galvão. Rio de Janeiro: Lumen Juris, 2016.

BARROS, L. D. Fornecimento judicial de medicamentos sem registro na ANVISA \& de uso off-label: judicialização do direito à saúde. Curitiba: Juruá, 2016.

BARROSO, L. R. Da falta de efetividade a judicialização excessiva - direito à saúde, fornecimento gratuito de medicamentos e parâmetros para a atuação judicial. In: Interesse Público - Revista Bimestral de Direito Público, vol. 09, no 46, p. 31-62. São Paulo, nov./dez. 2007.

A dignidade da pessoa humana no direito constitucional contemporâneo: natureza jurídica, conteúdos mínimos e critérios de aplicação. Versão provisória para debate público. Mimeografado. Rio de Janeiro, 2010.

O novo direito constitucional brasileiro: contribuições para a construção teórica e prática da jurisdição constitucional no Brasil. Belo Horizonte: Fórum, 2014.

BERNARDES, F. C. P. A família contemporânea à luz da dignidade da pessoa humana. 205 f. Dissertação (Mestrado) - Instituição Toledo de Ensino. Centro de Pós-Graduação, Bauru, SP, 2007. 
BERTOTTI, B. M. de M. A. Da inefetividade à judicialização do direito fundamental à saúde: em busca de parâmetros adequados para a concessão de medicamentos de alto custo. In: Fórum Administrativo - Direito Público, vol. 16, no 187, p. 09-28. Belo Horizonte, set. 2016.

BÍBLIA SAGRADA. O velho e o novo testamento. Tradução de Euclides Martins Balancin, Ivo Storniolo e José Luiz Gonzaga do Prado. São Paulo: Sociedade Bíblica Católica Internacional e Paulus, 1990.

BOBBIO, N. A era dos direitos. Tradução de Carlos Nelson Coutinho. $5^{\underline{a}}$ ed. Rio de Janeiro: Campus, 1990.

BOLDRIN, P. H. M.; SEVERI, F. C. Desigualdades na judicialização de políticas públicas: um estudo de caso sobre demandas por direito à saúde ajuizadas pela Defensoria Pública do estado de São Paulo, regional de Ribeirão Preto. In: MARRARA, T.; AGUDO GONZÁLEZ, J. (orgs.). Controles da administração e judicialização de políticas públicas. São Paulo: Almedina, 2016.

BONAVIDES, P. Curso de direito constitucional. $25^{\underline{a}}$ ed. São Paulo: Malheiros Editores, 2010.

BOY, R.; BRAZ, M.; KRUG, B.; MIRANDA, A. B. B. de. Judicialização da saúde e assistência farmacêutica a doenças raras: o exemplo da mucopolissacaridose tipo I no Brasil. In: Revista da AJURIS, vol. 40, no 131, p. 271-283. São Paulo, set. 2013.

BRAGA, D. da C. Justiça é vida para Vanessa Valentina, frágil como uma borboleta, valente como uma guerreira. In: OLIVEIRA, A. V. de; FREITAS, V. P. de (coords.). Justiça Federal $\mathbf{5 0}$ anos: seus casos e suas causas contados por seus juízes. Curitiba: Prismas, 2017.

BRASIL. Código Civil Brasileiro (2002). Lei o 10.406, de 10 de janeiro de 2002. Brasília/DF. Câmara dos Deputados - Centro de Documentação e Informação, 2015.

Constituição (1988). Constituição da República Federativa do Brasil. Brasília/DF. Senado Federal; 2015.

BRAZ, K. V.; MONTENEGRO, S. L. A. Efetivação do direito à saúde e concessão de medicamentos via ação judicial. In: Temas de direito e saúde. Brasília/DF: Advocacia Geral da União, 2010. 4 vol. 
CAMBI, E. Neoconstitucionalismo e neoprocessualismo: direitos fundamentais, políticas públicas e protagonismo judiciário. São Paulo: Revista dos Tribunais, 2009.

CARLINI, A. A judicialização da saúde privada no Brasil: reflexões a partir da segurança jurídica e do protagonismo judicial. In: Segurança jurídica e protagonismo judicial: desafios em tempos de incertezas. Estudos jurídicos em homenagem ao Ministro Carlos Mário da Silva Velloso. Rio de Janeiro: GZ, 2017.

CARLOS NETO, D. Judicialização da saúde pública: uma análise contextualizada. $2^{\mathrm{a}}$ ed. rev. e ampl. Porto Velho: Motres, 2018.

CARNEIRO, B. L. V. A efetivação jurisdicional do direito à saúde: para uma análise da temática sob uma ótica tópica e concretista. Rio de Janeiro: Lumen Juris, 2016.

CARVALHO, A. S. D. de. (Des)governança na atuação do executivo e do judiciário na promoção da saúde brasileira. In: NOVELINO, M.; FELLET, A. (coords.). Separação de poderes: aspectos contemporâneos da relação entre Executivo, Legislativo e Judiciário. Salvador: JusPodivm, 2018.

CARVALHO, O. F. de; SOUZA, G. de A. O (des)equilíbrio da judicialização da saúde no Brasil: algumas perspectivas para o seu aperfeiçoamento. In: Fórum Administrativo - Direito Público, vol. 19, oㅡ 218, p. 91-107. Belo Horizonte, abr. 2019.

CASTELO, F. A. Direito à saúde e decisões estruturais: por uma judicialização mais racional e eficiente. In: Revista de Processo, vol. 42, no 274, p. 317-342. São Paulo, dez. 2017.

CASTRO, F. de A. V. de; VALLE, C.; ANSCHAU, L. C. D.; FERREIRA, M. B. Análise do impacto das decisões judiciais sobre o orçamento da União no caso da saúde pública: previsibilidade e contingenciamento dos riscos. In: Revista Tributária e de Finanças Públicas, vol. 20, oo 102, p. 15-40. São Paulo, jan./fev. 2012.

CAVALCANTI, A. B. V. R.; MACHADO, B. A. Democracia e os paradoxos da judicialização das políticas públicas de saúde no Brasil. In: Novos Estudos Jurídicos [eletrônica], vol. 22, noำ2, p. 624-652. Itajaí, mai./ago. 2017.

CHAVES, L. C. da S. Judicialização da política, direito à saúde e diálogos institucionais: a audiência pública no 04/2009. In: COÊLHO, M. V. F. (coord.). A 
Constituição entre o direito e a política: o futuro das instituições. Estudos em homenagem a José Afonso da Silva. Rio de Janeiro: GZ, 2018.

COMPARATO, F. K. Fundamento dos direitos humanos. In: DINIZ, J. J. (coord.). Direito constitucional. Brasília/DF: Consulex, 1998.

A afirmação histórica dos direitos humanos. São Paulo: Saraiva, 1999.

CORDEIRO, M. L. X. O direito à saúde e a atuação do Poder Judiciário: breves considerações. In: Temas de direito e saúde. Brasília/DF: Advocacia Geral da União, 2010. 4 vol.

CORVINO, J. D. F. A crise do sistema único de saúde e o fenômeno da judicialização da saúde. Rio de Janeiro: Gramma, 2017.

COSTA, F. V.; MOTTA, I. D. da; ARAÚJO, D. A. Judicialização da saúde: a dignidade da pessoa humana e a atuação do Supremo Tribunal Federal no caso dos medicamentos de alto custo. In: Revista Brasileira de Políticas Públicas [eletrônica], vol. 07, no 03, p. 844-874. Brasília/DF, set./dez. 2017.

COSTA, I. A. P. G. da. Judicialização: das medidas estatais colaboradoras à redução dos impactos nas políticas públicas de saúde. In: Revista Síntese - Direito Administrativo, vol. 07, oㅡ 82, p. 43-55. São Paulo, out. 2012.

CUEVA, R. V. B. Parâmetros para a judicialização do direito à saúde. In: LEMBO, C.; CAGGIANO, M. H. S.; ALMEIDA NETO, M. C. de (coords.). Juiz constitucional: estado e poder no século XXI. Homenagem ao Ministro Enrique Ricardo Lewandowski. São Paulo: Revista dos Tribunais, 2015.

DAHINTEN, B. F.; DAHINTEN, A. F. Judicialização do sistema de saúde complementar - possíveis causas. In: Interesse Público - Revista Bimestral de Direito Público, vol. 15, no 80, p. 155-185. São Paulo, jul./ago. 2013.

DALLARI, S. G. Os estados brasileiros e o direito à saúde. São Paulo: Hucitec Humanismo, Ciência e Tecnologia, 1995.

DANIELLI, R. A judicialização da saúde no Brasil: do viés individualista ao patamar de bem coletivo. Belo Horizonte: Fórum, 2018. 
DANTAS, B. Política judiciária para a saúde. In: Revista do Tribunal de Contas da União, vol. 47, no 133, p. 06-09. Brasília/DF, maio/ago. 2015.

DANTAS, F. P. F. Direitos fundamentais sociais no Brasil: desafios e mecanismos para sua concretização. 151 f. Dissertação (Mestrado) - Universidade Federal do Rio Grande do Norte, Natal, RN, 2015. Disponível em: <https://www2.jf. jus.br/pergamumweb/vinculos/00000c/00000cc2.pdf>. Acesso em: 12 set. 2016.

DESIMONI, L. M. El derecho a la dignidad humana: Orígenes y evolución. La problemática posmoderna. La contención de La violência em el tercero milênio. Buenos Aires: Ediciones Delpalma, 1999.

DIAS, M. S. de A. et al. Judicialização da saúde pública brasileira. In: Revista Brasileira de Políticas Públicas [eletrônica], vol. 06, noำ p2, p. 132-145. Brasília/DF, mai./ago. 2016.

DINIZ JÚNIOR, J. C. A eficácia das decisões judiciais na área de saúde. Rio de Janeiro: Lumen Juris, 2016.

FAGUNDES, M. C. D.; CATTANI, Y. N. Novos parâmetros para o ajuizamento das ações ligadas à assistência farmacêutica, universalidade do direito à saúde e representatividade democrática. In: Interesse Público - Revista Bimestral de Direito Público, vol. 20, № 110, p. 69-90. São Paulo, jul./ago. 2018.

FAIM FILHO, E. G. A judicialização da saúde e seus reflexos orçamentários. In: CONTI, J. M.; SCAFF, F. F. (orgs.). Orçamentos públicos e direito financeiro, São Paulo: Revista dos Tribunais, 2011.

FARIAS, R. N. Direito à saúde e sua judicialização. Curitiba: Juruá, 2018.

FAUNDES, A.; PINOTTI, J. A. A mulher e seu direito à saúde: por uma política de saúde no Brasil. São Paulo: Monole Ltda., 1988.

FELIPPE, M. S. Razão jurídica e dignidade humana. São Paulo: Max Limonad, 1996.

FERREIRA, S. L.; COSTA, A. M. da. Núcleos de assessoria técnica e judicialização da saúde: constitucionais ou inconstitucionais? In: Revista da Seção Judiciária do Rio de Janeiro, vol. 20, № 36, p. 219-240. Rio de Janeiro, abr. 2013. 
FIGUEIREDO, H. C. Saúde no Brasil: sistema constitucional assimétrico e as interfaces com as políticas públicas. Curitiba: Juruá, 2015.

FRANCHI, C. C.; VEIGA JUNIOR, H. Políticas públicas de saúde: entre a ineficiência estatal e a judicialização de uma política pública. In: VEIGA JUNIOR, H.; PEREIRA NETTO, J. P. (orgs.). Temas de seguridade social: reflexões contemporâneas sobre a efetividade das políticas públicas de inclusão. Rio de Janeiro: Lumen Juris, 2016.

GANDINI, J. A. D.; BARIONE, S. F. A judicialização do direito à saúde: a obtenção de atendimento médico, medicamentos e insumos terapêuticos por via judicial critérios e experiências. In: Revista IOB de Direito Administrativo, vol. 03, nº 28, p. 07-46. São Paulo, abr. 2008.

GASPARDO, M. Judicialização do fornecimento de medicamentos: entre a concretização e a violação do direito à saúde. In: Boletim de Direito Administrativo [acesso restrito], vol. 31, no 04, p. 422-433. São Paulo, abr. 2015.

GORDILHO, H. J. de S.; SILVA, T. T. de A. Eficácia dos direitos fundamentais e justiça distributiva: o interesse público como problema jurídico nos tratamentos de saúde. In: Juris Plenum, vol. 03, nº 09, p. 95-120. Caxias do Sul, jan./mar. 2016.

GRINOVER, A. P. Judiciário pode intervir no controle do Executivo. In: Revista Consultor Jurídico, 08 mai. 2009.

HUTZLER, F. S. O ativismo judicial e seus reflexos na seguridade social. Brasília/DF: Conselho da Justiça Federal, Centro de Estudos Judiciários, 2018.

JUCATELLI, J. P.; SILVA, J. B. Judicialização da saúde, ativismo judicial e o consequente desequilíbrio do orçamento público. In: Revista Brasileira de Políticas Públicas [eletrônica], vol. 07, no 01, p. 98-115. Brasília/DF, jan./abr. 2017.

KANT, I. Fundamentação da metafísica dos costumes. Tradução de Paulo Quintela. Coimbra: Biblioteca Filosófica, 1960.

KOVACS, C. Do excesso de judicialização na concessão de medicamentos aos cidadãos e a reserva do possível. $69 \mathrm{f}$. Trabalho de Conclusão de Curso (Especialização) - Pontifícia Universidade Católica de São Paulo, SP, 2012. Disponível em: <https://www2.jf.jus.br/pergamumweb/vinculos/00001e/00001e2e.pdf >. Acesso em: 10 ago. 2017. 
LIMA, F. R. de S. Saúde e Supremo Tribunal Federal. $2^{\mathrm{a}}$ ed. rev. e atual. Curitiba: Juruá, 2018.

LIMA, M. R. de. A judicialização do direito fundamental à saúde e dos demais direitos fundamentais do artigo $6^{\circ}$ e os princípios da prevenção e da precaução. In: Diálogos constitucionais de direito público e privado, nº 02, p. 163-177. Porto Alegre: Jurídica, 2013.

LIMA, N. T. Saúde e democracia: história e perspectivas do SUS. Rio de Janeiro: FIOCRUZ, 2005.

LIMA, P. J. M. S. O princípio da proporcionalidade como instrumento jurídico para conformar a judicialização do direito à saúde e a função social do juiz no contexto do estado federal. Advocacia Geral da União. In: Pós-Graduação em Direito Público, vol. 34, tomo 04, p. 227-250. Brasília/DF: UnB, 2014.

LIMA, T. M. O direito à saúde revisitado: entre os ideais da Constituição de 1988 e o drama jurídico atual. In: Revista de Informação Legislativa, vol. 51, oㅡ 202, p. 181201. São Paulo, abr./jun. 2014.

LIMBERGER, T.; SALDANHA, J. M. L. O direito à saúde e sua efetividade: o debate democrático perante o Supremo Tribunal Federal. In: Interesse Público Revista Bimestral de Direito Público, vol. 12, oㅡ 64, p. 105-130. São Paulo, nov./dez. 2010.

LIXA, I. F. M.; WEEGE, S. A. Judicialização da saúde e política pública: reflexões a partir da experiência do município de Joinville. In: Juris Plenum, vol. 06, ํㅡ 21, p. 35-48. Caxias do Sul, jan./mar. 2019.

LOPO, P. Garantia constitucional dos direitos sociais no Brasil. Rio de Janeiro: Forense, 1983.

LUZ, R. G. A. de M. Judicialização do orçamento público: repercussões da ingerência do Judiciário nas contas públicas e no planejamento da gestão estatal em decisões referentes à saúde. Advocacia Geral da União. In: Pós-Graduação em Direito Público, vol. 30, tomo 02, p. 189-212. Brasília/DF: UnB, 2013.

MAAS, R. H.; LEAL, M. C. H. A decisão da saúde pelo Supremo Tribunal Federal: uma análise dos parâmetros para judicialização da saúde. In: Direito Público, vol. 14, № 82, p. 50-70. Porto Alegre, jul./ago. 2018. 
MAGALHÃES, M. A. O sistema único de saúde e suas diretrizes constitucionais. São Paulo: Verbatim, 2012.

MÂNICA, F. B. Saúde: um direito fundamental social individual. In: Revista Brasileira de Direito da Saúde, no 12. São Paulo, out. 2011.

MAPELLI JÚNIOR, R. Judicialização da saúde: regime jurídico do SUS e intervenção na administração pública. Rio de Janeiro: Atheneu, 2017.

MARANHÃO, C. Tutela jurisdicional do direito à saúde: arts. 83 e 84 - CDC. Temas atuais de direito processual civil. Coordenação de Luiz Guilherme Marinoni. São Paulo: Revista dos Tribunais, 2003.

MARMELSTEIN, G. You can't always get what you want: repensando a judicialização da saúde com base no fornecimento de medicamentos. In: Revista de Informação Legislativa, vol. 54, no 216, p. 105-130. Brasília/DF, out. 2017.

MARTÍNEZ, G. P. B. La dignidad de la persona desde la filosofia del derecho. Cuadernos Bartolomé de las Casas. Instituto de Derechos Humanos. Madrid: Universidad Carlos III, 2002.

MATTOS, K. D. G. de; SOUZA, G. A. de. Ativismo judicial e direito à saúde: uma análise da tutela jurisdicional nas ações de medicamentos. In: Direito Público, vol. 08, no 37, p. 07-23. São Paulo, jan./fev. 2011.

MENDES, G. F.; BRANCO, P. G. G. Curso de direito constitucional. $1^{\mathfrak{a}}$ ed. rev. e atual. São Paulo: Saraiva, 2012.

MENDES, K. R. Curso de direito da saúde. São Paulo: Saraiva, 2013.

MENEZES, V. H. M. de. Direito à saúde e reserva do possível. Curitiba: Juruá, 2015.

MIRANDA, J. Manual de direito constitucional. Coimbra: Coimbra Editora, 1998. tomo IV.

MONTEIRO, B. L.; ALLI, T. B. T. Desafios ao direito social à saúde: a criminalização da exigência de cheque-caução por planos de saúde. In: ABREU, C. B.; PEIXINHO, 
M. M.; MADEIRA FILHO, W. (coords.). Diálogos sobre direitos humanos fundamentais. $3^{\mathrm{a}}$ Rio de Janeiro: Lumen Juris, 2016.

MORAES, A. de. Direito constitucional. 13ª ed. São Paulo: Atlas, 2003.

MORANDINI, J.; LAWALL, C. O mínimo existencial como critério para analisar a (in)viabilidade do fornecimento de tratamento de saúde no exterior pela administração pública. In: MARQUES, A. D.; SANTOS, D. T. G. dos; SILVA, R. H. da (orgs.). A humanidade, o direito e seus (novos) caminhos. Curitiba: CRV, 2015.

NUNES JUNIOR, V. S.; DALLARI, S. G. Direito sanitário. São Paulo: Verbatim, 2010.

OLIVEIRA, E. C. de A. A judicialização da saúde e suas repercussões no Sistema Único de Saúde (SUS) e na defesa dos entes públicos em juízo. In: Advocacia Geral da União. In: Pós-Graduação em Direito Público, vol. 34, tomo 01, p. 77-120. Brasília/DF: UnB, 2014.

OLIVEIRA, G. H. J. de. Judicialização das parcerias na área da saúde: entrevista. In: Revista Jurídica Consulex, vol. 16, no 370, p. 06-08. São Paulo, jun. 2012.

OLIVEIRA, P. S. de; MARGRAF, A. F. Direito à saúde: um direito de todos? In: Revista de Direito Privado, vol. 17, oㅡ 66, p. 17-34. São Paulo, abr./jun. 2016.

OLIVEIRA, W. L. de. Judicialização da saúde pública. In: OLIVEIRA, W. L. de (org.). Advocacia pública em debate. Florianópolis: Empório do Direito, 2018.

PEDRINI, T. F.; VANDRESEN, T. A reserva do possível: entre a suposta insuficiência de recursos disponíveis e a execução do direito à saúde. In: Revista Bonijuris, vol. 28, № 633, p. 16-22. Curitiba, ago. 2016.

PEREIRA, W. M. Judicialização das políticas públicas de saúde. Belo Horizonte: D’Plácido, 2015.

PEREIRA JUNIOR, J. T. O formato jurídico da gestão da saúde pública: a opção da MP no 520/10 por modelo empresarial, sob a perspectiva jurisprudencial. In: Boletim de Direito Administrativo, vol. 27, no 05, p. 529-550 e 570-577. São Paulo, mai. 2011. 
PIERRO, B. Demandas crescentes. In: Revista Pesquisa FAPESP, ano 18, № 252. São Paulo, fev. 2017. Disponível em: <http://www.revistapesquisa.fapesp.br>. Acesso em: 08 jan. 2019.

PINTO, É. G.; BAHIA, A. G. M. F.; SANTOS, L. O financiamento da saúde na Constituição de 1988: um estudo em busca da efetividade do direito fundamental por meio da equalização federativa do dever do seu custeio mínimo. In: AeC Revista de Direito Administrativo e Constitucional, vol. 16, № 66, p. 209-237. Belo Horizonte, out./dez. 2016.

PIOVESAN, F. Temas de direitos humanos. 4⿳亠丷a ed. atual. e rev. São Paulo: Saraiva, 2010.

RAMOS, P. A crise na saúde, seus impactos e quais são as soluções. In: Seminário Caminhos para a Saída da Crise. Praia do Forte: Anais Centro de Memória Jurídica, 2016.

REALE, M. Questões de direito público. São Paulo: Saraiva, 1997.

Filosofia do direito. 18ª ed. São Paulo: Saraiva, 1998.

REIS, W. J. dos. Terceirização: solução à judicialização da saúde pública? In: Revista Jurídica Consulex, vol. 16, no 361, p. 48-50. São Paulo, fev. 2012.

ROCHA, A. S. A gestão do Poder Judiciário e a judicialização da saúde: órgãos técnicos de mediação como mecanismo de solução de controvérsias no acesso a medicamentos e tratamentos de saúde. In: 2ª Jornada de Planejamento e Gestão, p. 09-14. Brasília/DF, 2012.

RODRIGUES, R. M. et al. A (i)legitimidade das políticas públicas: a República entre a igualdade e a especificidade. São Paulo: Malheiros, 2015.

RONALD, D. Uma questão de princípio. São Paulo: Martins Fontes; 2001.

ROTHENBURG, W. C. Princípios constitucionais. Porto Alegre: Sérgio Antonio Fabris Editor, 1998.

SABINO, M. A. da C. Saúde \& Judiciário: a atuação judicial, limites, excessos e remédios. Curitiba: Juruá, 2016. 
SANTOS, F. F. dos. Princípio constitucional da dignidade da pessoa humana. São Paulo: Celso Bastos Editor: IBDC, 1999.

SANTOS, R. C. C. dos. Financiamento da saúde pública no Brasil. Belo Horizonte: Fórum, 2016.

SARLET, I. W. Dignidade da pessoa humana e direitos fundamentais. Porto Alegre: Livraria do Advogado, 2001.

A eficácia dos direitos fundamentais: uma teoria geral dos direitos fundamentais na perspectiva constitucional. $11^{\underline{a}} \mathrm{ed}$. rev. e atual. Porto Alegre: Livraria do Advogado Editora, 2012.

Algumas considerações em torno do conteúdo, eficácia e efetividade do direito à saúde na constituição de 1988. In: Revista Diálogo Jurídico, vol. 10, nos 02-03. São Paulo, 2002. Disponível em: <http://www.direitopublico.com.br>. Acesso em: 10 nov. 2018.

SCHWARTZ, G. A. D. A tutela antecipada no direito à saúde: a aplicabilidade da teoria sistêmica (de acordo com a Lei no 10.444/02). Porto Alegre: Sérgio Antonio Fabris Editor, 2003.

SESSAREGO, C. F. Apuntes sobre el daño a la persona. In: BORDA, G. A. (coord.). La persona humana. Buenos Aires: La Ley, 2001.

SILVA, A. C. Q. da; SILVA, G. G. e. Aspectos polêmicos da concretização do direito à saúde em face das ações judiciais para fornecimento de medicamentos no Brasil. In: Direitos Fundamentais e Justiça [eletrônica], vol. 09, no 32, p. 26-54. Porto Alegre, jul./set. 2015.

SILVA, J. A. Curso de direito constitucional positivo. $38^{a}$ ed. ver. e atual. São Paulo: Malheiros Editores, 2014.

SPAOLONZI, M. G. P. A constituição da norma de decisão na judicialização da saúde. In: DE PRETTO, R. S.; KIM, R. P.; TERAOKA, T. M. C. (coords.). Interpretação Constitucional no Brasil. São Paulo: Escola Paulista da Magistratura, 2017.

STRECK, L. L. Jurisdição constitucional e hermenêutica: uma nova crítica do direito. $2^{\mathrm{a}}$ ed. Rio de Janeiro: Forense, 2004. 
TEIXEIRA, I. C. D. Direito social à saúde e ativismo judicial: gerenciamento das políticas públicas. Porto Alegre: Sérgio Antônio Fabris, 2015.

WEIS, C. Direitos humanos contemporâneos. $2^{\underline{a}}$ ed. $2^{\underline{a}}$ tirag. São Paulo: Malheiros Editores, 2011.

WOLKMER, A. C. Pluralismo jurídico: fundamentos de uma nova cultura no Direito. São Paulo: Alfa Omega, 2001. 
$\underline{\text { Apêndices }}$ 



\section{APÊNDICE A - Tabela com a Relação dos Processos Judiciais Pesquisados}

\begin{tabular}{|c|c|c|c|c|c|c|c|}
\hline ITEM & № PROCESSO & $\begin{array}{c}\text { PROCESSO } \\
\text { ADMINISTRATIVO }\end{array}$ & $\begin{array}{c}\text { DATA } \\
\text { DISTRIBUIÇÃO }\end{array}$ & TIPO AÇÃO & $\begin{array}{l}\text { LIMINAR OU } \\
\text { ANTECIPAÇÃO } \\
\text { DE TUTELA }\end{array}$ & $\begin{array}{c}\text { SITUAÇÃO } \\
\text { (JULGADAS EM } 1^{\circ} \text { OU } 2^{\circ} \text { INSTÂNCIA) }\end{array}$ & OBJETO \\
\hline 1 & $\begin{array}{c}\text { 0008162- } \\
77.2014 .8 .26 .0071\end{array}$ & $18719 / 2014$ & 01/01/2014 & $\begin{array}{l}\text { Mandado de } \\
\text { Segurança }\end{array}$ & 25/03/2014 & $\begin{array}{l}22 / 04 / 2014 \text { - concedo a segurança pleiteada por ....... } \\
\text { contra ato do secretário municipal de saúde de Bauru, } \\
\text { para que o impetrado providencie o agendamento de } \\
\text { consulta na especialidade de endocrinologia para a } \\
\text { impetrante, nos termos da petição inicial, e julgo extinto o } \\
\text { processo, com resolução de mérito. }\end{array}$ & $\begin{array}{l}\text { CONSULTA } \\
\text { MÉDICA }\end{array}$ \\
\hline 2 & $\begin{array}{c}1012437- \\
52.2014 .8 .26 .0071\end{array}$ & $\begin{array}{c}\text { 41022/2014 - Ap. } \\
\text { 42028/2015 }\end{array}$ & 01/01/2014 & $\begin{array}{l}\text { Mandado de } \\
\text { Segurança }\end{array}$ & 22/07/2014 & $\begin{array}{l}22 / 09 / 2014 \text { - julgo procedente o pedido, mantendo a } \\
\text { obrigação imposta ao requerido de fornecer a requerente } \\
\text { o medicamento colágeno hidrolisado ( } 30 \text { saches por mês). }\end{array}$ & MEDICAMENTO \\
\hline 3 & $\begin{array}{c}1022125- \\
38.2014 .8 .26 .0071\end{array}$ & $1953 / 2015$ & $12 / 01 / 2014$ & $\begin{array}{l}\text { Mandado de } \\
\text { Segurança }\end{array}$ & 08/01/2015 & $\begin{array}{l}21 / 01 / 2015 \text { - concedo a segurança, determinando que o } \\
\text { impetrado providencie o fornecimento à impetrante das } \\
\text { fraldas geriátricas descartáveis (tamanho xg } 180 \text { unidades } \\
\text { por mês), conforme a prescrição médica de fls. } 30 \text {, sob } \\
\text { pena de responder por crime de desobediência, sem } \\
\text { prejuízo das sanções administrativas. }\end{array}$ & FRALDA \\
\hline 4 & $\begin{array}{c}0000342- \\
07.2014 .4,8,26.007 \\
1\end{array}$ & $2885 / 2014$ & $15 / 01 / 2014$ & $\begin{array}{l}\text { Mandado de } \\
\text { Segurança }\end{array}$ & $10 / 01 / 2014$ & $\begin{array}{l}27 / 01 / 2014 \text { - concedo a segurança pleiteada por ......... } \\
\text { contra ato do secretário municipal de saúde de Bauru, } \\
\text { para que o impetrado forneça à impetrante fraldas } \\
\text { geriátricas descartáveis - tamanho "m" (150 unidades por } \\
\text { mês), nos termos da petição inicial, e julgo extinto o } \\
\text { processo, com resolução de mérito. }\end{array}$ & FRALDA \\
\hline 5 & $\begin{array}{c}000008-70.2014 .8- \\
26.0071\end{array}$ & $2891 / 2014$ & $15 / 01 / 2014$ & $\begin{array}{l}\text { Mandado de } \\
\text { Segurança }\end{array}$ & 03/04/2014 & $\begin{array}{l}31 / 03 / 2014 \text { - ratifico a liminar de fls. } 32 \text { e concedo a } \\
\text { segurança pleiteada por ...... contra ato do secretário } \\
\text { municipal de saúde de Bauru, para que o impetrado } \\
\text { providencie o fornecimento ao impetrante do } \\
\text { medicamento rivastigmina patch } 10(9,5 \mathrm{mg} / 24 \text { horas }-01 \\
\text { adesivo por dia), conforme prescrição médica de fls. } 24 \text {, } \\
\text { nos termos da petição inicial, e julgo extinto o processo, } \\
\text { com resolução de mérito. }\end{array}$ & MEDICAMENTO \\
\hline
\end{tabular}




\begin{tabular}{|c|c|c|c|c|c|c|c|}
\hline 6 & \begin{tabular}{|c|}
$0000456-$ \\
43.2014 .8 .26 .0071
\end{tabular} & $3290 / 2014$ & $16 / 01 / 2014$ & $\begin{array}{l}\text { Mandado de } \\
\text { Segurança }\end{array}$ & 03/02/2014 & $\begin{array}{l}\text { 05/02/2014 - concedo a segurança pleiteada por ........ } \\
\text { contra ato do secretário municipal de saúde de Bauru, } \\
\text { para que o impetrado forneça à impetrante fraldas } \\
\text { geriátricas descartáveis - tamanho "g" (120 unidades por } \\
\text { mês), nos termos da petição inicial, e julgo extinto o } \\
\text { processo, com resolução de mérito. }\end{array}$ & FRALDA \\
\hline 7 & $\begin{array}{c}0000947- \\
50.2014 .8 .26 .0071\end{array}$ & $3671 / 2014$ & $17 / 01 / 2014$ & $\begin{array}{l}\text { Mandado de } \\
\text { Segurança }\end{array}$ & $15 / 01 / 2014$ & $\begin{array}{l}\text { 19/02/2014 - concedo a segurança pleiteada por ..... } \\
\text { contra ato do secretário municipal de saúde de Bauru, } \\
\text { para que o impetrado forneça à impetrante fraldas } \\
\text { geriátricas descartáveis - tamanho "g" (120 unidades por } \\
\text { mês), nos termos da petição inicial, e julgo extinto o } \\
\text { processo. }\end{array}$ & MEDICAMENTO \\
\hline 8 & $\begin{array}{c}0000874.78 .2014 .8 \\
26.0071\end{array}$ & $3872 / 2014$ & $20 / 01 / 2014$ & $\begin{array}{l}\text { Outros } \\
\text { Procediment } \\
\quad \text { os }\end{array}$ & & $\begin{array}{l}26 / 05 / 2014 \text { - rejeito a preliminar arguída, ratifico a } \\
\text { decisão de fls. 29/29v. e julgo procedente o pedido } \\
\text { formulado por .... contra prefeitura municipal de Bauru, } \\
\text { determinando que a requerida forneça à requerente } \\
\text { agendamento de cirurgia plástica, sem prejuízo da da } \\
\text { realização dos exames pré-cirúrgicos obrigatórios, nos } \\
\text { termos da petição inicial, e extinto o processo, com } \\
\text { resolução de mérito, nos termos do artigo } 269, \text { i do código } \\
\text { de processo civil. condeno, ainda, a requerida ao } \\
\text { pagamento de custas, despesas processuais e, } \\
\text { honorários advocatícios que fixo em r } \$ 400,00 \\
\text { (quatrocentos reais). }\end{array}$ & CIRURGIA \\
\hline 9 & \begin{tabular}{|c|}
$0001084-$ \\
32.2014 .8 .26 .0071
\end{tabular} & $4123 / 2014$ & $21 / 01 / 2014$ & $\begin{array}{l}\text { Mandado de } \\
\text { Segurança }\end{array}$ & $16 / 01 / 2014$ & $\begin{array}{l}\text { 28/05/2014 - foi noticiado o falecimento da impetrante. } \\
\text { assim, evidente a carência superveniente da ação pela } \\
\text { perda do objeto. ante o exposto, julgo extinto o processo. }\end{array}$ & FRALDA \\
\hline 10 & \begin{tabular}{|c|}
$0001586-$ \\
68.2014 .8 .26 .0071
\end{tabular} & $5370 / 2014$ & $27 / 01 / 2014$ & $\begin{array}{l}\text { Mandado de } \\
\text { Segurança }\end{array}$ & $22 / 01 / 2014$ & $\begin{array}{l}25 / 02 / 2014 \text { - concedo a segurança pleiteada por ....... } \\
\text { contra ato do secretário municipal de saúde de Bauru, } \\
\text { para que o impetrado providencie o agendamento de } \\
\text { consulta na especialidade de neurologia para a } \\
\text { impetrante, nos termos da petição inicial, e julgo extinto o } \\
\text { processo, com resolução de mérito. }\end{array}$ & $\begin{array}{l}\text { CONSULTA } \\
\text { MÉDICA }\end{array}$ \\
\hline 11 & \begin{tabular}{|c|}
$0001594-$ \\
45.2014 .8 .26 .0071
\end{tabular} & $5484 / 2014$ & $28 / 01 / 2014$ & $\begin{array}{l}\text { Mandado de } \\
\text { Segurança }\end{array}$ & $22 / 01 / 2014$ & $\begin{array}{l}12 / 02 / 2014 \text { - concedo a segurança pleiteada por ..... } \\
\text { contra ato do secretário municipal de saúde de Bauru, } \\
\text { para que o impetrado forneça ao impetrante fraldas } \\
\text { geriátricas descartáveis - tamanho "m" (120 unidades por } \\
\text { mês), nos termos da petição inicial, e julgo extinto o } \\
\text { processo, com resolução de mérito }\end{array}$ & FRALDA \\
\hline
\end{tabular}




\begin{tabular}{|c|c|c|c|c|c|c|c|}
\hline 12 & $\begin{array}{c}0002144- \\
40.2014 .8 .26 .0071\end{array}$ & $5545 / 2014$ & $28 / 01 / 2014$ & $\begin{array}{l}\text { Mandado de } \\
\text { Segurança }\end{array}$ & & $\begin{array}{l}\text { 30/01/0/2014 - município informa a entrega de } 14 \text { latas } \\
\text { prescristas. }\end{array}$ & $\begin{array}{l}\text { ALIMENTAÇÃO } \\
\text { ESPECIAL }\end{array}$ \\
\hline 13 & $\begin{array}{c}\text { 0002152- } \\
17.2014 .8 .26 .0071\end{array}$ & $5842 / 2014$ & 29/01/2014 & $\begin{array}{l}\text { Mandado de } \\
\text { Segurança }\end{array}$ & 27/01/2014 & $\begin{array}{l}\text { 07/03/2014 - concedo parcialmente a segurança pleiteada } \\
\text { por ..... contra ato do secretário municipal de saúde de } \\
\text { Bauru, para que o impetrado providencie o agendamento } \\
\text { de consulta na especialidade vascular para o impetrante, } \\
\text { nos termos da petição inicial, e julgo extinto o processo, } \\
\text { com resolução de mérito. }\end{array}$ & MEDICAMENTO \\
\hline 14 & $\begin{array}{c}0002514- \\
19.2014 .8 .26 .0071\end{array}$ & $6191 / 2014$ & $31 / 01 / 2014$ & $\begin{array}{l}\text { Mandado de } \\
\text { Segurança }\end{array}$ & 29/01/2014 & $\begin{array}{l}\text { 13/02/2014 - concedo a segurança, determinando que o } \\
\text { impetrado providencie o fornecimento ao impetrante das } \\
\text { fraldas geriátricas descartáveis (tamanho g } 150 \text { unidades } \\
\text { por mês), conforme a prescrição médica de fls. } 13 \text {, sob } \\
\text { pena de responder por crime de desobediência, sem } \\
\text { prejuízo das sanções administrativas. para efeito de de } \\
\text { efetivo controle do tempo em que o impetrante necessita } \\
\text { dos itens a serem fornecidos e para evitar compras } \\
\text { desnecessárias pelo órgão público, deverá ser } \\
\text { apresentada prescrição médica atualizada à secretaria } \\
\text { municipal de saúde, a cada } 03 \text { (três) meses. nos termos } \\
\text { do artigo } 13 \text {, caput, da lei } 12.016 / 09 \text {, por mandado, } \\
\text { transmitir o inteiro teor da decisão ao impetrado e à } \\
\text { procuradoria municipal. fixo os honorários advocatícios do } \\
\text { dr. ..., nomeado nos termos do convênio entre a } \\
\text { defensoria publica do estado regional de Bauru e ordem } \\
\text { dos advogados do brasil, seção de são paulo (fls. 09), em } \\
70 \% \text { (setenta por cento) no valor constante da tabela de } \\
\text { honorários. não cabe condenação em honorários (artigo } \\
25 \text { da lei } 12.016 / 09 \text { ). após o decurso do prazo para } \\
\text { recurso voluntário, remetam-se os autos ao e. tribunal de } \\
\text { justiça para reexame necessário. }\end{array}$ & FRALDA \\
\hline
\end{tabular}




\begin{tabular}{|c|c|c|c|c|c|c|c|}
\hline 15 & $\begin{array}{c}\text { 1020982- } \\
14.2014 .8 .26 .0071\end{array}$ & $70150 / 2014$ & 03/02/2014 & $\begin{array}{l}\text { Mandado de } \\
\text { Segurança }\end{array}$ & $27 / 11 / 2014$ & $\begin{array}{l}\text { 16/12/2014 - concedo a segurança pleiteada por ..... } \\
\text { representada por ......, contra ato do secretário municipal } \\
\text { de saúde de Bauru, para que o impetrado providencie o } \\
\text { fornecimento à impetrante: dieta adulto hipercalórica (1,5 } \\
\text { kcal/ml), hiperproteíca (18\% vct) isenta de lactose e glúten } \\
(08 \text { latas de } 400 \mathrm{~g} \text { por mês) e módulo de amido } \\
\text { modificado, espessante alimentar instantâneo, isento de } \\
\text { sabor (03 latas por mês), nos termos da petição inicial, e } \\
\text { julgo extinto o processo, com resolução de mérito. }\end{array}$ & $\begin{array}{l}\text { ALIMENTAÇÃO } \\
\text { ESPECIAL }\end{array}$ \\
\hline 16 & $\begin{array}{c}\text { 1021345- } \\
\text { 98.2014.8.26.0071 }\end{array}$ & $71305 / 2014$ & 03/02/2014 & $\begin{array}{c}\text { Outros } \\
\text { Procediment } \\
\text { os }\end{array}$ & 04/12/2014 & $\begin{array}{l}\text { 25/02/2015 - julgo procedente o pedido formulado por .... } \\
\text { em face do município de Bauru, determinando que este } \\
\text { forneça à requerente sulfato de glicosamina } 1,5 \mathrm{~g} .+ \\
\text { sulfato de condroitina } 1,2 \mathrm{~g} \text {. }\end{array}$ & MEDICAMENTO \\
\hline 17 & $\begin{array}{c}0001599- \\
67.2014 .8 .26 .0071\end{array}$ & 7026/2014 & 05/02/2014 & $\begin{array}{l}\text { Mandado de } \\
\text { Segurança }\end{array}$ & 03/02/2014 & $\begin{array}{l}\text { 13/03/2014 - concedo parcialmente a segurança, } \\
\text { determinando que o impetrado providencie o fornecimento } \\
\text { à impetrante os suplementos alimentares hipercalóricas, } \\
\text { hiperprotéica } 2 \text { unidades por dia } 250 \mathrm{kccal} \text { em } 200 \mathrm{ml} 30 \% \\
\text { de proteína, } 44 \% \text { de carboidrato e } 26 \% \text { de lipídeo com } \\
\text { arginina e w3 (60 unidades por mês) e a dieta padrão, } \\
\text { polimérica, normocalórica, normoprotéica, sem fibras, sem } \\
\text { sacarose e lactose ( } 38 \text { litros por mês), conforme } \\
\text { recomendações médicas de fls. } 12 \text { e 13, sob pena de } \\
\text { responder por rime de desobediência, sem prejuízo das } \\
\text { sanções administrativas. }\end{array}$ & MEDICAMENTO \\
\hline 18 & $\begin{array}{c}0002618- \\
11.2014 .8 .26 .0071\end{array}$ & 7057/2014 & 05/02/2014 & $\begin{array}{l}\text { Mandado de } \\
\text { Segurança }\end{array}$ & $31 / 01 / 2014$ & $\begin{array}{l}\text { 22/02/2014 - concedo a segurança pleiteada por...... } \\
\text { contra ato do secretário municipal de saúde de Bauru, } \\
\text { para que o impetrado forneça ao impetrante fraldas } \\
\text { geriátricas descartáveis - tamanho "g" (150 unidades por } \\
\text { mês). }\end{array}$ & FRALDA \\
\hline 19 & $\begin{array}{c}\text { 0002134- } \\
\text { 93.2014.8.26.0071 }\end{array}$ & $8925 / 2014$ & 13/02/2014 & $\begin{array}{l}\text { Outros } \\
\text { Procediment } \\
\text { os }\end{array}$ & $\begin{array}{l}\text { 07/02/2014 } \\
\text { CONCEDO A } \\
\text { ANTECIPAÇÃO } \\
\text { DA TUTELA }\end{array}$ & $\begin{array}{l}\text { 04/06/2014 - julgo procedente o pedido formulado por ..... } \\
\text { em face da prefeitura municipal de Bauru, determinando } \\
\text { que esta forneça à requerente fraldas descartáveis } \\
\text { geriátricas - tamanho "g" (180 unidades por mês), nos } \\
\text { termos da petição inicial, e extinto o processo, com } \\
\text { resolução de mérito. }\end{array}$ & FRALDA \\
\hline
\end{tabular}




\begin{tabular}{|c|c|c|c|c|c|c|c|}
\hline 20 & $\begin{array}{c}0003973- \\
56.2014 .8 .26 .0071\end{array}$ & $10362 / 2014$ & 20/02/2014 & $\begin{array}{l}\text { Mandado de } \\
\text { Segurança }\end{array}$ & $17 / 02 / 2014$ & $\begin{array}{l}\text { 13/03/2014 - concedo a segurança pleiteada por ........ } \\
\text { representado por ......, contra ato do secretário municipal } \\
\text { de saúde de Bauru, para que forneça ao impetrante: } \\
\text { fraldas descartáveis, tamanho "p" (05 unidades por dia), } \\
\text { nos termos da petição inicial e, extinto o processo. }\end{array}$ & FRALDA \\
\hline 21 & $\begin{array}{c}\text { 0004357- } \\
19.2014 .8 .26 .0071\end{array}$ & $10474 / 2014$ & 21/02/2014 & $\begin{array}{l}\text { Mandado de } \\
\text { Segurança }\end{array}$ & $14 / 02 / 2014$ & $\begin{array}{l}21 / 05 / 2014 \text { - concedo a segurança pleiteada por .... } \\
\text { contra ato do secretário municipal de saúde de Bauru, } \\
\text { para que o impetrado forneça ao impetrante fraldas } \\
\text { geriátricas descartáveis - tamanho "m" (03 unidades por } \\
\text { dia), nos termos da petição inicial, e julgo extinto o } \\
\text { processo, com resolução de mérito. }\end{array}$ & FRALDA \\
\hline 22 & $\begin{array}{c}0004940- \\
04.2014 .8 .26 .0071\end{array}$ & $11141 / 2014$ & $25 / 02 / 2014$ & $\begin{array}{l}\text { Mandado de } \\
\text { Segurança }\end{array}$ & 21/02/2014 & $\begin{array}{l}\text { 14/03/2014 - concedo a segurança, determinando que o } \\
\text { impetrado providencie o fornecimento ao impetrante do } \\
\text { medicamento cloridrato de cinacalcete } 30 \mathrm{mg} \text {. }\end{array}$ & MEDICAMENTO \\
\hline 23 & $\begin{array}{c}\text { 0004657- } \\
78.2014 .8 .26 .0071\end{array}$ & $11425 / 2014$ & $26 / 02 / 2014$ & $\begin{array}{l}\text { Mandado de } \\
\text { Segurança }\end{array}$ & $\begin{array}{l}\text { INDEFIRO A } \\
\text { LIMINAR }\end{array}$ & $\begin{array}{l}\text { posto isso, denego a segurança pleiteada por contra ato } \\
\text { do secretario municipal de sáude de Bauru, e julgo extinto } \\
\text { o processo, com resolução de mérito. }\end{array}$ & $\begin{array}{l}\text { CUIDADOR/HOM } \\
\text { E CARE }\end{array}$ \\
\hline 24 & $\begin{array}{c}0005060- \\
47.2014 .8 .26 .0071\end{array}$ & $11416 / 2014$ & $26 / 02 / 2014$ & $\begin{array}{l}\text { Mandado de } \\
\text { Segurança }\end{array}$ & 24/02/2014 & $\begin{array}{l}\text { 17/03/2014 - concedo a segurança, determinando que o } \\
\text { impetrado providencie o fornecimento ao impetrante das } \\
\text { fraldas geriátricas descartáveis (tamanho g }-180 \\
\text { unidades por mês), conforme a prescrição médica de fls. } \\
24 \text {, sob pena de responder por crime de desobediência, } \\
\text { sem prejuízo das sanções administrativas. }\end{array}$ & FRALDA \\
\hline 25 & $\begin{array}{c}0005108- \\
06.2014 .8 .26 .0071\end{array}$ & $11882 / 2014$ & 28/02/2014 & $\begin{array}{l}\text { Mandado de } \\
\text { Segurança }\end{array}$ & 24/02/2014 & $\begin{array}{l}\text { 20/03/2014 - oncedo a segurança pleiteada por ..... contra } \\
\text { ato do secretário municipal de saúde de Bauru, para que } \\
\text { forneça ao impetrante: fraldas descartáveis, tamanho "g" } \\
\text { (90 unidades por mês), nos termos da petição inicial e, } \\
\text { extinto o processo, com resolução de mérito. }\end{array}$ & FRALDA \\
\hline 26 & $\begin{array}{c}0005333- \\
26.2014 .8 .26 .0071\end{array}$ & $12215 / 2014$ & 05/03/2014 & $\begin{array}{l}\text { Mandado de } \\
\text { Segurança }\end{array}$ & 26/02/2014 & $\begin{array}{l}\text { 19/03/2014 - concedo a segurança pleiteada por ... contra } \\
\text { ato do secretário municipal de saúde de Bauru, para que } \\
\text { o impetrado providencie o agendamento de consulta na } \\
\text { especialidade, nos termos da petição inicial, e julgo } \\
\text { extinto o processo, com resolução de mérito. }\end{array}$ & $\begin{array}{l}\text { CONSULTA } \\
\text { MÉDICA }\end{array}$ \\
\hline 27 & $\begin{array}{c}\text { 0005639- } \\
92.2014 .8 .26 .0071\end{array}$ & $12992 / 2014$ & 07/03/2014 & $\begin{array}{l}\text { Mandado de } \\
\text { Segurança }\end{array}$ & 28/02/2014 & $\begin{array}{l}25 / 03 / 2014 \text { - oncedo a segurança pleiteada por .... contra } \\
\text { ato do secretário municipal de saúde de Bauru, para que } \\
\text { o impetrado providencie o agendamento de cirurgia para } \\
\text { tratamento de hérnia abdominal para o impetrante, sem } \\
\text { prejuízo dos exames pré-cirúrgicos obrigatórios, nos } \\
\text { termos da petição inicial, e julgo extinto o processo, com } \\
\text { resolução de mérito. }\end{array}$ & $\begin{array}{l}\text { CONSULTA } \\
\text { MÉDICA }\end{array}$ \\
\hline
\end{tabular}




\begin{tabular}{|c|c|c|c|c|c|c|c|}
\hline 28 & \begin{tabular}{c|}
$0004011-$ \\
68.2014 .8 .26 .0071
\end{tabular} & $13498 / 2014$ & $11 / 03 / 2014$ & $\begin{array}{l}\text { Mandado de } \\
\text { Segurança }\end{array}$ & & SEGREDO DE JUSTIÇA & $\begin{array}{c}\text { SEGREDO DE } \\
\text { JUSTIÇA }\end{array}$ \\
\hline 29 & $\begin{array}{c}\text { 0005995- } \\
87.2014 .8 .26 .0071\end{array}$ & $13837 / 2014$ & $12 / 03 / 2014$ & $\begin{array}{l}\text { Outros } \\
\text { Procediment } \\
\text { os }\end{array}$ & & $\begin{array}{l}\text { 07/04/2014 - fundamento e decido. no caso dos autos, } \\
\text { evidente a carência da ação por falta de interesse de agir, } \\
\text { pois conforme noticiado a fls. } 29 / 30 \text {, antes da propositura } \\
\text { da ação, o paciente já estava sendo transportado em } \\
\text { veículo disponibilizado pela secretaria municipal de } \\
\text { saúde. ante o exposto, julgo extinta a presente ação. }\end{array}$ & TRANSPORTE \\
\hline 30 & $\begin{array}{c}0006988- \\
33.2014 .8 .26 .0071\end{array}$ & $15190 / 2014$ & 18/03/2014 & $\begin{array}{l}\text { Mandado de } \\
\text { Segurança }\end{array}$ & $14 / 03 / 2014$ & $\begin{array}{l}\text { 14/05/2014 - concedo a segurança pleiteada por ..... } \\
\text { contra ato do secretário municiaal de saúde de Bauru, } \\
\text { para que o impetrado forneça ao impetrante fraldas } \\
\text { geriátricas descartáveis - tamanho "g" (150 unidades por } \\
\text { mês), nos termos da petição inicial, e julgo extinto o } \\
\text { processo. }\end{array}$ & FRALDA \\
\hline 31 & $\begin{array}{c}0007151- \\
13.2014 .8 .26 .0071\end{array}$ & $15770 / 2014$ & 20/03/2014 & $\begin{array}{l}\text { Mandado de } \\
\text { Segurança }\end{array}$ & $14 / 03 / 2014$ & $\begin{array}{l}\text { 22/04/2014 - concedo a segurança pleiteada por ...... } \\
\text { contra ato do secretário municipal de saúde de Bauru, } \\
\text { para que o impetrado providencie o agendamento de } \\
\text { exame de ultrassonografia na região lombar para o } \\
\text { impetrante, nos termos da petição inicial, e julgo extinto o } \\
\text { processo. }\end{array}$ & $\begin{array}{l}\text { CONSULTA } \\
\text { MÉDICA }\end{array}$ \\
\hline 32 & $\begin{array}{c}0007625- \\
81.2014 .8 .26 .0071\end{array}$ & $16626 / 2014$ & $25 / 03 / 2014$ & $\begin{array}{l}\text { Mandado de } \\
\text { Segurança }\end{array}$ & 19/03/2014 & $\begin{array}{l}\text { concedo a segurança pleiteada por...... contra ato do } \\
\text { secretário municipal de saúde de Bauru, para que o } \\
\text { impetrado forneça ao impetrante fraldas geriátricas } \\
\text { descartáveis - tamanho "m" (06 unidades por dia), nos } \\
\text { termos da petição inicial, e julgo extinto o processo. }\end{array}$ & FRALDA \\
\hline 33 & $\begin{array}{c}0007811- \\
07.2014 .8 .26 .0071\end{array}$ & $17327 / 2014$ & $27 / 03 / 2014$ & $\begin{array}{l}\text { Mandado de } \\
\text { Segurança }\end{array}$ & $21 / 03 / 2014$ & $\begin{array}{l}\text { 29/05/2014 - concedo a segurança pleiteada por...... } \\
\text { contra ato do secretário municipal de saúde de Bauru, } \\
\text { para que o impetrado forneça à impetrante fraldas } \\
\text { geriátricas descartáveis - tamanho "m" (120 unidades por } \\
\text { mês), nos termos da petição inicial, e julgo extinto o } \\
\text { processo. }\end{array}$ & FRALDA \\
\hline
\end{tabular}




\begin{tabular}{|c|c|c|c|c|c|c|c|}
\hline 34 & $\begin{array}{c}0007745- \\
27.2014 .8 .26 .0071\end{array}$ & $17371 / 2014$ & 27/03/2014 & $\begin{array}{l}\text { Outros } \\
\text { Procediment } \\
\text { os }\end{array}$ & $\begin{array}{l}19 / 03 / 2014 \\
\text { CONCEDO A } \\
\text { ANTECIPAÇÃO } \\
\text { DA TUTELA }\end{array}$ & $\begin{array}{l}\text { 17/07/2014 - julgo procedente o pedido formulado por .... } \\
\text { em face da prefeitura municipal de Bauru, determinando } \\
\text { que esta forneça ao requerente: suplemento alimentar } \\
\text { nutrison soya } 1,2 \text { ou tropic fiber } 1,2 \text { ( } 47 \text { litros por mês) ou } \\
\text { nutrison soya mf (10 latas de } 800 \mathrm{~g} \text { por mês), quetiapina } \\
100 \mathrm{mg} \text { (01 comprimido por dia), aristab 10mg (01 } \\
\text { comprimido por dia) e fraldas descartáveis geriátricas - } \\
\text { tamamho "eg" (240 unidades por mês), conforme } \\
\text { prescrições médicas de fls. } 16 \text { e } 18 / 20 \text {, nos termos da } \\
\text { petição inicial, e extinto o processo. }\end{array}$ & FRALDA \\
\hline 35 & $\begin{array}{c}0007965- \\
25.2014 .8 .26 .0071\end{array}$ & $17372 / 2014$ & $27 / 03 / 2014$ & $\begin{array}{l}\text { Outros } \\
\text { Procediment } \\
\text { os }\end{array}$ & $\begin{array}{c}\text { 22/03/2014 } \\
\text { ANTECIPAÇÃO } \\
\text { DA TUTELA }\end{array}$ & $\begin{array}{l}\text { 22/07/2014 - julgo procedente o pedido, formulado por } \\
\ldots \ldots . \text { contra prefeitura municipal de Bauru, determinando } \\
\text { que a requerida forneça à requerente: agendamento de } \\
\text { cirurgia plastica, nos termos da petição inicial e, extinto o } \\
\text { processo, com resolução de mérito. }\end{array}$ & CIRURGIA \\
\hline 36 & $\begin{array}{c}\text { 0007028- } \\
\text { 15.2014.8.26.0071 }\end{array}$ & $17373 / 2014$ & $27 / 03 / 2014$ & $\begin{array}{l}\text { Mandado de } \\
\text { Segurança }\end{array}$ & 22/03/2014 & $\begin{array}{l}14 / 04 / 2014 \text { - concedo a segurança pleiteada por ......contra } \\
\text { ato do secretário municipal de saude de Bauru, para que } \\
\text { o impetrado forneça ao impetrante fraldas geriátricas } \\
\text { descartáveis - tamanho "g" (05 unidades por dia), nos } \\
\text { termos da petição inicial, e julgo extinto o processo. }\end{array}$ & FRALDA \\
\hline 37 & $\begin{array}{c}0008029- \\
35.2014 .8 .26 .0071\end{array}$ & $17604 / 2014$ & 28/03/2014 & $\begin{array}{l}\text { Outros } \\
\text { Procediment } \\
\text { os }\end{array}$ & $25 / 03 / 2014$ & $\begin{array}{l}\text { 30/06/2014 - julgo procedente o pedido formulado por ..... } \\
\text { em face do município de Bauru, determinando que este } \\
\text { forneça à requerente fraldas descartáveis geriátricas - } \\
\text { tamanho "m" (120 unidades por mês), nos termos da } \\
\text { petição inicial, e extinto o processo. }\end{array}$ & FRALDA \\
\hline 38 & $\begin{array}{c}0007862- \\
18.2014 .8 .26 .0071\end{array}$ & $17739 / 2014$ & 28/03/2014 & $\begin{array}{l}\text { Mandado de } \\
\text { Segurança }\end{array}$ & 25/03/2014 & $\begin{array}{l}14 / 04 / 2014 \text { - concedo a segurança pleiteada por .... } \\
\text { contra ato do secretário municipal de saúde de Bauru, } \\
\text { para que o impetrado forneça ao impetrante fraldas } \\
\text { geriátricas descartáveis - tamanho "g" (130 unidades por } \\
\text { mês), nos termos da petição inicial, e julgo extinto o } \\
\text { processo. }\end{array}$ & FRALDA \\
\hline 39 & $\begin{array}{c}0004276- \\
70.2014 .8 .26 .0071\end{array}$ & $17747 / 2014$ & 28/03/2014 & $\begin{array}{l}\text { Outros } \\
\text { Procediment } \\
\text { os }\end{array}$ & $23 / 04 / 2014$ & $\begin{array}{l}\text { 24/04/2014 - denego a segurança pleiteada por .... contra } \\
\text { ato do SECRETARIO MUNICIPAL DE SÁUDE DE } \\
\text { BAURU, e julgo extinto o processo, com resolução de } \\
\text { mérito, nos termos do artigo } 269 \text {, I, do Código de } \\
\text { Processo Civil. }\end{array}$ & $\begin{array}{c}\text { CUIDADOR/HOM } \\
\text { E CARE }\end{array}$ \\
\hline
\end{tabular}




\begin{tabular}{|c|c|c|c|c|c|c|c|}
\hline 40 & $\begin{array}{c}0008784- \\
59.2014 .8 .26 .0071\end{array}$ & $19500 / 2014$ & 04/04/2014 & $\begin{array}{l}\text { Outros } \\
\text { Procediment } \\
\text { os }\end{array}$ & $\begin{array}{c}\text { 02/04/2014 } \\
\text { CONCEDO } \\
\text { PARCIALMENT } \\
\text { E A } \\
\text { ANTECIPAÇÃO } \\
\text { DA TUTELA } \\
\end{array}$ & $\begin{array}{l}16 / 07 / 2014 \text { - julgo parcialmente procedente o pedido } \\
\text { formulado por .... contra prefeitura municipal de Bauru, } \\
\text { determinando que a requerida forneça ao requerente: } \\
\text { agendamento de consulta na especialidade de ortopedia, } \\
\text { nos termos da petição inicial, e extinto o processo, com } \\
\text { resolução de mérito. }\end{array}$ & $\begin{array}{l}\text { CONSULTA } \\
\text { MÉDICA }\end{array}$ \\
\hline 41 & $\begin{array}{l}0004599- \\
75.2014 .8 .26 .0071\end{array}$ & 20386/2014 & 08/04/2014 & $\begin{array}{l}\text { Mandado de } \\
\text { Segurança }\end{array}$ & 04/04/2014 & $\begin{array}{l}02 / 07 / 2014 \text { - concedo a segurança pleiteada por .... } \\
\text { contra ato do secretário municipal de saúde de Bauru, } \\
\text { para que o impetrado forneça à impetrante transporte de } \\
\text { sua casa até o hospital estadual de Bauru nos dias de } \\
\text { tratamento de hemodiálise (03 vezes por semana), nos } \\
\text { termos da petição inicial, e julgo extinto o processo. }\end{array}$ & TRANSPORTE \\
\hline 42 & $\begin{array}{c}0008674- \\
60.2014 .8 .26 .0071\end{array}$ & 20687/2014 & 09/04/2014 & $\begin{array}{l}\text { Mandado de } \\
\text { Segurança }\end{array}$ & 07/04/2014 & $\begin{array}{l}\text { 30/04/2014 - concedo parcialmente a segurança pleiteada } \\
\text { por .... contra ato do secretário municipal de saúde de } \\
\text { Bauru, para que o impetrado providencie o agendamento } \\
\text { de consultas nas especialidades de gastroenterologia e } \\
\text { cirurgia geral, para avaliação da necessidade de } \\
\text { intervenção cirúrgica quanto à impetrante, nos termos da } \\
\text { petição inicial, e julgo extinto o processo. }\end{array}$ & $\begin{array}{l}\text { CONSULTA } \\
\text { MÉDICA }\end{array}$ \\
\hline 43 & $\begin{array}{c}0007854- \\
41.2014 .8 .26 .0071\end{array}$ & $21038 / 2014$ & $10 / 04 / 2014$ & $\begin{array}{l}\text { Mandado de } \\
\text { Segurança }\end{array}$ & 07/04/2014 & $\begin{array}{l}24 / 04 / 2014 \text { - concedo a segurança pleiteada por .... } \\
\text { contra ato do secretário municipal de saúde de Bauru, } \\
\text { para que o impetrado providencie o fornecimento ao } \\
\text { impetrante dos medicamentos concor } 5 \mathrm{mg} \text { (02 } \\
\text { comprimidos por dia) e xarelto } 20 \mathrm{mg}(01 \mathrm{comprimido} \text { por } \\
\text { dia), conforme prescrição médica de fls. } 29 \text {, nos termos } \\
\text { da petição inicial, e julgo extinto o processo, com } \\
\text { resolução de mérito. }\end{array}$ & MEDICAMENTO \\
\hline 44 & $\begin{array}{c}0009255- \\
75.2014 .8 .26 .0071\end{array}$ & $21451 / 2014$ & $11 / 04 / 2014$ & $\begin{array}{l}\text { Outros } \\
\text { Procediment } \\
\text { os }\end{array}$ & & $\begin{array}{l}\text { 12/02/16 - mantenho a sentença e determino a remessa } \\
\text { dos autos à Superior Instância para reexame voluntário. }\end{array}$ & $\begin{array}{l}\text { CONSULTA } \\
\text { MÉDICA }\end{array}$ \\
\hline
\end{tabular}




\begin{tabular}{|c|c|c|c|c|c|c|c|}
\hline 45 & $\begin{array}{c}\text { 0009691- } \\
34.2014 .8 .26 .0071\end{array}$ & $21963 / 2014$ & $14 / 04 / 2014$ & $\begin{array}{l}\text { Mandado de } \\
\text { Segurança }\end{array}$ & 08/04/2014 & $\begin{array}{l}\text { 08/08/2014 - concedo a segurança, determinando que o } \\
\text { impetrado providencie o fornecimento à impetrante da } \\
\text { dieta normocalórica, normoprotéica isenta de sacarose, } \\
\text { lactose e glúten com fibras ( } 14 \text { latas de } 800 \text { gramas por } \\
\text { mês), conforme recomendação nutricional de fls. } 18 \text {, sob } \\
\text { pena de responder por crime de desobediência, sem } \\
\text { prejuízo das sanções administrativas. }\end{array}$ & $\begin{array}{c}\text { ALIMENTAÇÃO } \\
\text { ESPECIAL }\end{array}$ \\
\hline 46 & $\begin{array}{c}0000159- \\
36.2014 .8 .26 .0071 \\
\end{array}$ & $21971 / 2014$ & $14 / 04 / 2014$ & $\begin{array}{c}\text { Mandado de } \\
\text { Segurança }\end{array}$ & $\begin{array}{c}\text { SEGREDO DE } \\
\text { JUSTIÇA }\end{array}$ & SEGREDO DE JUSTIÇA & $\begin{array}{c}\text { ALIMENTAÇÃO } \\
\text { ESPECIAL }\end{array}$ \\
\hline 47 & $\begin{array}{c}\text { 0003611- } \\
54.2014 .8 .26 .0071\end{array}$ & $22702 / 2014$ & $16 / 04 / 2014$ & $\begin{array}{l}\text { Mandado de } \\
\text { Segurança }\end{array}$ & 08/04/2014 & $\begin{array}{l}\text { 06/05/2014 - concedo a segurança pleiteada por .... } \\
\text { contra ato do secretário municipal de saúde de Bauru, } \\
\text { para que o impetrado forneça ao impetrante fraldas } \\
\text { geriátricas descartáveis - tamanho "m" (120 unidades por } \\
\text { mês), nos termos da petição inicial, e julgo extinto o } \\
\text { processo, com resolução de mérito. }\end{array}$ & FRALDA \\
\hline 48 & $\begin{array}{c}0009610- \\
85.2014 .8 .26 .0071\end{array}$ & 22707/2014 & $16 / 04 / 2014$ & $\begin{array}{l}\text { Mandado de } \\
\text { Segurança }\end{array}$ & 08/04/2014 & $\begin{array}{l}\text { 29/05/2014 - concedo a segurança pleiteada por .... } \\
\text { contra ato do secretário municipal de saúde de Bauru, } \\
\text { para que o impetrado providencie o fornecimento à } \\
\text { impetrante de tratamento de oxigenoterapia em câmara } \\
\text { hiperbárica ( } 30 \text { sessões), conforme prescrição médica de } \\
\text { fls. } 16 \text {, nos termos da petição inicial, e julgo extinto o } \\
\text { processo, com resolução de mérito. }\end{array}$ & $\begin{array}{l}\text { CONSULTA } \\
\text { MÉDICA }\end{array}$ \\
\hline 49 & $\begin{array}{c}\text { 0002560- } \\
08.2014 .8 .26 .0071\end{array}$ & $23028 / 2014$ & $17 / 04 / 2014$ & $\begin{array}{l}\text { Mandado de } \\
\text { Segurança }\end{array}$ & $\begin{array}{l}\text { 10/04/2014 } \\
\text { DEFIRO } \\
\text { PARCIALMENT } \\
\text { E A LIMINAR }\end{array}$ & $\begin{array}{l}\text { 03/07/2014 - concedo parcialmente a segurança, } \\
\text { determinando que o impetrado providencie o fornecimento } \\
\text { à impetrante dos medicamentos pantoprazol } 40 \mathrm{mg} \text { ( } 30 \\
\text { comprimidos pro mês) e trimebutina 200mg }(60 \\
\text { comprimidos por mês), conforme receituário de fls. } 14 ; \\
\text { colágeno hidrolisado, em pó, tipo } 2 \text { (30 sachês por mês } \\
\text { prescriçãa médica de fls. 13) e estradiol creme (1 frasco } \\
\text { por mês receituário médico de fls. 45), sob pena de } \\
\text { responder por crime de desobediência, sem prejuízo das } \\
\text { sanções administrativas. }\end{array}$ & MEDICAMENTO \\
\hline
\end{tabular}




\begin{tabular}{|c|c|c|c|c|c|c|c|}
\hline 50 & $\begin{array}{c}\text { 0007865- } \\
\text { 70.2014.8.26. } 0071\end{array}$ & $23033 / 2014$ & $17 / 04 / 2014$ & $\begin{array}{l}\text { Mandado de } \\
\text { Segurança }\end{array}$ & $\begin{array}{l}11 / 04 / 2014 \\
\text { DEFIRO } \\
\text { PARCIALMENT } \\
\text { E A LIMINAR }\end{array}$ & $\begin{array}{l}\text { 28/05/2014 - concedo a segurança pleiteada por .... } \\
\text { contra ato do secretário municipal de saúde de Bauru, } \\
\text { para que o impetrado providencie o agendamento de } \\
\text { consulta na especialidade de ortopedia (coluna) e exame } \\
\text { neurológico (eletroencefalograma) para a impetrante, nos } \\
\text { termos da petição inicial, e julgo extinto o processo, com } \\
\text { resolução de mérito. }\end{array}$ & $\begin{array}{l}\text { CONSULTA } \\
\text { MÉDICA }\end{array}$ \\
\hline 51 & $\begin{array}{c}\text { 0010875- } \\
\text { 25.2014.8.26.0071 }\end{array}$ & $24926 / 2014$ & 28/04/2014 & $\begin{array}{l}\text { Mandado de } \\
\text { Segurança }\end{array}$ & $23 / 04 / 2014$ & $\begin{array}{l}22 / 50 / 2014 \text { - concedo a segurança pleiteada por .... } \\
\text { contra ato do secretário municipal de saúde de Bauru, } \\
\text { para que o impetrado forneça à impetrante fraldas } \\
\text { geriátricas descartáveis - tamanho "g" (60 unidades por } \\
\text { mês), nos termos da petição inicial, e julgo extinto o } \\
\text { processo, com resolução de mérito. }\end{array}$ & FRALDA \\
\hline 52 & $\begin{array}{c}0009162- \\
15.2014 .8 .26 .0071\end{array}$ & $25014 / 2014$ & 29/04/2014 & $\begin{array}{l}\text { Mandado de } \\
\text { Segurança }\end{array}$ & $\begin{array}{l}\text { 25/04/2014 } \\
\text { DEFIRO } \\
\text { PARCIALMENT } \\
\text { E A LIMINAR }\end{array}$ & $\begin{array}{l}\text { 16/06/2014 - concedo parcialmente a segurança, } \\
\text { determinando que o impetrado providencie o fornecimento } \\
\text { ao impetrante das fraldas geriátricas descartáveis } \\
\text { (tamanho g } 180 \text { unidades por mês), conforme a } \\
\text { prescrição médica de fls. } 21 \text {, sob pena de responder por } \\
\text { crime de desobediência, sem prejuízo das sanções } \\
\text { administrativas. }\end{array}$ & FRALDA \\
\hline 53 & $\begin{array}{c}0010854- \\
49.2014 .8 .26 .0071\end{array}$ & $26413 / 2014$ & $07 / 05 / 2014$ & $\begin{array}{l}\text { Mandado de } \\
\text { Segurança }\end{array}$ & 05/05/2014 & $\begin{array}{l}21 / 05 / 2014 \text { - concedo a segurança, determinando que o } \\
\text { impetrado providencie o fornecimento ao impetrante das } \\
\text { fraldas geriátricas descartáveis (tamanho g } 120 \text { unidades } \\
\text { por mês), conforme a prescrição médica de fls. } 14 \text {, sob } \\
\text { pena de responder por crime de desobediência, sem } \\
\text { prejuízo das sanções administrativas. }\end{array}$ & FRALDA \\
\hline 54 & $\begin{array}{c}0011890- \\
29.2014 .8 .26 .0071\end{array}$ & $26565 / 2014$ & 07/05/2014 & $\begin{array}{l}\text { Mandado de } \\
\text { Segurança }\end{array}$ & 05/05/2014 & $\begin{array}{l}\text { 16/06/2014 - concedo a segurança, determinando que o } \\
\text { impetrado providencie o fornecimento à impetrante das } \\
\text { fraldas geriátricas descartáveis (tamanho grande } 120 \\
\text { unidades por mês), conforme a prescrição médica de fls. } \\
11 \text {, sob pena de responder por crime de desobediência, } \\
\text { sem prejuízo das sanções administrativas. }\end{array}$ & FRALDA \\
\hline 55 & $\begin{array}{c}\text { 0009637- } \\
68.2014 .8 .26 .0071\end{array}$ & $26586 / 2014$ & 07/05/2014 & $\begin{array}{l}\text { Mandado de } \\
\text { Segurança }\end{array}$ & 29/04/2014 & $\begin{array}{l}\text { 26/05/2014 - concedo parcialmente a segurança pleiteada } \\
\text { por ... contra ato do secretário municipal de saúde de } \\
\text { Bauru, para que o impetrado forneça aa impetrante } \\
\text { fraldas geriátricas descartáveis - tamanho "g" (06 } \\
\text { unidades por dia), nos termos da petição inicial, e julgo } \\
\text { extinto o processo, com resolução de mérito. }\end{array}$ & FRALDA \\
\hline
\end{tabular}




\begin{tabular}{|c|c|c|c|c|c|c|c|}
\hline 56 & $\begin{array}{c}\text { 0012127- } \\
\text { 63.2014.8.26.0071 }\end{array}$ & 27238/2014 & 07/05/2014 & $\begin{array}{l}\text { Mandado de } \\
\text { Segurança }\end{array}$ & 06/05/2014 & $\begin{array}{l}25 / 07 / 2014 \text { - concedo a segurança pleiteada por .... } \\
\text { contra ato do secretário municipal de saúde de Bauru, } \\
\text { para que o impetrado providencie o agendamento de } \\
\text { consulta na especialidade de cardiologia para a } \\
\text { impetrante, nos termos da petição inicial, e julgo extinto o } \\
\text { processo, com resolucão de mérito. }\end{array}$ & $\begin{array}{l}\text { CONSULTA } \\
\text { MÉDICA }\end{array}$ \\
\hline 57 & $\begin{array}{c}\text { 1007616- } \\
\text { 05.2014.8.26.0071 }\end{array}$ & $27676 / 2014$ & $13 / 05 / 2014$ & $\begin{array}{l}\text { Mandado de } \\
\text { Segurança }\end{array}$ & 09/05/2014 & $\begin{array}{l}02 / 06 / 2014 \text { - concedo a segurança pleiteada por ..... } \\
\text { contra ato do secretário municipal de saúde de Bauru, } \\
\text { para que o impetrado providencie o fornecimento à } \\
\text { impetrante de mobility ( } 01 \text { sache por dia, por seis meses), } \\
\text { conforme prescrição médica de fls. } 24 \text {, nos termos da } \\
\text { petição inicial, e julgo extinto o processo, com resolução } \\
\text { de mérito. }\end{array}$ & MEDICAMENTO \\
\hline 58 & $\begin{array}{c}\text { 1007781- } \\
\text { 52.2014.8.26.0071 }\end{array}$ & $28603 / 2014$ & $16 / 05 / 2014$ & $\begin{array}{l}\text { Mandado de } \\
\text { Segurança }\end{array}$ & $\begin{array}{l}13 / 05 / 2014 \\
\text { DEFIRO } \\
\text { PARCIALMENT } \\
\text { E A LIMINAR }\end{array}$ & $\begin{array}{l}\text { 02/06/2014 - concedo parcialmente a segurança pleiteada } \\
\text { por.... contra ato do secretário municipal de saúde de } \\
\text { Bauru, para que o impetrado forneça ao impetrante } \\
\text { absorventes geriátricos descartáveis maxi absorvente } \\
\text { (100 unidades por mês), e julgo extinto o processo, com } \\
\text { resolução de mérito. }\end{array}$ & FRALDA \\
\hline 59 & $\begin{array}{c}\text { 0010799- } \\
\text { 98.2014.8.26.0071 }\end{array}$ & $29410 / 2014$ & $21 / 05 / 2014$ & $\begin{array}{l}\text { Outros } \\
\text { Procediment } \\
\text { os }\end{array}$ & $\begin{array}{c}\text { 15/05/2014 } \\
\text { ANTECIPAÇÃO } \\
\text { DA TUTELA }\end{array}$ & $\begin{array}{l}09 / 12 / 2014 \text { - julgo parcialmente procedente o pedido, } \\
\text { formulado por .... contra prefeitura municipal de Bauru, } \\
\text { determinando que o requerido forneça à requerente: } \\
\text { agendamento de consulta na especialidade de } \\
\text { gastroenterologia, nos termos da petição inicial, e extinto } \\
\text { o processo, com resolução de mérito. }\end{array}$ & $\begin{array}{l}\text { CONSULTA } \\
\text { MÉDICA }\end{array}$ \\
\hline 60 & $\begin{array}{c}0007930- \\
65.2014 .8 .26 .0071\end{array}$ & $30423 / 2014$ & $26 / 05 / 2014$ & $\begin{array}{l}\text { Mandado de } \\
\text { Segurança }\end{array}$ & $22 / 05 / 2014$ & $\begin{array}{l}\text { 18/03/2015 - concedo a segurança, para determinar que o } \\
\text { impetrado forneça à impetrante a dieta normocalórica, } \\
\text { hiperproteica, com fibras nutrison protein plus multi fiber } \\
1,25 \mathrm{kcal} / \mathrm{ml} \text { ( } 31 \text { litros por mês, conforme receituário em fls. } \\
18) \text {, sob pena de responder por crime de desobediência, } \\
\text { sem prejuízo das sanções administrativas. }\end{array}$ & $\begin{array}{l}\text { ALIMENTAÇÃO } \\
\text { ESPECIAL }\end{array}$ \\
\hline
\end{tabular}




\begin{tabular}{|c|c|c|c|c|c|c|c|}
\hline 61 & $\begin{array}{c}\text { 0010839- } \\
80.2014 .8 .26 .0071\end{array}$ & $30946 / 2014$ & $28 / 05 / 2014$ & $\begin{array}{l}\text { Mandado de } \\
\text { Segurança }\end{array}$ & $27 / 05 / 2014$ & $\begin{array}{l}\text { 02/07/2014 - concedo a segurança, determinando que o } \\
\text { impetrado providencie o fornecimento à impetrante dos } \\
\text { medicamentos e insumos insulina glargina ( } 03 \text { refis por } \\
\text { mês fls. 24), insulina humalog u } 100 \text { (03 refis por mês fls. } \\
\text { 24), tiras reagentes para glicemia capilar ( } 150 \text { unidades } \\
\text { por mês fls. 24), glicosímetro (01 unidade) e agulhas } \\
\text { descartáveis bd para canetas de insulina } 5 / 025 \mathrm{~mm} \text { ( } 120 \\
\text { unidades por mês) conforme recomendação de fls. } 24, \\
\text { sob pena de responder por crime de desobediência, sem } \\
\text { prejuízo das sanções administrativas. }\end{array}$ & MEDICAMENTO \\
\hline 62 & $\begin{array}{c}\text { 1008668- } \\
36.2014 .8 .26 .0071\end{array}$ & $31355 / 2014$ & $28 / 05 / 2014$ & $\begin{array}{l}\text { Outros } \\
\text { Procediment } \\
\text { os }\end{array}$ & $\begin{array}{l}27 / 05 / 2014 \\
\text { CONCEDO A } \\
\text { LIMINAR }\end{array}$ & $\begin{array}{l}\text { 02/07/2014 - julgo procedente o pedido formulado por .... } \\
\text { em face do municipio de Bauru, determinando que este } \\
\text { forneça à requerente fraldas descartáveis geriátricas - } \\
\text { tamanho "g" (180 unidades por mês), nos termos da } \\
\text { petição inicial, e extinto o processo. }\end{array}$ & FRALDA \\
\hline 63 & $\begin{array}{c}\text { 0010445- } \\
\text { 73.2014.8.26.0071 }\end{array}$ & $31663 / 2014$ & 02/06/2014 & $\begin{array}{c}\text { Mandado de } \\
\text { Segurança }\end{array}$ & 29/05/2014 & $\begin{array}{l}21 / 07 / 2014 \text { - noticiado o óbito da impetrante. assim, } \\
\text { evidente a carência superveniente da ação por falta de } \\
\text { interesse processual. ante o exposto, julgo extinto o } \\
\text { processo. }\end{array}$ & FRALDA \\
\hline 64 & $\begin{array}{c}\text { 1008816- } \\
47.2014 .8 .26 .0071\end{array}$ & $31730 / 2014$ & 02/06/2014 & $\begin{array}{c}\text { Mandado de } \\
\text { Segurançaa }\end{array}$ & $28 / 05 / 2014$ & $\begin{array}{l}12 / 06 / 2014 \text { - concedo a segurança pleiteada por .... } \\
\text { contra ato do secretário municipal de saúde de Bauru, } \\
\text { para que o impetrado providencie o fornecimento ao } \\
\text { impetrante de suplemento específico para pacientes com } \\
\text { diabetes, com fibras, isento de sacarose e glúten ( } 114 \mathrm{~g} \\
\text { de pó por dia - } 3.420 \mathrm{~kg} \text { por mês, ou líquido } 02 \text { unidades } \\
\text { de } 200 \mathrm{ml} \text { por dia - } 60 \text { unidades por mês), nos termos da } \\
\text { petição inicial, e julgo extinto o processo, com resolução } \\
\text { de mérito. }\end{array}$ & $\begin{array}{l}\text { ALIMENTAÇÃO } \\
\text { ESPECIAL }\end{array}$ \\
\hline
\end{tabular}




\begin{tabular}{|c|c|c|c|c|c|c|c|}
\hline 65 & $\begin{array}{c}\text { 10086694- } \\
34.2014 .8 .26 .0071\end{array}$ & $31743 / 2014$ & 02/06/2014 & $\begin{array}{l}\text { Mandado de } \\
\text { Segurança }\end{array}$ & 27/05/2014 & $\begin{array}{l}25 / 06 / 2014 \text { - concedo a segurança pleiteada por .... } \\
\text { contra ato do secretário municipal de saúde de Bauru, } \\
\text { para que o impetrado providencie o agendamento de } \\
\text { consulta na especialidade de oftalmologia no ambulatório } \\
\text { de estrabismo para o impetrante, nos termos da petição } \\
\text { inicial, e julgo extinto o processo, com resolução de } \\
\text { mérito. }\end{array}$ & $\begin{array}{l}\text { CONSULTA } \\
\text { MÉDICA }\end{array}$ \\
\hline 66 & $\begin{array}{c}\text { 1009035- } \\
60.2014 .8 .26 .0071\end{array}$ & $32299 / 2014$ & 04/06/2014 & $\begin{array}{l}\text { Mandado de } \\
\text { Segurança }\end{array}$ & 29/05/2014 & $\begin{array}{l}02 / 10 / 2014 \text { - concedo a segurança pleiteada por .... } \\
\text { contra ato do secretário municipal de saúde de Bauru, } \\
\text { para que o impetrado forneça ao impetrante fraldas } \\
\text { geriátricas descartáveis - tamanho "eg" (05 unidades por } \\
\text { dia, pelo período de noventa dias), nos termos da petição } \\
\text { inicial, e julgo extinto o processo, com resolução de } \\
\text { mérito. }\end{array}$ & FRALDA \\
\hline 67 & $\begin{array}{c}\text { 10088822- } \\
\text { 54.2014.8.26.0071 }\end{array}$ & $33681 / 14$ & $11 / 06 / 2014$ & $\begin{array}{l}\text { Mandado de } \\
\text { Segurança }\end{array}$ & 06/06/2014 & $\begin{array}{l}11 / 07 / 2014 \text { - concedo a segurança, determinando que o } \\
\text { impetrado providencie o fornecimento à impetrante das } \\
\text { fraldas geriátricas descartáveis (tamanho } \mathrm{m} 150 \text { unidades } \\
\text { por mês prescrição médica de fls. } 17) \text {, colchão casca de } \\
\text { ovo (01 unidade) e colchão impermeável (01 unidade), } \\
\text { sob pena de responder por crime de desobediência, sem } \\
\text { prejuízo das sanções administrativas. }\end{array}$ & FRALDA \\
\hline 68 & $\begin{array}{c}\text { 1009535- } \\
\text { 29.2014.8.26.0071 }\end{array}$ & $34143 / 2014$ & $13 / 06 / 2014$ & $\begin{array}{l}\text { Mandado de } \\
\text { Segurança }\end{array}$ & 09/06/2014 & $\begin{array}{l}\text { 16/07/2014 - concedo parcialmente a segurança pleiteada } \\
\text { por ... contra ato do secretário municipal de saúde de } \\
\text { Bauru, para que o impetrado providencie o agendamento } \\
\text { de consulta na especialidade de ortopedia para o } \\
\text { impetrante. }\end{array}$ & $\begin{array}{l}\text { CONSULTA } \\
\text { MÉDICA }\end{array}$ \\
\hline 69 & $\begin{array}{c}1009940- \\
65.2014 .8 .26 .0071\end{array}$ & $34650 / 2014$ & $18 / 06 / 2014$ & $\begin{array}{l}\text { Mandado de } \\
\text { Segurança }\end{array}$ & $13 / 06 / 2014$ & $\begin{array}{l}\text { 16/07/2014 - concedo a segurança, determinando que o } \\
\text { impetrado providencie o fornecimento à impetrante das } \\
\text { fraldas geriátricas descartáveis (tamanho g } 120 \text { unidades } \\
\text { por mês prescrição médica de fls. } 33 \text { ), sob pena de } \\
\text { responder por crime de desobediência, sem prejuízo das } \\
\text { sancões administrativas }\end{array}$ & FRALDA \\
\hline 70 & $\begin{array}{c}\text { 1009972- } \\
\text { 70.2014.8.26.0071 }\end{array}$ & $35241 / 2014$ & $24 / 06 / 2014$ & $\begin{array}{l}\text { Mandado de } \\
\text { Segurança }\end{array}$ & $16 / 06 / 2014$ & $\begin{array}{l}\text { 16/07/2014 - CONCEDO A SEGURANCCA pleiteada por } \\
\text { ‥ contra ato do SECRETÁRIO MUNICIPAL DE SAÚDE } \\
\text { DE BAURU, para que o impetrado forneça ao impetrante } \\
\text { FRALDAS GERIÁTRICAS DESCARTÁVEIS - tamanho } \\
\text { "G" (120 unidades por mês), nos termos da petição inicial, } \\
\text { e julgo extinto o processo, com resolução de mérito. }\end{array}$ & FRALDA \\
\hline
\end{tabular}




\begin{tabular}{|c|c|c|c|c|c|c|c|}
\hline 71 & $\begin{array}{c}\text { 1010179- } \\
\text { 69.2014.8.26.0071 }\end{array}$ & $35243 / 2014$ & $24 / 06 / 2014$ & $\begin{array}{l}\text { Mandado de } \\
\text { Segurança }\end{array}$ & $16 / 06 / 2014$ & $\begin{array}{l}\text { 16/07/2014 - concedo a segurança pleiteada por..... contra } \\
\text { ato do secretário municipal de saúde de Bauru, para que } \\
\text { o impetrado forneça ao impetrante fraldas geriátricas } \\
\text { descartáveis - tamanho "g" (120 unidades por mês), nos } \\
\text { termos da petição inicial, e julgo extinto o processo, com } \\
\text { resolução de mérito. }\end{array}$ & FRALDA \\
\hline 72 & $\begin{array}{c}\text { 1010289- } \\
\text { 68.2014.8.26.0071 }\end{array}$ & $36125 / 2014$ & $26 / 06 / 2014$ & $\begin{array}{l}\text { Mandado de } \\
\text { Segurança }\end{array}$ & 24/06/2014 & $\begin{array}{l}16 / 07 / 2014 \text { - concedo a segurança pleiteada por .... } \\
\text { contra ato do secretário municipal de saúde de Bauru, } \\
\text { para que o impetrado forneça ao impetrante fraldas } \\
\text { geriátricas descartáveis - tamanho "g" (08 unidades por } \\
\text { dia), nos termos da petição inicial, e julgo extinto o } \\
\text { processo, com resolução de mérito }\end{array}$ & FRALDA \\
\hline 73 & $\begin{array}{c}\text { 1010747- } \\
85.2014 .8 .26 .0071\end{array}$ & $36811 / 2014$ & 01/07/2014 & $\begin{array}{l}\text { Mandado de } \\
\text { Segurança }\end{array}$ & 27/06/2014 & $\begin{array}{l}23 / 07 / 2014 \text { - concedo a segurança pleiteada por .... } \\
\text { contra ato do secretário municipal de saúde de Bauru, } \\
\text { para que o impetrado forneça ao impetrante fraldas } \\
\text { geriátricas descartáveis - tamanho "g" (180 unidades por } \\
\text { mês), nos termos da petição inicial, e julgo extinto o } \\
\text { processo, com resolução de mérito. }\end{array}$ & FRALDA \\
\hline 74 & $\begin{array}{c}\text { 0009161- } \\
30.2014 .8 .26 .0071\end{array}$ & $37586 / 2014$ & 04/07/2014 & $\begin{array}{l}\text { Mandado de } \\
\text { Segurança }\end{array}$ & $\begin{array}{l}\text { Indefiro o } \\
\text { pedido de } \\
\text { liminar. }\end{array}$ & 24/07/2014 - denego a segurança pleiteada. & $\begin{array}{l}\text { CONSULTA } \\
\text { MÉDICA }\end{array}$ \\
\hline 75 & $\begin{array}{l}0018833- \\
62.2014 .8 .26 .0071\end{array}$ & $38824 / 2014$ & $14 / 07 / 2014$ & $\begin{array}{l}\text { Mandado de } \\
\text { Segurança }\end{array}$ & $11 / 07 / 2014$ & 03/12/14 - Julgo extinto com resolução do mérito. & $\begin{array}{l}\text { ALIMENTAÇÃO } \\
\text { ESPECIAL }\end{array}$ \\
\hline 76 & $\begin{array}{c}0013965- \\
41.2014 .8 .26 .0071\end{array}$ & 39578/2014 & 16/07/2014 & $\begin{array}{l}\text { Mandado de } \\
\text { Segurança }\end{array}$ & $15 / 07 / 2014$ & $\begin{array}{l}\text { 08/08/2014 - Torna definitiva a liminar determina o SMS } \\
\text { fornecer fórmula de partida } 10 \text { latas/mês. }\end{array}$ & $\begin{array}{l}\text { ALIMENTAÇÃO } \\
\text { ESPECIAL }\end{array}$ \\
\hline
\end{tabular}




\begin{tabular}{|c|c|c|c|c|c|c|c|}
\hline 77 & $\begin{array}{c}1011514- \\
26.2014 .8 .26 .0071\end{array}$ & $39746 / 2014$ & $17 / 07 / 2014$ & $\begin{array}{l}\text { Mandado de } \\
\text { Segurança }\end{array}$ & $11 / 07 / 2014$ & $\begin{array}{l}\text { 31/07/2014 - concedo a segurança pleiteada por .... contra } \\
\text { ato do secretário municipal de saúde de Bauru, para que } \\
\text { o impetrado forneça à impetrante fraldas geriátricas } \\
\text { descartáveis - tamanho "m" (120 unidades por mês), nos } \\
\text { termos da petição inicial, e julgo extinto o processo. }\end{array}$ & FRALDA \\
\hline 78 & $\begin{array}{c}1011430- \\
25.2014 .8 .26 .0071\end{array}$ & $40354 / 2014$ & $21 / 07 / 2014$ & $\begin{array}{l}\text { Mandado de } \\
\text { Segurança }\end{array}$ & $16 / 07 / 2014$ & $\begin{array}{l}31 / 07 / 2014 \text { - concedo a segurança, determinando que o } \\
\text { impetrado providencie o fornecimento à impetrante os } \\
\text { medicamentos acarbose } 50 \mathrm{mg} \text { ( } 90 \text { comprimidos por } \\
\text { mês), linagliptina } 5 \mathrm{mg} \text { ( } 30 \mathrm{comprimidos} \text { por mês), insulina } \\
\text { asparte u } 100 \text { ( } 01 \mathrm{refil} \text { por mês) e insulina glargina u } 100 \\
\text { ( } 02 \text { refis por mês), bem como agulha bd ultrafine } 4 \mathrm{~mm} \\
\text { ( } 100 \text { unidades por mês), conforme recomendação médica } \\
\text { de fls. } 21 \text {, sob pena de responder por crime de } \\
\text { desobediência, sem prejuízo das sanções administrativas. }\end{array}$ & MEDICAMENTO \\
\hline 79 & $\begin{array}{c}1012437- \\
52.2014 .8 .26 .0071\end{array}$ & $41022 / 2014$ & $24 / 07 / 2014$ & $\begin{array}{c}\text { Outros } \\
\text { Procediment } \\
\text { os }\end{array}$ & $22 / 07 / 2014$ & $\begin{array}{l}\text { 22/09/2014 - ratifico a antecipação de tutela concedida a } \\
\text { fls. 29/30, e julgo procedente o pedido, mantendo a } \\
\text { obrigação imposta ao requerido de fornecer a requerente } \\
\text { o medicamento colágeno hidrolisado ( } 30 \text { saches por mês). }\end{array}$ & MEDICAMENTO \\
\hline 80 & $\begin{array}{c}1012436- \\
67.2014 .8 .26 .0071\end{array}$ & $41590 / 2014$ & $28 / 07 / 2014$ & $\begin{array}{c}\text { Outros } \\
\text { Procediment } \\
\text { os }\end{array}$ & $23 / 07 / 2014$ & $\begin{array}{l}25 / 08 / 2014 \text { - julgo procedente o pedido formulado por .... } \\
\text { em face do município de Bauru, determinando que este } \\
\text { forneça ao requerente o medicamento pradaxa } \\
\text { (dabigatrana) } 110 \mathrm{mg}(02 \text { comprimidos por dia), nos } \\
\text { termos da petição inicial, e extinto o processo, com } \\
\text { resolução de mérito. }\end{array}$ & MEDICAMENTO \\
\hline 81 & $\begin{array}{c}1013066- \\
26.2014 .8 .26 .0071\end{array}$ & $42959 / 2014$ & 06/08/2014 & $\begin{array}{l}\text { Mandado de } \\
\text { Segurança }\end{array}$ & & SEGREDO DE JUSTIÇA & MEDICAMENTO \\
\hline 82 & $\begin{array}{c}1013329- \\
58.2014 .8 .26 .0071\end{array}$ & $43170 / 2014$ & $07 / 08 / 2014$ & $\begin{array}{l}\text { Mandado de } \\
\text { Segurança }\end{array}$ & 05/08/2014 & $\begin{array}{l}\text { 03/11/2014 - concedo a segurança pleiteada por ..... } \\
\text { contra ato do secretário municipal de saúde de Bauru, } \\
\text { para que o impetrado providencie o fornecimento ao } \\
\text { impetrante do medicamento cinacalcete } 30 \mathrm{mg}(01 \\
\text { comprimido por dia), conforme prescrição médica de fls. } \\
22 \text {, nos termos da petição inicial, e julgo extinto o } \\
\text { processo, com resolução de mérito. }\end{array}$ & MEDICAMENTO \\
\hline
\end{tabular}




\begin{tabular}{|c|c|c|c|c|c|c|c|}
\hline 83 & $\begin{array}{c}\text { 1013409- } \\
22.2014 .8 .26 .0071\end{array}$ & $43947 / 2014$ & $11 / 08 / 2014$ & $\begin{array}{l}\text { Mandado de } \\
\text { Segurança }\end{array}$ & 05/08/2014 & $\begin{array}{l}\text { 26/08/2014 - concedo a segurança, determinando que o } \\
\text { impetrado providencie o fornecimento ao impetrante os } \\
\text { medicamentos ezetimiba } 10 \mathrm{mg} \text { ( } 30 \text { comprimidos por mês) } \\
\text { e saxagliptina } 2,5 \mathrm{mg} \text { ( } 30 \text { comprimidos por mês), além de } \\
\text { agulhas para aplicação de insulina } 0,25 / 8 \mathrm{~mm} \text { ( } 30 \text { unidade } \\
\text { por mês), conforme recomendação médica de fls. } 19,21 \text { e } \\
\text { 22, sob pena de responder por crime de desobediência, } \\
\text { sem prejuízo das sanções administrativas. }\end{array}$ & MEDICAMENTO \\
\hline 84 & $\begin{array}{c}\text { 1013683- } \\
\text { 83.2014.8.26.0071 }\end{array}$ & $44837 / 2014$ & $15 / 08 / 2014$ & $\begin{array}{l}\text { Mandado de } \\
\text { Segurança }\end{array}$ & $11 / 08 / 2014$ & $\begin{array}{l}\text { 10/09/2014 - concedo a segurança pleiteada por .... } \\
\text { contra ato do secretário municipal de saúde de Bauru, } \\
\text { para que o impetrado forneça ao impetrante fraldas } \\
\text { geriátricas descartáveis - tamanho "m" (60 unidades por } \\
\text { mês), nos termos da petição inicial, e julgo extinto o } \\
\text { processo, com resolução de mérito. }\end{array}$ & FRALDA \\
\hline 85 & $\begin{array}{c}\text { 1013894- } \\
22.2014 .8 .26 .0071\end{array}$ & $45022 / 2014$ & $15 / 08 / 2014$ & $\begin{array}{l}\text { Mandado de } \\
\text { Segurança }\end{array}$ & $14 / 08 / 2014$ & $\begin{array}{l}\text { 02/10/2014 - concedo a segurança, determinando que o } \\
\text { impetrado providencie o fornecimento ao impetrante das } \\
\text { fraldas geriátricas descartáveis, tamanho } g \text { ( } 120 \text { unidades } \\
\text { por mês), conforme a prescrição médica de fls. } 23 \text {, sob } \\
\text { pena de responder por crime de desobediência, sem } \\
\text { prejuízo das sanções administrativas. }\end{array}$ & FRALDA \\
\hline 86 & $\begin{array}{c}0018829- \\
25.2014 .8 .26 .0071\end{array}$ & $45206 / 2014$ & 18/08/2014 & $\begin{array}{l}\text { Outros } \\
\text { Procediment } \\
\text { os }\end{array}$ & & SEGREDO DE JUSTIÇA & $\begin{array}{c}\text { SEGREDO DE } \\
\text { JUSTIÇA }\end{array}$ \\
\hline 87 & $\begin{array}{c}\text { 1013899- } \\
44.2014 .8 .26 .0071\end{array}$ & $45471 / 2014$ & 19/08/2014 & $\begin{array}{l}\text { Mandado de } \\
\text { Segurança }\end{array}$ & $14 / 08 / 2014$ & $\begin{array}{l}\text { 27/08/2014 - concedo a segurança pleiteada por .... contra } \\
\text { ato do secretário municipal de saúde de Bauru, para que } \\
\text { o impetrado forneça ao impetrante fraldas geriátricas } \\
\text { descartáveis - tamanho "m" (90 unidades por mês), nos } \\
\text { termos da petição inicial, e julgo extinto o processo, com } \\
\text { resolução de mérito. }\end{array}$ & FRALDA \\
\hline 88 & $\begin{array}{c}\text { 1012454- } \\
\text { 88.2014.8.26.0071 }\end{array}$ & $45862 / 2014$ & $21 / 08 / 2014$ & $\begin{array}{c}\text { Mandado de } \\
\text { Segurança }\end{array}$ & $15 / 08 / 2014$ & $\begin{array}{l}\text { 03/09/2014 - concedo a segurança pleiteada por .... } \\
\text { contra ato do secretário municipal de saúde de Bauru, } \\
\text { para que o impetrado forneça ao impetrante fraldas } \\
\text { geriátricas descartáveis - tamanho "gg" (150 unidades por } \\
\text { mês), nos termos da petição inicial, e julgo extinto o } \\
\text { processo. }\end{array}$ & FRALDA \\
\hline 89 & $\begin{array}{c}\text { 1014441- } \\
\text { 62.2014.8.26.0071 }\end{array}$ & $46869 / 2014$ & 27/08/2014 & $\begin{array}{l}\text { Mandado de } \\
\text { Segurança }\end{array}$ & 27/08/2014 & $\begin{array}{l}\text { 09/09/2014 - concedo a segurança pleiteada por ..... } \\
\text { contra ato do secretário municipal de saúde de Bauru, } \\
\text { para que o impetrado forneça à impetrante fraldas } \\
\text { geriátricas descartáveis - tamanho "gg" (180 unidades por } \\
\text { mês), nos termos da petição inicial, e julgo extinto o } \\
\text { processo, com resolução de mérito. }\end{array}$ & FRALDA \\
\hline
\end{tabular}




\begin{tabular}{|c|c|c|c|c|c|c|c|}
\hline 90 & $\begin{array}{c}\text { 0015161- } \\
46.2014 .8 .26 .0071\end{array}$ & $47047 / 2014$ & $28 / 08 / 2014$ & $\begin{array}{l}\text { Outros } \\
\text { Procediment } \\
\text { os }\end{array}$ & & $\begin{array}{l}\text { Considerando-se XXX, antes internado na Fundação } \\
\text { Casa, está cumprindo medida socioeducativa de liberdade } \\
\text { assistida e residindo com a avó, nesta cidade de Bauru } \\
\text { (fls. 30/34), tenho que não subsiste mais interesse na } \\
\text { presente ação de acolhimento institucional por isso julgo } \\
\text { extinto o processo, sem resolução do mérito, nos termos } \\
\text { do artigo 485, inciso VI, do CPC combinado com o artigo } \\
152 \text { do ECA. }\end{array}$ & INTERNAÇÃO \\
\hline 91 & $\begin{array}{c}\text { 1014525- } \\
\text { 63.2014.8.26.0071 }\end{array}$ & $47051 / 2014$ & 28/08/2014 & $\begin{array}{l}\text { Mandado de } \\
\text { Segurança }\end{array}$ & $25 / 08 / 2014$ & $\begin{array}{l}\text { 17/09/2014 - concedo a segurança pleiteada por ..... } \\
\text { contra ato do secretário municipal de saúde de Bauru, } \\
\text { para que o impetrado providencie o fornecimento à a } \\
\text { impetrante do medicamento hialuronato de sódio } \\
20 \mathrm{mg} / 2 \mathrm{ml} \text { ( } 10 \text { ampolas), conforme prescrição médica de } \\
\text { fls. } 23 \text {, nos termos da petição inicial, e julgo extinto o } \\
\text { processo, com resolução de mérito. }\end{array}$ & MEDICAMENTO \\
\hline 92 & $\begin{array}{c}1013790- \\
30.2014 .8 .26 .0071\end{array}$ & $47213 / 2014$ & 28/08/2014 & $\begin{array}{l}\text { Mandado de } \\
\text { Segurança }\end{array}$ & $25 / 08 / 2014$ & $\begin{array}{l}\text { 05/09/2014 - concedo a segurança pleiteada por .... } \\
\text { contra ato do secretário municipal de saúde de Bauru, } \\
\text { para que o impetrado forneça ao impetrante fraldas } \\
\text { geriátricas descartáveis - tamanho "eg" (240 unidades por } \\
\text { mês), nos termos da petição inicial, e julgo extinto o } \\
\text { processo com resolucão de mérito. }\end{array}$ & FRALDA \\
\hline 93 & $\begin{array}{c}\text { 1014191- } \\
29.2014 .8 .26 .0071\end{array}$ & $47377 / 2014$ & 29/08/2014 & $\begin{array}{c}\text { Mandado de } \\
\text { Segurança }\end{array}$ & $27 / 08 / 2014$ & $\begin{array}{l}\text { 05/11/2014 - foi comunicado o óbito do impetrante (fls. } \\
\text { 84). é o relatório. fundamento e decido. com a } \\
\text { comprovação do óbito do impetrante, ocorreu a perda do } \\
\text { objeto da ação. }\end{array}$ & FRALDA \\
\hline 94 & $\begin{array}{c}\text { 1015391- } \\
71.2014 .8 .26 .0071\end{array}$ & $49654 / 2014$ & 09/09/2014 & $\begin{array}{l}\text { Mandado de } \\
\text { Segurança }\end{array}$ & 04/09/2014 & $\begin{array}{l}27 / 10 / 2014 \text { - concedo a segurança pleiteada por .... } \\
\text { contra ato do secretário municipal de saúde de Bauru, } \\
\text { para que o impetrado providencie o o fornecimento à } \\
\text { impetrante dos medicamentos memantina } 10 \mathrm{mg} \text { (01 } \\
\text { comprimido e meio por dia }-45 \text { comprimidos por mês) e } \\
\text { venlafaxina } 75 \mathrm{mg} \text { ( } 01 \text { comprimido por dia), conforme } \\
\text { prescrição médica de fls. } 11 \text {, nos termos da petição inicial, } \\
\text { e julgo extinto o processo, com resolução de mérito. }\end{array}$ & MEDICAMENTO \\
\hline 95 & $\begin{array}{c}1012962- \\
34.2014 .8 .26 .0071\end{array}$ & 49659/2014 & 09/09/2014 & $\begin{array}{l}\text { Mandado de } \\
\text { Segurança }\end{array}$ & 04/09/2014 & $\begin{array}{l}\text { 08/10/2014 - concedo a segurança pleiteada por ..... } \\
\text { contra ato do secretário municipal de saúde de Bauru, } \\
\text { para que o impetrado forneça à impetrante fraldas } \\
\text { geriátricas descartáveis - tamanho "g" (120 unidades por } \\
\text { mês), nos termos da petição inicial, e julgo extinto o } \\
\text { processo, com resolução de mérito. }\end{array}$ & FRALDA \\
\hline
\end{tabular}




\begin{tabular}{|c|c|c|c|c|c|c|c|}
\hline 96 & $\begin{array}{c}\text { 1014231- } \\
11.2014 .8 .26 .0071\end{array}$ & $50335 / 2014$ & $11 / 09 / 2014$ & $\begin{array}{l}\text { Outros } \\
\text { Procediment } \\
\text { os }\end{array}$ & 08/09/2014 & $\begin{array}{l}\text { 13/10/2014 - ratifico a antecipação de tutela concedida a } \\
\text { fls. 43/44, e julgo procedente o pedido, mantendo a } \\
\text { obrigação imposta ao requerido de fornecer a requerente } \\
\text { as fraldas geriátricas descartáveis (tamanho m } 120 \\
\text { unidades por mês). }\end{array}$ & FRALDA \\
\hline 97 & $\begin{array}{c}1012556- \\
13.2014 .8 .26 .0071\end{array}$ & $51207 / 2014$ & $15 / 09 / 2014$ & $\begin{array}{l}\text { Mandado de } \\
\text { Segurança }\end{array}$ & $10 / 09 / 2014$ & $\begin{array}{l}\text { 10/10/2014 - concedo a segurança, determinando que o } \\
\text { impetrado forneça ao impetrante uma cama hospitalar, } \\
\text { conforme a prescrição médica de fls. } 41 \text {, sob pena de } \\
\text { responder por crime de desobediência, sem prejuízo das } \\
\text { sanções administrativas. }\end{array}$ & $\begin{array}{c}\text { INSUMOS/MATE } \\
\text { RIAL } \\
\text { HOSPITALAR }\end{array}$ \\
\hline 98 & $6325003950 / 2014$ & $53264 / 2014$ & $23 / 09 / 2014$ & $\begin{array}{c}\text { Mandado de } \\
\text { Segurança }\end{array}$ & & & FRALDA \\
\hline 99 & $\begin{array}{c}1016485- \\
54.2014 .8 .26 .0071\end{array}$ & $54030 / 2014$ & $25 / 09 / 2014$ & $\begin{array}{l}\text { Mandado de } \\
\text { Segurança }\end{array}$ & $18 / 09 / 2014$ & $\begin{array}{l}\text { 28Q10/2014 - CONCEDO A SEGURANĈA pleiteada } \\
\text { por..... contra ato do SECRETÁRIO MUNICIPAL DE } \\
\text { SAÚDE DEBAURU,para que O impetrado forneça à } \\
\text { impetrante FRALDAS GERIÁTRICASDESCARTÁVEIS - } \\
\text { tamanho "G" (120 unidades por mês), nos termos da } \\
\text { petiçáoinicial, e julgo extinto o processo, com resolução } \\
\text { de mérito, nos termos do art.269, I, do CPC. }\end{array}$ & FRALDA \\
\hline 100 & $\begin{array}{c}\text { 1016837- } \\
12.2014 .8 .26 .0071\end{array}$ & $55043 / 2014$ & $30 / 09 / 2014$ & $\begin{array}{l}\text { Mandado de } \\
\text { Segurança }\end{array}$ & $25 / 09 / 2014$ & $\begin{array}{l}\text { 07/11/2014 - concedo a segurança, determinando que o } \\
\text { impetrado providencie o fornecimento à impetrante do } \\
\text { medicamento hialuronato de sódio } 20 \mathrm{mg} / 2 \mathrm{ml} \text { (10 } \\
\text { ampolas), bem como o necessário para a aplicação, } \\
\text { conforme recomendação médica de fls. } 19 \text {, sob pena de } \\
\text { responder por crime de desobediência, sem prejuízo das } \\
\text { sanções administrativas. }\end{array}$ & MEDICAMENTO \\
\hline 101 & $\begin{array}{c}\text { 1016927- } \\
20.2014 .8 .26 .0071\end{array}$ & $55125 / 2014$ & $30 / 09 / 2014$ & $\begin{array}{l}\text { Mandado de } \\
\text { Segurança }\end{array}$ & $26 / 09 / 2014$ & $\begin{array}{l}\text { 20/10/2014 - concedo a segurança, determinando que o } \\
\text { impetrado providencie o fornecimento à impetrante das } \\
\text { fraldas geriátricas descartáveis (tamanho m } 120 \text { unidades } \\
\text { por mês), conforme a prescrição médica de fls. } 15 \text {, sob } \\
\text { pena de responder por crime de desobediência, sem } \\
\text { prejuízo das sançôes administrativas. }\end{array}$ & FRALDA \\
\hline 102 & $\begin{array}{c}\text { 1016922- } \\
\text { 95.2014.8.26.0071 }\end{array}$ & $55937 / 2014$ & 02/10/2014 & $\begin{array}{l}\text { Mandado de } \\
\text { Segurança }\end{array}$ & $30 / 09 / 2014$ & $\begin{array}{l}30 / 10 / 2014 \text { - concedo a segurança pleiteada por .... } \\
\text { contra ato do secretário municipal de saúde de Bauru, } \\
\text { para que o impetrado forneça ao impetrante fraldas } \\
\text { geriátricas descartáveis - tamanho "egg" (120 unidades } \\
\text { por mês), nos termos da petição inicial, e julgo extinto o } \\
\text { processo, com resolução de mérito. }\end{array}$ & FRALDA \\
\hline 103 & $\begin{array}{c}0023795- \\
31.2014 .8 .26 .0071\end{array}$ & $57073 / 2014$ & 07/10/2014 & $\begin{array}{l}\text { Outros } \\
\text { Procediment } \\
\text { os }\end{array}$ & & SEGREDO DE JUSTIÇA & $\begin{array}{c}\text { SEGREDO DE } \\
\text { JUSTIÇA }\end{array}$ \\
\hline
\end{tabular}




\begin{tabular}{|c|c|c|c|c|c|c|c|}
\hline 104 & $\begin{array}{c}1015078- \\
13.2014 .8 .26 .0071\end{array}$ & $57854 / 2014$ & 09/10/2014 & $\begin{array}{l}\text { Mandado de } \\
\text { Segurança }\end{array}$ & 07/10/2014 & $\begin{array}{l}27 / 10 / 2014 \text { - concedo a segurança, determinando que o } \\
\text { impetrado providencie o fornecimento à impetrante dos } \\
\text { medicamentos sertralina } 50 \mathrm{mg} \text { ( } 30 \text { comprimidos por } \\
\text { mês), fenitoina } 100 \mathrm{mg} \text { ( } 60 \text { comprimidos por mês), bem } \\
\text { como fraldas geriátricas descartáveis (tamanho } \mathrm{g} 120 \\
\text { unidades por mês), conforme recomendação médica de } \\
\text { fls. } 16 \text { e } 49 \text {, sob pena de responder por crime de } \\
\text { desobediência, sem prejuízo das sanções administrativas. }\end{array}$ & FRALDA \\
\hline 105 & $\begin{array}{c}0028467- \\
82.2014 .8 .26 .0071\end{array}$ & $59373 / 2014$ & $15 / 10 / 2014$ & $\begin{array}{c}\text { Outros } \\
\text { Procediment } \\
\text { os }\end{array}$ & & SEGREDO DE JUSTIÇA & $\begin{array}{c}\text { SEGREDO DE } \\
\text { JUSTIÇA }\end{array}$ \\
\hline 106 & $\begin{array}{c}1015029- \\
69.2014 .8 .26 .0071\end{array}$ & $59421 / 2014$ & $15 / 10 / 2014$ & $\begin{array}{l}\text { Mandado de } \\
\text { Segurança }\end{array}$ & $14 / 10 / 2014$ & 31/08/15 - Extinção do processo - agendamento exames. & EXAME \\
\hline 107 & $\begin{array}{c}\text { 1017948- } \\
31.2014 .8 .26 .0071\end{array}$ & $59393 / 2014$ & $15 / 10 / 2014$ & $\begin{array}{l}\text { Outros } \\
\text { Procediment } \\
\text { os }\end{array}$ & $10 / 10 / 2014$ & $\begin{array}{l}\text { 25/11/2014 - antecipação de tutela concedida a fls. 29/30, } \\
\text { e julgo procedente o pedido, mantendo a obrigação } \\
\text { imposta ao requerido de fornecer a requerente as fraldas } \\
\text { geriátricas descartáveis (tamanho gg } 180 \text { unidades por } \\
\text { mês). }\end{array}$ & FRALDA \\
\hline 108 & $\begin{array}{c}1016875- \\
24.2014 .8 .26 .0071\end{array}$ & $59632 / 2014$ & $16 / 10 / 2014$ & $\begin{array}{c}\text { Outros } \\
\text { Procediment } \\
\text { os }\end{array}$ & $10 / 10 / 2014$ & $\begin{array}{l}\text { 18/11/2014 - julgo procedente o pedido formulado por ..... } \\
\text { em face do município de Bauru, determinando que este } \\
\text { forneça à requerente fraldas descartáveis geriátricas - } \\
\text { tamanho "g" (150 unidades por mês), nos termos da } \\
\text { petição inicial, e extinto o processo, com resolução de } \\
\text { mérito. }\end{array}$ & FRALDA \\
\hline 109 & $\begin{array}{c}1018063- \\
52.2014 .8 .26 .0071\end{array}$ & $60072 / 2014$ & $17 / 10 / 2014$ & $\begin{array}{l}\text { Outros } \\
\text { Procediment } \\
\text { os }\end{array}$ & $23 / 10 / 2014$ & $\begin{array}{l}25 / 11 / 2014 \text { - julgo procedente o pedido, determinando } \\
\text { que a requerida forneça ao requerente o tratamento de } \\
\text { oxigenoterapia domiciliar, bem como o aparelho oxímetro } \\
\text { de pulso digital, nos termos da petição inicial. }\end{array}$ & $\begin{array}{l}\text { CONSULTA } \\
\text { MÉDICA }\end{array}$ \\
\hline
\end{tabular}




\begin{tabular}{|c|c|c|c|c|c|c|c|}
\hline 110 & $\begin{array}{c}\text { 1015694- } \\
\text { 85.2014.8.26.0071 }\end{array}$ & $60107 / 2014$ & 17/10/2014 & $\begin{array}{c}\text { Mandado de } \\
\text { Segurança }\end{array}$ & $14 / 10 / 2014$ & $\begin{array}{l}\text { 10/11/2014 - concedo parcialmente a segurança pleiteada } \\
\text { por .... contra ato do secretário municipal de saúde de } \\
\text { Bauru, para que o impetrado providencie o fornecimento à } \\
\text { impetrante dos medicamentos: foraseq } 12 / 400 \text { (formoterol } \\
12 \mathrm{mcg}+\text { budesonida } 400 \mathrm{mcg} \text { ) ( } 01 \text { capsula de } 12 / 12 \mathrm{~h}), \\
\text { onbrize } 150 \text { ( } 01 \text { capsula por dia), fluimucil } 600 \\
\text { (acetilcisteina) ( } 1 \text { envelope por dia), abrilar - (hedera hélix) } \\
\text { (01 medida de 8/8horas) e alektos (bilastina) (01 } \\
\text { comprimido } 24 / 24 h) \text {, nos termos da petição inicial, e julgo } \\
\text { extinto o processo, com resolução de mérito. }\end{array}$ & MEDICAMENTO \\
\hline 111 & $\begin{array}{c}0018093- \\
87.2014 .8 .26 .0071\end{array}$ & $60180 / 2014$ & 17/10/2014 & $\begin{array}{l}\text { Mandado de } \\
\text { Segurança }\end{array}$ & & SEGREDO DE JUSTIÇA & $\begin{array}{l}\text { SEGREDO DE } \\
\text { JUSTIÇA }\end{array}$ \\
\hline 112 & $\begin{array}{c}1017788- \\
06.2014 .8 .26 .0071\end{array}$ & $60597 / 2014$ & $21 / 10 / 2014$ & $\begin{array}{l}\text { Mandado de } \\
\text { Segurança }\end{array}$ & 20/10/2014 & $\begin{array}{l}\text { 07/11/2014 - concedo a segurança, determinando que o } \\
\text { impetrado providencie o fornecimento à impetrante das } \\
\text { fraldas geriátricas descartáveis (tamanho m } 90 \text { unidades } \\
\text { por mês), conforme a prescrição médica de fls. 20, sob } \\
\text { pena de responder por crime de desobediência, sem } \\
\text { prejuízo das sanções administrativas. }\end{array}$ & FRALDA \\
\hline 113 & $\begin{array}{c}\text { 1017840- } \\
02.2014 .8 .26 .0071-\end{array}$ & $61249 / 2014$ & 23/10/2014 & $\begin{array}{l}\text { Outros } \\
\text { Procediment } \\
\text { os }\end{array}$ & $30 / 10 / 2014$ & $\begin{array}{l}\text { 14/04/2015 - ratifico a antecipação da tutela de fls. } 42 / 44, \\
\text { julgando parcialmente procedente o pedido para condenar } \\
\text { a ré a fornecer ao autor o transporte em veículo que o } \\
\text { possibilite viajar em posição sentada e com acessibilidade } \\
\text { adequada, considerando o quadro motor e respiratório e } \\
\text { necessidade de reposicionamento e atendimento durante } \\
\text { o percurso, dentre aqueles indicados pela própria } \\
\text { administração a fls. } 41 \text { (renault sandero, nissan livina e } \\
\text { fiat doblò). }\end{array}$ & TRANSPORTE \\
\hline 114 & $\begin{array}{c}\text { 1018232- } \\
39.2014 .8 .26 .0071\end{array}$ & $61388 / 2014$ & $23 / 10 / 2014$ & $\begin{array}{l}\text { Mandado de } \\
\text { Segurança }\end{array}$ & & $\begin{array}{l}\text { 16/12/2014 - fornecimento do cartão de passe saúde (fls. } \\
29 / 30 \text { ). à fls. } 53 \text { a impetrante requereu a prolação de } \\
\text { sentença. considerando que o fornecimento dos passes } \\
\text { foi deferido administrativamente, evidente a carência } \\
\text { superveniente da ação por falta de interesse de agir. ante } \\
\text { o exposto, julgo extinto o presente mandado de } \\
\text { segurança impetrado por.... contra secretário municipal } \\
\text { de saúde de Bauru. }\end{array}$ & TRANSPORTE \\
\hline
\end{tabular}




\begin{tabular}{|c|c|c|c|c|c|c|c|}
\hline 115 & $\begin{array}{c}\text { 1018279- } \\
\text { 13.2014.8.26.0071 }\end{array}$ & $62572 / 2014$ & 29/10/2014 & $\begin{array}{l}\text { Mandado de } \\
\text { Segurança }\end{array}$ & 29/10/2014 & $\begin{array}{l}\text { 13/11/2014 - concedo a segurança pleiteada por .... } \\
\text { contra ato do secretário municipal de saúde de Bauru, } \\
\text { para que o impetrado providencie o fornecimento ao } \\
\text { impetrante dos medicamentos vildagliptina + metformina } \\
50 / 1000 \mathrm{mg}(60 \text { comprimidos por mês - } 01 \text { comprimido } \\
\text { duas vezes por dia) e insulina glargina (03 refis de } 3 \mathrm{ml} \\
\text { por mês), conforme prescrições médicas de fls. } 21 \text { e } 22 \text {, } \\
\text { nos termos da petição inicial, e julgo extinto o processo. }\end{array}$ & MEDICAMENTO \\
\hline 116 & $\begin{array}{c}\text { 1018482- } \\
\text { 72.2014.8.26.0071 }\end{array}$ & $62952 / 2014$ & $30 / 10 / 2014$ & $\begin{array}{c}\text { Outros } \\
\text { Procediment } \\
\text { os }\end{array}$ & 28/10/2014 & $\begin{array}{l}\text { 09/04/2015 - ratifico a antecipação da tutela concedida a } \\
\text { fls. } 37 / 38 \text { e julgo procedente o pedido condenando a ré a } \\
\text { fornecer ao autor o suplemento alimentar reabilit immuno } \\
\text { (15 latas por mês conforme receituário nutricional. }\end{array}$ & MEDICAMENTO \\
\hline 117 & $\begin{array}{c}\text { 1019209- } \\
312014.8 .26 .0071\end{array}$ & $64018 / 2014$ & 05/11/2014 & $\begin{array}{l}\text { Mandado de } \\
\text { Segurança }\end{array}$ & $30 / 10 / 2014$ & $\begin{array}{l}\text { 19/11/2014 - concedo a segurança, determinando que o } \\
\text { impetrado providencie o fornecimento ao impetrante do } \\
\text { medicamento rivastigmina patch } 10 \text { (18mg) ( } 30 \text { adesivos } \\
\text { por mês), conforme recomendação médica de fls. } 15 \text {, sob } \\
\text { pena de responder por crime de desobediência, sem } \\
\text { prejuízo das sanções administrativas. }\end{array}$ & MEDICAMENTO \\
\hline 118 & $\begin{array}{c}\text { 1019569- } \\
\text { 63.2014.8.26.0071 }\end{array}$ & $64752 / 2014$ & 07/11/2014 & $\begin{array}{l}\text { Mandado de } \\
\text { Segurança }\end{array}$ & $11 / 11 / 2014$ & $\begin{array}{l}\text { 22/01/2015 - concedo a segurança, determinando que o } \\
\text { impetrado providencie o fornecimento à impetrante das } \\
\text { fraldas geriátricas descartáveis (tamanho xg } 180 \text { unidades } \\
\text { por mês), conforme a prescrição médica de fls. } 23 \text {, sob } \\
\text { pena de responder por crime de desobediência, sem } \\
\text { prejuízo das sançôes administrativas. }\end{array}$ & FRALDA \\
\hline 119 & $\begin{array}{c}\text { 1019477- } \\
\text { 85.2014.8.26.0071 }\end{array}$ & $64750 / 2014$ & 07/11/2014 & $\begin{array}{l}\text { Mandado de } \\
\text { Segurança }\end{array}$ & 07/11/2014 & $\begin{array}{l}\text { 28/11/2014 - concedo a segurança pleiteada por ..... } \\
\text { contra ato do secretário municipal de saúde de Bauru, } \\
\text { para que o impetrado forneça ao impetrante fraldas } \\
\text { geriátricas descartáveis - tamanho "m" ( } 180 \text { unidades por } \\
\text { mês) e cadeira de rodas ( } 01 \text { unidade, em comodato), nos } \\
\text { termos da petição inicial, e julgo extinto. }\end{array}$ & FRALDA \\
\hline 120 & $\begin{array}{c}\text { 1019770- } \\
\text { 55.2014.8.26.0071 }\end{array}$ & $65494 / 2014$ & $11 / 11 / 2014$ & $\begin{array}{l}\text { Outros } \\
\text { Procediment } \\
\text { os }\end{array}$ & 07/11/2014 & $\begin{array}{l}\text { 09/01/2015 - julgo procedente o pedido formulado por .... } \\
\text { em face do município de Bauru, determinando que este } \\
\text { forneça à requerente fraldas descartáveis geriátricas - } \\
\text { tamanho "g" (180 unidades por mês), nos termos da } \\
\text { petição inicial, e extinto o processo, com resolução de } \\
\text { mérito. }\end{array}$ & FRALDA \\
\hline 121 & $\begin{array}{c}\text { 1019971- } \\
\text { 47.2014.8.26.0071 }\end{array}$ & $66239 / 2014$ & 13/11/2014 & $\begin{array}{l}\text { Mandado de } \\
\text { Segurança }\end{array}$ & $14 / 11 / 2014$ & $\begin{array}{l}\text { 16/12/2014 - concedo a segurança pleiteada por ..... } \\
\text { representado por ....., contra ato do secretário municipal } \\
\text { de saúde de Bauru, para que forneça ao impetrante: } \\
\text { fraldas descartáveis, tamanho "g" (120 unidades por } \\
\text { mês), nos termos da petição inicial e, extinto o processo. }\end{array}$ & FRALDA \\
\hline
\end{tabular}




\begin{tabular}{|c|c|c|c|c|c|c|c|}
\hline 122 & $\begin{array}{c}\text { 1019019- } \\
\text { 68.2014.8.26.0071 }\end{array}$ & 67094/2014 & 18/11/2014 & $\begin{array}{l}\text { Mandado de } \\
\text { Segurança }\end{array}$ & $11 / 11 / 2014$ & $\begin{array}{l}\text { 16/12/2014 - concedo a segurança pleiteada por .... } \\
\text { representado por ....., contra ato do secretário municipal } \\
\text { de saúde de Bauru, para que o impetrado forneça ao } \\
\text { impetrante fraldas geriátricas descartáveis - tamanho "xg" } \\
\text { (150 unidades por mês), nos termos da petição inicial, e } \\
\text { julgo extinto o processo, com resolução de mérito. }\end{array}$ & FRALDA \\
\hline 123 & $\begin{array}{c}\text { 1016392- } \\
91.2014 .8 .26 .0071\end{array}$ & 67098/2014 & $18 / 11 / 2014$ & $\begin{array}{l}\text { Outros } \\
\text { Procediment } \\
\text { os }\end{array}$ & 18/09/2014 & $\begin{array}{l}\text { 09/01/2015 - julgo procedente o pedido formulado por .... } \\
\text { representado por rita tetti covolan, em face da prefeitura } \\
\text { municipal de Bauru, determinando que este forneça ao } \\
\text { requerente fraldas descartáveis geriátricas - tamanho "g" } \\
\text { (180 unidades por mês), nos termos da petição inicial, e } \\
\text { extinto o processo. }\end{array}$ & FRALDA \\
\hline 124 & $\begin{array}{c}\text { 1020151- } \\
\text { 63.2014.8.26.0071 }\end{array}$ & 68332/2014 & $25 / 11 / 2014$ & $\begin{array}{l}\text { Mandado de } \\
\text { Segurança }\end{array}$ & 21/11/2014 & $\begin{array}{l}16 / 12 / 2014 \text { - concedo a segurança pleiteada por .... } \\
\text { contra ato do secretário municipal de saúde de Bauru, } \\
\text { para que o impetrado providencie o fornecimento à } \\
\text { impetrante do medicamento linagliptina } 5 \mathrm{mg} \text { (01 } \\
\text { comprimido por dia), nos termos da petição inicial, e julgo } \\
\text { extinto o processo, com resolução de mérito. }\end{array}$ & MEDICAMENTO \\
\hline 125 & $\begin{array}{c}\text { 1020247- } \\
\text { 78.2014.8.26.0071 }\end{array}$ & 68362/2014 & $25 / 11 / 2014$ & $\begin{array}{l}\text { Outros } \\
\text { Procediment } \\
\text { os }\end{array}$ & 17/11/2014 & $\begin{array}{l}\text { 15/01/2015 - ratifico a antecipação de tutela concedida a } \\
\text { fls. } 21 / 22 \text {, e julgo procedente o pedido, mantendo a } \\
\text { obrigação imposta ao requerido de fornecer a requerente } \\
\text { as fraldas geriátricas descartáveis. }\end{array}$ & FRALDA \\
\hline 126 & $\begin{array}{c}\text { 1020194- } \\
97.2014 .8 .26 .0071\end{array}$ & $68485 / 2014$ & $25 / 11 / 2014$ & $\begin{array}{l}\text { Outros } \\
\text { Procediment } \\
\text { os }\end{array}$ & 25/11/2014 & $\begin{array}{l}\text { 13/02/2015 - ratifico a liminar concedida a fls. } 38 / 39 \text {, e } \\
\text { julgo procedente o pedido, mantendo a obrigação imposta } \\
\text { ao requerido de fornecer à autora o medicamento } \\
\text { hialuronato de sódio } 20 \mathrm{mg} / 2 \mathrm{ml} \text {. }\end{array}$ & MEDICAMENTO \\
\hline 127 & $\begin{array}{c}\text { 1021233- } \\
\text { 32.2014.8.26.0071 }\end{array}$ & $71306 / 2014$ & 09/12/2014 & $\begin{array}{l}\text { Mandado de } \\
\text { Segurança }\end{array}$ & $03 / 12 / 2014$ & $\begin{array}{l}09 / 01 / 2015 \text { - concedo a segurança pleiteada por .... } \\
\text { contra ato do secretário municipal de saúde de Bauru, } \\
\text { para que o impetrado forneça à impetrante fraldas } \\
\text { geriátricas descartáveis - tamanho "g" (120 unidades por } \\
\text { mês), nos termos da petição inicial, e julgo extinto o } \\
\text { processo. }\end{array}$ & FRALDA \\
\hline 128 & $\begin{array}{c}1021680- \\
20.2014 .8 .26 .0071\end{array}$ & 71913/2014 & $11 / 12 / 2014$ & $\begin{array}{l}\text { Outros } \\
\text { Procediment } \\
\quad \text { os }\end{array}$ & & $\begin{array}{l}21 / 01 / 2015 \text { - autora informou que está recebendo o } \\
\text { transporte para a realizacão de seu tratamento de saúde. } \\
\text { assim, evidente a carência superveniente da ação por } \\
\text { falta de interesse processual. ante o exposto, julgo extinto } \\
\text { o processo nos termos do artigo } 267 \text {, vi do cpc. }\end{array}$ & TRANSPORTE \\
\hline 129 & $\begin{array}{c}\text { 1021171- } \\
89.2014 .8 .26 .0071\end{array}$ & 72518/2014 & $15 / 12 / 2014$ & $\begin{array}{l}\text { Mandado de } \\
\text { Segurança }\end{array}$ & 10/12/2014 & $\begin{array}{l}\text { 20/04/2016 - abandono da causa, julgo extinto o } \\
\text { processo nos termos do artigo } 485 \text {, iii do cpc.oficie-se o } \\
\text { impetrado, com cópia desta decisão, para as providências } \\
\text { cabíveis.com o trânsito em julgado. }\end{array}$ & FRALDA \\
\hline
\end{tabular}




\begin{tabular}{|c|c|c|c|c|c|c|c|}
\hline 130 & $\begin{array}{c}\text { 1020849- } \\
69.2014 .8 .26 .0071\end{array}$ & $72541 / 2014$ & 15/12/2014 & $\begin{array}{l}\text { Outros } \\
\text { Procediment } \\
\text { os }\end{array}$ & $10 / 12 / 2014$ & $\begin{array}{l}\text { 25/02/2015 - ulgo procedente o pedido formulado por ..... } \\
\text { em face do munićpio de Bauru, determinando que este } \\
\text { forneça à requerente fraldas descartáveis geriátricas - } \\
\text { tamanho "g" (180 unidades por mês), nos termos da } \\
\text { petição inicial, e extinto o processo, com resolução de } \\
\text { mérito. }\end{array}$ & FRALDA \\
\hline 131 & $\begin{array}{c}10211995- \\
48.2014 .8 .26 .0071 \\
\end{array}$ & $73549 / 2014$ & 19/12/2014 & $\begin{array}{c}\text { Mandado de } \\
\text { Segurança }\end{array}$ & & SEGREDO DE JUSTIÇA & $\begin{array}{l}\text { CONSULTA } \\
\text { MÉDICA }\end{array}$ \\
\hline 132 & $\begin{array}{c}\text { 1016633- } \\
\text { 65.2014.8.26.0071 }\end{array}$ & 1067/2015 & 08/01/2015 & $\begin{array}{l}\text { Mandado de } \\
\text { Segurança }\end{array}$ & 18/12/2014 & $\begin{array}{l}\text { 22/01/2015 - concedo a segurança pleiteada por.... contra } \\
\text { ato do secretário municipal de saúde de Bauru, para que } \\
\text { o impetrado providencie o fornecimento à impetrante do } \\
\text { medicamento hialuronato de sódio } 20 \mathrm{mg} / 2 \mathrm{ml} \text { (05 } \\
\text { ampolas), conforme prescrição médica de fls. } 25 \text {, nos } \\
\text { termos da petição inicial, e julgo extinto o processo. } \\
\end{array}$ & MEDICAMENTO \\
\hline 133 & $\begin{array}{c}\text { 1022731- } \\
66.2014 .8 .26 .0071\end{array}$ & 1083/2015 & 08/01/2015 & $\begin{array}{l}\text { Mandado de } \\
\text { Segurança }\end{array}$ & 19/12/2014 & $\begin{array}{l}\text { 17/03/2015 - concedo a segurança, determinando que o } \\
\text { secretário municipal de saúde forneçaa ao impetrante as } \\
\text { fraldas geriátricas descartáveis, tamanho gg (180 } \\
\text { unidades por mês - conforme receituário de fls. 35) e que } \\
\text { o diretor do drs vi, forneça ao impetrante a dieta enteral } \\
\text { polimérica hipercalórica e hiperprotéica (39 litros por mês } \\
\text { conforme receituário de fls. 34), bem como os aparelhos } \\
\text { bipap, aspirador de secreção traqueal. }\end{array}$ & FRALDA \\
\hline 134 & $\begin{array}{c}\text { 1022685- } \\
77.2014 .8 .26 .0071\end{array}$ & 2329/2015 & 14/01/2015 & $\begin{array}{l}\text { Mandado de } \\
\text { Segurança }\end{array}$ & $12 / 01 / 2015$ & $\begin{array}{l}\text { 25/02/2015 - concedo a segurança pleiteada por .... } \\
\text { contra ato do secretário municipal de saúde de Bauru, } \\
\text { para que o impetrado providencie a realização de } \\
\text { procedimento de laqueadura para a impetrante, nos } \\
\text { termos da petição inicial, e julgo extinto o processo, com } \\
\text { resolução de mérito. }\end{array}$ & CIRURGIA \\
\hline 135 & $\begin{array}{c}1000284- \\
50.2015 .8 .26 .0071\end{array}$ & $3902 / 2015$ & 22/01/2015 & $\begin{array}{c}\text { Outros } \\
\text { Procediment } \\
\text { os }\end{array}$ & & $\begin{array}{l}\text { 10/11/2015 - POSTO ISSO e considerando o mais que } \\
\text { dosautos constam julgo EXTINTA a presente ação de } \\
\text { indenização por danos morais movida por ... contra } \\
\text { PREFEITURA MUNICIPAL DE BAURU, sem resolução de } \\
\text { mérito, nos termos do artigo 267, VI do Código } \\
\text { deProcesso Civil. }\end{array}$ & MEDICAMENTO \\
\hline 136 & $\begin{array}{c}0002344- \\
13.2015 .8 .26 .0071\end{array}$ & $8293 / 2015$ & 06/02/2015 & $\begin{array}{l}\text { Mandado de } \\
\text { Segurança }\end{array}$ & & SEGREDO DE JUSTIÇA & $\begin{array}{l}\text { SEGREDO DE } \\
\text { JUSTIÇA }\end{array}$ \\
\hline 137 & $\begin{array}{c}\text { 1001372- } \\
26.2015 .8 .26 .0071\end{array}$ & $8861 / 2015$ & 09/02/2015 & $\begin{array}{c}\text { Outros } \\
\text { Procediment } \\
\text { os }\end{array}$ & $04 / 02 / 2015$ & \begin{tabular}{|l|l|l} 
08/04/2015 - julgo parcialmente procedente o pedido \\
formulado por $\ldots$ em face do município de & Bauru, \\
determinando que este forneça ao requerente fraldas \\
descartáveis geriátricas tamanhog $(180$ unidades por mês).
\end{tabular} & FRALDA \\
\hline
\end{tabular}




\begin{tabular}{|c|c|c|c|c|c|c|c|}
\hline 138 & $\begin{array}{c}\text { 0009297- } \\
\text { 22.2017.8.26.0071 }\end{array}$ & $9418 / 2015$ & 10/02/2015 & $\begin{array}{l}\text { Mandado de } \\
\text { Segurança }\end{array}$ & 16/05/2016 & $\begin{array}{l}05 / 07 / 2016 \text { - concedo a segurança pleiteada por ..... } \\
\text { contra ato do diretor técnico do departamento regional de } \\
\text { saúde drs-vi, para que o impetrado providencie o } \\
\text { fornecimento à impetrante a aplicação de injeção } \\
\text { intravítrea com o medicamento antiangiogênico } \\
\text { (ranibizumabe) }(0,06 \mathrm{ml} \text { intravíreo no olho direito de forma } \\
\text { continuada), conforme receituário médico de fls. } 50 \text {, e } \\
\text { julgo extinto o processo. }\end{array}$ & MEDICAMENTO \\
\hline 139 & $\begin{array}{c}\text { 0000107- } \\
\text { 86.2015.8.26.0594 }\end{array}$ & 10599/2015 & $18 / 02 / 2015$ & $\begin{array}{l}\text { Outros } \\
\text { Procediment } \\
\text { os }\end{array}$ & & $\begin{array}{l}27 / 07 / 2018 \text { - afasto a preliminar de ilegitimidade ativa, na } \\
\text { medida em que, não obstante eventual dano sofrido pela } \\
\text { criança pela suposta falha na prestação do serviço pela, } \\
\text { haveria o reflexo na esfera moral dos pais, o que adentra } \\
\text { ao mérito da demanda. declaro saneado o feito. é questão } \\
\text { de direito relevante para o julgamento: a) se existe } \\
\text { sucedâneo legal para embasar o pedido dos autores. fixo } \\
\text { como questão de fato relevante para o julgamento: a) a } \\
\text { verificação de falha na prestação de serviço, assim como } \\
\text { a ocorrência de eventual dano moral declaro, por se tratar } \\
\text { de relação de consumo, ser da requerida o ônus da prova. } \\
\text { as partes requerem a produção de prova pericial e tal } \\
\text { direito lhes assiste. para realização. }\end{array}$ & TRANSPORTE \\
\hline 140 & $\begin{array}{c}\text { 1002382- } \\
08.2015 .8 .26 .0071\end{array}$ & 10746/2015 & 19/02/2015 & $\begin{array}{l}\text { Mandado de } \\
\text { Segurança }\end{array}$ & $13 / 02 / 2015$ & $\begin{array}{l}27 / 02 / 2015 \text { - concedo a segurança pleiteada por .... } \\
\text { contra ato do secretário municipal de saúde de Bauru, } \\
\text { para que o impetrado forneça à impetrante fraldas } \\
\text { geriátricas descartáveis - tamanho "g" (180 unidades por } \\
\text { mês), nos termos da petição inicial, e julgo extinto o } \\
\text { processo. }\end{array}$ & FRALDA \\
\hline 141 & $\begin{array}{c}\text { 1022436- } \\
\text { 29.2014.8.26.0071 }\end{array}$ & 11589/2015 & 23/02/2015 & $\begin{array}{l}\text { Mandado de } \\
\text { Segurança }\end{array}$ & 18/02/2015 & $\begin{array}{l}\text { 16/03/2015 - concedo a segurança, determinando que o } \\
\text { impetrado providencie o fornecimento à impetrante das } \\
\text { fraldas geriátricas descartáveis (tamanho m } 240 \text { unidades } \\
\text { por mês), conforme a prescrição médica de fls. } 12 \text {, sob } \\
\text { pena de responder por crime de desobediência, sem } \\
\text { prejuízo das sanções administrativas. para efeito de } \\
\text { efetivo controle do tempo em que a impetrante necessita } \\
\text { do item a ser fornecido e para evitar compras } \\
\text { desnecessárias pelo órgão público, deverá ser } \\
\text { apresentada prescrição médica atualizada à secretaria } \\
\text { municipal de saúde. }\end{array}$ & FRALDA \\
\hline
\end{tabular}




\begin{tabular}{|c|c|c|c|c|c|c|c|}
\hline 142 & $\begin{array}{c}\text { 1002589- } \\
07.2015 .8 .26 .0071\end{array}$ & $12505 / 15$ & 25/02/2015 & $\begin{array}{l}\text { Mandado de } \\
\text { Segurança }\end{array}$ & 24/02/2015 & $\begin{array}{l}\text { 05/03/2015 - concedo a segurança, determinando que o } \\
\text { impetrado providencie o fornecimento ao impetrante das } \\
\text { fraldas geriátricas descartáveis (tamanho m } 120 \text { unidades } \\
\text { por mês), conforme a prescrição médica de fls. } 13 \text {, sob } \\
\text { pena de responder por crime de desobediência, sem } \\
\text { prejuízo das sanções administrativas. para efeito de } \\
\text { efetivo controle do tempo em que a impetrante necessita } \\
\text { do item a ser fornecido e para evitar compras } \\
\text { desnecessárias pelo órgão público, deverá ser } \\
\text { apresentada prescrição médica atualizada à secretaria } \\
\text { municipal de saúde. }\end{array}$ & FRALDA \\
\hline 143 & $\begin{array}{c}\text { 1002471- } \\
31.2015 .8 .26 .0071\end{array}$ & $13154 / 2015$ & $27 / 02 / 2015$ & $\begin{array}{l}\text { Mandado de } \\
\text { Segurança }\end{array}$ & $25 / 02 / 2015$ & $\begin{array}{l}17 / 03 / 2015 \text { - concedo a segurança, determinando que o } \\
\text { impetrado providencie o fornecimento à impetrante do } \\
\text { medicamento linagliptina } 2,5 \mathrm{mg} \text { metformina } 850 \mathrm{mg} \text { (60 } \\
\text { comprimidos - conforme receituário de fls. } 31 \text { ), sob pena } \\
\text { de responder por crime de desobediência, sem prejuízo } \\
\text { das sanções administrativas. para efeito de efetivo } \\
\text { controle do tempo em que a impetrante necessita do item } \\
\text { a ser fornecido e para evitar compras desnecessárias pelo } \\
\text { órgão público, deverá ser apresentada prescrição médica } \\
\text { atualizada à secretaria municipal de saúde. }\end{array}$ & MEDICAMENTO \\
\hline 144 & $\begin{array}{c}\text { 1002991- } \\
88.2015 .8 .26 .0071\end{array}$ & $13774 / 2015$ & 03/03/2015 & $\begin{array}{l}\text { Mandado de } \\
\text { Segurança }\end{array}$ & 27/02/2015 & $\begin{array}{l}01 / 04 / 2015 \text { - concedo a segurança pleiteada por ..... } \\
\text { contra ato do secretário municipal de saúde de Bauru, } \\
\text { para que o impetrado providencie o fornecimento ao } \\
\text { impetrante do medicamento fingolimode } 0,5 \mathrm{mg}(01 \\
\text { comprimido por dia), conforme prescrição médica de fls. } \\
13 / 14 \text {, nos termos da petição inicial, e julgo extinto o } \\
\text { processo. }\end{array}$ & MEDICAMENTO \\
\hline 145 & $\begin{array}{c}\text { 1001478- } \\
85.2015 .8 .26 .0071\end{array}$ & $13747 / 2015$ & 03/03/2015 & $\begin{array}{l}\text { Mandado de } \\
\text { Segurança }\end{array}$ & $27 / 02 / 2015$ & $\begin{array}{l}11 / 03 / 2015 \text { - concedo a segurança pleiteada por ........ } \\
\text { contra ato do secretário municipal de saúde de Bauru, } \\
\text { para que o impetrado forneça à impetrante fraldas } \\
\text { geriátricas descartáveis - tamanho "g" (180 unidades por } \\
\text { mês), nos termos da petição inicial, e julgo extinto o } \\
\text { processo, com resolução de mérito. }\end{array}$ & FRALDA \\
\hline 146 & $\begin{array}{c}\text { 1002915- } \\
64.2015 .8 .26 .0071\end{array}$ & $13780 / 2015$ & 03/03/2015 & $\begin{array}{l}\text { Outros } \\
\text { Procediment } \\
\text { os }\end{array}$ & 27/02/2015 & $\begin{array}{l}28 / 05 / 2015 \text { - julgo parcialmente procedente o pedido } \\
\text { formulado por .... contra prefeitura municipal de Bauru, } \\
\text { determinando que a ré forneça ao requerente: transporte } \\
\text { por ambulância para a realizacãa de tratamento junto ao } \\
\text { hospital das clínicas de botucatu, nos termos da petição } \\
\text { inicial e, extinto o processo, com resolução de mérito. }\end{array}$ & TRANSPORTE \\
\hline
\end{tabular}




\begin{tabular}{|c|c|c|c|c|c|c|c|}
\hline 147 & $\begin{array}{c}\text { 1003427- } \\
\text { 47.2015.8.26.0071 }\end{array}$ & $16029 / 2015$ & $12 / 03 / 2015$ & $\begin{array}{l}\text { Mandado de } \\
\text { Segurança }\end{array}$ & 09/03/2015 & $\begin{array}{l}\text { 30/03/2015 - concedo parcialmente a segurança pleiteada } \\
\text { por .... contra ato do secretário municipal de saúde de } \\
\text { Bauru, para que o impetrado forneça à impetrante fraldas } \\
\text { geriátricas descartáveis - tamanho "m" (150 unidades por } \\
\text { mês), nos termos da petição inicial, e julgo extinto o } \\
\text { processo, com resolução de mérito. }\end{array}$ & FRALDA \\
\hline 148 & $\begin{array}{c}1003803- \\
33.2015 .8 .26 .0071\end{array}$ & $17045 / 2015$ & $17 / 03 / 2015$ & $\begin{array}{l}\text { Mandado de } \\
\text { Segurança }\end{array}$ & 09/03/2015 & $\begin{array}{l}\text { 30/03/2015 - concedo a segurança pleiteada por .... contra } \\
\text { ato do secretário municipal de saúde de Bauru, para que } \\
\text { o impetrado forneça ao impetrante fraldas geriátricas } \\
\text { descartáveis - tamanho "eg" (180 unidades por mês), nos } \\
\text { termos da petição inicial, e julgo extinto o processo, com } \\
\text { resolução de mérito. }\end{array}$ & FRALDA \\
\hline 149 & $\begin{array}{c}\text { 1000273- } \\
21.2015 .8 .26 .0071\end{array}$ & $18926 / 2015$ & $25 / 03 / 2015$ & $\begin{array}{l}\text { Mandado de } \\
\text { Segurança }\end{array}$ & 19/03/2015 & $\begin{array}{l}\text { 09/04/2015 - concedo a segurança pleiteada por ..... contra } \\
\text { ato do secretário municipal de saúde de Bauru, para que o } \\
\text { impetrado forneça ao impetrante dieta enteral líquida } \\
\text { polimérica hipercalórica (densidade } 1,2 \text { kcal/ml), } \\
\text { hiperproteica ( } 2 \% \text { de proteínas/l), com fibras, sem } \\
\text { sacarose, sem lactose, espećfica para controle glicêmico } \\
\text { (47 litros por mês) ou dieta enteral polimérica em pó, } \\
\text { hipercalórica (densidade } 1,2 \mathrm{kcal} / \mathrm{ml}) \text {, normoproteica }(16 \% \\
\text { de proteína/l), com fibras, sem sacarose, sem lactose, } \\
\text { específica para controle glicêmico (28 latas de } 40 \mathrm{~g} \text { cada } \\
\text { uma, por mês), e fraldas geriátricas descartáveis - tamanhho } \\
\text { "g" (150 unidades por mês), nos termos da petição inicial, e } \\
\text { julgo extinto o processo, com resolução de mérito. }\end{array}$ & FRALDA \\
\hline 150 & $\begin{array}{c}1004950- \\
94.2015 .8 .26 .0071\end{array}$ & $20054 / 2015$ & $31 / 03 / 2015$ & $\begin{array}{l}\text { Outros } \\
\text { Procediment } \\
\text { os }\end{array}$ & $25 / 03 / 2015$ & $\begin{array}{l}\text { 19/06/2015 - julgo procedente o pedido, formulado por .... } \\
\text { contra o município de Bauru, determinando que o } \\
\text { requerido forneça à requerente o medicamento sulfato de } \\
\text { glicosamina } 1,5 \mathrm{~g} \text {. + sulfato de condroitina } 1,2 \mathrm{~g} \text {. (01 } \\
\text { sache por dia), conforme prescrição médica de fls. } 22, \text { e } \\
\text { extinto o processo, com resoluçăa de mérito. }\end{array}$ & MEDICAMENTO \\
\hline 151 & $\begin{array}{c}\text { 100562- } \\
\text { 70.2015.8.26.0071 }\end{array}$ & 20399/2015 & 01/04/2015 & $\begin{array}{c}\text { Mandado de } \\
\text { Segurança }\end{array}$ & & SEGREDO DE JUSTIÇA & MEDICAMENTO \\
\hline 152 & $\begin{array}{c}\text { 1004538- } \\
66.2015 .8 .26 .0071\end{array}$ & $22307 / 2015$ & 10/04/2015 & $\begin{array}{l}\text { Mandado de } \\
\text { Segurança }\end{array}$ & 01/04/2015 & $\begin{array}{l}27 / 04 / 2015 \text { - concedo a segurança pleiteada por .... contra } \\
\text { ato do secretário municipal de saúde de Bauru, para que } \\
\text { o impetrado providencie o agendamento do exame de } \\
\text { endoscopia, nos termos da petição inicial, e julgo extinto o } \\
\text { processo. }\end{array}$ & EXAME \\
\hline
\end{tabular}




\begin{tabular}{|c|c|c|c|c|c|c|c|}
\hline 153 & $\begin{array}{c}\text { 1005801- } \\
\text { 36.2015.8.26.0071 }\end{array}$ & 22540/2015 & 10/04/2015 & $\begin{array}{l}\text { Outros } \\
\text { Procediment } \\
\text { os }\end{array}$ & 06/04/2015 & $\begin{array}{l}23 / 04 / 2015 \text { - concedo a segurança pleiteada por ...... } \\
\text { representada por ....., contra ato do secretário municipal } \\
\text { de saúde de Bauru, para que forneça ao impetrante: } \\
\text { fraldas descartáveis, tamanho "eg" ( } 05 \text { unidades por dia), } \\
\text { nos termos da petição inicial e, extinto o processo, com } \\
\text { resolução de mérito. }\end{array}$ & FRALDA \\
\hline 154 & $\begin{array}{c}\text { 1000714- } \\
\text { 02.2015.8.26.0071 }\end{array}$ & $23283 / 2015$ & $14 / 04 / 2015$ & $\begin{array}{l}\text { Mandado de } \\
\text { Segurança }\end{array}$ & 08/04/2015 & $\begin{array}{l}29 / 04 / 2015 \text { - concedo a segurança pleiteada por .... } \\
\text { contra ato do secretário municipal de saúde de Bauru, } \\
\text { para que forneça à impetrante: fraldas descartáveis, } \\
\text { tamanho "g" (06 unidades por dia), nos termos da petição } \\
\text { inicial e, extinto o processo, com resolução de mérito. }\end{array}$ & FRALDA \\
\hline 155 & $\begin{array}{c}\text { 1006397- } \\
20.2015 .8 .26 .0071\end{array}$ & 24411/2015 & 17/04/2015 & $\begin{array}{l}\text { Outros } \\
\text { Procediment } \\
\text { os }\end{array}$ & $14 / 04 / 2015$ & $\begin{array}{l}07 / 05 / 2015 \text { - concedo a segurança pleiteada por .....contra } \\
\text { ato do secretário municipal de saúde de Bauru, para que } \\
\text { o impetrado providencie o agendamento de consulta na } \\
\text { especialidade de nefrologia. }\end{array}$ & $\begin{array}{l}\text { CONSULTA } \\
\text { MÉDICA }\end{array}$ \\
\hline 156 & $\begin{array}{c}1006639- \\
76.2015 .8 .26 .0071\end{array}$ & 24543/2015 & $17 / 04 / 2015$ & $\begin{array}{l}\text { Outros } \\
\text { Procediment } \\
\text { os }\end{array}$ & $15 / 04 / 2015$ & $\begin{array}{l}\text { 17/06/2015 - julgo procedente o pedido formulado por .... } \\
\text { em face do município de Bauru, determinando que este } \\
\text { forneça à requerente fraldas descartáveis geriátricas - } \\
\text { tamanho "g" (180 unidades por mês), nos termos da } \\
\text { petição inicial, e extinto o processo, com resolução de } \\
\text { mérito. }\end{array}$ & FRALDA \\
\hline 157 & $\begin{array}{c}\text { 1005775- } \\
38.2015 .8 .26 .0071\end{array}$ & 24899/2015 & $22 / 04 / 2015$ & $\begin{array}{l}\text { Mandado de } \\
\text { Segurança }\end{array}$ & $14 / 04 / 2015$ & $\begin{array}{l}\text { 30/04/2015 - concedo a segurança pleiteada por ....., } \\
\text { representado por ...., contra ato do secretário municipal } \\
\text { de saúde de Bauru, para que o impetrado forneça ao } \\
\text { impetrante fraldas geriátricas descartáveis - tamanho "m" } \\
\text { (90 unidades por mês), nos termos da petição inicial, e } \\
\text { julgo extinto o processo, com resolução de mérito. }\end{array}$ & FRALDA \\
\hline 158 & $\begin{array}{c}\text { 1003367- } \\
\text { 74.2015.8.26.0071 }\end{array}$ & $25752 / 2015$ & 24/04/2015 & $\begin{array}{l}\text { Mandado de } \\
\text { Segurança }\end{array}$ & 22/04/2015 & $\begin{array}{l}07 / 05 / 2015 \text { - oncedo a segurança pleiteada por ...... } \\
\text { representada por ....., contra ato do secretário municipal } \\
\text { de saúde de Bauru, para que o impetrado providencie à } \\
\text { impetrante: cama hospitalar com colchão casca de ovo, } \\
\text { em comodato, nos termos da petição inicial, e julgo extinto } \\
\text { o processo, com resolução de mérito. }\end{array}$ & $\begin{array}{c}\text { INSUMOS/MATE } \\
\text { RIAL } \\
\text { HOSPITALAR }\end{array}$ \\
\hline 159 & $\begin{array}{c}\text { 1007235- } \\
60.2015 .8 .26 .0071\end{array}$ & 27398/2015 & $30 / 04 / 2015$ & $\begin{array}{l}\text { Mandado de } \\
\text { Segurança }\end{array}$ & $27 / 04 / 2015$ & $\begin{array}{l}\text { 20/08/2015 - à fls. } 189 \text { foi informado o falecimento do } \\
\text { impetrante. por tratar-se de direito personalíssimo, houve } \\
\text { a perda do objeto da impetração. ante o exposto, revogo a } \\
\text { liminar de fls. } 24 / 25 \text { e julgo extinta a presente ação. }\end{array}$ & MEDICAMENTO \\
\hline 160 & $\begin{array}{c}\text { 1006852- } \\
\text { 82.2015.8.26.0071 }\end{array}$ & 27809/2015 & 04/05/2015 & $\begin{array}{l}\text { Mandado de } \\
\text { Segurança }\end{array}$ & & SEGREDO DE JUSTIÇA & $\begin{array}{l}\text { SEGREDO DE } \\
\text { JUSTIÇA }\end{array}$ \\
\hline
\end{tabular}




\begin{tabular}{|c|c|c|c|c|c|c|c|}
\hline 161 & $\begin{array}{c}\text { 1006613- } \\
\text { 78.2015.8.26.0071 }\end{array}$ & $28555 / 2015$ & 07/05/2015 & $\begin{array}{l}\text { Outros } \\
\text { Procediment } \\
\quad \text { os }\end{array}$ & & $\begin{array}{l}\text { 11/08/2016 - informado os óbitos das autora, com pedido } \\
\text { de extinção do processo que contou com a anuência das } \\
\text { requeridas.é o relatório. decido.considerando tratar-se de } \\
\text { direito personalíssimo, houve a perda do objeto da } \\
\text { presente ação. Ante o exposto, julgo extinta a presente } \\
\text { açãa. }\end{array}$ & MEDICAMENTO \\
\hline 162 & $\begin{array}{l}\text { 1007085- } \\
79.2015 .8 .26 .0071\end{array}$ & 29494/2015 & 12/05/2015 & $\begin{array}{l}\text { Outros } \\
\text { Procediment } \\
\text { os }\end{array}$ & 08/05/2015 & $\begin{array}{l}30 / 07 / 2015 \text { - julgo procedente o pedido, mantendo a } \\
\text { obrigação imposta ao requerido de fornecer ao requerente } \\
\text { as fraldas geriátricas descartáveis tamanho m } \mathrm{m} \text { (150 } \\
\text { unidades por mês conforme receituário de fls. 23). }\end{array}$ & FRALDA \\
\hline 163 & $\begin{array}{l}0034798- \\
80.2014 .8 .26 .0071\end{array}$ & 30558/2015 & 15/05/2015 & $\begin{array}{l}\text { Mandado de } \\
\text { Segurança }\end{array}$ & & $\begin{array}{l}\text { Extinto nos termos do art. } 267 \text { VIII CPC - a PMB já } \\
\text { fornece. }\end{array}$ & $\begin{array}{l}\text { ALIMENTAÇÃO } \\
\text { ESPECIAL }\end{array}$ \\
\hline 164 & $\begin{array}{l}\text { 1008334- } \\
\text { 65.2015.8.26.0071 }\end{array}$ & $30775 / 2015$ & 18/05/2015 & $\begin{array}{l}\text { Mandado de } \\
\text { Segurança }\end{array}$ & 13/05/2015 & $\begin{array}{l}\text { 03/08/2015 - concedo a segurança pleiteada por ..... } \\
\text { contra ato do secretario municipal de saúde de Bauru, } \\
\text { para que providencie o agendamento da consulta na } \\
\text { especialidade de ortopedia, nos termos da petição inicial e } \\
\text { julgo extinto o processo, com resolução de mérito. }\end{array}$ & $\begin{array}{l}\text { CONSULTA } \\
\text { MÉDICA }\end{array}$ \\
\hline 165 & $\begin{array}{c}\text { 1007823- } \\
67.2015 .8 .26 .0071\end{array}$ & $31299 / 2015$ & 20/05/2015 & $\begin{array}{l}\text { Mandado de } \\
\text { Segurança }\end{array}$ & 19/05/2015 & $\begin{array}{l}26 / 06 / 2015 \text { - concedo a segurança, determinando que o } \\
\text { impetrado providencie o fornecimento à impetrante do } \\
\text { medicamento hialuronato de sódio } 20 \mathrm{mg} / 2 \mathrm{ml}(06 \text { ampolas } \\
\text { - conforme receituário de fls. } 15) \text {, bem como o necessário } \\
\text { para a aplicação. }\end{array}$ & MEDICAMENTO \\
\hline 166 & $\begin{array}{l}\text { 1007909- } \\
\text { 38.2015.8.26.0071 }\end{array}$ & $31782 / 2015$ & 21/05/2015 & $\begin{array}{l}\text { Mandado de } \\
\text { Segurança }\end{array}$ & & $\begin{array}{l}\text { 14/07/2016 - julgo procedentes os pedidos da presente } \\
\text { ação de mandado de segurança para tornar definitiva a } \\
\text { liminar deferida e determinar ao diretor do Departamento } \\
\text { Regional de Saúde da Secretaria do Estado de Saúde em } \\
\text { Bauru/SP e Secretário Municipal de Saúde de Bauru da } \\
\text { Secretaria Municipal de Bauru. }\end{array}$ & $\begin{array}{l}\text { ALIMENTAÇÃO } \\
\text { ESPECIAL }\end{array}$ \\
\hline 167 & $\begin{array}{l}\text { 1007587- } \\
\text { 18.2015.8.26.0071 }\end{array}$ & $32265 / 2015$ & $25 / 05 / 2015$ & $\begin{array}{l}\text { Mandado de } \\
\text { Segurança }\end{array}$ & $21 / 05 / 2015$ & $\begin{array}{l}09 / 06 / 2015 \text { - concedo a segurança, determinando que o } \\
\text { impetrado providencie o fornecimento à impetrante do } \\
\text { medicamento colágeno hidrolisado mobility sachê ( } 30 \\
\text { sachês por mês conforme receituário e relatório médico. }\end{array}$ & MEDICAMENTO \\
\hline 168 & $\begin{array}{l}\text { 1007725- } \\
\text { 82.2015.8.26.0071 }\end{array}$ & $34635 / 2015$ & 08/06/2015 & $\begin{array}{l}\text { Mandado de } \\
\text { Segurança }\end{array}$ & 03/06/2015 & $\begin{array}{l}14 / 07 / 2015 \text { - concedo a segurança, determinando que o } \\
\text { impetrado providencie o fornecimento ao impetrante as } \\
\text { fraldas geriátricas descartáveis (tamanho g } 200 \text { unidades } \\
\text { por mês), conforme a receituário médico. }\end{array}$ & FRALDA \\
\hline 169 & $\begin{array}{c}1008742- \\
56.2015 .8 .26 .0071\end{array}$ & $35368 / 2015$ & $11 / 06 / 2015$ & $\begin{array}{l}\text { Mandado de } \\
\text { Segurança }\end{array}$ & 09/06/2015 & $\begin{array}{l}24 / 06 / 2015 \text { - concedo a segurança, determinando que o } \\
\text { impetrado providencie o fornecimento à impetrante dos } \\
\text { medicamentos sulfato de glicosamina } 1.500 \mathrm{mg} \text { e sulfato } \\
\text { de condroitina } 1.200 \mathrm{mg} \text { ( } 30 \text { sachês por mês. }\end{array}$ & MEDICAMENTO \\
\hline
\end{tabular}




\begin{tabular}{|c|c|c|c|c|c|c|c|}
\hline 170 & $\begin{array}{c}\text { 1005535- } \\
\text { 49.2015.8.26.0071 }\end{array}$ & $35390 / 2015$ & $11 / 06 / 2015$ & $\begin{array}{l}\text { Outros } \\
\text { Procediment } \\
\text { os }\end{array}$ & $24 / 04 / 2015$ & $\begin{array}{l}\text { 28/06/2017 - julgo procedente o pedido formulado por..... } \\
\text { contra a fazenda pública do estado de são paulo, } \\
\text { determinando que a requerida providencie o imediato } \\
\text { agendamento da cirurgia vitrectomia via pars plana olho } \\
\text { esquerdo e tratamento ocular quimioterápico - lucentis, } \\
\text { conforme encaminhamento médico de fls. } 51 \text {, e extinto o } \\
\text { processo, com resolução de mérito. }\end{array}$ & CIRURGIA \\
\hline 171 & $\begin{array}{c}\text { 1009988- } \\
87.2015 .8 .26 .0071\end{array}$ & $37585 / 2015$ & $24 / 06 / 2015$ & $\begin{array}{l}\text { Mandado de } \\
\text { Segurança }\end{array}$ & 22/06/2015 & $\begin{array}{l}\text { 13/07/2015 - concedo a segurança, determinando que o } \\
\text { impetrado providencie o fornecimento à impetrante das } \\
\text { fraldas geriátricas descartáveis (tamanho m } 180 \text { unidades } \\
\text { por mês), conforme a receituário médico. }\end{array}$ & FRALDA \\
\hline 172 & $\begin{array}{c}\text { 1011474- } \\
\text { 10.2015.8.26.0071 }\end{array}$ & $37867 / 2015$ & $25 / 06 / 2015$ & $\begin{array}{l}\text { Mandado de } \\
\text { Segurança }\end{array}$ & 23/06/2015 & $\begin{array}{l}\text { 13/07/2015 - concedo a segurança, determinando que o } \\
\text { impetrado providencie o fornecimento à impetrante das } \\
\text { fraldas geriátricas descartáveis (tamanho m } 180 \text { unidades } \\
\text { por mês), conforme a receituário médico. }\end{array}$ & FRALDA \\
\hline 173 & $\begin{array}{c}\text { 1008306- } \\
97.2015 .8 .26 .0071\end{array}$ & $38015 / 2015$ & $25 / 06 / 2015$ & $\begin{array}{l}\text { Mandado de } \\
\text { Segurança }\end{array}$ & 28/05/2015 & $\begin{array}{l}\text { 13/07/2015 - concedo a segurança, determinando que os } \\
\text { impetrados providenciem o fornecimento ao impetrante } \\
\text { cateter uretral lubrificado oㅡ } 12 \text { (150 unidades por mês), sob } \\
\text { pena de responderem por crime de desobediência, sem } \\
\text { prejuízo das sanções administrativas. para efeito de efetivo } \\
\text { controle do tempo em que a impetrante necessita do item a } \\
\text { ser fornecido e para evitar compras desnecessárias pelo } \\
\text { órgáo público, deverá o impetrante apresentar prescrição } \\
\text { médica atualizada ou à secretaria municipal de saúde ou } \\
\text { departamento regional de saúde. }\end{array}$ & $\begin{array}{c}\text { INSUMOS/MATE } \\
\text { RIAL } \\
\text { HOSPITALAR }\end{array}$ \\
\hline 174 & $\begin{array}{c}\text { 1011452- } \\
49.2015 .8 .26 .0071\end{array}$ & $38374 / 2015$ & 29/06/2015 & $\begin{array}{l}\text { Mandado de } \\
\text { Segurança }\end{array}$ & 23/06/2015 & $\begin{array}{l}\text { 13/07/2015 - concedo a segurança, determinando que o } \\
\text { impetrado providencie o fornecimento ao impetrante as } \\
\text { fraldas geriátricas descartáveis (tamanho m } 180 \text { unidades } \\
\text { por mês). }\end{array}$ & FRALDA \\
\hline 175 & $\begin{array}{c}\text { 1011691- } \\
53.2015 .8 .26 .0071\end{array}$ & $38886 / 2015$ & 01/07/2015 & $\begin{array}{l}\text { Mandado de } \\
\text { Segurança }\end{array}$ & $26 / 06 / 2015$ & $\begin{array}{l}13 / 07 / 2015 \text { - concedo a segurança pleiteada por .... } \\
\text { contra ato do secretário municipal de saúde de Bauru, } \\
\text { para que forneça ao impetrante: fraldas descartáveis, } \\
\text { tamanho "m" (120 unidades por mês). }\end{array}$ & FRALDA \\
\hline 176 & $\begin{array}{c}\text { 1011875- } \\
09.2015 .8 .26 .0071\end{array}$ & $39122 / 2015$ & 02/07/2015 & $\begin{array}{l}\text { Mandado de } \\
\text { Segurança }\end{array}$ & 29/06/2015 & $\begin{array}{l}\text { 20/07/2015 - concedo a segurança pleiteada por .... } \\
\text { contra ato do secretário municipal de saúde de Bauru, } \\
\text { para que o impetrado forneça ao impetrante fraldas } \\
\text { geriátricas descartáveis - tamanho "g" (130 unidades por } \\
\text { mês), nos termos da petição inicial, e julgo extinto o } \\
\text { processo, com resolução de mérito. }\end{array}$ & FRALDA \\
\hline
\end{tabular}




\begin{tabular}{|c|c|c|c|c|c|c|c|}
\hline 177 & $\begin{array}{c}\text { 1012013- } \\
\text { 73.2015.8.26.0071 }\end{array}$ & $39126 / 2015$ & 02/07/2015 & $\begin{array}{l}\text { Mandado de } \\
\text { Segurança }\end{array}$ & $30 / 06 / 2015$ & $\begin{array}{l}\text { 13/07/2015 - concedo a segurança pleiteada por ...... } \\
\text { representado por ......., contra ato do secretário municipal } \\
\text { de saúde de Bauru, para que forneça ao impetrante: } \\
\text { fraldas descartáveis, tamanho "m" (180 unidades por } \\
\text { mês), nos termos da petição inicial e, extinto o processo, } \\
\text { com resolução de mérito. }\end{array}$ & FRALDA \\
\hline 178 & \begin{tabular}{|c|} 
1011746- \\
04.2015.8.26.0071
\end{tabular} & $39326 / 2015$ & 03/07/2015 & $\begin{array}{l}\text { Mandado de } \\
\text { Segurança }\end{array}$ & 26/06/2015 & $\begin{array}{l}\text { 22/07/2015 - concedo a segurança, determinando que o } \\
\text { impetrado providencie o fornecimento à impetrante dos } \\
\text { medicamentos: sofosbuvir } 400 \mathrm{mg} \text { e daclatasvir } 60 \mathrm{mg} \text {, } \\
\text { (168 cápsulas de cada, por período de } 24 \text { semanas } \\
\text { conforme receituário médico. }\end{array}$ & MEDICAMENTO \\
\hline 179 & $\begin{array}{c}\text { 1011477- } \\
62.2015 .8 .26 .0071\end{array}$ & $39378 / 2015$ & 03/07/2015 & $\begin{array}{l}\text { Mandado de } \\
\text { Segurança }\end{array}$ & $30 / 06 / 2015$ & $\begin{array}{l}\text { 23/07/2015 - concedo a segurança pleiteada por ..... } \\
\text { contra ato do secretário municipal de saúde de Bauru, } \\
\text { para que o impetrado forneça à impetrante fraldas } \\
\text { geriátricas descartáveis - tamanho "m" (120 unidades por } \\
\text { mês). }\end{array}$ & FRALDA \\
\hline 180 & $\begin{array}{c}\text { 1011554- } \\
71.2015 .8 .26 .0071\end{array}$ & $39372 / 2015$ & 03/07/2015 & $\begin{array}{l}\text { Mandado de } \\
\text { Segurança }\end{array}$ & 29/06/2015 & $\begin{array}{l}\text { 24/07/2015 - concedo a segurança pleiteada por ......contra } \\
\text { ato do secretário municipal de saúde de Bauru, para que } \\
\text { o impetrado forneça à impetrante fraldas geriátricas } \\
\text { descartáveis - tamanho "g" (120 unidades por mês). }\end{array}$ & FRALDA \\
\hline 181 & $\begin{array}{c}1012308- \\
13.2015 .8 .26 .0071\end{array}$ & $40330 / 2015$ & 08/07/2015 & $\begin{array}{l}\text { Mandado de } \\
\text { Segurança }\end{array}$ & 03/07/2015 & $\begin{array}{l}21 / 07 / 2015 \text { - concedo a segurança pleiteada por .... } \\
\text { contra ato do secretário municipal de saúde de Bauru, } \\
\text { para que o impetrado forneça à impetrante fraldas } \\
\text { geriátricas descartáveis - tamanho "g" (240 unidades por } \\
\text { mês). }\end{array}$ & FRALDA \\
\hline 182 & $\begin{array}{c}\text { 1012497- } \\
88.2015 .8 .26 .0071\end{array}$ & $40988 / 2015$ & 14/07/2015 & $\begin{array}{l}\text { Mandado de } \\
\text { Segurança }\end{array}$ & 07/07/2015 & $\begin{array}{l}\text { 24/07/2015 - concedo a segurança pleiteada por.... contra } \\
\text { ato do secretário municipal de saúde de Bauru, para que } \\
\text { o impetrado forneça ao impetrante fraldas geriátricas } \\
\text { descartáveis - tamanho " "g" (150 unidades por mês), nos } \\
\text { termos do receituário médico (fls. 14), e julgo extinto o } \\
\text { processo, com resolução de mérito. }\end{array}$ & FRALDA \\
\hline 183 & \begin{tabular}{|c|} 
1012746- \\
39.2015 .8 .26 .0071
\end{tabular} & $41178 / 2015$ & 15/07/2015 & $\begin{array}{l}\text { Mandado de } \\
\text { Segurança }\end{array}$ & 13/07/2015 & $\begin{array}{l}\text { 23/07/2015 - concedo a segurança pleiteada por .... contra } \\
\text { ato do secretário municipal de saúde de Bauru, para que } \\
\text { o impetrado forneça ao impetrante fraldas geriátricas } \\
\text { descartáveis - tamanho "m" (05 unidades por dia), nos } \\
\text { termos da petição inicial, e julgo extinto o processo, com } \\
\text { resolução de mérito. }\end{array}$ & FRALDA \\
\hline 184 & $\begin{array}{c}\text { 1011695- } \\
90.2015 .8 .26 .0071-\end{array}$ & $41242 / 2015$ & 15/07/2015 & $\begin{array}{l}\text { Mandado de } \\
\text { Segurança }\end{array}$ & 07/07/2015 & $\begin{array}{l}\text { 19/08/2015 - concedo a segurança, determinando que o } \\
\text { impetrado providencie o fornecimento ao impetrante das } \\
\text { fraldas geriátricas descartáveis (tamanho g } 120 \text { unidades } \\
\text { por mês), conforme documento assinado por médico. }\end{array}$ & FRALDA \\
\hline
\end{tabular}




\begin{tabular}{|c|c|c|c|c|c|c|c|}
\hline 185 & $\begin{array}{c}1012591- \\
36.2015 .8 .26 .0071\end{array}$ & $41277 / 2015$ & $15 / 07 / 2015$ & $\begin{array}{l}\text { Mandado de } \\
\text { Segurança }\end{array}$ & 08/07/2015 & $\begin{array}{l}\text { 23/07/2015 - concedo a segurança, determinando que o } \\
\text { impetrado providencie o fornecimento ao impetrante as } \\
\text { fraldas geriátricas descartáveis (tamanho gg } 180 \text { unidades } \\
\text { por mês). }\end{array}$ & FRALDA \\
\hline 186 & $\begin{array}{c}1012669- \\
30.2015 .8 .26 .0071\end{array}$ & $41285 / 2015$ & 15/07/2015 & $\begin{array}{l}\text { Mandado de } \\
\text { Segurança }\end{array}$ & $13 / 07 / 2015$ & $\begin{array}{l}28 / 07 / 2015 \text { - concedo a segurança pleiteada por .... } \\
\text { contra ato do secretário municipal de saúde de Bauru, } \\
\text { para que forneça ao impetrante: fraldas geriátricas } \\
\text { descartáveis - tamanho "g" (180 unidades por mês), nos } \\
\text { termos da petição inicial, e julgo extinto o processo. }\end{array}$ & FRALDA \\
\hline 187 & $\begin{array}{c}1013168- \\
14.2015 .8 .26 .0071\end{array}$ & $41682 / 2015$ & 17/07/2015 & $\begin{array}{l}\text { Mandado de } \\
\text { Segurança }\end{array}$ & $16 / 07 / 2015$ & $\begin{array}{l}\text { 17/08/2015 - concedo a segurança, mantendo a ordem } \\
\text { para que o impetrado providencie o fornecimento à } \\
\text { impetrante as fraldas geriátricas descartáveis (tamanho g } \\
120 \text { unidades por mês). }\end{array}$ & FRALDA \\
\hline 188 & $\begin{array}{c}1013254- \\
82.2015 .8 .26 .0071\end{array}$ & $42213 / 2015$ & 21/07/2015 & $\begin{array}{l}\text { Mandado de } \\
\text { Segurança }\end{array}$ & $17 / 07 / 2015$ & $\begin{array}{l}31 / 07 / 2015 \text { - concedo a segurança, determinando que o } \\
\text { impetrado providencie o fornecimento ao impetrante as } \\
\text { fraldas geriátricas descartáveis (tamanho g } 120 \text { unidades } \\
\text { por mês). }\end{array}$ & FRALDA \\
\hline 189 & $\begin{array}{c}1013360- \\
44.2015 .8 .26 .0071\end{array}$ & $42297 / 2015$ & $21 / 07 / 2015$ & $\begin{array}{l}\text { Mandado de } \\
\text { Segurança }\end{array}$ & 20/07/2015 & $\begin{array}{l}\text { 04/08/2015 - concedo a segurança, determinando que o } \\
\text { impetrado providencie o fornecimento à impetrante as } \\
\text { fraldas geriátricas descartáveis (tamanho m } 120 \text { unidades } \\
\text { por mês). }\end{array}$ & FRALDA \\
\hline 190 & $\begin{array}{c}1012155- \\
77.2015 .8 .26 .0071\end{array}$ & $42578 / 2015$ & 22/07/2015 & $\begin{array}{l}\text { Outros } \\
\text { Procediment } \\
\text { os }\end{array}$ & 29/07/2015 & $\begin{array}{l}02 / 09 / 2015 \text { - julgo procedente o pedido, formulado por .... } \\
\text { contra o município de Bauru, determinando que o } \\
\text { requerido disponibilize à requerente transporte público } \\
\text { para tratamento de saúde, e extinto o processo, com } \\
\text { resolução de mérito. }\end{array}$ & TRANSPORTE \\
\hline 191 & $\begin{array}{c}1013000- \\
12.2015 .8 .26 .0071\end{array}$ & $43252 / 2015$ & 27/07/2015 & $\begin{array}{l}\text { Outros } \\
\text { Procediment } \\
\text { os }\end{array}$ & 22/07/2015 & $\begin{array}{l}\text { 02/09/2015 - julgo procedente o pedido formulado por ..... } \\
\text { em face do município de Bauru, determinando que este } \\
\text { forneça à requerente insulina glargina (03 refis de } 3 \mathrm{ml} \text { por } \\
\text { mês), insulina glulisina ( } 03 \text { refis de } 3 \mathrm{ml} \text { por mês), } \\
\text { vildagliptina }+ \text { metformina } 50 / 850 \mathrm{mg}(02 \text { comprimidos por } \\
\text { dia) e alisquireno + hidroclorotiazida } 300 / 12,5 \mathrm{~g}(01 \\
\text { comprimido por dia), nos termos da petição inicial, e } \\
\text { extinto o processo, com resolução de mérito. }\end{array}$ & MEDICAMENTO \\
\hline 192 & $\begin{array}{c}1009664- \\
97.2015 .8 .26 .0071\end{array}$ & $45546 / 2015$ & 07/08/2015 & $\begin{array}{l}\text { Mandado de } \\
\text { Segurança }\end{array}$ & & $\begin{array}{l}\text { 03/12/2018 -Apelação - Negaram provimento ao apelo e } \\
\text { ao reexame necessário. }\end{array}$ & MEDICAMENTO \\
\hline
\end{tabular}




\begin{tabular}{|c|c|c|c|c|c|c|c|}
\hline 193 & $\begin{array}{c}\text { 1014543- } \\
50.2015 .8 .26 .0071\end{array}$ & $45544 / 2015$ & 07/08/2015 & $\begin{array}{l}\text { Mandado de } \\
\text { Segurança }\end{array}$ & 03/08/2015 & $\begin{array}{l}21 / 08 / 2015 \text { - concedo a segurança pleiteada por .... } \\
\text { contra ato do secretário municipal de saúde de Bauru, } \\
\text { para que o impetrado forneça à impetrante fraldas } \\
\text { geriátricas descartáveis - tamanho "g" (120 unidades por } \\
\text { mês), nos termos da prescrição médica de fls. 14, e julgo } \\
\text { extinto o processo, com resolução de mérito. }\end{array}$ & FRALDA \\
\hline 194 & $\begin{array}{c}\text { 1014755- } \\
71.2015 .8 .26 .0071\end{array}$ & $45897 / 2015$ & 10/08/2015 & $\begin{array}{l}\text { Mandado de } \\
\text { Segurança }\end{array}$ & 06/08/2015 & $\begin{array}{l}\text { 26/08/2015 - concedo a segurança pleiteada por .... } \\
\text { contra ato do secretário municipal de saúde de Bauru, } \\
\text { para que o impetrado forneça à impetrante fraldas } \\
\text { geriátricas descartáveis - tamanho "g" (150 unidades ao } \\
\text { mês), nos termos da prescrição médica de fls. 17, e julgo } \\
\text { extinto o processo, com resolução de mérito. }\end{array}$ & FRALDA \\
\hline 195 & $\begin{array}{c}\text { 1015013- } \\
\text { 81.2015.8.26.0071 }\end{array}$ & 46389/2015 & $12 / 08 / 2015$ & $\begin{array}{l}\text { Mandado de } \\
\text { Segurança }\end{array}$ & 07/08/2015 & $\begin{array}{l}21 / 08 / 2015 \text { - concedo a segurança pleiteada por ..... a } \\
\text { contra ato do secretário municipal de saúde de Bauru, } \\
\text { para que o impetrado forneça à impetrante fraldas } \\
\text { geriátricas descartáveis - tamanho "m" (180 unidades por } \\
\text { mês) e julgo extinto o processo. }\end{array}$ & FRALDA \\
\hline 196 & $\begin{array}{c}\text { 1014976- } \\
54.2015 .8 .26 .0071\end{array}$ & $46385 / 2015$ & 12/08/2015 & $\begin{array}{l}\text { Mandado de } \\
\text { Segurança }\end{array}$ & 07/08/2015 & $\begin{array}{l}21 / 08 / 2015 \text { - concedo a segurança, mantendo a ordem } \\
\text { para que o impetrado providencie o fornecimento ao } \\
\text { impetrante as fraldas geriátricas descartáveis (tamanho g } \\
04 \text { unidades por dia). }\end{array}$ & FRALDA \\
\hline 197 & $\begin{array}{c}\text { 1015092- } \\
60.2015 .8 .26 .0071\end{array}$ & $46589 / 2015$ & 13/08/2015 & $\begin{array}{l}\text { Mandado de } \\
\text { Segurança }\end{array}$ & 10/08/2015 & $\begin{array}{l}\text { 27/08/2015 - concedo a segurança pleiteada por ..... } \\
\text { contra ato do secretário municipal de saúde de Bauru, } \\
\text { para que o impetrado forneça ao impetrante fraldas } \\
\text { geriátricas descartáveis - tamanho "g" (110 unidades por } \\
\text { mês), nos termos da prescrição médica de fls. 13, e julgo } \\
\text { extinto o processo, com resolução de mérito. }\end{array}$ & FRALDA \\
\hline 198 & $\begin{array}{c}\text { 1012719- } \\
56.2015 .8 .26 .0071\end{array}$ & $47359 / 2015$ & 18/08/2015 & $\begin{array}{l}\text { Mandado de } \\
\text { Segurança }\end{array}$ & $13 / 07 / 2015$ & $\begin{array}{l}\text { 25/02/2016 - concedo a segurança pleiteada por ...... } \\
\text { contra ato do diretor técnico do departamento regional de } \\
\text { saúde de Bauru - drs vi, para que o impetrado providencie } \\
\text { o fornecimento à impetrante dos medicamentos: } \\
\text { infliximabe (ramicade) (05 mg/kg - ev em } 2 \mathrm{~h} \text {, a cada trinta } \\
\text { dias) e modulen (10 latas por mês), conforme prescrições } \\
\text { médicas de fls. } 33 \text { e } 35 \text {, e julgo extinto o processo, com } \\
\text { resolução de mérito. }\end{array}$ & MEDICAMENTO \\
\hline 199 & $\begin{array}{c}\text { 1015597- } \\
51.2015 .8 .26 .0071\end{array}$ & $47677 / 2015$ & 19/08/2015 & $\begin{array}{l}\text { Mandado de } \\
\text { Segurança }\end{array}$ & $14 / 08 / 2015$ & $\begin{array}{l}\text { 11/01/2016 - concedo a segurança pleiteada por ....... } \\
\text { contra ato do secretário municipal de saúde de Bauru, } \\
\text { para que o impetrado forneça à impetrante fraldas } \\
\text { geriátricas descartáveis - tamanho "gg" (180 unidades por } \\
\text { mês), conforme prescrição médica de fls. 21, e julgo } \\
\text { extinto o processo, com resolução de mérito. }\end{array}$ & FRALDA \\
\hline
\end{tabular}




\begin{tabular}{|c|c|c|c|c|c|c|c|}
\hline 200 & $\begin{array}{c}1015554- \\
17.2015 .8 .26 .0071\end{array}$ & $47682 / 2015$ & 19/08/2015 & $\begin{array}{l}\text { Mandado de } \\
\text { Segurança }\end{array}$ & $14 / 08 / 2015$ & $\begin{array}{l}\text { 30/08/2015 - concedo a segurança pleiteada por .... } \\
\text { contra ato do secretário municipal de saúde de Bauru, } \\
\text { para que o impetrado forneça à impetrante fraldas } \\
\text { geriátricas descartáveis - tamanho "gg" (180 unidades por } \\
\text { mês), conforme prescrição médica de fls. 21, e julgo } \\
\text { extinto o processo, com resolução de mérito. }\end{array}$ & FRALDA \\
\hline 201 & $\begin{array}{c}\text { 1010397- } \\
63.2015 .8 .26 .0071\end{array}$ & $47990 / 2015$ & $20 / 08 / 2015$ & $\begin{array}{l}\text { Mandado de } \\
\text { Segurança }\end{array}$ & $17 / 08 / 2015$ & $\begin{array}{l}\text { 02/09/2015 - concedo a segurança pleiteada por .... } \\
\text { contra ato do secretário municipal de saúde de Bauru, } \\
\text { para que o impetrado forneça ao impetrante hialuronato } \\
\text { de sódio } 20 \mathrm{mg} / \mathrm{ml}(03 \text { ampolas) e triancil }(01 \text { ampola), } \\
\text { nos termos da petição inicial, e julgo extinto o processo, } \\
\text { com resoluçãa de mérito. }\end{array}$ & MEDICAMENTO \\
\hline 202 & $\begin{array}{c}1015838- \\
25.2015 .8 .26 .0071 \\
- \\
\end{array}$ & $48435 / 2015$ & $24 / 08 / 2015$ & $\begin{array}{l}\text { Mandado de } \\
\text { Segurança }\end{array}$ & $18 / 08 / 2015$ & $\begin{array}{l}\text { 31/08/2015 - à fls. } 29 \text { foi informado o falecimento do } \\
\text { impetrante. por tratar-se de direito personalíssimo, houve } \\
\text { a perda do objeto da impetração. ante o exposto, revogo a } \\
\text { liminar de fls. } 23 / 24 \text { e julgo extinta a presente ação. }\end{array}$ & FRALDA \\
\hline 203 & $\begin{array}{c}1015886- \\
81.2015 .8 .26 .0071\end{array}$ & $48740 / 2015$ & $25 / 08 / 2015$ & $\begin{array}{c}\text { Outros } \\
\text { Procediment } \\
\text { os }\end{array}$ & 19/08/2015 & $\begin{array}{l}24 / 09 / 2015 \text { - julgo procedente o pedido, mantendo a } \\
\text { obrigação imposta ao réu de fornecer à requerente as } \\
\text { fraldas geriátricas descartáveis, tamanho g. }\end{array}$ & FRALDA \\
\hline 204 & $\begin{array}{c}1015855- \\
61.2015 .8 .26 .0071\end{array}$ & $48749 / 2015$ & $25 / 08 / 2015$ & $\begin{array}{l}\text { Mandado de } \\
\text { Segurança }\end{array}$ & $18 / 08 / 2015$ & $\begin{array}{l}\text { 10/11/2015 - concedo a segurança, mantendo a ordem } \\
\text { para que o impetrado providencie o fornecimento ao } \\
\text { impetrante das fraldas geriátricas descartáveis, tamanho } \\
\text { m ( } 150 \text { unidades por mês. }\end{array}$ & FRALDA \\
\hline 205 & $\begin{array}{c}1013511- \\
10.2015 .8 .26 .0071 \\
\end{array}$ & $48738 / 2015$ & $25 / 08 / 2015$ & $\begin{array}{l}\text { Mandado de } \\
\text { Segurança }\end{array}$ & $21 / 08 / 2015$ & 07/12/2015 - Julga procedente o pedido. & FRALDA \\
\hline 206 & $\begin{array}{c}\text { 1004141- } \\
\text { 07.2015.8.26.0071 }\end{array}$ & $49216 / 2015$ & $27 / 08 / 2015$ & $\begin{array}{l}\text { Outros } \\
\text { Procediment } \\
\quad \text { os }\end{array}$ & & $\begin{array}{l}\text { 17/08/2016 - Ante o exposto e pelo mais que dos autos } \\
\text { consta, julgo procedentes os pedidos da presente ação de } \\
\text { obrigação de fazer, com pedido de tutela antecipada. }\end{array}$ & EXAME \\
\hline 207 & $\begin{array}{c}\text { 1016794- } \\
\text { 41.2015.8.26.0071 }\end{array}$ & $49993 / 2015$ & $01 / 09 / 2015$ & $\begin{array}{l}\text { Mandado de } \\
\text { Segurança }\end{array}$ & 27/08/2015 & $\begin{array}{l}\text { 23/09/2015 - concedo a segurança pleiteada por ...... } \\
\text { contra ato do secretário municipal de saúde de Bauru, } \\
\text { para que o impetrado forneça à impetrante fraldas } \\
\text { geriátricas descartáveis - tamanho "g" (120 unidades por } \\
\text { mês). }\end{array}$ & FRALDA \\
\hline 208 & $\begin{array}{c}\text { 1019398- } \\
\text { 72.2015.8.26.0071 }\end{array}$ & $55309 / 2015$ & $03 / 09 / 2015$ & $\begin{array}{l}\text { Mandado de } \\
\text { Segurança }\end{array}$ & $28 / 09 / 2015$ & $\begin{array}{l}31 / 05 / 2016 \text { - concedo a segurança pleiteada por .... } \\
\text { contra ato do secretário municipal de saúde de Bauru, } \\
\text { para que o impetrado forneça à impetrante fraldas } \\
\text { geriátricas - tamanho "m" (120 unidades/mês), - } \\
06 / 05 / 2017 \text { - recebidos os autos do tribunal de justiça - } \\
\text { arquivado definitivamente. }\end{array}$ & FRALDA \\
\hline
\end{tabular}




\begin{tabular}{|c|c|c|c|c|c|c|c|}
\hline 209 & $\begin{array}{c}\text { 1013652- } \\
29.2015 .8 .26 .0071\end{array}$ & $50706 / 2015$ & 04/09/2015 & $\begin{array}{l}\text { Mandado de } \\
\text { Segurança }\end{array}$ & 01/09/2015 & $\begin{array}{l}\text { 15/10/2015 - concedo a segurança, mantendo a ordem } \\
\text { para que o impetrado providencie o fornecimento à } \\
\text { impetrante das fraldas geriátricas descartáveis (tamanho } \\
\text { g } 200 \text { unidades por mês). }\end{array}$ & FRALDA \\
\hline 210 & $\begin{array}{c}\text { 1012134- } \\
\text { 04.2015.8.26.0071- }\end{array}$ & $50775 / 2015$ & 04/09/2015 & $\begin{array}{l}\text { Mandado de } \\
\text { Segurança }\end{array}$ & 01/07/2015 & $\begin{array}{l}\text { 04/11/2015 - concedo a segurança, mantendo a ordem } \\
\text { para que: } 1 \text { - a impetrada diretora do drs vi forneça ao } \\
\text { impetrante o medicamento ombitasvir } 75 \mathrm{mg}+\text { paritaprevir } \\
12,5 \mathrm{mg}+\text { ritonavir } 50 \mathrm{mg}(60 \text { comprimidos por mês } \\
\text { conforme receituário de fls. 20); e } 2 \text { - o impetrado } \\
\text { secretário municipal de saúde de Bauru forneça ao } \\
\text { impetrante o medicamento dasabuviur } 250 \mathrm{mg} \quad(60 \\
\text { comprimidos por mês conforme receituário de fls. 20). }\end{array}$ & MEDICAMENTO \\
\hline 211 & $\begin{array}{c}\text { 1017263- } \\
87.2015 .8 .26 .0071\end{array}$ & $51283 / 2015$ & 09/09/2015 & $\begin{array}{l}\text { Mandado de } \\
\text { Segurança }\end{array}$ & 02/09/2015 & $\begin{array}{l}\text { 15/09/2015 - concedo a segurança pleiteada por .... } \\
\text { contra ato do secretário municipal de saúde de Bauru, } \\
\text { para que o impetrado forneça à impetrante: fraldas } \\
\text { geriátricas descartáveis - tamanho "eg" (150 unidades por } \\
\text { mês), nos termos da petição inicial, e julgo extinto o } \\
\text { processo, com resolução de mérito. }\end{array}$ & FRALDA \\
\hline 212 & $\begin{array}{c}\text { 1017588- } \\
62.2015 .8 .26 .0071\end{array}$ & $51568 / 2015$ & 10/09/2015 & $\begin{array}{l}\text { Mandado de } \\
\text { Segurança }\end{array}$ & 09/09/2015 & $\begin{array}{l}\text { 30/09/2015 - concedo a segurança, mantendo a ordem } \\
\text { para que impetrado providencie o fornecimento à } \\
\text { impetrante das fraldas geriátricas descartáveis (tamanho } \\
\text { g } 180 \text { unidades por mês). }\end{array}$ & FRALDA \\
\hline 213 & $\begin{array}{c}\text { 1012738- } \\
\text { 62.2015.8.26.0071 }\end{array}$ & $51566 / 2015$ & 10/09/2015 & $\begin{array}{c}\text { Outros } \\
\text { Procediment } \\
\text { os } \\
\end{array}$ & & SEGREDO DE JUSTIÇA & $\begin{array}{l}\text { SEGREDO DE } \\
\text { JUSTIÇA }\end{array}$ \\
\hline 214 & $\begin{array}{c}\text { 1017576- } \\
48.2015 .8 .26 .0071\end{array}$ & $51885 / 2015$ & 11/09/2015 & $\begin{array}{l}\text { Mandado de } \\
\text { Segurança }\end{array}$ & 09/09/2015 & $\begin{array}{l}\text { 23/09/2015 - concedo a segurança pleiteada por .... contra } \\
\text { ato do secretário municipal de saúde de Bauru, para que o } \\
\text { impetrado forneça ao impetrante fraldas geriátricas } \\
\text { descartáveis - tamanho "g" (150 unidades por mês). }\end{array}$ & FRALDA \\
\hline 215 & $\begin{array}{c}\text { 1017575- } \\
\text { 63.2015.8.26.0071 }\end{array}$ & $51886 / 2015$ & 11/09/2015 & $\begin{array}{l}\text { Mandado de } \\
\text { Segurança }\end{array}$ & 09/09/2015 & $\begin{array}{l}21 / 09 / 2015 \text { - concedo a segurança, determinando que o } \\
\text { impetrado providencie o fornecimento à impetrante das } \\
\text { fraldas geriátricas descartáveis (tamanho gg } 180 \text { unidades } \\
\text { por mês), conforme a prescrição médica de fls. } 17, \text { sob } \\
\text { pena de responder por crime de desobediência, sem } \\
\text { prejuízo das sanções administrativas. }\end{array}$ & FRALDA \\
\hline 216 & $\begin{array}{c}\text { 1017621- } \\
52.2015 .8 .26 .0071\end{array}$ & $52154 / 2015$ & $14 / 09 / 2015$ & $\begin{array}{l}\text { Mandado de } \\
\text { Segurança }\end{array}$ & 09/09/2015 & $\begin{array}{l}\text { 28/09/2015 - concedo a segurança pleiteada por.... contra } \\
\text { ato do secretário municipal de saúde de Bauru, para que } \\
\text { o impetrado forneça à impetrante fraldas geriátricas } \\
\text { descartáveis - tamanho "ex" (180 unidades por mês), nos } \\
\text { termos da petiçãa inicial, e julgo extinto o processo, com } \\
\text { resoluçẫo de mérito. }\end{array}$ & FRALDA \\
\hline
\end{tabular}




\begin{tabular}{|c|c|c|c|c|c|c|c|}
\hline 217 & $\begin{array}{l}1018021- \\
66.2015 .8 .26 .0071\end{array}$ & $52151 / 2015$ & $14 / 09 / 2015$ & $\begin{array}{l}\text { Mandado de } \\
\text { Segurança }\end{array}$ & $11 / 09 / 2015$ & $\begin{array}{l}\text { 29/03/2017 - denegada a segurança - fundamento e } \\
\text { decido.verifica-se dos autos que a assistente social do } \\
\text { município de Bauru, em visita ao endereço fornecido na } \\
\text { inicial, constatou que a impetrante nãa reside mais nesta } \\
\text { cidade e que não está retirando as fraldas que lle foram } \\
\text { fornecidas por força da liminar deferida nos presentes } \\
\text { autos.salienta-se que a competência para fornecimento } \\
\text { de medicamentos/insumos pela secretaria municipal de } \\
\text { Bauru se restringe a esta comarca.ante o exposto, revogo } \\
\text { a liminar deferida às fls. } 34 / 35 \text {, reconheço a carência } \\
\text { superveniente, e julgo extinto o processo sem resolução } \\
\text { de mérito. }\end{array}$ & FRALDA \\
\hline 218 & $\begin{array}{c}\text { 1017498- } \\
54.2015 .8 .26 .0071\end{array}$ & $52149 / 2015$ & 14/09/2015 & $\begin{array}{l}\text { Mandado de } \\
\text { Segurança }\end{array}$ & $11 / 09 / 2015$ & $\begin{array}{l}\text { 26/12/2015 - considerando a morte da impetrante, julgo } \\
\text { extinto o processo, sem julgamento do mérito. }\end{array}$ & MEDICAMENTO \\
\hline 219 & $\begin{array}{c}1017620- \\
67.2015 .8 .26 .0071\end{array}$ & $52234 / 2015$ & $14 / 09 / 2015$ & $\begin{array}{l}\text { Mandado de } \\
\text { Segurança }\end{array}$ & & SEGREDO DE JUSTIÇA & $\begin{array}{l}\text { SEGREDO DE } \\
\text { JUSTIÇA }\end{array}$ \\
\hline 220 & $\begin{array}{c}\text { 1014347- } \\
80.2015 .8 .26 .0071\end{array}$ & $52377 / 2015$ & 15/09/2015 & $\begin{array}{l}\text { Outros } \\
\text { Procediment } \\
\text { os }\end{array}$ & & $\begin{array}{l}\text { 17/08/16 - Com o advento da maioridade, cessou a } \\
\text { competência desta justiça especializada e o processo } \\
\text { deve prosseguir perante uma das Varas de Fazenda } \\
\text { Pública desta cidade e comarca. Por isso, reconheço a } \\
\text { incompetência superveniente desta justiça especializada } \\
\text { e determino a imediata distribuição dos autos a uma das } \\
\text { Varas de Fazenda Pública desta cidade e comarca. }\end{array}$ & FRALDA \\
\hline 221 & $\begin{array}{c}1017893- \\
46.2015 .8 .26 .0071\end{array}$ & $52374 / 2015$ & $15 / 09 / 2015$ & $\begin{array}{l}\text { Mandado de } \\
\text { Segurança }\end{array}$ & & $\begin{array}{l}\text { 17/07/17 - julgo procedente o pedido da presente ação de } \\
\text { mandado de segurança. }\end{array}$ & MEDICAMENTO \\
\hline 222 & $\begin{array}{c}1016443- \\
68.2015 .8 .26 .0071\end{array}$ & $52396 / 2015$ & $15 / 09 / 2015$ & $\begin{array}{l}\text { Mandado de } \\
\text { Segurança }\end{array}$ & & SEGREDO DE JUSTIÇA & MEDICAMENTO \\
\hline 223 & $\begin{array}{c}1016078- \\
14.2015 .8 .26 .0071\end{array}$ & $52436 / 2015$ & $15 / 09 / 2015$ & $\begin{array}{l}\text { Mandado de } \\
\text { Segurança }\end{array}$ & & SEGREDO DE JUSTIÇA & MEDICAMENTO \\
\hline
\end{tabular}




\begin{tabular}{|c|c|c|c|c|c|c|c|}
\hline 224 & $\begin{array}{c}1015003- \\
37.2015 .8 .26 .0071\end{array}$ & $52924 / 2015$ & 17/09/2015 & $\begin{array}{l}\text { Mandado de } \\
\text { Segurança }\end{array}$ & 06/08/2015 & $\begin{array}{l}\text { 29/09/2015 - concedo a segurança, mantendo a ordem de } \\
\text { transferência/internação do impetrante para unidade } \\
\text { hospitalar pública ou privada, bem como o tratamento } \\
\text { adequado para o restabelecimento de sua saúde. nos } \\
\text { termos do artigo } 13 \text {, caput, da lei } 12.016 / 09 \text {, por } \\
\text { mandado, transmitir o inteiro teor da decisão ao impetrado } \\
\text { e a fesp. não cabe condenação em honorários (artigo } 25 \\
\text { da lei } 12.016 / 09 \text { ). comunique-se, com urgência, o } \\
\text { julgamento da lide à desembargadora relatora do agravo } \\
\text { de instrumento } 2177708-81.2015 .8 .26 .0000 \text { (fls. } 43 / 45 \text { ). p. } \\
\text { r. e i - - 05/08/2016 - recebidos os autos do tribunal de } \\
\text { justiça - data do julgamento: } 11 / 04 / 2016 \text { trânsito em } \\
\text { julgado: tipo de julgamento: acórdão decisão: negaram } \\
\text { provimento aos recursos. }\end{array}$ & INTERNAÇÃO \\
\hline 225 & $\begin{array}{c}1018630- \\
49.2015 .8 .26 .0071-\end{array}$ & $53446 / 2015$ & 21/09/2015 & $\begin{array}{l}\text { Mandado de } \\
\text { Segurança }\end{array}$ & 17/09/2015 & $\begin{array}{l}\text { 06/10/2015 - concedo a segurança, mantendo a ordem } \\
\text { para que impetrado providencie o fornecimento à } \\
\text { impetrante das fraldas geriátricas descartáveis (tamanho } \\
\text { eg } 120 \text { unidades por mês), conforme a receituário médico } \\
\text { de fls. 12, sob pena de responder por crime de } \\
\text { desobediência, sem prejuízo das sanções administrativas. }\end{array}$ & FRALDA \\
\hline 226 & $\begin{array}{c}1015732- \\
63.2015 .8 .26 .0071\end{array}$ & $53443 / 2015$ & 21/09/2015 & $\begin{array}{c}\text { Outros } \\
\text { Procediment } \\
\text { os }\end{array}$ & & SEGREDO DE JUSTIÇA & $\begin{array}{l}\text { SEGREDO DE } \\
\text { JUSTIÇA }\end{array}$ \\
\hline 227 & $\begin{array}{c}1018780- \\
30.2015 .8 .26 .0071\end{array}$ & $53934 / 2015$ & 23/09/2015 & $\begin{array}{l}\text { Mandado de } \\
\text { Segurança }\end{array}$ & 18/09/2015 & $\begin{array}{l}\text { 07/10/2015 - concedo a segurança, determinando que o } \\
\text { impetrado providencie o fornecimento à impetrante das } \\
\text { fraldas geriátricas descartáveis (tamanho g } 200 \text { unidades } \\
\text { por mês conforme documento de fls. } 14 \text { ) - remetido ao } \\
\text { dje - relação: } 0413 / 2016 \text { teor do ato: ciência às partes da } \\
\text { certidão de trânsito em julgado/retorno dos autos da } 2^{\mathrm{a}} \\
\text { instância. aguarda-se manifestação do interessado em } \\
\text { termos de prosseguimento do feito, no prazo de } 30 \text { dias, } \\
\text { pena de arquivamentoeventual cumprimento de sentença. }\end{array}$ & FRALDA \\
\hline 228 & $\begin{array}{c}1015220- \\
80.2015 .8 .26 .0071\end{array}$ & $53932 / 2015$ & $23 / 09 / 2015$ & $\begin{array}{l}\text { Mandado de } \\
\text { Segurança }\end{array}$ & 10/08/2015 & $\begin{array}{l}\text { 02/10/2015 - foi informado o falecimento do impetrante. } \\
\text { por tratar-se de direito personalíssimo, houve a perda do } \\
\text { objeto da impetraçấo. }\end{array}$ & INTERNAÇÃO \\
\hline 229 & $\begin{array}{c}\text { 1016335- } \\
39.2015 .8 .26 .0071\end{array}$ & $54169 / 2015$ & 24/09/2015 & $\begin{array}{l}\text { Mandado de } \\
\text { Segurança }\end{array}$ & $21 / 09 / 2015$ & $\begin{array}{l}\text { 01/10/2015 - concedo a segurança pleiteada por.... contra } \\
\text { ato do secretário municipal de saúde de Bauru, para que } \\
\text { o impetrado forneça ao impetrante fraldas geriátricas } \\
\text { descartáveis - tamanho "m" (30 unidades por mês) e } \\
\text { fraldas infantis descartáveis. }\end{array}$ & FRALDA \\
\hline
\end{tabular}




\begin{tabular}{|c|c|c|c|c|c|c|c|}
\hline 230 & $\begin{array}{c}\text { 1018848- } \\
77.2015 .8 .26 .0071\end{array}$ & $54165 / 2015$ & 24/09/2015 & $\begin{array}{l}\text { Mandado de } \\
\text { Segurança }\end{array}$ & 18/09/2015 & $\begin{array}{l}\text { 06/10/2015 - concedo a segurança, mantendo a ordem } \\
\text { para que impetrado providencie o fornecimento ao } \\
\text { impetrante das fraldas geriátricas descartáveis. }\end{array}$ & FRALDA \\
\hline 231 & $\begin{array}{c}1018850- \\
47.2015 .8 .26 .0071\end{array}$ & $54185 / 2015$ & 24/09/2015 & $\begin{array}{l}\text { Outros } \\
\text { Procediment } \\
\text { os }\end{array}$ & 18/09/2015 & $\begin{array}{l}\text { 20/10/2015 - julgo procedente o pedido formulado por .... } \\
\text { em face do município de Bauru, determinando que este } \\
\text { forneça ao requerente fraldas descartáveis geriátricas - } \\
\text { tamanho "m" (120 unidades por mês). }\end{array}$ & MEDICAMENTO \\
\hline 232 & $\begin{array}{c}\text { 1016233- } \\
17.2015 .8 .26 .0071\end{array}$ & $54918 / 2015$ & 29/09/2015 & $\begin{array}{l}\text { Mandado de } \\
\text { Segurança }\end{array}$ & $21 / 08 / 2015$ & $\begin{array}{l}\text { 14/10/2015 - concedo a segurança, mantendo a ordem } \\
\text { para que os impetrados providenciem o fornecimento à } \\
\text { impetrante do medicamento hialuronato de sódio } \\
20 \mathrm{mg} / 2 \mathrm{ml} \text { ( } 10 \text { ampolas conforme receituário. }\end{array}$ & MEDICAMENTO \\
\hline 233 & $\begin{array}{c}\text { 1019755- } \\
52.2015 .8 .26 .0071\end{array}$ & $55525 / 2015$ & 01/10/2015 & $\begin{array}{l}\text { Mandado de } \\
\text { Segurança }\end{array}$ & 29/09/2015 & $\begin{array}{l}\text { 24/11/2015 - os impetrados informaram a transferência da } \\
\text { impetrante (fls. 32/34). posteriormente a impetrante } \\
\text { informou que foi internada pelo tempo necessário para } \\
\text { garantir sua recuperação e já se encontra em casa, } \\
\text { pedindo a extinção do feito.. nesse passo, como a } \\
\text { requerente informou que foi internada pelo tempo } \\
\text { necessário para garantir sua recuperação e já se encontra } \\
\text { em casa, restou satisfeita sua pretensão, ocorrendo a } \\
\text { perda do objeto da ação, vez que se tornou } \\
\text { desnecessária a tutela jurisdicional. ante o exposto, } \\
\text { reconheço a carência superveniente, e julgo extinto o } \\
\text { processo sem resolução de mérito. }\end{array}$ & $\begin{array}{l}\text { CONSULTA } \\
\text { MÉDICA }\end{array}$ \\
\hline 234 & $\begin{array}{c}1019668- \\
96.2015 .8 .26 .0071 \\
\end{array}$ & $55534 / 2015$ & 01/10/2015 & $\begin{array}{c}\text { Mandado de } \\
\text { Segurança }\end{array}$ & 29/09/2015 & \#VALOR! & FRALDA \\
\hline 235 & $\begin{array}{c}\text { 1020089- } \\
86.2015 .8 .26 .0071-\end{array}$ & $56445 / 2015$ & 07/10/2015 & $\begin{array}{l}\text { Mandado de } \\
\text { Segurança }\end{array}$ & $02 / 10 / 2015$ & $\begin{array}{l}\text { 26/10/2015 - concedo a segurança, mantendo a ordem } \\
\text { para que impetrado providencie o fornecimento ao } \\
\text { impetrante das fraldas geriátricas descartáveis (tamanho } \\
\text { p } 120 \text { unidades por mês) - - 08/05/2017 - remetido ao dje } \\
\text { - arquivado definitivamente. }\end{array}$ & FRALDA \\
\hline 236 & $\begin{array}{c}1019200- \\
35.2015 .8 .26 .0071\end{array}$ & $56443 / 2015$ & 07/10/2015 & $\begin{array}{c}\text { Outros } \\
\text { Procediment } \\
\text { os }\end{array}$ & & SEGREDO DE JUSTIÇA & $\begin{array}{l}\text { APRESENTACÃO } \\
\text { DE PRONTUÁRIO }\end{array}$ \\
\hline 237 & $\begin{array}{c}1020290- \\
78.2015 .8 .26 .0071\end{array}$ & $56731 / 2015$ & 08/10/2015 & $\begin{array}{l}\text { Mandado de } \\
\text { Segurança }\end{array}$ & 06/10/2015 & $\begin{array}{l}\text { 23/10/2015 - concedo a segurança, mantendo a ordem para } \\
\text { que o impetrado providencie o fornecimento à impetrante das } \\
\text { fraldas geriátricas descartáveis (tamanho m } 180 \text { unidades } \\
\text { por mês), - - 17/12/2016 - recebidos os autos do tribunal de } \\
\text { justiça - data do julgamento: 20/04/2016 10:56:15 tipo de } \\
\text { julgamento: decisão monocrática decisão: (...) ante o } \\
\text { exposto, nego provimento ao reexame necessário. (...). }\end{array}$ & FRALDA \\
\hline
\end{tabular}




\begin{tabular}{|c|c|c|c|c|c|c|c|}
\hline 238 & $\begin{array}{c}\text { 1019511- } \\
26.2015 .8 .26 .0071\end{array}$ & $56692 / 2015$ & 08/10/2015 & $\begin{array}{l}\text { Mandado de } \\
\text { Segurança }\end{array}$ & 28/09/2015 & $\begin{array}{l}26 / 10 / 2015 \text { - concedo a segurança pleiteada por .... } \\
\text { contra ato do secretário municipal de saúde de Bauru, } \\
\text { para que o impetrado forneça à impetrante: fraldas } \\
\text { geriátricas descartáveis - tamanho "m" (120 unidades por } \\
\text { mês), nos termos da petição inicial, e julgo extinto o } \\
\text { processo, com resolução de mérito, - - } 11 / 04 / 2016- \\
\text { remetido ao dje - relaçãa: } 0150 / 2016 \text { teor do ato: } \\
\text { vistos.arquivem-se.int. advogados(s): ..., ..., ... }\end{array}$ & FRALDA \\
\hline 239 & $\begin{array}{c}0000541- \\
75.2015 .8 .26 .0594\end{array}$ & $56938 / 2015$ & 09/10/2015 & $\begin{array}{l}\text { Outros } \\
\text { Procediment } \\
\text { os }\end{array}$ & & SEGREDO DE JUSTIÇA & INTERNAÇÃO \\
\hline 240 & $\begin{array}{c}\text { 1016398- } \\
\text { 64.2015.8.26.0071 }\end{array}$ & $56939 / 2015$ & 09/10/2015 & $\begin{array}{l}\text { Mandado de } \\
\text { Segurança }\end{array}$ & 06/10/2015 & $\begin{array}{l}\text { 26/10/2015 - concedo a segurança, mantendo a ordem } \\
\text { para que o impetrado providencie o fornecimento ao } \\
\text { impetrante as fraldas geriátricas descartáveis (tamanho g } \\
180 \text { unidades por mês), - - 17/11/2015 - comprovado o } \\
\text { óbito do impetrante, é evidente a perda do objeto do } \\
\text { presente mandado de segurança. ante o exposto, torno } \\
\text { sem efeito a decisão que determinou o fornecimento das } \\
\text { fraldas geriátricas descartáveis. oficie-se ao impetrado, } \\
\text { com urgênncia, comunicando o ocorrido. após, procedidas } \\
\text { às necessárias anotações, arquivem-se os autos. }\end{array}$ & FRALDA \\
\hline 241 & $\begin{array}{c}1016088- \\
58.2015 .8 .26 .0071\end{array}$ & $58040 / 2015$ & $16 / 10 / 2015$ & $\begin{array}{l}\text { Outros } \\
\text { Procediment } \\
\text { os }\end{array}$ & & SEGREDO DE JUSTIÇA & $\begin{array}{c}\text { SEGREDO DE } \\
\text { JUSTIÇA }\end{array}$ \\
\hline 242 & $\begin{array}{c}\text { 1019771- } \\
06.2015 .8 .26 .0071\end{array}$ & $58253 / 2015$ & 19/10/2015 & $\begin{array}{l}\text { Mandado de } \\
\text { Segurança }\end{array}$ & 15/10/2015 & $\begin{array}{l}\text { 01/03/2016 - concedo a segurança pleiteada por ... contra } \\
\text { ato do diretor técnico do departamento regional de saúde } \\
\text { de Bauru - drs vi e do secretário municipal de saúde de } \\
\text { Bauru, para que os impetrados providenciem o } \\
\text { fornecimento à impetrante do medicamento dabigatrana } \\
150 \mathrm{mg} \text { ( } 60 \text { comprimidos por mês). Ciência da baixa dos } \\
\text { autos, bem como da certidâa do trânsito em julgado. } \\
\text { aguarda-se manifestação da autora acerca de fls. } 159 / 162 \\
\text { e } 164 / 167 \text {. nada requerido em } 30 \text { dias, os autos serão } \\
\text { remetidos ao arquivo. advogados(s): ..., ..., ... }\end{array}$ & MEDICAMENTO \\
\hline 243 & $\begin{array}{c}\text { 1021362- } \\
\text { 03.2015.8.26.0071 }\end{array}$ & $58855 / 2015$ & 21/10/2015 & $\begin{array}{l}\text { Mandado de } \\
\text { Segurança }\end{array}$ & 20/10/2015 & $\begin{array}{l}\text { 04/11/2015 - concedo a segurança, mantendo a ordem } \\
\text { para que o impetrado providencie o fornecimento ao } \\
\text { impetrante das fraldas geriátricas descartáveis (tamanho } \\
\text { m adulto } 120 \text { unidades por mês) - - 29/06/2017 - remetido } \\
\text { ao dje - relação: } 0506 / 2017 \text { teor do ato: vistos.ciência às } \\
\text { partes do retorno dos autos. nada sendo requerido em } 30 \\
\text { dias, arquivem-se.int. advogados(s): ...., ... }\end{array}$ & FRALDA \\
\hline
\end{tabular}




\begin{tabular}{|c|c|c|c|c|c|c|c|}
\hline 244 & $\begin{array}{c}1021571- \\
69.2015 .8 .26 .0071\end{array}$ & $60328 / 2015$ & 28/10/2015 & $\begin{array}{l}\text { Mandado de } \\
\text { Segurança }\end{array}$ & $22 / 10 / 2015$ & $\begin{array}{l}\text { 05/11/2015 - concedo a segurança pleiteada por .... } \\
\text { contra ato do secretário municipal de saúde de Bauru, } \\
\text { para que o impetrado forneça à impetrante fraldas } \\
\text { geriátricas descartáveis - tamanho "eg" ( } 240 \text { unidades por } \\
\text { mês) - - 03/03/2016 - remetido ao dje - relação: } \\
0094 / 2016 \text { teor do ato: vistos. considerando a certidão de } \\
\text { fls. } 75 \text {, oportunamente ao arquivo. int. advogados(s):..., ..., } \\
\text {... }\end{array}$ & FRALDA \\
\hline 245 & $\begin{array}{c}1019756- \\
37.2015 .8 .26 .0071\end{array}$ & $60711 / 2015$ & 29/10/2015 & $\begin{array}{l}\text { Outros } \\
\text { Procediment } \\
\text { os }\end{array}$ & & $\begin{array}{l}\text { *desistência da ação e julgo extinto o processo sem } \\
\text { resolução do mérito. }\end{array}$ & INTERNAÇÃO \\
\hline 246 & $\begin{array}{c}1021919- \\
87.2015 .8 .26 .0071\end{array}$ & $61119 / 2015$ & 03/11/2015 & $\begin{array}{l}\text { Mandado de } \\
\text { Segurança }\end{array}$ & $27 / 10 / 2015$ & $\begin{array}{l}\text { 13/11/2015 - concedo a segurança pleiteada por .... } \\
\text { contra ato do secretário municipal de saúde de Bauru, } \\
\text { para que o impetrado forneça à impetrante fraldas } \\
\text { descartáveis - tamanho "xg" adulto ( } 150 \text { unidades por } \\
\text { mês) - - } 25 / 08 / 2016 \text { - remetido ao dje - relação: } \\
0362 / 2016 \text { teor do ato: vistos.considerando a certidão de } \\
\text { fls. } 66 \text {, arquivem-se os autos com as cautelas de } \\
\text { praxe.intime-se. advogados(s): ..., ... }\end{array}$ & FRALDA \\
\hline 247 & $\begin{array}{c}\text { 1019728- } \\
69.2015 .8 .26 .0071\end{array}$ & $61862 / 2015$ & $05 / 11 / 2015$ & $\begin{array}{l}\text { Mandado de } \\
\text { Segurança }\end{array}$ & $29 / 09 / 2015$ & $\begin{array}{l}\text { 29/06/2016 - julgo extinta a presente ação, em razão de } \\
\text { carência superveniente, nos termos do artigo 485, inciso } \\
\text { vi do código de processo civil.autor falecido. }\end{array}$ & INTERNAÇÃO \\
\hline 248 & $\begin{array}{c}\text { 1022262- } \\
83.2015 .8 .26 .0071\end{array}$ & $62198 / 2015$ & $06 / 11 / 2015$ & $\begin{array}{l}\text { Outros } \\
\text { Procediment } \\
\text { os }\end{array}$ & $04 / 11 / 2015$ & $\begin{array}{l}\text { 16/12/2015 - julgo procedente o pedido, formulado por .... } \\
\text { contra o município de Bauru, determinando que o } \\
\text { requerido forneça à requerente glargina (lantus) } 50 \text { refil } \\
100 \text { ui/ml continuado ( } 50 \mathrm{cc} \text { diariamente sub cutâneo), } \\
\text { linagliptina (trayenta) } 5 \mathrm{mg} / \text { dia (um comprimido ao dia), } \\
\text { fitas reagentes (para dosagens glicemicas) (três vezes por } \\
\text { dia) e agulha para caneta } 29 \times 1 / 2(12-7 \mathrm{~mm} \text { ) ( } 01 \text { unidade } \\
\text { por dia) - - 07/07/2017 - remetido ao dje - relação: } \\
0439 / 2017 \text { teor do ato: vistos.determino o arquivamento } \\
\text { dos presentes autos, com as cautelas de praxe, } \\
\text { ressaltando que em caso de eventual descumprimento, a } \\
\text { requerente deverá proceder a novo peticionamento } \\
\text { eletrônico, de acordo com o comunicado cg no } 438 / 2016 \\
\text { (cumprimento de sentença. }\end{array}$ & MEDICAMENTO \\
\hline
\end{tabular}




\begin{tabular}{|c|c|c|c|c|c|c|c|}
\hline 249 & $\begin{array}{c}\text { 1022552- } \\
98.2015 .8 .26 .0071\end{array}$ & 62202/2015 & 06/11/2015 & $\begin{array}{l}\text { Mandado de } \\
\text { Segurança }\end{array}$ & 04/11/2015 & $\begin{array}{l}17 / 11 / 2015 \text { - concedo a segurança pleiteada por .... } \\
\text { contra ato do secretário municipal de saúde de Bauru, } \\
\text { para que o impetrado forneça à impetrante fraldas } \\
\text { descartáveis - tamanho "m" adulto - }-25 / 08 / 2016- \\
\text { remetido ao dje - relação: 0362/2016 teor do ato: } \\
\text { vistos.considerando a certidão de fls. } 61 \text {, arquivem-se os } \\
\text { autos com as cautelas de praxe.intime-se. advogados(s): }\end{array}$ & FRALDA \\
\hline 250 & $\begin{array}{c}\text { 1022267- } \\
08.2015 .8 .26 .0071\end{array}$ & 62287/2015 & 06/11/2015 & $\begin{array}{l}\text { Mandado de } \\
\text { Segurança }\end{array}$ & 29/10/2015 & $\begin{array}{l}\text { 18/11/2015 - concedo a segurança, mantendo a ordem } \\
\text { para que o impetrado providencie o fornecimento à } \\
\text { impetrante das fraldas geriátricas descartáveis (tamanho } \\
\text { g } 120 \text { unidades por mês) - - - 23/06/2017 - remetido ao } \\
\text { dje - relação: 0488/2017 teor do ato: vistos.ciência às } \\
\text { partes do retorno dos autos.nada sendo requerido em } 30 \\
\text { dias, arquivem-se.int. advogados(s): ..., ..., ... }\end{array}$ & FRALDA \\
\hline 251 & $\begin{array}{c}\text { 1019213- } \\
34.2015 .8 .26 .0071 \\
\end{array}$ & 62430/2015 & 06/11/2015 & $\begin{array}{c}\text { Mandado de } \\
\text { Segurança }\end{array}$ & & SEGREDO DE JUSTIÇA & $\begin{array}{c}\text { SEGREDO DE } \\
\text { JUSTIÇA }\end{array}$ \\
\hline 252 & \begin{tabular}{c|}
$1021169-$ \\
85.2015 .8 .26 .0071
\end{tabular} & $62445 / 2015$ & 06/11/2015 & $\begin{array}{l}\text { Mandado de } \\
\text { Segurança }\end{array}$ & & SEGREDO DE JUSTIÇA & $\begin{array}{l}\text { SEGREDO DE } \\
\text { JUSTIÇA }\end{array}$ \\
\hline 253 & $\begin{array}{c}1021175- \\
92.2015 .8 .26 .0071\end{array}$ & $63164 / 2015$ & 10/11/2015 & $\begin{array}{l}\text { Mandado de } \\
\text { Segurança }\end{array}$ & & SEGREDO DE JUSTIÇA & $\begin{array}{l}\text { CONSULTA } \\
\text { MÉDICA }\end{array}$ \\
\hline 254 & $\begin{array}{c}\text { 1021959- } \\
69.2015 .8 .26 .0071\end{array}$ & $63171 / 2015$ & 10/11/2015 & $\begin{array}{l}\text { Outros } \\
\text { Procediment } \\
\text { os }\end{array}$ & 04/11/2015 & $\begin{array}{l}\text { 08/03/2016 - julgo procedente o pedido formulado por .... } \\
\text { em face do município de Bauru, determinando que o } \\
\text { requerido forneça ao requerente o medicamento sporanox } \\
200 \mathrm{mg} \text { ( } 180 \text { comprimidos por mês por } 3 \text { meses e, } \\
\text { posteriormente, } 400 \mathrm{mg} \text { ao dia por mais } 18 \text { meses), - } \\
17 / 05 / 2017 \text { - remetido ao dje - relação: } 0403 / 2017 \text { teor do } \\
\text { ato: vistos.considerando a informação de fls. } 182 \text {, digam } \\
\text { as partes se tem algo mais a requerer nestes autos.no } \\
\text { silêncio, conclusos. int. advogados(s): ..., ..., ..., ... }\end{array}$ & MEDICAMENTO \\
\hline
\end{tabular}




\begin{tabular}{|c|c|c|c|c|c|c|c|}
\hline 255 & $\begin{array}{c}\text { 1021532- } \\
72.2015 .8 .26 .0071\end{array}$ & $63198 / 2015$ & 10/11/2015 & $\begin{array}{l}\text { Mandado de } \\
\text { Segurança }\end{array}$ & $04 / 11 / 2015$ & $\begin{array}{l}\text { 23/11/2015 - concedo a segurança pleiteada por ... contra } \\
\text { ato do secretário municipal de saúde de Bauru, para que o } \\
\text { impetrado forneça à impetrante: fraldas geriátricas } \\
\text { descartáveis - tamanho "m" (180 unidades por mês), dieta } \\
\text { polimérica líquida, hipercalórica (1.5 kcal/ml), hiperproteica, } \\
\text { sem fibras e sacarose (38 litros por mês) e sonda } \\
\text { nasogástrica (acompanha dieta) - - 19/08/2016 - remetido } \\
\text { ao dje - relação: 0350/2016 teor do ato: ciência às partes } \\
\text { da certidão de trânsito em julgado/retorno dos autos da } 2^{\mathrm{a}} \\
\text { instância. aguarda-se manifestação do interessado em } \\
\text { termos de prosseguimento do feito, no prazo de } 30 \text { dias, } \\
\text { pena de arquivamentoeventual cumprimento de sentença } \\
\text { deverá tramitar em formato digital, ainda que o processo } \\
\text { principal seja físico, observadas as disposições dos arts. } \\
1285 \text { a } 1289 \text { das normas de serviço da corregedoria geral } \\
\text { de justiça. advogados(s): ....... }\end{array}$ & FRALDA \\
\hline 256 & $\begin{array}{c}\text { 1022825- } \\
77.2015 .8 .26 .0071\end{array}$ & $64004 / 2015$ & 12/11/2015 & $\begin{array}{l}\text { Outros } \\
\text { Procediment } \\
\text { os }\end{array}$ & & SEGREDO DE JUSTIÇA & $\begin{array}{c}\text { SEGREDO DE } \\
\text { JUSTIÇA }\end{array}$ \\
\hline 257 & $\begin{array}{c}\text { 1022961- } \\
74.2015 .8 .26 .0071\end{array}$ & $64334 / 2015$ & 13/11/2015 & $\begin{array}{l}\text { Mandado de } \\
\text { Segurança }\end{array}$ & $11 / 11 / 2015$ & $\begin{array}{l}\text { 18/12/2015 - concedo a segurança pleiteada por .... } \\
\text { contra ato do secretário municipal de saúde de Bauru, } \\
\text { para que o impetrado forneça ao impetrante fraldas } \\
\text { geriátricas descartáveis - tamanho "gg" (180 unidades por } \\
\text { mês). Vistos.procedidas as devidas anotações, arquivem- } \\
\text { se os autos, com as cautelas de praxe.intime-se. }\end{array}$ & FRALDA \\
\hline 258 & $\begin{array}{c}1020458- \\
80.2015 .8 .26 .0071 \\
\end{array}$ & $64314 / 2015$ & 13/11/2015 & $\begin{array}{l}\text { Mandado de } \\
\text { Segurança }\end{array}$ & & SEGREDO DE JUSTIÇA & $\begin{array}{l}\text { CONSULTA } \\
\text { MÉDICA }\end{array}$ \\
\hline 259 & $\begin{array}{c}\text { 1022639- } \\
54.2015 .8 .26 .0071\end{array}$ & $64327 / 2015$ & 13/11/2015 & $\begin{array}{l}\text { Mandado de } \\
\text { Segurança }\end{array}$ & & SEGREDO DE JUSTIÇA & $\begin{array}{l}\text { SEGREDO DE } \\
\text { JUSTIÇA }\end{array}$ \\
\hline 260 & $\begin{array}{c}\text { 1020847- } \\
65.2015 .8 .26 .0071\end{array}$ & $65146 / 2015$ & 17/11/2015 & $\begin{array}{l}\text { Mandado de } \\
\text { Segurança }\end{array}$ & 13/11/2015 & $\begin{array}{l}27 / 11 / 2015 \text { - concedo a segurança pleiteada por ..... } \\
\text { contra ato do secretário municipal de saúde de Bauru, } \\
\text { para que o impetrado providencie o fornecimento à } \\
\text { impetrante de fraldas descartáveis adulto - tamanho "g" } \\
\text { (200 unidades por mês), sonda para gastronomia nível de } \\
\text { pele mickeyzofe/2,3cm para alimentação enteral ( }(11 \text { por } \\
\text { mês) e dieta normocalórica, normoproteica, normolipidica, } \\
\text { sem sacarose com fibras (16 latas de } 800 \mathrm{~g} \text { por mês), } \\
11 / 07 / 2017 \text { - remetido ao dje. }\end{array}$ & FRALDA \\
\hline
\end{tabular}




\begin{tabular}{|c|c|c|c|c|c|c|c|}
\hline 261 & $\begin{array}{c}1013687- \\
86.2015 .8 .26 .0071\end{array}$ & $65623 / 2015$ & $18 / 11 / 2015$ & $\begin{array}{c}\text { Mandado de } \\
\text { Segurança }\end{array}$ & & SEGREDO DE JUSTIÇA & FRALDA \\
\hline 262 & $\begin{array}{c}\text { 1023453- } \\
66.2015 .8 .26 .0071\end{array}$ & $66854 / 2015$ & 23/11/2015 & $\begin{array}{l}\text { Mandado de } \\
\text { Segurança }\end{array}$ & 18/11/2015 & $\begin{array}{l}\text { 03/12/2015 - concedo a segurança pleiteada por .... } \\
\text { contra ato do secretário municipal de saúde de Bauru, } \\
\text { para que o impetrado fornecaa à impetrante fraldas } \\
\text { geriátricas descartáveis - tamanho "g" (180 unidades por } \\
\text { mês), e julgo extinto o processo, com resolução de mérito } \\
- \text { - 16/09/2016 - remetido ao dje - relação: 0398/2016 teor } \\
\text { do ato: vistos.arquivem-se os autos com as cautelas de } \\
\text { praxe.int. advogados(s): ..., ..., ... }\end{array}$ & FRALDA \\
\hline 263 & $\begin{array}{c}\text { 1023397- } \\
33.2015 .8 .26 .0071\end{array}$ & $66930 / 2015$ & 23/11/2015 & $\begin{array}{l}\text { Mandado de } \\
\text { Segurança }\end{array}$ & 17/11/2015 & $\begin{array}{l}\text { 11/12/2015 - concedo a segurança, determinando que o } \\
\text { impetrado providencie o fornecimento ao impetrante a } \\
\text { suplementação oral, hipercalórica e hiperprotéica, não } \\
\text { contendo glúten (6,6 litros por mês conforme receituário } \\
\text { médico de fls. } 18) \text {, sob pena de responder por crime de } \\
\text { desobediência, sem prejuízo das sanções administrativas. } \\
--15 / 07 / 2016 \text { - remetido ao dje - relação: } 0316 / 2016 \\
\text { teor do ato: ciência às partes da certidão de trânsito em } \\
\text { julgado/retorno dos autos da } 2^{\mathrm{a}} \text { instância. aguarda-se } \\
\text { manifestação do interessado em termos de do } \\
\text { prosseguimento do feito, no prazo de } 30 \text { dias, pena de } \\
\text { arquivamento eventual. }\end{array}$ & MEDICAMENTO \\
\hline 264 & $\begin{array}{c}1023618- \\
16.2015 .8 .26 .0071 \\
-\end{array}$ & $67284 / 2015$ & 24/11/2015 & $\begin{array}{l}\text { Mandado de } \\
\text { Segurança }\end{array}$ & 20/11/2015 & $\begin{array}{l}\text { 02/12/2015 - concedo a segurança, mantendo a ordem } \\
\text { para que o impetrado providencie o fornecimento à } \\
\text { impetrante das fraldas geriátricas descartáveis (tamanho } \\
\text { g } 120 \text { unidades por mês) - - 08/05/2017 - remetido ao dje } \\
\text { - relação: } 0370 / 2017 \text { teor do ato: vistos.ciência às partes } \\
\text { do retorno dos autos.nada sendo requerido em } 30 \text { dias, } \\
\text { arquivem-se. }\end{array}$ & FRALDA \\
\hline 265 & $\begin{array}{c}\text { 1023664- } \\
05.2015 .8 .26 .0071\end{array}$ & $67341 / 2015$ & $24 / 11 / 2015$ & $\begin{array}{l}\text { Outros } \\
\text { Procediment } \\
\text { os }\end{array}$ & 09/12/2015 & $\begin{array}{l}\text { 28/03/2016 - julgo procedente o pedido formulado por .... } \\
\text { em face do município de Bauru, determinando que este } \\
\text { disponibilize ao autor o transporte por van para a } \\
\text { realização de cirurgia, consultas e fisioterapias, enquanto } \\
\text { perdurar sua necessidade, e extinto o processo, com } \\
\text { resolução de mérito - - } 15 / 07 / 2016 \text { - remetido ao dje - } \\
\text { relação: 0316/2016 teor do ato: ciência às partes da } \\
\text { certidão de trânsito em julgado.aguarda-se, o } \\
\text { requerimento do credor para o início do cumprimento } \\
\text { definitivo da sentença no prazo de } 30 \text { dias, pena de } \\
\text { arquivamento. }\end{array}$ & MEDICAMENTO \\
\hline
\end{tabular}




\begin{tabular}{|c|c|c|c|c|c|c|c|}
\hline 266 & $\begin{array}{c}\text { 1023611- } \\
\text { 24.2015.8.26.0071 }\end{array}$ & $67358 / 2015$ & $24 / 11 / 2015$ & $\begin{array}{l}\text { Mandado de } \\
\text { Segurança }\end{array}$ & $20 / 11 / 2015$ & $\begin{array}{l}\text { 03/12/2015 - concedo a segurança, determinando que o } \\
\text { impetrado providencie o fornecimento à impetrante das } \\
\text { fraldas geriátricas descartáveis (tamanho g } 90 \text { unidades } \\
\text { por mês) - - 23/06/2017 - remetido ao dje - relação: } \\
0488 / 2017 \text { teor do ato: vistos.ciência às partes do retorno } \\
\text { dos autos.nada sendo requerido em } 30 \text { dias, arquivem-se. }\end{array}$ & FRALDA \\
\hline 267 & $\begin{array}{c}\text { 1022675- } \\
96.2015 .8 .26 .0071\end{array}$ & 67773/2015 & $25 / 11 / 2015$ & $\begin{array}{l}\text { Mandado de } \\
\text { Segurança }\end{array}$ & $23 / 11 / 2015$ & $\begin{array}{l}\text { 31/03/2016 - concedo a segurança pleiteada por .... contra } \\
\text { ato do secretário municipal de saúde de Bauru e da diretora } \\
\text { do departamento regional de saúde de Bauru drs vi, para que } \\
\text { os impetrados forneçam à impetrante fraldas geriátricas } \\
\text { descartáveis - tamanho "xg" (260 unidades por mês) e } \\
\text { toalhas umedecidas ( } 450 \text { unidades por mês), conforme } \\
\text { prescrição médica de fls. } 41 \text {, e julgo extinto o processo, com } \\
\text { resolução de mérito - - } 29 / 06 / 2017 \text { - remetido ao dje - } \\
\text { relação: } 0503 / 2017 \text { teor do ato: ciência as partes acerca do } \\
\text { retorno dos autos do e. tribunal.em sendo o caso de } \\
\text { cumprimento de sentença, o requerimento deverá se } \\
\text { realizado por peticionamento eletrônico e instruído com as } \\
\text { seguintes peças:i - sentença e acórdão, se existente;ii - } \\
\text { certidãa de trânsito em julgado; se o casoiii - demonstrativo } \\
\text { do débito atualizado ou planilha do órgão pagador, quando } \\
\text { se tratar de execução por quantia certa; i - mandado de } \\
\text { citação cumprido e procurações outorgadas aos advogados } \\
\text { das partes, além de outras peças processuais que o } \\
\text { exequente considere necessárias.nada sendo requerido em } \\
30 \text { dias, os autos serão remetidos ao arquivo. }\end{array}$ & FRALDA \\
\hline 268 & $\begin{array}{c}\text { 1023538- } \\
\text { 52.2015.8.26.0071 }\end{array}$ & $67775 / 2015$ & $25 / 11 / 2015$ & $\begin{array}{l}\text { Mandado de } \\
\text { Segurança }\end{array}$ & $19 / 11 / 2015$ & $\begin{array}{l}\text { 03/12/2015 - concedo a segurança pleiteada por .... } \\
\text { contra ato do secretário municipal de saúde de Bauru, } \\
\text { para que o impetrado forneça ao impetrante fraldas } \\
\text { geriátricas descartáveis - tamanho "g" (150 unidades por } \\
\text { mês), e julgo extinto o processo, com resolução de mérito, } \\
\text { - - 03/03/2016 - emetido ao dje - relação: 0094/2016 teor } \\
\text { do ato: vistos. considerando a certidão de fls. } 69, \\
\text { oportunamente ao arquivo. }\end{array}$ & FRALDA \\
\hline 269 & $\begin{array}{c}\text { 1023615- } \\
61.2015 .8 .26 .0071\end{array}$ & 68046/2015 & 25/11/2015 & $\begin{array}{l}\text { Mandado de } \\
\text { Segurança }\end{array}$ & 20/11/2015 & $\begin{array}{l}\text { 04/12/2015 - concedo a segurança pleiteada por .... } \\
\text { contra ato do secretário municipal de saúde de Bauru, } \\
\text { para que o impetrado forneça à impetrante fraldas } \\
\text { geriátricas descartáveis - tamanho "g" (120 unidades por } \\
\text { mês), e julgo extinto o processo, com resolução de mérito } \\
\text { - - 11/04/2016 - emetido ao dje - relação: } 0150 / 2016 \text { teor } \\
\text { do ato: vistos.arquivem-se. }\end{array}$ & FRALDA \\
\hline
\end{tabular}




\begin{tabular}{|c|c|c|c|c|c|c|c|}
\hline 270 & $\begin{array}{c}\text { 1023919- } \\
98.2015 .8 .26 .0071\end{array}$ & $68193 / 2015$ & 26/11/2015 & $\begin{array}{l}\text { Mandado de } \\
\text { Segurança }\end{array}$ & & SEGREDO DE JUSTIÇA & MEDICAMENTO \\
\hline 271 & $\begin{array}{c}\text { 1023454- } \\
51.2015 .8 .26 .0071\end{array}$ & $68242 / 2015$ & $26 / 11 / 2015$ & $\begin{array}{l}\text { Mandado de } \\
\text { Segurança }\end{array}$ & 18/11/2015 & $\begin{array}{l}\text { 07/12/2015 - concedo a segurança, determinando que o } \\
\text { impetrado providencie o fornecimento à impetrante das } \\
\text { fraldas geriátricas descartáveis (tamanho g } 150 \text { unidades } \\
\text { por mês) - - 08/05/2017 - remetido ao dje - relação: } \\
0370 / 2017 \text { teor do ato: vistos.ciência às partes do retorno } \\
\text { dos autos.nada sendo requerido em } 30 \text { dias, arquivem-se } \\
\text { - relação: } 0370 / 2017 \text { teor do ato: vistos.ciência às partes } \\
\text { do retorno dos autos.nada sendo requerido em } 30 \text { dias, } \\
\text { arquivem-se. }\end{array}$ & FRALDA \\
\hline 272 & $\begin{array}{c}1022131- \\
11.2015 .8 .26 .0071\end{array}$ & $68372 / 2015$ & $26 / 11 / 2015$ & $\begin{array}{l}\text { Mandado de } \\
\text { Segurança }\end{array}$ & & SEGREDO DE JUSTIÇA & MEDICAMENTO \\
\hline 273 & $\begin{array}{c}1023274- \\
35.2015 .8 .26 .0071 \\
\end{array}$ & $68385 / 2015$ & $26 / 11 / 2015$ & $\begin{array}{l}\text { Mandado de } \\
\text { Segurança }\end{array}$ & & SEGREDO DE JUSTIÇA & $\begin{array}{c}\text { SEGREDO DE } \\
\text { JUSTIÇA }\end{array}$ \\
\hline 274 & $\begin{array}{c}1023810- \\
46.2015 .8 .26 .0071\end{array}$ & $69336 / 2015$ & $30 / 11 / 2015$ & $\begin{array}{c}\text { Outros } \\
\text { Procediment } \\
\text { os }\end{array}$ & & SEGREDO DE JUSTIÇA & $\begin{array}{l}\text { SEGREDO DE } \\
\text { JUSTIÇA }\end{array}$ \\
\hline 275 & $\begin{array}{c}\text { 1023669- } \\
27.2015 .8 .26 .0071 \\
\end{array}$ & $70033 / 2015$ & 02/12/2015 & $\begin{array}{c}\text { Outros } \\
\text { Procediment } \\
\text { os }\end{array}$ & $30 / 11 / 2015$ & $\begin{array}{l}\text { 04/04/16 - julga procedente e Condena Estado e o } \\
\text { Município a fornecer acompanhamento fonoaudiólogo, } \\
\text { psicóloga e terapia ocupacional. }\end{array}$ & $\begin{array}{l}\text { CONSULTA } \\
\text { MÉDICA }\end{array}$ \\
\hline 276 & $\begin{array}{c}\text { 1020493- } \\
40.2015 .8 .26 .0071\end{array}$ & $70156 / 2015$ & 02/12/2015 & $\begin{array}{l}\text { Mandado de } \\
\text { Segurança }\end{array}$ & $27 / 11 / 2015$ & $\begin{array}{l}\text { 09/11/2016 - concedo a segurança pleiteada por .... } \\
\text { contra ato do secretário municipal de saúde, para que o } \\
\text { impetrado forneça à impetrante fraldas geriátricas } \\
\text { tamanho "xg" adulta } 180 \text { (cento e oitenta) unidades por } \\
\text { mês, bem como dieta liquida polimérica hipercalórica } \\
1,5 \mathrm{kcal} / \mathrm{ml} \text {, hiperproteica (45 litros por mês conforme } \\
\text { receituário médico de fls. } 45 \text {, e julgo extinto o processo, } \\
\text { com resolução de mérito - - 18/10/2017 - remetido ao dje } \\
\text { - relação: } 0701 / 2017 \text { teor do ato: vistos.considerando que } \\
\text { o impetrante veio a falecer após a prolação de sentença, } \\
\text { conforme documento de fls. } 379 \text {, fica prejudicada a } \\
\text { apreciação do recurso interposto pelos impetrados.assim, } \\
\text { certifique a serventia o trânsito em julgado, comunicando- } \\
\text { se os impetrados para cancelamento do fornecimento das } \\
\text { fraldas e da dieta.após, arquivem-se os autos. }\end{array}$ & MEDICAMENTO \\
\hline
\end{tabular}




\begin{tabular}{|c|c|c|c|c|c|c|c|}
\hline 277 & $\begin{array}{c}1024243- \\
50.2015 .8 .26 .0071\end{array}$ & $70782 / 2015$ & 03/12/2015 & $\begin{array}{l}\text { Mandado de } \\
\text { Segurança }\end{array}$ & $27 / 11 / 2015$ & $\begin{array}{l}11 / 01 / 2016 \text { - concedo a segurança, determinando que o } \\
\text { impetrado providencie o fornecimento à impetrante das } \\
\text { fraldas geriátricas descartáveis (tamanho g } 120 \text { unidades } \\
\text { por mês conforme documento de fls. } 18 \text { ), sob pena de } \\
\text { responder por crime de desobediência - }-08 / 05 / 2017 \text { - } \\
\text { remetido ao dje - relação: 0369/2017 teor do ato: } \\
\text { vistos.ciência às partes do retorno dos autos.nada sendo } \\
\text { requerido em } 30 \text { dias, arquivem-se. }\end{array}$ & FRALDA \\
\hline 278 & $\begin{array}{c}1023067- \\
36.2015 .8 .26 .0071\end{array}$ & $71022 / 2015$ & $04 / 12 / 2015$ & $\begin{array}{l}\text { Mandado de } \\
\text { Segurança }\end{array}$ & $12 / 11 / 2015$ & $\begin{array}{l}\text { 18/12/2015 - concedo a segurança pleiteada por .... } \\
\text { contra ato do secretário municipal de saúde de Bauru, } \\
\text { para que o impetrado providencie o fornecimento à } \\
\text { impetrante dos medicamentos capecitabina } 500 \mathrm{mg} \text { ( } 42 \\
\text { cápsulas) e } 150 \mathrm{mg} \text { ( } 14 \text { cápsulas), nos termos da petição } \\
\text { inicial, e julgo extinto o processo, com resolução de } \\
\text { mérito, - - 04/08/2016 - remetido ao dje - relação: } \\
0323 / 2016 \text { teor do ato: vistos.ciência às partes do v. } \\
\text { acórdão de fls. 182/186.aguarde-se por trinta dias } \\
\text { eventual manifestação.no silêncio, arquivem-se. }\end{array}$ & MEDICAMENTO \\
\hline 279 & $\begin{array}{c}1012640- \\
77.2015 .8 .26 .0071\end{array}$ & $71299 / 2015$ & $04 / 12 / 2015$ & $\begin{array}{l}\text { Mandado de } \\
\text { Segurança }\end{array}$ & & SEGREDO DE JUSTIÇA & $\begin{array}{l}\text { SEGREDO DE } \\
\text { JUSTIÇA }\end{array}$ \\
\hline 280 & $\begin{array}{c}1024682- \\
61.2015 .8 .26 .0071\end{array}$ & $71620 / 2015$ & 07/12/2015 & $\begin{array}{l}\text { Mandado de } \\
\text { Segurança }\end{array}$ & $03 / 12 / 2015$ & $\begin{array}{l}\text { 14/01/2016 - concedo a segurança, determinando que o } \\
\text { impetrado providencie o fornecimento à impetrante das } \\
\text { fraldas geriátricas descartáveis - - 23/06/2017 - remetido } \\
\text { ao dje - relação: } 0488 / 2017 \text { teor do ato: vistos.ciência às } \\
\text { partes do retorno dos autos. nada sendo requerido em } \\
\text { trinta dias, arquivem-se. }\end{array}$ & FRALDA \\
\hline 281 & $\begin{array}{c}\text { 1012557- } \\
61.2015 .8 .26 .0071\end{array}$ & $72101 / 2015$ & 08/12/2015 & $\begin{array}{c}\text { Outros } \\
\text { Procediment } \\
\text { os }\end{array}$ & & SEGREDO DE JUSTIÇA & $\begin{array}{l}\text { CONSULTA } \\
\text { MÉDICA }\end{array}$ \\
\hline 282 & $\begin{array}{c}1024532- \\
80.2015 .8 .26 .0071\end{array}$ & $72108 / 2015$ & 08/12/2015 & $\begin{array}{l}\text { Mandado de } \\
\text { Segurança }\end{array}$ & $02 / 12 / 2015$ & $\begin{array}{l}18 / 12 / 2015 \text { - concedo a segurança pleiteada por .... } \\
\text { contra ato do secretário municipal de saúde de Bauru, } \\
\text { para que o impetrado forneça ao impetrante fraldas } \\
\text { geriátricas descartáveis - tamanho "g" - - 22/09/2016 - } \\
\text { remetido ao dje - relação: 0408/2016 teor do ato: } \\
\text { vistos.procedidas as devidas anotações, arquivem-se os } \\
\text { autos. }\end{array}$ & FRALDA \\
\hline
\end{tabular}




\begin{tabular}{|c|c|c|c|c|c|c|c|}
\hline 283 & $\begin{array}{c}1024680- \\
91.2015 .8 .26 .0071\end{array}$ & $72116 / 2015$ & 08/12/2015 & $\begin{array}{l}\text { Mandado de } \\
\text { Segurança }\end{array}$ & 03/12/2015 & $\begin{array}{l}\text { 11/01/2016 - concedo a segurança, determinando que o } \\
\text { impetrado providencie o fornecimento ao impetrante das } \\
\text { fraldas geriátricas descartáveis - - 05/02/2016 - vistos. } \\
\text { comprovado o óbito do impetrante, é evidente a perda do } \\
\text { objeto do presente mandado de segurança. ante o } \\
\text { exposto, torno sem efeito a decisão que determinou o } \\
\text { fornecimento das fraldas geriátricas descartáveis de fls. } \\
\text { 22/24. oficie-se ao impetrado, com urgência, para as } \\
\text { providencias necessárias no sentido de cessar os } \\
\text { fornecimentos. após, procedidas às necessárias } \\
\text { anotações, arquivem-se. }\end{array}$ & FRALDA \\
\hline 284 & $\begin{array}{c}1016986- \\
71.2015 .8 .26 .0071\end{array}$ & $72176 / 2015$ & 08/12/2015 & $\begin{array}{c}\text { Outros } \\
\text { Procediment } \\
\text { os }\end{array}$ & 04/05/2015 & Agendem consulta em 72 horas sob pena de bloqueio. & $\begin{array}{l}\text { CONSULTA } \\
\text { MÉDICA }\end{array}$ \\
\hline 285 & $\begin{array}{c}\text { 1023426- } \\
\text { 83.2015.8.26.0071 }\end{array}$ & 72209/2015 & 08/12/2015 & $\begin{array}{l}\text { Outros } \\
\text { Procediment } \\
\text { os }\end{array}$ & 04/12/2015 & $\begin{array}{l}\text { 25/02/2016 - julgo procedente o pedido formulado por .... } \\
\text { em face da prefeitura municipal de Bauru, determinando } \\
\text { que este forneça ao requerente quetiapina } 25 \mathrm{mg} \text { ( } 01 \\
\text { comprimido por dia } 30 \text { comprimidos por mês) e paroxetina } \\
10 \mathrm{mg}(01 \text { comprimido por dia } 30 \text { comprimidos por mês }- \text { - } \\
-26 / 07 / 2016 \text { - ecebidos os autos do tribunal de justiça - } \\
\text { data do julgamento: } 24 / 05 / 2016 \text { trânsito em julgado: tipo } \\
\text { de julgamento: acórdão decisão: negaram provimento ao } \\
\text { apelo e ao reexame necessário. }\end{array}$ & MEDICAMENTO \\
\hline 286 & $\begin{array}{c}\text { 1023437- } \\
\text { 15.2015.8.26.0071 }\end{array}$ & $72203 / 2015$ & 08/12/2015 & $\begin{array}{l}\text { Mandado de } \\
\text { Segurança }\end{array}$ & $30 / 11 / 2015$ & $\begin{array}{l}\text { 14/01/2016 - concedo a segurança pleiteada por .... } \\
\text { contra ato do secretário municipal de saúde de Bauru, } \\
\text { para que o impetrado forneça à impetrante fraldas } \\
\text { geriátricas descartáveis com gel superabsorvente, difusor } \\
\text { de liquidos e barreiras antivazamento - tamanho "ex" (150 } \\
\text { unidades por mês) - } 22 / 09 / 2016 \text { - remetido ao dje - } \\
\text { relaçãa: 0408/2016 teor do ato: vistos.procedidas as } \\
\text { devidas anotações, arquivem-se os autos. }\end{array}$ & FRALDA \\
\hline 287 & $\begin{array}{c}\text { 1024837- } \\
\text { 64.2015.8.26.0071 }\end{array}$ & $72992 / 2015$ & 10/12/2015 & $\begin{array}{l}\text { Mandado de } \\
\text { Segurança }\end{array}$ & 04/12/2015 & $\begin{array}{l}11 / 01 / 2016 \text { - concedo a segurança pleiteada por .... } \\
\text { contra ato do secretário municipal de saúde de Bauru, } \\
\text { para que o impetrado forneça à impetrante fraldas } \\
\text { descartáveis - tamanho "g" - } 03 / 02 / 2016 \text { - remetido ao } \\
\text { dje - relação: } 0042 / 2016 \text { teor do ato: vistos. considerando } \\
\text { a informação de falecimento da impetrante, oficie-se ao } \\
\text { impetrado para o cancelamento do fornecimento das } \\
\text { fraldas. apos, certifique-se o trânsito em julgado e } \\
\text { arquive-se. }\end{array}$ & FRALDA \\
\hline
\end{tabular}




\begin{tabular}{|c|c|c|c|c|c|c|c|}
\hline 288 & $\begin{array}{c}\text { 1019581- } \\
\text { 43.2015.8.26.0071 }\end{array}$ & 73129/2015 & 10/12/2015 & $\begin{array}{l}\text { Outros } \\
\text { Procediment } \\
\text { os }\end{array}$ & & SEGREDO DE JUSTIÇA & $\begin{array}{l}\text { SEGREDO DE } \\
\text { JUSTIÇA }\end{array}$ \\
\hline 289 & $\begin{array}{c}\text { 1024824- } \\
\text { 65.2015.8.26.0071 }\end{array}$ & $73771 / 2015$ & 11/12/2015 & $\begin{array}{l}\text { Outros } \\
\text { Procediment } \\
\text { os }\end{array}$ & 07/12/2015 & $\begin{array}{l}\text { 12/02/2016 - decido. considerando que o requerido exibiu } \\
\text { a documentação descrita na inicial, é de rigor a } \\
\text { procedência do pedido. pelo exposto, ratifico a liminar de } \\
\text { fls. } 28 / 29 \text { e julgo procedente a presente açãa cautelar de } \\
\text { exibição de documento proposta por ..., ... e ... } \\
\text { qualificados nos autos, contra município de Bauru, } \\
\text { determinando que o requerido apresente o prontuário } \\
\text { médico de ... e, extinto o processo, com resolução de } \\
\text { mérito - - 29/11/2016 - recebidos os autos do tribunal de } \\
\text { justiça - data do julgamento: 01/08/2016 trânsito em } \\
\text { julgado: tipo de julgamento: acórdão decisão: deram } \\
\text { provimento ao recurso. }\end{array}$ & $\begin{array}{l}\text { APRESENTAÇÃO } \\
\text { DE PRONTUÁRIO }\end{array}$ \\
\hline 290 & $\begin{array}{c}1024624- \\
58.2015 .8 .26 .0071\end{array}$ & $74753 / 2015$ & $15 / 12 / 2015$ & $\begin{array}{l}\text { Mandado de } \\
\text { Segurança }\end{array}$ & & SEGREDO DE JUSTIÇA & $\begin{array}{c}\text { ALIMENTAÇÃO } \\
\text { ESPECIAL }\end{array}$ \\
\hline 291 & $\begin{array}{c}\text { 1026075- } \\
21.2015 .8 .26 .0071 \text { - }\end{array}$ & $75018 / 2015$ & 15/12/2015 & $\begin{array}{l}\text { Mandado de } \\
\text { Segurança }\end{array}$ & 10/12/2015 & $\begin{array}{l}\text { 14/01/2016 - concedo a segurança, determinando que o } \\
\text { impetrado providencie o fornecimento à impetrante das } \\
\text { fraldas geriátricas descartáveis - - 18/05/2016 - remetido } \\
\text { ao dje - relação: } 0223 / 2016 \text { teor do ato: vistos.uma vez } \\
\text { comprovado o óbito do(a) impetrante, é evidente a perda } \\
\text { do objeto do presente mandado de segurança.ante o } \\
\text { exposto, torno sem efeito a decisão que determinou o } \\
\text { fornecimento das fraldas geriátricas. oficie-se ao (à) } \\
\text { impetrado (a). cumpridas as providências necessárias, } \\
\text { arquivem-se os autos }\end{array}$ & FRALDA \\
\hline 292 & $\begin{array}{c}\text { 1026962- } \\
\text { 05.2015.8.26.0071 }\end{array}$ & $76515 / 2015$ & 18/12/2015 & $\begin{array}{l}\text { Mandado de } \\
\text { Segurança }\end{array}$ & 17/12/2015 & $\begin{array}{l}03 / 03 / 2016 \text { - concedo a segurança pleiteada por ..... } \\
\text { contra ato do secretário municipal de saúde de Bauru, } \\
\text { para que o impetrado forneça ao impetrante alimento para } \\
\text { situações metabólicas especiais, para pacientes com } \\
\text { função renal comprometida, com restrições de eletrólitos e } \\
\text { fluídos, baixo teor de sódio e potássio ( } 02 \text { saches ou } 02 \\
\text { litros por dia) - - 28/04/2017 - remetido ao dje - relação: } \\
\text { 0348/2017 teor do ato: vistos.procedidas as devidas } \\
\text { anotações de baixa, arquivem-se }\end{array}$ & $\begin{array}{c}\text { ALIMENTACCÃO } \\
\text { ESPECIAL }\end{array}$ \\
\hline
\end{tabular}




\begin{tabular}{|c|c|c|c|c|c|c|c|}
\hline 293 & $\begin{array}{c}\text { 1026565- } \\
\text { 43.2015.8.26.0071 }\end{array}$ & $76631 / 2015$ & 18/12/2015 & $\begin{array}{l}\text { Mandado de } \\
\text { Segurança }\end{array}$ & 14/12/2015 & $\begin{array}{l}\text { 14/01/2016 - concedo a segurança, determinando que o } \\
\text { impetrado providencie o fornecimento à impetrante das } \\
\text { fraldas geriátricas descartáveis (tamanho g } 180 \text { unidades } \\
\text { por mês - - 08/05/2017 - remetido ao dje - relação: } \\
\text { 0370/2017 teor do ato: vistos.ciência às partes do retorno } \\
\text { dos autos.nada sendo requerido em } 30 \text { dias, arquivem-se. }\end{array}$ & FRALDA \\
\hline 294 & $\begin{array}{c}\text { 1023369- } \\
\text { 65.2015.8.26.0071 }\end{array}$ & $77391 / 2015$ & 21/12/2015 & $\begin{array}{l}\text { Outros } \\
\text { Procediment } \\
\text { os }\end{array}$ & & SEGREDO DE JUSTIÇA & $\begin{array}{l}\text { CONSULTA } \\
\text { MÉDICA }\end{array}$ \\
\hline 295 & $\begin{array}{c}\text { 1023897- } \\
02.2015 .8 .26 .0071\end{array}$ & 2034/2016 & 01/01/2016 & $\begin{array}{l}\text { Mandado de } \\
\text { Segurança }\end{array}$ & $13 / 01 / 2016$ & $\begin{array}{l}\text { 09/06/16 - julgo procedente o pedido da presente ação de } \\
\text { mandado de segurança que .... ajuizou contra ato do } \\
\text { Diretor do Departamento Regional de Saúde VI e do } \\
\text { Diretor da Secretaria de Saúde de Bauru. }\end{array}$ & MEDICAMENTO \\
\hline 296 & $\begin{array}{c}\text { 1027166- } \\
49.2015 .8 .26 .0071\end{array}$ & $2368 / 2016$ & 01/01/2016 & $\begin{array}{l}\text { Mandado de } \\
\text { Segurança }\end{array}$ & 18/12/2015 & $\begin{array}{l}\text { 21/01/2016 - concedo a segurança pleiteada por .... } \\
\text { contra ato do secretário municipal de saúde de Bauru, } \\
\text { para que o impetrado forneça à impetrante fraldas } \\
\text { descartáveis - - 22/09/2016 - remetido ao dje - relação: } \\
\text { 0408/2016 teor do ato: vistos.procedidas as devidas } \\
\text { anotações, arquivem-se. }\end{array}$ & FRALDA \\
\hline 297 & $\begin{array}{c}\text { 1027389- } \\
02.2015 .8 .26 .0071\end{array}$ & $2377 / 2016$ & $01 / 01 / 2016$ & $\begin{array}{l}\text { Mandado de } \\
\text { Segurança }\end{array}$ & 08/01/2016 & $\begin{array}{l}\text { 05/02/2016 - concedo a segurança, determinando que o } \\
\text { impetrado providencie o fornecimento ao impetrante das } \\
\text { fraldas geriátricas descartáveis - - 29/06/2017 - remetido } \\
\text { ao dje - relação: } 0506 / 2017 \text { teor do ato: vistos.ciência às } \\
\text { partes do retorno dos autos. nada sendo requerido em } 30 \\
\text { dias, arquivem-se. }\end{array}$ & FRALDA \\
\hline 298 & $\begin{array}{c}\text { 1027401- } \\
\text { 16.2015.8.26.0071 }\end{array}$ & $2373 / 2016$ & $01 / 01 / 2016$ & $\begin{array}{l}\text { Mandado de } \\
\text { Segurança }\end{array}$ & 08/01/2016 & $\begin{array}{l}27 / 01 / 2016 \text { - concedo a segurança pleiteada por ..... } \\
\text { contra ato do secretário municipal de saúde de Bauru, } \\
\text { para que o impetrado forneça à impetrante fraldas } \\
\text { geriátricas descartáveis - - } 22 / 09 / 2016 \text { - elação: } \\
0408 / 2016 \text { teor do ato: vistos.procedidas as devidas } \\
\text { anotações, arquivem-se. }\end{array}$ & FRALDA \\
\hline 299 & $\begin{array}{c}1027170- \\
86.2015 .8 .26 .0071\end{array}$ & $2421 / 2016$ & $01 / 01 / 2016$ & $\begin{array}{l}\text { Mandado de } \\
\text { Segurança }\end{array}$ & $18 / 12 / 2015$ & $\begin{array}{l}22 / 01 / 2016 \text { - concedo a segurança pleiteada por .... } \\
\text { contra ato do secretário municipal de saúde de Bauru, } \\
\text { para que o impetrado forneça à impetrante fraldas } \\
\text { descartáveis - - 08/05/2017 - remetido ao dje - relação: } \\
\text { 0296/2017 teor do ato: vistos.ciência às partes do retorno } \\
\text { dos autos.nada sendo requerido em } 30 \text { dias, arquivem-se. }\end{array}$ & FRALDA \\
\hline
\end{tabular}




\begin{tabular}{|c|c|c|c|c|c|c|c|}
\hline 300 & $\begin{array}{c}\text { 1027473- } \\
03.2015 .8 .26 .0071\end{array}$ & $2451 / 2016$ & 01/01/2016 & $\begin{array}{l}\text { Mandado de } \\
\text { Segurança }\end{array}$ & 08/01/2016 & $\begin{array}{l}27 / 01 / 2016 \text { - concedo a segurança pleiteada por .... } \\
\text { contra ato do secretário municipal de saúde de Bauru, } \\
\text { para que o impetrado forneça à impetrante fraldas } \\
\text { geriátricas descartáveis - - 22/09/2016 - remetido ao dje - } \\
\text { relação: 0408/2016 teor do ato: vistos.procedidas as } \\
\text { devidas anotaçôes, arquivem-se. }\end{array}$ & FRALDA \\
\hline 301 & $\begin{array}{c}\text { 1020437- } \\
07.2015 .8 .26 .0071\end{array}$ & $2591 / 2016$ & 01/01/2016 & $\begin{array}{l}\text { Mandado de } \\
\text { Segurança }\end{array}$ & 08/01/2016 & 01/02/18 - Transitado em julgado e arquivado. & MEDICAMENTO \\
\hline 302 & $\begin{array}{c}\text { 1027199- } \\
39.2015 .8 .26 .0071\end{array}$ & $3020 / 2016$ & 01/01/2016 & $\begin{array}{l}\text { Mandado de } \\
\text { Segurança }\end{array}$ & $11 / 01 / 2016$ & $\begin{array}{l}11 / 02 / 2016 \text { - vistos....., qualificada nos autos, impetrou } \\
\text { mandado de segurança contra ato do secretário municipal } \\
\text { de Bauru, objetivando fornecimento de fraldas } \\
\text { descartáveis. a liminar foi deferida a fls. } 24 / 25 \text {. à fls. } 64 / 65 \\
\text { foi informado o falecimento da impetrante. por tratar-se de } \\
\text { direito personalíssimo, houve a perda do objeto da } \\
\text { impetração. ante o exposto, revogo a liminar de fls. } 24 / 25 \\
\text { e julgo extinta. }\end{array}$ & FRALDA \\
\hline 303 & $\begin{array}{c}\text { 1027412- } \\
45.2015 .8 .26 .0071\end{array}$ & $3190 / 2016$ & $01 / 01 / 2016$ & $\begin{array}{l}\text { Mandado de } \\
\text { Segurança }\end{array}$ & 07/01/2016 & $\begin{array}{l}\text { 21/01/2016 - concedo a segurança, determinando que o } \\
\text { impetrado providencie o fornecimento à impetrante das } \\
\text { fraldas geriátricas descartáveis (tamanho g adulto } 120 \\
\text { unidades por mês) - - 23/10/2017 - remetido ao dje - } \\
\text { relaçãa: 0711/2017 teor do ato: ciência às partes do } \\
\text { retorno dos autos do e. tribunal.eventual cumprimento de } \\
\text { sentença deverá tramitar em formato digital, cujo } \\
\text { requerimento deverá ser realizado por peticionamento } \\
\text { eletrônico e instrúdo com as seguintes peças:i- sentença } \\
\text { e acórdão, se existente;ii- certidão de trânsito em julgado, } \\
\text { se o caso;iii- demonstrativo do débito atualizado, quando } \\
\text { se tratar de execução por quantia certa;iv- mandado de } \\
\text { citação cumpro e procurações outorgadas aos } \\
\text { advogados das partes, além de outras peças processuais } \\
\text { que o exequente considere necessárias.nada sendo } \\
\text { requerido em } 30 \text { (trinta) dias, os autos serão remetidos ao } \\
\text { arquivo. }\end{array}$ & FRALDA \\
\hline 304 & $\begin{array}{c}1000475- \\
61.2016 .8 .26 .0071\end{array}$ & $3918 / 2016$ & 01/01/2016 & $\begin{array}{l}\text { Mandado de } \\
\text { Segurança }\end{array}$ & 15/01/2016 & $\begin{array}{l}\text { 03/03/2016 - concedo a segurança pleiteada por.... contra } \\
\text { ato do secretário municipal de saúde de Bauru, para que } \\
\text { o impetrado forneça à impetrante fraldas geriátricas - - } \\
21 / 10 / 2016 \text { - remetido ao dje - relação: } 0504 / 2016 \text { teor do } \\
\text { ato: vistos.procedidas as devidas anotações, arquivem-se } \\
\text { os autos. }\end{array}$ & FRALDA \\
\hline
\end{tabular}




\begin{tabular}{|c|c|c|c|c|c|c|c|}
\hline 305 & $\begin{array}{l}\text { 1024507- } \\
67.2015 .8 .26 .0071\end{array}$ & $3921 / 2016$ & $01 / 01 / 2016$ & $\begin{array}{l}\text { Mandado de } \\
\text { Segurança }\end{array}$ & $12 / 01 / 2016$ & $\begin{array}{l}\text { 01/03/2016 - concedo a segurança pleiteada por .... contra } \\
\text { ato do secretário municipal de saúde de Bauru, para que } \\
\text { o impetrado forneça ao impetrante fraldas geriátricas } \\
\text { descartáveis - tamanho " } \mathrm{m} "-25 / 10 / 2016 \text { - remetido ao } \\
\text { dje - relação: } 0515 / 2016 \text { teor do ato: vistos.procedidas as } \\
\text { devidas anotações, arquivem-se. }\end{array}$ & FRALDA \\
\hline 306 & $\begin{array}{c}\text { 1000601- } \\
14.2016 .8 .26 .0071\end{array}$ & $4481 / 2016$ & $01 / 01 / 2016$ & $\begin{array}{l}\text { Mandado de } \\
\text { Segurança }\end{array}$ & 18/01/2016 & $\begin{array}{l}\text { 29/01/2016 - concedo a segurança pleiteada por .... } \\
\text { contra ato do secretário municipal de saúde de Bauru, } \\
\text { para que o impetrado forneça ao impetrante fraldas } \\
\text { geriátricas descartáveis - tamanho "g" }-22 / 09 / 2016- \\
\text { remetido ao dje - relação: 0408/2016 teor do ato: } \\
\text { vistos.considerando a certidão de fls. } 69 \text {, arquivem-se. }\end{array}$ & FRALDA \\
\hline 307 & $\begin{array}{c}0000764- \\
28.2015 .8 .26 .0594\end{array}$ & $4529 / 2016$ & $01 / 01 / 2016$ & $\begin{array}{c}\text { Outros } \\
\text { Procediment } \\
\text { os }\end{array}$ & & $\begin{array}{l}\text { 14/12/2016 - SENTENCA PARCIALMENTE } \\
\text { REFORMADA. APELO DA PREFEITURA CONHECIDO E } \\
\text { DESPROVIDO. REMESSA NECESSÁRIA CONHECIDA } \\
\text { E PROVIDA EM PARTE. ART. } 1007 \text { CPC } \\
\end{array}$ & CIRURGIA \\
\hline 308 & $\begin{array}{c}\text { 1000679- } \\
08.2016 .8 .26 .0071\end{array}$ & $5084 / 2016$ & $01 / 01 / 2016$ & $\begin{array}{l}\text { Mandado de } \\
\text { Segurança }\end{array}$ & 19/01/2016 & $\begin{array}{l}\text { 29/01/2016 - concedo a segurança, mantendo a ordem } \\
\text { para que o impetrado providencie o fornecimento ao } \\
\text { impetrante das fraldas geriátricas descartáveis - } \\
23 / 06 / 2017 \text { - remetido ao dje - relação: } 0488 / 2017 \text { teor do } \\
\text { ato: vistos.ciência às partes do retorno dos autos.nada } \\
\text { sendo requerido em } 30 \text { dias, arquivem-se. }\end{array}$ & FRALDA \\
\hline 309 & $\begin{array}{c}1026970- \\
79.2015 .8 .26 .0071\end{array}$ & $5544 / 2016$ & $01 / 01 / 2016$ & $\begin{array}{l}\text { Mandado de } \\
\text { Segurança }\end{array}$ & $21 / 01 / 2016$ & $\begin{array}{l}\text { 04/03/2016 - concedo a segurança pleiteada por.... contra } \\
\text { ato do secretário municipal de saúde de Bauru, para que } \\
\text { o impetrado forneça à impetrante fraldas geriátricas - } \\
21 / 10 / 2016 \text { - remetido ao dje - relação: } 0504 / 2016 \text { teor do } \\
\text { ato: vistos.procedidas as devidas anotações, arquivem-se. }\end{array}$ & FRALDA \\
\hline 310 & $\begin{array}{c}\text { 1000984- } \\
89.2016 .8 .26 .0071\end{array}$ & $6080 / 2016$ & $01 / 01 / 2016$ & $\begin{array}{l}\text { Mandado de } \\
\text { Segurança }\end{array}$ & $25 / 01 / 2016$ & 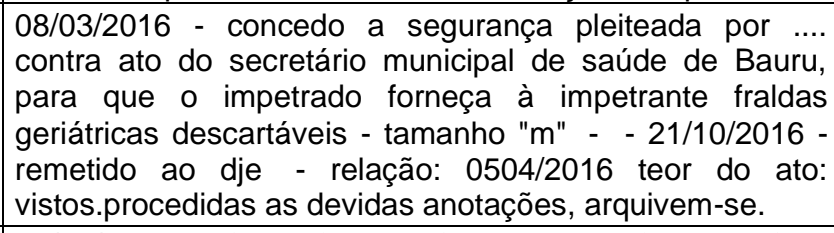 & FRALDA \\
\hline 311 & $\begin{array}{c}0000742- \\
67.2015 .8 .26 .0594\end{array}$ & $6078 / 2016$ & $01 / 01 / 2016$ & $\begin{array}{l}\text { Mandado de } \\
\text { Segurança }\end{array}$ & & 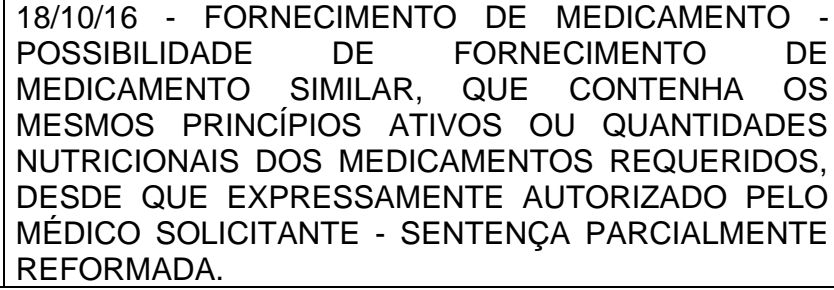 & MEDICAMENTO \\
\hline
\end{tabular}




\begin{tabular}{|c|c|c|c|c|c|c|c|}
\hline 312 & $\begin{array}{c}\text { 1000711- } \\
13.2016 .8 .26 .0071\end{array}$ & $6345 / 2016$ & $01 / 01 / 2016$ & $\begin{array}{l}\text { Outros } \\
\text { Procediment } \\
\text { os }\end{array}$ & $26 / 01 / 2016$ & $\begin{array}{l}\text { 16/05/2016 - julgo procedente o pedido, formulado por .... } \\
\text { contra o município de Bauru, determinando que o } \\
\text { requerido forneça ao requerente o medicamento } \\
\text { erbitux/cetuximabe } 660 \mathrm{mg} \text { (de } 15 \text { em } 15 \text { dias) - } \\
\text { 05/05/2017 - remetido ao dje - relação: } 0364 / 2017 \text { teor do } \\
\text { ato: manifestar-se, em prosseguimento, ante o retorno } \\
\text { dos autos do e. tribunal, no prazo de } 30 \text { dias. em caso de } \\
\text { eventual cumprimento de sentença, deverá se realizado } \\
\text { por peticionamento eletrônico e instruído com as a } \\
\text { seguintes peças:i - sentença e acórdão, se existente; ii - } \\
\text { certidão de trânsito em julgado; se o caso iii - } \\
\text { demonstrativo do débito atualizado ou planilha do órgão } \\
\text { pagador, quando se tratar de execução por quantia certa; } \\
\text { iv - mandado de citação cumprido e procurações } \\
\text { outorgadas aos advogados das partes, além de outras } \\
\text { peças processuais que o exequente considere } \\
\text { necessárias.nada sendo requerido, os autos serão } \\
\text { arquivados }\end{array}$ & MEDICAMENTO \\
\hline 313 & $\begin{array}{c}\text { 1010961- } \\
\text { 42.2015.8.26.0071 }\end{array}$ & $6354 / 2016$ & $01 / 01 / 2016$ & $\begin{array}{l}\text { Outros } \\
\text { Procediment } \\
\text { os }\end{array}$ & & SEGREDO DE JUSTIÇA & $\begin{array}{l}\text { SEGREDO DE } \\
\text { JUSTIÇA }\end{array}$ \\
\hline 314 & $\begin{array}{c}\text { 1001236- } \\
92.2016 .8 .26 .0071\end{array}$ & $6356 / 2016$ & $01 / 01 / 2016$ & $\begin{array}{l}\text { Mandado de } \\
\text { Segurança }\end{array}$ & $27 / 01 / 2016$ & 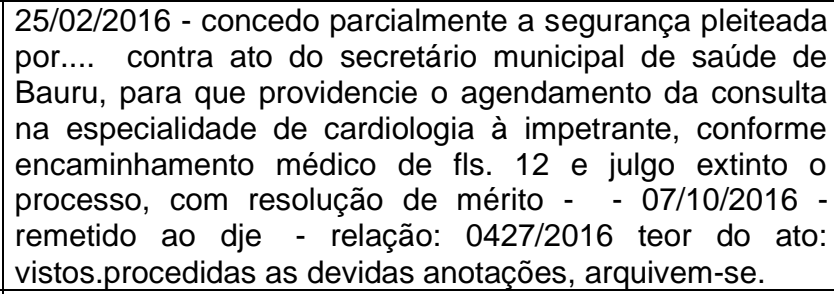 & $\begin{array}{l}\text { CONSULTA } \\
\text { MÉDICA }\end{array}$ \\
\hline 315 & $\begin{array}{c}\text { 1001458- } \\
60.2016 .8 .26 .0071\end{array}$ & $7418 / 2016$ & $01 / 01 / 2016$ & $\begin{array}{l}\text { Mandado de } \\
\text { Segurança }\end{array}$ & 02/02/2016 & $\begin{array}{l}\text { 04/03/2016 - concedo a segurança pleiteada por ..... } \\
\text { contra ato do secretário municipal de saúde de Bauru, } \\
\text { para que o impetrado forneça ao impetrante fraldas } \\
\text { geriátricas - tamamho "g" - - 22/09/2016 - remetido ao dje } \\
\text { - relação: } 0455 / 2016 \text { teor do ato: vistos.procedidas as } \\
\text { devidas anotaçóes arquivem-se. }\end{array}$ & FRALDA \\
\hline
\end{tabular}




\begin{tabular}{|c|c|c|c|c|c|c|c|}
\hline 316 & $\begin{array}{c}\text { 1001867- } \\
36.2016 .8 .26 .0071\end{array}$ & $7426 / 2016$ & $01 / 01 / 2016$ & $\begin{array}{l}\text { Mandado de } \\
\text { Segurança }\end{array}$ & 03/02/2016 & $\begin{array}{l}\text { 15/03/2016 - concedo a segurança pleiteada por ..... } \\
\text { contra ato do diretor técnico do departamento regional de } \\
\text { saúde de Bauru - drs vi e do secretário municipal de } \\
\text { saúde de Bauru, para que os impetrados providenciem o } \\
\text { fornecimento à impetrante do medicamento } \\
\text { imunoglobulina anti-rh (01 ampola de } 5 \mathrm{ml} \text { a cada } 90 \text { dias - } \\
\text { conforme prescrição médica de fls. } 13 \text { e } 16 / 18) \text {, bem } \\
\text { como sua aplicação, e julgo extinto o processo, com } \\
\text { resolução de mérito - - 08/05/2017 - emetido ao dje - } \\
\text { relação: 0369/2017 teor do ato: vistos.ciência às partes do } \\
\text { retorno dos autos.nada sendo requerido em } 30 \text { dias, } \\
\text { arquivem-se. }\end{array}$ & MEDICAMENTO \\
\hline 317 & $\begin{array}{c}1001440- \\
39.2016 .8 .26 .0071\end{array}$ & $7675 / 2016$ & $01 / 01 / 2016$ & $\begin{array}{l}\text { Mandado de } \\
\text { Segurança }\end{array}$ & 29/01/2016 & $\begin{array}{l}\text { 25/02/2016 - concedo a segurança pleiteada por.... contra } \\
\text { ato do secretário municipal de saúde de Bauru, para que } \\
\text { o impetrado forneça à impetrante fraldas descartáveis } \\
\text { para adulto - tamanho "xg" - - 07/10/2016 - remetido ao } \\
\text { dje - relação: } 0427 / 2016 \text { teor do ato: vistos.procedidas as } \\
\text { devidas anotações, arquivem-se } \\
\end{array}$ & FRALDA \\
\hline 318 & $\begin{array}{c}1001020- \\
34.2016 .8 .26 .0071\end{array}$ & $8371 / 2016$ & 01/01/2016 & $\begin{array}{l}\text { Mandado de } \\
\text { Segurança }\end{array}$ & & $\begin{array}{l}\text { 09/06/16 - julgo procedentes os pedidos da presente ação } \\
\text { de mandado de segurança, para tornar definitva a liminar } \\
\text { deferida e determinar ao Secretário Municipal de Saúde } \\
\text { do Município de Bauru o fornecimento do leite Enfamil AR } \\
120 \text { ml com o acréscimo de } 3 \% \text { de medida de espesante } \\
\text { Thick EASY por tempo indeterminado. }\end{array}$ & $\begin{array}{l}\text { ALIMENTAĈ̃O } \\
\text { ESPECIAL }\end{array}$ \\
\hline 319 & $\begin{array}{c}\text { 1002477- } \\
\text { 04.2016.8.26.0071 }\end{array}$ & $8417 / 2016$ & 01/01/2016 & $\begin{array}{c}\text { Outros } \\
\text { Procediment } \\
\text { os }\end{array}$ & & SEGREDO DE JUSTIÇA & $\begin{array}{c}\text { SEGREDO DE } \\
\text { JUSTIÇA }\end{array}$ \\
\hline 320 & $\begin{array}{c}\text { 1001951- } \\
37.2016 .8 .26 .0071\end{array}$ & $8993 / 2016$ & $01 / 01 / 2016$ & $\begin{array}{l}\text { Mandado de } \\
\text { Segurança }\end{array}$ & 04/02/2016 & $\begin{array}{l}\text { 09/03/2016 - concedo a segurança pleiteada por ..... } \\
\text { contra ato do secretário municipal de saúde de Bauru, } \\
\text { para que o impetrado forneça ao impetrante fraldas } \\
\text { geriátricas descartáveis - tamanho "exg" - - 08/06/2016 - } \\
\text { remetido ao dje - relação: 0250/2016 teor do ato: } \\
\text { vistos.considerando a certidão de fls. 101, digam as } \\
\text { partes se tem algo mais a requerer.no silêncio, ao } \\
\text { arquivo. }\end{array}$ & FRALDA \\
\hline
\end{tabular}




\begin{tabular}{|c|c|c|c|c|c|c|c|}
\hline 321 & $\begin{array}{c}\text { 1002085- } \\
64.2016 .8 .26 .0071\end{array}$ & $9060 / 2016$ & 01/01/2016 & $\begin{array}{l}\text { Mandado de } \\
\text { Segurança }\end{array}$ & 05/02/2016 & $\begin{array}{l}21 / 03 / 2016 \text { - concedo a segurança pleiteada por .... } \\
\text { contra ato do secretário municipal de saúde de Bauru, } \\
\text { para que o impetrado forneça ao impetrante fraldas } \\
\text { geriátricas descartáveis - tamanho "g" (180 unidades por } \\
\text { mês) - } 03 / 11 / 2016 \text { - remetido ao dje - relação: } \\
0475 / 2016 \text { teor do ato: vistos.procedidas as devidas } \\
\text { anotações, arquivem-se. }\end{array}$ & FRALDA \\
\hline 322 & $\begin{array}{c}\text { 1002087- } \\
34.2016 .8 .26 .0071\end{array}$ & $9640 / 2016$ & 01/01/2016 & $\begin{array}{l}\text { Mandado de } \\
\text { Segurança }\end{array}$ & 05/02/2016 & $\begin{array}{l}\text { 21/03/2016 - concedo a segurança pleiteada por.... contra } \\
\text { ato do secretário municipal de saúde de Bauru, para que } \\
\text { o impetrado forneça à impetrante fraldas geriátricas } \\
\text { descartáveis - tamanho "g" - - 01/11/2016 - remetido ao } \\
\text { dje - relação: } 0470 / 2016 \text { teor do ato: vistos.procedidas as } \\
\text { devidas anotacões, arquivem-se }\end{array}$ & FRALDA \\
\hline 323 & $\begin{array}{c}\text { 1002624- } \\
30.2016 .8 .26 .0071\end{array}$ & 10059/2016 & 01/01/2016 & $\begin{array}{l}\text { Mandado de } \\
\text { Segurança }\end{array}$ & 15/02/2016 & $\begin{array}{l}\text { 09/03/2016 - concedo a segurança pleiteada por .... } \\
\text { contra ato do secretário municipal de saúde de Bauru, } \\
\text { para que o impetrado forneça à impetrante fraldas } \\
\text { geriátricas descartáveis - tamanho "g" (120 unidades por } \\
\text { mês),conforme prescrição médica de fls. } 14 \text {, e julgo } \\
\text { extinto o processo, com resolução de mérito - } \\
13 / 03 / 2017 \text { - remetido ao dje - relação: } 0232 / 2017 \text { teor do } \\
\text { ato: vistos.fls. 100: nada mais sendo requerido, arquivem- } \\
\text { se. }\end{array}$ & FRALDA \\
\hline 324 & $\begin{array}{c}\text { 1002810- } \\
\text { 53.2016.8.26.0071 }\end{array}$ & 10120/2016 & 01/01/2016 & $\begin{array}{l}\text { Mandado de } \\
\text { Segurança }\end{array}$ & 17/02/2016 & $\begin{array}{l}\text { 10/03/2016 - las e/ou portarias não estão contemplados e } \\
\text { padronizados os remédios, como se estivesse a lidar com } \\
\text { ciência exata e não com ciência médica." ante o exposto, } \\
\text { rejeito as preliminares arguidas, ratifico a liminar de fls. } \\
34 / 35 \text { e concedo a segurança pleiteada por .... contra ato } \\
\text { do secretário municipal de saúde de Bauru, para que o } \\
\text { impetrado forneça ao impetrante fraldas geriátricas } \\
\text { descartáveis - tamanho "gg" - - 17/01/2017 - emetido ao } \\
\text { dje - relação: } 0033 / 2017 \text { teor do ato: vistos.procedidas as } \\
\text { devidas anotações, arquivem-se. }\end{array}$ & FRALDA \\
\hline 325 & $\begin{array}{c}\text { 1002811- } \\
\text { 38.2016.8.26.0071 }\end{array}$ & 10119/2016 & 01/01/2016 & $\begin{array}{l}\text { Mandado de } \\
\text { Segurança }\end{array}$ & 17/02/2016 & $\begin{array}{l}14 / 03 / 2016 \text { - concedo a segurança pleiteada por ..... } \\
\text { contra ato do secretário municipal de saúde de Bauru, } \\
\text { para que o impetrado forneça à impetrante fraldas } \\
\text { descartáveis - tamanho "m" - - } 10 / 01 / 2017 \text { - remetido ao } \\
\text { dje - relação: } 0005 / 2017 \text { teor do ato: vistos.procedidas as } \\
\text { devidas anotações, arquivem-se }\end{array}$ & FRALDA \\
\hline 326 & $\begin{array}{c}0000449- \\
14.2016 .4 .03 .6325 \\
\end{array}$ & 10156/2016 & 01/01/2016 & $\begin{array}{l}\text { Outros } \\
\text { Procediment } \\
\text { os }\end{array}$ & $01 / 02 / 2016$ & $\begin{array}{l}\text { 02/09/2016 - SENTENÇA SEM RESOLUÇÃO DE } \\
\text { MÉRITO - TERMO № 2016/6325013218 }\end{array}$ & MEDICAMENTO \\
\hline
\end{tabular}




\begin{tabular}{|c|c|c|c|c|c|c|c|}
\hline 327 & $\begin{array}{c}\text { 1001949- } \\
67.2016 .8 .26 .0071\end{array}$ & $10344 / 2016$ & 01/01/2016 & $\begin{array}{l}\text { Mandado de } \\
\text { Segurança }\end{array}$ & 04/02/2016 & $\begin{array}{l}\text { 02/03/2016 - concedo a segurança pleiteada por .... } \\
\text { contra ato do secretário municipal de saúde de Bauru, } \\
\text { para que o impetrado forneça à impetrante fraldas } \\
\text { geriátricas descartáveis - tamanho "m" }-31 / 10 / 2016- \\
\text { emetido ao dje - relação: 0466/2016 teor do ato: } \\
\text { vistos.procedidas as devidas anotações, arquivem-se. }\end{array}$ & FRALDA \\
\hline 328 & $\begin{array}{c}1003368- \\
25.2016 .8 .26 .0071\end{array}$ & $11995 / 2016$ & 01/01/2016 & $\begin{array}{l}\text { Mandado de } \\
\text { Segurança }\end{array}$ & $25 / 02 / 2016$ & $\begin{array}{l}\text { 15/03/2016 - concedo a segurança pleiteada por ... contra } \\
\text { ato do secretário municipal de saúde de Bauru, para que } \\
\text { o impetrado forneça à impetrante fraldas geriátricas } \\
\text { descartáveis - tamanho "g" - - 01/11/2016 - emetido ao } \\
\text { dje - relação: } 0470 / 2016 \text { teor do ato: vistos.procedidas as } \\
\text { devidas anotações, arquivem-se }\end{array}$ & FRALDA \\
\hline 329 & $\begin{array}{c}\text { 1002639- } \\
96.2016 .8 .26 .0071\end{array}$ & 11994/2016 & 01/01/2016 & $\begin{array}{l}\text { Mandado de } \\
\text { Segurança }\end{array}$ & 25/02/2016 & $\begin{array}{l}10 / 06 / 2016 \text { - concedo a segurança pleiteada por .... } \\
\text { contra ato do secretário municipal de saúde de Bauru, } \\
\text { para que o impetrado providencie o fornecimento ao } \\
\text { impetrante de } 180 \text { (cento e oitenta) catéteres urinários } \mathrm{n}^{\circ} \\
12 \text { actreen lite tiemann (bbbraun); } 180 \text { (cento e oitenta) } \\
\text { luvas de procedimento; } 50 \text { (cinquenta) gazes estéreis; } 02 \\
\text { (duas) unidades de povidine antisséptico tópico (1 I); } \\
\text { cloridrato de tansulosina 0,4mg (omnic ocas) - } 30 \\
\text { comprimidos/mês; succinato de solifenacina } 10 \mathrm{mg} \\
\text { (vesicare) - } 30 \text { comprimidos/mês, conforme prescrições } \\
\text { médicas de fls. } 16,24 \text { e } 26 \text {, e julgo extinto o processo, } \\
\text { com resolução de mérito, - - } 08 / 08 / 2017 \text { - remetido ao } \\
\text { dje - relação: } 0557 / 2017 \text { teor do ato: vistos.procedidas as } \\
\text { devidas anotações de baixa, arquivem-se. }\end{array}$ & MEDICAMENTO \\
\hline
\end{tabular}




\begin{tabular}{|c|c|c|c|c|c|c|c|}
\hline 330 & $\begin{array}{c}1003432- \\
35.2016 .8 .26 .0071\end{array}$ & $12107 / 2016$ & 01/01/2016 & $\begin{array}{l}\text { Mandado de } \\
\text { Segurança }\end{array}$ & $26 / 02 / 2016$ & $\begin{array}{l}\text { 22/03/2016 - concedo a segurança pleiteada por álvaro da } \\
\text { silva contra ato do secretário municipal de saúde de } \\
\text { Bauru, para que o impetrado providencie o fornecimento } \\
\text { ao impetrante do item pilhas de zinco-ar, tamanhos } 675 \text { e } \\
13 \text { (03 unidades por mês de cada pílha), conforme } \\
\text { prescrição médica de fls. 15/17, e julgo extinto o } \\
\text { processo, com resolução de mérito - } 23 / 06 / 2017 \text { - } \\
\text { remetido ao dje - relação: } 0488 / 2017 \text { teor do ato: } \\
\text { vistos.ciência às partes do retorno dos autos.nada sendo } \\
\text { requerido em } 30 \text { dias, arquivem-se. }\end{array}$ & $\begin{array}{c}\text { INSUMOS/MATE } \\
\text { RIAL } \\
\text { HOSPITALAR }\end{array}$ \\
\hline 331 & $\begin{array}{c}1003674- \\
91.2016 .8 .26 .0071\end{array}$ & $12319 / 2016$ & 01/01/2016 & $\begin{array}{l}\text { Outros } \\
\text { Procediment } \\
\text { os }\end{array}$ & & SEGREDO DE JUSTIÇA & $\begin{array}{l}\text { SEGREDO DE } \\
\text { JUSTIÇA }\end{array}$ \\
\hline 332 & $\begin{array}{c}\text { 1023710- } \\
91.2015 .8 .26 .0071\end{array}$ & $12481 / 2016$ & 01/01/2016 & $\begin{array}{l}\text { Mandado de } \\
\text { Segurança }\end{array}$ & 25/02/2016 & $\begin{array}{l}\text { 15/03/2016 - concedo a segurança pleiteada por .... } \\
\text { contra ato do secretário municipal de saúde de Bauru, } \\
\text { para que o impetrado forneça à impetrante fraldas } \\
\text { geriátricas descartáveis - tamanho "m" - }-17 / 01 / 2017 \text { - }-170 \text { - } \\
\text { remetido ao dje - relação: 0033/2017 teor do ato: } \\
\text { vistos.procedidas as devidas anotações, arquivem-se. }\end{array}$ & FRALDA \\
\hline 333 & $\begin{array}{c}\text { 1001277- } \\
59.2016 .8 .26 .0071\end{array}$ & $12482 / 2016$ & 01/01/2016 & $\begin{array}{l}\text { Outros } \\
\text { Procediment } \\
\text { os }\end{array}$ & 26/02/2016 & $\begin{array}{l}\text { 18/04/2016 - julgo parcialmente procedente o pedido } \\
\text { formulado por.... em face do município de Bauru, } \\
\text { determinando que o requerido forneça à requerente } \\
\text { fraldas descartáveis - tamanho "g" (150 unidades por } \\
\text { mês), - - 25/01/2017 - remetido ao dje - relação: } \\
0087 / 2017 \text { teor do ato: providenciar o requerido o } \\
\text { protocolo da petiçãa de fls. } 70 \text { nos autos do respectivo } \\
\text { cumprimento de sentença em andamento. }\end{array}$ & FRALDA \\
\hline 334 & $\begin{array}{c}\text { 1003917- } \\
\text { 35.2016.8.26.0071 }\end{array}$ & $13142 / 2016$ & 01/01/2016 & $\begin{array}{l}\text { Outros } \\
\text { Procediment } \\
\text { os }\end{array}$ & 02/03/2016 & $\begin{array}{l}\text { 21/10/2016 - julgo extinta a presente ação proposta por .... } \\
\text { em face de doulas magalhães de almeida e município de } \\
\text { Bauru, sem resolução do mérito - - *o réu recebeu alta da } \\
\text { internação e esta em casa recebendo tratamento junto ao } \\
\text { caps. }\end{array}$ & INTERNAÇÃO \\
\hline
\end{tabular}




\begin{tabular}{|c|c|c|c|c|c|c|c|}
\hline 335 & $\begin{array}{c}1003784- \\
90.2016 .8 .26 .0071\end{array}$ & $13403 / 2016$ & 01/01/2016 & $\begin{array}{l}\text { Outros } \\
\text { Procediment } \\
\text { os }\end{array}$ & 04/03/2016 & $\begin{array}{l}05 / 05 / 2016 \text { - julgo procedente o pedido formulado por .... } \\
\text { em face do município de Bauru, determinando que este } \\
\text { forneça ao requerente sondas vesicais de espera foley no } \\
14 \text { ( } 25 \text { unidades por mês), sondas vesicais lubrificadas } \\
\text { (marca coloplast - speedy cath ou de marca similar) (60 } \\
\text { unidades por mês), coletores externos de urina de silicone } \\
\text { (não látex) com cola em formato de camisinha } \\
\text { (preservativo - condom), tamanho } 30 \mathrm{~mm} \text { ( } 30 \text { unidades por } \\
\text { mês), bolsa de urina de perna, de capacidade para } 750 \mathrm{ml} \\
\text { (01 unidade por mês), bolsa de urina de cama, } \\
\text { capacidade para } 2 \text { (dois) litros ou } 2.00 \mathrm{ml}(04 \text { unidades } \\
\text { por mês), bisnaga de laxante minilax (21 unidades por } \\
\text { mês), rolo de micropore } 3 \mathrm{~m} \text { de } 25 \mathrm{~mm} \text { por } 10 \mathrm{~m} \text { (04 } \\
\text { unidades por mês) e rolo de micropore } 3 \mathrm{~m} \text { de } 50 \mathrm{~mm} \text { por } \\
10 \mathrm{~m} \text { (02 unidades por mês) - - 08/06/2017 - emetido ao } \\
\text { dje - relação: } 0376 / 2017 \text { teor do ato: vistos.considerando } \\
\text { que o presente feito encontra-se atualmente em grau de } \\
\text { recurso no e. tribunal de justiça do estado de são paulo, } \\
\text { bem como o v. despacho de fls. } 219 / 220 \text {, o qual } \\
\text { determina a suspensão do andamento do mesmo, } \\
\text { eventual cumprimento de sentença deverá tramitar pela } \\
\text { via adequada (cumprimento de sentença: - - } 1003784- \\
90.2016 .8 .26 .0071 \text { em grau de recurso. }\end{array}$ & MEDICAMENTO \\
\hline 336 & $\begin{array}{c}1004176- \\
30.2016 .8 .26 .0071\end{array}$ & $13585 / 2016$ & 01/01/2016 & $\begin{array}{l}\text { Outros } \\
\text { Procediment } \\
\quad \text { os }\end{array}$ & $04 / 03 / 2016$ & $\begin{array}{l}25 / 08 / 2016 \text { - julgo procedente a presente ação cautelar de } \\
\text { exibição de documento proposta por ... contra prefeitura } \\
\text { municipal de Bauru determinando que a requerida } \\
\text { apresente o prontuário médico de ... e, extinto o processo, } \\
\text { com resolução de mérito - - } 10 / 03 / 2017 \text { - remetido ao dje } \\
\text { - relação: } 0168 / 2017 \text { teor do ato: vistos.considerando a } \\
\text { certidão de fls. } 55 \text { e, ante a inexistência de cumprimento } \\
\text { de sentença, procedidas as anotações de baixa, } \\
\text { arquivem-se os autos }\end{array}$ & $\begin{array}{l}\text { APRESENTAÇÃO } \\
\text { DE PRONTUÁRIO }\end{array}$ \\
\hline 337 & $\begin{array}{c}\text { 1004297- } \\
58.2016 .8 .26 .0071\end{array}$ & $13682 / 2016$ & 01/01/2016 & $\begin{array}{l}\text { Mandado de } \\
\text { Segurança }\end{array}$ & 04/03/2016 & $\begin{array}{l}27 / 04 / 2016 \text { - concedo a segurança pleiteada por ... contra } \\
\text { ato do secretário municipal de saúde de Bauru, para que } \\
\text { o impetrado forneça à impetrante fraldas geriátricas } \\
\text { descartáveis - tamanho "m" - - 20/01/2017 - remetido ao } \\
\text { dje - relação: 0069/2017 teor do ato: vistos.arquive-se }\end{array}$ & FRALDA \\
\hline 338 & $\begin{array}{c}\text { 1004899- } \\
49.2016 .8 .26 .0071\end{array}$ & $14139 / 2016$ & 01/01/2016 & $\begin{array}{l}\text { Outros } \\
\text { Procediment } \\
\text { os }\end{array}$ & 20/03/2017 & $\begin{array}{l}\text { 08/08/2017 - vistos.homologo, para que produza seus } \\
\text { jurídicos e legais efeitos, o pedido de desistência } \\
\text { formulado pela parte autora às fls. } 190 \text {, que conta com a } \\
\text { anuência da parte contrária, e julgo extinto o processo }\end{array}$ & CIRURGIA \\
\hline
\end{tabular}




\begin{tabular}{|c|c|c|c|c|c|c|c|}
\hline 339 & $\begin{array}{c}\text { 1001373- } \\
74.2016 .8 .26 .0071\end{array}$ & $14142 / 2016$ & $01 / 01 / 2016$ & $\begin{array}{l}\text { Mandado de } \\
\text { Segurança }\end{array}$ & $10 / 03 / 2016$ & $\begin{array}{l}\text { 04/05/2016 - concedo a segurança pleiteada por.... contra } \\
\text { ato do secretário municipal de saúde de Bauru, para que } \\
\text { o impetrado providencie o fornecimento à impetrante do } \\
\text { medicamento galvus met } 50 / 500 \mathrm{mg} \text { e thioctacid hr } 600 \\
\text { (30 cápsulas ao mês de cada medicamento) - - } \\
\text { 10/03/2017 - vistos.ciência ao mp.após, arquivem-se. } \\
\end{array}$ & MEDICAMENTO \\
\hline 340 & $\begin{array}{c}\text { 1002097- } \\
\text { 78.2016.8.26.0071 }\end{array}$ & $14239 / 2016$ & $01 / 01 / 2016$ & $\begin{array}{l}\text { Mandado de } \\
\text { Segurança }\end{array}$ & 09/03/2016 & $\begin{array}{l}\text { 10/06/2016 - concedo a segurança pleiteada por ... contra } \\
\text { ato do secretário municipal de saúde de Bauru, para que } \\
\text { o impetrado forneça ao impetrante fraldas geriátricas } \\
\text { descartáveis - tamanho "xg" (06 unidades por dia), e julgo } \\
\text { extinto o processo - - 23/10/2017 - remetido ao dje - } \\
\text { relação: 0711/2017 teor do ato: ciência às partes do } \\
\text { retorno dos autos do e. tribunal.eventual cumprimento de } \\
\text { sentença deverá tramitar em formato digital, cujo } \\
\text { requerimento deverá ser realizado por peticionamento } \\
\text { eletrônico e instrúdo com as seguintes peças:i- sentença } \\
\text { e acórdão, se existente;ii- certidão de trânsito em julgado, } \\
\text { se o caso;iii- demonstrativo do débito atualizado, quando } \\
\text { se tratar de execução por quantia certa;iv- mandado de } \\
\text { citação cumprido e procurações outorgadas aos } \\
\text { advogados das partes, além de outras peças processuais } \\
\text { que o exequente considere necessárias.nada sendo } \\
\text { requerido em } 30 \text { (trinta) dias, os autos serão remetidos ao } \\
\text { arquivo. }\end{array}$ & FRALDA \\
\hline 341 & $\begin{array}{c}0000682- \\
11.2016 .4 .03 .6325\end{array}$ & $14598 / 2016$ & 01/01/2016 & $\begin{array}{c}\text { Outros } \\
\text { Procediment } \\
\text { os }\end{array}$ & $11 / 02 / 2016$ & $\begin{array}{lll}06 / 12 / 2016 & \text { - SENTENCCA COM RESOLUĈÃO } & \text { DE } \\
\text { MÉRITO IMPROCEDENTE A AÇÃO - TERMO № } \\
\text { 2016/6325018013 }\end{array}$ & MEDICAMENTO \\
\hline 342 & $\begin{array}{c}\text { 1005359- } \\
36.2016 .8 .26 .0071\end{array}$ & $15848 / 2016$ & 01/01/2016 & $\begin{array}{l}\text { Mandado de } \\
\text { Segurança }\end{array}$ & $16 / 03 / 2016$ & $\begin{array}{l}\text { 29/04/2016 - concedo a segurança pleiteada por.... contra } \\
\text { ato do secretário municipal de saúde de Bauru, para que } \\
\text { o impetrado forneça à impetrante fraldas geriátricas } \\
\text { descartáveis - tamanho " } \mathrm{m} " \text { (180 unidades por mês) - - } \\
\text { 23/01/2017 - remetido ao dje - relação: } 0080 / 2017 \text { teor do } \\
\text { ato: vistos.procedidas as devidas anotações de baixa, } \\
\text { arquivem-se }\end{array}$ & FRALDA \\
\hline 343 & $\begin{array}{c}\text { 1005510- } \\
02.2016 .8 .26 .0071\end{array}$ & $16135 / 2016$ & $01 / 01 / 2016$ & $\begin{array}{l}\text { Mandado de } \\
\text { Segurança }\end{array}$ & $17 / 03 / 2016$ & $\begin{array}{l}\text { 20/04/2016 - concedo a segurança pleiteada por .... } \\
\text { contra ato do secretário municipal de saúde de Bauru, } \\
\text { para que o impetrado forneça à impetrante fraldas } \\
\text { geriátricas descartáveis - tamanho "g" - }-06 / 03 / 2017 \text { - } \\
\text { emetido ao dje - relação: } 0158 / 2017 \text { teor do ato: } \\
\text { vistos.precedidas as devidas anotações de baixa, arquive- } \\
\text { se }\end{array}$ & FRALDA \\
\hline
\end{tabular}




\begin{tabular}{|c|c|c|c|c|c|c|c|}
\hline 344 & $\begin{array}{c}1005530- \\
90.2016 .8 .26 .0071\end{array}$ & $16152 / 2016$ & 01/01/2016 & $\begin{array}{l}\text { Mandado de } \\
\text { Segurança }\end{array}$ & 20/03/2016 & $\begin{array}{l}27 / 04 / 2016 \text { - concedo a segurança pleiteada por .... } \\
\text { contra ato do secretário municipal de saúde de Bauru, } \\
\text { para que o impetrado forneça à impetrante fraldas } \\
\text { geriátricas descartáveis - - }-23 / 03 / 2017 \text { - remetido ao } \\
\text { dje - relação: } 0265 / 2017 \text { teor do ato: vistos.procedidas as } \\
\text { devidas anotações de baixa, arquivem-se }\end{array}$ & FRALDA \\
\hline 345 & $\begin{array}{c}\text { 1007032- } \\
98.2015 .8 .26 .0071\end{array}$ & $16326 / 2016$ & 01/01/2016 & $\begin{array}{l}\text { Outros } \\
\text { Procediment } \\
\text { os }\end{array}$ & 24/06/2015 & $\begin{array}{l}\text { 26/05/2016 - julgo procedentes os pedidos da presente } \\
\text { ação de obrigação de fazer, com pedido de tutela } \\
\text { antecipada que ... ajuizou em ao estado de são paulo e } \\
\text { ao município de Bauru para o fim de condenar os } \\
\text { requeridos na obrigação de fazer consistente no } \\
\text { fornecimento de } 300 \text { tiras testes, marca confour ts (bayer) } \\
\text { por mês, lancetas e } 100 \text { agulhas } 0,25 \times 5,0 \mathrm{~mm}- \\
19 / 02 / 2018 \text { - remetido ao dje cumpra-se o v v } \\
\text { acórdão.ciência às partes da baixa dos auto. após } \\
\text { aguarde-se por } 30 \text { dias, nada sendo requerido, arquivem- } \\
\text { se }\end{array}$ & $\begin{array}{c}\text { INSUMOS/MATE } \\
\text { RIAL } \\
\text { HOSPITALAR }\end{array}$ \\
\hline 346 & $\begin{array}{c}\text { 1005603- } \\
62.2016 .8 .26 .0071\end{array}$ & $16339 / 2016$ & 01/01/2016 & $\begin{array}{l}\text { Mandado de } \\
\text { Segurança }\end{array}$ & 20/03/2016 & $\begin{array}{l}\text { 26/04/2016 - concedo a segurança pleiteada por .... } \\
\text { contra ato do secretário municipal de saúde de Bauru, } \\
\text { para que o impetrado forneça à impetrante fraldas } \\
\text { geriátricas descartáveis - tamanho "g" }-13 / 03 / 2017 \text { - }-17 \text { - } \\
\text { remetido ao dje - relação: 0232/2017 teor do ato: } \\
\text { vistos.fls. } 79 \text { : nada mais sendo requerido, arquivem-se }\end{array}$ & FRALDA \\
\hline 347 & $\begin{array}{c}\text { 1020561- } \\
87.2015 .8 .26 .0071\end{array}$ & $16687 / 2016$ & 01/01/2016 & $\begin{array}{l}\text { Mandado de } \\
\text { Segurança }\end{array}$ & & SEGREDO DE JUSTIÇA & $\begin{array}{l}\text { SEGREDO DE } \\
\text { JUSTIÇA }\end{array}$ \\
\hline 348 & $\begin{array}{c}1006089- \\
47.2016 .8 .26 .0071\end{array}$ & $17549 / 2016$ & 01/01/2016 & $\begin{array}{l}\text { Outros } \\
\text { Procediment } \\
\text { os }\end{array}$ & 28/03/2016 & $\begin{array}{l}\text { 20/06/2017 - julgo extinto o processo sem resolução do } \\
\text { mérito nos termos do artigo } 485 \text {, inciso i c/c artigo } 321 \text {, do } \\
\text { cpc combinado com o artigo } 152 \text { do eca.custas, despesas } \\
\text { e honorários indevidos. p.i.c.com o trânsito em julgado, } \\
\text { arquivem-se os autos. }\end{array}$ & MEDICAMENTO \\
\hline 349 & $\begin{array}{c}\text { 1001376- } \\
\text { 29.2016.8.26.0071 } \\
\end{array}$ & $18641 / 2016$ & 01/01/2016 & $\begin{array}{l}\text { Mandado de } \\
\text { Segurança }\end{array}$ & & SEGREDO DE JUSTIÇA & $\begin{array}{c}\text { SEGREDO DE } \\
\text { JUSTIÇA }\end{array}$ \\
\hline 350 & $\begin{array}{c}\text { 1027343- } \\
\text { 13.2015.8.26.0071 }\end{array}$ & 19049/2016 & 01/01/2016 & $\begin{array}{l}\text { Mandado de } \\
\text { Segurança }\end{array}$ & 01/04/2016 & $\begin{array}{l}\text { 27/04/2016 - concedo a segurança pleiteada por .... } \\
\text { contra ato do secretário municipal de saúde de Bauru, } \\
\text { para que o impetrado forneça à impetrante fraldas } \\
\text { geriátricas descartáveis hipoalérgicas - tamanho "g" (160 } \\
\text { unidades por mês) - } 14 / 02 / 2017 \text { - remetido ao dje - } \\
\text { relaçãa: 0156/2017 teor do ato: vistos.considerando a } \\
\text { certidão de fls. } 80 \text {, digam as partes se tem algo mais a } \\
\text { requer.no silêncio, ao arquivo }\end{array}$ & FRALDA \\
\hline
\end{tabular}




\begin{tabular}{|c|c|c|c|c|c|c|c|}
\hline 351 & $\begin{array}{c}\text { 1005529- } \\
08.2016 .8 .26 .0071\end{array}$ & $19075 / 2016$ & $01 / 01 / 2016$ & $\begin{array}{l}\text { Mandado de } \\
\text { Segurança }\end{array}$ & 05/04/2016 & $\begin{array}{l}\text { 09/05/2016 - concedo a segurança pleiteada por ..... } \\
\text { contra ato do secretário municipal de saúde de Bauru, } \\
\text { para que o impetrado forneça à impetrante fraldas } \\
\text { geriátricas descartáveis - tamanho eg (180 unidades por } \\
\text { mês) e colchão caixa de ovo ( } 01 \text { unidade a cada três } \\
\text { meses), e julgo extinto o processo, com resolução de } \\
\text { mérito - } 08 / 05 / 2017 \text { - remetido ao dje - relação: } \\
\text { 0296/2017 teor do ato: vistos.ciência às partes do retorno } \\
\text { dos autos.nada sendo requerido em } 30 \text { dias, arquivem-se. }\end{array}$ & FRALDA \\
\hline 352 & $\begin{array}{c}\text { 1006440- } \\
20.2016 .8 .26 .0071\end{array}$ & $19093 / 2016$ & $01 / 01 / 2016$ & $\begin{array}{l}\text { Outros } \\
\text { Procediment } \\
\text { os }\end{array}$ & & $\begin{array}{l}\text { 25/05/2018 - julgo improcedente esta ação de } \\
\text { indenizatória movida por .... contra prefeitura municipal } \\
\text { de Bauru e ... dando por extinto este processo, com } \\
\text { julgamento do mérito - }-11 / 07 / 2018 \text { - vistos. certifique a } \\
\text { serventia o trânsito em julgado. após, expeça-se certidão } \\
\text { de honorários de acordo com o convênio defensoria/oab, - }\end{array}$ & $\begin{array}{c}\text { DANO MATERIAL } \\
\text { E MORAL }\end{array}$ \\
\hline 353 & $\begin{array}{c}\text { 1006398- } \\
68.2016 .8 .26 .0071\end{array}$ & $19416 / 2016$ & $01 / 01 / 2016$ & $\begin{array}{l}\text { Mandado de } \\
\text { Segurança }\end{array}$ & 01/04/2016 & $\begin{array}{l}\text { 25/04/2016 - concedo a segurança pleiteada por .... } \\
\text { contra ato do secretário municipal de saúde de Bauru, } \\
\text { para que o impetrado forneça à impetrante fraldas } \\
\text { geriátricas descartáveis - - } 31 / 10 / 2016 \text { - remetido ao dje } \\
\text { - relação: 0466/2016 teor do ato: vistos.certifique a } \\
\text { serventia o trânsito em julgado da sentença de fls. } \\
\text { 49/54.apos, considerando a informação de fls. 93, } \\
\text { procedidas as devidas anotações, arquivem-se }\end{array}$ & FRALDA \\
\hline 354 & $\begin{array}{c}\text { 1006689- } \\
68.2016 .8 .26 .0071\end{array}$ & $19762 / 2016$ & $01 / 01 / 2016$ & $\begin{array}{l}\text { Mandado de } \\
\text { Segurança }\end{array}$ & 07/04/2016 & $\begin{array}{l}\text { 27/04/2016 - concedo a segurança pleiteada por .... } \\
\text { contra ato do secretário municipal de saúde de Bauru, } \\
\text { para que o impetrado forneça à impetrante fraldas } \\
\text { geriátricas - tamanho "g" (120 unidades por mês), } \\
\text { conforme receituário de fls. } 24, \text { e julgo extinto o processo, } \\
\text { com resolução de mérito - - 23/03/2017 - remetido ao dje } \\
\text { - relação: 0265/2017 teor do ato: vistos.procedidas as } \\
\text { devidas anotações de baixa, arquivem-se }\end{array}$ & FRALDA \\
\hline 355 & $\begin{array}{c}\text { 1006692- } \\
\text { 23.2016.8.26.0071 }\end{array}$ & $20040 / 2016$ & $01 / 01 / 2016$ & $\begin{array}{l}\text { Mandado de } \\
\text { Segurança }\end{array}$ & 07/04/2016 & $\begin{array}{l}\text { 04/05/2016 - concedo a segurança pleiteada por .... } \\
\text { contra ato do secretário municipal de saúde de Bauru, } \\
\text { para que o impetrado forneça ao impetrante fraldas } \\
\text { geriátricas - tamanho "m" - - 10/03/2017 - remetido ao } \\
\text { dje - relação: } 0222 / 2017 \text { teor do ato: vistos. arquivem-se }\end{array}$ & FRALDA \\
\hline
\end{tabular}




\begin{tabular}{|c|c|c|c|c|c|c|c|}
\hline 356 & \begin{tabular}{c|}
$1006765-$ \\
92.2016 .8 .236 .0071
\end{tabular} & $20048 / 2016$ & 01/01/2016 & $\begin{array}{l}\text { Mandado de } \\
\text { Segurança }\end{array}$ & 08/04/2016 & $\begin{array}{l}\text { 29/04/2016 - concedo a segurança pleiteada por .... } \\
\text { contra ato do secretário municipal de saúde de Bauru, } \\
\text { para que o impetrado forneça à impetrante fraldas } \\
\text { geriátricas - tamanho "gg" (04 unidades por dia), conforme } \\
\text { receituário de fls. } 19 \text {, e julgo extinto o processo, com } \\
\text { resolução de mérito - - 19/10/2016 - remetido ao dje - } \\
\text { procedidas as devidas anotações, arquivem-se }\end{array}$ & FRALDA \\
\hline 357 & \begin{tabular}{|c|}
$1022718-$ \\
33.2015 .8 .26 .0071
\end{tabular} & $20481 / 2016$ & 01/01/2016 & $\begin{array}{l}\text { Mandado de } \\
\text { Segurança }\end{array}$ & $17 / 03 / 2016$ & $\begin{array}{l}\text { 29/04/2016 - concedo a segurança pleiteada por ... } \\
\text { contra ato do secretário municipal de saúde de Bauru, } \\
\text { para que o impetrado providencie o fornecimento ao } \\
\text { impetrante dos medicamentos insulina glargina } 100 \text { ui/ml } \\
\text { (lantus) caneta descartável (solostar) contendo } 3 \mathrm{ml} \text { de } \\
\text { solução injetável (5 canetas por mês) e insulina glulisina } \\
100 \text { ui/ml (adipra) caneta descartável (solostar) contendo } \\
3 \text { ml de solução injetável (09 canetas por mês), - - } \\
28 / 06 / 2017 \text { - remetido ao dje - relação: } 0415 / 2017 \text { teor do } \\
\text { ato: ciência às partes do retorno dos autos do e. } \\
\text { tribunal.eventual cumprimento de sentença deverá } \\
\text { tramitar em formato digital, cujo requerimento deverá ser } \\
\text { realizado por peticionamento eletrônico e instruído com as } \\
\text { seguintes peças:i- sentença e acórdão, se existente;ii- } \\
\text { certidão de trânsito em julgado, se o caso;iii- } \\
\text { demonstrativo do débito atualizado, quando se tratar de } \\
\text { execução por quantia certa;iv- mandado de citação } \\
\text { cumprido e procurações outorgadas aos advogados das } \\
\text { partes, além de outras peças processuais que o } \\
\text { exequente considere necessárias.nada sendo requerido } \\
\text { em } 30 \text { (trinta) dias, os autos serão remetidos ao arquivo. }\end{array}$ & MEDICAMENTO \\
\hline 358 & \begin{tabular}{|c|}
$1000981-$ \\
37.2016 .8 .26 .0071
\end{tabular} & 20528/2016 & 01/01/2016 & $\begin{array}{l}\text { Mandado de } \\
\text { Segurança }\end{array}$ & 08/04/2016 & $\begin{array}{l}\text { 29/04/2016 - as e/ou portarias não estão contemplados e } \\
\text { padronizados os remédios, como se estivesse a lidar com } \\
\text { ciência exata e não com ciência médica." ante o exposto, } \\
\text { rejeito as preliminares arguidas, ratifico a liminar de fls. } \\
45 / 46 \text { e concedo a segurança pleiteada por .... contra ato } \\
\text { do secretário municipal de saúde de Bauru, para que o } \\
\text { impetrado forneça à impetrante fraldas geriátricas } \\
\text { descartáveis - tamanho "gg" - - 03/02/2017 - remetido ao } \\
\text { dje - relação: } 0080 / 2017 \text { teor do ato: vistos.procedidas as } \\
\text { devidas anotações de baixa, arquivem-se }\end{array}$ & FRALDA \\
\hline
\end{tabular}




\begin{tabular}{|c|c|c|c|c|c|c|c|}
\hline 359 & $\begin{array}{c}\text { 1006885- } \\
\text { 38.2016.8.26.0071 }\end{array}$ & $20751 / 2016$ & 01/01/2016 & $\begin{array}{l}\text { Mandado de } \\
\text { Segurança }\end{array}$ & 08/04/2016 & $\begin{array}{l}\text { 02/05/2016 - concedo a segurança pleiteada por .... } \\
\text { contra ato do secretário municipal de saúde de Bauru, } \\
\text { para que o impetrado forneça ao impetrante fraldas } \\
\text { descartáveis - tamanho "m" adulta ( } 180 \text { unidades por } \\
\text { mês), conforme prescrição médica de fls. } 11 \text {, e julgo } \\
\text { extinto o processo, com resolução de mérito - } \\
25 / 08 / 2016 \text { - emetido ao dje - relação: } 0362 / 2016 \text { teor do } \\
\text { ato: vistos.considerando a anuência do impetrado (fls. } \\
72 / 75 \text { ), defiro o pedido do impetrante (fls. 67/68), } \\
\text { determinando o fornecimento de } 180 \text { fraldas geriátricas } \\
\text { descartáveis - tamanho g.oportunamente, certificado o } \\
\text { trânsito em julgado, arquivem-se }\end{array}$ & FRALDA \\
\hline 360 & $\begin{array}{c}\text { 1003377- } \\
\text { 84.2016.8.26.0071 }\end{array}$ & $21559 / 2016$ & 01/01/2016 & $\begin{array}{l}\text { Outros } \\
\text { Procediment } \\
\text { os }\end{array}$ & $14 / 04 / 2016$ & $\begin{array}{l}\text { 11/04/2017 - remetido ao dje - relação: 0305/2017 teor do } \\
\text { ato: vistos.fls. } 145 \text { e } 146 / 166 \text { : considerando a informação } \\
\text { do municíio de Bauru de que faz os agendamentos para } \\
\text { internação por intermédio do drs vi, o que se comprova } \\
\text { pelo documento de fls. } 160 \text {, por ora determino a intimação } \\
\text { do drs vi, por email, com urgência, para que disponibilize } \\
\text { novamente a vaga em questão, a qual deverá permanecer } \\
\text { à disposição da autora pelo prazo de cinco dias, - - } \\
\text { 13/06/2017 - remetido ao dje }\end{array}$ & INTERNAÇÃO \\
\hline 361 & $\begin{array}{c}\text { 1007329- } \\
71.2016 .8 .26 .0071\end{array}$ & $22186 / 2016$ & 01/01/2016 & $\begin{array}{l}\text { Mandado de } \\
\text { Segurança }\end{array}$ & $18 / 04 / 2016$ & $\begin{array}{l}\text { 03/05/2016 - concedo a segurança pleiteada por.... contra } \\
\text { ato do secretário municipal de saúde de Bauru, para que } \\
\text { o impetrado forneça ao impetrante fraldas descartáveis - } \\
\text { tamanho "g" adulta - - 24/07/2017 - remetido ao dje - } \\
\text { relação: } 0466 / 2017 \text { teor do ato: vistos.fls. } 71 \text { : ciente. } \\
\text { certificado o trânsito em julgado, arquivem-se }\end{array}$ & FRALDA \\
\hline 362 & $\begin{array}{c}\text { 0027872- } \\
30.2007 .8 .26 .0071\end{array}$ & $21802 / 2016$ & 20/04/2016 & $\begin{array}{c}\text { Outros } \\
\text { Procediment } \\
\text { os }\end{array}$ & & SEGREDO DE JUSTIÇA & $\begin{array}{c}\text { SEGREDO DE } \\
\text { JUSTIÇA }\end{array}$ \\
\hline 363 & $\begin{array}{c}1007525- \\
41.2016 .8 .26 .0071\end{array}$ & $23022 / 2016$ & 27/04/2016 & $\begin{array}{l}\text { Mandado de } \\
\text { Segurança }\end{array}$ & 20/04/2016 & $\begin{array}{l}\text { 10/05/2016 - concedo a segurança pleiteada por .... } \\
\text { contra ato do secretário municipal de saúde de Bauru, } \\
\text { para que o impetrado forneça à impetrante fraldas } \\
\text { geriátricas descartáveis - - 07/06/2017 - remetido ao dje } \\
\text { - relação: 0374/2017 teor do ato: vistos.procedidas as } \\
\text { devidas anotacões de baixa, arquivem-se. }\end{array}$ & FRALDA \\
\hline
\end{tabular}




\begin{tabular}{|c|c|c|c|c|c|c|c|}
\hline 364 & $\begin{array}{c}1007596- \\
\text { 43.2016.8.26.0071 }\end{array}$ & $23274 / 2016$ & $28 / 04 / 2016$ & $\begin{array}{l}\text { Mandado de } \\
\text { Segurança }\end{array}$ & $20 / 04 / 2016$ & $\begin{array}{l}13 / 05 / 2016 \text { - concedo a segurança pleiteada por .... } \\
\text { contra ato do secretário municipal de saúde de Bauru, } \\
\text { para que o impetrado providencie o fornecimento à } \\
\text { impetrante de dieta enteral polimérica hipercalórica, } \\
\text { hiperproteica, com fibras, ( } 1.20 \mathrm{ml} \text { por dia). }\end{array}$ & $\begin{array}{c}\text { ALIMENTAÇÃO } \\
\text { ESPECIAL }\end{array}$ \\
\hline 365 & $\begin{array}{c}1006568- \\
40.2016 .8 .26 .0071 \\
\end{array}$ & $23276 / 2016$ & $28 / 04 / 2016$ & $\begin{array}{l}\text { Mandado de } \\
\text { Segurança }\end{array}$ & & SEGREDO DE JUSTIÇA & $\begin{array}{l}\text { SEGREDO DE } \\
\text { JUSTIÇA }\end{array}$ \\
\hline 366 & $\begin{array}{c}1008034- \\
69.2016 .8 .26 .0071 \\
\end{array}$ & 24698/2016 & 05/05/2016 & $\begin{array}{l}\text { Mandado de } \\
\text { Segurança }\end{array}$ & & SEGREDO DE JUSTIÇA & $\begin{array}{l}\text { SEGREDO DE } \\
\text { JUSTIÇA }\end{array}$ \\
\hline 367 & $\begin{array}{c}\text { 1007789- } \\
\text { 58.2016.8.26.0071 }\end{array}$ & 25545/2016 & 10/05/2016 & $\begin{array}{l}\text { Mandado de } \\
\text { Segurança }\end{array}$ & 05/05/2016 & $\begin{array}{l}\text { 19/05/2016 - concedo a segurança pleiteada por .... } \\
\text { contra ato do secretário municipal de saúde de Bauru, } \\
\text { para que o impetrado forneça à impetrante fraldas } \\
\text { geriátricas descartáveis - tamanho "eg" - - 30/03/2017 - } \\
\text { procedidas as devidas anotações de baixa, arquivem-se - }\end{array}$ & FRALDA \\
\hline 368 & $\begin{array}{c}\text { 10085575- } \\
\text { 05.2016.8.26.0071 }\end{array}$ & 25879/2016 & $11 / 05 / 2016$ & $\begin{array}{l}\text { Mandado de } \\
\text { Segurança }\end{array}$ & 06/05/2016 & $\begin{array}{l}\text { 23/05/2016 - concedo a segurança pleiteada por ... contra } \\
\text { ato do secretário municipal de saúde de Bauru, para que o } \\
\text { impetrado forneça à impetrante fraldas geriátricas } \\
\text { descartáveis, tamanho "m" 19/06/17 arquivo - int. defensoria. }\end{array}$ & FRALDA \\
\hline 369 & $\begin{array}{c}\text { 1008584- } \\
\text { 64.2016.8.26.0071 }\end{array}$ & $26056 / 2016$ & $12 / 05 / 2016$ & $\begin{array}{l}\text { Mandado de } \\
\text { Segurança }\end{array}$ & $10 / 05 / 2016$ & $\begin{array}{l}\text { 09/10/2018 - fundamento e decido. a impetrante requereu } \\
\text { a extinção do presente feito, tendo em vista que já } \\
\text { realizou o exame e recebeu o laudo médica. dessa forma, } \\
\text { ocorreu a perda do objeto da presente ação. ante o } \\
\text { exposto, reconheço a carência superveniente, e julgo } \\
\text { extinto o processo sem resolução de mérito. }\end{array}$ & $\begin{array}{l}\text { INSUMOS/MATE } \\
\text { RIAL } \\
\text { HOSPITALAR }\end{array}$ \\
\hline 370 & $\begin{array}{c}\text { 1008558- } \\
66.2016 .8 .26 .0071\end{array}$ & $26080 / 2016$ & $12 / 05 / 2016$ & $\begin{array}{l}\text { Mandado de } \\
\text { Segurança }\end{array}$ & 06/05/2016 & $\begin{array}{l}31 / 05 / 2016 \text { - concedo a segurança pleiteada por .... } \\
\text { contra ato do secretário municipal de saúde de Bauru, } \\
\text { para que o impetrado providencie o agendamento da } \\
\text { consulta na especialidade ortopedia à impetrante, e julgo } \\
\text { extinto o processo, com resolução de mérito - } \\
23 / 06 / 2017 \text { - remetido ao dje - relação: } 0488 / 2017 \text { teor do } \\
\text { ato: vistos.ciência às partes do retorno dos autos.nada } \\
\text { sendo requerido em } 30 \text { dias, arquivem-se. }\end{array}$ & $\begin{array}{l}\text { CONSULTA } \\
\text { MÉDICA }\end{array}$ \\
\hline 371 & $\begin{array}{c}\text { 1007527- } \\
11.2016 .8 .26 .0071\end{array}$ & 26089/2016 & $12 / 05 / 2016$ & $\begin{array}{l}\text { Mandado de } \\
\text { Segurança }\end{array}$ & 09/05/2016 & $\begin{array}{l}\text { 02/06/2016 - concedo a segurança pleiteada por .... } \\
\text { contra ato do secretário municipal de saúde de Bauru, } \\
\text { para que o impetrado forneça ao impetrante fraldas } \\
\text { geriátricas - tamanho "gg" (180 unidades por mês) - - } \\
\text { 23/03/2017 - remetido ao dje - relação: 0265/2017 teor do } \\
\text { ato: vistos.procedidas as devidas anotações de baixa, } \\
\text { arquivem-se }\end{array}$ & FRALDA \\
\hline
\end{tabular}




\begin{tabular}{|c|c|c|c|c|c|c|c|}
\hline 372 & $\begin{array}{c}1008594- \\
11.2016 .8 .26 .0071\end{array}$ & $26371 / 2016$ & $13 / 05 / 2016$ & $\begin{array}{l}\text { Mandado de } \\
\text { Segurança }\end{array}$ & 09/05/2016 & $\begin{array}{l}03 / 06 / 2016 \text { - concedo a segurança pleiteada por .... } \\
\text { contra ato do secretário municipal de saúde de Bauru, } \\
\text { para que o impetrado providencie o fornecimento à } \\
\text { impetrante de dieta enteral normocalórica, normoprotéica, } \\
\text { sem fibras e sem sacarose, para uso via oral ou enteral } \\
\text { (04 latas de } 800 \mathrm{~g} \text { por mês). }\end{array}$ & $\begin{array}{l}\text { ALIMENTAÇÃO } \\
\text { ESPECIAL }\end{array}$ \\
\hline 373 & $\begin{array}{c}\text { 1008391- } \\
49.2016 .8 .26 .0071\end{array}$ & $26897 / 2016$ & $17 / 05 / 2016$ & $\begin{array}{l}\text { Mandado de } \\
\text { Segurança }\end{array}$ & 05/05/2016 & $\begin{array}{l}\text { 24/05/2016 - concedo a segurança pleiteada por .... } \\
\text { contra ato do secretário municipal de saúde de Bauru, } \\
\text { para que o impetrado forneça à impetrante fraldas } \\
\text { geriátricas descartáveis - tamanho "g" - - 20/06/2017 - } \\
\text { remetido ao die - relacão: 0397/2017 teor do ato: arquivo }\end{array}$ & FRALDA \\
\hline 374 & $\begin{array}{c}\text { 1009069- } \\
64.2016 .8 .26 .0071\end{array}$ & $27545 / 2016$ & 19/05/2016 & $\begin{array}{l}\text { Mandado de } \\
\text { Segurança }\end{array}$ & 13/05/2016 & $\begin{array}{l}21 / 06 / 2016 \text { - concedo a segurança pleiteada por .... } \\
\text { contra ato do secretário municipal de saúde de Bauru, } \\
\text { para que o impetrado forneça ao impetrante fraldas } \\
\text { geriátricas descartáveis - tamanho "m" }-27 / 03 / 2017 \text { - } \\
\text { remetido ao dje - relação: 0223/2017 teor do ato: } \\
\text { vistos.procedidas as devidas anotações de baixa, } \\
\text { arquivem-se }\end{array}$ & FRALDA \\
\hline 375 & $\begin{array}{c}\text { 1009190- } \\
92.2016 .8 .26 .0071\end{array}$ & $27603 / 2016$ & $19 / 05 / 2016$ & $\begin{array}{l}\text { Mandado de } \\
\text { Segurança }\end{array}$ & $16 / 05 / 2016$ & $\begin{array}{l}17 / 06 / 2016 \text { - denego a segurança pleiteada por ... e ..., } \\
\text { representado por ..., representado por ..., contra ato do } \\
\text { secretario municipal de saúde de Bauru, e julgo extinto o } \\
\text { processo, com resolução de mérito, - - 23/06/2017 - } \\
\text { remetido ao dje - relação: 0488/2017 teor do ato: } \\
\text { vistos.ciência às partes do retorno dos autos.nada sendo } \\
\text { requerido em } 30 \text { dias, arquivem-se. }\end{array}$ & $\begin{array}{c}\text { CUIDADOR/HOM } \\
\text { E CARE }\end{array}$ \\
\hline 376 & $\begin{array}{c}\text { 1009182- } \\
\text { 18.2016.8.26.0071 }\end{array}$ & $27746 / 2016$ & $20 / 05 / 2016$ & $\begin{array}{l}\text { Mandado de } \\
\text { Segurança }\end{array}$ & $16 / 05 / 2016$ & $\begin{array}{l}03 / 06 / 2016 \text { - concedo a segurança pleiteada por .... } \\
\text { contra ato do secretário municipal de saúde de Bauru, } \\
\text { para que o impetrado providencie o fornecimento ao } \\
\text { impetrante de dieta polimérica hipercalórica, hiperproteica, } \\
\text { com fibra - } 25 \mathrm{cal} / \mathrm{kg} / \mathrm{dia} \text { e } 1,1 \mathrm{~g} \text { proteína/kg/dia }(1.050 \\
\mathrm{ml} / \mathrm{dia}, 1.600 \mathrm{cal} / \mathrm{dia}, 63 \mathrm{~g} \text { proteína/dia e } 16 \mathrm{~g} \text { fibras/dia), } \\
\text { conforme prescrição médica de fls. } 24, \text { e julgo extinto o } \\
\text { processo, com resolução de mérito - } 01 / 11 / 2017 \text { - } \\
\text { recebidos os autos do tribunal de justiça - data do } \\
\text { julgamento: } 22 / 08 / 2017 \text { trânsito em julgado: tipo de } \\
\text { julgamento: acórdão decisão: negaram provimento aos } \\
\text { recursos. }\end{array}$ & $\begin{array}{l}\text { ALIMENTAÇÃO } \\
\text { ESPECIAL }\end{array}$ \\
\hline
\end{tabular}




\begin{tabular}{|c|c|c|c|c|c|c|c|}
\hline 377 & $\begin{array}{c}\text { 1009336- } \\
36.2016 .8 .26 .0071\end{array}$ & $28343 / 2016$ & $24 / 05 / 2016$ & $\begin{array}{l}\text { Mandado de } \\
\text { Segurança }\end{array}$ & $18 / 05 / 2016$ & $\begin{array}{l}\text { 06/06/2016 - concedo a segurança pleiteada por .... } \\
\text { contra ato do secretário municipal de saúde de Bauru, } \\
\text { para que o impetrado forneça ao impetrante fraldas } \\
\text { geriátricas - tamanho "g" (120 unidades por mês) - } \\
16 / 02 / 2018 \text { - remetido ao dje - relação: } 0100 / 2018 \text { teor do } \\
\text { ato: vistos.procedidas as anotaçōes de baixa, arquivem- } \\
\text { se. }\end{array}$ & FRALDA \\
\hline 378 & $\begin{array}{c}1008428- \\
76.2016 .8 .26 .0071\end{array}$ & $28374 / 2016$ & $24 / 05 / 2016$ & $\begin{array}{l}\text { Mandado de } \\
\text { Segurança }\end{array}$ & $18 / 05 / 2016$ & $\begin{array}{l}\text { 13/06/2016 - concedo a segurança pleiteada por.... contra } \\
\text { ato do secretário municipal de saúde de Bauru, para que } \\
\text { o impetrado forneça ao impetrante fraldas geriátricas } \\
\text { tamanho "g"- - - 09/06/2017 - remetido ao dje - relação: } \\
\text { 0459/2017 teor do ato: arquivo. }\end{array}$ & FRALDA \\
\hline 379 & $\begin{array}{c}\text { 1008693- } \\
78.2016 .8 .26 .0071\end{array}$ & $28351 / 2016$ & $24 / 05 / 2016$ & $\begin{array}{l}\text { Outros } \\
\text { Procediment } \\
\quad \text { os }\end{array}$ & $18 / 05 / 2016$ & $\begin{array}{l}\text { 17/05/2018 - o autor não cumpriu determinação que the } \\
\text { foi imposta, deixando o processo paralisado por mais de } \\
30 \text { dias. - ante o exposto, julgo extinto o processo. }\end{array}$ & $\begin{array}{l}\text { APRESENTAÇÃO } \\
\text { DE PRONTUÁRIO }\end{array}$ \\
\hline 380 & $\begin{array}{c}1009348- \\
50.2016 .8 .26 .0071\end{array}$ & 28899/2016 & $30 / 05 / 2016$ & $\begin{array}{l}\text { Mandado de } \\
\text { Segurança }\end{array}$ & & $\begin{array}{l}\text { 15-05/17 - tornar definitiva a liminar deferida e determinar } \\
\text { ao Secretário Municipal de Saúde o fornecimento de } \\
\text { fraldas descartáveis geriátricas BIGFRAL PLUS, tamanho } \\
G \text { noturno, 240 unidades, por mês, por tempo } \\
\text { indeterminado. }\end{array}$ & FRALDA \\
\hline 381 & $\begin{array}{c}\text { 1009727- } \\
\text { 88.2016.8.26.0071 }\end{array}$ & $28978 / 2016$ & $30 / 05 / 2016$ & $\begin{array}{l}\text { Mandado de } \\
\text { Segurança }\end{array}$ & & $\begin{array}{l}\text { 27/04/2017 - FORNECIMENTO DE MEDICAMENTOS E } \\
\text { INSUMOS - CRIANCA PORTADORA DE ALERGIA Ầ } \\
\text { PROTEÍNA DO LEITE DE VACA, QUE NECESSITA DO } \\
\text { FORNECIMENTO DO LEITE NEOCATE, NA } \\
\text { QUANTIDADE DE } 12 \text { LATAS POR MESS. }\end{array}$ & $\begin{array}{l}\text { ALIMENTAÇÃO } \\
\text { ESPECIAL }\end{array}$ \\
\hline 382 & $\begin{array}{c}1009352- \\
87.2016 .8 .26 .0071\end{array}$ & $29166 / 2016$ & $31 / 05 / 2016$ & $\begin{array}{c}\text { Outros } \\
\text { Procediment } \\
\text { os }\end{array}$ & & 28/03/18 - Negaram provimento ao reexame necessário. & $\begin{array}{l}\text { CONSULTA } \\
\text { MÉDICA }\end{array}$ \\
\hline 383 & $\begin{array}{c}\text { 1009643- } \\
87.2016 .8 .26 .0071\end{array}$ & $29243 / 2016$ & $31 / 05 / 2016$ & $\begin{array}{l}\text { Mandado de } \\
\text { Segurança }\end{array}$ & $24 / 05 / 2016$ & $\begin{array}{l}\text { 14/06/2016 - concedo a segurança pleiteada por .... } \\
\text { contra ato do secretário municipal de saúde de Bauru, } \\
\text { para que o impetrado forneça à impetrante fraldas } \\
\text { geriátricas tamanho "xg" - - - remetido ao dje - relação: } \\
0403 / 2017 \text { teor do ato: vistos.procedias as devidas } \\
\text { anotações de baixa, arquivem-se }\end{array}$ & FRALDA \\
\hline 384 & $\begin{array}{c}\text { 1009703- } \\
60.2016 .8 .26 .0071\end{array}$ & $29494 / 2016$ & $01 / 06 / 2016$ & $\begin{array}{l}\text { Mandado de } \\
\text { Segurança }\end{array}$ & $25 / 05 / 2016$ & $\begin{array}{l}27 / 06 / 2016 \text { - concedo a segurança pleiteada por .... } \\
\text { contra ato do secretário municipal de saúde, para que o } \\
\text { impetrado forneça à impetrante fraldas geriátricas } \\
\text { tamanho "g" - 09/06/2017 - remetido ao dje - relação: } \\
\text { 0459/2017 teor do ato: arquivo. }\end{array}$ & FRALDA \\
\hline
\end{tabular}




\begin{tabular}{|c|c|c|c|c|c|c|c|}
\hline 385 & $\begin{array}{c}\text { 1009697- } \\
\text { 53.2016.8.26.0071 }\end{array}$ & $29751 / 2016$ & $02 / 06 / 2016$ & $\begin{array}{l}\text { Mandado de } \\
\text { Segurança }\end{array}$ & $25 / 05 / 2016$ & $\begin{array}{l}10 / 06 / 2016 \text { - concedo a segurança pleiteada por .... } \\
\text { contra ato do secretário municipal de saúde de Bauru, } \\
\text { para que o impetrado forneça ao impetrante fraldas } \\
\text { descartáveis tamanho "gg" - }-16 / 05 / 2017 \\
\text { vistos.procedias as devidas anotações de baixa, } \\
\text { arquivem-se os autos. }\end{array}$ & FRALDA \\
\hline 386 & $\begin{array}{c}\text { 1009806- } \\
67.2016 .8 .26 .0071\end{array}$ & 29757/2016 & 02/06/2016 & $\begin{array}{l}\text { Mandado de } \\
\text { Segurança }\end{array}$ & $31 / 05 / 2016$ & $\begin{array}{l}\text { 22/06/2016 - concedo a segurança pleiteada por.... contra } \\
\text { ato do secretário municipal de saúde de Bauru, para que } \\
\text { o impetrado forneça à impetrante fraldas geriátricas } \\
\text { descartáveis - tamanho "g" - - 20/06/2017 - relação: } \\
\text { 0397/2017 teor do ato: vistos. procedidas as devidas } \\
\text { anotações de baixa, arquivem-se. }\end{array}$ & FRALDA \\
\hline 387 & $\begin{array}{c}\text { 1008276- } \\
\text { 28.2016.8.26.0071 }\end{array}$ & 29778/2016 & 02/06/2016 & $\begin{array}{l}\text { Mandado de } \\
\text { Segurança }\end{array}$ & $31 / 05 / 2016$ & $\begin{array}{l}\text { 28/06/2016 - concedo a segurança pleiteada por .... contra } \\
\text { ato do secretário municipal de saúde de Bauru, para que o } \\
\text { impetrado forneça à impetrante fraldas geriátricas } \\
\text { descartáveis - tamanho "g" ( } 240 \text { unidades por mês), e julgo } \\
\text { extinto o processo, com resolução de mérito - - 20/06/2017 } \\
\text { - relação: 0397/2017 teor do ato: vistos.procedidas as } \\
\text { devidas anotações de baixa, arquivem-se - }\end{array}$ & FRALDA \\
\hline 388 & $\begin{array}{c}1009803- \\
15.2016 .8 .26 .0071\end{array}$ & 29828/2016 & 02/06/2016 & $\begin{array}{l}\text { Mandado de } \\
\text { Segurança }\end{array}$ & $31 / 05 / 2016$ & $\begin{array}{l}\text { 22/06/2016 - concedo a segurança pleiteada por ... contra } \\
\text { ato do secretário municipal de saúde de Bauru, para que } \\
\text { o impetrado forneça ao impetrante fraldas geriátricas } \\
\text { descartáveis - tamanho "g" - - 09/06/2017 - remetido ao } \\
\text { dje - relação: 0385/2017 teor do ato: arquivo }\end{array}$ & FRALDA \\
\hline 389 & $\begin{array}{c}\text { 1009337- } \\
\text { 21.2016.8.26.0071 }\end{array}$ & $30049 / 2016$ & 03/06/2016 & $\begin{array}{l}\text { Mandado de } \\
\text { Segurança }\end{array}$ & $31 / 05 / 2016$ & $\begin{array}{l}24 / 06 / 2016 \text { - concedo a segurança pleiteada por .... } \\
\text { contra ato do secretário municipal de saúde de Bauru, } \\
\text { para que o impetrado forneça ao impetrante fraldas } \\
\text { geriátricas descartáveis - tamanho "g" - } 08 / 05 / 2017 \text { - } \\
\text { remetido ao dje - relação: 0296/2017 teor do ato: } \\
\text { vistos.ciência às partes do retorno dos autos.nada sendo } \\
\text { requerido em } 30 \text { dias, arquivem-se. }\end{array}$ & FRALDA \\
\hline 390 & $\begin{array}{c}\text { 1009625- } \\
66.2016 .8 .26 .0071\end{array}$ & $30582 / 2016$ & 07/06/2016 & $\begin{array}{l}\text { Mandado de } \\
\text { Segurança }\end{array}$ & $31 / 05 / 2016$ & $\begin{array}{l}30 / 06 / 2016 \text { - concedo a segurança pleiteada por .... contra } \\
\text { ato do secretário municipal de saúde de Bauru, para que o } \\
\text { impetrado providencie o fornecimento à impetrante de dieta } \\
\text { polimérica normocalórica e normoproteica com fibras } \\
\text { espećífica para paciente diabético - } 28 \mathrm{kcal} / \mathrm{kg} / \mathrm{dia} \text { e } 1.3 \mathrm{~g} \\
\text { proteína/gg/dia (42 litros por mês), e julgo extinto o } \\
\text { processo, com resolução de mérito - }-25 / 11 / 2016- \\
\text { remetido ao dje - relação: 0578/2016 teor do ato: } \\
\text { vistos.certifique a serventia o decurso do prazo para } \\
\text { interposição de recurso.após, arquive-se. }\end{array}$ & MEDICAMENTO \\
\hline
\end{tabular}




\begin{tabular}{|c|c|c|c|c|c|c|c|}
\hline 391 & $\begin{array}{c}\text { 1011947- } \\
93.2015 .8 .26 .0071\end{array}$ & $30711 / 2016$ & 07/06/2016 & $\begin{array}{l}\text { Mandado de } \\
\text { Segurança }\end{array}$ & & SEGREDO DE JUSTIÇA & $\begin{array}{l}\text { SEGREDO DE } \\
\text { JUSTIÇA }\end{array}$ \\
\hline 392 & $\begin{array}{c}1007946- \\
31.2016 .8 .26 .0071\end{array}$ & $31007 / 2016$ & 08/06/2016 & $\begin{array}{l}\text { Mandado de } \\
\text { Segurança }\end{array}$ & 03/06/2016 & $\begin{array}{l}\text { 06/07/2016 - concedo a segurança pleiteada por .... } \\
\text { contra ato do secretário municipal de saúde, para que o } \\
\text { impetrado forneça à impetrante fraldas geriátricas } \\
\text { tamanho "m" - -09/06/2017 - arquivo. }\end{array}$ & FRALDA \\
\hline 393 & $\begin{array}{c}1010252- \\
70.2016 .8 .26 .0071\end{array}$ & $31010 / 2016$ & 08/06/2016 & $\begin{array}{l}\text { Mandado de } \\
\text { Segurança }\end{array}$ & 03/06/2016 & $\begin{array}{l}\text { 06/07/2016 - concedo a segurança pleiteada por ... contra } \\
\text { ato do diretor da secretária municipal de saúde de Bauru, } \\
\text { para que o impetrado forneça ao impetrante fraldas } \\
\text { geriátricas tamanho "g" - - } 21 / 02 / 2018 \text { - remetido ao dje - } \\
\text { relação: } 0119 / 2018 \text { teor do ato: vistos.procedidas as } \\
\text { anotações de baixa, arquivem-se. }\end{array}$ & FRALDA \\
\hline 394 & $\begin{array}{c}1025108- \\
73.2015 .8 .26 .0071\end{array}$ & $32409 / 2016$ & $15 / 06 / 2016$ & $\begin{array}{l}\text { Outros } \\
\text { Procediment } \\
\text { os }\end{array}$ & & $\begin{array}{l}\text { 04/11/16 - julgo procedentes os pedidos da presente } \\
\text { ação de obrigação de fazer, com pedido de tutela } \\
\text { antecipada. }\end{array}$ & $\begin{array}{l}\text { CONSULTA } \\
\text { MÉDICA }\end{array}$ \\
\hline 395 & $\begin{array}{c}1010449- \\
25.2016 .8 .26 .0071\end{array}$ & $32489 / 2016$ & $16 / 06 / 2016$ & $\begin{array}{l}\text { Mandado de } \\
\text { Segurança }\end{array}$ & 07/06/2016 & $\begin{array}{l}\text { 06/07/2016 - concedo a segurança pleiteada por .... } \\
\text { contra ato do secretário municipal de saúde, para que o } \\
\text { impetrado forneça à impetrante fraldas geriátricas } \\
\text { tamanho "g" } 06 \text { (seis) unidades por dia, conforme } \\
\text { receituário de fls. 17, e julgo extinto o processo, com } \\
\text { resolução de mérito. }\end{array}$ & FRALDA \\
\hline 396 & $\begin{array}{c}1010234- \\
49.2016 .8 .26 .0071\end{array}$ & $32540 / 2016$ & $16 / 06 / 2016$ & $\begin{array}{l}\text { Mandado de } \\
\text { Segurança }\end{array}$ & $13 / 06 / 2016$ & $\begin{array}{l}21 / 09 / 2016 \text { - Julga procedente pedido fornecimento de } \\
\text { leite Neocate. }\end{array}$ & $\begin{array}{l}\text { ALIMENTAÇÃO } \\
\text { ESPECIAL }\end{array}$ \\
\hline 397 & $\begin{array}{c}1010773- \\
15.2016 .8 .26 .0071\end{array}$ & $32787 / 2016$ & $20 / 06 / 2016$ & $\begin{array}{l}\text { Mandado de } \\
\text { Segurança }\end{array}$ & $13 / 06 / 2016$ & $\begin{array}{l}\text { 07/07/2016 - concedo a segurança pleiteada por .... } \\
\text { contra ato do secretário municipal de saúde de Bauru, } \\
\text { para que o impetrado forneça à impetrante fraldas } \\
\text { geriátricas descartáveis - }-29 / 11 / 2017 \text { - arquivado } \\
\text { definitivamente. }\end{array}$ & FRALDA \\
\hline 398 & $\begin{array}{c}1007496- \\
88.2016 .8 .26 .0071\end{array}$ & $33084 / 2016$ & $20 / 06 / 2016$ & $\begin{array}{l}\text { Mandado de } \\
\text { Segurança }\end{array}$ & $15 / 06 / 2016$ & $\begin{array}{l}14 / 07 / 2016 \text { - concedo a segurança pleiteada por .... } \\
\text { contra ato do secretaria municipal de saúde, para que o } \\
\text { impetrado forneça à impetrante fraldas geriátricas } \\
\text { tamanho "g" - - } 17 / 05 / 2017 \text { - remetido ao dje - relação: } \\
0403 / 2017 \text { teor do ato: vistos.procedias as devidas } \\
\text { anotações de baixa, arquivem-se }\end{array}$ & FRALDA \\
\hline
\end{tabular}




\begin{tabular}{|c|c|c|c|c|c|c|c|}
\hline 399 & $\begin{array}{c}\text { 1010915- } \\
19.2016 .8 .26 .0071\end{array}$ & $33495 / 2016$ & $22 / 06 / 2016$ & $\begin{array}{l}\text { Mandado de } \\
\text { Segurança }\end{array}$ & $15 / 06 / 2016$ & $\begin{array}{l}11 / 07 / 2016 \text { - concedo a segurança pleiteada por .... } \\
\text { contra ato do secretário municipal de saúde de Bauru, } \\
\text { para que o impetrado forneça à impetrante fraldas } \\
\text { geriátricas descartáveis - tamanho "g" }-23 / 03 / 2017 \text { - } \\
\text { remetido ao dje - relação: 0205/2017 teor do ato: } \\
\text { vistos.procedidas as devidas anotações de baixa, } \\
\text { arquivem-se. }\end{array}$ & FRALDA \\
\hline 400 & $\begin{array}{c}1000683- \\
45.2016 .8 .26 .0071\end{array}$ & $33519 / 2016$ & $22 / 06 / 2016$ & $\begin{array}{l}\text { Mandado de } \\
\text { Segurança }\end{array}$ & & $\begin{array}{l}\text { 05/06/19. - APELAÇÃO E REMESSA NECESSÁRIA ÀS } \\
\text { QUAIS SE NEGA PROVIMENTO }\end{array}$ & MEDICAMENTO \\
\hline 401 & $\begin{array}{c}1005903- \\
24.2016 .8 .26 .0071\end{array}$ & $33523 / 2016$ & $22 / 06 / 2016$ & $\begin{array}{l}\text { Mandado de } \\
\text { Segurança }\end{array}$ & & SEGREDO DE JUSTIÇA & $\begin{array}{l}\text { SEGREDO DE } \\
\text { JUSTIÇA }\end{array}$ \\
\hline 402 & $\begin{array}{c}\text { 1011247- } \\
\text { 83.2016.8.26.0071 }\end{array}$ & $33583 / 2016$ & 22/06/2016 & $\begin{array}{l}\text { Mandado de } \\
\text { Segurança }\end{array}$ & 17/06/2016 & $\begin{array}{l}\text { 07/07/2016 - concedo a segurança pleiteada por .... } \\
\text { contra ato do secretário municipal de saúde de Bauru, } \\
\text { para que o impetrado forneça à impetrante fraldas } \\
\text { geriátricas descartáveis - tamanho "g" (120 unidades por } \\
\text { mês), e julgo extinto o processo, com resolução de mérito } \\
\text { - - 05/10/2017 - arquivado definitivamente - }\end{array}$ & FRALDA \\
\hline 403 & $\begin{array}{c}1010679- \\
67.2016 .8 .26 .0071 \\
\end{array}$ & $33644 / 2016$ & $22 / 06 / 2016$ & $\begin{array}{c}\text { Mandado de } \\
\text { Segurança }\end{array}$ & & SEGREDO DE JUSTIÇA & $\begin{array}{c}\text { SEGREDO DE } \\
\text { JUSTIÇA }\end{array}$ \\
\hline 404 & $\begin{array}{c}1010480- \\
45.2016 .8 .26 .0071\end{array}$ & $33739 / 2016$ & $23 / 06 / 2016$ & $\begin{array}{l}\text { Mandado de } \\
\text { Segurança }\end{array}$ & $20 / 06 / 2016$ & $\begin{array}{l}\text { 12/07/2016 - concedo a segurança pleiteada por ..... } \\
\text { contra ato do secretário municipal de saúde de Bauru, } \\
\text { para que o impetrado forneça à impetrante fraldas } \\
\text { geriátricas - - 24/04/2017 - considerando que a r. } \text {. } \\
\text { sentença transitou em julgado, precedidas as devidas } \\
\text { anotaçôes de baixa, arquivem-se }\end{array}$ & FRALDA \\
\hline 405 & $\begin{array}{l}\text { 1006730- } \\
35.2016 .8 .26 .0071\end{array}$ & $33983 / 2016$ & $24 / 06 / 2016$ & $\begin{array}{l}\text { Mandado de } \\
\text { Segurança }\end{array}$ & & SEGREDO DE JUSTIÇA & $\begin{array}{l}\text { SEGREDO DE } \\
\text { JUSTIÇA }\end{array}$ \\
\hline 406 & $\begin{array}{c}1009680- \\
17.2016 .8 .26 .0071\end{array}$ & $34020 / 2016$ & $24 / 06 / 2016$ & $\begin{array}{l}\text { Mandado de } \\
\text { Segurança }\end{array}$ & $21 / 06 / 2016$ & $\begin{array}{l}\text { 03/08/2016 - concedo a segurança pleiteada por .... } \\
\text { contra ato do secretário municipal de saúde, para que o } \\
\text { impetrado forneça à impetrante fraldas geriátricas } \\
\text { tamanho "xg" - -09/06/2017- remetido ao dje - relação: } \\
\text { 0459/2017 teor do ato: vistos.procedidas as devidas } \\
\text { anotações de baixa, arquivem-se. }\end{array}$ & FRALDA \\
\hline
\end{tabular}




\begin{tabular}{|c|c|c|c|c|c|c|c|}
\hline 407 & $\begin{array}{c}1011052- \\
98.2016 .8 .26 .0071\end{array}$ & $34722 / 2016$ & 29/06/2016 & $\begin{array}{c}\text { Mandado de } \\
\text { Segurança }\end{array}$ & 17/06/2016 & $\begin{array}{l}\text { 03/08/2016 - concedo a segurança pleiteada por .... } \\
\text { contra ato do secretário municipal de saúde, para que o } \\
\text { impetrado forneça à impetrante fraldas geriátricas - - } \\
04 / 07 / 2017 \text { - remetido ao dje - relação: } 0518 / 2017 \text { teor do } \\
\text { ato: vistos.procedidas as devidas anotações de baixa, } \\
\text { arquivem-se. }\end{array}$ & FRALDA \\
\hline 408 & $\begin{array}{c}\text { 1011673- } \\
95.2016 .8 .26 .0071\end{array}$ & $35069 / 2016$ & 30/06/2016 & $\begin{array}{l}\text { Mandado de } \\
\text { Segurança }\end{array}$ & 27/06/2016 & $\begin{array}{l}19 / 07 / 2016 \text { - concedo a segurança pleiteada por .... } \\
\text { contra ato do secretário municipal de saúde, para que o } \\
\text { impetrado forneça a impetrante fraldas geriátricas } \\
\text { tamanho "g" - - 28/03/2017 - remetido ao dje - relação: } \\
0282 / 2017 \text { teor do ato: vistos. arquivem-se. }\end{array}$ & FRALDA \\
\hline 409 & $\begin{array}{c}\text { 1010334- } \\
\text { 04.2016.8.26.0071 }\end{array}$ & $35066 / 2016$ & $30 / 06 / 2016$ & $\begin{array}{l}\text { Outros } \\
\text { Procediment } \\
\text { os }\end{array}$ & & 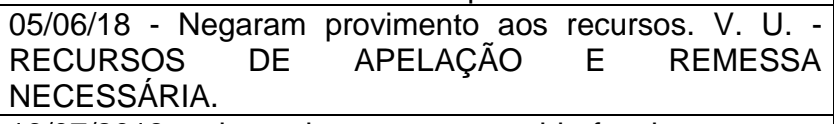 & CIRURGIA \\
\hline 410 & $\begin{array}{c}\text { 1010733- } \\
\text { 33.2016.8.26.0071 }\end{array}$ & $35074 / 2016$ & $30 / 06 / 2016$ & $\begin{array}{l}\text { Outros } \\
\text { Procediment } \\
\quad \text { os }\end{array}$ & $24 / 06 / 2016$ & $\begin{array}{l}\text { 13/07/2018 - determino que o requerido faculte o acesso } \\
\text { dos autores aos documentos originais em questão, pelo } \\
\text { prazo de } 15 \text { dias, contados da respectiva juntada aos } \\
\text { autos de informação a ser prestada pela municipalidade } \\
\text { quanto ao local em que estarão disponíveis. }\end{array}$ & $\begin{array}{l}\text { APRESENTACCÃO } \\
\text { DE PRONTUÁRIO }\end{array}$ \\
\hline 411 & $\begin{array}{c}1010333- \\
19.2016 .8 .26 .0071\end{array}$ & $35985 / 2016$ & 05/07/2016 & $\begin{array}{c}\text { Mandado de } \\
\text { Segurança }\end{array}$ & & $\begin{array}{l}\text { 26/04/17 - Negaram provimento aos apelos voluntários } \\
\text { do Município. }\end{array}$ & $\begin{array}{l}\text { INSUMOS/MATE } \\
\text { RIAL } \\
\text { HOSPITALAR }\end{array}$ \\
\hline 412 & $\begin{array}{c}\text { 1011802- } \\
\text { 03.2016.8.26.0071 }\end{array}$ & $36126 / 2016$ & 05/07/2016 & $\begin{array}{c}\text { Mandado de } \\
\text { Segurança }\end{array}$ & 28/06/2016 & $\begin{array}{l}\text { 18/07/2016 - CONCEDO A SEGURANÇA pleiteada por ... } \\
\text { contra ato do SECRETÁRIO MUNICIPAL DE SAÚDE DE } \\
\text { BAURU, para que o impetrado forneça ao impetrante } \\
\text { FRALDAS DESCARTÁVEIS - tamanho "M" adulto ( } 180 \\
\text { unidades por mês), e julgo extinto o processo, com } \\
\text { resolução de mérito, nos termos do art. 487, I do Código } \\
\text { de Processo Civil. }\end{array}$ & FRALDA \\
\hline 413 & $\begin{array}{c}\text { 1011439- } \\
16.2016 .8 .26 .0071\end{array}$ & $36771 / 2016$ & 08/07/2016 & $\begin{array}{l}\text { Outros } \\
\text { Procediment } \\
\quad \text { os }\end{array}$ & 05/07/2016 & $\begin{array}{l}\text { 15/03/2017 - reconheço a carência superveniente, e julgo } \\
\text { extinto o processo sem resolução de mérito, com base } \\
\text { nos artigos } 485 \text {, vi, c.c. } 493 \text {, ambos do cpc.após o trânsito } \\
\text { em julgado, expeça-se a competente certidão de } \\
\text { honorários e arquivem-se. }\end{array}$ & INTERNAÇÃO \\
\hline 414 & $\begin{array}{c}\text { 1012185- } \\
78.2016 .8 .26 .0071\end{array}$ & $36974 / 2016$ & 11/07/2016 & $\begin{array}{l}\text { Mandado de } \\
\text { Segurança }\end{array}$ & 05/07/2016 & $\begin{array}{l}\text { 26/07/2016 - concedo a segurança pleiteada por ... contra } \\
\text { ato do secretário municipal de saúde, para que o } \\
\text { impetrado forneça ao impetrante fraldas geriátricas - - } \\
\text { 19/10/2017 - arquivado definitivamente - }\end{array}$ & FRALDA \\
\hline
\end{tabular}




\begin{tabular}{|c|c|c|c|c|c|c|c|}
\hline 415 & $\begin{array}{c}\text { 1012588- } \\
47.2016 .8 .26 .0071\end{array}$ & $37274 / 2016$ & 12/07/2016 & $\begin{array}{l}\text { Mandado de } \\
\text { Segurança }\end{array}$ & 08/07/2016 & $\begin{array}{l}\text { 27/07/2016 - concedo a segurança pleiteada por .... } \\
\text { contra ato do secretaria municipal de saúde, para que o } \\
\text { impetrado forneça à impetrante fraldas geriátricas } \\
\text { tamanho "xg" - - 19/10/2017 - arquivado definitivamente. }\end{array}$ & FRALDA \\
\hline 416 & $\begin{array}{c}1010231- \\
94.2016 .8 .26 .0071\end{array}$ & $37859 / 2016$ & $14 / 07 / 2016$ & $\begin{array}{l}\text { Mandado de } \\
\text { Segurança }\end{array}$ & & $\begin{array}{l}\text { 27/04/2017 - fornecimento do medicamento Canabidiol } \\
\text { (Oil Hemp - 10g), por tempo indeterminado. }\end{array}$ & MEDICAMENTO \\
\hline 417 & $\begin{array}{c}\text { 1010310- } \\
\text { 73.2016.8.26.0071 }\end{array}$ & $38274 / 2016$ & 18/07/2016 & $\begin{array}{l}\text { Mandado de } \\
\text { Segurança }\end{array}$ & 14/07/2016 & $\begin{array}{l}\text { 15/08/2016 - concedo a segurança pleiteada por .... } \\
\text { contra ato do secretário municipal de saúde, para que o } \\
\text { impetrado forneça à impetrante fraldas geriátricas } \\
\text { tamanho "g" - - 04/07/2017 - relação: } 0518 / 2017 \text { teor do } \\
\text { ato: vistos.procedidas as devidas anotações de baixa, } \\
\text { arquivem-se. }\end{array}$ & FRALDA \\
\hline 418 & $\begin{array}{c}\text { 1011567- } \\
36.2016 .8 .26 .0071\end{array}$ & $38432 / 2016$ & 19/07/2016 & $\begin{array}{l}\text { Outros } \\
\text { Procediment } \\
\text { os }\end{array}$ & $11 / 07 / 2016$ & $\begin{array}{l}\text { 11/05/2017 - julgo procedente o pedido, formulado por ... } \\
\text { contra o municipio de Bauru, determinando que o } \\
\text { requerido forneça a requerente: fraldas descartáveis } \\
\text { geriátricas - - } 02 / 05 / 2018 \text { - arquivado definitivamente. }\end{array}$ & FRALDA \\
\hline 419 & $\begin{array}{c}\text { 1012695- } \\
91.2016 .8 .26 .0071\end{array}$ & $38443 / 2016$ & 19/07/2016 & $\begin{array}{l}\text { Mandado de } \\
\text { Segurança }\end{array}$ & $11 / 07 / 2016$ & $\begin{array}{l}\text { 25/07/2016 - concedo a segurança pleiteada por .... } \\
\text { contra ato do secretário municipal de saúde de Bauru, } \\
\text { para que o impetrado forneça ao impetrante fraldas } \\
\text { geriátricas descartáveis - }-11 / 01 / 2018 \text { - arquivado } \\
\text { definitivamente. }\end{array}$ & FRALDA \\
\hline 420 & $\begin{array}{c}0003042- \\
16.2016 .4 .03 .6325\end{array}$ & $38509 / 2016$ & 19/07/2016 & $\begin{array}{c}\text { Outros } \\
\text { Procediment } \\
\text { os }\end{array}$ & $27 / 06 / 2016$ & $\begin{array}{lll}\text { 02/03/2017 - SENTENCCA COM RESOLUÇÃO } & \text { DE } \\
\text { MÉRITO IMPROCEDENTE A AÇÃO - TERMO } & \text { № } \\
\text { 2017/6325002538. } & & \\
\end{array}$ & MEDICAMENTO \\
\hline 421 & $\begin{array}{c}0003600- \\
85.2016 .4 .03 .6325\end{array}$ & $38511 / 2016$ & 19/07/2016 & $\begin{array}{c}\text { Outros } \\
\text { Procediment } \\
\text { os }\end{array}$ & 15/07/2016 & $\begin{array}{l}\text { - 11/04/2017 - JULGO EXTINTO o processo sem } \\
\text { resolução de mérito, ante a perda superveniente do objeto } \\
\text { da ação. }\end{array}$ & $\begin{array}{l}\text { INSUMOS/MATE } \\
\text { RIAL } \\
\text { HOSPITALAR }\end{array}$ \\
\hline 422 & $\begin{array}{c}0002372- \\
75.2016 .4 .03 .6325\end{array}$ & $38517 / 2016$ & 19/07/2016 & $\begin{array}{l}\text { Outros } \\
\text { Procediment } \\
\text { os }\end{array}$ & $22 / 06 / 2016$ & $\begin{array}{l}\text { - } 19 / 01 / 2018 \text { - SENTENÇA COM RESOLUÇÃO DE } \\
\text { MÉRITO PROCEDENTE A AÇÃO - 20/09/2018 - } \\
\text { JULGAMENTO MANTÉM A SENTENÇA/DECISÃO - } \\
\text { TERMO № 2018/9301183143. }\end{array}$ & MEDICAMENTO \\
\hline
\end{tabular}




\begin{tabular}{|c|c|c|c|c|c|c|c|}
\hline 423 & $\begin{array}{c}0002859- \\
45.2016 .4 .03 .6325\end{array}$ & $38519 / 2016$ & 19/07/2016 & $\begin{array}{l}\text { Outros } \\
\text { Procediment } \\
\text { os }\end{array}$ & & $\begin{array}{l}\text { 05/07/17 - julgo PROCEDENTE o pedido, para } \\
\text { condenação dos réus ao 2017/632500052099-53854-JEF } \\
\text { Assinado digitalmente por: CLAUDIO ROBERTO } \\
\text { CANATA:10167 Documento №: 2017/632500052099- } \\
53854 \quad \text { Consulte autenticidade eme em: } \\
\text { http://web.trf3.jus.br/autenticacaojef fornecimento contínuo } \\
\text { à autora dos medicamentos Daflon 500 (Daflon ou } \\
\text { Perivasc - Diosmina + Hesperidina) e Venalot ou } \\
\text { similares, com idêntico(s) princípio(s) ativo(s), bem como } \\
\text { meias elásticas de compressão, uma (um "par") a cada } \\
\text { quatro meses, conforme receituário médico que instrui a } \\
\text { petição inicial, e extingo o processo }\end{array}$ & MEDICAMENTO \\
\hline 424 & $\begin{array}{c}\text { 0003061- } \\
22.2016 .4 .03 .6325\end{array}$ & $38522 / 2016$ & 19/07/2016 & $\begin{array}{c}\text { Outros } \\
\text { Procediment } \\
\text { os }\end{array}$ & & $\begin{array}{l}11 / 04 / 2017 \text { - JULGO EXTINTO o processo sem } \\
\text { resolução de mérito, ante a perda superveniente do objeto } \\
\text { da ação, nos termos do artigo } 485 \mathrm{VI} \text {, segunda figura, } \\
\text { CPC. }\end{array}$ & INTERNAÇÃO \\
\hline 425 & $\begin{array}{c}0002199- \\
51.2016 .4 .03 .6325\end{array}$ & $38662 / 2016$ & 20/07/2016 & $\begin{array}{l}\text { Outros } \\
\text { Procediment } \\
\text { os }\end{array}$ & 18/05/2017 & $\begin{array}{l}18 / 05 / 2017 \text { - julgo PROCEDENTE o pedido, para } \\
\text { condenação os réus ao fornecimento contínuo ao autor de } \\
\text { insulina, adequada ao diagnóstico de diabetes mellitus } \\
\text { tipo } 1 \text {, de que é portador, bem como de fitas ou tiras } \\
\text { reagentes, utilizadas para o controle diário do diabetes, } \\
\text { suficientes para o tratamento, na forma da prescrição } \\
\text { médica, e extingo o processo, nos termos do artigo } 485 \text {, I, } \\
\text { do Código de Processo Civil }\end{array}$ & MEDICAMENTO \\
\hline 426 & $\begin{array}{c}\text { 1013007- } \\
67.2016 .8 .26 .0071\end{array}$ & 38722/2016 & 20/07/2016 & $\begin{array}{l}\text { Mandado de } \\
\text { Segurança }\end{array}$ & 15/07/2016 & $\begin{array}{l}\text { 08/08/2016 - concedo a segurança pleiteada por .... } \\
\text { contra ato do secretário municipal de saúde de Bauru, } \\
\text { para que o impetrado providencie o fornecimento ao } \\
\text { impetrante de suplemento líquido hiperproteico específico } \\
\text { para cicatrização de feridas, sabor baunilha (02 unidades } \\
\text { ao dia - } 60 \text { unidades/mês), e julgo extinto o processo, com } \\
\text { resolução de mérito, - - } 23 / 03 / 2017 \text { - remetido ao dje - } \\
\text { relação: 0205/2017 teor do ato: vistos.procedidas as } \\
\text { devidas anotações de baixa, arquivem-se }\end{array}$ & $\begin{array}{l}\text { ALIMENTAÇÃO } \\
\text { ESPECIAL }\end{array}$ \\
\hline 427 & $\begin{array}{c}1013008- \\
52.2016 .8 .26 .0071\end{array}$ & $38759 / 2016$ & 20/07/2016 & $\begin{array}{l}\text { Mandado de } \\
\text { Segurança }\end{array}$ & 14/07/2016 & $\begin{array}{l}\text { 26/07/2016 - concedo a segurança pleiteada por ..... } \\
\text { contra ato do secretário municipal de saúde, para que o } \\
\text { impetrado forneça ao impetrante fraldas geriátricas - } \\
\text { 26/10/2017 - remetido ao dje - relação: } 0738 / 2017 \text { teor do } \\
\text { ato: vistos.procedidas as devidas anotações de baixa, } \\
\text { arquivem-se - }\end{array}$ & FRALDA \\
\hline
\end{tabular}




\begin{tabular}{|c|c|c|c|c|c|c|c|}
\hline 428 & $\begin{array}{c}1013293- \\
45.2016 .8 .26 .0071\end{array}$ & $39450 / 2016$ & $25 / 07 / 2016$ & $\begin{array}{l}\text { Mandado de } \\
\text { Segurança }\end{array}$ & 20/07/2016 & $\begin{array}{l}12 / 08 / 2016 \text { - concedo a segurança pleiteada por .... } \\
\text { contra ato do secretário municipal de saúde, para que o } \\
\text { impetrado forneça à impetrante fraldas geriátricas } \\
\text { tamanho "g" - - 04/07/2017 - remetido ao dje - relação: } \\
0518 / 2017 \text { teor do ato: vistos.procedidas as devidas } \\
\text { anotações de baixa, arquivem-se }\end{array}$ & FRALDA \\
\hline 429 & $\begin{array}{c}1013300- \\
37.2016 .8 .26 .0071\end{array}$ & $39452 / 2016$ & 25/07/2016 & $\begin{array}{l}\text { Mandado de } \\
\text { Segurança }\end{array}$ & 20/07/2016 & $\begin{array}{l}17 / 08 / 2016 \text { - concedo a segurança pleiteada por .... } \\
\text { contra ato do secretário municipal de saúde de Bauru, } \\
\text { para que o impetrado forneça à impetrante fraldas } \\
\text { geriátricas descartáveis - - 20/06/2017 - remetido ao dje } \\
\text { - relação: 0397/2017 teor do ato: vistos. procedidas as } \\
\text { devidas anotações de baixa, arquivem-se }\end{array}$ & FRALDA \\
\hline 430 & $\begin{array}{c}\text { 1013276- } \\
09.2016 .8 .26 .0071\end{array}$ & $39603 / 2016$ & $26 / 07 / 2016$ & $\begin{array}{l}\text { Mandado de } \\
\text { Segurança }\end{array}$ & 19/07/2016 & $\begin{array}{l}\text { 17/08/2016 - concedo parcialmente a segurança pleiteada } \\
\text { por .... contra ato do secretário municipal de saúde de } \\
\text { Bauru, para que o impetrado forneça à impetrante fraldas } \\
\text { geriátricas descartáveis - - 29/11/2017 - arquivado } \\
\text { definitivamente. }\end{array}$ & FRALDA \\
\hline 431 & $\begin{array}{c}\text { 1013449- } \\
33.2016 .8 .26 .0071\end{array}$ & $39661 / 2016$ & $26 / 07 / 2016$ & $\begin{array}{l}\text { Mandado de } \\
\text { Segurança }\end{array}$ & 21/07/2016 & $\begin{array}{l}\text { 09/08/2016 - concedo a segurança pleiteada por .... } \\
\text { contra ato do secretário municipal de saúde de Bauru, } \\
\text { para que o impetrado forneça à impetrante fraldas } \\
\text { geriátricas descartáveis - }-23 / 06 / 2017 \text { - arquivado } \\
\text { definitivamente. }\end{array}$ & FRALDA \\
\hline 432 & $\begin{array}{c}\text { 1013534- } \\
\text { 19.2016.8.26.0071 }\end{array}$ & $39893 / 2016$ & 27/07/2016 & $\begin{array}{l}\text { Mandado de } \\
\text { Segurança }\end{array}$ & 22/07/2016 & $\begin{array}{l}\text { 08/08/2016 - concedo parcialmente a segurança pleiteada } \\
\text { por .... contra ato do secretário municipal de saúde de } \\
\text { Bauru, para que o impetrado forneça à impetrante fraldas } \\
\text { geriátricas descartáveis - - 20/06/2017 - emetido ao dje - } \\
\text { relação: 0397/2017 teor do ato: vistos. procedidas as } \\
\text { devidas anotações de baixa, arquivem-se. }\end{array}$ & FRALDA \\
\hline 433 & $\begin{array}{c}\text { 1013589- } \\
67.2016 .8 .26 .0071\end{array}$ & $39896 / 2016$ & $27 / 07 / 2016$ & $\begin{array}{l}\text { Mandado de } \\
\text { Segurança }\end{array}$ & $22 / 07 / 2016$ & $\begin{array}{l}\text { 17/08/2016 - concedo parcialmente a segurança pleiteada } \\
\text { por .... contra ato do secretário municipal de saúde de } \\
\text { Bauru, para que o impetrado forneça à impetrante fraldas } \\
\text { geriátricas descartáveis - - } 23 / 06 / 2017 \text { - arquivado } \\
\text { definitivamente. }\end{array}$ & FRALDA \\
\hline 434 & $\begin{array}{c}\text { 1010594- } \\
\text { 81.2016.8.26.0071 }\end{array}$ & $40408 / 2016$ & 29/07/2016 & $\begin{array}{l}\text { Outros } \\
\text { Procediment } \\
\text { os }\end{array}$ & & SEGREDO DE JUSTIÇA & $\begin{array}{l}\text { SEGREDO DE } \\
\text { JUSTIÇA }\end{array}$ \\
\hline
\end{tabular}




\begin{tabular}{|c|c|c|c|c|c|c|c|}
\hline 435 & $\begin{array}{c}\text { 1013931- } \\
78.2016 .8 .26 .0071\end{array}$ & 40922/2016 & 03/08/2016 & $\begin{array}{l}\text { Mandado de } \\
\text { Segurança }\end{array}$ & 28/07/2016 & $\begin{array}{l}17 / 08 / 2016 \text { - concedo a segurança pleiteada por .... } \\
\text { contra ato do secretário municipal de saúde de Bauru, } \\
\text { para que o impetrado forneça à impetrante fraldas } \\
\text { geriátricas descartáveis hipoalergênicas - tamanho "m" } \\
\text { (120 unidades por mês), e julgo extinto o processo, com } \\
\text { resolução de mérito - - 28/04/2017 - arquivado } \\
\text { definitivamente - }\end{array}$ & FRALDA \\
\hline 436 & $\begin{array}{c}\text { 1013979- } \\
37.2016 .8 .26 .0071\end{array}$ & $41390 / 2016$ & 05/08/2016 & $\begin{array}{l}\text { Mandado de } \\
\text { Segurança }\end{array}$ & 29/07/2016 & $\begin{array}{l}\text { 19/08/2016 - concedo a segurança pleiteada por .... } \\
\text { contra ato do secretário municipal de saúde, para que o } \\
\text { impetrado forneça à impetrante fraldas geriátricas } \\
\text { tamanho "m" (180 unidades por mês), conforme } \\
\text { receituário médico de fls. 14/16, e julgo extinto o } \\
\text { processo, com resolução de mérito - } 07 / 06 / 2017 \text { - } \\
\text { arquivado definitivamente. }\end{array}$ & FRALDA \\
\hline 437 & $\begin{array}{c}1014264- \\
30.2016 .8 .26 .0071\end{array}$ & $41423 / 2016$ & 05/08/2016 & $\begin{array}{l}\text { Mandado de } \\
\text { Segurança }\end{array}$ & 03/08/2016 & $\begin{array}{l}17 / 08 / 2016 \text { - concedo a segurança pleiteada por .... } \\
\text { contra ato do secretário municipal de saúde de Bauru, } \\
\text { para que o impetrado forneça à impetrante fraldas } \\
\text { geriátricas descartáveis - - } 23 / 06 / 2017 \text { - arquivado } \\
\text { definitivamente - }\end{array}$ & FRALDA \\
\hline 438 & $\begin{array}{c}\text { 1014382- } \\
\text { 06.2016.8.26.0071 }\end{array}$ & $41660 / 2016$ & 08/08/2016 & $\begin{array}{l}\text { Mandado de } \\
\text { Segurança }\end{array}$ & 03/08/2016 & $\begin{array}{l}\text { 05/09/2016 - concedo a segurança pleiteada por .... } \\
\text { contra ato do secretário municipal de saúde, para que o } \\
\text { impetrado forneça ao impetrante fraldas geriátricas } \\
\text { tamanho "g" } 120 \text { (cento e vinte) unidades por mês, } \\
\text { conforme receituário de fls. 18, e julgo extinto o processo, } \\
\text { com resolução de mérito - - 19/10/2017 - arquivado } \\
\text { definitivamente - - }\end{array}$ & FRALDA \\
\hline 439 & $\begin{array}{c}1014446- \\
16.2016 .8 .26 .0071\end{array}$ & $41799 / 2016$ & 09/08/2016 & $\begin{array}{l}\text { Mandado de } \\
\text { Segurança }\end{array}$ & 04/08/2016 & \begin{tabular}{|l|}
$31 / 08 / 2016$ - concedo a segurança pleiteada por \\
contra ato do secretário municipal de saúde, para que o \\
impetrado forneça à impetrante fraldas geriátricas - - \\
$01 / 11 / 2017$ - arquivado definitivamente -
\end{tabular} & FRALDA \\
\hline
\end{tabular}




\begin{tabular}{|c|c|c|c|c|c|c|c|}
\hline 440 & $\begin{array}{c}\text { 1012747- } \\
\text { 87.2016.8.26.0071 }\end{array}$ & $41809 / 2016$ & 09/08/2016 & $\begin{array}{l}\text { Mandado de } \\
\text { Segurança }\end{array}$ & 20/07/2016 & $\begin{array}{l}\text { 30/08/2016 - concedo a segurança pleiteada por ... contra } \\
\text { ato do secretário municipal de saúde, para que o } \\
\text { impetrado providencie o fornecimento à impetrante do } \\
\text { medicamento capecitabina } 500 \mathrm{mg} \text { ( } 42 \text { cápsulas) e } 150 \mathrm{mg} \\
\text { (14 cápsulas) a cada } 21 \text { (vinte e um) dias, e julgo extinto o } \\
\text { processo, com resolução de mérito - - } 27 / 11 / 2017 \text { - } \\
\text { remetido ao dje - relação: } 0874 / 2017 \text { teor do ato: ciência } \\
\text { às partes do retorno dos autos do e. tribunal.eventual } \\
\text { cumprimento de sentença deverá tramitar em formato } \\
\text { digital, cujo requerimento deverá ser realizado por } \\
\text { peticionamento eletrônico e instruído com as seguintes } \\
\text { peças:i- sentença e acórdão, se existente;ii- certidão de } \\
\text { trânsito em julgado, se o caso;iii- demonstrativo do débito } \\
\text { atualizado, quando se tratar de execução por quantia } \\
\text { certa;iv- mandado de citação cumprido e procurações } \\
\text { outorgadas aos advogados das partes, além de outras } \\
\text { peças processuais que o exequente considere } \\
\text { necessárias.nada sendo requerido em } 30 \text { (trinta) dias, os } \\
\text { autos serão remetidos ao arquivo. }\end{array}$ & MEDICAMENTO \\
\hline 441 & $\begin{array}{c}\text { 1014444- } \\
46.2016 .8 .26 .0071\end{array}$ & $41998 / 2016$ & 09/08/2016 & $\begin{array}{l}\text { Mandado de } \\
\text { Segurança }\end{array}$ & 05/08/2016 & $\begin{array}{l}\text { 05/08/2016 - oncedo a segurança pleiteada por .... contra } \\
\text { ato do secretário municipal de saúde, para que o } \\
\text { impetrado forneça ao impetrante fraldas geriátricas - - } \\
16 / 03 / 2018 \text { - arquivado definitivamente - }\end{array}$ & FRALDA \\
\hline 442 & $\begin{array}{c}1007215- \\
35.2016 .8 .26 .0071\end{array}$ & $41995 / 2016$ & 09/08/2016 & $\begin{array}{l}\text { Mandado de } \\
\text { Segurança }\end{array}$ & & SEGREDO DE JUSTIÇA & $\begin{array}{c}\text { SEGREDO DE } \\
\text { JUSTIÇA }\end{array}$ \\
\hline 443 & $\begin{array}{c}\text { 1012696- } \\
76.2016 .8 .26 .0071\end{array}$ & $42369 / 2016$ & 10/08/2016 & $\begin{array}{l}\text { Mandado de } \\
\text { Segurança }\end{array}$ & 11/07/2016 & $\begin{array}{l}\text { 05/09/2016 - concedo a segurança pleiteada por .... } \\
\text { contra ato do secretário municipal de saúde, para que o } \\
\text { impetrado forneça ao impetrante fraldas geriátricas - - } \\
\text { 16/03/2018 - arquivado definitivamente. }\end{array}$ & FRALDA \\
\hline
\end{tabular}




\begin{tabular}{|c|c|c|c|c|c|c|c|}
\hline 444 & $\begin{array}{c}\text { 1013801- } \\
\text { 88.2016.8.26.0071 }\end{array}$ & $43643 / 2016$ & 18/08/2016 & $\begin{array}{l}\text { Outros } \\
\text { Procediment } \\
\text { os }\end{array}$ & $26 / 08 / 2016$ & $\begin{array}{l}\text { 25/01/2017 - julgo procedente o pedido para obrigar a } \\
\text { requerida prefeitura municipal de Bauru a fornecer cópia } \\
\text { integral do prontuário médico referente ao atendimento da } \\
\text { paciente e genitora do autor ..., na upa do geisel em } \\
\text { Bauru, no dia } 11 \text { de abril de } 2016 \text { sucumbente, condeno a } \\
\text { requerida ao pagamento de custas processuais e } \\
\text { honorários advocatícios que fixo em r\$ } 900,00 \\
\text { (novecentos) reais - - } 12 / 12 / 2017 \text { - ciência às partes do } \\
\text { retorno dos autos do e. tribunal.eventual cumprimento de } \\
\text { sentença deverá tramitar em formato digital, cujo } \\
\text { requerimento deverá ser realizado por peticionamento } \\
\text { eletrônico e instruído com demonstrativo do débito } \\
\text { atualizado, quando se tratar de execução por quantia } \\
\text { certa.nada sendo requerido em } 30 \text { (trinta) dias, os autos } \\
\text { serão remetidos ao arquivo. }\end{array}$ & $\begin{array}{l}\text { APRESENTACCÃO } \\
\text { DE PRONTUÁRIO }\end{array}$ \\
\hline 445 & $\begin{array}{c}\text { 1015147- } \\
74.2016 .8 .26 .0071\end{array}$ & $43726 / 2016$ & 18/08/2016 & $\begin{array}{l}\text { Mandado de } \\
\text { Segurança }\end{array}$ & $12 / 08 / 2016$ & $\begin{array}{l}\text { 05/09/2016 - concedo a segurança pleiteada por ..... } \\
\text { contra ato do secretário municipal de saúde, para que o } \\
\text { impetrado forneça ao impetrante fraldas geriátricas - - } \\
13 / 03 / 2017 \text { - remetido ao dje - relação: } 0232 / 2017 \text { teor do } \\
\text { ato: vistos.procedidas as devidas anotações de baixa, } \\
\text { arquivem-se }\end{array}$ & FRALDA \\
\hline 446 & $\begin{array}{c}1015462- \\
39.2015 .8 .26 .0071\end{array}$ & $47375 / 2015$ & 18/08/2016 & $\begin{array}{l}\text { Mandado de } \\
\text { Segurança }\end{array}$ & 13/08/2015 & $\begin{array}{l}\text { 03/09/2015 - concedo a segurança pleiteada por .... } \\
\text { contra ato do secretário municipal de saúde de Bauru, } \\
\text { para que o impetrado forneça à impetrante fraldas } \\
\text { geriátricas descartáveis - tamanho "m" (180 unidades por } \\
\text { mês), nos termos da petição inicial, e julgo extinto o } \\
\text { processo, com resolução de mérito. }\end{array}$ & FRALDA \\
\hline 447 & $\begin{array}{c}1014735- \\
46.2016 .8 .26 .0071\end{array}$ & $43850 / 2016$ & 19/08/2016 & $\begin{array}{l}\text { Outros } \\
\text { Procediment } \\
\text { os }\end{array}$ & & $\begin{array}{l}\text { 22/02/2017 - A persistir a omissão, o seu quadro poderá } \\
\text { sofrer agravo. Por isso, intimem-se por mandado os } \\
\text { requeridos para que agendem imediatamente a cirurgia } \\
\text { sob pena de multa diária de } \mathrm{R} \$ 100.000,00 \text {. Apresente o } \\
\text { requerente três orçamentos para a realização da cirurgia } \\
\text { pela rede particular de saúde, nos termos do artigo } 213 \text { do } \\
\text { ECA. }\end{array}$ & CIRURGIA \\
\hline 448 & $\begin{array}{c}1011755- \\
29.2016 .8 .26 .0071\end{array}$ & $43930 / 2016$ & 19/08/2016 & $\begin{array}{c}\text { Mandado de } \\
\text { Segurança }\end{array}$ & 16/08/2016 & \begin{tabular}{|l|} 
06/09/2016 - concedo a segurança pleiteada por ..... \\
contra ato do secretário municipal de saúde, para que o \\
impetrado forneça ao impetrante fraldas geriátricas - - \\
28/03/2017 - arquivado definitivamente.
\end{tabular} & FRALDA \\
\hline
\end{tabular}




\begin{tabular}{|c|c|c|c|c|c|c|c|}
\hline 449 & $\begin{array}{c}1015552- \\
47.2015 .8 .26 .0071\end{array}$ & $47670 / 2015$ & 19/08/2016 & $\begin{array}{l}\text { Mandado de } \\
\text { Segurança }\end{array}$ & $14 / 08 / 2015$ & $\begin{array}{l}27 / 08 / 2015 \text { - concedo a segurança pleiteada por .... } \\
\text { contra ato do secretário municipal de saúde de Bauru, } \\
\text { para que o impetrado forneça ao impetrante fraldas } \\
\text { geriátricas descartáveis - tamanho "g" (200 unidades por } \\
\text { mês), conforme prescrição médica de fls. 13, e julgo } \\
\text { extinto o processo, com resolução de mérito. }\end{array}$ & FRALDA \\
\hline 450 & $\begin{array}{c}\text { 1016252- } \\
86.2016 .8 .26 .0071\end{array}$ & $44161 / 2016$ & $22 / 08 / 2016$ & $\begin{array}{l}\text { Mandado de } \\
\text { Segurança }\end{array}$ & $16 / 08 / 2016$ & $\begin{array}{l}\text { 26/09/2016 - concedo a segurança pleiteada por .... } \\
\text { contra ato do secretário municipal de saúde, para que o } \\
\text { impetrado forneça ao impetrante fraldas geriátricas - - } \\
\text { 10/11/2017 - arquivado definitivamente - }\end{array}$ & FRALDA \\
\hline 451 & $\begin{array}{c}\text { 1011208- } \\
86.2016 .8 .26 .0071\end{array}$ & $44359 / 2016$ & $23 / 08 / 2016$ & $\begin{array}{c}\text { Outros } \\
\text { Procediment } \\
\text { os }\end{array}$ & & SEGREDO DE JUSTIÇA & $\begin{array}{c}\text { SEGREDO DE } \\
\text { JUSTIÇA }\end{array}$ \\
\hline 452 & $\begin{array}{c}\text { 1016442- } \\
49.2016 .8 .26 .0071\end{array}$ & $44630 / 2016$ & $24 / 08 / 2016$ & $\begin{array}{l}\text { Mandado de } \\
\text { Segurança }\end{array}$ & 19/08/2016 & $\begin{array}{l}13 / 09 / 2016 \text { - concedo a segurança pleiteada por .... } \\
\text { contra ato do secretário municipal de saúde de Bauru, } \\
\text { para que o impetrado forneça à impetrante fraldas } \\
\text { geriátricas descartáveis - }-28 / 04 / 2017 \text { - arquivado } \\
\text { definitivamente - }\end{array}$ & FRALDA \\
\hline 453 & $\begin{array}{c}1013725- \\
64.2016 .8 .26 .0071\end{array}$ & $44949 / 2016$ & $25 / 08 / 2016$ & $\begin{array}{l}\text { Mandado de } \\
\text { Segurança }\end{array}$ & 23/08/2016 & $\begin{array}{l}\text { 19/09/2016 - concedo a segurança pleiteada por ... contra } \\
\text { ato do secretário municipal de saúde, para que o } \\
\text { impetrado forneça ao impetrante fraldas geriátricas - - } \\
\text { 21/02/2018 - arquivado definitivamente - }\end{array}$ & FRALDA \\
\hline 454 & $\begin{array}{c}\text { 1014563- } \\
07.2016 .8 .26 .0071\end{array}$ & $45255 / 2016$ & $26 / 08 / 2016$ & $\begin{array}{l}\text { Mandado de } \\
\text { Segurança }\end{array}$ & $23 / 08 / 2016$ & $\begin{array}{l}\text { 22/09/2016 - concedo a segurança, para que o impetrado } \\
\text { forneça à impetrante fraldas geriátricas tamanho "g" } 180 \\
\text { (cento e oitenta) unidades por mês, bem como } \\
\text { absorventes higiênicos - }-13 / 03 / 2018 \text { - arquivado } \\
\text { definitivamente - }\end{array}$ & FRALDA \\
\hline 455 & $\begin{array}{c}\text { 1016227- } \\
73.2016 .8 .26 .0071\end{array}$ & $45435 / 2016$ & 29/08/2016 & $\begin{array}{l}\text { Mandado de } \\
\text { Segurança }\end{array}$ & $24 / 08 / 2016$ & $\begin{array}{l}\text { 22/09/2016 - concedo a segurança pleiteada por ... contra } \\
\text { ato do secretario municipal de saúde de Bauru, para que } \\
\text { o impetrado providencie o fornecimento à impetrante dieta } \\
\text { enteral hipercalórica, hiperproteica, com fibras } \\
(1,5 \mathrm{kcal} / \mathrm{ml}) \text {, na quantidade de } 47 \text { litros no mês - } \\
16 / 03 / 2018 \text { - arquivado definitivamente - }\end{array}$ & $\begin{array}{l}\text { ALIMENTAÇÃO } \\
\text { ESPECIAL }\end{array}$ \\
\hline 456 & $\begin{array}{c}1021328- \\
28.2015 .8 .26 .0071\end{array}$ & $45581 / 2016$ & 29/08/2016 & $\begin{array}{l}\text { Mandado de } \\
\text { Segurança }\end{array}$ & & SEGREDO DE JUSTIÇA & $\begin{array}{c}\text { SEGREDO DE } \\
\text { JUSTICCA }\end{array}$ \\
\hline 457 & $\begin{array}{c}\text { 1017057- } \\
39.2016 .8 .26 .0071\end{array}$ & $45777 / 2016$ & $30 / 08 / 2016$ & $\begin{array}{l}\text { Mandado de } \\
\text { Segurança }\end{array}$ & $25 / 08 / 2016$ & $\begin{array}{l}\text { 20/09/2016 - concedo a segurança pleiteada por .... } \\
\text { contra ato do secretário municipal de saúde de Bauru, } \\
\text { para que o impetrado forneça à impetrante fraldas } \\
\text { descartáveis - - 09/02/2018 - arquivado definitivamente. }\end{array}$ & FRALDA \\
\hline
\end{tabular}




\begin{tabular}{|c|c|c|c|c|c|c|c|}
\hline 458 & $\begin{array}{c}\text { 1016937- } \\
93.2016 .8 .26 .0071\end{array}$ & $45775 / 2016$ & $30 / 08 / 2016$ & $\begin{array}{l}\text { Outros } \\
\text { Procediment } \\
\text { os }\end{array}$ & $25 / 08 / 2016$ & \begin{tabular}{|l|}
$11 / 10 / 2016$ - julgo procedente o pedido, formulado por .... \\
contra o município de Bauru, determinando que o \\
requerido forneça ao requerente os medicamentos \\
vidalgliptina $50 \mathrm{mg}+$ metformina $1000 \mathrm{mg}$ (60) \\
cápsulas/mês - duas vezes ao dia), canaglifozina $300 \mathrm{mg}$ \\
(30 cápsulas/mês - uma vez ao dia), simvastatina $20 \mathrm{mg}$ \\
(30 cápsulas/mês - uma vez ao dia) e invokana $300 \mathrm{mg}$ \\
(30 cápsulas/mês de uso - uma vez ao dia), e extinto o \\
processo, com resolução de mérito - - $30 / 08 / 2017$ - \\
arquivado definitivamente.
\end{tabular} & MEDICAMENTO \\
\hline 459 & $\begin{array}{c}1017060- \\
91.2016 .8 .26 .0071\end{array}$ & $46368 / 2016$ & 01/09/2016 & $\begin{array}{l}\text { Mandado de } \\
\text { Segurança }\end{array}$ & $26 / 08 / 2016$ & $\begin{array}{l}\text { 07/10/2016 - concedo a segurança pleiteada por .... } \\
\text { contra ato do secretário municipal de saúde de Bauru, } \\
\text { para que o impetrado forneça à impetrante fraldas } \\
\text { geriátricas descartáveis - }-17 / 05 / 2017 \text { - arquivado } \\
\text { definitivamente - }\end{array}$ & FRALDA \\
\hline 460 & $\begin{array}{c}\text { 1017296- } \\
\text { 43.2016.8.26.0071 }\end{array}$ & $46443 / 2016$ & 02/09/2016 & $\begin{array}{l}\text { Mandado de } \\
\text { Segurança }\end{array}$ & $30 / 08 / 2016$ & $\begin{array}{l}\text { 30/09/2016 - concedo a segurança pleiteada por .... } \\
\text { contra ato do secretário municipal de saúde, para que o } \\
\text { impetrado forneça ao impetrante fraldas geriátricas } \\
\text { tamanho "gg" } 120 \text { (cento e vinte) unidades por mês, } \\
\text { conforme receituário de fls. 15, e julgo extinto o processo, } \\
\text { com resolução de mérito - - 09/06/2017 - arquivado } \\
\text { definitivamente - }\end{array}$ & FRALDA \\
\hline 461 & $\begin{array}{c}\text { 1017487- } \\
88.2016 .8 .26 .0071\end{array}$ & $47258 / 2016$ & 08/09/2016 & $\begin{array}{l}\text { Mandado de } \\
\text { Segurança }\end{array}$ & 01/09/2016 & $\begin{array}{l}\text { 07/10/2016 - concedo a segurança pleiteada por ... contra } \\
\text { ato do secretário municipal de saúde de Bauru, para que } \\
\text { o impetrado providencie o fornecimento à impetrante do } \\
\text { medicamento dabigatrana } 150 \mathrm{mg} \text { (02 comprimidos por } \\
\text { dia), e julgo extinto o processo, com resolução de mérito - } \\
\text { - 26/03/2018 - arquivado definitivamente. }\end{array}$ & MEDICAMENTO \\
\hline 462 & $\begin{array}{c}1017722- \\
55.2016 .8 .26 .0071\end{array}$ & $47489 / 2016$ & 09/09/2016 & $\begin{array}{c}\text { Outros } \\
\text { Procediment } \\
\text { os }\end{array}$ & & SEGREDO DE JUSTIÇA & $\begin{array}{l}\text { SEGREDO DE } \\
\text { JUSTIÇA }\end{array}$ \\
\hline 463 & $\begin{array}{c}\text { 1017939- } \\
98.2016 .8 .26 .0071\end{array}$ & $48178 / 2016$ & 13/09/2016 & $\begin{array}{l}\text { Mandado de } \\
\text { Segurança }\end{array}$ & 06/09/2016 & $\begin{array}{l}\text { 13/10/2016 - concedo a segurança pleiteada por .... } \\
\text { contra ato do secretário municipal de saúde de Bauru, } \\
\text { para que o impetrado forneça ao impetrante: fraldas } \\
\text { geriátricas - - 09/06/2017 - arquivado definitivamente. }\end{array}$ & FRALDA \\
\hline 464 & $\begin{array}{c}\text { 1018583- } \\
41.2016 .8 .26 .0071\end{array}$ & $48363 / 2016$ & $14 / 09 / 2016$ & $\begin{array}{l}\text { Outros } \\
\text { Procediment } \\
\text { os }\end{array}$ & 13/09/2016 & $\begin{array}{l}\text { 22/08/2017 - a parte autora apresentou a certidão de óbito } \\
\text { (fls. 58/59).dessa forma, com a informação do óbito da } \\
\text { impetrante, ocorreu a perda do objeto da presente } \\
\text { açãa.ante o exposto, reconheço a carência superveniente, } \\
\text { e julgo extinto o processo sem resolução de mérito. }\end{array}$ & INTERNAÇÃO \\
\hline
\end{tabular}




\begin{tabular}{|c|c|c|c|c|c|c|c|}
\hline 465 & $\begin{array}{c}\text { 1018032- } \\
61.2016 .8 .26 .0071\end{array}$ & $48610 / 2016$ & $15 / 09 / 2016$ & $\begin{array}{l}\text { Mandado de } \\
\text { Segurança }\end{array}$ & 09/09/2016 & $\begin{array}{l}\text { 07/10/2016 - concedo a segurança pleiteada por priscilla } \\
\text { del nero fragoso fernandes da costa contra ato do } \\
\text { secretário municipal de saúde de Bauru, para que o } \\
\text { impetrado providencie o fornecimento à impetrante } \\
\text { montelucaste } 10 \mathrm{mg} \text { (01 caixa com } 30 \text { capsulas por mês), } \\
\text { bambuterol } 100 \mathrm{ml}(03 \text { caixas por mês) e budesunida } 0,25 \\
\text { mg (60 frascos por mês), e julgo extinto o processo, com } \\
\text { resolução de mérito - - } 18 / 10 / 2017 \text { - remetido ao dje - } \\
\text { relação: } 0603 / 2017 \text { teor do ato: ciência às partes do } \\
\text { retorno dos autos do e. tribunal.eventual cumprimento de } \\
\text { sentença deverá tramitar em formato digital, cujo } \\
\text { requerimento deverá ser realizado por peticionamento } \\
\text { eletrônico e instruído com as seguintes peças:i- sentença } \\
\text { e acórdão, se existente;ii- certidão de trânsito em julgado, } \\
\text { se o caso;iii- demonstrativo do débito atualizado, quando } \\
\text { se tratar de execução por quantia certa;iv- mandado de } \\
\text { citação cumprido e procurações outorgadas aos } \\
\text { advogados das partes, além de outras peças processuais } \\
\text { que o exequente considere necessárias.nada sendo } \\
\text { requerido em } 30 \text { (trinta) dias, os autos serão remetidos ao } \\
\text { arquivo. }\end{array}$ & MEDICAMENTO \\
\hline 466 & $\begin{array}{c}\text { 1008676- } \\
\text { 42.2016.8.26.0071 }\end{array}$ & $48612 / 2016$ & 15/09/2016 & $\begin{array}{l}\text { Outros } \\
\text { Procediment } \\
\quad \text { os }\end{array}$ & & $\begin{array}{l}\text { - *determino, com urgência, o agendamento de perícia } \\
\text { médica, ficando desde já determinado que, em não sendo } \\
\text { possível o comparecimento do requerido, deverá o perito } \\
\text { realiza-la no local onde possa o periciando ser } \\
\text { encontrado, ficando, ainda, se necessário, deferido } \\
\text { reforço policial.o laudo deverá consubstanciar integral } \\
\text { relatório médico. }\end{array}$ & INTERNAÇÃO \\
\hline 467 & $\begin{array}{c}\text { 1018772- } \\
\text { 19.2016.8.26.0071 }\end{array}$ & 49029/2016 & 19/09/2016 & $\begin{array}{l}\text { Mandado de } \\
\text { Segurança }\end{array}$ & $15 / 09 / 2016$ & $\begin{array}{l}\text { 18/10/2016 - concedo a segurança pleiteada por .... } \\
\text { contra ato do secretário municipal de saúde de Bauru, } \\
\text { para que o impetrado forneça ao impetrante: fraldas } \\
\text { geriátricas - - 09/11/2017 - arquivado definitivamente. }\end{array}$ & FRALDA \\
\hline 468 & $\begin{array}{c}\text { 1017637- } \\
\text { 69.2016.8.26.0071 }\end{array}$ & 49294/2016 & 20/09/2016 & $\begin{array}{l}\text { Outros } \\
\text { Procediment } \\
\quad \text { os }\end{array}$ & & $\begin{array}{l}\text { 09/02/2017 - determino prova médica pericial na } \\
\text { especialidade de ortopedia - }-23 / 07 / 2018-\text { julgo } \\
\text { improcedente a presente ação e, extinto o processo, com } \\
\text { resolução de mérito - }-28 / 11 / 2018 \text { - remetido ao dje - } \\
\text { relação: 0866/2018 teor do ato: ciência da baixa dos } \\
\text { autos, bem como da certidão do trânsito em julgado. nada } \\
\text { requerido em } 30 \text { dias, os autos serão remetidos ao } \\
\text { arquivo. }\end{array}$ & $\begin{array}{l}\text { DANO MATERIAL } \\
\text { E MORAL }\end{array}$ \\
\hline
\end{tabular}




\begin{tabular}{|c|c|c|c|c|c|c|c|}
\hline 469 & $\begin{array}{c}\text { 1017805- } \\
71.2016 .8 .26 .0071\end{array}$ & $49301 / 2016$ & 20/09/2016 & $\begin{array}{l}\text { Outros } \\
\text { Procediment } \\
\text { os }\end{array}$ & 19/10/2016 & $\begin{array}{l}\text { 18/11/2016 - considerando a informação de que o } \\
\text { requerido wilson renato vieira rodrigues não foi internado } \\
\text { (fls. 85/86), determino a intimação do secretário municipal } \\
\text { de saúde de Bauru, com urgência, para que disponibilize } \\
\text { novamente a vaga em questão, a qual deverá permanecer } \\
\text { à disposição pelo prazo de cinco dias - - 24/07/2017 } \\
\text { julgo procedente o pedido, formulado por .... em face de } \\
\text { wilson renato vieira rodrigues e fazenda pública do } \\
\text { município de Bauru determinando que o segundo } \\
\text { requerido providencie a imediata disponibilização de vaga } \\
\text { para internação para tratamento psiquiátrico ao primeiro } \\
\text { requerido. }\end{array}$ & INTERNAÇÃO \\
\hline 470 & $\begin{array}{c}1018629- \\
30.2016 .8 .26 .0071\end{array}$ & $49300 / 2016$ & 20/09/2016 & $\begin{array}{l}\text { Mandado de } \\
\text { Segurança }\end{array}$ & 14/09/2016 & $\begin{array}{l}\text { 10/10/2016 - oncedo a segurança pleiteada por .... contra } \\
\text { ato do secretário municipal de saúde de Bauru, para que } \\
\text { o impetrado providencie o fornecimento ao impetrante de } \\
\text { tiras reagentes accu-chek performa (06 caixas a cada } 03 \\
\text { meses), e julgo extinto o processo, com resolução de } \\
\text { mérito - - } 21 / 11 / 2016 \text { - remetidos os autos para o tribunal } \\
\text { de justiça/colégio recursal - processo digital - } \\
\end{array}$ & $\begin{array}{c}\text { INSUMOS/MATE } \\
\text { RIAL } \\
\text { HOSPITALAR }\end{array}$ \\
\hline 471 & $\begin{array}{c}1017425- \\
48.2016 .8 .26 .0071\end{array}$ & $49809 / 2016$ & 22/09/2016 & $\begin{array}{l}\text { Mandado de } \\
\text { Segurança }\end{array}$ & 19/09/2016 & $\begin{array}{l}\text { 20/10/2016 - concedo a segurança pleiteada por .... } \\
\text { contra ato do secretário municipal de saúde de Bauru, } \\
\text { para que o impetrado forneça ao impetrante: fraldas } \\
\text { geriátricas - - 09/06/2017 - arquivado definitivamente - }\end{array}$ & FRALDA \\
\hline 472 & $\begin{array}{c}\text { 1018866- } \\
64.2016 .8 .26 .0071\end{array}$ & $49812 / 2016$ & 22/09/2016 & $\begin{array}{l}\text { Mandado de } \\
\text { Segurança }\end{array}$ & 19/09/2016 & $\begin{array}{l}18 / 10 / 2016 \text { - concedo a segurança pleiteada por .... } \\
\text { contra ato do secretário municipal de saúde de Bauru, } \\
\text { para que o impetrado forneça ao impetrante fraldas } \\
\text { geriátricas descartáveis - }-14 / 06 / 2017 \text { - arquivado } \\
\text { definitivamente - }\end{array}$ & FRALDA \\
\hline 473 & $\begin{array}{c}\text { 1019324- } \\
81.2016 .8 .26 .0071\end{array}$ & $50218 / 2016$ & 26/09/2016 & $\begin{array}{l}\text { Mandado de } \\
\text { Segurança }\end{array}$ & 21/09/2016 & $\begin{array}{l}21 / 10 / 2016 \text { - concedo a segurança pleiteada por .... } \\
\text { contra ato do secretário municipal de saúde de Bauru, } \\
\text { para que o impetrado forneça ao impetrante: fraldas } \\
\text { geriátricas - - 20/02/2018 - arquivado definitivamente - }\end{array}$ & FRALDA \\
\hline 474 & $\begin{array}{c}\text { 1019313- } \\
\text { 52.2016.8.26.0071 }\end{array}$ & $50700 / 2016$ & 28/09/2016 & $\begin{array}{l}\text { Mandado de } \\
\text { Segurança }\end{array}$ & 22/09/2016 & $\begin{array}{l}\text { 11/10/2016 - concedo a segurança pleiteada por ..... } \\
\text { contra ato do secretário municipal de saúde de Bauru, } \\
\text { para que o impetrado forneça ao impetrante fraldas } \\
\text { geriátricas descartáveis - - } 23 / 06 / 2017 \text { - arquivado } \\
\text { definitivamente - }\end{array}$ & FRALDA \\
\hline 475 & $\begin{array}{c}\text { 1019598- } \\
45.2016 .8 .26 .0071\end{array}$ & $50830 / 2016$ & $28 / 09 / 2016$ & $\begin{array}{l}\text { Mandado de } \\
\text { Segurança }\end{array}$ & 23/09/2016 & $\begin{array}{l}\text { 20/10/2016 - concedo a segurança pleiteada por .... } \\
\text { contra ato do secretário municipal de saúde de Bauru, } \\
\text { para que o impetrado forneça ao impetrante: fraldas } \\
\text { geriátricas - - 09/06/2017 - arquivado definitivamente - }\end{array}$ & FRALDA \\
\hline
\end{tabular}




\begin{tabular}{|c|c|c|c|c|c|c|c|}
\hline 476 & $\begin{array}{c}1002124- \\
61.2016 .8 .26 .0071 \\
\end{array}$ & $51320 / 2016$ & $30 / 09 / 2016$ & $\begin{array}{l}\text { Mandado de } \\
\text { Segurança }\end{array}$ & & SEGREDO DE JUSTIÇA & $\begin{array}{l}\text { SEGREDO DE } \\
\text { JUSTIÇA }\end{array}$ \\
\hline 477 & $\begin{array}{c}1019791- \\
60.2016 .8 .26 .0071\end{array}$ & $51431 / 2016$ & 03/10/2016 & $\begin{array}{l}\text { Mandado de } \\
\text { Segurança }\end{array}$ & 28/09/2016 & $\begin{array}{l}\text { 09/11/2016 - concedo a segurança pleiteada por .... contra } \\
\text { ato do secretário municipal de saúde de Bauru, para que } \\
\text { o impetrado forneça a impetrante: fraldas geriátricas - - } \\
25 / 07 / 2017 \text { - arquivado definitivamente - }\end{array}$ & FRALDA \\
\hline 478 & $\begin{array}{c}1014446- \\
16.2016 .8 .26 .0071\end{array}$ & $51429 / 2016$ & 03/10/2016 & $\begin{array}{l}\text { Mandado de } \\
\text { Segurança }\end{array}$ & 04/08/2016 & $\begin{array}{l}31 / 08 / 2016 \text { - concedo a segurança pleiteada por ... contra } \\
\text { ato do secretário municipal de saúde, para que o } \\
\text { impetrado forneça à impetrante fraldas geriátricas - }- \\
01 / 11 / 2017 \text { - arquivado definitivamente - }\end{array}$ & FRALDA \\
\hline 479 & $\begin{array}{c}1019933- \\
64.2016 .8 .26 .0071\end{array}$ & $51719 / 2016$ & 04/10/2016 & $\begin{array}{l}\text { Mandado de } \\
\text { Segurança }\end{array}$ & 29/09/2016 & $\begin{array}{l}\text { 20/10/2016 - concedo a segurança pleiteada por ... contra } \\
\text { ato do secretário municipal de saúde de Bauru, para que } \\
\text { o impetrado forneça ao impetrante: fraldas geriátricas - - } \\
\text { 09/06/2017 - arquivado definitivamente - }\end{array}$ & FRALDA \\
\hline 480 & $\begin{array}{c}1020190- \\
89.2016 .8 .26 .0071\end{array}$ & $51722 / 2016$ & $04 / 10 / 2016$ & $\begin{array}{l}\text { Mandado de } \\
\text { Segurança }\end{array}$ & $30 / 09 / 2016$ & $\begin{array}{l}27 / 10 / 2016 \text { - concedo a segurança pleiteada por .... } \\
\text { contra ato do secretário municipal de saúde de Bauru, } \\
\text { para que o impetrado forneça ao impetrante: fraldas } \\
\text { geriátricas - - 09/06/2017 - arquivado definitivamente - }\end{array}$ & FRALDA \\
\hline 481 & $\begin{array}{c}1019029- \\
44.2016 .8 .26 .0071\end{array}$ & $52870 / 2016$ & $10 / 10 / 2016$ & $\begin{array}{l}\text { Mandado de } \\
\text { Segurança }\end{array}$ & $19 / 09 / 2016$ & $\begin{array}{l}24 / 10 / 2016 \text { - concedo a segurança pleiteada por .... } \\
\text { contra ato do secretário municipal de saúde de Bauru, } \\
\text { para que o impetrado forneça à impetrante fraldas } \\
\text { descartáveis hipoalérgicas - }-05 / 10 / 2017 \text { - arquivado } \\
\text { definitivamente - }\end{array}$ & FRALDA \\
\hline 482 & $\begin{array}{c}1020697- \\
50.2016 .8 .26 .0071\end{array}$ & $52923 / 2016$ & $11 / 10 / 2016$ & $\begin{array}{l}\text { Mandado de } \\
\text { Segurança }\end{array}$ & 07/10/2016 & $\begin{array}{l}\text { 27/10/2016 - concedo a segurança pleiteada por ... contra } \\
\text { ato do secretário municipal de saúde de Bauru, para que } \\
\text { o impetrado forneça ao impetrante: fraldas geriátricas - - } \\
\text { 09/06/2017 - arquivado definitivamente - }\end{array}$ & FRALDA \\
\hline 483 & $\begin{array}{c}\text { 1017116- } \\
27.2016 .8 .26 .0071\end{array}$ & $53663 / 2016$ & $17 / 10 / 2016$ & $\begin{array}{l}\text { Mandado de } \\
\text { Segurança }\end{array}$ & & $\begin{array}{l}\text { julgo procedentes os pedidos da presente ação de } \\
\text { mandado de segurança, para tornar definitiva a liminar } \\
\text { deferida e determinar ao Secretário Municipal de Saúde o } \\
\text { fornecimento de fraldas, } 180 \text { unidades, por mês, por } \\
\text { tempo indeterminado }\end{array}$ & FRALDA \\
\hline 484 & $\begin{array}{c}1020826- \\
55.2016 .8 .26 .0071\end{array}$ & $53802 / 2016$ & $18 / 10 / 2016$ & $\begin{array}{c}\text { Outros } \\
\text { Procediment } \\
\text { os }\end{array}$ & & SEGREDO DE JUSTIÇA & $\begin{array}{l}\text { SEGREDO DE } \\
\text { JUSTIÇA }\end{array}$ \\
\hline 485 & $\begin{array}{c}1019707- \\
59.2016 .8 .26 .0071\end{array}$ & $53891 / 2016$ & $18 / 10 / 2016$ & $\begin{array}{l}\text { Mandado de } \\
\text { Segurança }\end{array}$ & & $\begin{array}{l}\text { 08/11/18 - nega-se provimento à apelação e ao reexame } \\
\text { necessário. }\end{array}$ & MEDICAMENTO \\
\hline 486 & $\begin{array}{c}1020028- \\
94.2016 .8 .26 .0071\end{array}$ & $53895 / 2016$ & $18 / 10 / 2016$ & $\begin{array}{l}\text { Mandado de } \\
\text { Segurança }\end{array}$ & & SEGREDO DE JUSTIÇA & $\begin{array}{l}\text { SEGREDO DE } \\
\text { JUSTIÇA }\end{array}$ \\
\hline
\end{tabular}




\begin{tabular}{|c|c|c|c|c|c|c|c|}
\hline 487 & $\begin{array}{c}\text { 1021481- } \\
27.2016 .8 .26 .0071\end{array}$ & $54056 / 2016$ & 19/10/2016 & $\begin{array}{l}\text { Mandado de } \\
\text { Segurança }\end{array}$ & $14 / 10 / 2016$ & $\begin{array}{l}\text { 09/11/2016 - concedo a segurança pleiteada por ..... } \\
\text { contra ato do secretário municipal de saúde de Bauru, } \\
\text { para que o impetrado forneça à impetrante fraldas } \\
\text { geriátricas descartáveis - }-05 / 10 / 2017 \text { - arquivado } \\
\text { definitivamente - }\end{array}$ & FRALDA \\
\hline 488 & $\begin{array}{c}\text { 1020614- } \\
34.2016 .8 .26 .0071\end{array}$ & $54051 / 2016$ & 19/10/2016 & $\begin{array}{l}\text { Mandado de } \\
\text { Segurança }\end{array}$ & $14 / 10 / 2016$ & $\begin{array}{l}\text { 07/11/2016 - concedo a segurança pleiteada por ... contra } \\
\text { ato do secretário municipal de saúde de Bauru, para que } \\
\text { o impetrado forneça à impetrante fraldas geriátricas } \\
\text { descartáveis - - - 09/02/2018 - remetido ao dje - relação: } \\
0075 / 2018 \text { teor do ato: petição de fls. } 128 / 129 \text { : proceder o } \\
\text { peticionário o seu protocolo junto ao cumprimento de } \\
\text { sentença em andamento, proc. n. } 0025821 \text { - } \\
94.2016 .8 .26 .0071 \text {. }\end{array}$ & FRALDA \\
\hline 489 & $\begin{array}{c}\text { 1017915- } \\
70.2016 .8 .26 .0071\end{array}$ & $54471 / 2016$ & 20/10/2016 & $\begin{array}{l}\text { Outros } \\
\text { Procediment } \\
\text { os }\end{array}$ & $17 / 10 / 2016$ & 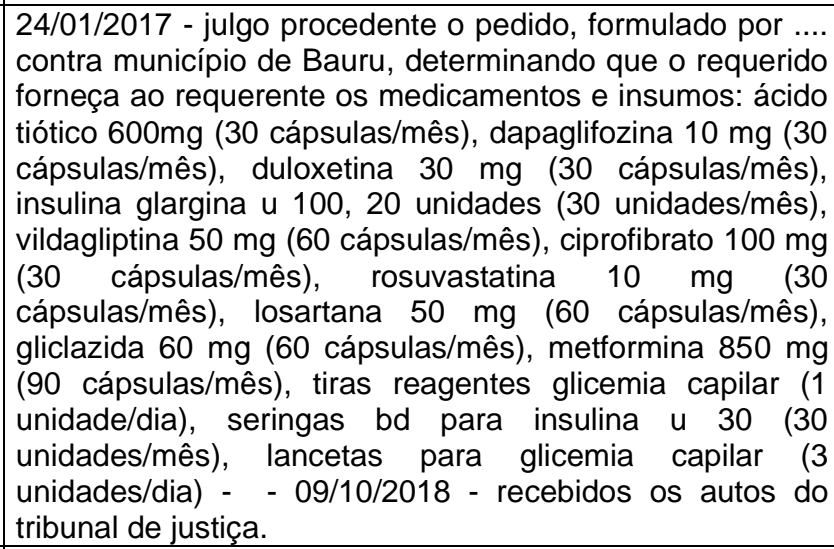 & MEDICAMENTO \\
\hline 490 & $\begin{array}{c}\text { 1021480- } \\
42.2016 .8 .26 .0071\end{array}$ & $54572 / 2016$ & $21 / 10 / 2016$ & $\begin{array}{l}\text { Mandado de } \\
\text { Segurança }\end{array}$ & 14/10/2016 & $\begin{array}{l}\text { 16/11/2016 - concedo a segurança pleiteada por .... } \\
\text { contra ato do secretário municipal de saúde de Bauru, } \\
\text { para que o impetrado forneça ao impetrante: absorventes } \\
\text { griátricos - - 19/10/2017 - arquivado definitivamente - }\end{array}$ & FRALDA \\
\hline 491 & $\begin{array}{c}\text { 1020935- } \\
69.2016 .8 .26 .0071\end{array}$ & $54781 / 2016$ & $24 / 10 / 2016$ & $\begin{array}{c}\text { Outros } \\
\text { Procediment } \\
\text { os } \\
\end{array}$ & & SEGREDO DE JUSTIÇA & $\begin{array}{c}\text { SEGREDO DE } \\
\text { JUSTIÇA }\end{array}$ \\
\hline
\end{tabular}




\begin{tabular}{|c|c|c|c|c|c|c|c|}
\hline 492 & $\begin{array}{c}\text { 1022058- } \\
05.2016 .8 .26 .0071\end{array}$ & $55706 / 2016$ & $27 / 10 / 2016$ & $\begin{array}{l}\text { Mandado de } \\
\text { Segurança }\end{array}$ & $26 / 10 / 2016$ & $\begin{array}{l}\text { 14/12/2016 - concedo a segurança pleiteada por .... } \\
\text { contra ato do secretário municipal de saúde de Bauru, } \\
\text { para que o impetrado providencie o fornecimento à } \\
\text { impetrante de enoxaparina sódica } 40 \mathrm{mg} \text { (15 injeções), e } \\
\text { julgo extinto o processo, com resolução de mérito - - } \\
23 / 11 / 2017 \text { - ecebidos os autos do tribunal de justiça - } \\
\text { data do julgamento: } 22 / 08 / 2017 \text { trânsito em julgado: tipo } \\
\text { de julgamento: acórdão decisão: negaram provimento ao } \\
\text { apelo e ao reexame necessário. - - } 26 / 03 / 2018 \text { - } \\
\text { arquivado definitivamente }\end{array}$ & MEDICAMENTO \\
\hline 493 & $\begin{array}{c}\text { 1018443- } \\
07.2016 .8 .26 .0071\end{array}$ & $55722 / 2016$ & $27 / 10 / 2016$ & $\begin{array}{l}\text { Outros } \\
\text { Procediment } \\
\quad \text { os }\end{array}$ & $24 / 10 / 2016$ & $\begin{array}{l}\text { 31/01/2017 - julgo procedente o pedido, formulado por .... } \\
\text { contra o municipio de Bauru e a fazenda pública do } \\
\text { estado de são paulo, determinando que os requeridos } \\
\text { forneçam a autora: azitromicina } 500 \mathrm{mg} \text { (um comprimido } \\
\text { em dias alternados), seebri } 50 \mathrm{mg} \text { (uma unidade ao dia), } \\
\text { dexas } 500 \mathrm{mg} \text { (um comprimido em dias alternados), relvar } \\
200 / 25 \mathrm{mcg} \text { (duas unidades ao dia), anafranil sr } 75 \mathrm{mg} \\
\text { (dois comprimidos ao dia), champix 0,5 mg (um } \\
\text { comprimido branco ao dia, do } 1^{0} \text { ao } 3^{\circ} \text { dia, e dois } \\
\text { comprimidos brancos do } 4^{0} \text { ao } 7^{\circ} \text { dia) e champix (dois } \\
\text { comprimidos azuis ao dia do } 8^{\circ} \text { ao } 14^{\circ} \text { dia, e dois } \\
\text { comprimidos azuis ao dia a partir do } 15^{\circ} \text { dia até o fim do } \\
\text { tratamento) conforme prescrição médica de fls. } 91 / 92 \text {, e } \\
\text { julgo extinto o processo, com resolução de mérito - - } \\
18 / 10 / 2018 \text { - ecebidos os autos do tribunal de justiça - - } \\
\text { data do julgamento: } 18 / 07 / 2018 \text { trânsito em julgado: tipo } \\
\text { de julgamento: acórdão decisão: negaram provimento aos } \\
\text { apelos e deram parcial provimento ao reexame } \\
\text { necessário v.u. situação do provimento: provimento em } \\
\text { parte. }\end{array}$ & MEDICAMENTO \\
\hline 494 & $\begin{array}{c}\text { 1019255- } \\
\text { 49.2016.8.26.0071 }\end{array}$ & $56188 / 2016$ & $01 / 11 / 2016$ & $\begin{array}{l}\text { Outros } \\
\text { Procediment } \\
\text { os }\end{array}$ & $24 / 10 / 2016$ & $\begin{array}{l}\text { 31/01/2017 - julgo procedente o pedido, formulado por ... } \\
\text { contra a secretaria municipal de saúde, determinando que } \\
\text { o requerido forneça ao requerente fraldas descartáveis } \\
\text { geriátricas - - 08/03/2018 - arquivado provisoriamente - }\end{array}$ & FRALDA \\
\hline 495 & $\begin{array}{c}1022009- \\
61.2016 .8 .26 .0071\end{array}$ & $56234 / 2016$ & $01 / 11 / 2016$ & $\begin{array}{l}\text { Mandado de } \\
\text { Segurança }\end{array}$ & & SEGREDO DE JUSTIÇA & $\begin{array}{l}\text { SEGREDO DE } \\
\text { JUSTIÇA }\end{array}$ \\
\hline 496 & $\begin{array}{c}\text { 1022702- } \\
45.2016 .8 .26 .0071\end{array}$ & $56247 / 2016$ & $01 / 11 / 2016$ & $\begin{array}{l}\text { Mandado de } \\
\text { Segurança }\end{array}$ & $27 / 10 / 2016$ & $\begin{array}{l}\text { 13/12/2016 - concedo a segurança pleiteada por .... } \\
\text { contra ato do secretário municipal de saúde de Bauru, } \\
\text { para que o impetrado forneça ao impetrante: fraldas } \\
\text { geriátricas hipoalergênicas - }-10 / 07 / 2017 \text { - arquivado } \\
\text { definitivamente - }\end{array}$ & FRALDA \\
\hline
\end{tabular}




\begin{tabular}{|c|c|c|c|c|c|c|c|}
\hline 497 & $\begin{array}{c}\text { 1022587- } \\
24.2016 .8 .26 .0071\end{array}$ & $56841 / 2016$ & $04 / 11 / 2016$ & $\begin{array}{l}\text { Mandado de } \\
\text { Segurança }\end{array}$ & $26 / 10 / 2016$ & $\begin{array}{l}\text { 05/12/2016 - concedo a segurança pleiteada por .... } \\
\text { contra ato do secretário municipal de saúde de Bauru, } \\
\text { para que o impetrado forneça ao impetrante: fraldas } \\
\text { geriátricas - - 19/10/2017 - arquivado definitivamente - }\end{array}$ & FRALDA \\
\hline 498 & $\begin{array}{c}\text { 1022430- } \\
51.2016 .8 .26 .0071\end{array}$ & $56842 / 2016$ & 04/11/2016 & $\begin{array}{l}\text { Mandado de } \\
\text { Segurança }\end{array}$ & $31 / 10 / 2016$ & $\begin{array}{l}25 / 11 / 2016 \text { - concedo a segurança pleiteada por .... } \\
\text { contra ato do secretário municipal de saúde de Bauru, } \\
\text { para que o impetrado forneça à impetrante fraldas } \\
\text { geriátricas descartáveis - - 09/06/2017 - arquivado } \\
\text { definitivamente - }\end{array}$ & FRALDA \\
\hline 499 & $\begin{array}{c}\text { 1022376- } \\
85.2016 .8 .26 .0071\end{array}$ & $56862 / 2016$ & 04/11/2016 & $\begin{array}{l}\text { Mandado de } \\
\text { Segurança }\end{array}$ & $31 / 10 / 2016$ & $\begin{array}{l}16 / 01 / 2017 \text { - concedo a segurança pleiteada por .... } \\
\text { contra ato do secretário municipal de saúde de Bauru, } \\
\text { para que o impetrado forneça à impetrante fraldas } \\
\text { geriátricas descartáveis - . - }\end{array}$ & FRALDA \\
\hline 500 & $\begin{array}{c}\text { 1022508- } \\
45.2016 .8 .26 .0071\end{array}$ & $56868 / 2016$ & $04 / 11 / 2016$ & $\begin{array}{l}\text { Mandado de } \\
\text { Segurança }\end{array}$ & $25 / 10 / 2016$ & $\begin{array}{l}11 / 01 / 2017 \text { - concedo a segurança pleiteada por ... contra } \\
\text { ato do secretário municipal de saúde de Bauru, para que } \\
\text { o impetrado forneça ao impetrante: fraldas geriátricas } \\
\text { tamanho "m" } 120 \text { (cento e vinte) unidades por mês, } \\
\text { conforme receituário de fls. 15, e julgo extinto o processo, } \\
\text { com resolução de mérito - - 10/07/2017 - arquivado } \\
\text { definitivamente - }\end{array}$ & FRALDA \\
\hline 501 & $\begin{array}{c}\text { 1022659- } \\
11.2016 .8 .26 .0071\end{array}$ & $56950 / 2016$ & $04 / 11 / 2016$ & $\begin{array}{l}\text { Mandado de } \\
\text { Segurança }\end{array}$ & 27/10/2016 & $\begin{array}{l}29 / 11 / 2016 \text { - concedo a segurança pleiteada por .... } \\
\text { contra ato do secretário municipal de saúde de Bauru, } \\
\text { para que o impetrado forneça ao impetrante: fraldas } \\
\text { geriátricas - }\end{array}$ & FRALDA \\
\hline 502 & $\begin{array}{c}\text { 1022684- } \\
24.2016 .8 .26 .0071\end{array}$ & $56953 / 2016$ & 04/11/2016 & $\begin{array}{l}\text { Mandado de } \\
\text { Segurança }\end{array}$ & $27 / 10 / 2016$ & $\begin{array}{l}30 / 11 / 2016 \text { - concedo a segurança pleiteada por .... } \\
\text { contra ato do secretário municipal de saúde de Bauru, } \\
\text { para que o impetrado forneça ao impetrante: fraldas } \\
\text { geriátricas - - 19/10/2017 - arquivado definitivamente - }\end{array}$ & FRALDA \\
\hline 503 & $\begin{array}{c}\text { 1022682- } \\
54.2016 .8 .26 .0071\end{array}$ & $57308 / 2016$ & $07 / 11 / 2016$ & $\begin{array}{l}\text { Mandado de } \\
\text { Segurança }\end{array}$ & $31 / 10 / 2016$ & $\begin{array}{l}\text { 19/01/2017 - concedo a segurança pleiteada por .... } \\
\text { contra ato do secretário municipal de saúde de Bauru, } \\
\text { para que o impetrado forneça ao impetrante fraldas } \\
\text { geriátricas descartáveis - }-29 / 11 / 2017 \text { - arquivado } \\
\text { definitivamente - }\end{array}$ & FRALDA \\
\hline 504 & $\begin{array}{c}\text { 1020312- } \\
05.2016 .8 .26 .0071\end{array}$ & $58136 / 2016$ & 10/11/2016 & $\begin{array}{l}\text { Outros } \\
\text { Procediment } \\
\text { os }\end{array}$ & 07/11/2016 & - 24/02/2017 - Procedente terapia intensiva - pediasuit & $\begin{array}{l}\text { INSUMOS/MATE } \\
\text { RIAL } \\
\text { HOSPITALAR }\end{array}$ \\
\hline 505 & $\begin{array}{c}1023600- \\
58.2016 .8 .26 .00714\end{array}$ & $58175 / 2016$ & $10 / 11 / 2016$ & $\begin{array}{l}\text { Mandado de } \\
\text { Segurança }\end{array}$ & 08/11/2016 & $\begin{array}{l}12 / 01 / 2017 \text { - concedo a segurança pleiteada por .... } \\
\text { contra ato do secretário municipal de saúde de Bauru, } \\
\text { para que o impetrado forneça ao impetrante: fraldas } \\
\text { geriátricas - - 28/04/2017 - arquivado definitivamente - }\end{array}$ & FRALDA \\
\hline
\end{tabular}




\begin{tabular}{|c|c|c|c|c|c|c|c|}
\hline 506 & $\begin{array}{c}1020816- \\
11.2016 .8 .26 .0071\end{array}$ & $58628 / 2016$ & $11 / 11 / 2016$ & $\begin{array}{c}\text { Outros } \\
\text { Procediment } \\
\text { os }\end{array}$ & & $\begin{array}{l}\text { 21/06/2017 - falecimento da autora. por tratar-se de direito } \\
\text { personalíssimo, houve a perda do objeto da ação.ante o } \\
\text { exposto, julgo extinta a presente ação de obrigação de } \\
\text { fazer. }\end{array}$ & TRANSPORTE \\
\hline 507 & $\begin{array}{c}1023601- \\
43.2016 .8 .26 .0071\end{array}$ & $58591 / 2016$ & $11 / 11 / 2016$ & $\begin{array}{l}\text { Mandado de } \\
\text { Segurança }\end{array}$ & $08 / 11 / 2016$ & $\begin{array}{l}\text { 14/12/2016 - concedo parcialmente a segurança pleiteada } \\
\text { por .... contra ato do secretário municipal de saúde de } \\
\text { Bauru, para que o impetrado forneça à impetrante fraldas } \\
\text { geriátricas descartáveis }--\quad-09 / 03 / 2018 \text { - arquivado } \\
\text { definitivamente. }\end{array}$ & FRALDA \\
\hline 508 & $\begin{array}{c}\text { 1023214- } \\
28.2016 .8 .26 .0071\end{array}$ & $58581 / 2016$ & $11 / 11 / 2016$ & $\begin{array}{l}\text { Mandado de } \\
\text { Segurança }\end{array}$ & $07 / 11 / 2016$ & $\begin{array}{l}\text { 14/12/2016 - concedo a segurança pleiteada por .... } \\
\text { contra ato do secretário municipal de saúde de Bauru, } \\
\text { para que o impetrado forneça ao impetrante fraldas } \\
\text { geriátricas descartáveis - }-07 / 11 / 2017 \text { - arquivado } \\
\text { definitivamente. }\end{array}$ & FRALDA \\
\hline 509 & $\begin{array}{c}1024693- \\
56.2016 .8 .26 .0071\end{array}$ & $59989 / 2016$ & $21 / 11 / 2016$ & $\begin{array}{l}\text { Mandado de } \\
\text { Segurança }\end{array}$ & $17 / 11 / 2016$ & $\begin{array}{l}11 / 01 / 2017 \text { - concedo a segurança pleiteada por .... } \\
\text { contra ato do secretário municipal de saúde de Bauru, } \\
\text { para que o impetrado forneça ao impetrante: fraldas } \\
\text { geriátricas tamanho - } \quad-25 / 07 / 2017 \text { - arquivado } \\
\text { definitivamente - }\end{array}$ & FRALDA \\
\hline 510 & $\begin{array}{c}1017125- \\
86.2016 .8 .26 .0071\end{array}$ & $60403 / 2016$ & $22 / 11 / 2016$ & $\begin{array}{l}\text { Mandado de } \\
\text { Segurança }\end{array}$ & $18 / 11 / 2016$ & $\begin{array}{l}\text { 11/01/2017 - ratifico a liminar de fls. 30/31 e CONCEDO A } \\
\text { SEGURANÇA pleiteada, para que o impetrado forneça ao } \\
\text { impetrante: FRALDAS DESCARTAVÉIS TAMANHO "P" } \\
180 \text { (cento e oitenta) unidades por mês conforme } \\
\text { receituário de fls. } 24 \text {, e julgo extinto o processo. }\end{array}$ & FRALDA \\
\hline 511 & $\begin{array}{c}1023414- \\
35.2016 .8 .26 .0071\end{array}$ & $60616 / 2016$ & $22 / 11 / 2016$ & $\begin{array}{l}\text { Mandado de } \\
\text { Segurança }\end{array}$ & & SEGREDO DE JUSTIÇA & $\begin{array}{c}\text { SEGREDO DE } \\
\text { JUSTIÇA }\end{array}$ \\
\hline 512 & $\begin{array}{c}1024734- \\
23.2016 .8 .26 .0071\end{array}$ & $60817 / 2016$ & $23 / 11 / 2016$ & $\begin{array}{l}\text { Mandado de } \\
\text { Segurança }\end{array}$ & $18 / 11 / 2016$ & $\begin{array}{l}11 / 01 / 2017 \text { - concedo a segurança pleiteada por ... contra } \\
\text { ato do secretário municipal de saúde de Bauru, para que } \\
\text { o impetrado forneça ao impetrante: fraldas geriátricas - - } \\
\text { 19/10/2017 - arquivado definitivamente - }\end{array}$ & FRALDA \\
\hline 513 & $\begin{array}{c}1024842- \\
52.2016 .8 .26 .0071\end{array}$ & $60811 / 2016$ & $23 / 11 / 2016$ & $\begin{array}{l}\text { Mandado de } \\
\text { Segurança }\end{array}$ & $18 / 11 / 2016$ & $\begin{array}{l}\text { 11/01/2017 - concedo a segurança pleiteada .... contra } \\
\text { ato do secretário municipal de saúde de Bauru, para que } \\
\text { o impetrado forneça ao impetrante: fraldas geriátricas - - } \\
07 / 07 / 2017 \text { - arquivado definitivamente - }\end{array}$ & FRALDA \\
\hline 514 & $\begin{array}{c}1024430- \\
24.2016 .8 .26 .0071\end{array}$ & $61184 / 2016$ & $24 / 11 / 2016$ & $\begin{array}{l}\text { Mandado de } \\
\text { Segurança }\end{array}$ & $21 / 11 / 2016$ & $\begin{array}{l}\text { 11/01/2017 - concedo a segurança pleiteada por ... contra } \\
\text { ato do secretário municipal de saúde de Bauru, para que } \\
\text { o impetrado forneça ao impetrante: fraldas descartavéis - } \\
\text { - 02/03/2018 - arquivado definitivamente - }\end{array}$ & FRALDA \\
\hline
\end{tabular}




\begin{tabular}{|c|c|c|c|c|c|c|c|}
\hline 515 & $\begin{array}{c}\text { 1024968- } \\
05.2016 .8 .26 .0071\end{array}$ & $61181 / 2016$ & $24 / 11 / 2016$ & $\begin{array}{l}\text { Mandado de } \\
\text { Segurança }\end{array}$ & $22 / 11 / 2016$ & $\begin{array}{l}11 / 01 / 2017 \text { - concedo a segurança pleiteada por .... } \\
\text { contra ato do secretário municipal de saúde de Bauru, } \\
\text { para que o impetrado forneça ao impetrante: fraldas } \\
\text { geriátricas - - 01/11/2017 - arquivado definitivamente - }\end{array}$ & FRALDA \\
\hline 516 & $\begin{array}{c}\text { 1024433- } \\
\text { 76.2016.8.26.0071 }\end{array}$ & $61187 / 2016$ & $24 / 11 / 2016$ & $\begin{array}{l}\text { Mandado de } \\
\text { Segurança }\end{array}$ & 18/11/2016 & $\begin{array}{l}16 / 01 / 2017 \text { - concedo a segurança pleiteada por .... } \\
\text { contra ato do secretário municipal de saúde de Bauru, } \\
\text { para que o impetrado forneça à impetrante fraldas } \\
\text { geriátricas descartáveis - }-07 / 05 / 2018 \text { - arquivado } \\
\text { definitivamente - }\end{array}$ & FRALDA \\
\hline 517 & $\begin{array}{c}\text { 1024733- } \\
\text { 38.2016.8.26.0071 }\end{array}$ & $61578 / 2016$ & $25 / 11 / 2016$ & $\begin{array}{l}\text { Mandado de } \\
\text { Segurança }\end{array}$ & 21/11/2016 & $\begin{array}{l}\text { 16/01/2017 - concedo a segurança pleiteada por .... contra } \\
\text { ato do secretário municipal de saúde de Bauru, para que } \\
\text { o impetrado forneça ao impetrante fraldas geriátricas } \\
\text { descartáveis - - 13/09/2017 - arquivado definitivamente - }\end{array}$ & FRALDA \\
\hline 518 & $\begin{array}{c}\text { 1023364- } \\
09.2016 .8 .26 .0071\end{array}$ & $61927 / 2016$ & 28/11/2016 & $\begin{array}{l}\text { Mandado de } \\
\text { Segurança }\end{array}$ & $23 / 11 / 2016$ & $\begin{array}{l}\text { 12/01/2017 - concedo a segurança pleiteada .... contra } \\
\text { ato do secretário municipal de saúde de Bauru, para que } \\
\text { o impetrado forneça ao impetrante: fraldas geriátricas - - } \\
27 / 02 / 2018 \text { - arquivado definitivamente - }\end{array}$ & FRALDA \\
\hline 519 & $\begin{array}{c}\text { 1025310- } \\
16.2016 .8 .26 .0071\end{array}$ & $63413 / 2016$ & 02/12/2016 & $\begin{array}{l}\text { Mandado de } \\
\text { Segurança }\end{array}$ & 29/11/2016 & $\begin{array}{l}\text { 19/01/2017 - concedo a segurança pleiteada por .... } \\
\text { contra ato secretário municipal de saúde de Bauru, para } \\
\text { que o impetrado forneça à impetrante fraldas geriátricas } \\
\text { descartáveis - tamanho "g" (180 unidades por mês), e } \\
\text { julgo extinto o processo, com resolução de mérito - - } \\
\text { 07/05/2018 - arquivado definitivamente - }\end{array}$ & FRALDA \\
\hline 520 & $\begin{array}{c}\text { 1016444- } \\
\text { 19.2016.8.26.0071 }\end{array}$ & $63858 / 2016$ & 05/12/2016 & $\begin{array}{l}\text { Mandado de } \\
\text { Segurança }\end{array}$ & $30 / 11 / 2016$ & $\begin{array}{l}13 / 01 / 2017 \text { - concedo a segurança pleiteada por .... } \\
\text { contra ato do secretário municipal de saúde de Bauru, } \\
\text { para que o impetrado forneça ao impetrante: fraldas } \\
\text { geriátricas - }\end{array}$ & FRALDA \\
\hline 521 & $\begin{array}{c}\text { 1026128- } \\
\text { 65.2016.8.26.0071 }\end{array}$ & $64223 / 2016$ & 06/12/2016 & $\begin{array}{l}\text { Mandado de } \\
\text { Segurança }\end{array}$ & $30 / 11 / 2016$ & $\begin{array}{l}\text { 16/01/2017 - concedo a segurança pleiteada por .... } \\
\text { contra ato do secretário municipal de saúde de Bauru, } \\
\text { para que o impetrado forneça ao impetrante fraldas } \\
\text { geriátricas descartáveis - - } 07 / 05 / 2018 \text { - arquivado } \\
\text { definitivamente - }\end{array}$ & FRALDA \\
\hline
\end{tabular}




\begin{tabular}{|c|c|c|c|c|c|c|c|}
\hline 522 & $\begin{array}{c}\text { 1026154- } \\
\text { 63.2016.8.26.0071 }\end{array}$ & $64890 / 2016$ & 07/12/2016 & $\begin{array}{l}\text { Mandado de } \\
\text { Segurança }\end{array}$ & $01 / 12 / 2016$ & $\begin{array}{l}16 / 01 / 2017 \text { - concedo a segurança pleiteada por .... } \\
\text { contra ato do secretário municipal de saúde de Bauru, } \\
\text { para que o impetrado providencie o fornecimento à parte } \\
\text { impetrante dieta enteral líquida normocalórica, } \\
\text { normoproteica, normolipidica, isenta de sacarose, lactose, } \\
\text { glúten, acrescida de fibras (1500 ml por dia / } 47 \text { litros por } \\
\text { mês), conforme prescrição médica de fls. } 12 \text {, e julgo } \\
\text { extinto o processo, com resolução de mérito - } \\
05 / 07 / 2017 \text { - recebidos os autos do tribunal de justiça - } \\
\text { data do julgamento: } 24 / 04 / 2017 \text { trânsito em julgado: tipo } \\
\text { de julgamento: acórdão decisão: negaram provimento ao } \\
\text { recurso - - 07/03/2018 - arquivado definitivamente }\end{array}$ & $\begin{array}{c}\text { ALIMENTAÇÃO } \\
\text { ESPECIAL }\end{array}$ \\
\hline 523 & $\begin{array}{c}\text { 1022799- } \\
\text { 45.2016.8.26.0071 }\end{array}$ & $66651 / 2016$ & 14/12/2016 & $\begin{array}{l}\text { Mandado de } \\
\text { Segurança }\end{array}$ & 02/12/2016 & $\begin{array}{l}25 / 01 / 2017 \text { - concedo a segurança pleiteada josé rosa } \\
\text { britto contra ato do secretário municipal de saúde de } \\
\text { Bauru, para que o impetrado forneça ao impetrante: } \\
\text { fraldas geriátricas tamanho "exg" } 150 \text { (c - - 07/07/2017 - } \\
\text { arquivado definitivamente - }\end{array}$ & FRALDA \\
\hline 524 & $\begin{array}{c}\text { 1027795- } \\
\text { 86.2016.8.26.0071 }\end{array}$ & $66805 / 2016$ & 14/12/2016 & $\begin{array}{l}\text { Mandado de } \\
\text { Segurança }\end{array}$ & 12/12/2016 & $\begin{array}{l}25 / 01 / 2017 \text { - concedo a segurança pleiteada .... contra } \\
\text { ato do secretário municipal de saúde de Bauru, para que } \\
\text { o impetrado forneça ao impetrante: fraldas geriátricas. }\end{array}$ & FRALDA \\
\hline 525 & $\begin{array}{c}\text { 1027791- } \\
\text { 49.2016.8.26.0071 }\end{array}$ & $66810 / 2016$ & $14 / 12 / 2016$ & $\begin{array}{l}\text { Mandado de } \\
\text { Segurança }\end{array}$ & $12 / 12 / 2016$ & $\begin{array}{l}\text { 27/01/2017 - concedo a segurança pleiteada .... contra } \\
\text { ato do secretário municipal de saúde de Bauru, para que } \\
\text { o impetrado forneça ao impetrante: fraldas geriátricas - - } \\
\text { 18/10/2017 - arquivado definitivamente - }\end{array}$ & FRALDA \\
\hline 526 & $\begin{array}{c}\text { 1027797- } \\
\text { 56.2016.8.26.0071 }\end{array}$ & 67266/2016 & $15 / 12 / 2016$ & $\begin{array}{l}\text { Mandado de } \\
\text { Segurança }\end{array}$ & 12/12/2016 & $\begin{array}{l}\text { 20/01/2017 - concedo a segurança pleiteada por .... } \\
\text { contra ato secretário municipal de saúde de Bauru, para } \\
\text { que o impetrado forneça à impetrante fraldas geriátricas } \\
\text { descartáveis - - 25/10/2017 - arquivado definitivamente - }\end{array}$ & FRALDA \\
\hline 527 & $\begin{array}{c}\text { 1027895- } \\
41.2016 .8 .26 .0071\end{array}$ & $67412 / 2016$ & 16/12/2016 & $\begin{array}{l}\text { Mandado de } \\
\text { Segurança }\end{array}$ & 13/12/2016 & $\begin{array}{l}17 / 02 / 2017 \text { - concedo a segurança pleiteada por .... } \\
\text { contra ato do secretário municipal de saúde de Bauru, } \\
\text { para que o impetrado forneça ao impetrante fraldas } \\
\text { geriátricas descartáveis - - } 16 / 03 / 2018 \text { - arquivado } \\
\text { definitivamente - }\end{array}$ & FRALDA \\
\hline 528 & $\begin{array}{c}\text { 1028484- } \\
\text { 33.2016.8.26.0071 }\end{array}$ & 67796/2016 & 19/12/2016 & $\begin{array}{l}\text { Mandado de } \\
\text { Segurança }\end{array}$ & 15/12/2016 & $\begin{array}{l}25 / 01 / 2017 \text { - concedo a segurança pleiteada ..... contra } \\
\text { ato do secretário municipal de saúde de Bauru, para que } \\
\text { o impetrado forneça ao impetrante: fraldas geriátricas - - } \\
\text { 29/11/2017 - arquivado definitivamente - }\end{array}$ & FRALDA \\
\hline 529 & $\begin{array}{c}0000734- \\
56.2016 .8 .26 .0594\end{array}$ & $68871 / 2016$ & 26/12/2016 & $\begin{array}{c}\text { Outros } \\
\text { Procediment } \\
\text { os }\end{array}$ & 16/01/2017 & 02/05/2017 - Extinto - Falecimento & INTERNAÇÃO \\
\hline
\end{tabular}




\begin{tabular}{|c|c|c|c|c|c|c|c|}
\hline 530 & $\begin{array}{c}\text { 1026125- } \\
\text { 13.2016.8.26.0071 }\end{array}$ & $1732 / 2017$ & 10/01/2017 & $\begin{array}{l}\text { Mandado de } \\
\text { Segurança }\end{array}$ & $30 / 11 / 2016$ & $\begin{array}{l}\text { 27/01/2017 - concedo a segurança pleiteada .... contra } \\
\text { ato do secretário municipal de saúde de Bauru, para que } \\
\text { o impetrado forneça ao impetrante: fraldas geriátricas - - } \\
\text { 02/03/2018 - arquivado definitivamente - } \\
\end{array}$ & FRALDA \\
\hline 531 & $\begin{array}{c}1028256- \\
58.2016 .8 .26 .0071\end{array}$ & 2022/2017 & $11 / 01 / 2017$ & $\begin{array}{l}\text { Mandado de } \\
\text { Segurança }\end{array}$ & 19/12/2016 & $\begin{array}{l}\text { 23/10/2018 - concedo a segurança pleiteada por ... contra } \\
\text { ato do diretor do departamento regional de saúde de } \\
\text { Bauru (drs-vi), para que o impetrado providencie o } \\
\text { fornecimento a impetrante do medicamento jakavi } \\
\text { (ruxolitinibe) } 5 \mathrm{mg} \text { - } 2 \text { (duas) cápsulas ao dia - }\end{array}$ & MEDICAMENTO \\
\hline 532 & $\begin{array}{c}\text { 1027322- } \\
\text { 03.2016.8.26.0071 }\end{array}$ & $2255 / 2017$ & 12/01/2017 & $\begin{array}{l}\text { Mandado de } \\
\text { Segurança }\end{array}$ & 17/12/2016 & $\begin{array}{l}\text { 03/03/2017 - julgo procedentes os pedidos da presente } \\
\text { ação de mandado de segurança, para tornar definitiva a } \\
\text { liminar deferida e determinar ao diretor do departamento } \\
\text { regional de saúde da secretaria do estado de saúde em } \\
\text { Bauru- drs vi e ao secretário municipal de saúde de } \\
\text { Bauru, o fornecimento mensal de } 240 \text { fraldas bigfral, } \\
\text { tamanho extra g, por tempo indeterminado, até a } \\
\text { convalescença, efetivando o tratamento de saúde de que } \\
\text { o autor necessita. - - } 13 / 03 / 2018 \text { - recebidos os autos do } \\
\text { tribunal de justiça - }-13 / 07 / 2018 \text { - arquivado } \\
\text { definitivamente - }\end{array}$ & FRALDA \\
\hline 533 & $\begin{array}{c}\text { 1029214- } \\
\text { 44.2016.8.26.0071 }\end{array}$ & $2375 / 2017$ & 12/01/2017 & $\begin{array}{l}\text { Mandado de } \\
\text { Segurança }\end{array}$ & 09/01/2017 & $\begin{array}{l}\text { 31/01/2017 - concedo a segurança pleiteada margarida } \\
\text { emilia dos santos lima contra ato do secretário municipal } \\
\text { de saúde de Bauru, para que o impetrado forneça ao } \\
\text { impetrante: fraldas geriátricas - - 18/04/2018 - arquivado } \\
\text { definitivamente - }\end{array}$ & FRALDA \\
\hline 534 & $\begin{array}{c}\text { 1000176- } \\
\text { 50.2017.8.26.0071 }\end{array}$ & $2576 / 2017$ & 13/01/2017 & $\begin{array}{l}\text { Mandado de } \\
\text { Segurança }\end{array}$ & 11/01/2017 & $\begin{array}{l}\text { 29/05/2017 - concedo a segurança pleiteada por .... } \\
\text { contra ato do secretário municipal de saúde de Bauru, } \\
\text { para que o impetrado forneça à parte impetrante fraldas } \\
\text { geriátricas descartáveis - - 30/11/2017 - arquivado } \\
\text { definitivamente - }\end{array}$ & FRALDA \\
\hline 535 & $\begin{array}{c}1000182- \\
57.2017 .8 .26 .0071 \\
\end{array}$ & $2588 / 2017$ & 13/01/2017 & $\begin{array}{l}\text { Mandado de } \\
\text { Segurança }\end{array}$ & & $\begin{array}{l}20 / 0617 \text { - Apelação - Reexame Necessário } \\
\text { medicamento "Concerta Metilfenidato } 54 \mathrm{Mg} / \mathrm{cp} \text { " }\end{array}$ & MEDICAMENTO \\
\hline 536 & $\begin{array}{c}1000059-- \\
59.2017 .8 .26 .0071\end{array}$ & $3257 / 2017$ & $17 / 01 / 2017$ & $\begin{array}{c}\text { Outros } \\
\text { Procediment } \\
\text { os }\end{array}$ & & SEGREDO DE JUSTIÇA & $\begin{array}{l}\text { SEGREDO DE } \\
\text { JUSTIÇA }\end{array}$ \\
\hline 537 & $\begin{array}{c}\text { 1022506- } \\
\text { 75.2016.8.26.0071 }\end{array}$ & $3954 / 2017$ & 20/01/2017 & $\begin{array}{l}\text { Mandado de } \\
\text { Segurança }\end{array}$ & $25 / 10 / 2016$ & $\begin{array}{l}\text { 13/12/2016 - concedo a segurança pleiteada por .... } \\
\text { contra ato do diretor do departamento regional de saúde } \\
\text { de Bauru (drs-vi), para que o impetrado providencie o } \\
\text { agendamento do exame de ressonância magnética de } \\
\text { crânio. }\end{array}$ & EXAME \\
\hline
\end{tabular}




\begin{tabular}{|c|c|c|c|c|c|c|c|}
\hline 538 & $\begin{array}{c}1027813- \\
10.2016 .8 .26 .0071\end{array}$ & $3904 / 2017$ & $20 / 01 / 2017$ & $\begin{array}{l}\text { Mandado de } \\
\text { Segurança }\end{array}$ & & $\begin{array}{l}\text { 24/03/2017 - denego o mandado de segurança impetrado } \\
\text { por ... em face de ato cometido pelo municíio de Bauru e } \\
\text { departamento de água e esgoto de Bauru - dae - }\end{array}$ & $\begin{array}{l}\text { INSUMOS/MATE } \\
\text { RIAL } \\
\text { HOSPITALAR }\end{array}$ \\
\hline 539 & $\begin{array}{c}1001044- \\
28.2017 .8 .26 .0071\end{array}$ & $4691 / 2017$ & $25 / 01 / 2017$ & $\begin{array}{c}\text { Outros } \\
\text { Procediment } \\
\text { os }\end{array}$ & & SEGREDO DE JUSTIÇA & $\begin{array}{l}\text { SEGREDO DE } \\
\text { JUSTIÇA }\end{array}$ \\
\hline 540 & $\begin{array}{c}\text { 1001131- } \\
\text { 81.2017.8.26.0071 }\end{array}$ & $5069 / 2017$ & $27 / 01 / 2017$ & $\begin{array}{l}\text { Mandado de } \\
\text { Segurança }\end{array}$ & $23 / 01 / 2017$ & $\begin{array}{l}\text { 02/03/2017 - concedo a segurança pleiteada .... contra } \\
\text { ato do secretário municipal de saúde de Bauru, para que } \\
\text { o impetrado forneça ao impetrante: fraldas geriátricas - - } \\
\text { 09/11/2017 - arquivado definitivamente - }\end{array}$ & FRALDA \\
\hline 541 & $\begin{array}{c}\text { 1001130- } \\
96.2017 .8 .26 .0071\end{array}$ & $5071 / 2017$ & $27 / 01 / 2017$ & $\begin{array}{l}\text { Mandado de } \\
\text { Segurança }\end{array}$ & $23 / 01 / 2017$ & $\begin{array}{l}02 / 03 / 2017 \text { - concedo a segurança pleiteada por .... } \\
\text { contra ato do secretário municipal de saúde de Bauru, } \\
\text { para que o impetrado forneça à impetrante fraldas } \\
\text { geriátricas descartáveis - }-15 / 12 / 2017 \text { - arquivado } \\
\text { definitivamente - }\end{array}$ & FRALDA \\
\hline 542 & $\begin{array}{c}1029188- \\
46.2016 .8 .26 .0071\end{array}$ & $5397 / 2017$ & $30 / 01 / 2017$ & $\begin{array}{l}\text { Mandado de } \\
\text { Segurança }\end{array}$ & $21 / 06 / 2017$ & 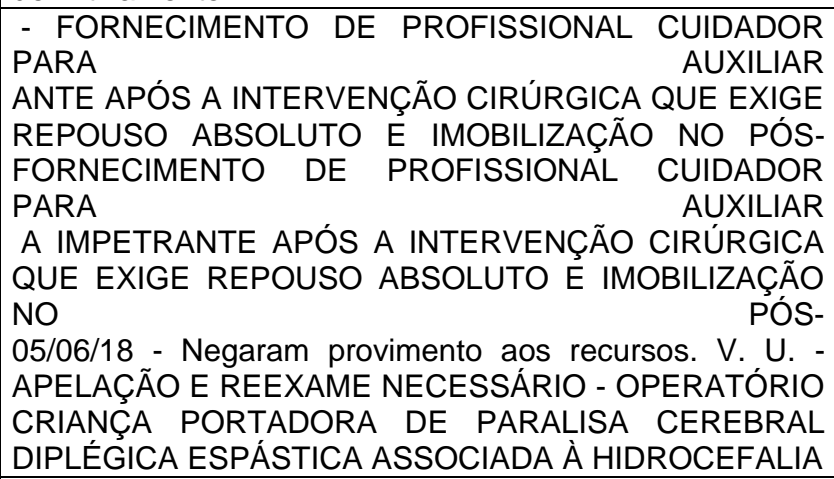 & $\begin{array}{c}\text { CUIDADOR/HOM } \\
\text { E CARE }\end{array}$ \\
\hline 543 & $\begin{array}{c}\text { 1001634- } \\
\text { 05.2017.8.26.0071 }\end{array}$ & $5385 / 2017$ & $30 / 01 / 2017$ & $\begin{array}{l}\text { Mandado de } \\
\text { Segurança }\end{array}$ & $26 / 01 / 2017$ & $\begin{array}{l}\text { 21/02/2017 - concedo a segurança pleiteada .... contra } \\
\text { ato do secretário municipal de saúde de Bauru, para que } \\
\text { o impetrado forneça ao impetrante: fraldas geriátricas - - } \\
\text { 09/11/2017 - arquivado definitivamente - }\end{array}$ & FRALDA \\
\hline 544 & $\begin{array}{c}1000225- \\
91.2017 .8 .26 .0071\end{array}$ & $5384 / 2017$ & $30 / 01 / 2017$ & $\begin{array}{l}\text { Mandado de } \\
\text { Segurança }\end{array}$ & $12 / 01 / 2017$ & $\begin{array}{l}\text { 21/02/2017 - concedo a segurança pleiteada .... contra } \\
\text { ato do secretário municipal de saúde de Bauru, para que } \\
\text { o impetrado forneça ao impetrante: fraldas geriátricas - - } \\
31 / 10 / 2017 \text { - arquivado definitivamente - }\end{array}$ & FRALDA \\
\hline 545 & $\begin{array}{c}\text { 1028482- } \\
\text { 63.2016.8.26.0071 }\end{array}$ & $5708 / 2017$ & $31 / 01 / 2017$ & $\begin{array}{l}\text { Mandado de } \\
\text { Segurança }\end{array}$ & $25 / 01 / 2017$ & $\begin{array}{l}\text { 15/03/2017 - concedo a segurança pleiteada por ... contra } \\
\text { ato do secretário municipal de saúde de Bauru, para que } \\
\text { o impetrado forneça à parte impetrante fraldas geriátricas } \\
\text { descartáveis - - 25/09/2017 - arquivado definitivamente - }\end{array}$ & FRALDA \\
\hline
\end{tabular}




\begin{tabular}{|c|c|c|c|c|c|c|c|}
\hline 546 & $\begin{array}{c}1027919- \\
69.2016 .8 .26 .0071\end{array}$ & $5826 / 2017$ & 01/02/2017 & $\begin{array}{l}\text { Mandado de } \\
\text { Segurança }\end{array}$ & $21 / 06 / 2017$ & $\begin{array}{l}\text { 13/03/19 - Apelação - RECURSO OFICIAL E APELO } \\
\text { VOLUNTÁRIO. AMBOS DESPROVIDOS }\end{array}$ & MEDICAMENTO \\
\hline 547 & $\begin{array}{c}1000064- \\
81.2017 .8 .26 .0071\end{array}$ & $5983 / 2017$ & $01 / 02 / 2017$ & $\begin{array}{l}\text { Mandado de } \\
\text { Segurança }\end{array}$ & & $\begin{array}{l}\text { 01/08/18 - Apelação / Remessa Necessária - } \\
\text { REALIZAÇÃO DE CONSULTA MÉDICA ESPECÍFICA. } \\
\text { SENTENÇA QUE CONCEDEU A SEGURANÇA. } \\
\text { PROCEDIMENTO QUE FOI REALIZADO EM MOMENTO } \\
\text { ANTERIOR À PROLAÇÃO DA SENTENÇA. HIPÓTESE } \\
\text { DE EXTINÇÃO DO FEITO, SEM RESOLUÇÃO DO } \\
\text { MÉRITO }\end{array}$ & $\begin{array}{l}\text { CONSULTA } \\
\text { MÉDICA }\end{array}$ \\
\hline 548 & $\begin{array}{c}1029426- \\
65.2016 .8 .26 .0071\end{array}$ & $6666 / 2017$ & 06/02/2017 & $\begin{array}{l}\text { Mandado de } \\
\text { Segurança }\end{array}$ & $27 / 01 / 2017$ & $\begin{array}{l}15 / 03 / 2017 \text { - concedo a segurança pleiteada por .... } \\
\text { contra ato do secretário municipal de saúde de Bauru, } \\
\text { para que o impetrado forneça ao impetrante: fraldas } \\
\text { geriátricas tamanho "exg" } 180 \text { (cento e oitenta) unidades } \\
\text { por mês, conforme receituário de fls. } 17 \text { e julgo extinto o } \\
\text { processo, com resolução de mérito - - 09/02/2018 - } \\
\text { arquivado definitivamente - }\end{array}$ & FRALDA \\
\hline 549 & $\begin{array}{c}1002273- \\
23.2017 .8 .26 .0071\end{array}$ & $6793 / 2017$ & 06/02/2017 & $\begin{array}{l}\text { Mandado de } \\
\text { Segurança }\end{array}$ & 01/02/2017 & $\begin{array}{l}\text { 22/06/2017 - concedo a segurança pleiteada por .... } \\
\text { contra ato do diretor do departamento regional de saúde } \\
\text { de Bauru (drs-vi), para que o impetrado providencie o } \\
\text { fornecimento ao impetrante: suplemento alimentar com } \\
\text { tgfb-2 (modulen/bd), } 6 \text { colheres medidas em } 210 \mathrm{ml} \text { de } \\
\text { água, } 2 x \text { ao dia, } 8 \text { latas/mês, conforme prescrição médica } \\
\text { de fls. } 24 \text {, e julgo extinto o processo, com resolução de } \\
\text { mérito - - 04/07/2017 - remetido ao dje - relação: } \\
\text { 0518/2017 teor do ato: vistos.o município de Bauru opôs } \\
\text { embargos de declaração apontando erro material com } \\
\text { relação ao nome da autoridade impetrada que aparece no } \\
\text { dispositivo da sentença, ... "ficam ratificados os demais } \\
\text { termos da sentença.intimem-se. advogados(s): ... - - } \\
24 / 08 / 2018 \text { - arquivado definitivamente }\end{array}$ & $\begin{array}{l}\text { ALIMENTAÇÃO } \\
\text { ESPECIAL }\end{array}$ \\
\hline 550 & $\begin{array}{c}1002472- \\
45.2017 .8 .26 .0071\end{array}$ & $6953 / 2017$ & 07/02/2017 & $\begin{array}{l}\text { Mandado de } \\
\text { Segurança }\end{array}$ & 02/02/2017 & $\begin{array}{l}20 / 04 / 2017 \text { - concedo a segurança pleiteada por ... contra } \\
\text { ato do secretário municipal de saúde de Bauru, para que } \\
\text { o impetrado forneça à parte impetrante fraldas geriátricas } \\
\text { descartáveis - - 14/08/2018 - arquivado definitivamente - }\end{array}$ & FRALDA \\
\hline 551 & $\begin{array}{l}\text { 1002684- } \\
66.2017 .8 .26 .0071\end{array}$ & $7242 / 2017$ & 08/02/2017 & $\begin{array}{l}\text { Mandado de } \\
\text { Segurança }\end{array}$ & 06/02/2017 & $\begin{array}{l}\text { 27/04/2017 - concedo a segurança pleiteada francisco } \\
\text { aparecido magalhaes contra ato do secretário municipal } \\
\text { de saúde de Bauru, para que o impetrado forneça ao } \\
\text { impetrante: fraldas geriátricas - - 18/10/2017 - arquivado } \\
\text { definitivamente - }\end{array}$ & FRALDA \\
\hline
\end{tabular}




\begin{tabular}{|c|c|c|c|c|c|c|c|}
\hline 552 & $\begin{array}{c}\text { 1002630- } \\
\text { 03.2017.8.26.0071 }\end{array}$ & $7654 / 2017$ & 09/02/2017 & $\begin{array}{l}\text { Outros } \\
\text { Procediment } \\
\text { os }\end{array}$ & 06/02/2017 & $\begin{array}{l}\text { 07/04/2017 - concedo a segurança pleiteada por .... } \\
\text { contra ato do secretário municipal de saúde de Bauru, } \\
\text { para que o impetrado forneça ao impetrante: fraldas } \\
\text { geriátricas tamanho "g" } 150 \text { (cento e cinquenta) unidades } \\
\text { por mês, conforme receituário de fls. } 20 \text { e julgo extinto o } \\
\text { processo, com resolução de mérito - - } 21 / 02 / 2018 \text { - } \\
\text { arquivado definitivamente - }\end{array}$ & FRALDA \\
\hline 553 & $\begin{array}{c}\text { 1001365- } \\
\text { 63.2017.8.26.0071 }\end{array}$ & $7662 / 2017$ & 09/02/2017 & $\begin{array}{l}\text { Outros } \\
\text { Procediment } \\
\text { os }\end{array}$ & 03/02/2017 & $\begin{array}{l}26 / 07 / 2017 \text { - julgo procedente a presente ação proposta } \\
\text { por ... contra prefeitura municipal de Bauru, } \\
\text { determinando que a requerida apresente laudos, } \\
\text { prontuários médicos e demais documentos constantes no } \\
\text { atendimento de olímpio akio yagi, e julgo extinto o } \\
\text { processo - - 25/05/2018 - arquivado definitivamente - }\end{array}$ & $\begin{array}{l}\text { APRESENTAÇÃO } \\
\text { DE PRONTUARRIO }\end{array}$ \\
\hline 554 & $\begin{array}{c}\text { 1002836- } \\
17.2017 .8 .26 .0071\end{array}$ & $7640 / 2017$ & 09/02/2017 & $\begin{array}{l}\text { Mandado de } \\
\text { Segurança }\end{array}$ & 06/02/2017 & $\begin{array}{l}\text { 06/06/2017 - concedo a segurança pleiteada pro .... contra } \\
\text { ato do secretário municipal de saúde de Bauru, para que } \\
\text { o impetrado forneça ao impetrante: fraldas geriátricas - - } \\
\text { 19/02/2018 - arquivado definitivamente - }\end{array}$ & FRALDA \\
\hline 555 & $\begin{array}{c}1002633- \\
55.2017 .8 .26 .0071\end{array}$ & $7799 / 2017$ & 10/02/2017 & $\begin{array}{c}\text { Mandado de } \\
\text { Segurança }\end{array}$ & 06/02/2017 & $\begin{array}{l}11 / 04 / 2017 \text { - concedo a segurança pleiteada por .... } \\
\text { contra ato do secretário municial de saúde de Bauru, } \\
\text { para que o impetrado forneça à parte impetrante fraldas } \\
\text { geriátricas descartáveis - }-14 / 04 / 2018 \text { - arquivado } \\
\text { definitivamente - }\end{array}$ & FRALDA \\
\hline 556 & $\begin{array}{c}\text { 1019626- } \\
\text { 13.2016.8.26.0071 }\end{array}$ & $8144 / 2017$ & 13/02/2017 & $\begin{array}{l}\text { Outros } \\
\text { Procediment } \\
\text { os }\end{array}$ & 08/02/2017 & $\begin{array}{l}\text { 04/09/2017 - }{ }^{* * *} \text { considerando o ofício do colendo superior } \\
\text { tribunal de justiça (n. 222/2017 - nugep, de } 03 \text { de maio de } \\
2017 \text { ), encaminhado pela egrégia presidência deste } \\
\text { tribunal de justiça, no qual foi comunicada a afetação do } \\
\text { recurso especial no } 1657156 \text { para uniformização da } \\
\text { matéria referente à "obrigatoriedade de fornecimento, pelo } \\
\text { estado, de medicamentos não contemplados na portaria } \\
n^{0} 2.982 / 2009 \text { do ministério da saúde (programa de } \\
\text { medicamentos excepcionais)", bem como a determinação } \\
\text { de "suspensão do processamento de todos os processos } \\
\text { pendentes, individuais e coletivos, que versem sobre } \\
\text { idêntica questão e que tramitem no território nacional (art. } \\
1.037 \text {, ii do cpc)", providencie a serventia as anotações } \\
\text { necessárias no saj para a respectiva suspensão do } \\
\text { trâmite deste processo - }\end{array}$ & MEDICAMENTO \\
\hline
\end{tabular}




\begin{tabular}{|c|c|c|c|c|c|c|c|}
\hline 557 & $\begin{array}{c}\text { 1002473- } \\
30.2017 .8 .26 .0071\end{array}$ & $8174 / 2017$ & $13 / 02 / 2017$ & $\begin{array}{l}\text { Mandado de } \\
\text { Segurança }\end{array}$ & 03/02/2017 & $\begin{array}{l}\text { 19/05/2017 - concedo a segurança pleiteada por .... } \\
\text { contra ato do diretor do departamento regional de saúde } \\
\text { de Bauru (drs-vi), para que o impetrado providencie o } \\
\text { fornecimento à impetrante: dieta enteral em pó } \\
\text { normocalórica e normoproteíca, } 1.0 \mathrm{kcal} / \mathrm{ml}, \text { com fibras, } \\
\text { sem sucarose, ( } 17 \text { postes de } 800 \mathrm{~g} \text { ao mês), conforme } \\
\text { prescrição nutricional de fls. } 13 \text {, óxido de zinco + óleo de } \\
\text { fígago de bacalhau }+ \text { vitamina a e d3 ( } 04 \text { tubos ao mês) e } \\
\text { clotrimazol } 10 \mathrm{mg} / \mathrm{g} \text { ( } 01 \text { bisnaga ao mês), conforme } \\
\text { receituário de fls. } 15 \text { e julgo extinto o processo, com } \\
\text { resolução de mérito. }\end{array}$ & MEDICAMENTO \\
\hline 558 & $\begin{array}{c}\text { 1028486- } \\
\text { 03.2016.8.26.0071 }\end{array}$ & $8978 / 2017$ & $16 / 02 / 2017$ & $\begin{array}{l}\text { Mandado de } \\
\text { Segurança }\end{array}$ & $14 / 02 / 2017$ & $\begin{array}{l}\text { 05/05/2017 - concedo a segurança pleiteada por ... contra } \\
\text { ato do secretário municipal de saúde de Bauru, para que } \\
\text { o impetrado forneça ao impetrante: fraldas geriátricas - - } \\
\text { 10/11/2017 - arquivado definitivamente - }\end{array}$ & FRALDA \\
\hline 559 & $\begin{array}{c}1003858- \\
13.2017 .8 .26 .0071\end{array}$ & $9238 / 2017$ & $17 / 02 / 2017$ & $\begin{array}{l}\text { Mandado de } \\
\text { Segurança }\end{array}$ & $15 / 02 / 2017$ & $\begin{array}{l}15 / 05 / 2017 \text { - concedo a segurança pleiteada por .... } \\
\text { contra ato do secretário municipal de saúde de Bauru, } \\
\text { para que o impetrado forneça à parte impetrante fraldas } \\
\text { geriátricas descartáveis - - 30/11/2017 - arquivado } \\
\text { definitivamente - }\end{array}$ & FRALDA \\
\hline 560 & $\begin{array}{c}\text { 1003666- } \\
80.2017 .8 .26 .0071\end{array}$ & $9240 / 2017$ & $17 / 02 / 2017$ & $\begin{array}{l}\text { Mandado de } \\
\text { Segurança }\end{array}$ & $31 / 03 / 2017$ & $\begin{array}{l}\text { 30/05/2017 - concedo a segurança pleiteada por .... } \\
\text { contra ato do secretário municipal de saúde de Bauru, } \\
\text { para que o impetrado forneça ao impetrante: fraldas } \\
\text { geriátricas - - 30/11/2017 - arquivado definitivamente - }\end{array}$ & FRALDA \\
\hline 561 & $\begin{array}{c}\text { 1003852- } \\
\text { 06.2017.8.26.0071 }\end{array}$ & $9600 / 2017$ & $20 / 02 / 2017$ & $\begin{array}{l}\text { Mandado de } \\
\text { Segurança }\end{array}$ & $15 / 02 / 2017$ & $\begin{array}{l}\text { 05/05/2017 - concedo a segurança pleiteada por .... } \\
\text { contra ato do secretário municipal de saúde de Bauru, } \\
\text { para que o impetrado forneça à parte impetrante fraldas } \\
\text { geriátricas descartáveis - } 07 / 11 / 2017 \text { - arquivado } \\
\text { definitivamente - }\end{array}$ & FRALDA \\
\hline 562 & $\begin{array}{c}\text { 1003859- } \\
95.2017 .8 .26 .0071\end{array}$ & $9760 / 2017$ & $21 / 02 / 2017$ & $\begin{array}{l}\text { Mandado de } \\
\text { Segurança }\end{array}$ & $16 / 02 / 2017$ & $\begin{array}{l}09 / 05 / 2017 \text { - concedo a segurança pleiteada por .... } \\
\text { contra ato do secretário municipal de saúde de Bauru, } \\
\text { para que o impetrado forneça ao impetrante: fraldas } \\
\text { geriátricas - - 10/11/2017 - arquivado definitivamente - }\end{array}$ & FRALDA \\
\hline 563 & $\begin{array}{c}\text { 1004331- } \\
\text { 96.2017.8.26.0071 }\end{array}$ & $10279 / 2017$ & $23 / 02 / 2017$ & $\begin{array}{l}\text { Mandado de } \\
\text { Segurança }\end{array}$ & $21 / 02 / 2017$ & $\begin{array}{l}\text { 04/05/2017 - oncedo a segurança pleiteada por .... contra } \\
\text { ato do secretário municipal de saúde de Bauru, para que } \\
\text { o impetrado forneça ao impetrante: fraldas geriátricas - - } \\
21 / 02 / 2018 \text { - arquivado definitivamente - }\end{array}$ & FRALDA \\
\hline 564 & $\begin{array}{c}\text { 1004810- } \\
\text { 89.2017.8.26.0071 }\end{array}$ & $10529 / 2017$ & $24 / 02 / 2017$ & $\begin{array}{l}\text { Mandado de } \\
\text { Segurança }\end{array}$ & 22/02/2017 & $\begin{array}{l}09 / 05 / 2017 \text { - concedo a segurança pleiteada por .... } \\
\text { contra ato do secretário municipal de saúde de Bauru, } \\
\text { para que o impetrado forneça ao impetrante: fraldas } \\
\text { geriátricas t - - 02/03/2018 - arquivado definitivamente - }\end{array}$ & FRALDA \\
\hline
\end{tabular}




\begin{tabular}{|c|c|c|c|c|c|c|c|}
\hline 565 & $\begin{array}{c}1004809- \\
07.2017 .8 .26 .0071\end{array}$ & $11014 / 2017$ & 02/03/2017 & $\begin{array}{l}\text { Mandado de } \\
\text { Segurança }\end{array}$ & 22/02/2017 & $\begin{array}{l}18 / 05 / 2017 \text { - concedo a segurança pleiteada por .... } \\
\text { contra ato do secretário municipal de saúde de Bauru, } \\
\text { para que o impetrado forneça à parte impetrante fraldas } \\
\text { geriátricas descartáveis - } \text { - 09/03/2018 - arquivado } \\
\text { definitivamente - }\end{array}$ & FRALDA \\
\hline 566 & $\begin{array}{c}\text { 0025996- } \\
25.2016 .8 .26 .0071\end{array}$ & $11047 / 2017$ & 02/03/2017 & $\begin{array}{l}\text { Outros } \\
\text { Procediment } \\
\text { os }\end{array}$ & & $\begin{array}{l}26 / 11 / 16 \text { - foram encontradas em situação precária de } \\
\text { higiene e saúde, sendo que uma delas precisou ser } \\
\text { internada devido a uma hérnia }\end{array}$ & INTERNAÇÃO \\
\hline 567 & $\begin{array}{c}\text { 1018946- } \\
\text { 62.2015.8.26.0071 }\end{array}$ & $11145 / 2017$ & 03/03/2017 & $\begin{array}{l}\text { Outros } \\
\text { Procediment } \\
\text { os }\end{array}$ & & SEGREDO DE JUSTIÇA & CIRURGIA \\
\hline 568 & $\begin{array}{c}1005273- \\
31.2017 .8 .26 .0071\end{array}$ & $11542 / 2017$ & 06/03/2017 & $\begin{array}{l}\text { Mandado de } \\
\text { Segurança }\end{array}$ & 01/03/2017 & $\begin{array}{l}\text { 09/05/2017 - concedo a segurança pleiteada por .... } \\
\text { contra ato do secretário municipal de saúde de Bauru, } \\
\text { para que o impetrado forneça ao impetrante: fraldas } \\
\text { geriátricas - - 22/11/2017 - arquivado definitivamente - }\end{array}$ & FRALDA \\
\hline 569 & $\begin{array}{l}\text { 1005278- } \\
\text { 53.2017.8.26.0071 }\end{array}$ & $12074 / 2017$ & 07/03/2017 & $\begin{array}{l}\text { Mandado de } \\
\text { Segurança }\end{array}$ & 01/03/2017 & $\begin{array}{l}17 / 05 / 2017 \text { - concedo a segurança pleiteada por .... } \\
\text { contra ato do secretário municipal de saúde de Bauru, } \\
\text { para que o impetrado forneça ao impetrante: fraldas } \\
\text { geriátricas - - 10/11/2017 - arquivado definitivamente - }\end{array}$ & FRALDA \\
\hline 570 & $\begin{array}{l}1004928- \\
65.2017 .8 .26 .0071\end{array}$ & 12080/2017 & 07/03/2017 & $\begin{array}{l}\text { Outros } \\
\text { Procediment } \\
\quad \text { os }\end{array}$ & 03/03/2017 & $\begin{array}{l}04 / 07 / 2017 \text { - julgo procedente o pedido, formulado por .... } \\
\text { contra prefeitura municipal de Bauru, determinando que o } \\
\text { requerido forneça ao requerente: dieta líquida polimérica } \\
\text { hipercalórica } 1,5 \text { cal/ml, hiperproteica com fibras } 1,51 / \text { dia - } \\
\text { 45l/mês, - - 16/04/2018 - arquivado definitivamente - }\end{array}$ & MEDICAMENTO \\
\hline 571 & $\begin{array}{c}\text { 1005750- } \\
54.2017 .8 .26 .0071\end{array}$ & $12502 / 2017$ & 09/03/2017 & $\begin{array}{l}\text { Mandado de } \\
\text { Segurança }\end{array}$ & 07/03/2017 & $\begin{array}{l}\text { 26/06/2017 - oncedo a segurança pleiteada por .... contra } \\
\text { ato do secretário municipal de saúde de Bauru, para que } \\
\text { o impetrado forneça à parte impetrante fraldas geriátricas } \\
\text { descartáveis - - 24/01/2018 - arquivado definitivamente - }\end{array}$ & FRALDA \\
\hline 572 & $\begin{array}{c}0000421- \\
12.2017 .4 .03 .6325\end{array}$ & 13322/2017 & 14/03/2017 & $\begin{array}{c}\text { Outros } \\
\text { Procediment } \\
\text { os }\end{array}$ & & SEGREDO DE JUSTIÇA & FRALDA \\
\hline 573 & $\begin{array}{l}\text { 1004391- } \\
\text { 69.2017.8.26.0071 }\end{array}$ & 13428/2017 & 14/03/2017 & $\begin{array}{l}\text { Outros } \\
\text { Procediment } \\
\text { os }\end{array}$ & 03/03/2017 & $\begin{array}{l}\text { 24/04/2017 - julgo procedente o pedido formulado por ... } \\
\text { em face do município de Bauru, determinando que este } \\
\text { forneça ao requerente fraldas descartáveis geriátricas - - } \\
\text { 18/08/2017 - trânsito em julgado às partes - com baixa - }\end{array}$ & FRALDA \\
\hline
\end{tabular}




\begin{tabular}{|c|c|c|c|c|c|c|c|}
\hline 574 & $\begin{array}{c}\text { 1028274- } \\
79.2016 .8 .26 .0071\end{array}$ & $13652 / 2017$ & $15 / 03 / 2017$ & $\begin{array}{l}\text { Outros } \\
\text { Procediment } \\
\quad \text { os }\end{array}$ & & $\begin{array}{l}\text { 06/09/2017 - trata-se de obrigação de fazer c/c } \\
\text { indenização por danos materiais e morais em face da } \\
\text { empresa de transporte coletivo grande Bauru Itda e } \\
\text { prefeitura municipal de Bauru.às fls. 183/184 a requerente } \\
\text { e a requerida transporte coletivo grande Bauru Itda } \\
\text { firmaram termo de acordo para pagamento das verbas } \\
\text { indenizatórias.intimada a ser manifestar, a requerida } \\
\text { prefeitura municipal de Bauru nada opôs ao referido } \\
\text { acordo (fl. 190).ante o exposto, homologo por sentença, } \\
\text { para que produza seus jurídicos e legais efeitos, o acordo } \\
\text { de fls. 183/184 celebrado entre as partes, e julgo extinto o } \\
\text { processo com resolução do mérito - }\end{array}$ & $\begin{array}{c}\text { DANO MATERIAL } \\
\text { E MORAL }\end{array}$ \\
\hline 575 & $\begin{array}{c}\text { 1008428- } \\
\text { 42.2017.8.26.0071 }\end{array}$ & $17573 / 2017$ & $30 / 03 / 2017$ & $\begin{array}{l}\text { Mandado de } \\
\text { Segurança }\end{array}$ & 28/03/2017 & $\begin{array}{l}29 / 05 / 2017 \text { - concedo a segurança pleiteada por .... } \\
\text { contra ato do secretário municipal de saúde de Bauru, } \\
\text { para que o impetrado forneça ao impetrante: fraldas } \\
\text { geriátricas - - 02/03/2018 - arquivado definitivamente - }\end{array}$ & FRALDA \\
\hline 576 & $\begin{array}{c}\text { 1008756- } \\
\text { 69.2017.8.26.0071 }\end{array}$ & 18149/2017 & 03/04/2017 & $\begin{array}{l}\text { Mandado de } \\
\text { Segurança }\end{array}$ & 30/03/2017 & $\begin{array}{l}17 / 04 / 2017 \text { - concedo a segurança pleiteada por .... } \\
\text { contra ato do secretário municipal de saúde de Bauru, } \\
\text { para que o impetrado providencie o fornecimento à parte } \\
\text { impetrante das agulhas bd ultra fine curta } 31 \mathrm{~g} \text { de } 8 \mathrm{~mm} \text { ( } 30 \\
\text { unidades por mês), conforme prescrição médica de fls. } \\
13, \text { e julgo extinto o processo, com resolução de mérito - } \\
-08 / 11 / 2017 \text { - arquivado definitivamente - }\end{array}$ & MEDICAMENTO \\
\hline 577 & $\begin{array}{c}\text { 1008910- } \\
87.2017 .8 .26 .0071\end{array}$ & 18460/2017 & 04/04/2017 & $\begin{array}{l}\text { Mandado de } \\
\text { Segurança }\end{array}$ & $31 / 03 / 2017$ & $\begin{array}{l}\text { 15/05/2017 - concedo a segurança pleiteada por ... contra } \\
\text { ato do secretário municipal de saúde de Bauru, para que } \\
\text { o impetrado forneça ao impetrante: fraldas geriátricas - - } \\
\text { 21/02/2018 - arquivado definitivamente - }\end{array}$ & FRALDA \\
\hline 578 & $\begin{array}{c}1007348- \\
43.2017 .8 .26 .0071\end{array}$ & $19253 / 2017$ & $06 / 04 / 2017$ & $\begin{array}{l}\text { Mandado de } \\
\text { Segurança }\end{array}$ & & $\begin{array}{l}\text { 17/04/2017 - concedo a segurança pleiteada por ... contra } \\
\text { ato do secretário municipal de saúde de Bauru, para que } \\
\text { o impetrado forneça à impetrante transporte de sua casa } \\
\text { até o hospital estadual de Bauru nos dias de tratamento } \\
\text { de hemodiálise (03 vezes por semana), nos termos da } \\
\text { petição inicial, e julgo extinto o processo - - 21/02/2018 - } \\
\text { arquivado definitivamente - }\end{array}$ & TRANSPORTE \\
\hline 579 & $\begin{array}{c}\text { 1014266- } \\
97.2016 .8 .26 .0071\end{array}$ & 23570/2017 & $27 / 04 / 2017$ & $\begin{array}{l}\text { Mandado de } \\
\text { Segurança }\end{array}$ & 03/08/2016 & $\begin{array}{l}13 / 06 / 2017 \text { - concedo a segurança pleiteada por .... } \\
\text { contra ato do secretário municipal de saúde de Bauru, } \\
\text { para que o impetrado forneça ao impetrante: fraldas } \\
\text { geriátricas - - 06/11/2018 - ciência da baixa dos autos, } \\
\text { bem como da certidão do trânsito em julgado. nada } \\
\text { requerido em } 30 \text { dias, os autos serão remetidos ao } \\
\text { arquivo. - }\end{array}$ & FRALDA \\
\hline
\end{tabular}




\begin{tabular}{|c|c|c|c|c|c|c|c|}
\hline 580 & $\begin{array}{c}\text { 1011303- } \\
82.2017 .8 .26 .0071\end{array}$ & $23569 / 2017$ & $27 / 04 / 2017$ & $\begin{array}{l}\text { Mandado de } \\
\text { Segurança }\end{array}$ & $24 / 04 / 2017$ & $\begin{array}{l}19 / 05 / 2017 \text { - precedentes do stf e do stj recurso } \\
\text { improvido. (ac no 0036412-28.2011.8.26.0071, tjesp, dês. } \\
\text { rel. josé luiz gavião de almeida)."ante o exposto, rejeito a } \\
\text { preliminar arguida, ratifico a liminar de fls. 26/27 e } \\
\text { concedo a segurança pleiteada por .... contra ato do } \\
\text { secretário municipal de saúde de Bauru, para que o } \\
\text { impetrado forneça à parte impetrante fraldas geriátricas } \\
\text { descartáveis - - 09/03/2018 - arquivado definitivamente - }\end{array}$ & FRALDA \\
\hline 581 & $\begin{array}{c}\text { 1011418- } \\
06.2017 .8 .26 .0071\end{array}$ & $23840 / 2017$ & $28 / 04 / 2017$ & $\begin{array}{l}\text { Mandado de } \\
\text { Segurança }\end{array}$ & $25 / 04 / 2017$ & $\begin{array}{l}13 / 06 / 2017 \text { - concedo a segurança pleiteada por .... } \\
\text { contra ato do secretário municipal de saúde de Bauru, } \\
\text { para que o impetrado forneça ao impetrante: fraldas } \\
\text { geriátricas - - 08/06/2018 - arquivado definitivamente - }\end{array}$ & FRALDA \\
\hline 582 & $\begin{array}{c}1028861- \\
04.2016 .8 .26 .0071\end{array}$ & $23847 / 2017$ & $28 / 04 / 2017$ & $\begin{array}{l}\text { Mandado de } \\
\text { Segurança }\end{array}$ & $24 / 04 / 2017$ & $\begin{array}{l}22 / 06 / 2017 \text { - concedo a segurança pleiteada por .... e } \\
\text { contra ato do diretor tecnico do departamento regional de } \\
\text { saúde de Bauru - drs vi, para que o impetrado providencie } \\
\text { o fornecimento ao impetrante de: fitas reagentes para } \\
\text { glicosímetro ( } 60 \text { unidades por mês) - }-15 / 05 / 2018- \\
\text { arquivado definitivamente - }\end{array}$ & $\begin{array}{l}\text { INSUMOS/MATE } \\
\text { RIAL } \\
\text { HOSPITALAR }\end{array}$ \\
\hline 583 & $\begin{array}{l}\text { 1012067- } \\
68.2017 .8 .26 .0071\end{array}$ & $25067 / 2017$ & $04 / 05 / 2017$ & $\begin{array}{l}\text { Mandado de } \\
\text { Segurança }\end{array}$ & 02/05/2017 & $\begin{array}{l}24 / 05 / 2017 \text { - concedo a segurança pleiteada por .... } \\
\text { contra ato do secretário municipal de saúde de Bauru, } \\
\text { para que o impetrado forneça ao impetrante: fraldas } \\
\text { geriátricas tamanho - } \\
\text { definitivamente - }\end{array}$ & FRALDA \\
\hline 584 & $\begin{array}{c}\text { 0011201- } \\
77.2017 .8 .26 .0071\end{array}$ & $26640 / 2017$ & $11 / 05 / 2017$ & $\begin{array}{l}\text { Outros } \\
\text { Procediment } \\
\text { os }\end{array}$ & 09/05/2017 & $\begin{array}{l}\text { 05/06/2017 - julgo procedente o pedido formulado por .... } \\
\text { contra prefeitura municipal de Bauru, para condenar a ré } \\
\text { que providencie o fornecimento de } 06 \text { (seis) fraldas } \\
\text { geriátricas - - } 31 / 08 / 2017 \text { - trânsito em julgado às partes - } \\
\text { com baixa - }\end{array}$ & FRALDA \\
\hline 585 & $\begin{array}{c}1013047- \\
15.2017 .8 .26 .0071\end{array}$ & $26927 / 2017$ & $12 / 05 / 2017$ & $\begin{array}{c}\text { Outros } \\
\text { Procediment } \\
\text { os }\end{array}$ & & SEGREDO DE JUSTIÇA & $\begin{array}{l}\text { SEGREDO DE } \\
\text { JUSTIÇA }\end{array}$ \\
\hline 586 & $\begin{array}{c}1009105- \\
72.2017 .8 .26 .0071 \\
\end{array}$ & $27210 / 2017$ & $15 / 05 / 2017$ & $\begin{array}{l}\text { Mandado de } \\
\text { Segurança }\end{array}$ & $10 / 05 / 2017$ & - 05/06/217 - julgo procedente pedido & FRALDA \\
\hline 587 & $\begin{array}{c}1013206- \\
55.2017 .8 .26 .0071\end{array}$ & $27272 / 2017$ & $15 / 05 / 2017$ & $\begin{array}{l}\text { Outros } \\
\text { Procediment } \\
\text { os }\end{array}$ & $15 / 05 / 2017$ & $\begin{array}{l}\text { 28/07/2017 - autor falecido - julgo extinto a presente ação } \\
\text { movida por .... contra hospital estadual de Bauru e } \\
\text { prefeitura municipal de Bauru, sem resolução de mérito - } \\
\text { - 02/03/2018 - arquivado definitivamente - }\end{array}$ & INTERNAÇÃO \\
\hline 588 & $\begin{array}{c}\text { 1012765- } \\
74.2017 .8 .26 .0071\end{array}$ & $27284 / 2017$ & $15 / 05 / 2017$ & $\begin{array}{l}\text { Mandado de } \\
\text { Segurança }\end{array}$ & 09/05/2017 & $\begin{array}{l}\text { 04/07/2017 - concedo a segurança pleiteada por .... } \\
\text { contra ato do secretário municipal de saúde de Bauru, } \\
\text { para que o impetrado forneça ao impetrante: fraldas } \\
\text { geriátricas - - 08/08/2018 - arquivado definitivamente - }\end{array}$ & FRALDA \\
\hline
\end{tabular}




\begin{tabular}{|c|c|c|c|c|c|c|c|}
\hline 589 & $\begin{array}{c}\text { 1025667- } \\
\text { 93.2016.8.26.0071 }\end{array}$ & $27622 / 2017$ & $16 / 05 / 2017$ & $\begin{array}{l}\text { Outros } \\
\text { Procediment } \\
\text { os }\end{array}$ & & $\begin{array}{l}\text { 27/07/2017 - julgo procedente o pedido, determinando à } \\
\text { requerida que entregue à autora as cópias dos } \\
\text { prontuários de atendimento das upa's do mary dota e do } \\
\text { geisel, - - 27/03/2018 - arquivado definitivamente - }\end{array}$ & $\begin{array}{l}\text { APRESENTAĈÃO } \\
\text { DE PRONTUÁRIO }\end{array}$ \\
\hline 590 & $\begin{array}{c}\text { 1012484- } \\
\text { 21.2017.8.26.0071 }\end{array}$ & $27835 / 2017$ & $17 / 05 / 2017$ & $\begin{array}{l}\text { Mandado de } \\
\text { Segurança }\end{array}$ & $10 / 05 / 2017$ & \begin{tabular}{|l|} 
19/06/2017 - concedo a segurança pleiteada por .... \\
contra ato do secretário municipal de saúde de Bauru, \\
para que o impetrado forneça ao impetrante: fraldas \\
geriátricas - - 21/02/2018 - arquivado definitivamente -
\end{tabular} & FRALDA \\
\hline 591 & $\begin{array}{c}\text { 1013215- } \\
17.2017 .8 .26 .0071\end{array}$ & $27840 / 2017$ & 17/05/2017 & $\begin{array}{l}\text { Mandado de } \\
\text { Segurança }\end{array}$ & $15 / 05 / 2017$ & $\begin{array}{l}\text { 27/11/2017 - concedo a segurança pleiteada por ... contra } \\
\text { ato do secretário municipal de saúde de Bauru, para que } \\
\text { a autoridade impetrada proceda à disponibilização da } \\
\text { vaga para internação hospitalar de que a parte impetrante } \\
\text { necessita, e julgo extinto o processo, com resolução de } \\
\text { mérito - - - 28/06/2018 - arquivado definitivamente - }\end{array}$ & INTERNAÇÃO \\
\hline 592 & $\begin{array}{c}\text { 1011147- } \\
94.2017 .8 .26 .0071\end{array}$ & 28122/2017 & $17 / 05 / 2017$ & $\begin{array}{l}\text { Mandado de } \\
\text { Segurança }\end{array}$ & 08/05/2017 & $\begin{array}{l}\text { 10/11/2017 - julgo procedentes os pedidos da presente } \\
\text { ação de mandado de segurança, para tornar definitiva a } \\
\text { liminar deferida e determinar ao Diretor do Departamento } \\
\text { Regional de Saúde de Bauru-DRS VI e ao Secretário } \\
\text { Municipal de Saúde de Bauru o fornecimento do guincho } \\
\text { para realização de transferencia, em Y, até a } \\
\text { convalescença, efetivando o tratamento de saúde. }\end{array}$ & $\begin{array}{l}\text { INSUMOS/MATE } \\
\text { RIAL } \\
\text { HOSPITALAR }\end{array}$ \\
\hline 593 & $\begin{array}{c}\text { 1012876- } \\
\text { 58.2017.8.26.0071 }\end{array}$ & 28123/2017 & $17 / 05 / 2017$ & $\begin{array}{l}\text { Outros } \\
\text { Procediment } \\
\quad \text { os }\end{array}$ & $16 / 05 / 2017$ & $\begin{array}{l}\text { 04/07/2017 - julgo procedente o pedido, formulado por .... } \\
\text { contra o diretor do departamento regional de saúde de } \\
\text { Bauru (drs vi), determinando que o requerido forneça ao } \\
\text { autor o tratamento: oxigenoterapia hiperbárica (60 } \\
\text { sessões), - - } 10 / 08 / 2017 \text { - erro material constante na } \\
\text { sentença de fls. } 123 / 124 \text { cujo o dispositivo passa a ser } \\
\text { assim lançado: "posto isso, ratifico a decisão de fls. 35/36 } \\
\text { e julgo parcialmente procedente o pedido, formulado por } \\
\text {... contra o prefeitura municipal de Bauru, determinando } \\
\text { que o requerido forneça ao autor o tratamento: } \\
\text { oxigenoterapia hiperbárica (60 sessões) - - -06/02/2018 - } \\
\text { e. tribunal.(trânsito em julgado com condenação) diante } \\
\text { do trânsito em julgado, fica o credor intimado a iniciar o } \\
\text { incidente de cumprimento de sentença - - 07/05/2018 - } \\
\text { arquivado definitivamente - }\end{array}$ & MEDICAMENTO \\
\hline 594 & $\begin{array}{c}\text { 1014030- } \\
14.2017 .8 .26 .0071\end{array}$ & $29514 / 2017$ & $25 / 05 / 2017$ & $\begin{array}{l}\text { Outros } \\
\text { Procediment } \\
\quad \text { os }\end{array}$ & $23 / 05 / 2017$ & $\begin{array}{l}\text { 17/08/2017 - julgo procedente o pedido formulado por .... } \\
\text { em face da fazenda pública do município de Bauru, } \\
\text { determinando que esta forneça à requerente fraldas } \\
\text { descartáveis geriátricas - - 06/10/2017 - trânsito em } \\
\text { julgado às partes - com baixa - }\end{array}$ & FRALDA \\
\hline
\end{tabular}




\begin{tabular}{|c|c|c|c|c|c|c|c|}
\hline 595 & $\begin{array}{c}\text { 1013622- } \\
23.2017 .8 .26 .0071\end{array}$ & $29516 / 2017$ & $25 / 05 / 2017$ & $\begin{array}{l}\text { Outros } \\
\text { Procediment } \\
\text { os }\end{array}$ & $22 / 05 / 2017$ & \begin{tabular}{|l|}
$27 / 03 / 2018$ - julgo parcialmente procedente o pedido \\
formulado por .... contra a prefeitura municipal de Bauru, \\
determinando que a requerida providencie o imediato \\
agendamento da cirurgia de que o requerente necessita, \\
bem como o respectivo tratamento necessário (inclusive \\
cirúrgico), conforme encaminhamento médico de (fls. \\
$17 / 18)$, e extinto o processo, com resolução de mérito - - \\
14/08/2018 - arquivado definitivamente -
\end{tabular} & CIRURGIA \\
\hline 596 & $\begin{array}{c}\text { 1009196- } \\
65.2017 .8 .26 .0071\end{array}$ & $30113 / 2017$ & $29 / 05 / 2017$ & $\begin{array}{l}\text { Outros } \\
\text { Procediment } \\
\text { os }\end{array}$ & $31 / 03 / 2017$ & $\begin{array}{l}\text { 21/02/2018 - julgo parcialmente procedente o pedido, } \\
\text { formulado por .... contra a fazenda pública do estado de } \\
\text { são paulo e outro, determinando que a parte requerida } \\
\text { disponibilize a vaga para a internação do requerente, uma } \\
\text { vez que o autor demonstrou a necessidade da internação } \\
\text { solicitada - - 28/11/2018 - fica o apelado intimado a } \\
\text { apresentar contrarrazões ao recurso de apelação, no } \\
\text { prazo de } 15 \text { dias. após remetam-se os autos ao e. tribunal } \\
\text { de justiça de são paulo - }\end{array}$ & INTERNAÇÃO \\
\hline 597 & $\begin{array}{c}1000546- \\
29.2017 .8 .26 .0071\end{array}$ & $30116 / 2017$ & $29 / 05 / 2017$ & $\begin{array}{l}\text { Outros } \\
\text { Procediment } \\
\text { os }\end{array}$ & $07 / 04 / 2017$ & $\begin{array}{l}\text { 31/08/2017 - julgo procedente o pedido formulado por .... } \\
\text { em face da prefeitura municipal de Bauru, determinando } \\
\text { que esta forneça à requerente fraldas descartáveis } \\
\text { geriátricas - - 19/06/2018 - arquivado definitivamente - }\end{array}$ & FRALDA \\
\hline 598 & $\begin{array}{c}0012719- \\
05.2017 .8 .26 .0071\end{array}$ & $30114 / 2017$ & 29/05/2017 & $\begin{array}{l}\text { Outros } \\
\text { Procediment } \\
\text { os }\end{array}$ & $01 / 06 / 2017$ & $\begin{array}{l}\text { 22/09/2017 - julgo procedente o pedido formulado por .... } \\
\text { em face da fazenda pública do municipio de Bauru, } \\
\text { determinando que esta forneça à requerente } 06 \text { (seis) } \\
\text { fraldas descartáveis geriátricas - - 06/11/2017 - trânsito } \\
\text { em julgado às partes - com baixa - }\end{array}$ & FRALDA \\
\hline 599 & $\begin{array}{c}\text { 0012767- } \\
61.2017 .8 .26 .0071\end{array}$ & $30512 / 2017$ & $31 / 05 / 2017$ & $\begin{array}{l}\text { Outros } \\
\text { Procediment } \\
\text { os }\end{array}$ & $26 / 05 / 2017$ & $\begin{array}{l}\text { 05/09/2017 - julgo procedente o pedido pleiteado por .... } \\
\text { contra ato da prefeitura municipal de Bauru, para que a } \\
\text { requerida forneça à parte autora fraldas geriátricas } \\
\text { descartáveis - } 28 / 09 / 2017 \text { - trânsito em julgado às } \\
\text { partes - com baixa - }\end{array}$ & FRALDA \\
\hline 600 & $\begin{array}{c}0012766- \\
76.2017 .8 .26 .0071\end{array}$ & $30566 / 2017$ & $31 / 05 / 2017$ & $\begin{array}{l}\text { Outros } \\
\text { Procediment } \\
\text { os }\end{array}$ & $26 / 05 / 2017$ & $\begin{array}{l}\text { 09/08/2017 - julgo procedente o pedido formulado por .... } \\
\text { em face da fazenda pública do município de Bauru, } \\
\text { determinando que esta forneça ao requerente fraldas } \\
\text { descartáveis geriátricas - - 17/10/2017 - trânsito em } \\
\text { julgado às partes - com baixa - }\end{array}$ & FRALDA \\
\hline 601 & $\begin{array}{c}\text { 1014641- } \\
\text { 64.2017.8.26.0071 }\end{array}$ & $30570 / 2017$ & $31 / 05 / 2017$ & $\begin{array}{l}\text { Mandado de } \\
\text { Segurança }\end{array}$ & $29 / 05 / 2017$ & $\begin{array}{l}03 / 07 / 2017 \text { - concedo a segurança pleiteada por .... } \\
\text { contra ato do secretário municipal de saúde de Bauru, } \\
\text { para que o impetrado forneça ao impetrante: fraldas } \\
\text { geriátricas - - 07/02/2018 - arquivado definitivamente - }\end{array}$ & FRALDA \\
\hline
\end{tabular}




\begin{tabular}{|c|c|c|c|c|c|c|c|}
\hline 602 & $\begin{array}{c}\text { 1015002- } \\
81.2017 .8 .26 .0071\end{array}$ & $31444 / 2017$ & 05/06/2017 & $\begin{array}{l}\text { Mandado de } \\
\text { Segurança }\end{array}$ & $30 / 05 / 2017$ & $\begin{array}{l}\text { 03/07/2017 - concedo a segurança pleiteada por ... contra } \\
\text { ato do secretário municipal de saúde de Bauru, para que } \\
\text { o impetrado forneça ao impetrante: fraldas geriátricas } \\
\text { tamanho - - 26/02/2018 - arquivado definitivamente - }\end{array}$ & FRALDA \\
\hline 603 & $\begin{array}{c}\text { 1015016- } \\
65.2017 .8 .26 .0071\end{array}$ & $31962 / 2017$ & 06/06/2017 & $\begin{array}{l}\text { Mandado de } \\
\text { Segurança }\end{array}$ & $30 / 05 / 2017$ & $\begin{array}{l}10 / 07 / 2017 \text { - concedo a segurança pleiteada por .... } \\
\text { contra ato do secretário municipal de saúde de Bauru, } \\
\text { para que o impetrado forneça à parte impetrante fraldas } \\
\text { geriátricas descartáveis - - 11/06/2018 - arquivado } \\
\text { definitivamente - }\end{array}$ & FRALDA \\
\hline 604 & $\begin{array}{c}\text { 1014156- } \\
64.2017 .8 .26 .0071\end{array}$ & $33156 / 2017$ & 09/06/2017 & $\begin{array}{l}\text { Outros } \\
\text { Procediment } \\
\text { os }\end{array}$ & $25 / 05 / 2017$ & $\begin{array}{l}\text { 27/04/2018 - fulcra-se na efetiva e real necessidade da } \\
\text { requerente submeter-se ao tratamento de terapia } \\
\text { intensiva através do Protocolo PediSuit por } 3 \text { horas } \\
\text { diárias, } 5 \text { dias na semana, durante o período de } 1 \text { mês, - } \\
\text { devendo serrepetido a cada } 4 \text { meses, por tempo } \\
\text { indeterminado.Sendo assim, defiro as provas úteis } \\
\text { tempestivamente requeridas }\end{array}$ & $\begin{array}{c}\text { INSUMOS/MATE } \\
\text { RIAL } \\
\text { HOSPITALAR }\end{array}$ \\
\hline 605 & $\begin{array}{c}1008365- \\
17.2017 .8 .26 .0071\end{array}$ & $33351 / 2017$ & 09/06/2017 & $\begin{array}{l}\text { Mandado de } \\
\text { Segurança }\end{array}$ & & SEGREDO DE JUSTIÇA & $\begin{array}{l}\text { SEGREDO DE } \\
\text { JUSTIÇA }\end{array}$ \\
\hline 606 & $\begin{array}{c}1009105- \\
72.2017 .8 .26 .0071\end{array}$ & $33664 / 2017$ & $12 / 06 / 2017$ & $\begin{array}{c}\text { Outros } \\
\text { Procediment } \\
\text { os }\end{array}$ & & $\begin{array}{l}\text { 29/08/17 - Apelação - Reexame Necessário - RECURSO } \\
\text { OFICIAL DESPROVIDO }\end{array}$ & FRALDA \\
\hline 607 & $\begin{array}{c}\text { 1015916- } \\
48.2017 .8 .26 .0071\end{array}$ & $34004 / 2017$ & $13 / 06 / 2017$ & $\begin{array}{l}\text { Mandado de } \\
\text { Segurança }\end{array}$ & 07/06/2017 & $\begin{array}{l}10 / 07 / 2017 \text { - concedo a segurança pleiteada por .... } \\
\text { contra ato do secretário municipal de saúde de Bauru, } \\
\text { para que o impetrado forneça à parte impetrante fraldas } \\
\text { geriátricas descartáveis - }-20 / 03 / 2018 \text { - arquivado } \\
\text { definitivamente - }\end{array}$ & FRALDA \\
\hline 608 & $\begin{array}{c}\text { 0014457- } \\
28.2017 .8 .26 .0071\end{array}$ & $34974 / 2017$ & 19/06/2017 & $\begin{array}{l}\text { Outros } \\
\text { Procediment } \\
\text { os }\end{array}$ & $13 / 06 / 2017$ & $\begin{array}{l}\text { 22/09/2017 - julgo procedente o pedido formulado por ... } \\
\text { em face da fazenda pública do município de Bauru, } \\
\text { determinando que esta forneça à requerente fraldas } \\
\text { descartáveis geriátricas - - 31/10/2017 - trânsito em } \\
\text { julgado às partes - com baixa - }\end{array}$ & FRALDA \\
\hline 609 & $\begin{array}{c}\text { 1016762- } \\
\text { 65.2017.8.26.0071 }\end{array}$ & $36046 / 2017$ & $22 / 06 / 2017$ & $\begin{array}{l}\text { Mandado de } \\
\text { Segurança }\end{array}$ & 20/06/2017 & $\begin{array}{l}\text { 14/07/2017 - concedo a segurança pleiteada por .... } \\
\text { contra ato do secretário municipal de saúde de Bauru, } \\
\text { para que o impetrado forneça à parte impetrante fraldas } \\
\text { geriátricas descartáveis - }-15 / 12 / 2017 \text { - arquivado } \\
\text { definitivamente - }\end{array}$ & FRALDA \\
\hline
\end{tabular}




\begin{tabular}{|c|c|c|c|c|c|c|c|}
\hline 610 & $\begin{array}{c}\text { 0014956- } \\
12.2017 .8 .26 .0071\end{array}$ & $36139 / 2017$ & $23 / 06 / 2017$ & $\begin{array}{l}\text { Outros } \\
\text { Procediment } \\
\text { os }\end{array}$ & 20/06/2017 & $\begin{array}{l}\text { 27/09/2017 - julgo procedente o pedido formulado por .... } \\
\text { em face da fazenda pública do município de Bauru, } \\
\text { determinando que esta forneça à requerente fraldas } \\
\text { descartáveis geriátricas - } 29 / 11 / 2017 \text { - trânsito em } \\
\text { julgado às partes - com baixa - }\end{array}$ & FRALDA \\
\hline 611 & $\begin{array}{c}1015680- \\
96.2017 .8 .26 .0071\end{array}$ & $36242 / 2017$ & 23/06/2017 & $\begin{array}{l}\text { Mandado de } \\
\text { Segurança }\end{array}$ & & SEGREDO DE JUSTIÇA & $\begin{array}{c}\text { SEGREDO DE } \\
\text { JUSTIÇA }\end{array}$ \\
\hline 612 & $\begin{array}{c}\text { 1017274- } \\
48.2017 .8 .26 .0071\end{array}$ & $36483 / 2017$ & 26/06/2017 & $\begin{array}{l}\text { Mandado de } \\
\text { Segurança }\end{array}$ & 22/06/2017 & $\begin{array}{l}\text { 23/02/2018 - concedo a segurança pleiteada por .... } \\
\text { contra ato do secretário municipal de saúde de Bauru, } \\
\text { para que o impetrado forneça à parte impetrante fraldas } \\
\text { geriátricas descartáveis - - 14/11/2018 - arquivado } \\
\text { definitivamente - }\end{array}$ & FRALDA \\
\hline 613 & $\begin{array}{c}\text { 1017058- } \\
87.2017 .8 .26 .0071\end{array}$ & $36780 / 2017$ & $27 / 06 / 2017$ & $\begin{array}{l}\text { Outros } \\
\text { Procediment } \\
\text { os }\end{array}$ & $22 / 06 / 2017$ & $\begin{array}{l}\text { 03/10/2017 - decido.considerando o ofício do colendo } \\
\text { superior tribunal de justiça (n. 222/2017 nugep, de } 03 \text { de } \\
\text { maio de 2017), encaminhado pela egrégia presidência } \\
\text { deste tribunal de justiça, no qual foi comunicada a } \\
\text { afetação do recurso especial no 1657156 para } \\
\text { uniformização da matéria referente à "obrigatoriedade de } \\
\text { fornecimento, pelo estado, de medicamentos não } \\
\text { contemplados na portaria no } 2.982 / 2009 \text { do ministério da } \\
\text { saúde (programa de medicamentos excepcionais)", bem } \\
\text { como a determinação de "suspensão do processamento } \\
\text { de todos os processos pendentes, individuais e coletivos, } \\
\text { que versem sobre idêntica questão e que tramitem no } \\
\text { território nacional (art. } 1.037 \text {, ii do cpc)", providencie a } \\
\text { serventia as anotações necessárias no saj para a } \\
\text { respectiva suspensão do trâmite deste processo. }\end{array}$ & FRALDA \\
\hline 614 & $\begin{array}{c}\text { 1016991- } \\
25.2017 .8 .26 .0071\end{array}$ & $36782 / 2017$ & 27/06/2017 & $\begin{array}{l}\text { Mandado de } \\
\text { Segurança }\end{array}$ & 20/06/2017 & $\begin{array}{l}\text { 10/07/2017 - concedo a segurança pleiteada por .... } \\
\text { contra ato do secretário municipal de saúde de Bauru, } \\
\text { para que o impetrado forneça à parte impetrante fraldas } \\
\text { geriátricas descartáveis - - 17/07/2018 - arquivado } \\
\text { definitivamente - }\end{array}$ & FRALDA \\
\hline 615 & $\begin{array}{c}\text { 1017739- } \\
91.2016 .8 .26 .0071\end{array}$ & $37393 / 2017$ & $29 / 06 / 2017$ & $\begin{array}{l}\text { Outros } \\
\text { Procediment } \\
\text { os }\end{array}$ & $27 / 06 / 2017$ & $\begin{array}{l}\text { 26/07/2018 - julgo extinta a presente ação, sem resolução } \\
\text { do mérito, nos termos do art. } 485 \text {, vi, do código de } \\
\text { processo civil. em razão da sucumbência dos requeridos, } \\
\text { considerando o disposto no artigo } 85, \S 20 \text {, i a iv, e } \S 10 \text {, } \\
\text { do cpc, bem como o fato de não se tratar de causa de } \\
\text { grande complexidade - - - - }\end{array}$ & INTERNAÇÃO \\
\hline
\end{tabular}




\begin{tabular}{|c|c|c|c|c|c|c|c|}
\hline 616 & $\begin{array}{c}\text { 1017883- } \\
31.2017 .8 .26 .0071\end{array}$ & $37801 / 2017$ & $30 / 06 / 2017$ & $\begin{array}{l}\text { Outros } \\
\text { Procediment } \\
\quad \text { os }\end{array}$ & $27 / 06 / 2017$ & $\begin{array}{l}\text { 05/12/2017 - julgo procedente o pedido formulado por .... } \\
\text { contra a fazenda pública do estado de são paula, } \\
\text { determinando que a requerida providencie o imediato } \\
\text { agendamento da cirurgia de que o requerente necessita, } \\
\text { bem como o respectivo tratamento necessário (inclusive } \\
\text { cirúrgico), conforme encaminhamento médico - } \\
05 / 06 / 2018 \text { - arquivado definitivamente - }\end{array}$ & $\begin{array}{l}\text { CONSULTA } \\
\text { MÉDICA }\end{array}$ \\
\hline 617 & $\begin{array}{c}0015369- \\
25.2017 .8 .26 .0071\end{array}$ & $37807 / 2017$ & 30/06/2017 & $\begin{array}{l}\text { Outros } \\
\text { Procediment } \\
\quad \text { os }\end{array}$ & 27/06/2017 & $\begin{array}{l}\text { 16/10/2017 - julgo procedente o pedido formulado por .... } \\
\text { em face da fazenda pública do município de Bauru, } \\
\text { determinando que esta forneça à requerente fraldas } \\
\text { descartáveis geriátricas - }\end{array}$ & FRALDA \\
\hline 618 & $\begin{array}{c}\text { 1016503- } \\
70.2017 .8 .26 .0071\end{array}$ & $38033 / 2017$ & 03/07/2017 & $\begin{array}{l}\text { Mandado de } \\
\text { Segurança }\end{array}$ & & \begin{tabular}{lllll|} 
10/06/19 & APELAÇÃO & CÍVEL & E & REMESSA \\
NECESSÁRIA & - & APELOS & VOLUNTÁRIOS & NÃO \\
PROVIDOS. & & & & \\
\end{tabular} & MEDICAMENTO \\
\hline 619 & $\begin{array}{c}\text { 1018292- } \\
07.2017 .8 .26 .0071\end{array}$ & $38152 / 2017$ & 03/07/2017 & $\begin{array}{l}\text { Mandado de } \\
\text { Segurança }\end{array}$ & 30/06/2017 & $\begin{array}{l}\text { 08/08/2017 - concedo a segurança pleiteada por .... } \\
\text { contra ato do secretario municipal de saúde de Bauru, } \\
\text { para que o impetrado providencie o fornecimento ao } \\
\text { impetrante de: dieta enteral industrializada, líquida, pronto } \\
\text { uso, hipercalórica (1,5kcal/ml), hiperproteica }(0,075 \mathrm{~g} / \mathrm{ml}) \text {, } \\
\text { na quanitdade de } 1,5 \text { litro ao dia, - }\end{array}$ & $\begin{array}{l}\text { ALIMENTAÇÃO } \\
\text { ESPECIAL }\end{array}$ \\
\hline 620 & $\begin{array}{c}0016018- \\
87.2017 .8 .26 .0071\end{array}$ & $38263 / 2017$ & 04/07/2017 & $\begin{array}{c}\text { Outros } \\
\text { Procediment } \\
\text { os }\end{array}$ & $30 / 06 / 2017$ & $\begin{array}{l}\text { 07/02/2018 - julgo extinto o processo sem exame do } \\
\text { mérito - falecimento do autor - - }\end{array}$ & FRALDA \\
\hline 621 & $\begin{array}{c}\text { 1018694- } \\
\text { 88.2017.8.26.0071 }\end{array}$ & $39544 / 2017$ & 10/07/2017 & $\begin{array}{l}\text { Mandado de } \\
\text { Segurança }\end{array}$ & 04/07/2017 & $\begin{array}{l}27 / 07 / 2017 \text { - concedo a segurança pleiteada por .... } \\
\text { contra ato do diretor técnico do departamento regional de } \\
\text { saúde de Bauru - drs vi, para que o impetrado providencie } \\
\text { o fornecimento à parte impetrante do suplemento: dieta } \\
\text { enteral líquida normocalórica, normoproteica, isenta de } \\
\text { sacarose, lactose e glúten - - 04/10/2017 - remetidos os } \\
\text { autos para o tribunal de justiça/colégio recursal. }\end{array}$ & $\begin{array}{l}\text { ALIMENTAÇÃO } \\
\text { ESPECIAL }\end{array}$ \\
\hline 622 & $\begin{array}{c}\text { 1018771- } \\
97.2017 .8 .26 .0071\end{array}$ & $39874 / 2017$ & 11/07/2017 & $\begin{array}{l}\text { Mandado de } \\
\text { Segurança }\end{array}$ & 05/07/2017 & $\begin{array}{l}\text { 16/02/2018 - concedo a segurança pleiteada por .... } \\
\text { contra ato do secretário municipal de saúde de Bauru, } \\
\text { para que o impetrado forneça à parte impetrante fraldas } \\
\text { geriátricas descartáveis - - 14/11/2018 - arquivado } \\
\text { definitivamente - }\end{array}$ & FRALDA \\
\hline 623 & $\begin{array}{l}1018563- \\
16.2017 .8 .26 .0071\end{array}$ & $40104 / 2017$ & 12/07/2017 & $\begin{array}{l}\text { Outros } \\
\text { Procediment } \\
\text { os }\end{array}$ & 06/07/2017 & $\begin{array}{l}\text { 21/03/2018 - julgo improcedente a presente demanda, e, } \\
\text { extinto o processo - - 13/04/2018 - trânsito em julgado às } \\
\text { partes - com baixa - }\end{array}$ & $\begin{array}{l}\text { CUIDADOR/HOM } \\
\text { E CARE }\end{array}$ \\
\hline
\end{tabular}




\begin{tabular}{|c|c|c|c|c|c|c|c|}
\hline 624 & $\begin{array}{c}0016789- \\
65.2017 .8 .26 .0071\end{array}$ & $40788 / 2017$ & $14 / 07 / 2017$ & $\begin{array}{l}\text { Outros } \\
\text { Procediment } \\
\quad \text { os }\end{array}$ & $12 / 07 / 2017$ & $\begin{array}{l}\text { 29/09/2017 - JULGO PROCEDENTE O PEDIDO, } \\
\text { determinando que esta forneça a(o) requerente FRALDAS } \\
\text { DESCARTÁVEIS GERIÁTRICAS - tamanho "G" (120 } \\
\text { unidades por mês. }\end{array}$ & FRALDA \\
\hline 625 & $\begin{array}{c}0017139- \\
53.2017 .8 .26 .0071\end{array}$ & $41812 / 2017$ & $20 / 07 / 2017$ & $\begin{array}{l}\text { Outros } \\
\text { Procediment } \\
\text { os }\end{array}$ & $12 / 07 / 2017$ & 28/09/2017 - JULGO PROCEDENTE O PEDIDO. & FRALDA \\
\hline 626 & $\begin{array}{c}\text { 1019701- } \\
18.2017 .8 .26 .0071\end{array}$ & $42698 / 2017$ & $25 / 07 / 2017$ & $\begin{array}{l}\text { Mandado de } \\
\text { Segurança }\end{array}$ & $19 / 07 / 2017$ & $\begin{array}{l}11 / 08 / 2017 \text { - concedo a segurança pleiteada por .... } \\
\text { contra ato do secretário municipal de saúde de Bauru, } \\
\text { para que o impetrado forneça ao impetrante: fraldas } \\
\text { geriátricas tamanho "eg" } 180 \text { (cento e oitenta). }\end{array}$ & FRALDA \\
\hline 627 & $\begin{array}{c}\text { 1020571- } \\
63.2017 .8 .26 .0071\end{array}$ & $42774 / 2017$ & $25 / 07 / 2017$ & $\begin{array}{l}\text { Mandado de } \\
\text { Segurança }\end{array}$ & $19 / 07 / 2017$ & $\begin{array}{l}\text { 08/08/2017 - concedo a segurança pleiteada por .... } \\
\text { contra ato do secretário municipal de saúde de Bauru, } \\
\text { para que o impetrado forneça à parte impetrante fraldas } \\
\text { geriátricas descartáveis - tamanho "g" (90 unidades por } \\
\text { mês) - }\end{array}$ & FRALDA \\
\hline 628 & $\begin{array}{c}\text { 1020866- } \\
03.2017 .8 .26 .0071\end{array}$ & $43398 / 2017$ & $27 / 07 / 2017$ & $\begin{array}{l}\text { Mandado de } \\
\text { Segurança }\end{array}$ & $21 / 07 / 2017$ & $\begin{array}{l}\text { 18/08/2017 - concedo a segurança pleiteada por .... } \\
\text { contra ato do secretário municipal de saúde de Bauru, } \\
\text { para que o impetrado forneça ao impetrante: fraldas } \\
\text { geriátricas - - 08/06/2018 - arquivado definitivamente - }\end{array}$ & FRALDA \\
\hline 629 & $\begin{array}{c}\text { 1021437- } \\
71.2017 .8 .26 .0071\end{array}$ & $44267 / 2017$ & 02/08/2017 & $\begin{array}{l}\text { Mandado de } \\
\text { Segurança }\end{array}$ & $27 / 07 / 2017$ & $\begin{array}{l}\text { 25/08/2017 - concedo a segurança pleiteada por ... contra } \\
\text { ato do secretário municipal de saúde de Bauru, para que } \\
\text { o impetrado forneça à parte impetrante fraldas geriátricas } \\
\text { descartáveis - - 31/08/2018 - arquivado definitivamente - }\end{array}$ & FRALDA \\
\hline 630 & $\begin{array}{c}1021806- \\
65.2017 .8 .26 .0071\end{array}$ & $45164 / 2017$ & 07/08/2017 & $\begin{array}{c}\text { Mandado de } \\
\text { Segurança }\end{array}$ & $31 / 07 / 2017$ & $\begin{array}{l}\text { 22/08/2017 - concedo a segurança pleiteada por .... contra } \\
\text { ato do secretário municipal de saúde de Bauru, para que } \\
\text { o impetrado forneça ao impetrante: fraldas geriátricas } \\
\text { descartáveis - - 08/06/2018 - arquivado definitivamente - }\end{array}$ & FRALDA \\
\hline 631 & $\begin{array}{c}0019044- \\
93.2017 .8 .26 .0071\end{array}$ & $45157 / 2017$ & 07/08/2017 & $\begin{array}{l}\text { Outros } \\
\text { Procediment } \\
\text { os }\end{array}$ & 02/08/2017 & $\begin{array}{l}\text { 13/09/2017 - falecimento do autor - julgo extinto o } \\
\text { processo sem exame do mérito com fundamento no artigo } \\
485 \text {, inciso ix, do cpc.revogo a tutela provisória - } \\
28 / 09 / 2017 \text { - trânsito em julgado às partes - com baixa. }\end{array}$ & FRALDA \\
\hline 632 & $\begin{array}{c}\text { 1021821- } \\
34.2017 .8 .26 .0071\end{array}$ & $45151 / 2017$ & 07/08/2017 & $\begin{array}{l}\text { Mandado de } \\
\text { Segurança }\end{array}$ & $31 / 07 / 2017$ & $\begin{array}{l}24 / 08 / 2017 \text { - concedo a segurança pleiteada por .... } \\
\text { contra ato do secretário municipal de saúde de Bauru, } \\
\text { para que o impetrado forneça ao impetrante: fraldas } \\
\text { geriátricas descartáveis - }-17 / 10 / 2018 \text { - arquivado } \\
\text { definitivamente - }\end{array}$ & FRALDA \\
\hline
\end{tabular}




\begin{tabular}{|c|c|c|c|c|c|c|c|}
\hline 633 & $\begin{array}{c}1022068- \\
15.2017 .8 .26 .0071\end{array}$ & $45437 / 2017$ & 08/08/2017 & $\begin{array}{l}\text { Mandado de } \\
\text { Segurança }\end{array}$ & 04/08/2017 & $\begin{array}{l}\text { 30/08/2017 - concedo a segurança pleiteada por .... contra } \\
\text { ato do secretário municipal de saúde de Bauru, para que o } \\
\text { impetrado providencie o fornecimento à parte impetrante do } \\
\text { medicamento "dieta líquida polimérica normocalórica } 1.0 \\
\text { cal/ml, hiperproteica suplementada com arginina - } \\
\text { 06/04/2018 - recebidos os autos do tribunal de justiça - } \\
\text { 18/04/2018 - remetido ao dje - relação: } 0310 / 2018 \text { teor do } \\
\text { ato: ciência as partes acerca do retorno dos autos do e. } \\
\text { tribunal.(gratuidade e/ou sem condenação) ante o trânsito } \\
\text { em julgado, e não havendo dívida pendente, arquivem-se - } \\
11 / 06 / 2018 \text { - arquivado definitivamente. }\end{array}$ & $\begin{array}{c}\text { ALIMENTAÇÃO } \\
\text { ESPECIAL }\end{array}$ \\
\hline 634 & $\begin{array}{c}1021649- \\
92.2017 .8 .26 .0071\end{array}$ & $45618 / 2017$ & 09/08/2017 & $\begin{array}{l}\text { Outros } \\
\text { Procediment } \\
\text { os }\end{array}$ & 03/08/2017 & $\begin{array}{l}\text { 25/07/2018 - não obstante a súmula } 37 \text { do tribunal de } \\
\text { justiça estabelecer que "a ação para fornecimento de } \\
\text { medicamento e afins pode ser proposta em face de } \\
\text { qualquer pessoa jurídica de direito público interno", a fim } \\
\text { de se evitar gastos desnecessários pela administração } \\
\text { pública ou tumulto processual, compelindo órgãos } \\
\text { distintos ao atendimento do mesmo pedido, providencie a } \\
\text { parte autora a emenda à petição inicial, indicando apenas } \\
\text { uma das autoridades requeridas para figurar no polo } \\
\text { passivo da presente ação. - - } 26 / 11 / 2018 \text { - conclusos } \\
\text { para decisão - }\end{array}$ & MEDICAMENTO \\
\hline 635 & $\begin{array}{c}\text { 0019195- } \\
59.2017 .8 .26 .0071\end{array}$ & $46308 / 2017$ & $11 / 08 / 2017$ & $\begin{array}{l}\text { Outros } \\
\text { Procediment } \\
\text { os }\end{array}$ & 08/08/2017 & $\begin{array}{l}28 / 09 / 2017 \text { - julgo procedente o pedido formulado por .... } \\
\text { em face da fazenda pública do município de Bauru, } \\
\text { determinando que esta forneça ao requerente fraldas } \\
\text { descartáveis geriátricas - - 08/11/2017 - baixa definitiva - }\end{array}$ & FRALDA \\
\hline 636 & $\begin{array}{c}1000059- \\
59.2017 .8 .26 .0071\end{array}$ & $47227 / 2017$ & $16 / 08 / 2017$ & $\begin{array}{c}\text { Outros } \\
\text { Procediment } \\
\text { os }\end{array}$ & & SEGREDO DE JUSTIÇA & $\begin{array}{l}\text { SEGREDO DE } \\
\text { JUSTIÇA }\end{array}$ \\
\hline 637 & $\begin{array}{c}1022922- \\
09.2017 .8 .26 .0071\end{array}$ & $47503 / 2017$ & $17 / 08 / 2017$ & $\begin{array}{l}\text { Mandado de } \\
\text { Segurança }\end{array}$ & $11 / 08 / 2017$ & $\begin{array}{l}\text { 15/09/2017 - concedo a segurança pleiteada por .... } \\
\text { contra ato do secretário municipal de saúde de Bauru, } \\
\text { para que o impetrado forneça ao impetrante: fraldas } \\
\text { geriátricas. }\end{array}$ & FRALDA \\
\hline 638 & $\begin{array}{c}1023550- \\
95.2017 .8 .26 .0071\end{array}$ & $47867 / 2017$ & $21 / 08 / 2017$ & $\begin{array}{l}\text { Mandado de } \\
\text { Segurança }\end{array}$ & $17 / 08 / 2017$ & $\begin{array}{l}\text { 19/09/2017 - concedo a segurança pleiteada por .... } \\
\text { contra ato do secretário municipal de saúde de Bauru, } \\
\text { para que o impetrado forneça à parte impetrante fraldas } \\
\text { geriátricas descartáveis - }-16 / 03 / 2018 \text { - arquivado } \\
\text { definitivamente - }\end{array}$ & FRALDA \\
\hline 639 & $\begin{array}{c}1023451- \\
28.2017 .8 .26 .0071\end{array}$ & $48485 / 2017$ & $23 / 08 / 2017$ & $\begin{array}{c}\text { Outros } \\
\text { Procediment } \\
\text { os }\end{array}$ & & SEGREDO DE JUSTIÇA & $\begin{array}{l}\text { SEGREDO DE } \\
\text { JUSTIÇA }\end{array}$ \\
\hline
\end{tabular}




\begin{tabular}{|c|c|c|c|c|c|c|c|}
\hline 640 & $\begin{array}{c}0021320- \\
97.2017 .8 .26 .0071\end{array}$ & $48582 / 2017$ & $24 / 08 / 2017$ & $\begin{array}{l}\text { Outros } \\
\text { Procediment } \\
\text { os }\end{array}$ & 22/08/2017 & $\begin{array}{l}29 / 01 / 2018 \text { - falecimento do autor - julgo extinto o } \\
\text { processo sem exame do mérito com fundamento no artigo } \\
485 \text {, inciso ix, do código de processo civil.revogo a tutela } \\
\text { provisória concedida. }\end{array}$ & FRALDA \\
\hline 641 & $\begin{array}{c}\text { 1016399- } \\
49.2015 .8 .26 .0071\end{array}$ & 49429/2015 & 28/08/2017 & $\begin{array}{l}\text { Mandado de } \\
\text { Segurança }\end{array}$ & $25 / 08 / 2015$ & $\begin{array}{l}15 / 09 / 2015 \text { - concedo a segurança pleiteada por .... } \\
\text { contra ato do secretário municipal de saúde de Bauru, } \\
\text { para que forneça ao impetrante: fraldas geriátricas } \\
\text { descartáveis - tamanho "g" (150 unidades por mês), nos } \\
\text { termos da petição inicial, e julgo extinto o processo, com } \\
\text { resolução de mérito }\end{array}$ & FRALDA \\
\hline 642 & $\begin{array}{c}1005138- \\
19.2017 .8 .26 .0071\end{array}$ & $49350 / 2017$ & 29/08/2017 & $\begin{array}{l}\text { Mandado de } \\
\text { Segurança }\end{array}$ & & SEGREDO DE JUSTIÇA & $\begin{array}{l}\text { SEGREDO DE } \\
\text { JUSTIÇA }\end{array}$ \\
\hline 643 & $\begin{array}{c}\text { 1023377- } \\
\text { 71.2017.8.26.0071 }\end{array}$ & $49642 / 2017$ & 30/08/2017 & $\begin{array}{l}\text { Outros } \\
\text { Procediment } \\
\text { os }\end{array}$ & $18 / 08 / 2017$ & $\begin{array}{l}\text { 19/03/2018 - ulgo procedente medida cautelar } \\
\text { antecedente de exibição de documentos ajuizada por .... } \\
\text { contra prefeitura municipal de Bauru, famesp fundação } \\
\text { para o desenvolvimento médido e hospitalar famesp e } \\
\text { fazenda pública do estado - - 28/11/2018 - trânsito em } \\
\text { julgado, proceda-se às devidas anotações de baixa e } \\
\text { arquivem-se - }\end{array}$ & $\begin{array}{l}\text { APRESENTAÇÃO } \\
\text { DE PRONTUÁRIO }\end{array}$ \\
\hline 644 & $\begin{array}{c}\text { 0018642- } \\
\text { 12.2017.8.26.0071 }\end{array}$ & $49713 / 2017$ & $30 / 08 / 2017$ & $\begin{array}{l}\text { Outros } \\
\text { Procediment } \\
\text { os }\end{array}$ & $25 / 08 / 2017$ & $\begin{array}{l}\text { 27/09/17 - julgo procedente o pedido formulado por .... } \\
\text { em face da fazenda pública do município de Bauru, } \\
\text { determinando que esta forneça ao requerente fraldas } \\
\text { descartáveis geriátricas - tamanho "g" (150 unidades por } \\
\text { mês), nos termos da petição inicial, e julgo extinto o } \\
\text { processo, com resolução de mérito - - } 07 / 11 / 2017 \text { - } \\
\text { trânsito em julgado às partes - com baixa - }\end{array}$ & FRALDA \\
\hline 645 & $\begin{array}{c}1023476- \\
41.2017 .8 .26 .0071\end{array}$ & $50761 / 2017$ & 05/09/2017 & $\begin{array}{l}\text { Mandado de } \\
\text { Segurança }\end{array}$ & & SEGREDO DE JUSTIÇA & $\begin{array}{l}\text { SEGREDO DE } \\
\text { JUSTIÇA }\end{array}$ \\
\hline 646 & $\begin{array}{c}\text { 1023474- } \\
71.2017 .8 .26 .0071\end{array}$ & $50770 / 2017$ & 05/09/2017 & $\begin{array}{c}\text { Outros } \\
\text { Procediment } \\
\text { os }\end{array}$ & & $\begin{array}{l}\text { 14/006/19 - Apelação reexame - tratamento médico, } \\
\text { psicológico/psiquiátrico, regime hospitalar ou ambulatorial. }\end{array}$ & $\begin{array}{l}\text { CONSULTA } \\
\text { MÉDICA }\end{array}$ \\
\hline 647 & $\begin{array}{c}\text { 1024901- } \\
06.2017 .8 .26 .0071\end{array}$ & $50809 / 2017$ & 05/09/2017 & $\begin{array}{l}\text { Mandado de } \\
\text { Segurança }\end{array}$ & $30 / 08 / 2017$ & $\begin{array}{l}\text { 04/10/2017 - concedo a segurança pleiteada por .... } \\
\text { contra ato do secretário municipal de saúde de Bauru, } \\
\text { para que o impetrado forneça ao impetrante: fraldas } \\
\text { geriátricas tamanho "g" } 05 \text { (cinco) unidades por dia, } \\
\text { totalizando } 150 \text { unidades por mês, julgo extinto o } \\
\text { processo, com resolução de mérito. }\end{array}$ & FRALDA \\
\hline
\end{tabular}




\begin{tabular}{|c|c|c|c|c|c|c|c|}
\hline 648 & $\begin{array}{c}0022855- \\
61.2017 .8 .26 .0071\end{array}$ & $50995 / 2017$ & 06/09/2017 & $\begin{array}{l}\text { Outros } \\
\text { Procediment } \\
\text { os }\end{array}$ & 04/09/2017 & $\begin{array}{l}\text { 16/10/2017 - julgo procedente o pedido formulado por ...., } \\
\text { devidamente representada por sua filha marlene } \\
\text { agostinho budoya em face da prefeitura municipal de } \\
\text { Bauru, determinando que esta forneça à requerente } \\
\text { fraldas descartáveis geriátricas - tamanho "m" ( } 180 \\
\text { unidades por mês), nos termos da petição inicial, e julgo } \\
\text { extinto o processo, com resolução de mérito - }\end{array}$ & FRALDA \\
\hline 649 & $\begin{array}{c}0023338- \\
91.2017 .8 .26 .0071\end{array}$ & $51411 / 2017$ & $11 / 09 / 2017$ & $\begin{array}{l}\text { Outros } \\
\text { Procediment } \\
\text { os }\end{array}$ & 05/09/2017 & $\begin{array}{l}\text { 28/09/2017 - julgo procedente o pedido formulado por } \\
\text { maria das dores marculino batista em face da fazenda } \\
\text { pública do município de Bauru, determinando que esta } \\
\text { forneça ao requerente fraldas descartáveis geriátricas - } \\
\text { tamanho "xg" (180 unidades por mês), nos termos da } \\
\text { petição inicial, e julgo extinto o processo, com resolução } \\
\text { de mérito - - 08/11/2017 - trânsito em julgado às partes - } \\
\text { com baixa - }\end{array}$ & FRALDA \\
\hline 650 & $\begin{array}{c}\text { 1023723- } \\
22.2017 .8 .26 .0071\end{array}$ & $51483 / 2017$ & $11 / 09 / 2017$ & $\begin{array}{l}\text { Outros } \\
\text { Procediment } \\
\text { os }\end{array}$ & 04/09/2017 & $\begin{array}{l}\text { 03/12/2018 - julgo procedente o pedido proposto por .... } \\
\text { em face do município de Bauru, confirmando a tutela } \\
\text { concedida em fls. } 24 / 25 \text {, para condenar o réu a } \\
\text { providenciar e fornecer à parte autora o medicamento } \\
\text { prescrito no receituário - }\end{array}$ & MEDICAMENTO \\
\hline 651 & $\begin{array}{c}1024788- \\
52.2017 .8 .26 .0071\end{array}$ & $53046 / 2017$ & 19/09/2017 & $\begin{array}{l}\text { Mandado de } \\
\text { Segurança }\end{array}$ & & 08/05/18 - Reexame Necessário & $\begin{array}{c}\text { INSUMOS/MATE } \\
\text { RIAL } \\
\text { HOSPITALAR } \\
\end{array}$ \\
\hline 652 & $\begin{array}{c}0024157- \\
28.2017 .8 .26 .0071\end{array}$ & $53053 / 2017$ & 19/09/2017 & $\begin{array}{l}\text { Outros } \\
\text { Procediment } \\
\text { os }\end{array}$ & 15/09/2017 & $\begin{array}{l}27 / 09 / 2017 \text { - julgo procedente o pedido formulado por .... } \\
\text { em face da fazenda pública do município de Bauru, } \\
\text { determinando que esta forneça à requerente fraldas } \\
\text { descartáveis geriátricas - tamanho "g" (180 unidades por } \\
\text { mês), nos termos da petição inicial, e julgo extinto o } \\
\text { processo, com resolução de mérito - - 07/11/2017 - } \\
\text { trânsito em julgado às partes - com baixa - }\end{array}$ & FRALDA \\
\hline 653 & $\begin{array}{c}0024097- \\
55.2017 .8 .26 .0071\end{array}$ & $53059 / 2017$ & 19/09/2017 & $\begin{array}{l}\text { Outros } \\
\text { Procediment } \\
\text { os }\end{array}$ & $14 / 09 / 2017$ & $\begin{array}{l}27 / 09 / 17 \text { - julgo procedente o pedido formulado por .... } \\
\text { em face da fazenda pública do município de Bauru, } \\
\text { determinando que esta forneça ao requerente fraldas } \\
\text { descartáveis geriátricas - tamanho "m" (120 unidades por } \\
\text { mês), nos termos da petição inicial, e julgo extinto o } \\
\text { processo, com resolução de mérito - - } 07 / 11 / 2017 \text { - } \\
\text { trânsito em julgado às partes - com baixa - }\end{array}$ & FRALDA \\
\hline
\end{tabular}




\begin{tabular}{|c|c|c|c|c|c|c|c|}
\hline 654 & $\begin{array}{c}0024282- \\
93.2017 .8 .26 .0071\end{array}$ & $53604 / 2017$ & 21/09/2017 & $\begin{array}{l}\text { Outros } \\
\text { Procediment } \\
\text { os }\end{array}$ & $26 / 09 / 2017$ & $\begin{array}{l}\text { 05/10/17 - julgo procedente o pedido formulado por ... em } \\
\text { face da fazenda pública do município de Bauru, } \\
\text { determinando que esta forneça ao requerente fraldas } \\
\text { descartáveis geriátricas - tamanho "g" (180 unidades por } \\
\text { mês), nos termos da petição inicial, e julgo extinto o } \\
\text { processo, com resolução de mérito - - 13/11/2017 - baixa } \\
\text { definitiva - }\end{array}$ & FRALDA \\
\hline 655 & $\begin{array}{c}1020625- \\
63.2016 .8 .26 .0071\end{array}$ & $53605 / 2017$ & 21/09/2017 & $\begin{array}{l}\text { Mandado de } \\
\text { Segurança }\end{array}$ & 23/11/2016 & $\begin{array}{l}22 / 08 / 17 \text { - denegada a segurança - vistos..... julgo extinto } \\
\text { o processo, sem resolução do mérito, com base no artigo } \\
485 \text {, vi, do código de processo civil.intime-se, servindo } \\
\text { cópia da presente sentença como mandado.custas pela } \\
\text { gratuidade judiciária.não há condenação ao pagamento } \\
\text { de honorários advocatícios, nos termos do artigo } 25 \text { da lei } \\
\text { 12.016/2009. p. r. i. - }\end{array}$ & CIRURGIA \\
\hline 656 & $\begin{array}{c}0024652- \\
72.2017 .8 .26 .0071\end{array}$ & $54145 / 2017$ & 25/09/2017 & $\begin{array}{l}\text { Outros } \\
\text { Procediment } \\
\text { os }\end{array}$ & $21 / 09 / 2017$ & $\begin{array}{l}\text { 05/10/2017 - julgo procedente o pedido formulado por .... } \\
\text { em face da fazenda pública do município de Bauru, } \\
\text { determinando que esta forneça à requerente fraldas } \\
\text { descartáveis geriátricas - tamanho "g" (180 unidades por } \\
\text { mês), nos termos da petição inicial, e julgo extinto o } \\
\text { processo, com resolução de mérito - - 14/11/2017 - baixa } \\
\text { definitiva - }\end{array}$ & FRALDA \\
\hline 657 & $\begin{array}{c}1023606- \\
31.2017 .8 .26 .0071\end{array}$ & $54178 / 2017$ & $25 / 09 / 2017$ & $\begin{array}{c}\text { Outros } \\
\text { Procediment } \\
\text { os }\end{array}$ & 19/09/2017 & $\begin{array}{l}\text { 13/11/2017 - julgo procedente o pedido formulado por .... } \\
\text { contra a fazenda pública do estado de são paulo e } \\
\text { prefeitura municipal de Bauru determinando que a } \\
\text { requerida providencie a requerente o imediato tratamento } \\
\text { de hemodiálise (três sessões por semana), - } \\
\text { 03/04/2018 - remetidos os autos para o tribunal de } \\
\text { justiça/colégio recursal - processo digital - }\end{array}$ & $\begin{array}{l}\text { CONSULTA } \\
\text { MÉDICA }\end{array}$ \\
\hline 658 & $\begin{array}{c}1026950- \\
20.2017 .8 .26 .0071\end{array}$ & $55625 / 2017$ & 03/10/2017 & $\begin{array}{c}\text { Outros } \\
\text { Procediment } \\
\text { os }\end{array}$ & 27/09/2017 & $\begin{array}{l}20 / 10 / 2017 \text { - julgo procedente o pedido formulado por .... } \\
\text { em face da fazenda pública do município de Bauru, } \\
\text { determinando que esta forneça à requerente fraldas } \\
\text { descartáveis geriátricas - tamanho "g" (180 unidades por } \\
\text { mês), nos termos da petição inicial, e julgo extinto o } \\
\text { processo, com resolução de mérito - - 16/11/2017 - baixa } \\
\text { definitiva - }\end{array}$ & FRALDA \\
\hline 659 & $\begin{array}{c}1022220- \\
63.2017 .8 .26 .0071\end{array}$ & $55672 / 2017$ & 03/10/2017 & $\begin{array}{l}\text { Outros } \\
\text { Procediment } \\
\text { os }\end{array}$ & & $\begin{array}{l}\text { 14/11/2018 - solicitação de perícia médica - medicina } \\
\text { legal - }\end{array}$ & $\begin{array}{l}\text { DANO MATERIAL } \\
\text { E MORAL }\end{array}$ \\
\hline
\end{tabular}




\begin{tabular}{|c|c|c|c|c|c|c|c|}
\hline 660 & $\begin{array}{c}\text { 1027767- } \\
\text { 84.2017.8.26.0071 }\end{array}$ & $56204 / 2017$ & 05/10/2017 & $\begin{array}{l}\text { Mandado de } \\
\text { Segurança }\end{array}$ & 02/10/2017 & $\begin{array}{l}\text { 19/10/2017 - concedo a segurança pleiteada por .... } \\
\text { contra ato do secretário municipal de saúde de Bauru, } \\
\text { para que o impetrado forneça à parte impetrante fraldas } \\
\text { geriátricas descartáveis - tamanho "extra-g" (180 } \\
\text { unidades por mês), nos termos da petição inicial, e julgo } \\
\text { extinto o processo, com resolução de mérito - } \\
\text { 22/03/2018 - arquivado definitivamente - }\end{array}$ & FRALDA \\
\hline 661 & $\begin{array}{c}0002942- \\
27.2017 .4 .03 .6325\end{array}$ & $56206 / 2017$ & 05/10/2017 & $\begin{array}{c}\text { Outros } \\
\text { Procediment } \\
\text { os }\end{array}$ & & 12/07/18 - Julgado improcedente & $\begin{array}{c}\text { INSUMOS/MATE } \\
\text { RIAL } \\
\text { HOSPITALAR }\end{array}$ \\
\hline 662 & $\begin{array}{c}\text { 1027769- } \\
54.2017 .8 .26 .0071\end{array}$ & $56353 / 2017$ & 05/10/2017 & $\begin{array}{l}\text { Mandado de } \\
\text { Segurança }\end{array}$ & 02/10/2017 & $\begin{array}{l}\text { 16/11/2017 - oncedo a segurança pleiteada por .... contra } \\
\text { ato do secretário municipal de saúde de Bauru, para que } \\
\text { o impetrado forneça ao impetrante: fraldas geriátricas } \\
\text { tamanho "g" } 120 \text { (cento e vinte) unidades por mês, } \\
\text { conforme receituário de fls. } 19 \text { e julgo extinto o processo, } \\
\text { com resolução de mérito - }-05 / 09 / 2018 \text { - recebidos os } \\
\text { autos do tribunal de justiça - - 07/11/2018 - rquivado } \\
\text { definitivamente - }\end{array}$ & FRALDA \\
\hline 663 & $\begin{array}{c}\text { 1027936- } \\
71.2017 .8 .26 .0071\end{array}$ & $57023 / 2017$ & 09/10/2017 & $\begin{array}{l}\text { Mandado de } \\
\text { Segurança }\end{array}$ & 03/10/2017 & $\begin{array}{l}26 / 10 / 17 \text { - CONCEDO A SEGURANÇA pleiteada por } \\
\text { ÂNGELO CARDOSO contra ato do SECRETÁRIO } \\
\text { MUNICIPAL DE SAÚDE DE BAURU, para que o } \\
\text { impetrado forneça à parte impetrante FRALDAS } \\
\text { GERIÁTRICAS DESCARTÁVEIS - tamanho "M" (180 } \\
\text { unidades por mês) }\end{array}$ & FRALDA \\
\hline 664 & $\begin{array}{c}1028215- \\
57.2017 .8 .26 .0071\end{array}$ & $57466 / 2017$ & $11 / 10 / 2017$ & $\begin{array}{l}\text { Mandado de } \\
\text { Segurança }\end{array}$ & 06/10/2017 & $\begin{array}{l}\text { 26/10/18 - concedo a segurança pleiteada por ... contra } \\
\text { ato do secretário municipal de saúde de Bauru, para que } \\
\text { o impetrado forneça à parte impetrante fraldas geriátricas } \\
\text { descartáveis - tamanho "g" (150 unidades por mês), nos } \\
\text { termos da petição inicial, e julgo extinto o processo, com } \\
\text { resolução de mérito - }-22 / 06 / 2018 \text { - arquivado } \\
\text { definitivamente - }\end{array}$ & FRALDA \\
\hline 665 & $\begin{array}{c}\text { 1028212- } \\
\text { 05.2017.8.26.0071 }\end{array}$ & $57481 / 2017$ & $11 / 10 / 2017$ & $\begin{array}{l}\text { Mandado de } \\
\text { Segurança }\end{array}$ & 05/10/2017 & $\begin{array}{l}01 / 11 / 2017 \text { - concedo a segurança pleiteada por .... } \\
\text { contra ato do secretário municipal de saúde de Bauru, } \\
\text { para que o impetrado forneça ao impetrante: fraldas } \\
\text { geriátricas descartáveis - tamanho "g" (120 unidades por } \\
\text { mês), conforme receituário de fls. } 12 \text { e julgo extinto o } \\
\text { processo, com resolução de mérito - - } 08 / 08 / 2018 \text { - } \\
\text { arquivado definitivamente - }\end{array}$ & FRALDA \\
\hline
\end{tabular}




\begin{tabular}{|c|c|c|c|c|c|c|c|}
\hline 666 & $\begin{array}{c}\text { 1028621- } \\
\text { 78.2017.8.26.0071 }\end{array}$ & $57824 / 2017$ & $16 / 10 / 2017$ & $\begin{array}{l}\text { Mandado de } \\
\text { Segurança }\end{array}$ & 10/10/2017 & $\begin{array}{l}08 / 11 / 2017 \text { - concedo a segurança pleiteada por .... } \\
\text { contra ato do secretário municipal de saúde de Bauru, } \\
\text { para que o impetrado forneça à parte impetrante fraldas } \\
\text { geriátricas descartáveis - tamanho "m" (120 unidades por } \\
\text { mês), nos termos da petição inicial, e julgo extinto o } \\
\text { processo, com resolução de mérito - - 05/07/2018 - } \\
\text { arquivado definitivamente - }\end{array}$ & FRALDA \\
\hline 667 & $\begin{array}{c}0027050- \\
89.2017 .8 .26 .0071\end{array}$ & $58776 / 2017$ & 20/10/2017 & $\begin{array}{l}\text { Outros } \\
\text { Procediment } \\
\text { os }\end{array}$ & 17/10/2017 & $\begin{array}{l}\text { 01/11/2017 - julgo procedente o pedido formulado por ... } \\
\text { em face da fazenda pública do município de Bauru, } \\
\text { determinando que esta forneça ao requerente fraldas } \\
\text { descartáveis geriátricas - tamanho "m" (120 unidades por } \\
\text { mês), nos termos da petição inicial, e julgo extinto o } \\
\text { processo, com resolução de mérito, - - } 21 / 11 / 2017 \text { - baixa } \\
\text { definitiva - }\end{array}$ & FRALDA \\
\hline 668 & $\begin{array}{c}\text { 1013185- } \\
\text { 79.2017.8.26.0071 }\end{array}$ & $59070 / 2017$ & $23 / 10 / 2017$ & $\begin{array}{l}\text { Outros } \\
\text { Procediment } \\
\text { os }\end{array}$ & $26 / 06 / 2017$ & $\begin{array}{l}\text { 13/08/18 - denegada a segurança - julgo extinto o } \\
\text { processo, proposto por .... em face de ato do secretário } \\
\text { municipal de saúde de Bauru, sem resolução do mérito - } \\
\text { 26/11/2018 - teor do ato: vistos. considerando a certidão } \\
\text { de fls. 112, arquivem-se os autos - }\end{array}$ & $\begin{array}{l}\text { APRESENTAĈ̃O } \\
\text { DE PRONTUÁRIO }\end{array}$ \\
\hline 669 & $\begin{array}{c}\text { 1028701- } \\
\text { 42.2017.8.26.0071 }\end{array}$ & $59332 / 2017$ & $24 / 10 / 2017$ & $\begin{array}{l}\text { Outros } \\
\text { Procediment } \\
\text { os }\end{array}$ & & $\begin{array}{l}\text { 24/01/18 - Defiro as provas úteis e tempestivamente } \\
\text { requeridas. Oficie-se ao IMESC solicitando a indicação de } \\
\text { médico fisiatra para a realização da perícia que terá como } \\
\text { objeto a necessidade e adequação do método objeto do } \\
\text { pedido (pediasuit) e a sua eficácia em relação aos } \\
\text { tratamentos disponibilizados pelo Poder Público. Com a } \\
\text { indicação, aos quesitos e à perícia que deverá ser } \\
\text { concluída em trinta dias }\end{array}$ & $\begin{array}{l}\text { CONSULTA } \\
\text { MÉDICA }\end{array}$ \\
\hline 670 & $\begin{array}{c}\text { 1029228- } \\
91.2017 .8 .26 .0071\end{array}$ & $59355 / 2017$ & $24 / 10 / 2017$ & $\begin{array}{l}\text { Outros } \\
\text { Procediment } \\
\text { os }\end{array}$ & 19/10/2017 & $\begin{array}{l}27 / 11 / 18 \text { - julgo procedente o pedido formulado por .... } \\
\text { em face da fazenda pública do municíio de de Bauru, } \\
\text { determinando que esta forneça ao requerente fraldas } \\
\text { descartáveis geriátricas - tamanho "g" (120 unidades por } \\
\text { mês), nos termos da petição inicial, e julgo extinto o } \\
\text { processo, com resolução de mérito - - 27/02/2018 - baixa } \\
\text { definitiva - }\end{array}$ & FRALDA \\
\hline 671 & $\begin{array}{c}\text { 0026763- } \\
\text { 29.2017.8.26.0071 }\end{array}$ & $59401 / 2017$ & 24/10/2017 & $\begin{array}{l}\text { Outros } \\
\text { Procediment } \\
\text { os }\end{array}$ & & $\begin{array}{l}\text { 22/11/17 - julgo procedente o pedido formulado por .... } \\
\text { em face da fazenda pública do município de Bauru, } \\
\text { determinando que esta forneça ao requerente fraldas } \\
\text { descartáveis geriátricas - tamanho "g" (150 unidades por } \\
\text { mês), nos termos da petição inicial, e julgo extinto o } \\
\text { processo, com resolução de mérito - - 13/12/2017 - } \\
\text { trânsito em julgado às partes - com baixa - }\end{array}$ & FRALDA \\
\hline
\end{tabular}




\begin{tabular}{|c|c|c|c|c|c|c|c|}
\hline 672 & $\begin{array}{c}1024788- \\
52.2017 .8 .26 .0071\end{array}$ & $59399 / 2017$ & $24 / 10 / 2017$ & $\begin{array}{l}\text { Mandado de } \\
\text { Segurança }\end{array}$ & & SEGREDO DE JUSTIÇA & $\begin{array}{l}\text { SEGREDO DE } \\
\text { JUSTIÇA }\end{array}$ \\
\hline 673 & $\begin{array}{c}1029228- \\
91.2017 .8 .26 .0071\end{array}$ & $59355 / 2017$ & $24 / 10 / 2017$ & $\begin{array}{l}\text { Outros } \\
\text { Procediment } \\
\text { os }\end{array}$ & $19 / 10 / 2017$ & $\begin{array}{l}27 / 11 / 2017 \text { - julgo procedente o pedido formulado por .... } \\
\text { em face da fazenda pública do município de Bauru, } \\
\text { determinando que esta forneça ao requerente fraldas } \\
\text { descartáveis geriátricas - tamanho "g" (120 unidades por } \\
\text { mês), nos termos da petição inicial, e julgo extinto o } \\
\text { processo, com resolução de mérito - - } 27 / 02 / 2018 \text { - baixa } \\
\text { definitiva - }\end{array}$ & FRALDA \\
\hline 674 & $\begin{array}{c}0027758- \\
42.2017 .8 .26 .0071\end{array}$ & $59727 / 2017$ & $25 / 10 / 2017$ & $\begin{array}{l}\text { Outros } \\
\text { Procediment } \\
\text { os }\end{array}$ & $23 / 10 / 2017$ & $\begin{array}{l}\text { 09/11/2017 - julgo procedente o pedido formulado por .... } \\
\text { em face da fazenda pública do município de Bauru, } \\
\text { determinando que esta forneça ao requerente fraldas } \\
\text { descartáveis geriátricas - tamanho "g" (180 unidades por } \\
\text { mês), nos termos da petição inicial, e julgo extinto o } \\
\text { processo, com resolução de mérit - - 05/12/2017 - baixa } \\
\text { definitiva - }\end{array}$ & FRALDA \\
\hline 675 & $\begin{array}{c}0005758- \\
05.2004 .8 .26 .0071\end{array}$ & $60168 / 2017$ & $27 / 10 / 2017$ & $\begin{array}{l}\text { Outros } \\
\text { Procediment } \\
\text { os }\end{array}$ & & $\begin{array}{l}\text { 03/12/2012 - fornecer medicamentos, tratamentos e } \\
\text { transportes necessários a sua reabilitação (males } \\
\text { relacionados à paraplegia). - - - diversos pedidos }\end{array}$ & MEDICAMENTO \\
\hline 676 & $\begin{array}{c}1029940- \\
81.2017 .8 .26 .0071\end{array}$ & $60197 / 2017$ & $27 / 10 / 2017$ & $\begin{array}{l}\text { Mandado de } \\
\text { Segurança }\end{array}$ & $25 / 10 / 2017$ & $\begin{array}{l}\text { 04/12/2017 - concedo a segurança pleiteada por .... } \\
\text { contra ato do secretário municipal de saúde de Bauru, } \\
\text { para que o impetrado forneça ao impetrante: fraldas } \\
\text { geriátricas tamanho "m" } 120 \text { (cento e vinte) unidades por } \\
\text { mês, conforme receituário de fls. } 14 \text { e julgo extinto o } \\
\text { processo, com resolução de mérito - - 15/08/2018 - } \\
\text { arquivado definitivamente - }\end{array}$ & FRALDA \\
\hline 677 & $\begin{array}{c}1025145- \\
32.2017 .8 .26 .0071\end{array}$ & $60199 / 2017$ & $27 / 10 / 2017$ & $\begin{array}{c}\text { Outros } \\
\text { Procediment } \\
\text { os }\end{array}$ & $25 / 10 / 2017$ & SEGREDO DE JUSTIÇA & MEDICAMENTO \\
\hline 678 & $\begin{array}{c}1029348- \\
37.2017 .8 .26 .0071\end{array}$ & $60970 / 2017$ & $31 / 10 / 2017$ & $\begin{array}{l}\text { Mandado de } \\
\text { Segurança }\end{array}$ & $25 / 10 / 2017$ & $\begin{array}{l}\text { - tornar definitiva a liminar deferida e determinar ao } \\
\text { Diretor do Departamento Regional de Saúde da } \\
\text { Secretaria do Estado de Saúde em Bauru - DRS VI e do } \\
\text { Secretário Municipal de Saúde de Bauru o fornecimento } \\
\text { de curativos Mepilex de } 20 \times 50 \mathrm{~cm} \text {, de uso diário, sendo } 60 \\
\text { unidades mensais, ASKINA de } 17 \times 17 \mathrm{~cm} \text {, de uso diário, } \\
\text { sendo } 55 \text { unidades mensais e do hidratante CETAPHIL } \\
\text { ADVANCED, por tempo indeterminado. }\end{array}$ & MEDICAMENTO \\
\hline
\end{tabular}




\begin{tabular}{|c|c|c|c|c|c|c|c|}
\hline 679 & $\begin{array}{c}\text { 1023288- } \\
\text { 48.2017.8.26.0071 }\end{array}$ & $61756 / 2017$ & 07/11/2017 & $\begin{array}{l}\text { Outros } \\
\text { Procediment } \\
\text { os }\end{array}$ & & $\begin{array}{l}\text { 28/09/2018 - ausência das condições da ação - vistos..... } \\
\text { ante o exposto, revogo a liminar de fls. 20/21 e julgo } \\
\text { extinta a presente ação proposta por .... em face de ..., } \\
\text { fazenda pública do estado de São Paulo e prefeitura } \\
\text { municipal de Bauru, sem resolução do mérito, nos termos } \\
\text { do art. } 485, \text { vi, do código de processo civil. em razão da } \\
\text { sucumbência dos requeridos, considerando o disposto no } \\
\text { artigo } 85, \S 2^{\circ}, \text { i a iv, e } \S 10 \text {, do cpc, bem como o fato de } \\
\text { não se tratar de causa de grande complexidade, fixo os } \\
\text { honorários advocatícios por equidade, em } \$ 1000,00 \text { (mil } \\
\text { reais), observado o disposto no artigo } 98, \S 3^{\circ} \text { do cpc } \\
\text { quanto ao requerido. }\end{array}$ & INTERNAÇÃO \\
\hline 680 & $\begin{array}{c}1026750- \\
13.2017 .8 .26 .0071\end{array}$ & $61761 / 2017$ & 07/11/2017 & $\begin{array}{l}\text { Mandado de } \\
\text { Segurança }\end{array}$ & $31 / 10 / 2017$ & $\begin{array}{l}21 / 02 / 2018 \text { - vistos..... } \text { reconheço a carência } \\
\text { superveniente, e julgo extinto o processo sem resolução } \\
\text { de mérito, com base nos artigos } 485 \text {, vi, c.c. } 493 \text {, ambos } \\
\text { do cpc.nos termos do artigo } 13 \text {, caput, da lei } 12.016 / 09, \\
\text { por mandado, transmitir o inteiro teor da decisão ao } \\
\text { impetrado e a pmb.não cabe condenação em honorários } \\
\text { (artigo } 25 \text { da lei } 12.016 / 09 \text { ).p. r. i. - - 22/10/2018 - } \\
\text { arquivado definitivamente - }\end{array}$ & $\begin{array}{l}\text { APRESENTAÇÃO } \\
\text { DE PRONTUÁRIO }\end{array}$ \\
\hline 681 & $\begin{array}{c}1030049- \\
95.2017 .8 .26 .0071\end{array}$ & $62193 / 2017$ & 09/11/2017 & $\begin{array}{l}\text { Outros } \\
\text { Procediment } \\
\text { os }\end{array}$ & & $\begin{array}{l}\text { - 06/12/2017 - julgo procedente o pedido formulado por } \\
\ldots . \quad \text { contra a fazenda pública municipal de Bauru, } \\
\text { determinando que a requerida providencie o fornecimento } \\
\text { do medicamento de que necessita o autor (clindamicina } \\
300 \mathrm{mg}-2 \text { cápsulas } 6 / 6 \text { horas - fls. } 14 / 15 \text { ), e extinto o } \\
\text { processo,com resolução de mérito, nos termos do artigo } \\
487, \text { i do novo código de processo civil.para efeito de } \\
\text { efetivo controle do tempo em que o autor necessita do } \\
\text { item a ser fornecido e para evitar compras desnecessárias } \\
\text { pelo órgão público, deverá ser apresentada prescrição } \\
\text { médica atualizada perante a secretaria municipal de } \\
\text { saúde de Bauru, a cada } 03 \text { meses.indevido o pagamento } \\
\text { de custas e despesas nesta fase processual - } \\
06 / 11 / 2018 \text { - arquivado definitivamente - }\end{array}$ & MEDICAMENTO \\
\hline 682 & $\begin{array}{c}1030442- \\
20.2017 .8 .26 .0071\end{array}$ & $62542 / 2017$ & 10/11/2017 & $\begin{array}{l}\text { Mandado de } \\
\text { Segurança }\end{array}$ & 07/11/2017 & $\begin{array}{l}\text { concedo a segurança pleiteada por .... contra ato do } \\
\text { secretário municipal de saúde de Bauru, para que o } \\
\text { impetrado forneça ao impetrante: fraldas geriátricas } \\
\text { descartáveis - tamanho xg - "tipo calcinha" (120 unidades } \\
\text { por mês), conforme receituário de fls. } 28 \text { e julgo extinto o } \\
\text { processo, com resolução de mérito - - 28/06/18 - } \\
\text { arquivado definitivamente - }\end{array}$ & FRALDA \\
\hline
\end{tabular}




\begin{tabular}{|c|c|c|c|c|c|c|c|}
\hline 683 & $\begin{array}{c}\text { 1030760- } \\
\text { 03.2017.8.26.0071 }\end{array}$ & $62547 / 2017$ & 10/11/2017 & $\begin{array}{l}\text { Mandado de } \\
\text { Segurança }\end{array}$ & $01 / 11 / 2017$ & $\begin{array}{l}\text { 20/11/2017 - concedo a segurança pleiteada por .... } \\
\text { contra ato do secretário municipal de saúde de Bauru, } \\
\text { para que o impetrado forneça à parte impetrante fraldas } \\
\text { geriátricas descartáveis - tamanho "g" (120 unidades por } \\
\text { mês), nos termos da petição inicial, e julgo extinto o } \\
\text { processo, com resoluçãa de mérito - - } 25 / 06 / 18 \text { - } \\
\text { arquivado definitivamente - }\end{array}$ & FRALDA \\
\hline 684 & $\begin{array}{c}\text { 1030871- } \\
\text { 84.2017.8.26.0071 }\end{array}$ & $62951 / 2017$ & 13/11/2017 & $\begin{array}{l}\text { Mandado de } \\
\text { Segurança }\end{array}$ & 07/11/2017 & $\begin{array}{l}\text { 30/11/2017 - concedo a segurança pleiteada por .... } \\
\text { contra ato do secretário municipal de saúde de Bauru, } \\
\text { para que o impetrado forneça à parte impetrante fraldas } \\
\text { geriátricas descartáveis - tamanho "g" (150 unidades por } \\
\text { mês), nos termos da petição inicial, e julgo extinto o } \\
\text { processo, com resolução de mérito - - 24/05/18 - } \\
\text { arquivado definitivamente - }\end{array}$ & FRALDA \\
\hline 685 & $\begin{array}{c}\text { 1030780- } \\
91.2017 .8 .26 .0071\end{array}$ & $62954 / 2017$ & $13 / 11 / 2017$ & $\begin{array}{l}\text { Outros } \\
\text { Procediment } \\
\text { os }\end{array}$ & & $\begin{array}{l}\text { 27/11/2017 - julgo procedente o pedido formulado por ... e } \\
\ldots \text { em face da fazenda pública do município de Bauru, } \\
\text { determinando que esta forneça aos requerentes fraldas } \\
\text { descartáveis geriátricas - tamanho "g" (180 unidades por } \\
\text { mês - para ele) e tamanho "m" (180 unidades por mês - } \\
\text { para ela), nos termos da petição inicial, e julgo extinto o } \\
\text { processo, com resolução de mérito - - } 15 / 12 / 2017 \text { - } \\
\text { trânsito em julgado às partes - com baixa - }\end{array}$ & FRALDA \\
\hline 686 & $\begin{array}{c}\text { 1031124- } \\
\text { 72.2017.8.26.0071 }\end{array}$ & 62973/2017 & $13 / 11 / 2017$ & $\begin{array}{l}\text { Mandado de } \\
\text { Segurança }\end{array}$ & 07/11/2017 & $\begin{array}{l}05 / 12 / 2017 \text { - concedo a segurança pleiteada por .... } \\
\text { contra ato do secretário municipal de saúde de Bauru, } \\
\text { para que o impetrado forneça ao impetrante: fraldas } \\
\text { geriátricas tamanho "m" } 120 \text { (cento e vinte) unidades por } \\
\text { mês, conforme receituário de fls. 15 e julgo extinto o } \\
\text { processo, com resolução de mérito - - 08/08/2018 - } \\
\text { arquivado definitivamente - }\end{array}$ & FRALDA \\
\hline 687 & $\begin{array}{c}\text { 1031063- } \\
17.2017 .8 .26 .0071\end{array}$ & 63083/2017 & $14 / 11 / 2017$ & $\begin{array}{l}\text { Mandado de } \\
\text { Segurança }\end{array}$ & 08/11/2017 & $\begin{array}{l}27 / 11 / 2017 \text { - concedo a segurança pleiteada por .... } \\
\text { contra ato do secretário municipal de saúde de Bauru, } \\
\text { para que o impetrado forneça à parte impetrante fraldas } \\
\text { geriátricas descartáveis - tamanho "g" (120 unidades por } \\
\text { mês) e julgo extinto o processo, com resolução de mérito - } \\
\text { 44/06/2018 - arquivado definitivamente - }\end{array}$ & FRALDA \\
\hline 688 & $\begin{array}{c}0030035- \\
31.2017 .8 .26 .0071\end{array}$ & 63136/2017 & 14/11/2017 & $\begin{array}{l}\text { Outros } \\
\text { Procediment } \\
\text { os }\end{array}$ & 10/11/2017 & $\begin{array}{l}\text { 07/12/2017 - julgo procedente o pedido formulado por .... } \\
\text { em face da fazenda pública do município de Bauru, } \\
\text { determinando que esta forneça ao requerente fraldas } \\
\text { descartáveis geriátricas - tamanho "p" (120 unidades por } \\
\text { mês), nos termos da petição inicial, e julgo extinto o } \\
\text { processo, com resolução de mérito - }\end{array}$ & FRALDA \\
\hline
\end{tabular}




\begin{tabular}{|c|c|c|c|c|c|c|c|}
\hline 689 & $\begin{array}{c}\text { 1027995- } \\
59.2017 .8 .26 .0071\end{array}$ & $63507 / 2017$ & $16 / 11 / 2017$ & $\begin{array}{l}\text { Outros } \\
\text { Procediment } \\
\quad \text { os }\end{array}$ & $10 / 11 / 2017$ & $\begin{array}{l}\text { 12/12/2017 - julgo procedente o pedido formulado por .... } \\
\text { em face da fazenda pública do município de Bauru, } \\
\text { determinando que esta forneça ao requerente fraldas } \\
\text { descartáveis geriátricas - tamanho "gg" (120 unidades por } \\
\text { mês), nos termos da petição inicial, e julgo extinto o } \\
\text { processo, com resolução de mérito - }\end{array}$ & FRALDA \\
\hline 690 & $\begin{array}{c}\text { 1024210- } \\
\text { 89.2017.8.26.0071 }\end{array}$ & $49549 / 2017$ & $17 / 11 / 2017$ & $\begin{array}{l}\text { Mandado de } \\
\text { Segurança }\end{array}$ & $23 / 08 / 2017$ & $\begin{array}{l}\text { 04/10/2017 - concedo a segurança pleiteada por .... } \\
\text { contra ato do secretário municipal de saúde de Bauru, } \\
\text { para que o impetrado forneça ao impetrante: fraldas } \\
\text { geriátricas - - 28/05/2018 - arquivado definitivamente - }\end{array}$ & FRALDA \\
\hline 691 & $\begin{array}{c}\text { 0029262- } \\
\text { 83.2017.8.26.0071 }\end{array}$ & $63800 / 2017$ & 17/11/2017 & $\begin{array}{l}\text { Outros } \\
\text { Procediment } \\
\text { os }\end{array}$ & $13 / 11 / 2017$ & $\begin{array}{l}\text { 19/12/2017 - julgo procedente o pedido formulado por ... } \\
\text { em face da fazenda pública do município de Bauru, } \\
\text { determinando que esta forneça ao requerente fraldas } \\
\text { descartáveis geriátricas - tamanho "gg" (120 unidades por } \\
\text { mês), nos termos da petição inicial, e julgo extinto o } \\
\text { processo, com resolução de mérito - }\end{array}$ & FRALDA \\
\hline 692 & $\begin{array}{c}\text { 0030373- } \\
\text { 05.2017.8.26.0071 }\end{array}$ & 64265/2017 & 21/11/2017 & $\begin{array}{l}\text { Outros } \\
\text { Procediment } \\
\text { os }\end{array}$ & & $\begin{array}{l}\text { 29/08/2018 - julgo extinta a presente ação nos termos do } \\
\text { art. } 485 \text {, iii do código de processo civil. após o trânsito em } \\
\text { julgado, arquivem-se. - - 20/11/2018 - arquivado } \\
\text { definitivamente - }\end{array}$ & $\begin{array}{l}\text { CONSULTA } \\
\text { MÉDICA }\end{array}$ \\
\hline 693 & $\begin{array}{c}\text { 1032659- } \\
36.2017 .8 .26 .0071\end{array}$ & $65509 / 2017$ & 28/11/2017 & $\begin{array}{l}\text { Mandado de } \\
\text { Segurança }\end{array}$ & $24 / 11 / 2017$ & $\begin{array}{l}11 / 01 / 2018 \text { - concedo a segurança pleiteada por .... } \\
\text { contra ato do secretário municipal de saúde de Bauru, } \\
\text { para que o impetrado forneça à parte impetrante fraldas } \\
\text { geriátricas descartáveis - tamanho "gg" (120 unidades por } \\
\text { mês), nos termos da petição inicial, e julgo extinto o } \\
\text { processo, com resolução de mérito - }\end{array}$ & FRALDA \\
\hline 694 & $\begin{array}{c}0031380- \\
32.2017 .8 .26 .0071\end{array}$ & $65510 / 2017$ & $28 / 11 / 2017$ & $\begin{array}{l}\text { Outros } \\
\text { Procediment } \\
\text { os }\end{array}$ & 24/11/2017 & $\begin{array}{l}\text { 26/01/18 - julgo procedente o pedido formulado por .... } \\
\text { em face da fazenda pública do município de Bauru, } \\
\text { determinando que esta forneça ao requerente fraldas } \\
\text { descartáveis geriátricas - tamanho "m - infantil" (180 } \\
\text { unidades por mês), nos termos da petição inicial, e julgo } \\
\text { extinto o processo, com resolução de mérito - }\end{array}$ & FRALDA \\
\hline 695 & $\begin{array}{c}\text { 1032665- } \\
\text { 43.2017.8.26.0071 }\end{array}$ & $65734 / 2017$ & 29/11/2017 & $\begin{array}{l}\text { Mandado de } \\
\text { Segurança }\end{array}$ & 24/11/2017 & $\begin{array}{l}\text { 12/12/2017 - concedo a segurança pleiteada por .... } \\
\text { contra ato do secretário municipal de saúde de Bauru, } \\
\text { para que o impetrado forneça à parte impetrante fraldas } \\
\text { geriátricas descartáveis - tamanho "g" (150 unidades por } \\
\text { mês), nos termos da petição inicial, e julgo extinto o } \\
\text { processo, com resolução de mérito - }\end{array}$ & FRALDA \\
\hline
\end{tabular}




\begin{tabular}{|c|c|c|c|c|c|c|c|}
\hline 696 & $\begin{array}{c}1010640- \\
36.2017 .8 .26 .0071\end{array}$ & 65736/2017 & 29/11/2017 & $\begin{array}{l}\text { Outros } \\
\text { Procediment } \\
\text { os }\end{array}$ & $13 / 08 / 2018$ & $\begin{array}{l}\text { 13/08/18 - julgo procedente o pedido, formulado por ... já } \\
\text { como em face da prefeitura municipal de Bauru e ..., } \\
\text { determinando que a secretaria municipal de saúde de } \\
\text { Bauru providencie a imediata disponibilização de vaga } \\
\text { para internação para tratamento psiquiátrico ao requerido } \\
\text {..., nos termos da petição inicial e, extinto o processo, com } \\
\text { resolução de mérito, nos termos do artigo } 487, \text { i do código } \\
\text { de processo civil. condeno, ainda, o primeiro requerido ao } \\
\text { pagamento de despesas processuais e honorários } \\
\text { advocatícios que arbitro em } \$ \$ 900,00 \text { (novecentos reais) - }\end{array}$ & INTERNAÇÃO \\
\hline 697 & $\begin{array}{c}\text { 1032738- } \\
\text { 15.2017.8.26.0071 }\end{array}$ & 65738/2017 & 29/11/2017 & $\begin{array}{l}\text { Mandado de } \\
\text { Segurança }\end{array}$ & 27/11/2017 & $\begin{array}{l}18 / 12 / 2017 \text { - concedo a segurança pleiteada por .... } \\
\text { contra ato do secretário municipal de saúde de Bauru, } \\
\text { para que o impetrado forneça ao impetrante: fraldas } \\
\text { geriátricas descartáveis tamanho "g" (150 unidades por } \\
\text { mês), conforme receituário de fls. 16, e julgo extinto o } \\
\text { processo, com resolução de mérito - }\end{array}$ & FRALDA \\
\hline 698 & $\begin{array}{c}\text { 1032662- } \\
88.2017 .8 .26 .0071\end{array}$ & $65945 / 2017$ & $30 / 11 / 2017$ & $\begin{array}{l}\text { Mandado de } \\
\text { Segurança }\end{array}$ & $28 / 11 / 2017$ & $\begin{array}{l}09 / 01 / 2018 \text { - concedo a segurança pleiteada por .... } \\
\text { contra ato do secretário municipal de saúde de Bauru, } \\
\text { para que o impetrado forneça ao impetrante: fraldas } \\
\text { geriátricas descartáveis tamanho "g' (150 unidades por } \\
\text { mês), conforme receituário de fls. 17, n e julgo extinto o } \\
\text { processo, com resolução de mérito - }\end{array}$ & FRALDA \\
\hline 699 & $\begin{array}{c}\text { 1032200- } \\
34.2017 .8 .26 .0071\end{array}$ & $66139 / 2017$ & 01/12/2017 & $\begin{array}{l}\text { Outros } \\
\text { Procediment } \\
\text { os }\end{array}$ & $27 / 11 / 2017$ & $\begin{array}{l}\text { 14/12/2017 - julgo procedente o pedido formulado por .... } \\
\text { em face da fazenda pública do município de Bauru, } \\
\text { determinando que esta forneça ao requerente } \\
\text { absorventes masculinos descartáveis (1 pacote por dia - } \\
\text { fls. 28), nos termos da petição inicial, e julgo extinto o } \\
\text { processo, com resolução de mérito - }\end{array}$ & FRALDA \\
\hline 700 & $\begin{array}{c}\text { 1027937- } \\
56.2017 .8 .26 .0071\end{array}$ & $66355 / 2017$ & 04/12/2017 & $\begin{array}{l}\text { Mandado de } \\
\text { Segurança }\end{array}$ & $30 / 11 / 2017$ & $\begin{array}{l}11 / 01 / 2018 \text { - concedo a segurança pleiteada por .... } \\
\text { contra ato do secretário municipal de saúde de Bauru, } \\
\text { para que o impetrado forneça ao impetrante: fraldas } \\
\text { geriátricas descartáveis tamanho "eg" (120 unidades por } \\
\text { mês), conforme receituário médico de fls. } 29 \text { e julgo } \\
\text { extinto o processo, com resolução de mérito - }\end{array}$ & FRALDA \\
\hline 701 & $\begin{array}{c}1030763- \\
55.2017 .8 .26 .0071\end{array}$ & $66364 / 2017$ & 04/12/2017 & $\begin{array}{c}\text { Outros } \\
\text { Procediment } \\
\text { os }\end{array}$ & & SEGREDO DE JUSTIÇA & $\begin{array}{c}\text { SEGREDO DE } \\
\text { JUSTIÇA }\end{array}$ \\
\hline
\end{tabular}




\begin{tabular}{|c|c|c|c|c|c|c|c|}
\hline 702 & $\begin{array}{c}0031928- \\
57.2017 .8 .26 .0071\end{array}$ & $66383 / 2017$ & $04 / 12 / 2017$ & $\begin{array}{c}\text { Outros } \\
\text { Procediment } \\
\text { os }\end{array}$ & $29 / 11 / 2017$ & $\begin{array}{l}\text { 14/02/18 - julgo procedente o pedido, formulado por .... } \\
\text { contra o prefeitura municipal de Bauru, determinando que } \\
\text { o requerido forneça a requerente: fraldas descartáveis } \\
\text { geriátricas tamanho "g" } 150 \text { (cento e cinquenta) unidades } \\
\text { por mês, conforme prescrição médica fls. } 10 \text { e extinto o } \\
\text { processo, com resolução de mérito. }\end{array}$ & FRALDA \\
\hline 703 & $\begin{array}{c}1016956- \\
02.2016 .8 .26 .0071\end{array}$ & $66721 / 2017$ & 05/12/2017 & $\begin{array}{c}\text { Outros } \\
\text { Procediment } \\
\text { os }\end{array}$ & 16/07/2018 & $\begin{array}{l}20 / 07 / 2018 \text { - internação compulsória em clínica } \\
\text { psiquiátrica especializada. a fls. } 273 / 274 \text {, veio aos autos } \\
\text { laudo pericial concluindo pela necessidade da medida } \\
\text { pleiteada. é o relatório. decido. estão presentes a } \\
\text { probabilidade do direito do autor, bem como urgência no } \\
\text { pedido e perigo de dano, pois no laudo pericial de fls. } \\
273 / 274 \text { foi concluído que a primeira requerida "apresenta } \\
\text { graves alterações comportamentais decorrentes de } \\
\text { retardo mental, necessita em caráter de urgência, de } \\
\text { internação em clínica psiquiátrica especializada por um } \\
\text { período mínimo de três meses e após seguimento } \\
\text { psiquiátrico ambulatorial". ante o exposto, defiro a tutela } \\
\text { provisória, determinando a internação compulsória do } \\
\text { requerido aparecida dos santos, devendo a requerida fesp } \\
\text { providenciar a imediata disponibilização da vaga } \\
\text { necessária para seu tratamento (período mínimo de três } \\
\text { meses) - }\end{array}$ & INTERNAÇÃO \\
\hline 704 & $\begin{array}{c}1032844- \\
74.2017 .8 .26 .0071\end{array}$ & $66860 / 2017$ & $06 / 12 / 2017$ & $\begin{array}{c}\text { Outros } \\
\text { Procediment } \\
\text { os }\end{array}$ & $01 / 12 / 2017$ & $\begin{array}{l}14 / 02 / 2018 \text { - julgo parcialmente procedente o pedido, } \\
\text { formulado por .... contra a prefeitura municipal de Bauru, } \\
\text { determinando que o requerido forneça ao requerente } \\
\text { fraldas descartáveis geriátricas tamanho "extra g" - } 180 \\
\text { (cento e oitenta) unidades por mês, e extinto o processo, } \\
\text { com resolução de mérito - }\end{array}$ & FRALDA \\
\hline 705 & $\begin{array}{c}1033433- \\
66.2017 .8 .26 .0071\end{array}$ & $67125 / 2017$ & 07/12/2017 & $\begin{array}{l}\text { Mandado de } \\
\text { Segurança }\end{array}$ & $30 / 11 / 2017$ & $\begin{array}{l}12 / 01 / 2017 \text { - concedo a segurança pleiteada por .... } \\
\text { contra ato do secretário municipal de saúde de Bauru, } \\
\text { para que o impetrado forneça ao impetrante: fraldas } \\
\text { geriátricas descartáveis tamanho "m" (120 unidades por } \\
\text { mês), conforme receituário de fls. } 11 \text {, e julgo extinto o } \\
\text { processo - }\end{array}$ & FRALDA \\
\hline 706 & $\begin{array}{c}1033169- \\
49.2017 .8 .26 .0071\end{array}$ & $67687 / 2017$ & $11 / 12 / 2017$ & $\begin{array}{c}\text { Outros } \\
\text { Procediment } \\
\text { os }\end{array}$ & $06 / 12 / 2017$ & $\begin{array}{l}\text { 30/04/18 - Procedente pedido, disponibilizar fisioterapia } \\
\text { respiratória diária. }\end{array}$ & MEDICAMENTO \\
\hline
\end{tabular}




\begin{tabular}{|c|c|c|c|c|c|c|c|}
\hline 707 & $\begin{array}{c}\text { 1032047- } \\
98.2017 .8 .26 .0071\end{array}$ & $68053 / 2017$ & $12 / 12 / 2017$ & $\begin{array}{l}\text { Mandado de } \\
\text { Segurança }\end{array}$ & & SEGREDO DE JUSTIÇA & $\begin{array}{l}\text { SEGREDO DE } \\
\text { JUSTIÇA }\end{array}$ \\
\hline 708 & $\begin{array}{l}\text { 1034267- } \\
69.2017 .8 .26 .0071\end{array}$ & $68315 / 2017$ & $13 / 12 / 2017$ & $\begin{array}{l}\text { Mandado de } \\
\text { Segurança }\end{array}$ & $11 / 12 / 2017$ & $\begin{array}{l}\text { 15/01/2018 - concedo a segurança pleiteada por ..... } \\
\text { contra ato do secretário municipal de saúde de Bauru, } \\
\text { para que o impetrado forneça ao impetrante: fraldas } \\
\text { geriátricas descartáveis tamanho "gg" (120 unidades por } \\
\text { mês), conforme receituário de fls. } 10 \text { e julgo extinto o } \\
\text { processo, com resoluçâo de mérito, nos termos do art. } \\
\text { 487, i do código de processo civil. - }\end{array}$ & FRALDA \\
\hline 709 & $\begin{array}{c}1032986- \\
78.2017 .8 .26 .0071\end{array}$ & $69041 / 2017$ & $15 / 12 / 2017$ & $\begin{array}{l}\text { Mandado de } \\
\text { Segurança }\end{array}$ & & SEGREDO DE JUSTIÇA & $\begin{array}{l}\text { SEGREDO DE } \\
\text { JUSTIÇA }\end{array}$ \\
\hline 710 & $\begin{array}{c}\text { 1034431- } \\
34.2017 .8 .26 .0071\end{array}$ & $69267 / 2017$ & $18 / 12 / 2017$ & $\begin{array}{l}\text { Mandado de } \\
\text { Segurança }\end{array}$ & $13 / 12 / 2017$ & $\begin{array}{l}\text { 15/01/2018 - autor falecido e sem habilitação de } \\
\text { sucessores - - 16/01/2018 - o informado o falecimento do } \\
\text { impetrante. por tratar-se de direito personalíssimo, houve } \\
\text { a perda do objeto da impetração.ante o exposto, revogo a } \\
\text { liminar de fls. } 21 / 22 \text { e julgo extinta a presente ação, - - }\end{array}$ & MEDICAMENTO \\
\hline 711 & $\begin{array}{c}\text { 1032042- } \\
76.2017 .8 .26 .0071\end{array}$ & $69564 / 2017$ & $19 / 12 / 2017$ & $\begin{array}{c}\text { Outros } \\
\text { Procediment } \\
\text { os } \\
\end{array}$ & & SEGREDO DE JUSTIÇA & $\begin{array}{l}\text { SEGREDO DE } \\
\text { JUSTIÇA }\end{array}$ \\
\hline 712 & $\begin{array}{c}\text { 1032041- } \\
91.2017 .8 .26 .0071\end{array}$ & $69800 / 2017$ & $20 / 12 / 2017$ & $\begin{array}{l}\text { Outros } \\
\text { Procediment } \\
\text { os }\end{array}$ & & SEGREDO DE JUSTIÇA & $\begin{array}{l}\text { SEGREDO DE } \\
\text { JUSTIÇA }\end{array}$ \\
\hline
\end{tabular}


Anexos 



\section{ANEXO A - Aprovação Comitê de Ética e Pesquisa}

\section{USP - FACULDADE DE ODONTOLOGIA DE BAURU DA Q Pratifil
USP}

\section{PARECER CONSUBSTANCIADO DO CEP}

\section{DADOS DO PROJETO DE PESQUISA}

Título da Pesquisa: A Judicializaçäo da Saúde e a Efetivaçäo de Direitos Fundamentais. Pesquisador: FATIMA CAROLINA PINTO BERNARDES

Área Temática:

Versäo: 1

CAAE: 29183020.5.0000.5417

Instituição Proponente: Universidade de São Paulo - Faculdade de Odontologia de Bauru

Patrocinador Principal: Financiamento Próprio

\section{DADOS DO PARECER}

\section{Número do Parecer: 3.912 .849}

Apresentação do Projeto:

O direito à saúde, a partir da Constituição Federal de 1988, ganhou status de direito fundamental, elencado expressamente no rol dos direitos sociais. $\mathrm{O}$ aumento da demanda na área da saúde, o surgimento de novas especialidades e técnicas, aliados à insuficiência de profissionais e estabelecimentos de saúde, levam à busca do cidadão pelo Poder Judiciário, dando origem a um fenômeno crescente, denominado judicialização da saúde.

Neste trabalho, abordaremos o assunto no âmbito do Município de Bauru, no período de 2014 a 2017 . O objetivo geral é verificar se a judicialização da saúde é um mecanismo para efetivação dos direitos fundamentais.

Para tanto, realizaremos uma análise descritiva das ações judiciais propostas, verificando o impacto orçamentário anual e administrativo, bem como os reflexos na efetivaçäo dos direitos fundamentais.

Assim, imperativa se faz a abordagem da judicialização da saúde e suas consequências práticas e sociais. É necessário repensar os mecanismos de controle e de garantia ao acesso universal, igualitário e de qualidade do direito à saúde, à luz dos princípios constitucionais, da reserva do possivel e do mínimo existencial.

Enderego: DOUTOR OCTAVIO PINHEIRO BRISOLLA 75 QUADRA 9
BairTo: VILA NOVA CIDADE UNIVERSITARIA CEP: $17.012-901$
UF: SP
$\begin{array}{llll}\text { MUniclplo: } & \text { BAURU } \\ \text { Telefone: } & \text { (14)3235-8356 } & \text { Fax: (14)3235-8356 } & \text { E-mall: cepgfob.usp.br }\end{array}$




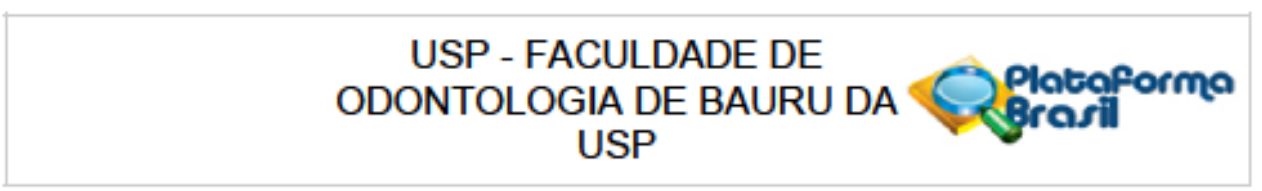

Contanusço do Parecer. 3.912 .849

A judicialização da saúde pode ser considerada um mecanismo de efetivaçäo de direitos fundamentais?

A judicialização contribui para a democratização da saúde ou fortalece grupos específicos com condições de acesso ao Judiciário?

Objetivo da Pesquisa:

Objetivo Primário:

Analisar o fenômeno da judicialização da saúde como mecanismo para efetivação dos direitos fundamentais.

Objetivo Secundário:

- Analisar a repartiçäo de competências, no âmbito da saúde, entre os entes federados: União, Estados e Municipios, à luz da Constituiçäo Federal e da legislaçäo infraconstitucional disciplinadora do assunto;

- Analisar os dados oriundos das ações judiciais, na área da saúde, em relação ao Município de Bauru, no período de 2014 a 2017 ;

- Analisar a reserva do possivel e o mínimo existencial na efetivação do direito fundamental à saúde:

-Analisar a importância da judicialização para o implemento de políticas públicas locais na área da saúde pública;

-Identificar as ações judiciais na área da saúde, com e sem procedència ao pedido, no âmbito do Município de Bauru/SP:

-Verificar o impacto orçamentário ocasionado pela judicialização da saúde, no âmbito do Município de Bauru, referente ao período de 2014 a 2017.

Avaliação dos Riscos e Benefícios:

Riscos:

Näo envolve riscos. Só serão coletados dados que não correm em segredo de justiça e estäo

Endereģ: DOUTOR OCTAVIO PINHEIRO BRISOLLA 75 QUADRA 9

BaIrTO: VILA NOVA CIDADE UNIVERSITARIA CEP: $17.012-901$

UF: SP Municliplo: BAURU

Telefone: (14)3235-8356 Fax: (14)3235-8356 E-mall: cepgrtob.usp.br 


\section{USP - FACULDADE DE ODONTOLOGIA DE BAURU DA USP}

Conthusą̧lo do Parecer. 3.912 .849

disponiveis no site do Tribunal de Justiça do Estado de São Paulo. Quanto aos dados coletados na Procuradoria do Município e na Secretaria de Saúde, cumpre informar que qualquer cidadão pode ter acesso a eles, em conformidade com a Lei de Acesso à Informação (Lei Federal $n^{\circ} 12.527 / 2011$ ).

Beneficios:

Verificar o impacto da judicialização da saúde no âmbito do Município de Bauru, inclusive sob o aspecto o orçamentário.

Comentários e Consideraçőes sobre a Pesquisa:

A pesquisa näo apresenta riscos éticos uma vez que destina-se a análise de banco de dados públicos.

Metodologia Proposta:

Os métodos utilizados na elaboração do estudo serão:

a) Bibliográfico: utilizado durante todo o estudo com base em obras, revistas científicas e jurisprudência dos Tribunais, que tratem de forma genérica e específica sobre o tema objeto do presente estudo. Referente às bases de dados utilizadas, parte do material de apoio foi extraida de sites como: Pubmed, Scielo, Lilacs, Google Acadêmico e Dedalus. Valeu-se, também, de sites de nossos Tribunais de Justiça, inclusive dos Superiores Tribunais - Superior Tribunal de Justiça e Supremo Tribunal Federal - para a extração de julgados pertinentes à pesquisa. Os descritores utilizados na pesquisa foram: judicialização, judicilialização da saúde, saúde pública, saúde coletiva, direitos fundamentais e direito à saúde.

b) Banco de Dados: será efetuado levantamento dos processos usando para tanto o banco de dados da Procuradoria do Município de Bauru e da Secretaria Municipal de Saúde, no que se refere às ações judiciais, bem como utilizaremos o sistema e-SAJ, do Tribunal de Justiça do Estado de São Paulo - TJ/SP.

Consideraçöes sobre os Termos de apresentação obrigatória:

Documentação obrigatória corretamente apresentada.

Recomendaçöes:

Alterar o tópico "dos riscos" na Plataforma Brasil, salientando que os dados e documentos pessoais

Endereģ: DOUTOR OCTAVIO PINHEIRO BRISOLLA 75 QUADRA 9

BalrTo: VILA NOVA CIDADE UNIVERSITARIA CEP: 17.012-901

UF: SP Municiplo: BAURU

Telefone: (14)3235-8356 Fax (14)3235-8356 E-mall: cepgfob.usp.br 


\section{USP - FACULDADE DE ODONTOLOGIA DE BAURU DA USP}

Conttnusçlo do Parecer. 3.912 .849

das partes envolvidas nos processos/decisões serão preservados, mantendo essas informações em sigilo.

Conclusöes ou Pendências e Lista de Inadequaçöes:

O projeto não apresenta pendências éticas, portanto, foi aprovado, porém com emenda para corrigir o item dos riscos na Plataforma Brasil conforme recomendaçöes acima. Deverá corrigir o tópico dos riscos para expor que há risco de exposiçäo de eventuais informaçöes ou documentos privados das partes envolvidas nos processos.

Consideraçöes Finais a critério do CEP:

Esse projeto foi considerado APROVADO na reuniäo ordinária do CEP de 04/03/2020, com base nas normas éticas da Resoluçäo CNS 466/12, no entanto solicita envio de emenda conforme descrito no item Conclusöes ou Pendèncias e Lista de Inadequaçöes. Ao término da pesquisa o CEP-FOB/USP exige a apresentaçäo de relatório final. Os relatórios parciais deverão estar de acordo com o cronograma e/ou parecer emitido pelo CEP. Alterações na metodologia, título, inclusäo ou exclusão de autores, cronograma $e$ quaisquer outras mudanças que sejam significativas deveräo ser previamente comunicadas a este CEP sob risco de não aprovação do relatório final. Quando da apresentação deste, deverão ser incluídos todos os TCLEs e/ou termos de doação assinados e rubricados, se pertinentes.

Este parecer foi elaborado baseado nos documentos abaixo relacionados:

\begin{tabular}{|c|c|c|c|c|}
\hline Tipo Documento & Arquivo & Postagem & Autor & Situação \\
\hline $\begin{array}{l}\text { Informações Básicas } \\
\text { do Projeto }\end{array}$ & $\begin{array}{l}\text { PB_INFORMAÇŌES_BÁSICAS_DO_P } \\
\text { ROJETO_1510068.pdf }\end{array}$ & $\begin{array}{c}12 / 02 / 2020 \\
18: 22: 41 \\
\end{array}$ & & Aceito \\
\hline Outros & $\begin{array}{l}\text { Declaracao_Secretario_Negocios_Juridi } \\
\text { cos_pdf }\end{array}$ & $\begin{array}{c}12 / 02 / 2020 \\
18: 22: 22 \\
\end{array}$ & \begin{tabular}{|l|} 
FATIMA CAROLINA \\
PINTO BERNARDES \\
\end{tabular} & Aceito \\
\hline $\begin{array}{l}\text { Projeto Detalhado / } \\
\text { Brochura } \\
\text { Investigador }\end{array}$ & Projeto.pdf & $\begin{array}{c}12 / 02 / 2020 \\
18: 12: 36\end{array}$ & $\begin{array}{l}\text { FATIMA CAROLINA } \\
\text { PINTO BERNARDES }\end{array}$ & Aceito \\
\hline Outros & Declaracao_Secretario_Saude.pdf & $\begin{array}{c}12 / 02 / 2020 \\
18: 09: 51\end{array}$ & $\begin{array}{l}\text { FATIMA CAROLINA } \\
\text { PINTO BERNARDES }\end{array}$ & Aceito \\
\hline Outros & Check_list.pdf & $\begin{array}{c}12 / 02 / 2020 \\
18: 09: 19\end{array}$ & $\begin{array}{l}\text { FATIMA CAROLINA } \\
\text { PINTO BERNARDES }\end{array}$ & Aceito \\
\hline Outros & Carta_encaminhamento.pdf & $\begin{array}{c}12 / 02 / 2020 \\
18: 08: 39\end{array}$ & \begin{tabular}{|l|} 
FATIMA CAROLINA \\
PINTO BERNARDES \\
\end{tabular} & Aceito \\
\hline $\begin{array}{l}\text { TCLE / Termos de } \\
\text { Assentimento / } \\
\text { Justificativa de }\end{array}$ & Requerimento_dispensa_TCLE.pdf & $\begin{array}{c}12 / 02 / 2020 \\
18: 07: 38\end{array}$ & $\begin{array}{l}\text { FATIMA CAROLINA } \\
\text { PINTO BERNARDES }\end{array}$ & Aceito \\
\hline
\end{tabular}

Endereģo: DOUTOR OCTAVIO PINHEIRO BRISOLLA 75 QUADRA 9

BairTo: VILA NOVA CIDADE UNIVERSITARIA CEP: 17.012-901

UF: SP Municiplo: BAURU

Telefone: (14)3235-8356 Fax (14)3235-8356 E-mall: cepgrob.usp.br 


\section{USP - FACULDADE DE ODONTOLOGIA DE BAURU DA USP}

Contnuaç̧o do Parecer. 3.912 .849

\begin{tabular}{|l|l|c|l|c|}
\hline Ausência & Requerimento_dispensa_TCLE.pdf & $12 / 02 / 2020$ & FATIMA CAROLINA & Aceito \\
& & $18: 07: 38$ & PINTO BERNARDES & \\
\hline Declaração de & Declaracao_pesquisador_pdf & $12 / 02 / 2020$ & FATIMA CAROLINA & Aceito \\
Pesquisadores & & $18: 07: 23$ & PINTO BERNARDES & \\
\hline Folha de Rosto & Folha_de_rosto.pdf & $12 / 02 / 2020$ & FATIMA CAROLINA & Aceito \\
& & $18: 06: 44$ & PINTO BERNARDES & \\
\hline
\end{tabular}

Situação do Parecer:

Aprovado

Necessita Apreciaçäo da CONEP

Näo

BAURU, 12 de Março de 2020

Assinado por:

CASSIA MARIA FISCHER RUBIRA

(Coordenador(a))

Endereģ: DOUTOR OCTAVIO PINHEIRO BRISOLLA 75 QUADRA 9

BairTo: VILA NOVA CIDADE UNIVERSITARIA CEP: 17.012-901

UF: SP Municiplo: BAURU

Telefone: (14)3235-8356 Fax (14)3235-8356 E-mall: cepgfob.usp.br 



\section{ANEXO B - Provimento no 84/2019 \\ PROVIMENTO № 84, DE 14 DE AGOSTO DE 2019. \\ Dispõe sobre o uso e o funcionamento do Sistema Nacional de Pareceres e Notas Técnicas (e-NatJus).}

O CORREGEDOR NACIONAL DE JUSTIÇA, no uso de suas atribuições legais e regimentais,

CONSIDERANDO a competência da Corregedoria Nacional de Justiça de expedir provimentos e outros atos normativos destinados ao aperfeiçoamento das atividades dos órgãos do Poder Judiciário (art. $8^{\circ}$, X, do Regimento Interno do Conselho Nacional de Justiça);

CONSIDERANDO que a Judicialização da Saúde envolve questões complexas que exigem a adoção de medidas para proporcionar a especialização dos Magistrados, de Primeiro e Segundo Graus, para proferirem decisões técnicas e precisas;

CONSIDERANDO que o Fórum Nacional do Judiciário para Monitoramento e Resolução das Demandas de Assistência à Saúde, criado pelo $\mathrm{CNJ}$, tem adotado medidas concretas e normativas voltadas à prevenção de conflitos judiciais e à qualificação das decisões tomadas pelos Magistrados, em sede de cognição sumária, além da definição de estratégias nas questões de direito sanitário, mediante estudos e formulação de proposições pertinentes;

CONSIDERANDO as diretrizes formuladas pela Resolução CNJ 107, de 6 de abril de 2010, que estabeleceu a necessidade de instituição de Comitês da Saúde Estaduais como instância adequada para encaminhar soluções para a melhor forma de prestação jurisdicional em área tão sensível quanto à da saúde;

CONSIDERANDO as diretrizes formuladas pela Resolução CNJ 238, de 6 de setembro de 2016, que estabeleceu a criação i) dos Comitês Estaduais/Distrital de Saúde; ii) de Núcleos de Apoio Técnico do Judiciário (NAT-JUS); iii) do Sistema Nacional de Pareceres e Notas Técnicas (e-NatJus); iv) da especialização de Varas; CONSIDERANDO que o Sistema e-NatJus foi lançado, em novembro de 2017, e implementado em dezembro de 2018, com o objetivo de dar ao Magistrado 
fundamentos para decidir com segurança, lastreado em evidência científica, sobre a concessão ou não, em sede de liminar, de fármaco, órtese, prótese ou qualquer outra tecnologia em saúde,

\section{RESOLVE:}

Art. $1^{\circ}$ Os Magistrados Estaduais e os Magistrados Federais com competência para processar e julgar ações que tenham por objeto o direito à saúde, ainda que durante $o$ plantão judicial, quando levados a decidir sobre a concessão de determinado medicamento, procedimento ou produto, poderão solicitar apoio técnico ao Núcleo de Apoio Técnico do Judiciário (NAT-JUS) do seu Estado ou ao NAT-JUS NACIONAL.

$\S 1^{\circ} \mathrm{O}$ apoio técnico previsto no caput, quando solicitado, deverá ser materializado por meio do Sistema Nacional de Pareceres e Notas Técnicas (e-NatJus), hospedado no sítio do Conselho Nacional de Justiça, podendo ser acessado através do link:www.cnj.jus.br/e-natjus.

$\S 2^{0}$ Nas hipóteses em que o Tribunal local já dispuser de um sistema próprio de apoio técnico, o Magistrado poderá solicitar por meio do sistema do seu Tribunal, sendo que emitido o parecer no caso concreto, o Núcleo de Apoio Técnico ao Judiciário (NAT-JUS) deverá alimentar a base de dados do Sistema Nacional de Pareceres e Notas Técnicas (e-NatJus), com suas respectivas notas técnicas.

$\S 3^{\circ}$ O Tribunal que já dispõe de sistema próprio de solicitação de apoio técnico, por intermédio do seu Núcleo de Apoio Técnico ao Judiciário (NAT-JUS), quando tiver a necessidade de tutoria para elaboração de suas notas técnicas, junto aos NATS selecionados, conforme previsto no Termo de Cooperação oㅡ 021/2016, celebrado entre o Conselho Nacional de Justiça e o Ministério da Saúde, deverá solicitar através do Sistema Nacional de Pareceres e Notas Técnicas (e-NatJus).

$\S 4^{\circ}$ Nas demandas com pedido de tutela antecipada sob a alegação de urgência, conforme previsto no Termo de Cooperação Técnica oㅡ 051/2018, celebrado entre o Conselho Nacional de Justiça e o Ministério da Saúde, o Magistrado, quando tiver a necessidade de apoio técnico do NAT-JUS NACIONAL, ainda que o Tribunal disponha de sistema próprio, determinará por decisão, a solicitação de nota técnica diretamente por meio do Sistema Nacional de Pareceres e Notas Técnicas (eNatJus). 
Art. $2^{\circ}$ Os Tribunais que já dispõem de sistema próprio, além de poder utilizar o sistema e-NatJus, nas formas anteriormente previstas, poderão utilizá-lo através dos mecanismos de integração de sistemas de processo eletrônico.

Art. 3ํ $\mathrm{O}$ acesso ao sistema e-NatJus será concedido aos servidores indicados pelos:

I - Magistrados com competência para processar e julgar ações que tenham por objeto o direito à saúde, cuja finalidade é dar início ao pedido de apoio técnico ao NAT-JUS do Estado ou NAT-JUS NACIONAL;

II - Núcleos de Apoio Técnico ao Judiciário (NAT-JUS), cuja finalidade é atender à solicitação de apoio técnico requerida pelo Magistrados.

Parágrafo único. Compete às Corregedorias dos Tribunais de Justiça e dos Tribunais Regionais Federais, quando solicitadas, conceder o acesso ao sistema eNatJus aos servidores mencionados no caput, por meio do Sistema de Controle de Acesso corporativo do CNJ.

Art. 4ํำ Conselho Nacional de Justiça disponibilizará manual de utilização do Sistema Nacional de Pareceres e Notas Técnicas (e-NatJus), com o objetivo de orientar a sua utilização e sanar eventuais dúvidas dos usuários.

Art. $5^{\circ}$ Este Provimento entrará em vigor na data de sua publicação.

\section{MINISTRO HUMBERTO MARTINS}

Corregedor Nacional de Justiça

S22

Brasília, 2019-09-13. 



\title{
ANEXO C - Resolução CNJ no 238/2016
}

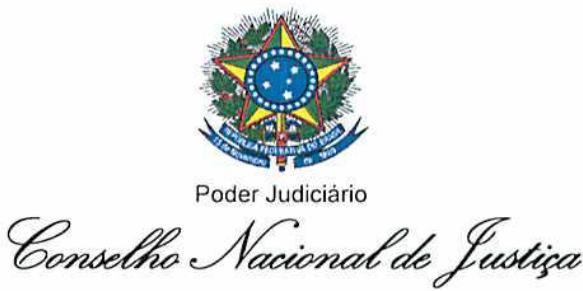

RESOLUÇÃO 238 DE

6 DE SETEMBRO DE 2016

\begin{abstract}
Dispõe sobre a criação e manutenção, pelos Tribunais de Justiça e Regionais Federais de Comitês Estaduais da Saúde, bem como a especialização de vara em comarcas com mais de uma vara de fazenda Pública.
\end{abstract}

O PRESIDENTE DO CONSELHO NACIONAL DE JUSTIÇA (CNJ), no uso de suas atribuiçöes legais e regimentais,

CONSIDERANDO que a judicialização da saúde envolve questões complexas que exigem a adoção de medidas para proporcionar a especialização dos magistrados para proferirem decisões mais técnicas e precisas;

CONSIDERANDO as diretrizes formuladas pela Resolução CNJ 107, de 6 de abril de 2010, que estabeleceu a necessidade de instituição de Comitês da Saúde Estaduais como instância adequada para encaminhar soluções para a melhor forma de prestação jurisdicional em área tão sensivel quanto à da saúde;

CONSIDERANDO que a Recomendação CNJ 43, de 20 de agosto de 2013, orienta os Tribunais indicados nos incisos III e VII do art. 92 da Constituição Federal a promoverem a especialização de varas para processar e julgar ações que tenham por objeto o direito à saúde pública e orientem as varas competentes a priorizar o julgamento dos processos relativos à saúde suplementar;

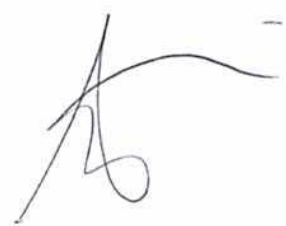




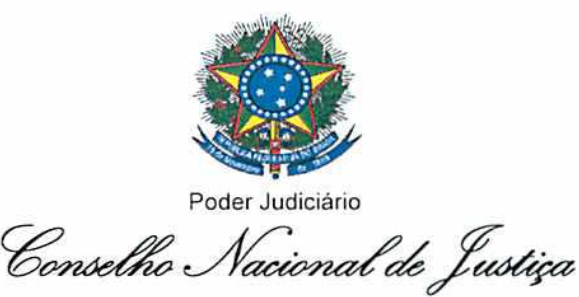

CONSIDERANDO que a referida especialização pode ser realizada por meio da concentração da distribuição de novas açöes que envolvam direito à saúde pública e à saúde suplementar em uma das varas civeis ou de Fazenda Pública de cada Comarca, com a devida compensação na distribuição de outros feitos;

CONSIDERANDO a deliberação do Plenário do CNJ no Ato Normativo 0003751-63.2016.2.00.0000 na 18 ${ }^{\mathrm{a}}$ Sessão Virtual, realizada em 30 de agosto de 2016;

RESOLVE:

Art. $1^{\circ}$ Os Tribunais de Justiça e os Tribunais Regionais Federais criarão no âmbito de sua jurisdição Comitê Estadual de Saúde, com representação minima de Magistrados de Primeiro ou Segundo Grau, Estadual e Federal, gestores da área da saúde (federal, estadual e municipal), e demais participantes do Sistema de Saúde (ANVISA, ANS, CONITEC, quando possivel) e de Justiça (Ministério Público Federal e Estadual, Defensoria Pública, Advogados Públicos e um Advogado representante da Seccional da Ordem dos Advogados do Brasil do respectivo Estado), bem como integrante do conselho estadual de saúde que represente os usuários do sistema público de saúde, e um representante dos usuário do sistema suplementar de saúde que deverá ser indicado pela Secretaria Nacional de Defesa do Consumidor por intermédio dos Procons de cada estado.

$\S 1^{\circ} \mathrm{O}$ Comitê Estadual da Saúde terá entre as suas atribuiçōes auxiliar os tribunais na criação de Núcleos de Apoio Técnico do Judiciário (NATJUS), constituido de profissionais da Saúde, para elaborar pareceres acerca da medicina baseada em evidências, observando-se na sua criação o disposto no parágrafo segundo do art. 156 do Código de Processo Civil Brasileiro.

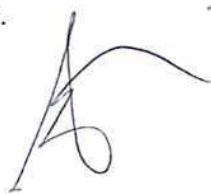




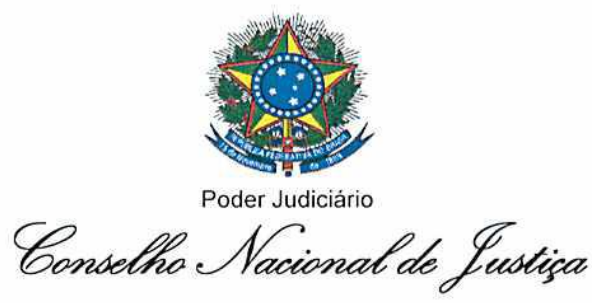

$\S 2^{\circ}$ Aplicam-se aos Comitês Estaduais de Saúde, naquilo que the compete, as mesmas atribuições previstas ao Comitê Executivo Nacional pela Resolução CNJ 107/2010, destacando-se aquela estabelecida no seu inciso IV do artigo $2^{\circ}$, que dispõe sobre a proposição de medidas concretas e normativas voltadas à prevenção de conflitos judiciais e à definição de estratégias nas questões de direito sanitário.

$\S 3^{\circ}$ As indicações dos magistrados integrantes dos Comitês Estaduais de Saúde serão realizadas pela presidência dos tribunais respectivos ou de acordo com norma prevista em regimento interno dos órgãos, de preferência dentre os magistrados que exerçam jurisdição em matéria de saúde pública ou suplementar, ou que tenham destacado saber juridico na área da saúde.

$\S 4^{\circ} \mathrm{A}$ presidência do Comitê Estadual será definida em comum acordo entre os magistrados participantes, sendo que, no caso de divergência, presidirá o magistrado mais antigo, independente da justiça originária.

$\S 5^{\circ}$ Os Núcleos de Apoio Técnico do Judiciário (NAT-JUS) terão função exclusivamente de apoio técnico não se aplicando às suas atribuições aquelas previstas na Resolução CNJ 125/2010.

Art. $2^{\circ}$ Os tribunais criarão sítio eletrônico que permita o acesso ao banco de dados com pareceres, notas técnicas e julgados na área da saúde, para consulta pelos Magistrados e demais operadores do Direito, que será criado e mantido por este Conselho Nacional de Justiça.

Parágrafo Único. Sem prejuizo do contido no caput deste artigo, cada tribunal poderá manter banco de dados próprio, nos moldes aqui estabelecidos.

Art. $3^{\circ}$ Os Tribunais Estaduais e Federais, nas Comarcas ou Seções Judiciárias onde houver mais de uma vara de Fazenda Pública, promoverão a especialização de uma das varas em matéria de saúde pública, compensando-se a distribuição.

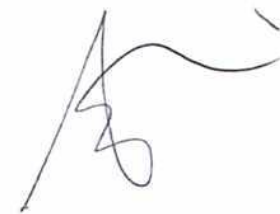




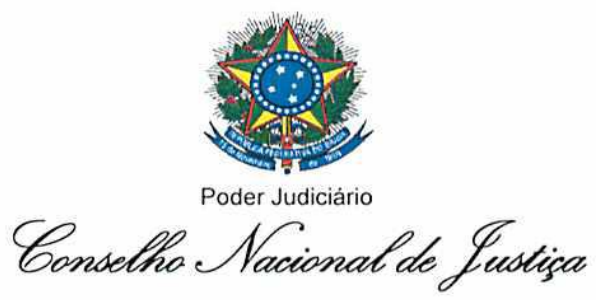

Parágrafo único. Nos tribunais onde houver mais de uma Câmara de Direito Público, recomenda-se que seja aplicado o mesmo critério do caput.

Art. $4^{\circ}$ Esta Resolução entra em vigor 60 (sessenta) dias após a data de sua publicação.

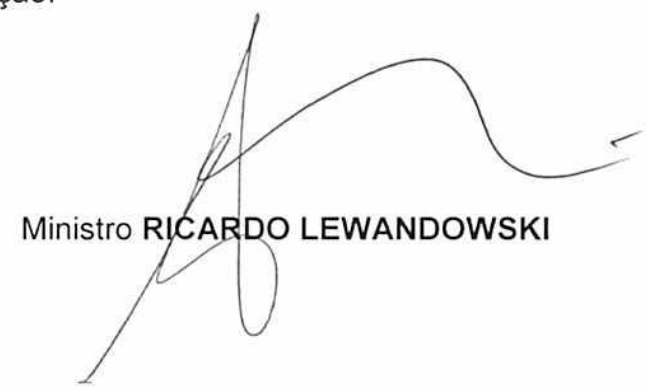

